\title{
COMUNICAÇÃO DA INFORMAÇÃO, GESTÃO DA INFORMAÇÃO E GESTÃO DO CONHECIMENTO

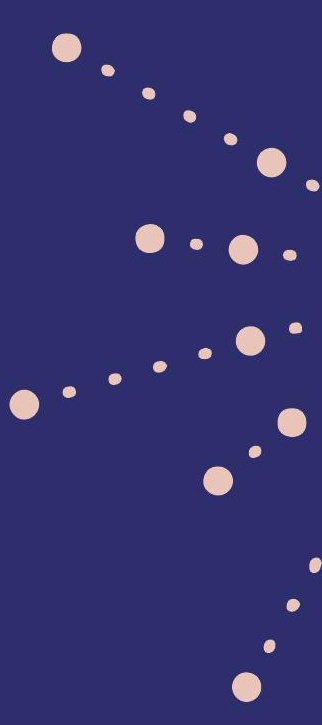

\section{Organizadores}

SELY MARIA DE SOUZA COSTA

FERNANDO CÉSAR LIMA LEITE

ROSEMEIRE BARBOSA TAVARES
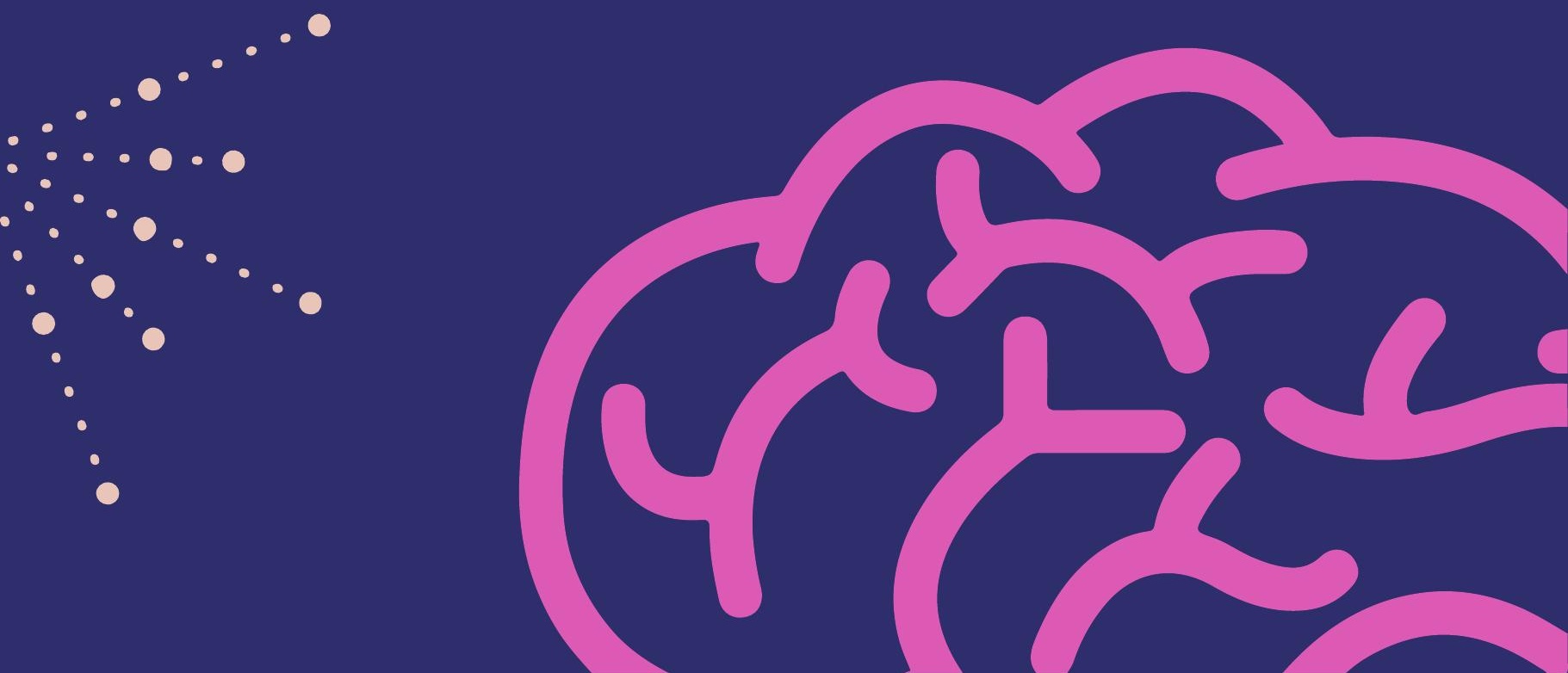
Comunicação da informação, gestão da Informação e gestão do conhecimento

ORGANIZADORES

SELY MARIA DE SOUZA COSTA FERNANDO CÉSAR LIMA LEITE ROSEMEIRE BARBOSA TAVARES

ibict

Brasília

2018 
Governo Federal

Ministério da Ciência, Tecnologia, Inovações e Comunicações

Ministro Gilberto Kassab

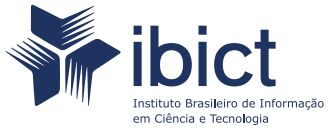

0 Instituto Brasileiro de Informação em Ciência e Tecnologia tem por finalidade promover a competência e o desenvolvimento de recursos e infraestrutura de Informação Científica e Tecnológica para a produção, a socialização e a integração do conhecimento científico-tecnológico

\section{DIRETORIA}

Diretora: Cecília Leite Oliveira

COORDENAÇÃO DE ADMINISTRAÇÃO - COADM

Coordenador: Reginaldo de Araújo Silva

COORDENAÇÃO DE ENSINO E PESQUISA, CIÊNCIA E TECNOLOGIA DA INFORMAÇÃO - COEPPE

Coordenadora: Lena Vânia Ribeiro Pinheiro

COORDENAÇÃO DE PLANEJAMENTO, ACOMPANHAMENTO E AVALIAÇÃO - COPAV

Coordenador: José Luis dos Santos Nascimento

COORDENAÇÃO GERAL DE PESQUISA E DESENVOLVIMENTO DE NOVOS PRODUTOS

- CGNP

Coordenador: Arthur Fernando Costa

COORDENAÇÃO DE ARTICULAÇÃO, GERAÇÃO E APLICAÇÃO DE TECNOLOGIA -

COTEC

Coordenador: Milton Shintaku

COORDENAÇÃO GERAL DE PESQUISA E MANUTENÇÃO DE PRODUTOS

CONSOLIDADOS - CGPC

Coordenadora: Bianca Amaro de Melo

COORDENAÇÃO GERAL DE TECNOLOGIAS DE INFORMAÇÃO E INFORMÁTICA - CGTI Coordenador: Marcos Pereira Novais 
Comunicação da informação, gestão da Informação e gestão do conhecimento

ORGANIZADORES

SELY MARIA DE SOUZA COSTA

FERNANDO CÉSAR LIMA LEITE

ROSEMEIRE BARBOSA TAVARES

ibict

Brasilia

2018 
(C) 2018 Instituto Brasileiro de Informação em Ciência e Tecnológica.

Esta obra é licenciada sob uma licença Creative Commons - Atribuição CC BY 4.0, sendo permitida a reprodução parcial ou total desde que mencionada a fonte.

\section{Conselho Científico}

Dra. Aidate Mussagy, professora auxiliar

Editora chefe da Revista Científica da UEM

Universidade Eduardo Mondlane, Moçambique

Dr. João Álvares de Carvalho, professor catedrático

Diretor do Departamento de Sistemas de Informação

Universidade do Minho, Portugal

Dra. Lena Vania Ribeiro Pinheiro, pesquisadora

Docente do Programa de Pós-Graduação em Ciência da Informação

Instituto Brasileiro de Informação em Ciência e

Tecnologia, Brasil

Dra. Marta Lígia Pomim Valentim, professora titular

Coordenadora do Programa de Pós-Graduação em

Ciência da Informação

Universidade Estadual Paulista, Brasi
Editor Executivo

Ramón Martins Sodoma da

Fonseca

Assistentes de Editoração

Davilene Ramos Chaves

Gislaine Russo de Moraes Brito

Revisão de Conteúdo

Jane Baptistone de Araújo

\section{Diagramação}

Rafael Fernandez

Tratamento de imagens

Marília Augusta de Freitas

\author{
Autores \\ Ana Matilde Fauat \\ Anderson Barros Torres \\ André Luiz Valença da Cruz \\ Angélica Calazans \\ Bruno Jorge Soares \\ Carlos Sousa Pinto \\ Claudia Augusto Dias \\ Fernando César Lima Leite \\ Joaquim Luís Costa \\ Kelley Cristine Gonçalves \\ Mark Hepworth (in memoriam) \\ Milton Shintaku \\ Roberto Campos da Rocha \\ Rosane Mendes Parmagnani \\ Rosemeire Barbosa Tavares \\ Rubi Nei Machado Oliveira \\ Sely Maria de Souza Costa
}

\section{Yirict}

IBICT - Brasília

Setor de Autarquias Sul (SAUS) Quadra 05 Lote 06, Bloco H - 50 andar Cep:70.070-912 - Brasília, DF

Telefones: 55 (61) 3217-6360/55/(61)3217-6350

IBICT - Rio de Janeiro

Rua Lauro Muller, 455 - 40 andar - Botafogo, RJ Cep: 22.290-160 - Rio de Janeiro, RJ

Telefone:55(21)2275-0321 Fax:55(21)2275-3590

http://www.ibict.br/capacitacao-e-ensino/pos-graduacao-em-ciencia-da-informacao

http://www.ppgci.ufrj.br

www.ibict.br 


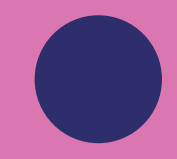

○

○

-

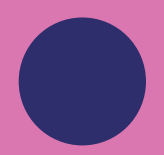

-

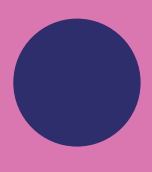

○

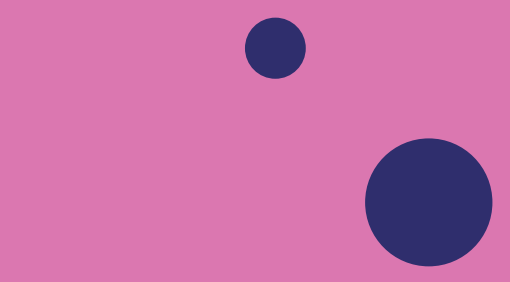

○

○

- 0

○
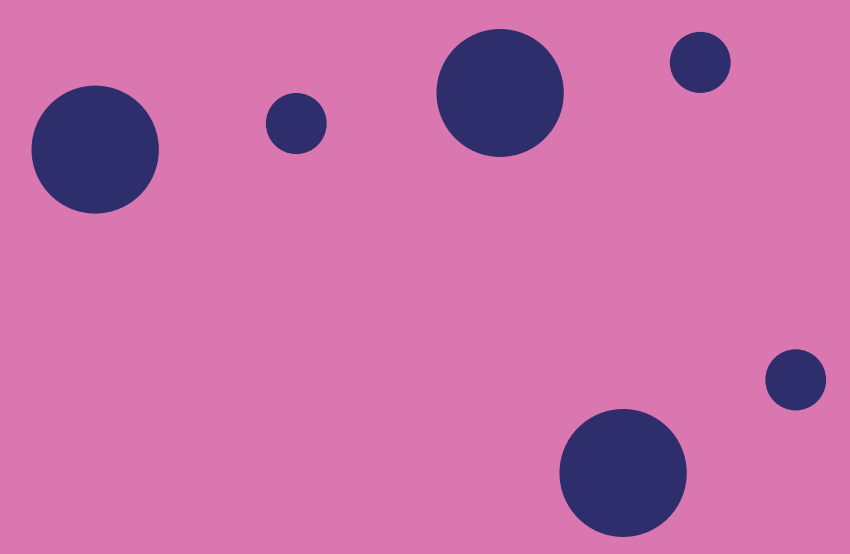


\section{SUMÁRIO}

AGRADECIMENTOS

10

PREFÁCIO

APRESENTAÇÃO

INTRODUÇÃO

IMBRICAÇÕES TEÓRICAS ENTRE COMUNICAÇÃO E GESTÃO DA INFORMAÇÃO E DO CONHECIMENTO NA CIÊNCIA DA INFORMAÇÃO

Sely Maria de Souza Costa

Fernando César Lima Leite

\section{CAPÍTULO 1}

EFETIVIDADE DO PROCESSO DE COMUNICAÇÃO COM BASE NA TEORIA DO COMPORTAMENTO INFORMACIONAL: O CASO DE UM ORGANISMO INTERNACIONAL DA ÁREA DA SAÚDE PÚBLICA SEDIADO NO BRASIL

Luciana de Deus Chagas

Sely Maria de Souza Costa

\section{CAPÍTULO 2}

COMUNICAÇÃO ORGANIZACIONAL E PADRÕES DE COMPORTAMENTO INFORMACIONAL DE GESTORES E ANALISTAS DE RISCO DE CRÉDITO EM INSTITUIÇÕES FINANCEIRAS GOVERNAMENTAIS

Ana Matilde Fauat

Sely Maria de Souza Costa

\section{CAPÍTULO 3}

O PROCESSO DE COMUNICAÇÃO ENTRE USUÁRIOS E ANALISTAS DE SISTEMAS NO CONTEXTO DAS ORGANIZAÇÕES

Rubi Nei Machado Oliveira

Sely Maria de Souza Costa 


\section{CAPÍTULO 4}

MÉTODO DE AVALIAÇÃO DE PROGRAMAS DE GOVERNO ELETRÔNICO SOB A ÓTICA DO CIDADÃO-CLIENTE

Cláudia Augusto Dias

Sely Maria de Souza Costa

\section{CAPÍTULO 5}

PADRÕES DE COMUNICAÇÃO EM DIFERENTES COMUNIDADES CIENTÍFICAS

Carlos Sousa Pinto

Joaquim Luís Costa

\section{CAPÍTULO 6}

A COMUNICAÇÃO CIENTÍFICA ENTRE PESQUISADORES DA SURDEZ DO PONTO DE VISTA DA LINGUAGEM

Milton Shintaku

Sely Maria de Souza Costa

\section{CAPÍTULO 7}

O PENSAMENTO REFLEXIVO NO LETRAMENTO INFORMACIONAL NAS PESQUISAS DE PÓS-GRADUAÇÃO

Kelley Cristine Gonçalves Dias Gasque

Sely Maria de Souza Costa

\section{CAPÍTULO 8}

PESQUISA E AÇÃO PARTICIPATÓRIA COM FOCO EM LETRAMENTO INFORMACIONAL E TRABALHO COLABORATIVO PARA DESENVOLVIMENTO DE CIDADANIA

Rosemeire Barbosa Tavares

Sely Maria de Souza Costa

Mark Hepworth (in memorian) 


\section{CAPÍTULO 9}

COMPORTAMENTO DE GESTORES DE EMPRESAS DE BASE TECNOLÓGICA NA BUSCA E NO USO DE INFORMAÇÕES

Bruno Jorge Soares

Sely Maria de Souza Costa

\section{CAPÍTULO 10}

SISTEMATIZAÇÃO DO FLUXO DE INFORMAÇÃO TECNOLÓGICA NO

ATENDIMENTO AO CLIENTE DA EMBRAPA HORTALIÇAS

Rosane Mendes Parmagnani

Sely Maria de Souza Costa

\section{CAPÍTULO 11}

CONSTRUÇÃO E IMPLEMENTAÇÃO DE MODELO PARA AVALIAR A QUALIDADE DA INFORMAÇÃO ESTRATÉGICA BANCÁRIA

Angélica Calazans

Sely Maria de Souza Costa

\section{CAPÍTULO 12}

GESTÃO DO CONHECIMENTO ESTRATÉGICO: METODOLOGIA E APLICAÇÕES

Roberto Campos da Rocha Miranda

Sely Maria de Souza Costa

\section{CAPÍTULO 13}

GESTÃO DO CONHECIMENTO CIENTÍFICO: PROPOSTA DE UM MODELO CONCEITUAL COM BASE EM PROCESSOS DE COMUNICAÇÃO CIENTÍFICA 315 Fernando César Lima Leite Sely Maria de Souza Costa 


\section{CAPÍTULO 14}

MODELO GENÉRICO DE GESTÃO DA INFORMAÇÃO CIENTÍFICA DIGITAL PARA INSTITUIÇÕES DE PESQUISA NA PERSPECTIVA DA COMUNICAÇÃO CIENTÍFICA E DO ACESSO ABERTO

Fernando César Lima Leite

Sely Maria de Souza Costa

\section{CAPÍTULO 15}

PORTAIS CORPORATIVOS COMO FERRAMENTAS DE COMUNICAÇÃO E GESTÃO DO CONHECIMENTO

Anderson Barros Torres

Sely Maria de Souza Costa

\section{CAPÍTULO 16}

COMUNICAÇÃO INFORMAL E SOCIALIZAÇÃO DO CONHECIMENTO EM INSTITUIÇÕES FINANCEIRAS

André Luiz Valença da Cruz

Sely Maria de Souza Costa

SOBRE OS AUTORES 


\section{AGRADECIMENTOS}

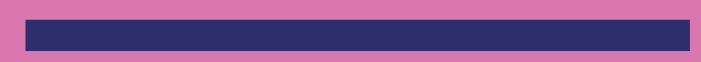


À Dra Cecília Leite pela publicação desse livro pelo Instituto Brasileiro de Informação em Ciência e Tecnologia (Ibict);

Aos autores pela disposição e confiança em entregar-nos os textos de seus capítulos;

À equipe da Coordenação de Articulação, Geração e Aplicação de Tecnologia do Ibict, na pessoa de seu coordenador, Milton Shintaku e de seus profissionais dedicados e competentes, especificamente, aos técnicos: Ingrid Torres Schiessl, Jaqueline de Jesus, Priscila Rodrigues e Rafael Fernandez Gomes, pelo empenho na revisão e padronização das normas bibliográficas e diagramação do livro.

À bibliotecária Marília Augusta de Freitas, da Universidade de Brasilia, pela diagramação das ilustrações. 


\section{PREFÁCIO}

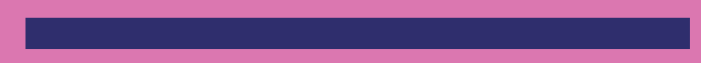

0
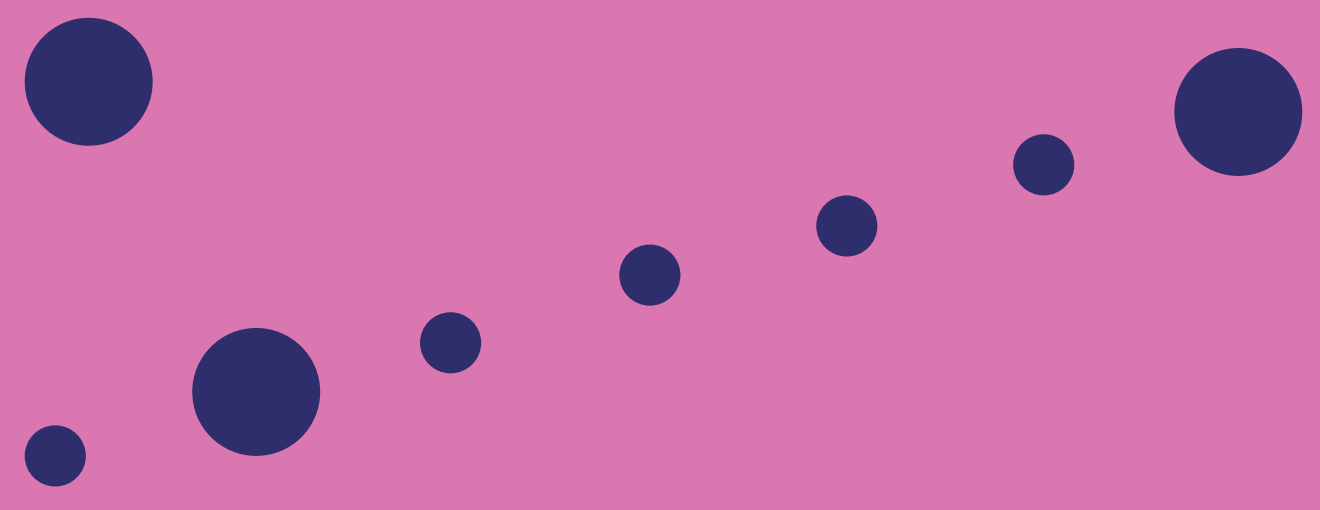

- 0

$\bullet$ 
Entre as características que desde sempre distinguem a Ciência da Informação das áreas como a Biblioteconomia e a Documentação e a Informática, duas merecem destaque. A primeira é a preocupação com a comunicação da informação entre seres humanos que, em sentido amplo, envolve questões relacionadas com a produção, compartilhamento e uso da informação nas sociedades. Este talvez seja o fenômeno nuclear e fundamental de interesse do campo, a partir do qual irradiam tópicos de grande relevância como é o caso do comportamento e práticas informacionais e organização da informação. A segunda, decorrente da primeira, é a noção de contexto, que diz respeito ao conjunto de forças - sociais, tecnológicas, culturais, econômicas e legais - que em qualquer medida exercem influência sobre as práticas de produção, compartilhamento e uso da informação. Subjacente e derivada de tais preocupações, a gestão da informação e, mais recentemente, a gestão do conhecimento - subáreas dedicadas às questões relacionadas com a sistematização dos processos de produção, compartilhamento e usos da informação e do conhecimento - têm sido fortemente desenvolvidas no campo da Ciência da Informação.

Esta obra, tal como indicada em seu título "Comunicação da informação, gestão da informação e gestão do conhecimento", trata fundamentalmente destas questões, ora dedicando-se a cada um deles, ora tratando-os de forma associada. Como característica comum às pesquisas, é sempre posto em relevo a noção de contexto, mais especificamente, o contexto da ciência, das organizações e das comunidades/cidadania. Como se trata de obra inteiramente constituída de resultados de pesquisas de mestrado e doutorado realizadas ao longo de mais de uma década, sob orientação da Profa. Sely Costa,, entre os anos de 2000 e 2012, intenta mostrar os resultados sob uma perspectiva histórica dentro do período coberto pelas investigações.

A qualidade e o rigor metodológico das pesquisas realizadas tornam-se clarividentes ao longo dos capítulos. Suas estruturas dão exata objetividade aos elementos fundamentais da atividade de investigação: problema/objetivo da pesquisa, fundamentação teórica, modelos conceituais que imprimem originalidade às pesquisas, discussão dos resultados e conclusões. A leitura dos capítulos permite perceber uma trajetória de mestre e pesquisadora conscientemente planejada e tangenciada por uma espécie de programa de investigação moldada em razão de fenômenos que a Profa. Sely Costa nutriu interesse ao longo de sua carreira.

A comunidade da Ciência da Informação tem nesta obra a excelente oportunidade de constatar, além de bons exemplos de condução de projetos de pesquisa, resultados que efetivamente acrescentaram novos conhecimentos aos tópicos comunicação da informação, gestão da informação e gestão do conhecimento, em diferentes contextos.

Boa leitura.

Cecília Leite de Oliveira

Diretora do Instituto Brasileiro de Informação em Ciência e Tecnologia 


\section{APRESENTAÇÃ̃O}
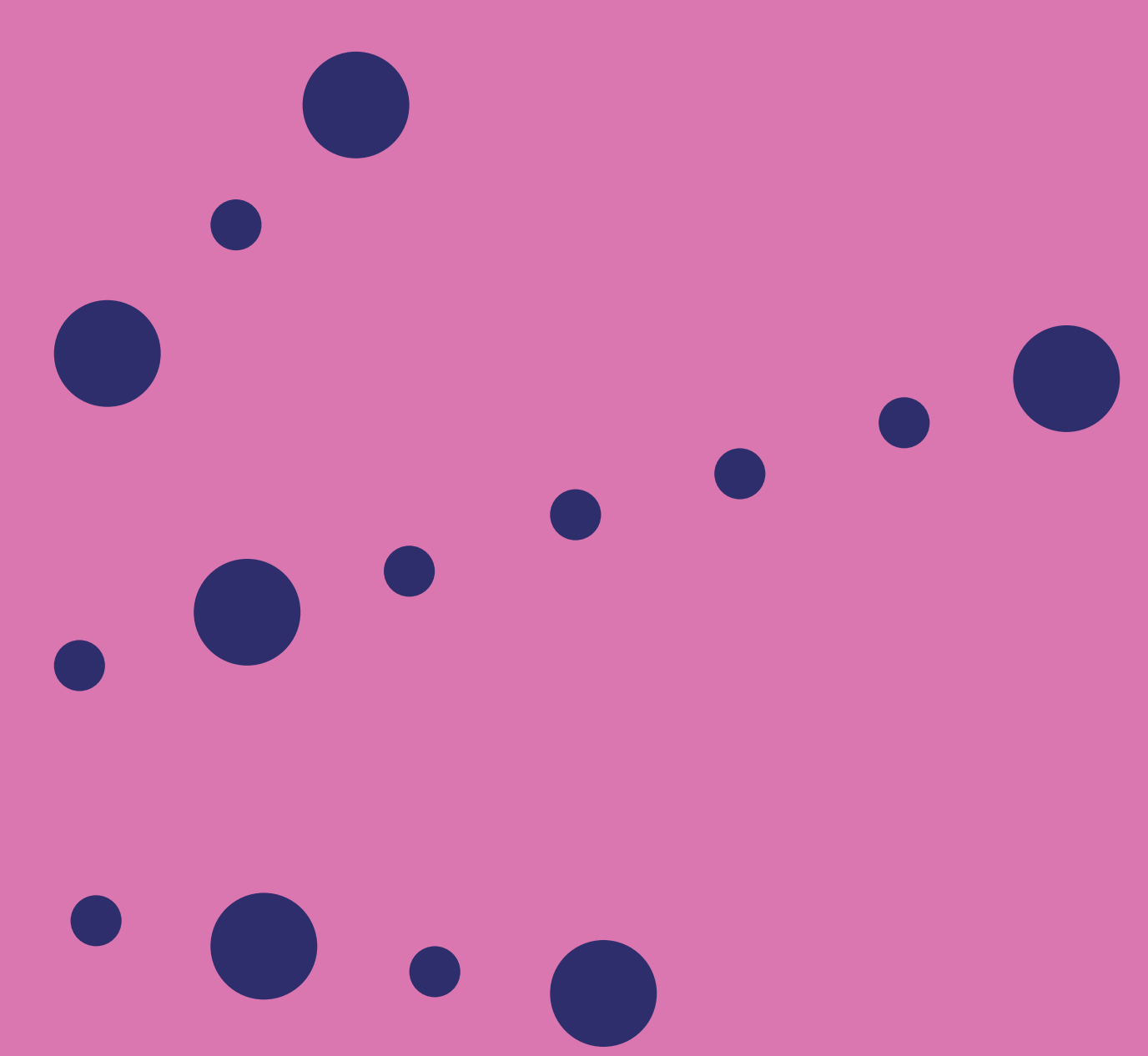

$\bullet$ 
Esta obra consubstancia resultados de pesquisas realizadas no campo da Ciência da Informação que adotaram quadros teóricos de referência dos tópicos comunicação da informação, gestão da informação e gestão do conhecimento. Ora abordados isoladamente um do outro, ora abordados de modo associado um com o outro, todos são tangenciados pela noção de contexto.

Assume-se contexto como o substrato social em que tanto a comunicação quanto a gestão da informação e gestão do conhecimento operam. Nele atua o conjunto de fatores de ordem social, cognitiva, cultural, política, tecnológica, econômica e legal que, em alguma medida, exerce influência sobre os processos de produção, compartilhamento e usos da informação e do conhecimento. Elementos e processos de comunicação e gestão da informação e do conhecimento estão presentes, invariavelmente, em qualquer contexto. No entanto, o conjunto de forças particulares de cada contexto imprime especificidades às práticas e comportamentos informacionais de quem produz, compartilha e utiliza informação. Por essa razão, a despeito dos mesmos elementos, assume-se que contextos influenciam a comunicação e, em decorrência disso, a própria gestão da informação e do conhecimento.

Se por um lado a comunicação da informação é responsável pelos fluxos de informação, e fenômenos associados, que viabilizam a atividade humana em diferentes contextos, a gestão da informação e a gestão do conhecimento são as responsáveis por sua sistematização e dão conta de sua complexidade na contemporaneidade. Trata-se de uma mão de via dupla. Primeiro porque a comunicação serve à gestão da informação e do conhecimento, uma vez que a produção, compartilhamento e usos constituem, essencialmente, processos de comunicação humana. Segundo porque a gestão da informação e do conhecimento promovem, em última análise, a interação entre sujeitos que alternam em seus papeis de produtores e usuários em diferentes contextos.

É com base nesse intricado de relações conceituais, que ganha maior robustez e complexidade nos textos, que todas as pesquisas cujos resultados são relatados nos capítulos da presente obra. Sua estrutura conta com cinco seções, sendo a primeira dedicada à Introdução, e as demais intituladas, respectivamente, Comunicação da Informação Organizacional, Comunicação da Informação Científica, Comunicação da Informação em Comunidades, Gestão da Informação e Gestão do Conhecimento, Comunicação e Gestão da Informação e do Conhecimento.

Por fim, é importante destacar que todas as pesquisas relatadas nos dezesseis capítulos do livro foram selecionadas entre aquelas orientadas pela professora Sely Maria de Souza Costa ao longo de pouco mais de uma década (2000-2012).

Os autores. 


\section{INTRODUÇÃO}

0

0
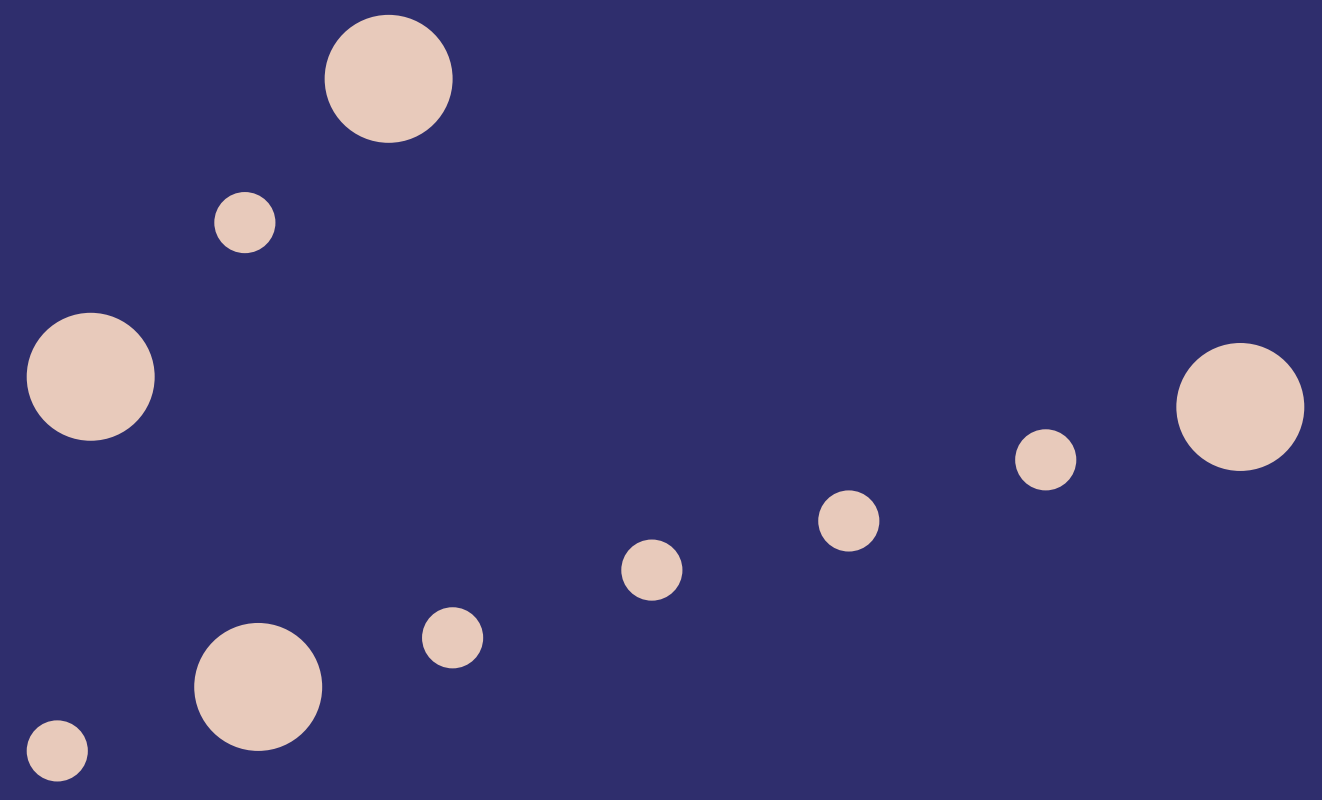

- 00 


\section{IMBRICAÇÕES TEÓRICAS ENTRE COMUNICAÇÃO E GESTÃO DA INFORMAÇÃO E DO CONHECIMENTO NA CIÊNCIA DA INFORMAÇÃO'}

SELY MARIA DE SOUZA COSTA FERNANDO CÉSAR LIMA LEITE

\section{INTRODUÇÃ̃O}

A Ciência da Informação tem estudado, desde a sua gênese, questões relacionadas com a comunicação científica como fenômeno central de interesse, uma vez que a disciplina surgiu em razão da preocupação de cientistas, tecnólogos e documentalistas de meados do século passado com os fluxos da informação em ciência e tecnologia. Entretanto, ao longo das últimas décadas, identifica-se expansão considerável nos fenômenos de interesse da área. Além da diversificação de fenômenos de interesse, os contextos em que a comunicação tem sido estudada vêm sendo igualmente ampliados. Esse alargamento no foco de estudos da área decorre, portanto, da identificação desses fenômenos e contextos, os quais, por sua vez, requerem novas abordagens.

Considerando que tal cenário não parece estar sendo claramente explorado nos estudos da área em razão do não reconhecimento desse alargamento no foco dos estudos por parte de alguns teóricos, o presente artigo visa a contribuir para o enriquecimento das discussões. Tal contribuição diz respeito às relações conceituais observadas entre comunicação e gestão como fenômenos da Ciência da Informação desde sua gênese. Portanto, o objetivo deste trabalho é apresentar modelo conceitual que ilustra imbricações teóricas entre comunicação, gestão da informação e gestão do conhecimento na Ciência da Informação. O trabalho resultou da identificação e análise de autores relevantes e seminais da área. Como resultado, discutem-se,

1 Versão modificada do artigo publicado na revista Investigatión Bibliotecológica: archivonomia, bibliotecológica e information, v. 32, n. 74, 2018. 
de início, questões epistemológicas da Ciência da Informação, as quais compreendem a natureza da área e a informação como seu objeto de estudo. Em seguida, são analisadas duas questões centrais do artigo. A primeira diz respeito à dimensão da comunicação sob a ótica da abordagem de Belkin (1978) e outros autores, tanto da Ciência da Informação quanto de outras áreas. A segunda trata da compreensão da gestão da informação e do conhecimento como fenômenos da Ciência da Informação, a partir do pensamento de Brookes (1980) associado a outros autores. Por fim, conclui-se com a apresentação gráfica do modelo teórico proposto e explicação textual das relações conceituais embutidas.

\section{ASPECTOS EPISTEMOLÓGICOS DA CIÊNCIA DA INFORMAÇÃO}

O aporte teórico adotado neste artigo mostra a contribuição de estudiosos da área para a fundamentação de pesquisas na Ciência da Informação, iniciando com Borko (1968) e a definição de Ciência da Informação. O autor apresentou sua definição a partir da análise que fez do trabalho de Taylor (1966), o qual, por sua vez, reportou definições e abordagens resultantes das discussões realizadas nos congressos do Georgia Institute of Technology. No entanto, apesar da inegável contribuição, tanto das discussões do congresso, registradas em seus anais, quanto do trabalho de Taylor, em seu artigo para o primeiro volume do Annual Review of Information Science and Technology (ARIST), Borko (1968) tem sido reconhecido como o autor da definição seminal - e ainda atual - de Ciência da Informação. Isso porque, a despeito das várias definições encontradas na literatura, até hoje a definição do autor mostra-se apropriada para a área, como bem observa Pinheiro (2005) em sua análise das questões epistemológicas da Ciência da Informação. Nas palavras de autor, portanto, a Ciência da Informação é:

Disciplina que investiga as propriedades e o comportamento da informação, as forças que governam o fluxo da informação e os meios para processar a informação, com o objetivo de atingir acessibilidade e utilidade ótimos (BORKO, 1968).

Ainda segundo o autor, a Ciência da Informação preocupa-se com o corpo de conhecimentos relacionados com a origem, coleta, organização, armazenamento, recuperação, interpretação, transmissão, transformação e utilização da informação. Isso inclui, segundo o autor, a investigação de três tipos de fenômenos. O primeiro é abordado como as formas de representação da informação em sistemas naturais e artificiais. O segundo relaciona-se com o uso de códigos para transmissão eficiente da mensagem. O último diz respeito ao estudo dos meios e das técnicas de processamento da informação.

Neste ponto, é relevante que sejam destacadas as duas questões fundamentais para os estudos em Ciência da Informação. A primeira diz respeito à interdisciplinaridade necessária tanto à definição quanto ao escopo, à abrangência e ao marco teórico das pesquisas. A segunda 
refere-se ao conceito de informação que define o objeto das pesquisas, em uma variedade de contextos, focos e abordagens, entre outros aspectos. É essa interdisciplinaridade no estudo da informação que reforça a propriedade dos vínculos entre a comunicação e a gestão na Ciência da Informação, como será mostrado ao longo deste artigo.

No âmbito da Ciência da Informação, são identificados diferentes conceitos, abordagens, contextos e enfoques para a informação. Análise da literatura da área permitiu identificar quatro diferentes - embora complementares - abordagens. A primeira refere-se à redução de incerteza versus tomada de decisão, identificada nos trabalhos de autores como Pignatari (1968) e como Yovits (1969) e Kochen (1983). A segunda relaciona-se com a noção de sentido (sense making), e o trabalho considerado relevante sobre esse tema é o de Dervin (1977). A terceira diz respeito ao conhecimento registrado versus substituto físico do conhecimento, e os autores representativos nesse artigo são Le Coadic (1996) e Farradane (1979). É importante observar que o trabalho de Farradane (1979) introduz a noção de significado da informação versus necessidade da presença de indivíduos e seus estados mentais, o que, por seu turno, chama o ponto de vista cognitivo para o foco desses estudos. Finalmente, a quarta abordagem identificada diz respeito a estruturas de conhecimento, sendo percebida nos trabalhos de Belkin (1978), Brookes (1980) e Ingwersen(1992), que reforçam e ampliam o ponto de vista cognitivo para os estudos da informação na Ciência da Informação. A seguir, são apresentadas, resumidamente, as definições de cada um desses autores.

Pignatari (1968) considera que a informação se relaciona com seleção e escolha (daquilo que soluciona uma dúvida/preenche uma lacuna). Nesse foco, o autor concebe informação como instruções seletivas. Segundo sua abordagem, só há informação quando há dúvidas, o que pressupõe um conjunto de alternativas (capazes de dirimi-las).

Kochen (1983) apresenta definição similar à de Yovits. Em suas palavras, informação constitui “dados de valor para a tomada de decisão". Nas palavras de Kochen (1983), informação constitui, de fato, dados relevantes para tomada de decisão (sobre o que soluciona uma lacuna, dúvida, necessidade).

Dervin (1977), aparentemente parafraseando Karl Popper, permanece no contexto da tomada de decisão, sugerindo três tipos distintos de informação, com base na interação indivíduo versus ambiente:

- Informação 1 - aquela que descreve a realidade, sua estrutura original ou seu padrão, e é externa ao homem.

- Informação 2 - consiste em um repertório subjetivo: ideias, estruturas ou imagens imputadas ao ambiente externo pelas pessoas. 
- Informação 3 - forma pela qual cada indivíduo lida com as informações 1 e 2 para consolidar seu processo decisório.

Ou seja, para Dervin (1977) há três tipos de informação. A primeira é a informação objetiva, externa ao homem e independente dele. A segunda é subjetiva, interna, inerente ao homem e independente da realidade objetiva. Finalmente, a terceira é resultante da combinação/ interação das duas primeiras, isto é, da decisão que resulta da interpretação por parte do homem dessas duas alternativas (informações 1 e 2). Na abordagem da autora, a questão do significado atribuído ao que é informação ganha relevância e requer processo de interpretação por parte de um indivíduo.

Em abordagem similar à de Dervin (1977), no sentido em que requer a presença do indivíduo e sua interpretação do que é informação, Farradane (1979) considera a informação "estéril" até que seja vinculada a um indivíduo que a produza ou seja afetado por ela. $\mathrm{O}$ autor analisa a informação como um fenômeno mental, enfatizando as diferenças de significado de uma comunicação na percepção de diferentes receptores, de acordo com o estado inicial de conhecimento destes e suas habilidades em entender a informação. No artigo analisado aqui, o autor dá continuidade à discussão anterior (FARRADANE , 1976), complementando o que definiu como informação: um substituto ou representante físico do conhecimento. Mais que isso, inclui os aspectos cognitivos em suas análises.

Le Coadic (1996), utilizando uma definição análoga - embora com diferente enfoque - à de Farradane (1976)), considera informação como conhecimento registrado sob a forma escrita, oral ou audiovisual. Do mesmo modo que Le Coadic (1996), vários autores da área da Ciência da Informação consideram a informação como objeto de pesquisa desde que seja produzida como conhecimento registrado.

Belkin (1978) define informação como a estrutura de qualquer texto (estrutura comunicável) capaz de modificar a estrutura cognitiva de um receptor. O texto, nesse caso, consiste de uma mensagem propositadamente estruturada por um gerador que decide comunicar determinado aspecto de seu conhecimento. Para isso, isola-o, modifica-o e o transforma em uma estrutura comunicável - o texto.

Ainda de forma similar a Belkin (1978), no sentido em que adota abordagem relacionada com aspectos cognitivos do indivíduo, Brookes (1980) afirma que conhecimento é um conjunto de conceitos ligados por suas relações, e informação é uma pequena parte dessa estrutura. Em sua equação fundamental, ilustrada na figura 3, Brookes (1980) exprime o conceito de informação como um fenômeno que produz efeitos no indivíduo, na medida em que altera suas estruturas de conhecimento. Segundo o autor, um estado atual de conhecimento mais 
um conhecimento novo (obtido por meio de uma nova informação) é igual a um novo estado de conhecimento, resultante do efeito da nova informação.

De forma semelhante e complementar a Belkin (1978), Ingwersen (1992), a partir da perspectiva da Ciência da Informação, considera que o conceito de informação tem de satisfazer a dois requisitos:

Por um lado a informação sendo o resultado da transformação das estruturas de conhecimento do gerador (por intencionalidade, modelo dos estados de conhecimento do receptor, e na forma de sinais); e, por outro lado, sendo algo que, quando percebido, afeta e transforma o estado de conhecimento do receptor (INGWERSEN, 1992).

É possível, portanto, observar que, segundo os autores analisados, informação na Ciência da Informação constitui um fenômeno a ser estudado tanto do ponto de vista físico, objetivo (conhecimento registrado em algum tipo de suporte e externo ao homem), quanto do ponto de vista cognitivo, subjetivo (processos realizados nos espaços/estruturas mentais dos indivíduos).

É importante ressaltar, neste ponto, a importância da comunicação no foco dos estudos da informação na Ciência da Informação. Nesse sentido, a seção a seguir discute o enfoque da comunicação na Ciência da Informação, a partir do pensamento de Belkin (1978).

\section{FOCO NA COMUNICAÇÃO A PARTIR DO PENSAMENTO DE BELKIN}

Belkin (1978), após exaustiva pesquisa acerca de conceitos de informação definidos no âmbito da Ciência da Informação, apresentou um conceito que reflete aspectos estruturais (cognitivos), nos quais oito requisitos devem ser preenchidos. Esses requisitos, por seu turno, estão agrupados com base em três abordagens, nomeadamente metodológica ( $\mathrm{M}$ - utilidade do conceito), comportamental ( $\mathrm{C}$ - fenômeno para o qual o conceito "conta") e definicional (D - relativo ao contexto do conceito). Conforme a abordagem do autor, portanto, um conceito de informação é apropriado à Ciência da Informação quando:

- refere-se à informação ocorrendo dentro de uma comunicação com propósito e significado (D);

- leva em conta a informação como um processo de comunicação social entre seres hu$\operatorname{manos}(\mathrm{D})$;

- leva em conta a informação como algo que é requerido ou desejado (D); 


\section{$22 \mid 23$}

- leva em conta a informação como algo que tem efeito em seu receptor (D; C);

- leva em conta a informação como algo que está relacionado ao "estado de conhecimento" de um gerador e de um receptor $(\mathrm{D} ; \mathrm{C})$;

- leva em conta a informação como tendo variados efeitos quando a mensagem é apresentada por diferentes meios $(\mathrm{C})$;

- é generalizável para além de casos individuais $(\mathrm{M})$;

- oferece um meio para predição do efeito da informação (M).

O conceito de informação de Belkin (1978) atende aos oito requisitos propostos por ele em seu trabalho de doutoramento. É relevante destacar que o autor usa a ideia de estrutura inserida na análise do que chama de "sistema de comunicação que interessa à Ciência da Informação" (BELKIN, 1978). Tal sistema é, segundo o autor, controlado pelo receptor, instigado por um estado anormal de conhecimento relativo a um tópico, podendo ser estudado nos níveis cognitivo e linguístico (figura 1):

Figura 1 - Elementos de um sistema de comunicação de interesse da Ciência da Informação

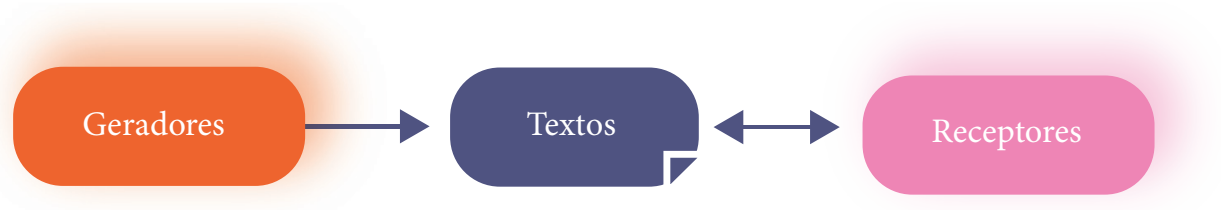

Nível Linguístico do Sistema

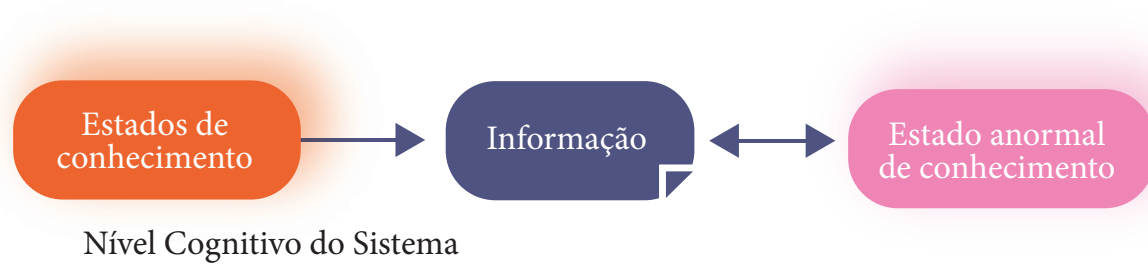

Fonte: Adaptado de Belkin (1978).

No nível linguístico, o autor insere a informação em um processo de comunicação entre seres humanos. Nesse sentido, o conceito conforma um sistema de comunicação em que a informação é associada a um texto (coleção de signos propositadamente estruturados por um gerador com a intenção de modificar a "imagem-estrutura" de um receptor). Informação associada a um texto, portanto, é a estrutura conceptual de um gerador - que a modifica de acordo com um propósito, uma intenção e com o conhecimento do estado de conhecimento 
do receptor -, e que é subjacente à estrutura da superfície (isto é, a linguagem) daquele texto. A figura 2 ilustra a abordagem do autor no nível linguístico, ou seja, relativa a um processo de comunicação da informação.

Figura 2 - Processo de comunicação da informação estudado no nível linguístico

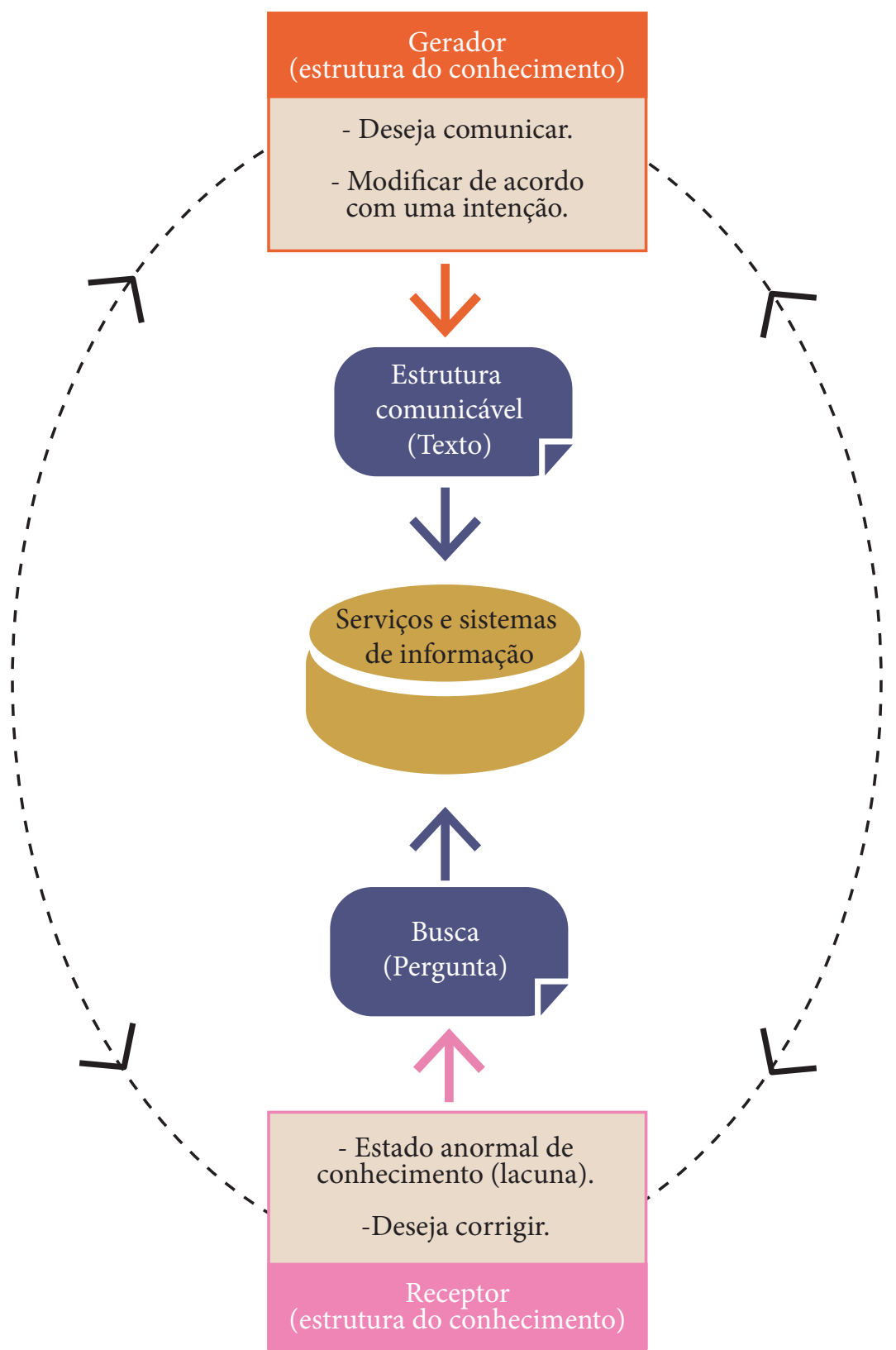

Fonte: Adaptado de Belkin (1978). 
É interessante notar que estudiosos da comunicação humana a definem de acordo com os atributos utilizados por Belkin (1978) em sua construção do conceito de informação para a Ciência da Informação no nível linguístico. Veja-se, por exemplo, no modelo de Tubbs (2003), os elementos que compõem o processo de comunicação. São eles: comunicadores 1 e 2 (respectivamente emissor e receptor, em outros autores), insumo (estímulos em ambos para a comunicação), filtros (utilizados pelos dois comunicadores), mensagem, interferências, canal e retroalimentação. Destaca-se, nos estudos dos autores, a relevância das intenções do emissor, no que se refere a provocar efeitos no receptor, ao emitir uma comunicação. Esse aspecto dos estudos da comunicação, aliás, está presente na abordagem de vários outros teóricos, desde o pioneiro Lasswell (1942) e sua fórmula (quem $\rightarrow$ diz o quê $\rightarrow$ em que canal $\rightarrow$ para quem $\rightarrow$ com que efeito) até os mais atuais, como McQuail e Windhal (1993), Barker e Gaut (2001), Ferreira et al.(1978), entre inúmeros outros autores.

No nível cognitivo, a abordagem de Belkin (1978) centra-se nas transformações ocorridas nos estados (ou estruturas) de conhecimento do indivíduo, quando este recebe a informação capaz de preencher uma necessidade ou lacuna em sua estrutura cognitiva. De fato, o que o autor chama de "estado anormal (ou anômalo) de conhecimento" pode ser entendido como necessidade de informação, dúvida, falha, lacuna na estrutura cognitiva. Essa abordagem, por sua vez, encontra eco na equação fundamental de Brookes (1980) para a Ciência da Informação (figura 3), pois foca nas mudanças provocadas por uma informação nova na estrutura de conhecimento do indivíduo. 
Figura 3 - Transformações na estrutura de conhecimento do indivíduo, provocadas por uma informação nova, estudada no nível cognitivo, como proposto por Belkin e de acordo com Brookes

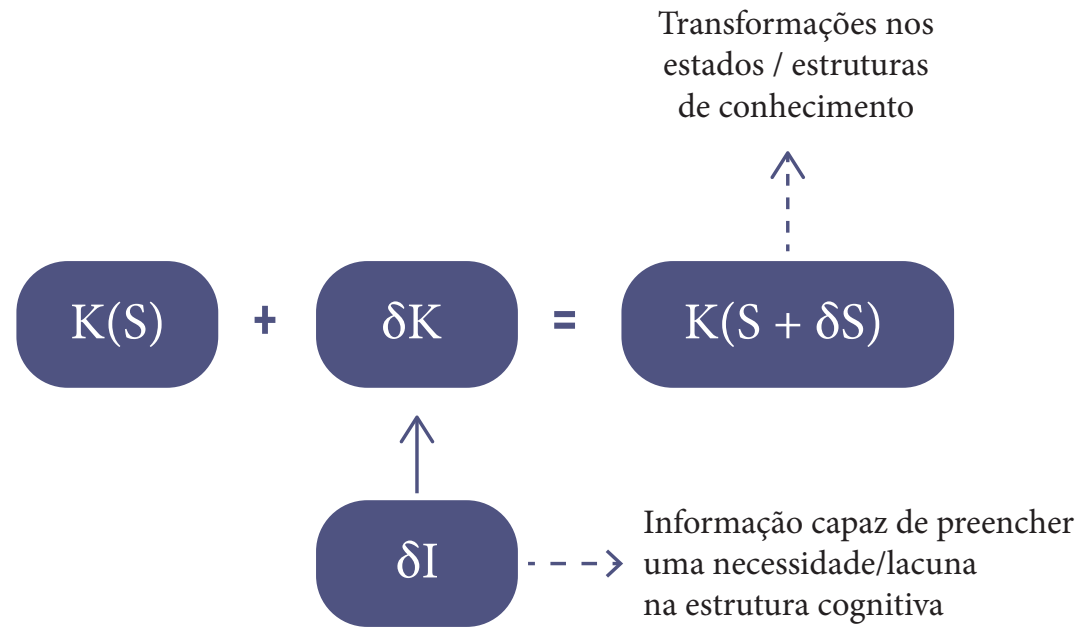

$\mathrm{K}(\mathrm{S})$ : estrutura atual do conhecimento

$\delta \mathrm{K}$ : novo conhecimento, obtido por meio de $\delta \mathrm{I}$

SI: nova informação

$\delta S$ : efeito de modificação $\delta I$

$\mathrm{K}(\mathrm{S}+\delta \mathrm{S})$ : novo estado de conhecimento

Fonte: Adaptado de Brookes (1980).

O estudo acerca de necessidades de informação, de comportamento na busca por informação, de uso da informação e de estados/estruturas de conhecimento embute os conceitos que constituem o estudo sobre comportamento informacional, estabelecendo - embora não somente - o foco da gestão da informação e do conhecimento na Ciência da Informação, discutido mais adiante.

Um esforço maior permite, na verdade, ver, nos dois níveis em que é expresso o conceito de informação de Belkin (1978), a comunicação como parte da gestão (e vice-versa). No primeiro - nível linguístico -, o autor aborda o processo de comunicação entre um gerador e um receptor, com todas as suas especificidades (intenção, propósito, estrutura conceitual, entre outras). No segundo - nível cognitivo -, o autor fornece os elementos necessários para o foco da gestão do conhecimento (que embute a gestão da informação) na Ciência da Informação. Isso porque Belkin (1978) relaciona a informação a algo que 
muda o estado de conhecimento do indivíduo. Isso, é importante ressaltar, exige de profissionais, produtos, serviços e sistemas, sintonia fina entre estados de conhecimento dos usuários e acervos (disponíveis e acessíveis) de informação.

O tratamento a ser dado a esses acervos e o ato de tornar disponíveis serviços e produtos deles resultantes fazem parte das preocupações da gestão da informação. Por sua vez, os efeitos ou benefícios dos resultados obtidos, isto é, a criação de conhecimento a partir da informação obtida e assimilada, sua aplicação nos melhores cursos de ação (inteligência), e seu compartilhamento em ambientes e comunidades específicas são o foco da gestão do conhecimento. Esta, por sua vez, requer, necessariamente, processos de comunicação da informação. Em suma, a abordagem de Belkin (1978) permite tanto fundamentar os estudos da comunicação da informação, quanto identificar bases para estudos da gestão da informação e da gestão do conhecimento no âmbito da Ciência da Informação.

Em relação à questão da gestão, Teixeira Filho(2001), por exemplo, comenta que a comunicação é um de seus componentes cruciais. Alguns estudos têm comprovado isso, especialmente no que concerne ao ambiente das organizações, isto é, em relação à comunicação organizacional e à gestão do conhecimento organizacional. Leite e Costa (2006) dão um passo à frente nessa discussão ao estudarem essa relação também no ambiente acadêmico, envolvendo a comunicação científica e a gestão do conhecimento científico.

Sem dúvida, esse tipo de discussão contribui para as construções teóricas em que a comunicação tem sido estudada, com dois enfoques, principalmente. O primeiro refere-se aos processos de comunicação que ocorrem em diferentes contextos (científico, organizacional, comunitário, tecnológico e para negócios, com ênfase maior nos dois primeiros). O segundo está relacionado à gestão do conhecimento. Brookes (1980) explora melhor a questão norteadora dos estudos de gestão da informação e do conhecimento na Ciência da Informação. Suas ideias estão resumidamente discutidas a seguir.

\section{FOCO NA GESTÃO DA INFORMAÇÃO E DO CONHECIMENTO A PARTIR DO PENSAMENTO DE BROOKES}

É importante iniciar esta discussão destacando o entendimento de diferentes autores sobre a relação entre a gestão do conhecimento e a gestão da informação. Como resumiu Leite (2006, p. 216), após ampla análise da literatura e reflexões sobre os temas:

A gestão do conhecimento engloba as práticas e metodologias de gestão da informação, especialmente no que concerne aos processos relacionados à coleta, armazenamento, recuperação de parte do conhecimento tácito, o qual é reduzido 
a estruturas de informação. Entretanto, a gestão do conhecimento não pode ser reduzida a, nem confundida com a gestão da informação. Isso porque quando o tipo de compartilhamento do conhecimento exige que ele seja veiculado por meio de sistemas formais que permitem o seu armazenamento e recuperação, o conhecimento é, de fato, reduzido a estruturas de informação. Esta, no entanto, poderá desencadear a criação de conhecimento no indivíduo.

Nessa perspectiva, a maioria dos autores estudiosos da Ciência da Informação considera que a área deve se ocupar do que Le Coadic (1996), entre outros autores, chama de conhecimento registrado. Críticos da gestão do conhecimento, de fato, consideram que, uma vez registrado ou passível de ser registrado, o conhecimento é informação. Bouthillier e Shearer (2002), no entanto, consideram o argumento de que conhecimento registrado (ou explícito) é informação como uma "avaliação inadequada das dimensões qualitativas dos vários tipos de informação e de conhecimento criados, usados e transferidos".

Entre as interessantes abordagens que discutem a relação entre informação e conhecimento está a Teoria do Conhecimento Objetivo de Popper (1975). Brookes (1980) se apropria dessa perspectiva e a aplica ao campo da Ciência da Informação, dando vazão a um ambiente teórico fértil para a discussão das relações entre gestão da informação e do conhecimento nessa disciplina.

Com base na abordagem dos três mundos de Karl Popper (1975), Brookes (1980) propõe uma relação entre informação e conhecimento nos estudos da Ciência da Informação baseada, principalmente, na noção de "espaços mentais únicos". O autor chama a atenção para o fato de que os eventos do Mundo 2 - individualidades mentais - ocorrem em espaços individuais privados, sendo, portanto, subjetivos. Para objetivá-los, é necessário expressá-los e depositar os registros no Mundo 3, onde são acessíveis a outros e podem, portanto, ser criticamente considerados.

Brookes (1980) relaciona o Mundo 3 de Popper à Biblioteconomia e à Ciência da Informação, ressaltando, entretanto, que o trabalho prático dos profissionais da área é coletar e organizar para uso os registros do Mundo 3. Suas atribuições teóricas, segundo o autor, são o estudo das interações entre o Mundo 2 e o Mundo 3, para os descrever e explicar, se puderem, e, então, ajudar na organização do conhecimento, mais do que de documentos, para o uso mais efetivo. Uma observação importante do autor para os estudos da gestão do conhecimento na Ciência da Informação, a partir das abordagens dos três mundos de Popper (1975), é a de que:

Essa abordagem, portanto, permite-nos escapar das subjetividades da velha abordagem de 2000 anos para as teorias do conhecimento e da psicologia subjetiva, assim 
como da filosofia tradicional. Mais que isso, ao adotar a interação entre os Mundos 2 e 3 como nosso campo de estudos, nós estamos reivindicando a propriedade de uma disciplina que nenhuma outra disciplina já reivindicou. (BROOKES, 1980, p. 128, tradução nossa)

O argumento do autor, como pode ser notado, e que está explícito em seu texto, é de que a Ciência da Informação não deveria ser uma combinação de abordagens de várias disciplinas, como a Linguística e a Ciência da Computação, entre outras. Isso porque a área tem, na verdade, segundo o autor, seu próprio território, seus próprios problemas e sua visão própria dos problemas humanos. Uma das leituras possíveis do argumento de Brookes (1980) diz respeito ao que se estuda como gestão do conhecimento. Nessa perspectiva, a conclusão das reflexões apresentadas por Batista et. al. (2007, online), após estudo minucioso do pensamento de Brookes (1980) no qual essas questões são discutidas, é de que:

a análise do modelo de Nonaka e Takeuchi [...] mostra que é a Gestão do Conhecimento que, ao se preocupar em descrever e analisar os processos de conversão das duas formas de conhecimento (tácito ou subjetivo e explícito ou objetivo) realiza a segunda proposta feita por Brookes aos cientistas da informação, isto é, estudar as interações entre os Mundos 2 e 3 de Popper.

Sem detalhar mais a abordagem de Brookes, é interessante retomar imediatamente sua proposta de uma "equação fundamental para a Ciência da Informação", ilustrada na figura 3. Como é possível perceber, a estrutura (ou estado) de conhecimento do indivíduo muda para uma nova estrutura, modificada por uma informação. Note-se que a mesma informação $(\partial \mathrm{I})$ pode ter diferentes efeitos em diferentes estruturas de conhecimento. Nesse sentido, Brookes (1980) considera que, sendo a informação uma pequena porção do conhecimento, seria correto substituir a notação $\partial \mathrm{I}$ pela notação $\partial \mathrm{K}$ na equação.

Observe-se, ainda, que o que Brookes (1980) chama de "espaços mentais únicos" pode, perfeitamente, ser considerado como o que Nonaka e Takeuchi (1997) chamam de "conhecimento tácito". Assim, o que Brookes (1980) chama de "objetivação" dos espaços individuais fornece a base para os processos de conversão do conhecimento de Nonaka e Takeuchi (1997), mais especificamente, os processos de socialização e externalização. Vale ainda a pena ressaltar que os dois autores basearam sua abordagem nos trabalhos de Sveiby (1994), um dos "pais" da gestão do conhecimento. Mais que isso, têm tido seu trabalho como norteador das abordagens de estudos da gestão do conhecimento na Ciência da Informação, como, por exemplo, em Choo (2003).

Acrescente-se a essas questões a definição de Teixeira Filho (2001) de que a comunicação é um componente crucial da gestão do conhecimento, porque trata de fazer com que "o 
conhecimento útil chegue à pessoa certa, em tempo hábil, de forma compreensível”. É importante notar que a definição de Teixeira Filho (2001) assemelha-se à de Mason (1990), cujo artigo sobre profissional da informação foca essas questões, as quais têm sido consideradas a base da gestão da informação e do conhecimento na Ciência da Informação. A preocupação, portanto, é que o conhecimento seja compartilhado o mais efetivamente possível. Ressalte-se, uma vez mais, que a gestão da informação é parte constitutiva da gestão do conhecimento. Vê-se, portanto, de modo claro, a contribuição de teóricos reconhecidamente da Ciência da Informação, como Brookes (1980) e Belkin (1978), entre outros, para a fundamentação dos estudos realizados na Ciência da Informação sobre gestão da informação e do conhecimento.

A figura 4 ilustra a reflexão sobre a Ciência da Informação e as abordagens de Belkin (1978), Brookes (1980), Popper (1975) e Nonaka e Takeuchi (1997), além de autores da comunicação, da gestão da informação e do conhecimento. Entretanto, contribui para reflexão sobre os diálogos entre a comunicação e a gestão na Ciência da Informação, como na seção a seguir.

Figura 4 - Relações entre comunicação e gestão da informação e do conhecimento para a Ciência da Informação, sob a ótica de Brookes

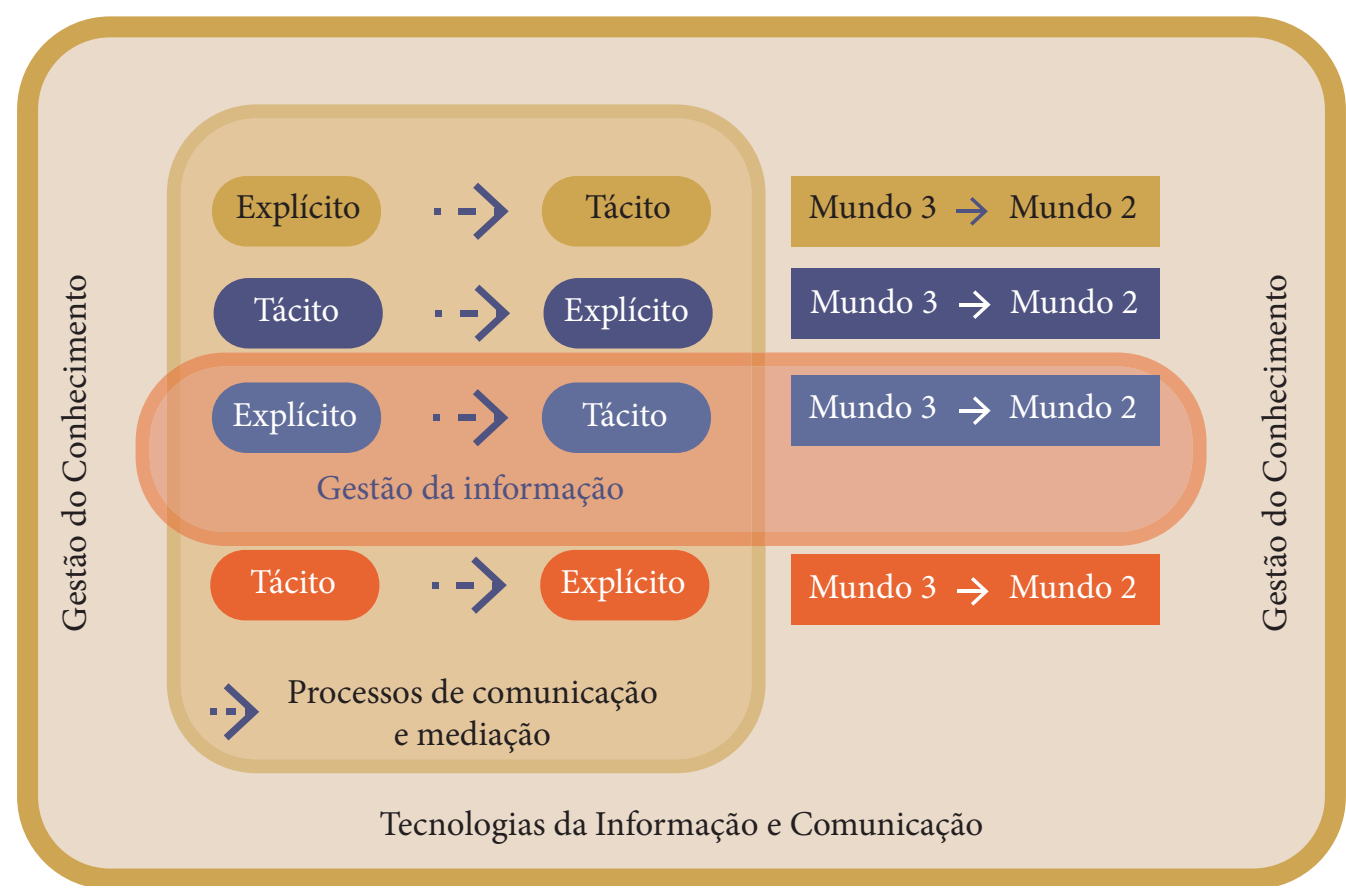

Fonte: Elaboração dos autores (2018). 


\section{$30 \mid 31$}

\section{DIÁLOGOS ENTRE COMUNICAÇÃO E GESTÃO NA CIÊNCIA DA INFORMAÇÃO}

As argumentações que sustentam as relações entre gestão da informação e do conhecimento e os processos de comunicação são apresentadas nesta seção. Em um primeiro momento, a partir da própria definição de Ciência da Informação feita por Borko (1968), associada a perspectivas de outros autores, discute-se, com base nos fenômenos entendidos como centrais e indissociáveis na área, as relações entre comunicação da informação e gestão da informação. No segundo momento, discute-se a relação entre gestão do conhecimento e processos de comunicação. Em ambas as subseções, dá-se vazão ao diálogo necessário entre comunicação e gestão no âmbito da Ciência da Informação.

\subsection{Comunicação e gestão da informação}

A definição apresentada por Borko (1968) está repleta de pistas que revelam os interesses mais imediatos da Ciência da Informação. Isso ocorre mais especificamente quando o autor afirma que a área se preocupa com o corpo de conhecimentos relacionados à origem, coleta, organização, armazenamento, recuperação, interpretação, transmissão, transformação e utilização da informação, Borko (1968) descortina duas grandes bases norteadoras tanto da investigação quanto da prática no campo, uma vez que os fenômenos considerados pelo autor incluem tanto questões da comunicação da informação, em uma perspectiva mais ampla, quanto questões relacionadas à gestão da informação, como perspectiva intermediária. Ambas as propostas são brevemente discutidas a seguir.

As questões da comunicação da informação estão clara e amplamente consideradas na definição de Borko (1968). O autor destaca a origem e a utilização da informação, posicionadas coerentemente como o primeiro e o último fenômeno na definição, os quais remetem a dois importantes elementos - ora entendidos como atores ora como processos - presentes na comunicação humana. O primeiro é a origem (emissores/ produtores); e o segundo, a utilização (receptores/usuários).

Nesta linha de raciocínio, considera-se que a comunicação da informação entre seres humanos - assim como toda a dinâmica existente entre a origem e o uso da informação - corresponde ao interesse mais amplo da Ciência da Informação e está presente na definição de Borko (1968). Alguns autores reclamam este como, de fato, o interesse central da área, como resumidamente apresentado a seguir.

Vickery (1973) considerou que o interesse da área desde o seu surgimento foi a facilitação da transmissão da informação entre seres humanos. Mais tarde, Vickery e 
Vickery (1987) observam que a Ciência da Informação investiga a comunicação da informação na sociedade, à época centrada em fenômenos específicos (organização da informação, recuperação da informação e disseminação da informação).

De modo coerente com esses autores, Ingwersen (1992) sugere que a área está predominantemente preocupada com o estudo de fenômenos ligados à geração, comunicação e utilização da informação. Perceba-se que Ingwersen (1992) inclui os processos mencionados no início e no fim da definição de Borko (1968), origem e utilização, e a comunicação por ele mencionada corresponde à dinâmica existente e viabilizadora dos dois processos destacados. Voltando a Belkin (1978), observa-se que sua abordagem não foge a essa noção, ao afirmar que a área visa a produzir conhecimento sobre a facilitação da efetiva comunicação de informação desejada - incluindo nesse momento um forte componente cognitivo - entre geradores e usuários humanos. Perceba-se, ainda, que Belkin (1978) também enfatiza a origem e a utilização, dois elementos centrais da comunicação humana.

Por fim, Saracevic (2010), em verbete da Encyclopedia of Library and Information Sciences, afirma que a área dedica-se às questões científicas e à prática profissional, voltadas para os problemas da efetiva comunicação da informação entre os seres humanos nos contextos social, institucional ou individual no que se refere ao uso e às necessidades de informação. São essas, portanto, as noções que fundamentaram a ideia de que, partindo da definição seminal de Ciência da Informação apresentada por Borko (1968), a qual se apoia posteriormente em outros estudiosos, a comunicação da informação entre seres humanos constitui o interesse mais amplo da Ciência da Informação.

Ao dar-se destaque à comunicação da informação entre seres humanos como o interesse mais amplo da área, representada pelas interações entre produtores e usuários da informação, quais seriam, então, os fenômenos mais específicos? A resposta a essa pergunta remete a processos justapostos pelo autor entre a origem e a utilização da informação. Ou seja, as questões relacionadas com o estudo da gestão da informação estão inteiramente relacionadas com os fenômenos intermediários, posicionados entre a origem e a utilização da informação na definição apresentada por Borko (1968). São fenômenos intermediários: a coleta, a organização, o armazenamento, a recuperação, a interpretação, a transmissão, a transformação e a utilização da informação. Nessa perspectiva, sugere-se que a interação entre produtores e usuários da informação ou, dito de outra forma, a criação da correspondência efetiva entre necessidades de informação e acervos de informação constitui processo de comunicação que somente é viabilizado por meio da sistematização dos processos de gestão da informação. Os processos de gestão da informação, por seu turno, equivalem aos fenômenos intermediários encontrados na definição de Borko (1968). 
A despeito de a definição apresentada por Borko (1968) datar da década de 1960, os elementos que a constituem tornam-na atemporal, na medida em que chamam a atenção para fenômenos essenciais até os dias atuais e, certamente, daqui por diante. Tais fenômenos, mesmo não sendo os únicos, parecem estar inteiramente presentes na essência da investigação que se realiza na área até os dias de hoje. Desse modo, a construção teórica aqui discutida pode ser representada pela figura 5 .

Figura 5 - Relações conceituais entre comunicação e gestão da informação

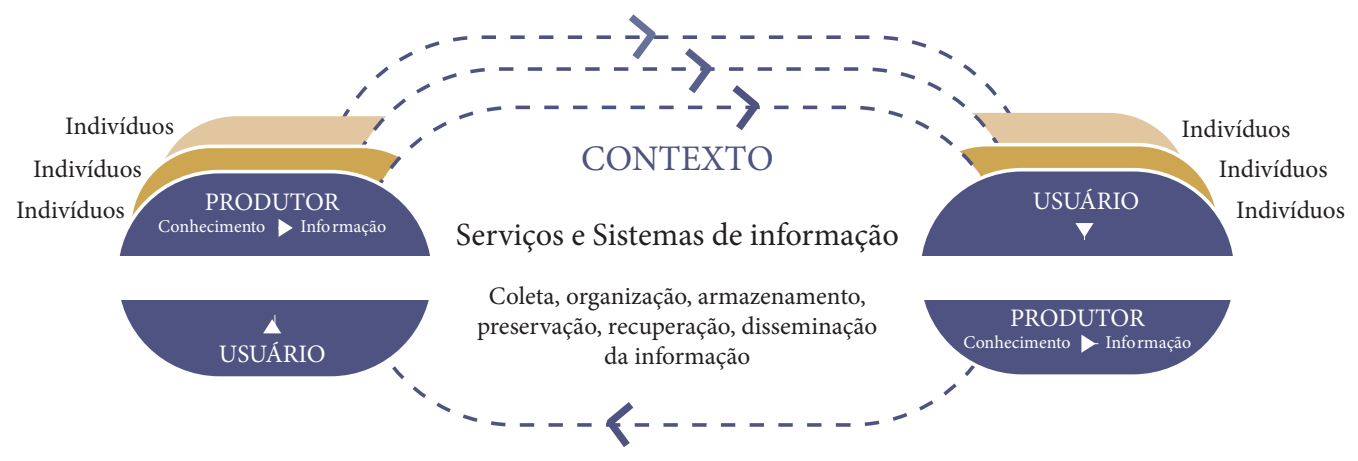

Fonte: Elaboração dos autores (2018).

Tanto para a investigação quanto para a aplicação de conhecimentos na solução de problemas reais relacionados com a melhoria da comunicação da informação entre seres humanos, a Ciência da Informação se vale da perspectiva de processos de gestão da informação. Quer-se dizer com isso que os processos mais básicos de gestão da informação, nomeadamente coleta, organização, armazenamento, preservação, recuperação e disseminação, são essenciais para a efetiva comunicação entre produtores (origem) e usuários (uso) da informação.

Para explicar a teoria embutida no modelo representado pela figura 5, chama-se a atenção para quatro aspectos cuja essência ilustra o entendimento da relação indissociável entre comunicação e gestão da informação e a necessidade do diálogo entre as duas perspectivas.

O primeiro aspecto é a presença dos elementos do sistema de comunicação de interesse da Ciência da Informação, propostos por Belkin (1978) e presentes na equação fundamental de Brookes (1980), discutidos anteriormente.

O segundo aspecto diz respeito aos atores do sistema de comunicação, produtores e usuários. É importante destacar que a produção e o uso da informação são atividades realizadas pelos mesmos indivíduos em momentos e contextos distintos. Como ilustrado na figura 5, a geração de conhecimento por parte de produtores é uma decorrência de, entre outros fatores, necessidades de informação plenamente satisfeitas. Ou seja, 
produtores são necessariamente usuários de informação. Em suma: na medida em que usuários satisfazem suas necessidades de informação geram novos conhecimentos e o ciclo da comunicação da informação é repetido.

O terceiro aspecto, por sua vez, chama a atenção para o elo responsável pela conexão e interação de produtores e usuários: os serviços e sistemas de informação, constituídos a partir de tecnologias de informação e comunicação viabilizadoras das condições para que haja a plena correspondência entre a informação produzida (origem) e as necessidades de informação (utilização). A operacionalização da interação de produtores e usuários está, portanto, na gestão da informação realizada pelos serviços e sistemas de informação, genericamente compreendida pelo conjunto de processos relacionados com a coleta, organização, armazenamento, preservação, recuperação e disseminação da informação.

O quarto e último aspecto trata do contexto em que tanto a comunicação quanto a gestão da informação operam. Por contexto entende-se o conjunto de fatores de ordem cognitiva, social, cultural, política, tecnológica, econômica e legal que, em alguma medida, exerce influência sobre a comunicação e a gestão da informação. Elementos e processos de comunicação e de gestão da informação estão presentes, invariavelmente, em qualquer contexto. O conjunto de forças particulares de cada contexto imprime especificidades no comportamento de quem produz, comunica e utiliza informação. Por essa razão, a despeito dos mesmos elementos, assume-se que contextos influenciam a comunicação e, em decorrência disso, requerem serviços e sistemas que considerem especificidades decorrentes dessa influência.

Em síntese, a definição de Ciência da Informação apresentada por Borko (1968) oferece todos os elementos necessários para a compreensão de que o interesse mais amplo da área por investigar e propor melhorias para a comunicação da informação entre seres humanos embute a investigação e a proposição de melhorias da gestão da informação em qualquer contexto.

Como dito anteriormente, a perspectiva proposta não esgota o conjunto de interesses da Ciência da Informação, mas representa a essência de fenômenos centrais sob os quais a área vem produzindo saberes que constituem talvez suas bases mais sólidas. Evidentemente, ao longo de quase sete décadas desde seu surgimento, a área expandiu consideravelmente tanto seus olhares quanto suas práticas. Mais que isso, emanaram fenômenos outros direta ou indiretamente relacionados à comunicação e à gestão da informação. Considerando-se que questões ligadas ao estudo da gestão do conhecimento não estavam nas preocupações dos estudiosos da Ciência da Informação - quiçá de nenhuma disciplina - na década de 1960, é compreensível que não estejam presentes nos fenômenos descritos por Borko (1968). Contudo, apresentam-se a seguir aspectos que sinalizam a convergência possível da gestão do conhecimento e a comunicação no âmbito da Ciência da Informação, identificada desde as abordagens de Brookes (1980) para a Ciência da Informação, como já discutido anteriormente. 


\subsection{Comunicação e gestão do conhecimento}

O pressuposto básico da argumentação que sustenta a relação entre a comunicação e a gestão do conhecimento é o fato de que a primeira, em seu aspecto da interação humana, e não reduzida, mas apoiada nas tecnologias, é um dos processos essenciais para o sucesso da gestão do conhecimento. Uma breve análise da literatura ofereceu uma série de argumentos que corroboram tal pressuposto.

Conforme pontuou Leite (2007), Jensen (1998) considera que a comunicação e a gestão do conhecimento estão ligadas. A diferença entre uma e outra, segundo a autora, é que a gestão do conhecimento é um pouco mais disciplinada em capturar, organizar e rastrear o que nós necessitamos para tomar decisões, enquanto a comunicação está mais voltada para as trocas. Na mesma linha de raciocínio, Ash (2000) afirma que uma comunicação efetiva é essencial para qualquer programa de gestão do conhecimento. Martensson (2000) e Sharp (2003) enumeraram elementos críticos para o sucesso da gestão do conhecimento, entre os quais está incluída a comunicação.

Tais definições induzem à consideração de que há relação de complementaridade e interdependência entre as duas práticas. Isso porque, por um lado, a gestão do conhecimento disciplina, sistematiza e torna mais efetivos os processos de comunicação. Por outro, a comunicação permite que a gestão do conhecimento seja viabilizada, na medida em que possibilita, entre outros processos, a interação entre indivíduos e, por consequência, a criação, o compartilhamento e o uso do conhecimento (LEITE, 2007).

Muito embora a questão da comunicação seja ressaltada como importante no âmbito da gestão do conhecimento, parecem ser raras as iniciativas de gestão do conhecimento que, de fato, levem em consideração os processos de comunicação - e não somente as tecnologias - como uma camada essencial de um projeto de gestão do conhecimento. De fato, pouco se tem dito a respeito da comunicação - do ponto de vista de seus processos - como um elemento da gestão do conhecimento. Ao considerar a comunicação sob o aspecto das tecnologias, o discurso da gestão do conhecimento apresenta-se reducionista. Por sua vez, a comunicação deve ser vista como um elemento de forte influência no desempenho das atividades organizacionais, sobretudo na gestão do conhecimento, uma vez que é responsável pelo compartilhamento de conhecimento, pela aprendizagem e pela difusão da cultura na organização (LEITE, 2007).

Ives et al. (1998) afirmam que Platão percebeu que a tradição oral de aprendizagem era baseada no diálogo; no entanto, na tradição escrita, o aprendiz tem pouca habilidade para conversar com o criador do conhecimento. Isso porque, segundo os autores, a criação do conhecimento é resultado da interação entre dois pontos de vista. Os autores acrescentam que é possível que a reintrodução do diálogo - agora em níveis globais, graças ao desenvolvimento de tecnologias 
de comunicação - possa iniciar uma das maiores contribuições cognitivas para a atual fase da gestão do conhecimento. Em argumento semelhante, Theunissen(2004) afirma acreditar que o insucesso de projetos de gestão do conhecimento que estão centrados nas tecnologias está diretamente relacionado ao argumento de Ives et al. de que o conhecimento é criado por meio de diálogo. Segundo Theunissen (2004), isso constitui comunicação entre dois pontos de vista.

A construção teórica de Kuhlen (2004) fundamenta a reflexão e os relacionamentos construídos até aqui em processos de comunicação e gestão do conhecimento. Nesse sentido, o autor discute duas abordagens para a gestão do conhecimento: o Knowledge Warehouse Paradigm e o Communicative Paradigm.

O Knowledge Warehouse Paradigm ou paradigma do estoque de conhecimento considera a gestão do conhecimento sem levar em conta os processos de comunicação. Kuhlen (2004) considera os modelos de Nonaka e Takeuchi(1997), Wiig (2002) e Probst et al. (2002) como representantes desse paradigma. O autor afirma que, com o advento das tecnologias de comunicação em grande escala, é possível observar uma mudança de paradigma, de uma visão mais estática da produção, da disseminação e do uso do conhecimento e da informação para uma visão dinâmica e colaborativa desses processos, principalmente no que diz respeito à geração e troca do conhecimento. Essa nova visão o autor denomina de Communicative Paradigm ou paradigma comunicativo da gestão do conhecimento (LEITE, 2007).

$\mathrm{Na}$ abordagem do paradigma comunicativo, além de ser levado em consideração o uso das fontes de informação existentes, são enfatizados os efeitos da combinação de indivíduos com diferentes backgrounds e diferentes níveis de expertise, além da manutenção do contexto ou da recontextualização do conhecimento que é compartilhado. A interação social entre indivíduos, a experiência compartilhada e as trocas de conhecimento são tão importantes quanto os próprios estoques de conhecimento (LEITE, 2007).

Segundo a linha argumentativa deste artigo, a gestão do conhecimento pode ser compreendida como a criação de condições férteis para que o conhecimento seja construído, compartilhado e utilizado. Os macroprocessos cíclicos de construção, compartilhamento e uso do conhecimento, representados na figura 6 , têm nos indivíduos seus protagonistas e na comunicação seu elemento viabilizador, em razão de três argumentos que justificam a gestão do conhecimento. O primeiro diz respeito ao fato de que a geração de novos conhecimentos tem como partida o uso de conhecimento existente - em sua dimensão subjetiva ou objetiva - previamente comunicado. O segundo diz respeito à dinâmica da interação - informal e formal - necessária ao compartilhamento do conhecimento. $\mathrm{O}$ compartilhamento diz respeito à própria ação de comunicar. O terceiro aspecto, decorrente dos dois anteriores, refere-se ao entendimento de que, entre os pré-requisitos para o uso do conhecimento, estão a disponibilidade e a acessibilidade a quem dele necessita. 
Dessa maneira, a dimensão comum e integradora dos macroprocessos que compõem a gestão do conhecimento é a comunicação, que engloba e promove o ciclo de construção, compartilhamento e uso do conhecimento. Tal ciclo está pautado nos modos de conversão do conhecimento de Nonaka e Tekeuchi (1997), que constituem a teoria de criação do conhecimento nas organizações por eles proposta e aqui estendida para ilustrar, além da criação, o compartilhamento e uso do conhecimento. Essa linha de raciocínio vem ao encontro e reforça o paradigma comunicativo da gestão do conhecimento de Kuhlen (2004).

Figura 06 - Relações entre comunicação e gestão do conhecimento

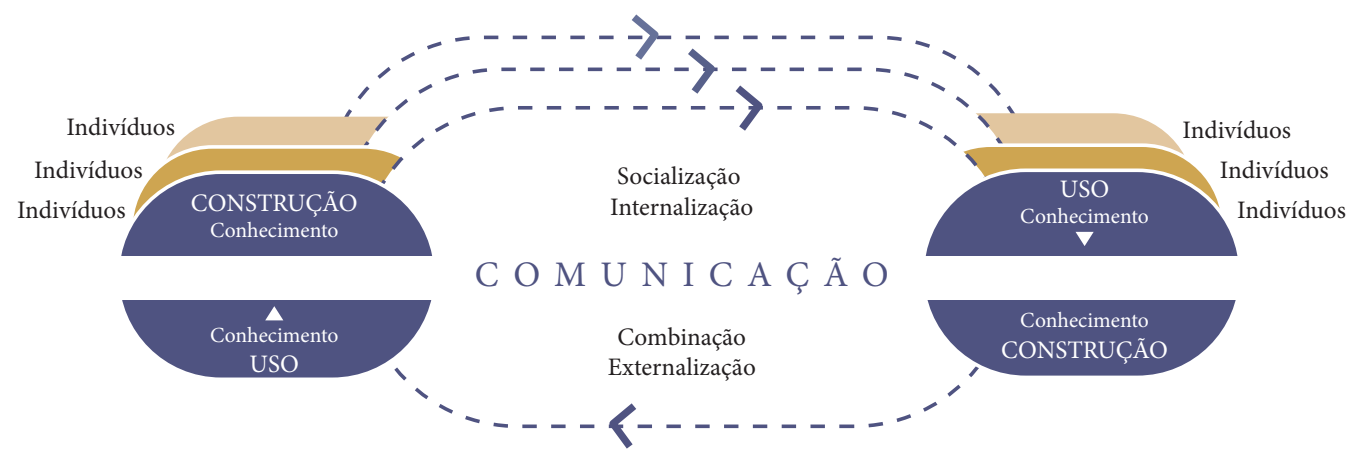

Fonte: Elaboração dos autores (2018).

\section{CONCLUSÕES}

A argumentação epistemológica apresentada resumidamente neste artigo visou a contribuir para o entendimento das relações conceituais entre comunicação da informação, gestão da informação e gestão do conhecimento, no contexto da Ciência da Informação, conforme genericamente ilustrado na figura 7. Como é possível notar, processos de comunicação, em diferentes contextos, são cruciais tanto para a gestão da informação quanto para a gestão do conhecimento. Constituem, de fato, um dos focos centrais dos estudos na Ciência da Informação. 
Figura 07 - Relações entre comunicação e gestão do conhecimento

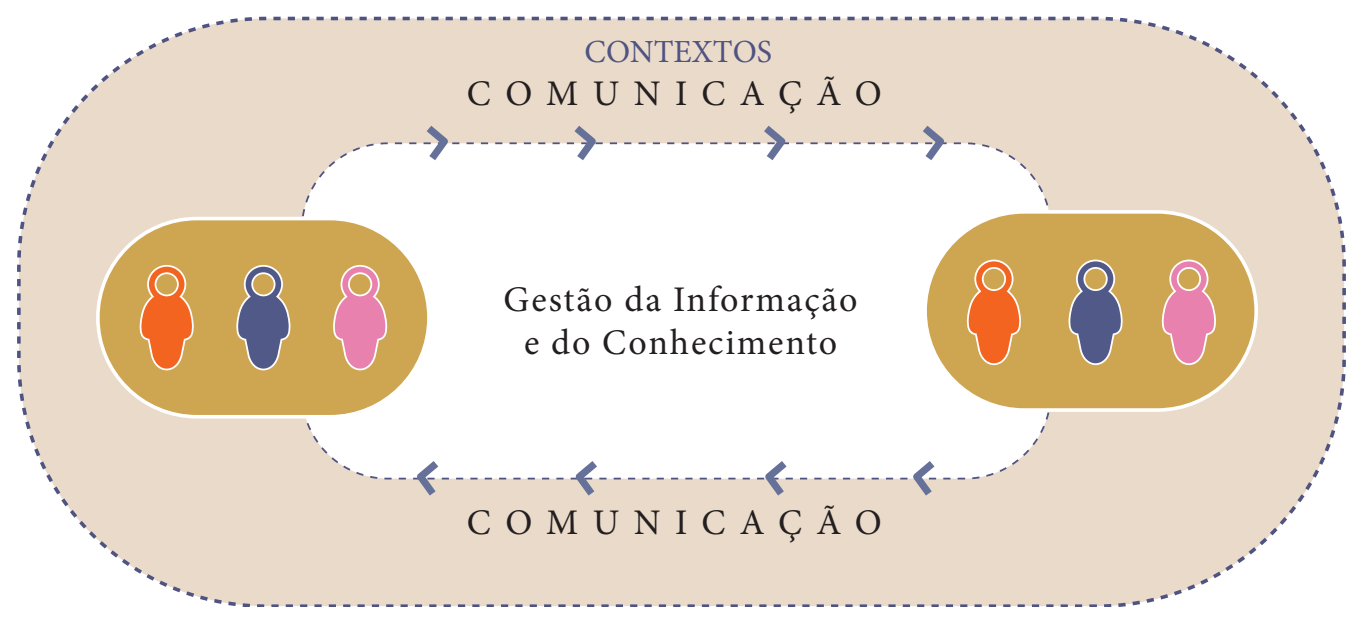

Fonte: Elaboração dos autores (2018).

Conclui-se, portanto, com base em argumentos sustentados na literatura que fundamenta, bem como nas construções teóricas propostas, que é pertinente realizar estudos tanto de comunicação quanto de gestão da informação e do conhecimento, no âmbito da Ciência da Informação, levando em consideração pelo menos três questões. A primeira questão está relacionada com os diferentes contextos em que a comunicação e a gestão ocorrem. Os contextos podem ser entendidos como conjunto de fatores de ordem cognitiva, social, cultural, política, tecnológica, econômica e legal que, em alguma medida, exerce influência sobre a gênese e os fluxos de informação e conhecimento. Por consequência, influenciam também seus processos de gestão e comunicação. São exemplos os contextos da informação científica, informação tecnológica, informação para negócios, informação organizacional, informação para cidadania e comunitária, entre outros. A segunda questão diz respeito às relações conceptuais entre comunicação e gestão da informação e do conhecimento. Entre as possibilidades de leitura de tais relações, a proposta teórica partiu do pressuposto de que, sob a ótica da Ciência da Informação, conforme discutido ao longo do artigo, processos apropriados de gestão da informação e do conhecimento levam à efetividade da comunicação. Ou seja, a gestão da informação e do conhecimento são condições propulsoras da comunicação entre seres humanos. Conversamente, a própria gestão do conhecimento, conforme proposto, depende de processos de comunicação. Isso porque os processos de conversão do conhecimento, cerne da teoria de criação do conhecimento de Nonaka e Takeuchi (1997), dependem, de fato, de processos de comunicação. Nesse sentido, considerou-se que a comunicação é crucial para a gestão. 
Por fim, é importante considerar que as propostas conceptuais constituem quadros teóricos de referência possíveis, mas não únicos para estudos de comunicação e gestão da informação e do conhecimento sob a ótica da Ciência da Informação. Além disso, ressalta-se a possibilidade de ocorrências pontuais de somente um ou outro desses tópicos (comunicação ou gestão) em estudos na Ciência da Informação, se considerados os conceitos de informação para a área apresentados por autores cujas abordagens - seminais - a fundamentam.

\section{REFERÊNCIAS}

ALVES, S. Revigorando a cultura da empresa: uma abordagem cultural da mudança nas organizações na era da globalização. São Paulo: Makron Books, 1997.

ASH, J. Communication missing from KM’s core strategies. 2000. Disponível em: <.http:// www.knowledgepoint.com.au/knowledge_management/Articles/KM_JA001.htm.> Acesso 10 mar. 2018.

BARKER, L. L.; GAUT, D. Communication. 8. ed. Boston: Allyn \& Bacon, 2001.

BATISTA, F. F.; COSTA, S. M. S.; ALVARES, L. M. A. R.. Gestão do conhecimento: a realização da proposta de Brookes para a ciência da informação?. Encontro Nacional de Pesquisa em Ciência da Informação, 8., 2007, Salvador. Anais... Salvador: ENANCIB, 2007.

BELKIN, N. Information concepts for information science. Journal of Documentation, v. 34, p. 55- 85, 1978.

BORKO, H. Information Science: what is it? American Documentation, v. 19, n. 1, p. 3-5, 1968.

BOUTHILLIER, F.; SHEARER, K. Understanding knowledge management and information management: the need for an empirical perspective. Information Research, v. 8, n. 1, 2002

BROOKES, B. C. The foundations of information science. Part I. Philosophical aspect. Journal of Information Science, n. 2, p. 125-133, 1980.

CHOO, C. W. A organização do conhecimento: como as organizações usam a informação para criar significado, construir conhecimento e tomar decisões. São Paulo: Editora Senac, 2003.

DAVENPORT, T; Prusak. L.. Conhecimento empresarial. Rio de Janeiro: Campus, 1999. 
DERVIN, B. Useful theory for librarianship: communication, not information. Drexel Library Quarterly, v. 13, n. 3, p. 16-32, 1977.

FARRADANE, J. The nature of information. Journal of Information Science, v. 1, n. 3, p. 13-17, 1979.

FARRADANE, J. Towards a true information science. Information Scientist, v. 10, n. 3, p. 91-101, 1976.

CURRAL, L.; CHAMBEL, M. J. A comunicação nas organizações. In: FERREIRA, J. M. C.; CAETANO, A.; NEVES, J. (Coords.). Manual de psicossociologia das organizações. Lisboa: McGraw-Hill de Portugal, 2001, p.357-376.

INGWERSEN, P. Information retrieval interaction. London: Taylor Graham, 1992.

IVES, W.; TORREY, B.; GORDON, C.. Knowledge management: an emerging discipline with a long history. Journal of Knowledge Management, v. 1, n. 4, p. 269-274, 1998.

JENSEN, B. 1998. Communication or knowledge management? It's time to wake up and smell the koffee. Communication World, 1998.

KOCHEN, M. Information and society. Annual Review of Information Science and Technology, v. 18, p. 277-304, 1983.

KUHLEN, R. Change of paradigm in knowledge management: framework for the collaborative production and exchange of knowledge. In HOBOHM, H. (Ed.). Knowledge management: libraries and librarians taking up the challenge. München: K. G. Saur, 2004, p. 21-38. (IFLA Publications).

LASSWELL, H. The structure and function of communication in society. In: BRYSON, L. (Ed). The communication of ideas. New York: Institute for Religious and Social Studies, 1948 , p. 32-51.

LE COADIC, Y. A ciência da informação. Brasília: Briquet de Lemos, 1996.

LEITE, F. C. L. Gestão do conhecimento científico no contexto acadêmico: proposta de um modelo conceitual. 2006. xiii, 240 f. Dissertação (Mestrado em Ciência da Informação) - Departamento de Ciência da Informação e Documentação, Universidade de Brasília, Brasília, 2006. 


\section{$40 \mid 41$}

LEITE, F. C. L. Comunicação científica e gestão do conhecimento: enlaces conceituais para a fundamentação da gestão do conhecimento científico no contexto de universidades. Transinformação, v. 19, n. 2, 2007, p. 139-151. Disponível em: http://www.scielo.br/scielo. php? script=sci_arttext\&pid=S0103-37862007000200005\&lng=en\&nrm=iso $>$. Acesso em: 10 Aug. 2016. http://dx.doi.org/10.1590/S0103-37862007000200005

LEITE, F. C. L.; COSTA, S. M. S. Gestão do conhecimento científico: proposta de um modelo conceitual com base em processos de comunicação científica. Ciência da Informação, v. 36, n. 1, 2007, p. 92-107.

MARTENSSON, M. A critical review of knowledge management as a management tool. Journal of Knowledge Management, v. 4, n. 3, 2000, p. 204-216.

MASON, R. O. What is an information professional?. Journal of Education for Library and Information Science, v. 31, n. 2, 1990, p. 122-138.

MCQUAIL, D.; WINDAHL, S. Communication models for the study of mass communication. Londres: Longman, 1993.

MILLER, K.. Organizational communication: approaches and processes. 4. ed. Belmont. CA: Thomson Wadsworth, 2006.

NONAKA, I.; TAKEUCHI, H. Criação do conhecimento na empresa: como as empresas geram a dinâmica da inovação. Rio de Janeiro: Campus, 1997.

PIGNATARI, D.. Informação, linguagem, comunicação. 2. ed. São Paulo: Perspectiva, 1968.

PINHEIRO, L. V. R. Processo evolutivo e tendências contemporâneas da Ciência da Informação. Informação \& Sociedade: Estudos, v. 15, n. 1, 2005, p. 1-21.

POPPER, K. R. Conhecimento objetivo: uma abordagem evolucionária. Belo Horizonte: Itatiaia, 1975.

PROBST, G.; RAUB, S.; ROMHARDT, K. Gestão do conhecimento: os elementos construtivos do sucesso. Porto Alegre: Bookman, 2002.

SARACEVIC, T. Information Science. In: BATES, Marcia J.; MAACK, Mary Niles (Eds.). Encyclopedia of Library and Information Sciences. 3. ed., 2010, p. 2570-2585. 
SHARP, D. Knowledge management today: challenges and opportunities. Information Processing and Management, v. 20, n. 2, 2003, p. 32-37.

SMOLIAR, S. W. Interaction management: the next (and necessary) step beyond knowledge management. Business Process Management Journal, v. 9, n. 3, 2003, p. 337-353.

SOARES, B. J. Comportamento de gestores de empresas de base tecnológica na busca e uso de informações. In: ENCONTRO NACIONAL DE PESQUISA EM CIÊNCIA DA INFORMAÇÃO, 5., 2003, Belo Horizonte. Anais... Salvador: ENANCIB, 2003.

SVEIBY, K. E. Towards a knowledge perspective on organisation. 1994. Dissertation (Doctoral Business Administration)- Department of Business Administration, University of Stockholm. 1994.

TAYLOR, R. S. Professional aspects of information science and technology. Annual Review of Information Science and Technology, v. 1, 1966, p. 15-40.

TEIXEIRA FILHO, J. Gestão do conhecimento e comunicação organizacional. Insight Informal, n. 44, 2001.

THEUNISSEN, P. Communication: the cornerstone of knowledge management. In: MAKING A DIFFERENCE: AUSTRALIAN AND NEW ZEALAND COMMUNICATION ASSOCIATION CONFERENCE, 2004, Sidney. Proceedings... Sydney : University of Sydney, 2004.

TUBBS, S; MOSS, S. Human communication: principles and contexts. 9. ed. Boston: McGrawHill, 2003.

VICKERY, B. C. Information systems. London: Butterworth, 1973.

VICKERY, B. C.; VICKERY, A. Information science in theory and practice. London: BowkerSaur, 1987.

WIIG, K. M. Knowledge management has many facets. Knowledge Research Institute. 2002. Disponível em: http://www.krii.com/downloads/Four_KM_Facets.pdf. Acesso em: 14 fev. 2018.

YOVITS, M. C. Information science: towards development of a true scientific discipline. American Documentation, v. 20, n. 4, 1969, p. 369-376. 


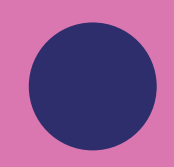

$\bullet$

○

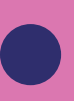

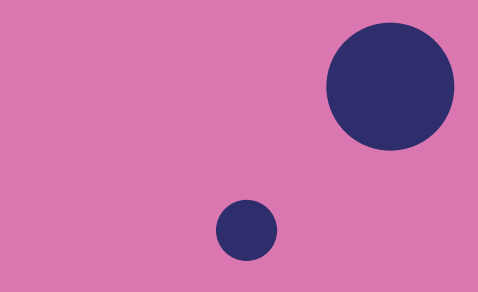

0

$.0^{\circ} \cdot \bullet$

$\cdot 0 \cdot 0$

0

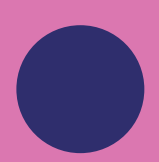

0

○

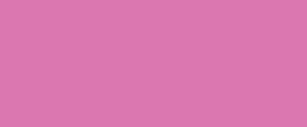

$$
.
$$

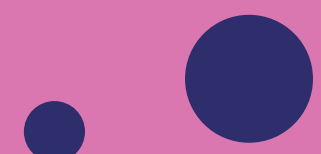$$
\text { . }
$$

$$
\text { . }
$$

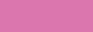

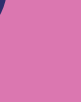




\section{PARTE I COMUNICAÇÃO DA INFORMAÇÃO ORGANIZACIONAL}




\section{CAPÍTULO 1}

0

O

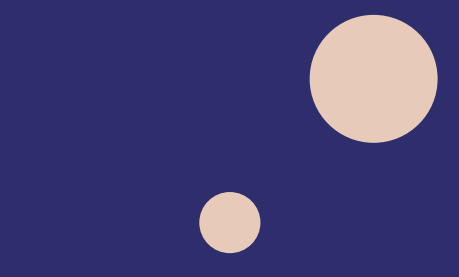

0

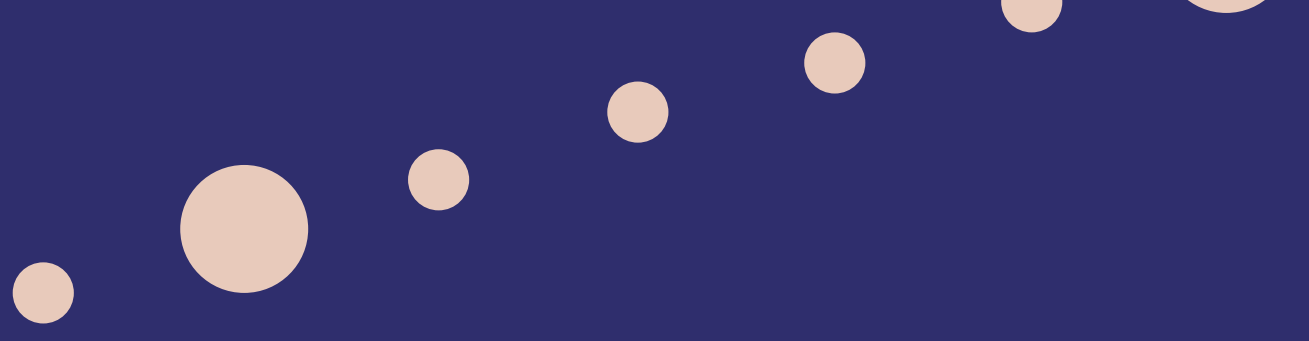

- 00

0 


\section{EFETIVIDADE DO PROCESSO DE COMUNICAÇÃO COM BASE NA TEORIA DO COMPORTAMENTO INFORMACIONAL: O CASO DE UM ORGANISMO INTERNACIONAL DA ÁREA DA SAÚDE PÚBLICA SEDIADO NO BRASIL ${ }^{1}$}

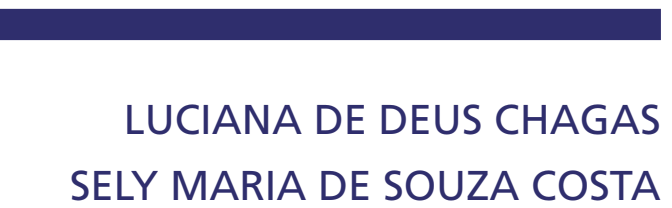

\section{INTRODUÇÃO}

Estudos de comunicação da informação têm constituído um dos aspectos relevantes por meio do qual a Ciência da Informação (CI) busca responder a problemas que dizem respeito à transferência da informação na sociedade. Embora historicamente - e até em função dos fatores que deram origem à CI - cientistas e tecnólogos tenham constituído o foco central de preocupação da área no que concerne a estudos de comunicação da informação, outros contextos têm atraído o interesse com relação ao tópico. Sem dúvida, o contexto organizacional constitui um dos mais relevantes. Isso porque as interações sociais, incluindo aí a comunicação, permeiam fortemente as atividades realizadas no âmbito das organizações. Mais que isso, tecnologias de informação e comunicação inseridas nesses contextos têm provocado mudanças significativas tanto nos processos de comunicação quanto nas interações entre seus atores.

1 Versão modificado do artigo: CHAGAS, L. de D.; COSTA, S. M. S.. Efetividade do processo de comunicação com base na abordagem do comportamento informacional: o caso de um organismo internacional da área da saúde pública sediado no Brasil. Ciência da Informação, v. 36, n. 3, set/dez. 2008 
Para a Organização Pan-Americana da Saúde (Opas/OMS), organismo internacional de saúde pública responsável por cooperar tecnicamente com o governo brasileiro, a iniciativa de prover informação via internet para tomada de decisão visa à redução das desigualdades na área da saúde e foi elaborada no ano 2000. Nessa ocasião, a Opas/OMS, por meio da Unidade Técnica de Desenvolvimento de Sistemas e Serviços de Saúde (HSD), concretizou a iniciativa do uso da internet como instrumento de cooperação técnica (ICT), com o lançamento de seu sítio web. Posteriormente, o portal da Opas/OMS foi aprimorado e as demais unidades técnicas desenvolveram suas próprias páginas. Isso levou a um aumento da disseminação de informação eletrônica, apoiada no desenvolvimento de recursos técnicos e informacionais e na definição dos objetivos relacionados com a cooperação técnica. No entanto, a iniciativa não considerou aspectos fundamentais do planejamento de qualquer serviço ou sistema de informação, sobretudo aqueles relacionados a questões relevantes dos usuários. Um dos aspectos que não parece ter sido levado em conta diz respeito à identificação dos padrões do comportamento informacional de seus usuários e sua relação com o delineamento de produtos e serviços de informação tornados disponíveis pela Opas/OMS.

Apesar da clareza na definição dos objetivos da proposta de ICT, não se estabeleceram mecanismos que permitissem identificar como alcançá-los de forma eficiente e eficaz. Dessa forma, é importante ressaltar que a HSD atua e colabora com o desenvolvimento do sistema de saúde brasileiro, entendendo que a informação contida em seu acervo e oferecida por meio de seus serviços e sistemas informacionais poderá contribuir nesse sentido. Além disso, considera que o cumprimento de sua função, de forma específica, e da Opas/OMS como um todo, poderá melhorar a condição de saúde da população brasileira.

Observa-se, portanto, a importância que adquire o processo de comunicação entre a Opas/ OMS e a sociedade brasileira. Acrescente-se ainda que, do lado da sociedade brasileira, nesse processo, estão os profissionais da área de gestão da saúde pública das três esferas de governo - federal, estadual e municipal. Dessa forma, resultados desta investigação podem contribuir para a melhoria do processo de comunicação entre a HSD e os profissionais da área de gestão da saúde pública. O problema que a pesquisa investigou pode ser, então, expresso na seguinte pergunta: que ações, com base nos padrões de comportamento informacional de profissionais da área de gestão da saúde pública, podem contribuir para tornar mais efetivo o processo de comunicação entre um organismo internacional de saúde e tomadores de decisão na área de saúde pública brasileira?

Considerando a relevância que o processo de comunicação, no contexto organizacional, tem para a CI, assim como para a gestão do conhecimento, o presente estudo teve como objetivo geral delinear uma proposta de ações com vistas a melhorar o processo de comunicação entre um organismo internacional e profissionais da área de gestão da saúde pública, tendo como base os padrões de comportamento informacional dos profissionais como usuários de 
um sistema de informação disponível na internet. Para o alcance do objetivo geral, foram definidos cinco objetivos específicos. O primeiro consistiu em caracterizar o processo de comunicação entre usuários e o sistema de informação da HSD (sítio web). O segundo objetivo foi caracterizar os padrões de comportamento informacional dos usuários do sítio web da HSD. O terceiro consistiu em identificar os serviços já delineados e oferecidos pelo sítio web da HSD. O quarto objetivo foi identificar semelhanças e discrepâncias entre os padrões de comportamento informacional e os serviços de informação oferecidos pelo sítio web da HSD. Finalmente, a pesquisa visou a propor ações que permitam aproximar o sistema de informação da HSD (sítio web) dos padrões de comportamento informacional de profissionais da área de gestão da saúde pública.

Tradicionalmente, até mesmo em razão dos fatores que contribuem para o surgimento da CI como disciplina, o contexto em que os estudos de comportamento informacional têm se realizado é o acadêmico. Isso significa que a CI tem se voltado para o estudo da necessidade, do uso e da busca de informação relacionados às atividades de pesquisa, visando a colaborar para a compreensão do processo da comunicação científica. No entanto, vários estudos que visam à solução de problemas em diferentes organizações têm contribuído para o surgimento de novas áreas de atuação de pesquisa da CI.

Nesse sentido, considerando que estudos de comunicação organizacional na CI ainda parecem incipientes e que esse é um tópico relativamente recente para estudo na área, o estudo aqui proposto visou a contribuir para o corpo de conhecimento na CI, no que concerne aos estudos de comportamento informacional de usuários em ambiente organizacional. Além disso, visou também a contribuir para a identificação e proposição de mudanças que permitissem à HSD alcançar uma relação mais efetiva entre padrões comportamentais identificados e características dos serviços disponíveis.

\section{FUNDAMENTAÇÃO TEÓRICA}

Na discussão das questões identificadas como relevantes para o embasamento teórico deste artigo, destaca-se o processo de comunicação e seus elementos como a questão de abordagem central. Sua discussão se fundamentou na análise da literatura sobre o assunto e permitiu a identificação das principais questões a seu respeito.

\subsection{0 processo de comunicação}

O processo de comunicação, neste estudo, é conformado por um organismo internacional, com o papel primordial de emissor, e por profissionais que atuam na gestão da saúde pública, 


\section{$48 \mid 49$}

no papel de receptores. A compreensão de como se dá esse processo tem relevância para a proposição de ações que possam torná-lo mais efetivo. Normalmente, para melhor entendimento do processo, são utilizados modelos que, apesar de não conseguirem registrar a dinamicidade do processo de comunicação, permitem visualizar a relação entre os principais elementos que o compõem, facilitando sua compreensão. O estudo da evolução dos modelos de comunicação permite identificar modelos que passam de lineares a circulares, helicoidais e na forma de espiral, todos apresentando elementos importantes a serem considerados quando de sua representação. A partir da consideração dos elementos apresentados por uma variedade de modelos, identificou-se o de Tubbs (TUBBS; MOSS, 2003) como o mais adequado para representar o processo de comunicação no contexto organizacional analisado. Dessa forma, o modelo do processo de comunicação proposto por Tubbs incorpora e/ou adapta elementos de modelos que o antecederam, propõe um aspecto dinâmico de representação e acrescenta o elemento "estímulo", como pode ser observado na figura 1.

Figura 1 - Modelo da comunicação de Tubbs (TUBBS; MOSS, 2003)

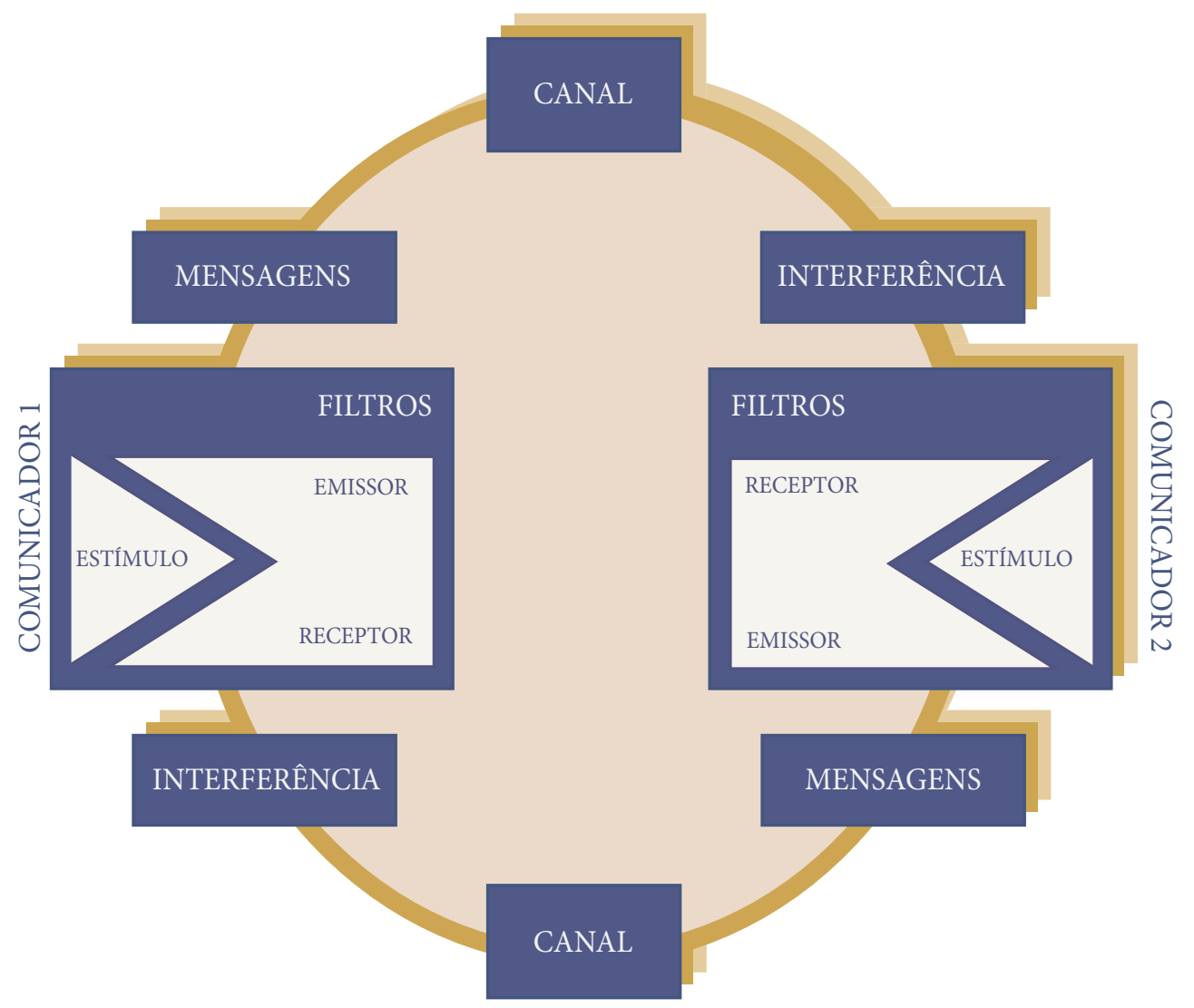

Fonte: Tubbs e Moss (2003). 
É importante destacar que a comunicação se torna efetiva quando permite a troca de informações e estas quando possibilitam a construção do conhecimento necessário à tomada de decisão. Nesse sentido, parece possível considerar que o processo de comunicação deve envolver, entre outras questões, os padrões de comportamento informacional de seus atores como elemento essencial para sua efetividade. Isso, por sua vez, requer o aprofundamento dos aspectos relacionados à informação, sua necessidade, busca e uso, e aos serviços e sistemas de informação.

No que concerne à informação, é interessante registrar o fato de que essa tem sido estudada dentro de uma variedade de campos do conhecimento. Por esse motivo, sua conceituação é diversificada e complexa, o que aponta para a dificuldade de análise, a depender do enfoque que lhe é atribuído e de suas diferentes dimensões explicativas e conceituais (MORAES, 1998). Ou seja, a definição do que seja informação não é uma tarefa simples, não havendo para ela uma abordagem central no campo científico, nem mesmo no campo da CI. Esse panorama é refletido por meio de diversas definições e/ou interpretações do termo “informação" adotadas por estudiosos da área.

No estudo em questão, a informação é considerada quanto a sua utilização por profissionais que atuam no contexto da saúde pública, representando a mensagem trocada entre emissor e receptores. É, pois, parte de um processo de comunicação que deve valorizar o receptor, preocupando-se com seu uso efetivo como etapa primordial para a ação.

A pertinência da informação no contexto da saúde pública relaciona-se ao modelo de gestão adotado por esse setor. Qualquer transformação das práticas sanitárias decorrentes de mudanças sociais, necessidades e problemas de saúde da população irá influenciar na forma como o gestor agirá para responder a essas questões. Dependerá, portanto, do tipo de informação a ser utilizada para dar subsídio a suas decisões e a suas ações (PAIM; ALMEIDA FILHO, 1998).

No Brasil, a partir da Constituição de 1988, a gestão da saúde passou por mudanças significativas nomeadas, em seu conjunto, como Reforma Sanitária Brasileira (CASTRO, 2002). Dessa forma, o novo perfil do gestor, delineado pela reforma sanitária, passou a demandar que os acervos oferecessem informação técnica e científica direcionada ao apoio à tomada de decisão em saúde pública, devendo ser ambas pertinentes e de qualidade.

Esse cenário apontou para outra questão abordada no presente estudo. Trata-se da compreensão de como os usuários de acervos informacionais se comportam em relação à informação e como isso constitui uma etapa importante na proposta de melhoria de serviços de informação. A abordagem implica, assim, estudar o comportamento informacional humano dentro do paradigma dos estudos de usuários, incluindo aspectos que interferem na necessidade, na busca e no uso da informação. 


\section{$\mathbf{5 0} \mid 51$}

\subsection{0 comportamento informacional}

Um dos modelos propostos para estudar o comportamento informacional humano foi elaborado por Wilson (1981), e inclui os conceitos de necessidade, busca, transferência e uso de informação. Em relação a essa questão, ao descrever os fatores que influenciam a necessidade e o comportamento de busca de informação, Wilson (1981) afirma que existem, além das concepções de necessidade afetivas, cognitivas e psicológicas, aquelas relacionadas ao ambiente em que o indivíduo está inserido. É esse o aspecto que fundamenta a discussão a respeito do comportamento informacional no presente estudo.

Wilson (1981) explica que o comportamento informacional humano ocorre com base no seguinte: o indivíduo, ao perceber sua necessidade de informação, engaja-se em um comportamento de busca de informação. Na busca, ele pode utilizar os sistemas ou outros canais formais de acesso à informação e até mesmo trocar informações de modo informal com outras pessoas. Tendo sucesso na busca, o indivíduo usa a informação que pode satisfazer a sua necessidade, além de poder transferi-la a outras pessoas.

Neste estudo, os padrões de comportamento informacional de usuários de um sistema são considerados parte importante no seu delineamento. São, também, tidos como parte do processo de comunicação no qual um sistema de comunicação está inserido, podendo, nesse sentido, influenciar a efetividade tanto do sistema de informação quanto do processo de comunicação. Isso, por sua vez, depende do quanto essas questões correspondem à situação do usuário e de quanto o usuário potencialmente usa os serviços de informação (SONNENWALD; IIVONEN, 1999). A identificação cuidadosa da real necessidade de informação do usuário é, portanto, base essencial para o planejamento, implementação e operacionalização de sistemas de informação (DEVADASON; PATRAP LINGAN, 1996), discutidos sucintamente a seguir.

\subsection{Sistemas de informação, tomada de decisão e tecnologia da informação}

Os sistemas de informação (SI) são tratados neste estudo sob o aspecto de sua relevância para a tomada de decisão (TD) e sua relação com a tecnologia, como o canal por meio do qual emissor e receptor trocam mensagens dentro de um processo de comunicação. Para Adeoti-Adekeye (1997), qualquer definição de sistemas de informação deve considerar pessoas, tecnologia e processos que facilitem a geração, o uso e a transferência da informação.

A provisão da informação por um sistema de informação deve permitir dar suporte à ação a ser realizada, utilizando tecnologia apropriada para apoiar seus usuários na seleção, ampliação, rejeição, atenuação ou distorção das informações recebidas, de acordo com suas próprias 
percepções. Isso permite que o conhecimento seja criado e, a partir dele, o estabelecimento de propostas de ação e tomada de decisão (CHECKLAND; HOLWELL, 1998). Considera-se neste estudo que, no contexto da saúde pública brasileira, o sistema de informação da HSD/ Opas pode desempenhar tarefa fundamental no processo de gestão em saúde, na medida em que ofereça subsídios para a tomada de decisão.

A tomada de decisão, por sua vez, constitui uma atividade importante para as ações governamentais no contexto da saúde pública, no qual, pode ser entendida como o filtro que ajuda a direcionar a troca de mensagens entre emissor e receptores. A informação técnica ou científica utilizada e processada pelos profissionais que atuam na gestão da saúde pública subsidia o planejamento das ações. Por seu turno, o impacto resultante dessas ações em saúde deve refletir os objetivos nacionais do setor e permitir que gestores sejam beneficiados pela sua utilização. Para que isso aconteça, deve-se considerar a utilização da tecnologia da informação como instrumento que potencializa o acesso à informação de qualidade.

A tecnologia da informação tem um papel primordial como base para sistemas de informação, por trazer a possibilidade do aumento no acesso à informação e na sua qualidade. Nos ambientes organizacionais, a tecnologia ocupa papel fundamental, compreendendo o conjunto de conhecimentos, sistemas e equipamentos que são utilizados para tratamento, organização e disseminação de informações necessárias à tomada de decisão (TAKAHASHI, 2000).

$\mathrm{Na}$ área da saúde pública, a crescente produção de informação técnica e científica, especificamente na atividade de gestão, trouxe a necessidade de adotar um recurso que facilitasse e agilizasse a transmissão da informação a ser usada na tomada de decisão. Com esse propósito, um número variado de instituições tem tornado disponível informações voltadas para a atividade de gestão no setor. Entre elas, citam-se o Ministério da Saúde, as secretarias estaduais e municipais de saúde, as instituições de ensino e de pesquisa e os organismos internacionais.

Neste estudo, portanto, o Sistema de Informação da HSD é considerado um instrumento de apoio à tomada de decisão. Agrega-se a essa questão as abordagens do processo de comunicação e dos padrões de comportamento informacional. O relacionamento entre esses três tópicos, portanto, conformam a abordagem teórica discutida a partir da literatura considerada relevante, a qual forneceu a base para montar o referencial teórico e os procedimentos metodológicos do estudo.

\section{METODOLOGIA}

A partir da revisão da literatura, foi possível construir um referencial teórico (modelo conceitual) que permitiu observar o problema a ser tratado sob dois enfoques. O primeiro, 


\section{$52 \mid 53$}

epistemológico, diz respeito ao processo de comunicação no contexto organizacional e ao papel de sistemas de informação, apoiados por tecnologias da informação e comunicação, levando em conta o comportamento informacional de seus usuários. O segundo, metodológico, relaciona-se com a contribuição da abordagem sistêmica e da fenomenologia, mais especificamente o conceito de sistema de atividade humana, com base na metodologia de sistemas flexíveis, de Peter Checkland, e o uso do método de pesquisa-ação.

\subsection{Modelo conceitual da pesquisa}

A base necessária para a construção do referencial teórico do estudo, fundamentado no relacionamento entre o processo de comunicação no contexto organizacional, foi o comportamento de necessidade, busca e uso de informação e o sistema de informação apoiado em tecnologia. Baseado nos modelos conceituais de Checkland e Howell (sistemas de informação), Tubbs (processo de comunicação) e Wilson (comportamento informacional de usuários), o estudo se fundamenta na premissa de que a efetividade do processo de comunicação entre um sistema de informação e seus usuários, no contexto organizacional, depende da correspondência próxima entre os estímulos (insumos) dos emissores e receptores.

É importante notar que as necessidades de informação dos gestores são influenciadas pela função que exercem, a qual, por sua vez, sofre influência do contexto "gestão de saúde pública no Brasil". É, portanto, pressuposto básico do presente estudo que o aperfeiçoamento de sistemas de informação, com base nos padrões de comportamento informacional de seus usuários, pode melhorar o processo de comunicação no ambiente organizacional. Assim, a relação entre os principais elementos do processo de comunicação, as questões que refletem o comportamento informacional de seus atores, usuários do sistema que compõem o processo, e as informações geradas e emitidas pelo sistema de informação, apoiado por tecnologias de informação e comunicação, configura o modelo que serve de embasamento teórico do presente estudo, como ilustrado na figura 2.
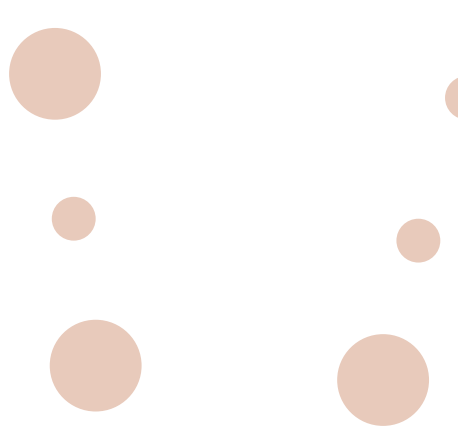
Figura 2 - Relação entre processo de comunicação, comportamento informacional de usuários e as tecnologias de informação e comunicação (TICs) como apoio ao sistema de informação, no contexto organizacional

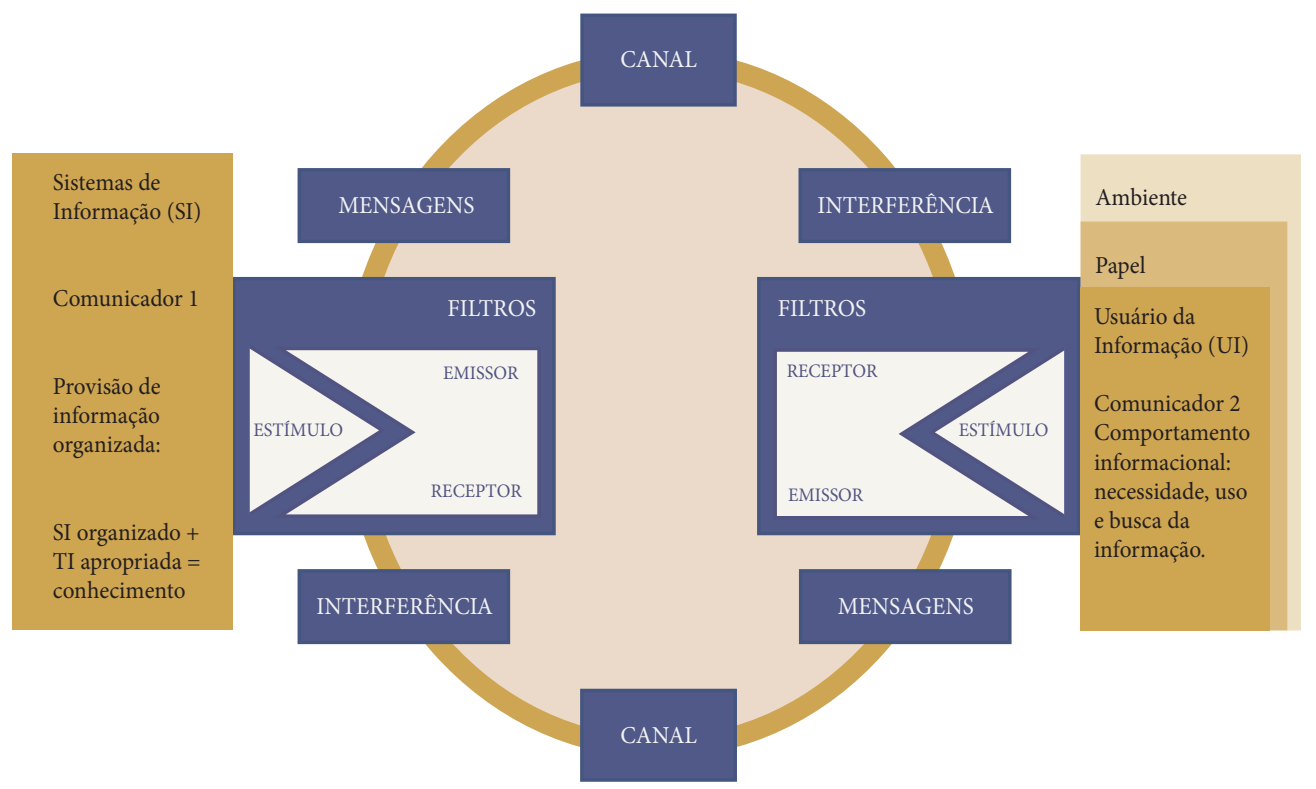

Fonte: Adaptado de Checkland e Howell (1998); Tubbs e Moss (2003); Wilson (1981).

\subsection{Fenomenologia, abordagem sistêmica e metodologia de sistemas flexíveis}

Para estudar possíveis melhorias no sistema de informação da HSD a partir de uma proposta de mudanças que leve em conta os padrões de comportamento informacional de seus usuários na busca e no uso das informações necessárias à consecução de suas atividades, foi utilizada a MSF. Tomou-se como base a abordagem fenomenológica, buscando identificar, dentro do ambiente organizacional em questão, aspectos relevantes do contexto a partir da perspectiva de cada ator e sua estrutura subjetiva de significados (MAYRING, 2002).

A aplicação da MSF busca incorporar a visão dos vários atores envolvidos no processo, explicitando a situação para a qual serão propostas melhorias (COSTA, 2003). A abordagem do problema fundamenta-se no pensamento sistêmico, uma vez que a metodologia a ser aplicada no contexto organizacional relaciona-se diretamente com o conceito de sistemas.

A MSF consiste em sete estágios de análise representados em forma de diagrama na figura 3, onde se notam dois tipos de atividade: as que se inserem no mundo real e as que representam o pensamento sistêmico a respeito do que se observa no mundo real. As questões representadas 


\section{$54 \mid 55$}

na figura 2 e o norteamento obtido por meio da MSF permitiram definir os procedimentos metodológicos adequados ao estudo.

Figura 3 - Estágios da metodologia de sistemas flexíveis (MSF)

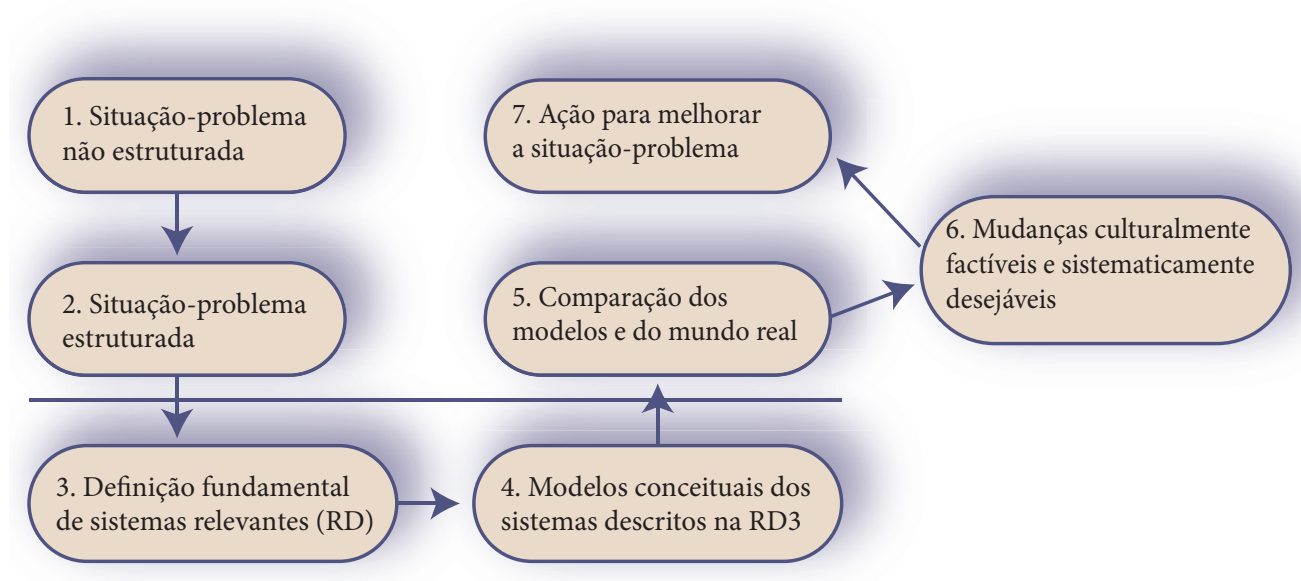

Fonte: Checkland (1999).

\subsection{Procedimentos metodológicos}

A MSF foi aplicada na situação considerada problemática do ambiente da Opas/OMS, mais especificamente na HSD. Foram coletados dados que permitissem analisar a efetividade do processo de comunicação, considerando a informação que se tornou disponível pelo sítio web HSD aos profissionais que atuam na área de gestão da saúde pública.

A coleta de dados consistiu em análise documental, entrevista e questionário. Os dados da pesquisa foram coletados e analisados no período de novembro de 2005 a fevereiro de 2006.

O Quadro 1 apresenta o universo total da gestão da saúde pública no Brasil e a amostra definida para o estudo. 
Quadro 1 - Universo total da gestão da saúde pública no Brasil e amostra do estudo

\begin{tabular}{|c|c|c|}
\hline \multirow{2}{*}{$\begin{array}{c}\text { Universo total da } \\
\text { gestão da saúde pública no } \\
\text { Brasil }\end{array}$} & Gestores municipais & 5.563 \\
\cline { 2 - 3 } & Gestores estaduais & 27 \\
\cline { 2 - 3 } & Ministro da saúde & 1 \\
\hline
\end{tabular}

\begin{tabular}{|c|c|c|c|}
\hline \multirow{4}{*}{$\begin{array}{l}\text { Amostra não probabilística } \\
\text { intencional }\end{array}$} & $\begin{array}{l}\text { Profissionais da Opas que se relacionam } \\
\text { diretamente com o sítio web HSD }\end{array}$ & \multicolumn{2}{|c|}{4} \\
\hline & $\begin{array}{l}\text { Profissionais que usam/conhecem o sítio web } \\
\text { HSD }\end{array}$ & \multicolumn{2}{|c|}{5} \\
\hline & $\begin{array}{l}\text { Novos profissionais da área de gestão da saúde } \\
\text { pública cadastrados no sítio web da HSD, de } \\
\text { janeiro a dezembro de } 2005\end{array}$ & 157 & \multirow{2}{*}{ Total: 620} \\
\hline & $\begin{array}{l}\text { Gestores estaduais e municipais da saúde que } \\
\text { possuem correio eletrônico disponível por seus } \\
\text { respectivos conselhos }\end{array}$ & 473 & \\
\hline
\end{tabular}

Fonte: Elaboração dos autores (2018).

Todos os profissionais que se relacionam diretamente com o sítio web (quatro, lotados na Unidade Técnica) foram incluídos nessa amostra. Do total dos que usam/conhecem o sítio web HSD, foram incluídos cinco, selecionados por nível de gestão (federal, estadual e municipal) e por região brasileira: um federal (Centro-Oeste), dois estaduais (Centro-Oeste e Sul) e dois municipais (Nordeste e Sudeste). A coleta de dados nesses dois grupos se deu por meio de entrevistas.

Novos profissionais e gestores foram abordados por meio de questionário, totalizando 630 questionários, encaminhados por meio de ferramenta de questionário eletrônico (www.surveymonkey. com). Foram selecionados todos os novos profissionais (157) cujo e-mail institucional foi cadastrado no sítio web entre janeiro e dezembro de 2005 (indicativo de maior interesse no uso da internet). No estrato dos gestores, foram incluídos todos os 27 estaduais e todos os municipais que possuíam e-mail atualizado na mala direta do Conselho Nacional dos Secretários Municipais de Saúde (446). Do total de questionários usados para coleta de dados (620), foram obtidas 50,16\% de respostas (316 questionários) até a data limite estabelecida para coleta.

\section{ANÁLISE E DISCUSSÃO DOS RESULTADOS}

A análise e a discussão dos resultados estão apresentadas com base nos estágios da MSF. É importante notar que o estágio 7 da MSF ("ação para melhorar a situação-problema") não está descrita, pois sua realização seria posterior ao término da presente pesquisa. 


\section{$56 \mid 57$}

\subsection{Situação-problema não estruturada (estágio 1 da MSF)}

Para caracterizar o processo de comunicação entre o sítio web da HSD e seus usuários, foram analisados documentos que permitiram identificar o momento político da definição de iniciativas que visem ao uso da internet como ICT da HSD. Assim, foram consultados os documentos que descrevem a missão e a visão da Opas/OMS, os principais eixos de cooperação técnica da HSD e o documento-fonte da iniciativa de utilização da Internet como ICT. Complementando a análise documental, foram analisados os dados coletados por meio dos cadastros no sítio HSD.

Os resultados dessa análise apontaram para o fato de que a informação disponibilizada pelo sistema de informação da HSD possui grande capilaridade, tanto no setor acadêmico quanto na área de gestão da saúde. Pode-se perceber que a ICT, realizada por meio da web da HSD, alcançou um nível considerável de acessos. Contudo, não se pode comprovar se essa informação está sendo utilizada de acordo com a finalidade própria dessa cooperação.

Dados complementares foram também coletados a partir de entrevistas realizadas com quatro profissionais que atuam diretamente nessa atividade e cinco profissionais da gestão da saúde pública que usam e/ou conhecem o sítio web HSD. Aos profissionais que atuam na gestão da saúde pública e aos profissionais da gestão estadual e municipal, definidos na amostra, foi aplicado um questionário via correio eletrônico. Os dados analisados permitiram identificar as principais questões relacionadas ao seu perfil de comportamento informacional, propiciando o que a MSF define como "estruturação da situação-problema" investigada, a qual foi analisada no estágio 2 da metodologia.

\subsection{Situação-problema estruturada (estágio 2 da MSF)}

Os resultados obtidos por meio da análise documental das entrevistas e dos questionários forneceram a base de informações necessária ao entendimento e à estruturação da situação-problema. Foram identificados os elementos da estrutura, dos processos e do meio ambiente dentro do contexto do estudo, bem como as relações entre esses elementos, a fim de que as características do sistema de informação, do comportamento informacional de seus usuários e do processo de comunicação permitissem estruturar a situação-problema. A figura 4 ilustra o processo de comunicação entre a HSD e os profissionais que atuam na gestão da saúde pública, adaptado do modelo de comunicação de Tubbs (TUBBS; MOSS, 2003), e norteia a elaboração da rich picture (RP), no intuito de apontar as questões relevantes a serem consideradas para a proposição de ações que melhorem o processo de comunicação estudado.

Como se pode observar, o processo de comunicação organizacional adaptado e considerado mais adequado apresenta como comunicador $1 \mathrm{a} \mathrm{HSD}$, a qual emite mensagens para os profissionais da área de gestão da saúde pública e da academia, entre outros, cadastrados ou não em sua web, 
via meio eletrônico. A informação previamente analisada pela HSD passa por um filtro baseado no conhecimento do comunicador 1 a respeito da missão/visão da organização, de sua vivência na área e do perfil/ambiente de trabalho do comunicador 2. Algumas interferências notadas nessa primeira parte do fluxo da informação são os problemas tecnológicos e a forma como esse conteúdo na web será divulgado. Os comunicadores 2 filtram a informação disponibilizada pela página de acordo com seu interesse. Supondo que a informação seja acessada, sua utilização poderá gerar a tomada de decisão, o que poderá retornar à HSD por canal formal, sob a interferência dos meios eletrônicos, caracterizando o feedback do processo.

Figura 4 - Modelo da comunicação organizacional da HSD, baseado em Tubbs e Moss (2003)

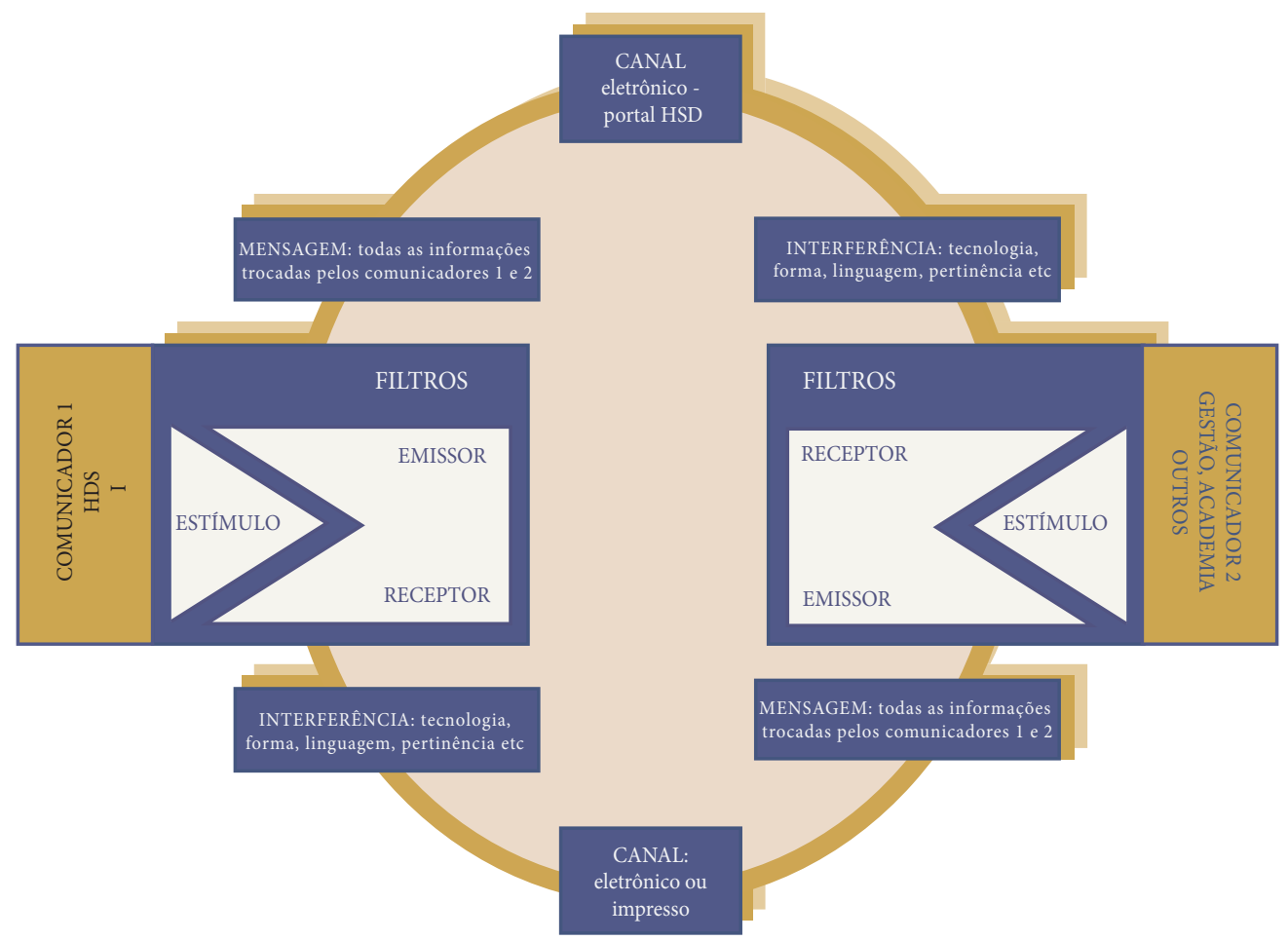

Fonte: baseado em Tubbs e Moss (2003).

Além de ter sido possível visualizar como se dá o processo de comunicação no contexto estudado, foi possível também analisar questões relevantes para nortear a proposição de um sistema capaz de melhorar a situação-problema investigada. Dessa forma, a RP elaborada para o estudo representa o processo de comunicação entre a Opas/OMS e os profissionais que atuam na área de gestão da saúde pública (figura 5). Mais que isso, permitiu apontar as questões relevantes a serem consideradas na fase seguinte, que é a definição de sistemas relevantes (root definitions). 


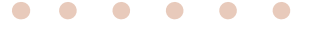

Figura 5 - Rich picture da situação-problema estruturada

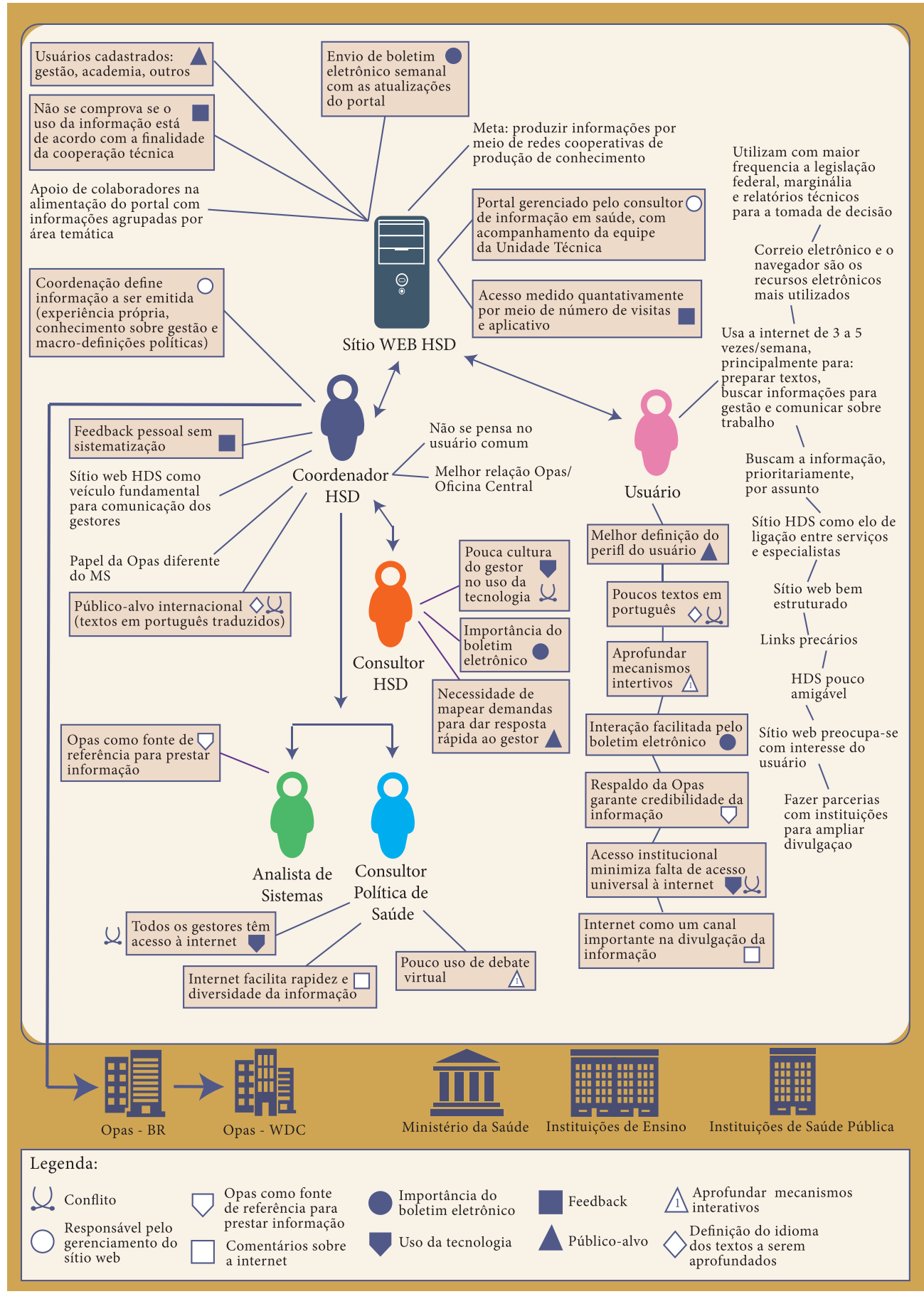

Fonte: Elaboração dos autores (2018). 


\subsection{Definições fundamentais de sistemas relevantes: root definitions - RD (estágio 3 da MSF)}

Na elaboração da definição fundamental (root definition - RD), buscou-se capturar a essência do sistema identificado como mais relevante, como consequência das questões relevantes retratadas na RP. O sistema proposto incorpora, portanto, as atividades consideradas significativas para seu desempenho, destacando os principais elementos que devem constar de uma $\mathrm{RD}$ bem formulada. Isso, por sua vez, foi possível a partir da definição dos elementos do CATWOE, como mostrado a seguir.

Quadro 2 - Definição do CATWOE

\begin{tabular}{|c|c|}
\hline \multicolumn{2}{|r|}{ CATWOE } \\
\hline C & $\begin{array}{l}\text { Clientes do sistema proposto } \\
\text { - Usuários do sítio web HSD com e-mails correspondentes a instituições de gestão da saúde pública, } \\
\text { cadastrados no período de janeiro a dezembro de } 2005 \text {. } \\
\text { - Profissionais que atuam na gestão da saúde pública, nas três esferas de governo, e que possuem } \\
\text { cadastro atualizado de e-mail. }\end{array}$ \\
\hline $\mathbf{A}$ & $\begin{array}{l}\text { Atores do sistema proposto } \\
\text { Profissionais diretamente ligados ao gerenciamento do sítio web HSD/OPAS. }\end{array}$ \\
\hline $\mathrm{T}$ & $\begin{array}{l}\text { Transformação realizada pelo sistema proposto } \\
\text { Transformar o processo de comunicação em que estão envolvidos a HSD e os profissionais que atuam } \\
\text { na área de gestão da saúde pública. Atualmente não há mecanismos que permitam identificar como } \\
\text { estabelecer uma comunicação organizacional efetiva e alcançar os objetivos já traçados pela iniciativa } \\
\text { de uso da internet como instrumento de cooperação técnica, por meio do sítio web HSD. }\end{array}$ \\
\hline W & $\begin{array}{l}\text { Weltanshuung (visão de mundo que norteou a escolha do que é relevante) } \\
\text { A comunicação organizacional de que fazem parte a HSD e os profissionais de gestão da saúde pública } \\
\text { não possui mecanismos para identificar sua efetividade nem para alcançar os objetivos já traçados pela } \\
\text { iniciativa de uso da internet como instrumento de cooperação técnica, por meio do sítio web HSD. }\end{array}$ \\
\hline $\mathrm{O}$ & $\begin{array}{l}\text { Proprietário(s) do sistema } \\
\text { Organização Pan-Americana da Saúde/Organização Mundial da Saúde (Opas/OMS) na pessoa do } \\
\text { Coordenador da Unidade Técnica de Sistemas e Serviços de Saúde (HSD). }\end{array}$ \\
\hline E & $\begin{array}{l}\text { Restrições impostas pelo ambiente do sistema } \\
\text { A própria Opas/OMS e suas principais contrapartes: Ministério da Saúde, Secretarias Estaduais e } \\
\text { Municipais de Saúde. }\end{array}$ \\
\hline
\end{tabular}

Fonte: Elaboração dos autores (2018). 
Quadro 3 - RD do sistema de comunicação organizacional proposto

RD do sistema de comunicação organizacional proposto

Sistema de atividade humana da HSD que transforma a comunicação organizacional, da qual fazem parte os profissionais que atuam diretamente no sítio web HSD e os profissionais da área de gestão da saúde pública nas três esferas de governo - atualmente sem mecanismos que permitam identificar como estabelecer uma comunicação organizacional efetiva e alcançar os objetivos já traçados pela iniciativa de uso da internet como instrumento de cooperação técnica, por meio do sítio web HSD - em um sistema que promova uma comunicação organizacional efetiva no intuito de prover informação que corresponda ao perfil de necessidades informacionais de seus usuários. A provisão de informação por meio de um sistema baseado em tecnologia terá seu escopo limitado ao sítio web da HSD devido às restrições impostas pela estrutura de comunicação organizacional da Opas/OMS como um todo e das suas contrapartes nacionais.

Fonte: Elaboração dos autores (2018).

Tal como estabelece a MSF, foi definido o modelo conceitual (estágio 4 da metodologia), derivado da $\mathrm{RD}$ elaborada. $\mathrm{O}$ objetivo do modelo é identificar e relacionar, logicamente, as ações necessárias à efetiva transformação proposta, tal como descrito a seguir.

\subsection{Modelo Conceitual (estágio 4 da MSF)}

A elaboração do modelo conceitual do presente estudo baseou-se no processo de transformação definido na $\mathrm{RD}$. A partir desse processo, foram definidas as ações necessárias para que a transformação ocorra de fato. Cada uma das ações do processo que melhora a comunicação organizacional entre a HSD e os profissionais que atuam na área da gestão da saúde pública foi organizada em ordem cronológica e ilustrada em um diagrama que representa o modelo conceitual (figura 6). Dentro da abordagem iterativa da MSF, o modelo conceitual embasa a elaboração de uma agenda de comparação que, conforme o resultado obtido, permite retornar a um ou mais dos estágios anteriores, se necessário, reiniciando a análise. É importante ressaltar que as ações constantes do modelo conceitual constituem, na orientação de Checkland, o mínimo necessário para que a transformação seja realizada (mínimo necessário considerando que as ações são apresentadas de modo abrangente). É possível, portanto, que uma ou mais ações sejam, no futuro, transformadas em subsistema, dependendo de sua complexidade.

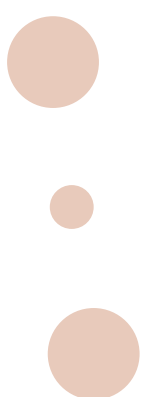


Figura 6 - Modelo conceitual do processo de comunicação organizacional entre sítio web HSD e usuários

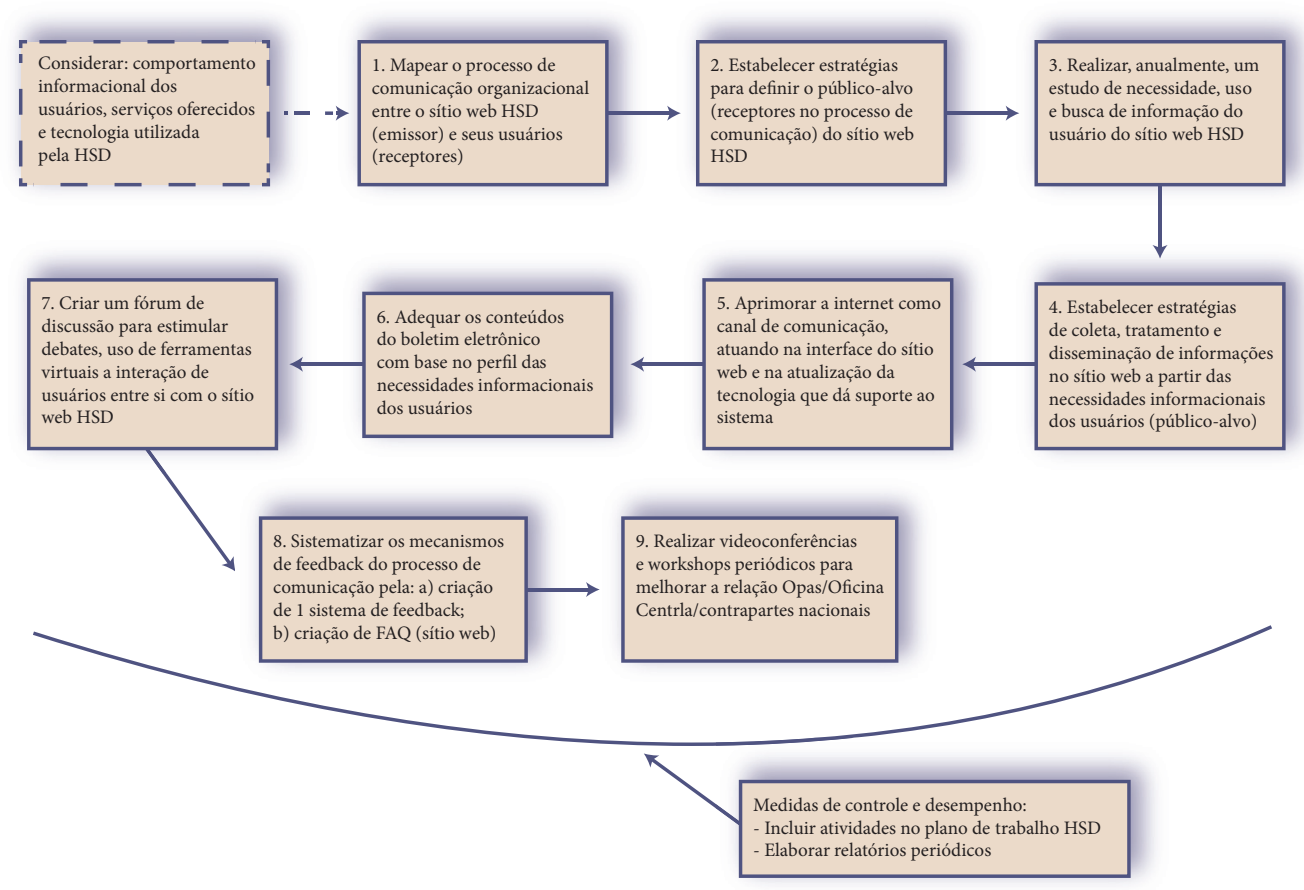

Fonte: Elaboração dos autores (2018).

\subsection{Comparação (estágio 5 da MSF)}

A partir das ações propostas no modelo conceitual, é possível pensar em uma agenda que permita voltar aos sujeitos cujas percepções e visões nortearam a definição do sistema de atividade humana proposto. É preciso, também, avaliar se são culturalmente viáveis e sistemicamente desejáveis. Por culturalmente viáveis entende-se a avaliação com base em valores, normas e padrões, entre outros aspectos culturais compartilhados no ambiente da HSD e que permitem sua implementação. Por sistemicamente desejáveis levam-se em conta as ações que devem se constituir em elementos do sistema proposto.

Neste estágio da metodologia, utilizou-se o método da discussão geral, conforme citado por Wilson (1990). Por meio desse método, confrontam-se aspectos da realidade atual (ilustrada na RP) com o modelo conceitual, definindo diferenças entre eles. Na comparação foram pensadas possíveis mudanças, de acordo com os sujeitos envolvidos na situação-problema. Na descrição, buscou-se iniciar um debate sobre "o que" existe e sobre "como" existe, a fim de que a mudança possa acontecer. O Quadro 4 sintetiza o resultado desse estágio da MSF. 


\subsection{Definição de mudanças desejáveis e viáveis (estágio 6 da MSF)}

A partir das considerações realizadas no estágio anterior, examinaram-se as mudanças propostas, definidas como desejáveis e viáveis, as quais devem ser incluídas em um plano de ação. Para seguir para o estágio de implementação de tais ações, é necessário discutir, em relação a cada uma das propostas, a técnica a ser utilizada, os recursos necessários e a duração. Devido ao tempo de elaboração deste estudo, não foi possível aprofundar esses aspectos do plano de ação, nem avançar para o estágio seguinte, o que sugere a necessidade de retomar essas questões em estudos futuros.

Quadro 4 - Resultado do estágio 5 (agenda de comparação entre as ações do sistema proposto e a situação-problema estruturada no estágio 2)

\begin{tabular}{|c|c|c|c|c|c|c|c|c|}
\hline \multirow[b]{3}{*}{ Ações propostas } & \multicolumn{8}{|c|}{ Critérios de julgamento } \\
\hline & \multirow[b]{2}{*}{$\begin{array}{l}\text { Existe } \\
\text { na } \\
\text { situação } \\
\text { real? }\end{array}$} & \multicolumn{4}{|c|}{$\underline{\text { Se sim: Como julga sua realização? }}$} & \multicolumn{2}{|c|}{ Se não: } & \multirow[b]{2}{*}{$\begin{array}{l}\text { A ação deve ser } \\
\text { implementada? }\end{array}$} \\
\hline & & Ruim & Regular & Bom & Excelente & $\begin{array}{c}\text { A ação } \\
\text { proposta é } \\
\text { culturalmente } \\
\text { viável?(1) }\end{array}$ & $\begin{array}{c}\hat{E} \\
\text { sistemicamente } \\
\text { desejável?(2) }\end{array}$ & \\
\hline $\begin{array}{l}\text { 1. Mapear o processo } \\
\text { de comunicação } \\
\text { organizacional entre o } \\
\text { sítio web HSD (emissor) e } \\
\text { seus usuários (receptores) }\end{array}$ & Não (3) & & & & & $\operatorname{Sim}(3)$ & $\operatorname{Sim}(3)$ & $\operatorname{Sim}(3)$ \\
\hline $\begin{array}{l}\text { 2. Estabelecer estratégias } \\
\text { para definir o público-alvo } \\
\text { (receptores no processo } \\
\text { de comunicação) do sítio } \\
\text { web HSD }\end{array}$ & Não (3) & & & & & $\operatorname{Sim}(3)$ & $\operatorname{Sim}(3)$ & $\operatorname{Sim}(3)$ \\
\hline $\begin{array}{l}\text { 3. Realizar, anualmente, } \\
\text { um estudo da necessidade, } \\
\text { uso e busca da informação } \\
\text { do usuário do sítio web } \\
\text { HSD }\end{array}$ & $\begin{array}{l}\text { Não (2) } \\
\text { Sim (1) }\end{array}$ & 1 & & & & $\operatorname{Sim}(2)$ & $\operatorname{Sim}(2)$ & $\operatorname{Sim}(2)$ \\
\hline $\begin{array}{l}\text { 4. Estabelecer estratégias } \\
\text { de coleta, tratamento } \\
\text { e disseminação de } \\
\text { informações no sítio web, } \\
\text { a partir das necessidades } \\
\text { informacionais dos } \\
\text { usuários (público-alvo) }\end{array}$ & $\begin{array}{l}\text { Não (2) } \\
\text { Sim (1) }\end{array}$ & & & 1 & & $\operatorname{Sim}(2)$ & $\operatorname{Sim}(2)$ & $\operatorname{Sim}(2)$ \\
\hline $\begin{array}{l}\text { 5. Aprimorar a } \\
\text { internet como canal de } \\
\text { comunicação, atuando na } \\
\text { interface do sítio web e na } \\
\text { atualização da tecnologia } \\
\text { que dá suporte ao sistema }\end{array}$ & $\begin{array}{l}\text { Sim (2) } \\
\text { Não (1) }\end{array}$ & & 1 & 1 & & $\operatorname{Sim}(1)$ & $\operatorname{Sim}(1)$ & $\operatorname{Sim}(1)$ \\
\hline $\begin{array}{l}\text { 6. Adequar os conteúdos } \\
\text { do boletim eletrônico } \\
\text { com base no perfil } \\
\text { das necessidades } \\
\text { informacionais dos } \\
\text { usuários }\end{array}$ & Não (3) & & & & & $\operatorname{Sim}(3)$ & $\operatorname{Sim}(3)$ & $\operatorname{Sim}(3)$ \\
\hline
\end{tabular}




\begin{tabular}{|c|c|c|c|c|c|c|c|c|}
\hline \multirow[b]{3}{*}{ Ações propostas } & \multicolumn{8}{|c|}{ Critérios de julgamento } \\
\hline & \multirow[b]{2}{*}{$\begin{array}{c}\text { Existe } \\
\text { na } \\
\text { situação } \\
\text { real? }\end{array}$} & \multicolumn{4}{|c|}{$\underline{\text { Se sim: Como julga sua realização? }}$} & \multicolumn{2}{|c|}{$\underline{\text { Se não: }}$} & \multirow[b]{2}{*}{$\begin{array}{l}\text { A ação deve ser } \\
\text { implementada? }\end{array}$} \\
\hline & & Ruim & Regular & Bom & Excelente & $\begin{array}{c}\text { A ação } \\
\text { proposta é } \\
\text { culturalmente } \\
\text { viável?(1) }\end{array}$ & $\begin{array}{c}\hat{E} \\
\text { sistemicamente } \\
\text { desejável?(2) }\end{array}$ & \\
\hline $\begin{array}{l}\text { 7. Criar um fórum } \\
\text { de discussão para } \\
\text { estimular debates, uso } \\
\text { de ferramentas virtuais } \\
\text { e interação de usuários } \\
\text { entre si e com o sítio } \\
\text { web HSD }\end{array}$ & Não (3) & & & & & $\operatorname{Sim}(3)$ & $\begin{array}{l}\text { Sim (2) } \\
\text { Não (1) }\end{array}$ & $\begin{array}{l}\text { Sim (2) } \\
\text { Não (1) }\end{array}$ \\
\hline $\begin{array}{l}\text { 8. Sistematizar os } \\
\text { mecanismos de } \\
\text { feedback do processo } \\
\text { de comunicação pela: a) } \\
\text { criação de um sistema de } \\
\text { informação de feedback; } \\
\text { b) criação de FAQ (sítio } \\
\text { web) }\end{array}$ & Não (3) & & & & & $\operatorname{Sim}(3)$ & $\operatorname{Sim}(3)$ & $\begin{array}{l}\text { Sim (2) } \\
\text { Não (1) }\end{array}$ \\
\hline $\begin{array}{c}\text { 9. Realizar } \\
\text { videoconferências e } \\
\text { workshops periódicos } \\
\text { para melhorar a } \\
\text { relação Opas/ oficina } \\
\text { central/ contrapartes } \\
\text { nacionaisvideoconferências } \\
\text { e workshops periódicos } \\
\text { para melhorar a relação } \\
\text { Opas / oficina central / } \\
\text { contrapartes nacionais }\end{array}$ & Não (3) & & & & & $\begin{array}{l}\text { Sim (2) } \\
\text { Não (1) }\end{array}$ & $\begin{array}{l}\text { Sim (2) } \\
\text { Não (1) }\end{array}$ & $\begin{array}{l}\text { Sim (2) } \\
\text { Não (1) }\end{array}$ \\
\hline
\end{tabular}

(1) Do ponto de vista da CULTURA (valores, crenças, normas, etc.) da HSD/Opas, o Sr.(a) considera possível mudar/criar a atividade?

(2) O Sr.(a) considera possível que a atividade constitua um elemento do sistema que transforma a comunicação em que está inserida a HSD/Opas do status atual para o proposto?

Fonte: Madeira (2005).

\section{CONCLUSÕES}

Dando destaque à questão da efetividade do processo de comunicação organizacional e aos elementos que o compõem, o presente estudo tomou por base um sistema de informação baseado em tecnologia apropriada que permite atender os usuários no que se refere à necessidade, à busca e ao uso de informação. Sob esse referencial, e em relação aos objetivos propostos para o estudo, foi possível chegar a duas conclusões. Primeiramente, conclui-se que, a partir da adaptação do modelo de Tubbs (TUBBS; MOSS, 2003), é possível caracterizar o processo de comunicação entre a HSD e os profissionais da gestão de saúde pública. Em segundo lugar, conclui-se que os perfis de necessidade dos usuários do sítio web HSD em relação ao uso de tecnologias da informação, como a internet, refletem tendências. A primeira delas refere-se ao fato de que a maioria dos profissionais é do sexo feminino, entre 41 e 50 anos, e bacharéis, que trabalham na gestão da saúde pública em média há 10 anos. A segunda tendência está 
relacionada a uma alta frequência de uso de internet, que amplia a capilaridade da informação. A terceira aponta para o correio eletrônico, os motores de busca, os editores de texto e o navegador como recursos mais utilizados para o trabalho. A quarta revela maior preferência do uso de sítios de instituições públicas nacionais, entre uma variedade de fontes utilizadas, além de maior frequência de uso da legislação federal e marginália e de relatórios técnicos como tipos de informação para a tomada de decisão. A quinta tendência aponta para a prioridade pela da busca da informação por assunto. A sexta mostra o boletim eletrônico como uma ferramenta que facilita a interação entre o sítio web HSD e seus usuários. Finalmente, a última tendência aponta para o fato de a informação disponibilizada pela Opas/OMS ser considerada de relevância e credibilidade na área da gestão da saúde pública.

O delineamento dos serviços oferecidos pelo sítio web HSD revela uma evolução de seu sistema de informação, com destaque para a capilaridade da informação disponível no sítio web HSD, além daquelas disponíveis no setor acadêmico e na área de gestão da saúde.

O conjunto de ações necessárias à efetividade do processo de comunicação entre a HSD/Opas e os profissionais da gestão de saúde pública no Brasil requer uma agenda tal como definido na MSF. Pelos resultados deste estudo, as melhorias no processo de comunicação entre HSD e os profissionais que atuam na gestão da saúde pública parecem estar relacionadas à inclusão dos padrões de comportamento informacional dos usuários como insumo (input) para as definições e decisões relacionadas ao desenho do sistema de informações. Portanto, para que haja efetividade no processo de comunicação entre HSD e seus usuários, é necessário que seu sistema de informação (sítio web) esteja baseado no padrão de comportamento informacional dos profissionais de gestão da saúde pública e proveja, pelo uso de tecnologia adequada, informação relevante para a tomada de decisão.

\section{REFERÊNCIAS}

ADEOTI-ADEKEYE, W. B. The importance of management information systems. Library Review, [s.l.], v. 46, n. 5, 1997. Disponível em: <http://miranda.emeraldinsight.com/vl=4296895/cl=59/nw=1/fm=docpdf $/$ rpsv/cw/mcb/00242535/v46n5/s2/p318> Acesso em: jun. 2005.

CASTRO, E. Informação para apoio à tomada de decisão em saúde: parâmetros de produção de informação territorializada. 2002. 79f. Dissertação (Mestrado em Ciência da Comunicação) - Universidade de São Paulo, São Paulo, 2002.

CHECKLAND, P. B. Systems thinking, systems practice: includes a 30-year retrospective. Chichester: Wiley, 1999. 
CHECKLAND, P.; HOLWELL, S. Information, systems and information systems. Lancaster: Wiley, 1998.

COSTA, S. M. S. A metodologia de sistemas flexíveis aplicada a estudos em ciência da informação: uma experiência pedagógica. Transinformação, Campinas, v. 15, n. 2, 2003.

DEVADASON, F. J: PATRAP LINGAM, P. A methodology for the identification of information needs of users. In: IFLA GENERAL CONFERENCE, 62, 1996, Beijing. Conference Proceedings. The Hage: IFLA, 1996.

MADEIRA, F. A comunicação organizacional e científica no âmbito do CID: a aplicação da metodologia de sistemas flexíveis. 2005. Monografia (Trabalho de conclusão de curso de graduação em biblioteconomia) - Departamento de Ciência da Informação, Universidade de Brasilia, 2005.

MAYRING, P. Introdução à pesquisa social qualitativa: uma introdução para pensar qualitativamente. 5 ed. Weinheim: Beltz, 2002.

MORAES, I. H. S. Informações em saúde: para andarilhos e argonautas de uma tecnodemocracia emancipadora. 1998. 274f. Tese (Doutorado em saúde pública) - Escola Nacional de Saúde Pública, Fundação Oswaldo Cruz, Rio de Janeiro, 1998.

PAIM, J. S.; ALMEIDA FILHO, N. Saúde coletiva: uma nova saúde pública ou campo aberto a novos paradigmas. Revista de Saúde Pública, São Paulo, v. 32, n. 4, p. 299-316, ago. 1998.

SONNENWALD, D.; IIVONEN, M. An integrated human information behavior research framework for information studies. Library \& Information Science Research, Chapel Hill, v. 21, n. 4, p. 429-457, nov. 1999.

TAKAHASHI, T. (org.) Sociedade da informação no Brasil: livro verde. Brasilia: Ministério da Ciência e Tecnologia, 2000. Disponível em: <http://diamante.socinfo.org.br/livro_verde/index.htm $>$. Acesso em: jan. 2006.

TUBBS, S. L:; MOSS, S. Human communication: principles and contexts. 9 ed. Boston:McGraw-Hill, 2003.

WILSON, B. Systems: concepts, methodologies and applications. 2ed. Chichester: Wiley, 1990.

WILSON, T. D. On user studies and information needs. Journal of Documentation, [s.l.], v. 37, n. 1, 1981.

WILSON, T. D. Human Information Behavior. Informing Science Research, [s.l.], v. 3, n. 2, 2000. 


\section{CAPÍTULO 2}

0

0
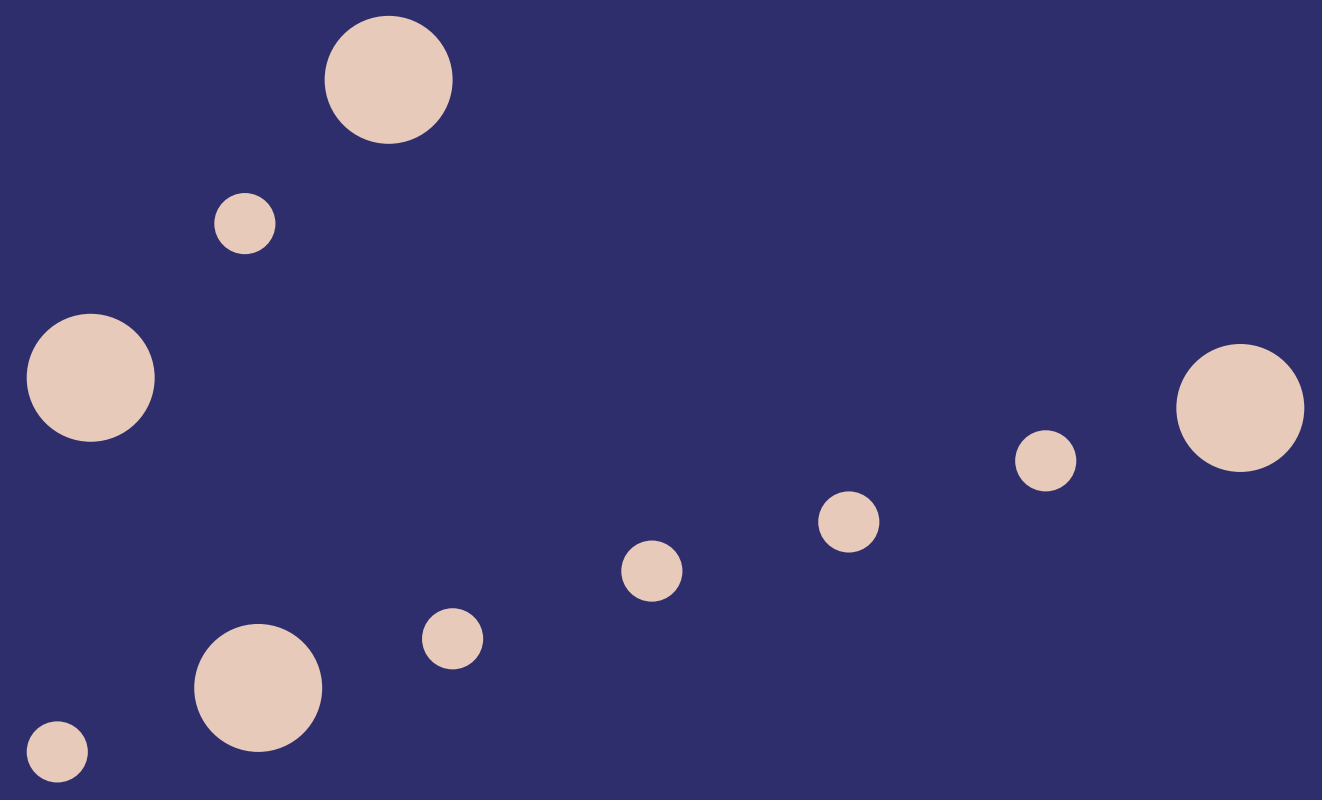

- 00

0 


\section{COMUNICAÇÃO ORGANIZACIONAL E PADRÕES DE COMPORTAMENTO INFORMACIONAL DE GESTORES E ANALISTAS DE RISCO DE CRÉDITO EM INSTITUIÇÕES FINANCEIRAS GOVERNAMENTAIS}

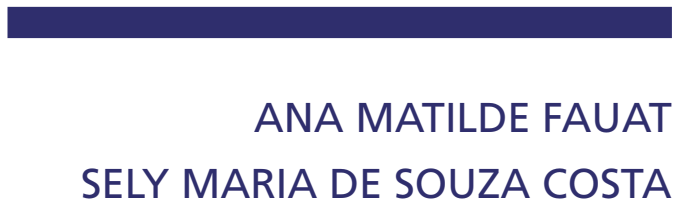

\section{INTRODUÇÃO}

O estudo visou a investigar a comunicação organizacional no contexto de instituições financeiras brasileiras. Centrou o foco na questão dos riscos de crédito de duas instituições nacionais brasileiras governamentais, cujas atividades nessa área são distintas.

A análise da literatura em Ciência da Informação revela que o comportamento de usuários de informação em diferentes contextos, no exercício diário de suas atividades, é semelhante em certas situações. Em outros casos, difere principalmente em relação às necessidades de informação. Coube investigar se a problemática de duas comunidades de gestores e analistas de duas empresas do mesmo ramo, mas com histórias culturais diferentes, têm padrões de comportamento informacional semelhante ou não.

Como em todo setor, os serviços e sistemas de informação que dão suporte ao processo de tomada de decisão no setor financeiro devem estar alinhados com os objetivos estratégicos das instituições, considerando, particularmente, que estão inseridas em ambientes de constante mudança e expostas a todo tipo de risco. Além disso, é necessário que os serviços e sistemas de informação estejam estruturados, de modo a permitir que se conheçam e identifiquem os diversos públicos. Por essa razão, e como observado por Torquato (1986, p. 10), a comunicação constitui, nesse contexto, uma ação integrada de meios, formas, recursos, canais e intenções. Isso porque é a comunicação que 
proporciona a reunião das partes distintas da empresa, constituindo o centro de processamento da eficiência organizacional. Como observado por Kunsch (2003, p. 153), a comunicação administrativa permite viabilizar todo o sistema organizacional, por meio de confluências de fluxos e redes, atingindo todos os níveis decisórios.

O primeiro fator a ser considerado nesse contexto é o da comunicação interna, que entra como um dos principais agentes de mudança. Além disso, como observa Pinheiro (1982, p. 3), "a comunicação interpessoal é um dos meios mais importantes para transmitir a informação”. Acrescente-se a essas ideias a questão relacionada a necessidades e usos da informação essencial ao trabalho diário nas organizações, levando à busca constante em uma variedade de sistemas de informação.

Outro fator a ser considerado é o comportamento do consumidor/cliente, que considera a empresa não só como mera geradora de produtos ou prestadora de serviços. A nova postura, tanto do cliente como da sociedade como um todo, imprime também nova postura na comunicação organizacional, que deve refletir os novos valores, os quais, por sua vez, devem ser incorporados às diretrizes, estratégias e políticas institucionais. A comunicação é vista, portanto, como fator estratégico essencial no processo de transferência de todos os tipos de informação, incluindo as de cunho normativo e de diretrizes e políticas institucionais na organização. É nesse cenário que se investigou quais são as relações entre o processo da comunicação organizacional em instituições financeiras governamentais e os padrões de comportamento informacional de gestores e analistas de risco de crédito.

Em razão das questões motivadoras do problema investigado nesta pesquisa, o objetivo geral do estudo foi identificar a relação entre comportamento informacional de gestores e analistas de risco de crédito e o processo de comunicação organizacional entre eles, em instituições financeiras governamentais. Para atingir o objetivo geral, estabeleceram-se quatro objetivos específicos: 1) caracterizar o perfil de gestores e analistas de risco de crédito em instituições financeiras governamentais; 2) caracterizar o processo da comunicação organizacional entre gestores e analistas de risco de crédito em instituições financeiras governamentais brasileiras; 3) identificar padrões de comportamento informacional de gestores e analistas de risco de crédito; 4) identificar aspectos do comportamento informacional de gestores e analistas de risco de crédito que podem constituir insumos (estímulos) à comunicação organizacional entre eles, na percepção desses sujeitos.

\section{COMUNICAÇÃO DA INFORMAÇÃO E COMPORTAMENTO INFORMACIONAL: ASPECTOS TEÓRICOS}

A problemática do estudo insere-se no contexto organizacional e foi construída com fundamentos nas teorias da comunicação, tomando como base o modelo de comunicação integrada de Kunsch (2003). Adicionalmente, são levados em conta o modelo de comunicação de 
Tubbs (TUBBS; MOSS, 2003) e o de comportamento informacional de Wilson (2000). Mais que isso, optou-se pela adoção de Allen (1977) para construção e entendimento das fontes de informações buscadas por especialistas em organizações.

\subsection{Modelo de Comunicação Organizacional}

Kunsch (2003, p. 149-162), tal como Torquato (1986) e Berlo (1989), pensou a comunicação organizacional considerando a convergência de diversas áreas por meio da junção da comunicação institucional, da comunicação mercadológica, da comunicação interna e da comunicação administrativa. A autora aprofundou seus estudos, propondo um modelo de comunicação organizacional integrada, como uma unidade harmoniosa, conforme ilustrado na figura 1

Figura 1 - Comunicação integrada proposta por Kunsch (2003, p. 151)

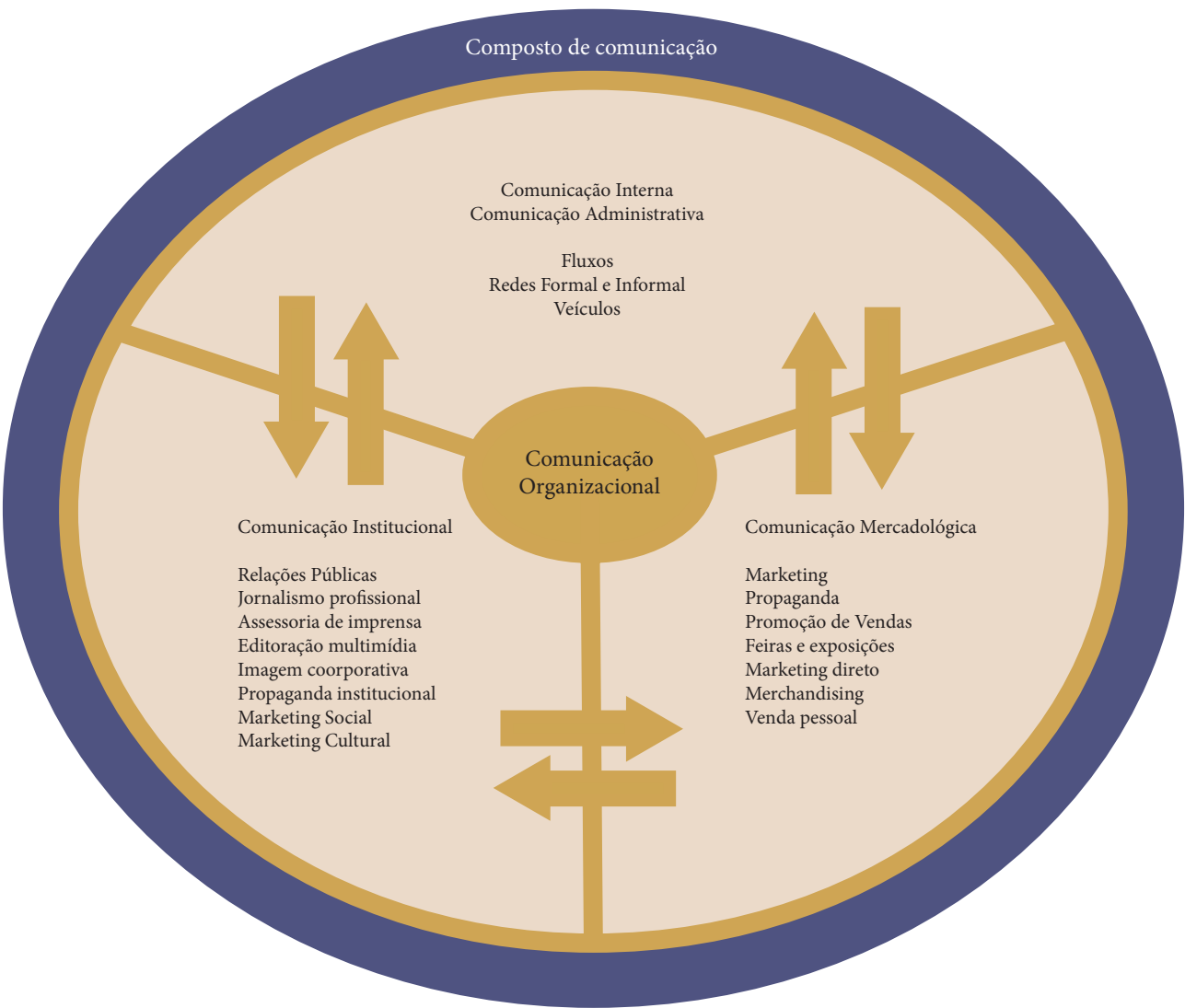

Fonte: Kunsch (2003, p. 151). 


\section{$70 \mid 71$}

Como é possível observar, o modelo de comunicação organizacional proposto pela autora permite a convergência de todas as atividades da organização e possibilita ações de comunicação mais pensadas e trabalhadas, visando à eficácia. Na Ciência da Informação, o foco no processo da comunicação organizacional parece estar relacionado com a comunicação interna e com a comunicação administrativa de Kunsch. Nesse sentido, o presente estudo aborda a comunicação administrativa como a que se processa dentro da organização no âmbito de funções administrativas (gestores e analistas de risco de crédito), permitindo a confluência de fluxos de informação (KUNSCH, 2003, p. 152). Quanto à comunicação interna, o estudo a aborda como um setor planejado, com objetivos bem definidos para viabilizar a interação entre gestores e analistas, assim como entre eles e as organizações estudadas.

Em relação ao processo da comunicação organizacional, a revisão da literatura sinalizou que o modelo de comunicação de Tubbs (TUBBS; MOSS, 2003) é apropriado para o estudo. É um dos modelos mais relevantes entre outros também estudados, por ilustrar os elementos do processo de comunicação de forma bastante completa. A partir da identificação do modelo de comunicação de Tubbs, foram definidos sete elementos que compõem o processo da comunicação organizacional no contexto de instituições financeiras governamentais. O primeiro elemento é o comunicador 1, no papel primordial de emissor (representado pelos gestores). O segundo elemento é o comunicador 2, no papel primordial de receptor (representado pelos analistas). O terceiro, a mensagem, significa todas as informações trocadas entre os comunicadores 1 e 2, ou seja, todas as informações relacionadas ao sistema de normas das organizações estudadas e que são trocadas, principalmente, mas não somente, entre gestores e analistas de risco de crédito. $\mathrm{O}$ quarto elemento, o canal, constitui o veículo por meio do qual a mensagem (escrita ou falada) é transmitida, como, por exemplo, caixas postais, telefones e veículos digitais. O quinto elemento são as interferências ou barreiras de comunicação, as quais são constituídas por qualquer problema, de ordem técnica e semântica, que distorça o significado da mensagem entre os comunicadores. O sexto elemento é o feedback, que é o retorno ao comunicador 1 (gestores) como resultado do comportamento por ele gerado, sendo uma característica essencial dos relacionamentos dele com seus interlocutores (principalmente analistas), assim como uma importante fonte de informação sobre ele próprio. Finalmente, o sétimo elemento é o estímulo (insumo), que se refere a tudo o que o emissor e o receptor sabem, assim como suas experiências a partir do mundo físico ou social, com base nos seus sentidos. No presente estudo, parte dos insumos que estão subjacentes às interações entre comunicadores 1 e 2 compõe-se de elementos de comportamento informacional, os quais, nesse sentido, parecem influenciar a eficácia da comunicação.

Buscou-se avaliar as conclusões e preocupações resultantes de 10 anos de estudos realizados por Allen (1977) em relação a integrar organização e variáveis de comunicação. O autor estudou uma diversidade de grupos de indivíduos, o modo como funcionam as redes de contato entre eles, e avaliou a intensidade versus diversidade de contatos entre departamentos, projetos e 
diversas organizações governamentais. Allen sugeriu, também, programas de pesquisas para descrever a comunicação organizacional e predizer as relações de suas várias facetas a outras variáveis organizacionais.

Parte do presente estudo fundamentou-se nas pesquisas e sugestões de estudos realizados por Allen (1977). Dos estudos do autor, foram adaptadas perguntas, assim como a relação de facetas da comunicação organizacional com variáveis do comportamento informacional, obtidas a partir do modelo de Wilson. As contribuições de Allen, portanto, serviram para construção e entendimento das fontes de informações buscadas por gestores e analistas de risco de crédito de instituições financeiras. Isso porque eles foram identificados como grupo semelhante aos técnicos e especialistas de planejamento e desenvolvimento ( $P \& D)$, entre administradores de equipes de diversos contratos do governo, estudados por Allen. Nesse aspecto, vale destacar a contribuição do autor para o estudo do comportamento de busca de informação, coleta e preparação da informação, em relação aos aspectos da comunicação nas organizações estudadas.

\subsection{Comportamento Informacional de Wilson}

Comportamento informacional, neste estudo, tal como abordado por Gasque (2003) e Soares (2003), compreende o estudo das necessidades, da busca e do uso de informação. Mais que isso, variáveis do comportamento informacional de gestores e analistas de risco de crédito são abordadas em relação ao processo de comunicação, tal como estudado por Chagas (2006). Sua construção teórica soma-se, portanto, a estudos anteriores que abordaram tema semelhante.

Entre os modelos de comportamento avaliados na literatura (WILSON, 1981; 1999; KUHLTHAU, 1991; CHOO, 2003), o que se mostrou mais adequado ao estudo é o modelo de Wilson (1981), ilustrado na figura 2. 
Figura 2 - Modelo de Comportamento Informacional (Wilson, 1981)

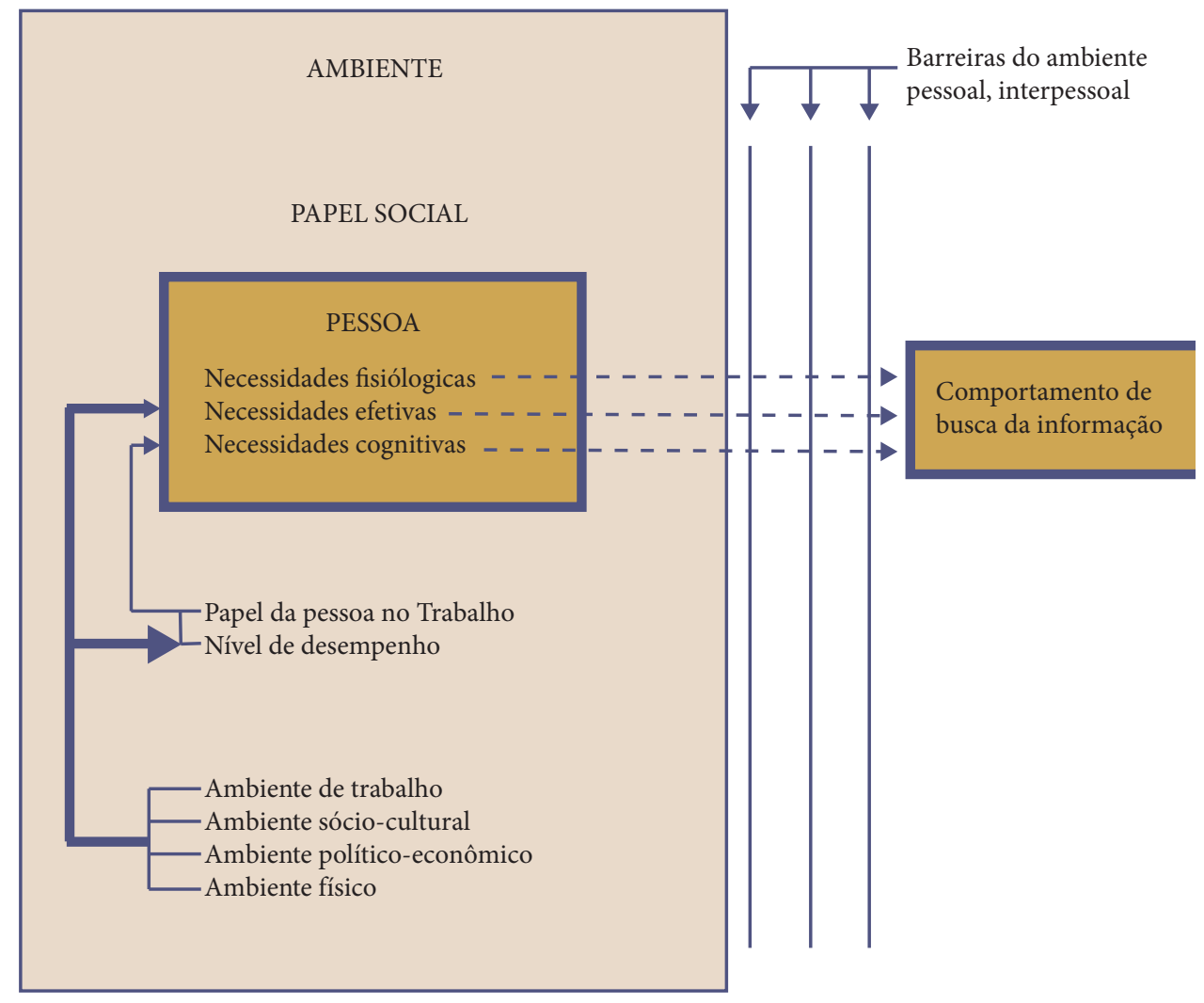

Fonte: Wilson (1981).

O próprio autor, em trabalho de revisão sobre a evolução de seus modelos de comportamento informacional (WILSON, 2005), considera o modelo de 1981, adotado neste estudo, como o mais citado na literatura, o qual desenvolveu a ideia de uma pessoa, um papel social e um contexto que provocam necessidade de informação. $\mathrm{O}$ autor, no entanto, apresentou sugestão de que necessidade de informação era um conceito inapropriado para o propósito de pesquisa, devendo o termo "comportamento na busca por informação" ser adotado, uma vez que o comportamento é observável, enquanto as necessidades, por serem estados mentais internos, não o são (WILSON, 2005, p.32).

Em seus trabalhos mais recentes, Wilson tem, gradualmente, agregado os modelos anteriores, na tentativa de chegar ao modelo mais completo. O objetivo é que seu modelo seja útil não só para o estudo do comportamento informacional no contexto acadêmico, mas também para estudos no contexto das organizações. Seu modelo, portanto, contribui para o entendimento de assuntos dentro das organizações, quando o foco das preocupações é o processo de busca e recuperação da informação. 


\section{PROCEDIMENTOS METODOLÓGICOS}

O relacionamento entre os conceitos adotados para a construção teórica deste estudo está representado na figura 3, que embute o marco teórico norteador da pesquisa. Como se pode observar, a ilustração incorpora elementos dos modelos de Wilson (1981), Tubbs (2003) e Kunsch (2003). Procura-se ilustrar de que modo as variáveis do comportamento informacional de gestores e analistas de risco de crédito devem ser levadas em conta para melhoria do processo de comunicação entre eles.

\subsection{Modelo conceitual da pesquisa}

O referencial teórico descrito nos parágrafos anteriores e ilustrado no modelo conceitual representado na figura 3 apontou os caminhos a serem seguidos quanto aos procedimentos metodológicos da pesquisa.

Figura 3 - Comportamento informacional e processo de comunicação organizacional

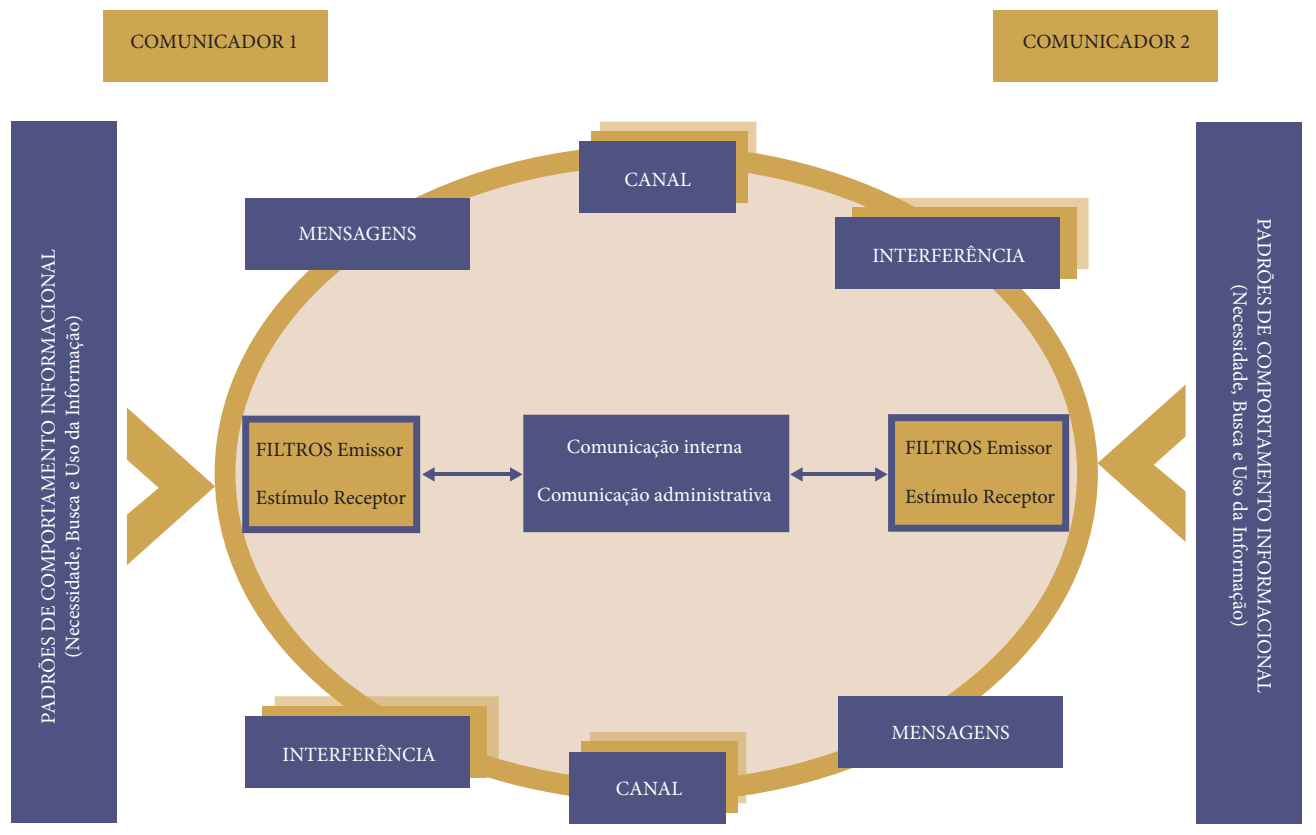

Fonte: Wilson (1981), Tubbs e Moss (2003) e Kunsch (2003).

Os conceitos estão relacionados de forma a explicitar uma interdependência entre comunicadores e instrumentos de mediação da comunicação. Desse modo, o modelo mostra como os comunicadores 1 e 2 interagem no ciclo de comunicação, enviando e recebendo mensagens, 


\section{$74 \mid 75$}

por meio de canais de comunicação que, por sua vez, sofrem interferências. Ressalta, ainda, que o receptor interpreta a mensagem que lhe foi enviada a partir de seu comportamento informacional, que, uma vez diferente do comportamento do emissor, pode gerar diferenças de entendimento. Tais diferenças são acertadas pelo caráter cíclico do modelo, que considera o retorno e o envio da mensagem tantas vezes quantas forem necessárias até que o seu entendimento, por parte do receptor, seja o mais próximo possível do entendimento do emissor.

\subsection{Desenho da pesquisa}

As estratégias utilizadas nesta pesquisa fundamentam-se em procedimentos qualitativos e quantitativos de coleta de dados. Trata-se, portanto, de um desenho combinado (mixed method design), denominado triangulação, especificamente, triangulação concorrente, conforme abordagem de Creswell e Clark (2007, p. 64). Nessa metodologia, o pesquisador tenta combinar os dois conjuntos de dados utilizando os resultados na interpretação. O propósito é entender melhor o problema da pesquisa pela obtenção de dados diferentes, mas complementares, sobre o mesmo tópico. A triangulação funciona como um meio de acrescentar rigor, amplitude e profundidade a qualquer investigação. Denzin e Lincoln (2000, p. 8) reconhecem a possibilidade de que o uso de metodologias diferentes clarifique visões diferentes de pesquisadores para o entendimento dos estudos.

A população, para fins desta pesquisa, é composta pelos entes do Sistema Monetário Nacional, compreendendo um universo de duas autoridades monetárias (Conselho Monetário Nacional e Banco Central), quatro autoridades de apoio (Comissão de Valores Mobiliários, Banco do Brasil, Banco Nacional de Desenvolvimento Econômico e Social e Caixa Econômica Federal) e grande número de instituições financeiras. Para identificar a relação entre comportamento informacional de gestores e analistas de risco de crédito e o processo de comunicação organizacional entre eles, em instituições financeiras governamentais, optou-se por mapear o ciclo da comunicação organizacional de duas instituições financeiras governamentais brasileiras. As duas instituições selecionadas, além de serem também autoridades monetárias de apoio, estão entre as maiores do País no que diz respeito ao número de agências e ao volume de investimentos.

A pesquisa descreve o fluxo da informação em todas as suas etapas, nomeadamente geração da informação, finalidade do uso, destino e canal por meio do qual é direcionada pelos atores do processo dentro do contexto profissional em que estão inseridos. Trata-se, portanto, de um estudo descritivo, pois tem por fim descrever características da população estudada, dos processos de comunicação entre seus principais atores, dos padrões de comportamento informacional e de elementos do comportamento informacional que têm relação com o processo de comunicação. 
O método utilizado para coleta de dados é denominado de levantamento (survey). Isso porque se considerou necessário o entendimento do fenômeno a partir das percepções dos sujeitos investigados a respeito do problema estudado. Para permitir e facilitar a identificação dessas relações, optou-se, primeiramente, por identificar o perfil das características demográficas da população estudada. Considerou-se necessário, em seguida, caracterizar o processo da comunicação organizacional entre os analistas e gestores, bem como identificar padrões de comportamento informacional. Finalmente, foi necessário identificar aspectos do comportamento informacional que são importantes para a comunicação organizacional entre os atores estudados.

Os dados foram coletados por meio de questionário, composto por 11 questões fechadas, e entrevista semiestruturada, com 8 questões abertas. As questões, tanto do questionário como da entrevista, são as mesmas para gestores e analistas, nas duas instituições estudadas. $\mathrm{O}$ Quadro 1 apresenta as questões formuladas para o questionário e a entrevista em relação aos objetivos propostos, mostrando os aspectos que cada questão identificou.

Quadro 1 - Questões formuladas para coleta de dados

\begin{tabular}{|c|c|c|c|}
\hline & & \multicolumn{2}{|c|}{ INSTRUMENTO DE PESQUISA } \\
\hline \multicolumn{2}{|c|}{ OBJETIVOS ESPECÍFICOS } & QUESTIONÁRIO & ENTREVISTA \\
\hline Objetivo 1 & \multicolumn{3}{|c|}{$\begin{array}{l}\text { Caracterizar o perfil de gestores e analistas de risco de crédito em instituições } \\
\text { financeiras do governo }\end{array}$} \\
\hline $1^{\text {a }}$ ação & $\begin{array}{l}\text { Identificar as características demográficas } \\
\text { de gestores e analistas de risco de crédito } \\
\text { em instituições financeiras governamentais } \\
\text { (sexo, idade, lotação, experiência profissional } \\
\text { e formação acadêmica) }\end{array}$ & 1,2 & 1 \\
\hline Objetivo 2 & \multicolumn{3}{|c|}{$\begin{array}{c}\text { Caracterizar o processo da comunicação organizacional entre gestores e analistas } \\
\text { de risco de crédito em instituições financeiras governamentais }\end{array}$} \\
\hline $1^{\mathrm{a}}$ ação & $\begin{array}{l}\text { Identificar o fluxo de informação entre os } \\
\text { atores do processo (emissor/ receptor) }\end{array}$ & 3,4 & 5,6 \\
\hline $2^{\mathrm{a}}$ ação & Identificar conteúdos das mensagens & 6 & 5 \\
\hline $3^{\mathrm{a}}$ ação & $\begin{array}{l}\text { Identificar quais são os veículos que } \\
\text { transmitem informação na comunicação } \\
\text { organizacional. }\end{array}$ & 5 & 5,6 \\
\hline $4^{\mathrm{a}}$ ação & $\begin{array}{l}\text { Identificar estímulos (insumos) à } \\
\text { comunicação - ver objetivo no } 4\end{array}$ & 8 & 8 \\
\hline $5^{\mathrm{a}}$ ação & $\begin{array}{l}\text { Identificar quais são as barreiras encontrados } \\
\text { no processo comunicação }\end{array}$ & 7 & 7 \\
\hline
\end{tabular}




\begin{tabular}{|c|c|c|c|}
\hline & & \multicolumn{2}{|c|}{ INSTRUMENTO DE PESQUISA } \\
\hline \multicolumn{2}{|c|}{ OBJETIVOS ESPECÍFICOS } & QUESTIONÁRIO & ENTREVISTA \\
\hline Objetivo 3 & \multicolumn{3}{|c|}{$\begin{array}{l}\text { Identificar padrões de comportamento informacional de gestores e analistas de } \\
\text { risco de crédito (necessidades, busca e uso de informação) }\end{array}$} \\
\hline $1^{\text {a }}$ ação & $\begin{array}{l}\text { Identificar quais são os canais de acesso às } \\
\text { fontes de informação interna e externas }\end{array}$ & 10 & 3 \\
\hline $2^{\mathrm{a}}$ ação & $\begin{array}{l}\text { Identificar quais são as fontes de informação } \\
\text { (frequência de uso) }\end{array}$ & 10 & 3 \\
\hline $3^{\text {a }}$ ação & $\begin{array}{l}\text { Identificar recursos tecnológicos usados } \\
\text { pelos sujeitos para executar as atividades }\end{array}$ & 9 & 3 \\
\hline $4^{\mathrm{a}}$ ação & $\begin{array}{l}\text { Identificar como é buscada e usada a } \\
\text { informação pelos gestores e analistas }\end{array}$ & 9,10 & 3 \\
\hline $5^{\mathrm{a}}$ ação & $\begin{array}{l}\text { Identificar tipos de informações requeridas } \\
\text { e com que fim são usadas (produto final) } \\
\text { (necessidade/busca e uso) }\end{array}$ & 11 & $2,3,4$ \\
\hline Objetivo 4 & \multicolumn{3}{|c|}{$\begin{array}{l}\text { Identificar aspectos do comportamento informacional de gestores e analistas de } \\
\text { risco de crédito que podem influenciar a comunicação organizacional entre eles, } \\
\text { na percepção desses sujeitos (fatores demográficos e do contexto) }\end{array}$} \\
\hline $1^{\text {a }}$ ação & $\begin{array}{l}\text { Identificar a percepção dos respondentes } \\
\text { sobre padrões de comportamento } \\
\text { informacional como estímulo (insumo) à } \\
\text { comunicação }\end{array}$ & 8 & 8 \\
\hline
\end{tabular}

Fonte: Elaboração dos autores (2018).

O questionário e a entrevista foram aplicados em 28/5/2007. A coleta de dados por meio dos questionários foi encerrada com a distribuição de 195 questionários, representando 35,39\%, do total de 551 questionários previamente reservados. O índice de distribuição e de respostas foi considerado satisfatório para fins deste estudo.

\section{O PROCESSO DE COMUNICAÇÃO EM ÁREAS DE RISCO DE CRÉDITO DE INSTITUIÇÕES FINANCEIRAS GOVERNAMENTAIS E O COMPORTAMENTO INFORMACIONAL DE GE- STORES E ANALISTAS}

O processo de comunicação em áreas de risco de crédito de instituições financeiras governamentais pode ser caracterizado e definido a partir do perfil de gestores e analistas e do comportamento informacional desses atores. A pesquisa apresentou, em consonância com estudos na área de comunicação e gestão da informação, um perfil específico de gestores e analistas de crédito e atribui a eles um comportamento informacional também peculiar em certas situações. 


\subsection{Perfil de gestores e analistas de risco de crédito em instituições financeiras gov- ernamentais}

Descrever as características dos sujeitos investigados torna-se fator importante em estudos de comportamento informacional, segundo Wilson (1997, p. 556). Nesse sentido, variáveis demográficas, como idade, sexo e outros fatores como a formação acadêmica, são questões importantes a serem levadas em conta. Sob esse aspecto, Allen (1977, p. 187), Rosenbloom e Wolek apud Baldwin e Rice (1997) constataram a importância de se conhecer a experiência do profissional. Os estudos desses autores identificaram influência dessas variáveis nos canais de busca de informações e de comunicação usados por cientistas e tecnologistas.

Os objetivos do presente estudo não incluíram investigar a influência desses fatores no comportamento dos sujeitos investigados. No entanto, considerou-se relevante caracterizá-los quanto a essas variáveis. Conforme demonstrado pelos resultados obtidos, a população, em sua maioria, é composta por homens, situa-se na faixa etária de 41 a 50 anos de idade e tem bom nível de experiência nas instituições. O tempo de experiência na função, em ambas as instituições, não é muito longo, porque as atividades do setor de risco de crédito tiveram início em 1996, a partir das definições do Acordo da Basileia.

Demonstrou-se pelas entrevistas que a experiência na função exerce influência nos canais de busca de informação, principalmente no sistema de normas. Isso significa que, quanto mais o analista tem domínio das normas, menor é a necessidade de acesso para consultas. Observouse, ainda, que, quando a empresa se candidata a crédito pela primeira vez, os procedimentos para análise e avaliação de risco de crédito são mais criteriosos, o que não ocorre mais a partir de sucessivas contratações, diminuindo até mesmo o tempo gasto pelos analistas. Baldwin e Rice (1997) e Allen (1997) identificaram situações semelhantes nas pesquisas que realizaram. Em Baldwin e Rice (1997), os resultados mostraram que as características individuais exercem pouca influência nas fontes de informações e em canais de comunicação usados pelos analistas no contexto das companhias de seguros dos Estados Unidos e do Reino Unido. Em contrapartida, destaca-se que, nos resultados dos pesquisadores, os recursos institucionais influenciam significativamente o uso das fontes de informações e dos canais de comunicação. Foi o que se observou em relação aos resultados sobre o trabalho dos analistas estudados.

Em relação à formação acadêmica, devido ao tipo de atividade exercida pelos analistas e gestores, os cursos de Administração de Empresas, Ciências Econômicas e Ciências Contábeis foram os que apresentaram maior concentração na comunidade. Vale destacar que os cursos de especialização também estão concentrados nessa linha de desenvolvimento profissional, demonstrando que os sujeitos inseridos nesse contexto profissional necessitam ter conhecimentos aprofundados das técnicas contábeis, administrativas e econômicas. Conforme Baldwin e Rice (1997), gerentes que trabalham com carteiras (portfólio) e analistas de seguros 


\section{$78 \mid 79$}

e investimentos, que trabalham com operações bancárias, devem compreender regras, novas leis da contabilidade, do mercado, além de serem versados nas exigências normativas de leis e regulamentos em geral.

\subsection{Caracterização do processo da comunicação organizacional entre gestores e ana- listas}

O processo de comunicação entre gestores e analistas de crédito das instituições financeiras investigadas corresponde, de modo bastante claro e adequado, aos modelos do processo de comunicação encontrados na literatura. Em outras palavras, os modelos identificados na literatura que ilustram o processo de comunicação organizacional demonstram com propriedade o processo de comunicação estudado. O presente estudo considerou o modelo de Tubbs (2003) como o mais adequado. De fato, pelos resultados obtidos, todos os elementos do processo de comunicação do modelo de Tubbs foram identificados no estudo (comunicador 1, comunicador 2, mensagem, canal, insumos à comunicação, interferências e feedback). O desenho do autor (figura 3) revela que há dinamismo no processo da comunicação.

No contexto estudado (instituições financeiras governamentais), o processo da comunicação ocorre internamente e concentra-se no setor de avaliação de risco de crédito, entre analistas, gestores do próprio setor, agências vinculadas e, com menor intensidade, outros gestores. Os comunicadores 1 e 2 são emissores e receptores de comunicação sobrepondo os papéis, assim como dito por Tubbs. A sobreposição de papéis gera interação e dinamismo recíproco entre as partes, porque o objetivo é que haja efetividade no atendimento, tanto por parte de analistas quanto de gestores, às demandas vindas das agências vinculadas. No processo de comunicação, os gestores, na função primordial de emissores, fazem divulgação do produto/serviço e modelos, publicam normas e esclarecem dúvidas sobre as atividades da unidade relacionada ao processo de avaliação de risco de crédito. Na função de emissores, analistas emitem súmulas e pareceres sobre os processos que avaliam, bem como esclarecem dúvidas e complementam pareceres sobre avaliações do crédito. Gestores e analistas, quando na função de receptores da informação, recebem mensagens vindas das agências sobre demandas de avaliação de risco de crédito e solicitações de esclarecimentos de dúvidas e/ou questionamentos sobre normas e operacionalização de produtos/processos.

Evidenciou-se que existe uma hierarquia no fluxo da comunicação organizacional, em que, primeiramente, as mensagens são avaliadas, interpretadas e, posteriormente, distribuídas pelos gestores aos respectivos subordinados. Ou seja, todas as mensagens chegam primeiramente ao gestor, o que o caracteriza como emissor primordial desse processo. 
Conforme resultados obtidos a partir das entrevistas e por meio dos questionários, o conteúdo das mensagens caracteriza-se, conforme dito por Thayer (1972), Torquato (2002) e Kunsch (2003), como comunicação administrativa. Isso, por sua vez, abrange os conteúdos relativos ao cotidiano da administração e se processa dentro da organização, no âmbito das funções administrativas (gestor e analista) que viabilizam todo o sistema organizacional por meio da confluência de fluxos e redes.

As interferências no processo da comunicação organizacional, tal como definidas no modelo de Tubbs, são abordadas por Kunsch (2003) e Thayer (1972) como barreiras ou ruídos, os quais foram identificados a partir dos dados coletados nas entrevistas e nos questionários. A análise dos dados mostrou que há diversidade de barreiras citadas pelos respondentes. Embora tenha havido essa diversidade, o excesso de informação causado pela falta de filtros nas mensagens constitui uma sobrecarga de informação, tal como discutido tanto por Thayer (1972, p. 222) e, posteriormente, por Kunsch (2003, p. 75). Os resultados quanto a outras barreiras identificadas, tais como falta de clareza e objetividade no conteúdo das normas, distância física entre analistas e gestores, implicando diferentes culturas e entendimento de linguagem, excessivos procedimentos técnicos e sucessivas alterações normativas são todos elementos da análise de autores como Torquato (2002, p. 45), Thayer (1972, p. 215-223) e Kunsch (2003, p. 74-78)

A comunicação interpessoal entre gestores e analistas pode ser considerada como de boa qualidade. Os respondentes da pesquisa não concordaram que haja dificuldade na comunicação entre eles. A frequência de comunicação face a face (reuniões, bate papo e outros) é muito alta no dia a dia. Tais descobertas são compatíveis com o que definem Adler e Towne (2002, p. 10) sobre aspectos qualitativos da comunicação interpessoal. Freitas (2006, p. 100) complementa e chama a atenção para a importância desse tipo de comunicação (face a face) como "maior facilitadora" para o estabelecimento de redes informais de interação.

Um dos elementos mais importantes, que consta no modelo de Tubbs (2003, p. 9) e o diferencia dos demais modelos, é o estímulo à comunicação, abordado neste estudo como insumos usados ao enviar uma comunicação. Pela análise dos dados, constata-se que tanto gestores como analistas levam em consideração o conhecimento sobre uma diversidade de questões. Entre essas questões, a que parece motivar a comunicação é a preocupação com a sua eficácia (comunicação escrita e oral) e com a agilidade na transmissão da informação. Outros aspectos que motivam a comunicação e determinam a sua eficácia são os seguintes: os modos como compõem a mensagem, o correto cumprimento da instrução embutida na mensagem e a não repetição de questões consideradas de amplo conhecimento (não redundância de informações).

O canal também foi citado como fator a ser considerado nas emissões de mensagens, assim como o tipo de mensagem, seja ela rotineira seja de maior relevância, e o público-alvo, fatores esses que podem atingir a eficácia na comunicação. Conforme dito por Ferreira (1998, p. 
190), o modo de comunicar compreende não só a natureza da informação que é transmitida - conteúdo da mensagem -, mas também a forma como a mensagem é transmitida, esses dois processos determinam o processo de comunicação. Meadows (2001, p 251) complementa que o impacto da comunicação pode variar de acordo com o contexto e com o canal. Além disso, o autor (MEADOWS, 2001, p. 247) ressalta que a natureza da interação entre participantes pode depender do canal de comunicação empregado. Meadows (2001, p. 251) destaca que discussões com colegas são categorizadas como de alta importância para aquisição de informações relevantes e para o compartilhamento de informações sobre conhecimento técnico e conceitos mais complexos. Nesse sentido, analistas e gestores estudados comunicam-se intensamente face a face para discutir assuntos relacionados às atividades rotineiras do trabalho, com colegas e os próprios gestores da área. $\mathrm{O}$ telefone é usado geralmente para a comunicação com as agências que estão distribuídas geograficamente em regiões mais distantes e para tratar de assuntos operacionais mais complexos. O e-mail é usado frequentemente para comunicação interna sobre rotinas de trabalho, tanto o e-mail corporativo pessoal como o e-mail da empresa, ou seja, aquele que representa o nome da unidade.

É importante destacar as conclusões de Allen (1977, p. 115-269) sobre o layout físico no ambiente de trabalho, que gera impactos na comunicação organizacional, favorecendo-a ou desestimulando-a. Segundo o autor, os padrões de comunicação interpessoal de pessoas que ocupam uma área particular no escritório, laboratório ou outra divisão são especialmente suscetíveis às restrições arquitetônicas.

O principal determinante na escolha do "comunicador" é a distância física que separa as áreas na organização. Portanto, a oportunidade para o estabelecimento de contatos interpessoais face a face com colegas de trabalho para discussões e compartilhamento de ideias é favorecida pelo layout físico. Esses contatos constituem o veículo principal para transmitir ideias, conceitos e outras informações necessárias a fim de assegurar desempenho efetivo no trabalho. Dessa maneira, um grupo pode alcançar efetividade na resolução de problemas onde informações compartilhadas realçarão a qualidade de produção de grupo. Isso é percebido nas duas organizações estudadas. Em uma delas, os analistas estão mais centralizados e segmentados por tipos de avaliações e, em outra, estão mais distribuídos em unidades geográficas mais distantes. Em razão disso, as experiências e o compartilhamento de informações estão centralizados no mesmo grupo. Da mesma forma, o tipo de avaliação interfere na maior ou menor influência da comunicação interna ou externa. Conforme registrado em entrevista, quanto mais distantes estão os analistas, mais a comunicação perde sua efetividade. No entanto, quando eles estão mais próximos, melhor se comunicam e compartilham informações.

Outro elemento do modelo de Tubbs, o feedback, constitui, para o autor, fonte de informação, pois retorna ao emissor mensagens e comportamentos, tanto esperados como não esperados. Isso ficou evidenciado de forma clara no processo da comunicação da instituição Banco do 
Brasil, onde as mensagens com dúvidas são tratadas tempestivamente e por diversos canais. $\mathrm{O}$ banco, até mesmo, está qualificado pela ISO no processo de atendimento às agências. Na instituição Caixa, o processo de comunicação entre gestor e agências, analistas e gestor ou analista e agência segue a hierarquia da comunicação estabelecida na empresa, que tende a dificultar e causar demora no atendimento às necessidades de informação.

\subsection{Padrões de comportamento informacional de gestores e analistas de risco de crédito}

Neste estudo, o modelo de comportamento adotado para o estudo dos padrões de comportamento informacional de gestores e analistas de risco de crédito foi o de Wilson (1981). É importante relembrar que o autor considera o comportamento informacional como a totalidade do comportamento humano em relação a fontes e canais de informação. Sob a perspectiva fenomenológica, Wilson observa que a pessoa está sempre construindo seu mundo social, inclusive o profissional, e que as necessidades de informação nascem das tentativas de dar sentido a esses mundos. Assim, no ambiente de trabalho, a necessidade de informação surge do trabalho e dos papéis que a pessoa desempenha na organização e na vida social. Daí, as necessidades pessoais podem ser de natureza psicológica, emocional ou cognitiva.

O presente estudo levou em conta, basicamente, necessidades cognitivas dos sujeitos investigados. Os resultados obtidos mostram que, como definido no modelo de Wilson (1981), tanto o papel profissional desempenhado por gestores e analistas das instituições financeiras estudadas quanto suas necessidades pessoais são influenciados pelo ambiente de trabalho e têm dimensões socioculturais, político-econômicas e físicas.

Considerando que gestores e analistas das duas instituições estudadas têm o computador e a internet como instrumentos de trabalho, a maioria usa diariamente o correio eletrônico e outros recursos tecnológicos como os principais canais para busca e uso das informações necessárias à condução de suas atividades, incluindo a comunicação. Esses resultados são compatíveis com a maioria dos estudos que incluem o uso do e-mail na comunicação. De fato, desde o final da década de 1990, o correio eletrônico tem sido o meio mais usado na comunicação, em diferentes contextos. Soares (2003) e Chagas (2006), por exemplo, identificaram resultados semelhantes em suas pesquisas, nos contextos de empresas de base tecnológica e de gestão da saúde pública, respectivamente.

Fontes internas como a intranet e o sistema de normas das instituições estudadas aparecem como as fontes mais usadas pelos gestores e analistas. Isso se justifica pelo perfil e pelo tipo de organização com forte influência normativa por parte das autoridades monetárias. Colegas da própria unidade são usados como fontes de informações internas e as conversas acontecem 
face a face. As fontes externas mais usadas, como é de se esperar, são o site do Bacen e os jornais de conteúdo notadamente econômico. O tipo de informação mais usado é a informação organizacional que consta no sistema de normas e nas páginas da intranet, conforme ilustrado no Quadro 2. Analistas buscam diariamente informações organizacionais constantes no sistema de normas e nos sistemas corporativos. Além disso, buscam também, diariamente, informações sobre negócios que constam nos documentos entregues pelas empresas como, por exemplo, a informação financeira contábil sobre empresas, demonstrações financeiras, bolsa de valores (ações), cotações, preços, financiamentos, investimentos, endividamentos, informações cadastrais, documentos pessoais dos sócios e representantes da empresa. Buscam também informações de natureza tecnológica, embora com frequência mais baixa, mais especificamente para desenvolvimento de modelos de riscos e informação para desenvolvimento de produtos de crédito. A informação científica, ainda que em menor frequência, também é usada pela comunidade de analistas e gestores, como consultas a monografias, teses, dissertações, periódicos, abstracts, índices, anais de conferências, congressos ou outros eventos científicos.

Quadro 2 - Fontes de informação versus tipos de informação

\begin{tabular}{|c|c|c|c|c|c|}
\hline \multicolumn{3}{|c|}{ FONTES INTERNAS } & \multicolumn{2}{c|}{ TIPOS DE INFORMAÇÃO } \\
\hline & No & $\%$ & ORGANIZACIONAL & No & $\%$ \\
\hline $\begin{array}{c}\text { Sistema de } \\
\text { normas }\end{array}$ & 175 & 89,7 & Informação normativa & 178 & 91,3 \\
\hline $\begin{array}{c}\text { Páginas da } \\
\text { intranet }\end{array}$ & 161 & 82,6 & $\begin{array}{c}\text { Informação corporativa } \\
\text { (sites e portais de } \\
\text { informação internos) }\end{array}$ & 147 & 75,4 \\
\hline
\end{tabular}

Fontes: Dados da pesquisa.

Em outros contextos organizacionais e em outras profissões, foram encontrados resultados semelhantes. Em estudo sobre gestores de empresas de softwares, Soares (2003) identificou a informação tecnológica e a informação para negócios como os tipos de informação produzida e utilizada pelos gestores. Damásio (2001) identificou os tipos de informação especializada mais usados no setor das indústrias de grande porte, constatando que a utilização de tipos e fontes de informação industrial visa, principalmente, a responder questões sobre empresas concorrentes, e que as indústrias procuram utilizar informações que respondam as situações que requerem soluções imediatas, subsidiando a competitividade.

Quanto ao uso das informações buscadas por gestores e analistas, os resultados mostraram o desenvolvimento de modelos e de metodologias de risco de crédito para avaliação e análise de clientes. Esse comportamento também foi identificado, por Soares (2003), nos gestores das EDCSs. 
O comportamento de gestores e analistas de risco de crédito de instituições financeiras federais no Brasil no que se refere à busca e ao uso de informações e à comunicação entre eles e as agências pode verificado nos resultados obtidos. Isso significa que as mensagens trocadas entre os atores do processo de comunicação estudado estão centradas nas questões relacionadas ao sistema de normas das instituições e visam a responder com eficácia às demandas por crédito nas duas instituições estudadas. Para isso, buscam informações em fontes especializadas, realizam a análise e a avaliação de risco (analistas) e geram produtos, serviços e normas de crédito (gestores).

\subsection{Comportamento informacional comunicação organizacional}

Neste estudo, o objetivo de identificar aspectos do comportamento informacional que podem ser considerados como insumos à comunicação entre gestores e analistas de risco de crédito vem ao encontro das observações de Thayer (1972) e das sugestões de Allen (1977). Considerando que a Ciência da Informação tem expandido seu campo de estudo, inicialmente centrado na ciência e tecnologia, para outros contextos, incluindo o das organizações, cabe pensar nas reflexões de Allen e considerar as variáveis dos estudos de comportamento informacional em organizações (conhecidos como estudos de usuários), incluindo-as como variáveis da comunicação organizacional.

Chagas (2006) realizou estudo com os profissionais de gestão da saúde pública no Brasil, concluindo que a efetividade do processo de comunicação resulta da inserção dos padrões de comportamento informacional desses profissionais como subsídio ao delineamento do sistema de informação da empresa, com vistas a melhorar a comunicação.

De fato, parece importante que o emissor tenha conhecimento dos aspectos de comportamento do receptor (necessidades, busca e uso de informação) para melhorar a comunicação. Na interpretação de Costa (2007), os trabalhos de Belkin (1978, p. 81) permitem inserir a informação no processo de comunicação, quando esta é estudada no nível linguístico. Na visão de Belkin, o conceito de informação conforma um sistema de comunicação, associando a informação à estrutura conceptual de um gerador, que a modifica em função de um propósito, intenção ou conhecimento do estado de conhecimento do receptor. No nível cognitivo, Belkin centra o foco da informação nas transformações que ocorrem nos estados de conhecimento do indivíduo. Nesse contexto, o que o autor aborda como estado anormal de conhecimento pode ser entendido como necessidade de informação, conceito que conforma, tal como busca e uso, o estudo do comportamento informacional.

Nesse aspecto, entende-se que todas as ações relacionadas às rotinas de trabalho de gestores e analistas de risco de crédito constituem insumos à comunicação organizacional entre eles, 
na medida em que são avaliadas e incorporadas nos padrões de comportamento dos gestores com retorno ao próprio ciclo da comunicação. O resultado da inserção dos padrões de comportamento informacional desses profissionais como subsídio à elaboração de normas de forma eficaz e o aprimoramento dos sistemas corporativos de forma a facilitar o processo de busca e uso de informações dinamizam a comunicação, tornando-a ágil e com menos incertezas, ou seja, reduzindo o estado de anomalia.

Os resultados obtidos por meio da análise das entrevistas e dos questionários mostraram que o ambiente de trabalho desses especialistas é altamente influenciado pela necessidade do uso das normas internas e externas e pela necessidade de produtividade com o mínimo de riscos operacionais. Isso ocorre de acordo com as necessidades de informação e com as atribuições das funções inerentes ao cargo, que levam a uma interação com colegas da própria unidade e colegas de agências para concretização dos negócios com o cliente. Dessa forma, o comportamento comunicacional e informacional entre esses especialistas é intenso e muito dinâmico, a fim de que possam executar as suas atividades em conformidade com as normas, buscar informações e comunicar um resultado esperado pelas agências.

Os resultados alcançados no presente estudo permitem afirmar que os gestores e analistas de risco de crédito estudados têm levado em conta aspectos da natureza da informação que será transmitida, o conteúdo da mensagem e, também, a forma como é transmitida. Nesse contexto, consideram importante a inclusão dos padrões de busca e uso da informação dos interlocutores, bem como dos recursos usados para executar as atividades inerentes ao cargo, como insumo na comunicação entre eles. Parecem, portanto, que, em relação a essa questão, estão de acordo com a abordagem de Belkin (1978) e de autores como Allen (1977).

\section{CONCLUSÕES}

A adoção das abordagens qualitativa e quantitativa e a respectiva triangulação das informações obtidas pelo uso de questionários e entrevistas possibilitaram minimizar algumas das desvantagens específicas de cada um dos instrumentos adotados. Assim, o estudo permitiu, de acordo com cada objetivo específico, identificar o perfil dos gestores e analistas de risco de crédito de instituições financeiras governamentais. É possível afirmar que esses atores são profissionais de nível superior, principalmente das áreas de Administração, Contabilidade e Economia, e que a grande maioria possui pós-graduação em nível de especialização.

Em relação ao processo da comunicação organizacional, é possível afirmar que o modelo de Tubbs é adequado e retrata bem as relações entre gestores e analistas. O estudo emitiu a identificação dos principais elementos do processo da comunicação organizacional nas instituições Caixa e Banco do Brasil S/A, no intuito de obter respostas para questões do tipo: quem gera o quê? Para quem? 
Com que objetivo? Qual o conteúdo? Qual o fluxo das mensagens? Que estímulos motivam a comunicação? Que barreiras dificultam a comunicação? Como se dá o feedback?

Já na parte do estudo sobre padrões de comportamento informacional de gestores e analistas de risco de crédito, fundamentado no modelo de Wilson, foi possível identificar a influência dos papéis exercidos sobre esse comportamento. Nesse sentido, o estudo pode identificar que atividades desenvolvidas por analistas e gestores influenciam suas necessidades de informação e seu comportamento na busca e no uso de informações.

A tentativa de relacionar, teoricamente, aspectos do comportamento informacional (necessidades, busca e uso de informação) como insumo (estímulo) à comunicação, é um exercício que vem sendo praticado com frequência. Nesse sentido, o presente estudo inseriu a abordagem como fundamentação para proposição de um dos seus objetivos. Observou-se, pelos dados obtidos, que essa não parece constituir uma questão entendida com clareza pelos sujeitos estudados. No entanto, pode-se concluir, a partir dos resultados obtidos sobre essa questão, que os gestores e analistas mostram preocupação com a comunicação, principalmente a escrita, associando o seu significado às normas e aos padrões institucionais. Desse modo, esses atores entendem que o conhecimento sobre necessidades, busca e uso de informação facilita a comunicação com eles.

\section{REFERÊNCIAS}

ADLER, R. B.; TOWNE, N. Comunicação interpessoal. 9. ed. Rio de Janeiro: LTC, 2002. 50 p.

ALLEN, T. J. Managing the flow of technology: technology transfer and the dissemination of technological information within the R \& D Organization. Cambridge, Mass.: MIT Press, 1977.

BALDWIN, N. S.; RICE, R. E. The information-seeking behavior of securities analysts: individual and institutional influences, sources and channels, and outcomes. Journal of the American Society for Information Science. v. 48, n. 1, p. 674-693, 1997.

BELKIN, N. J.; ODDY, R. N. Document retrieval base on the automatic determination of the user's information needs. Journal of Informatics, v.2, n.1, p.8-11, 1978.

BERLO, D. K. O Processo da comunicação: introdução à teoria e à prática. São Paulo: Martins Fontes, 1989.

CHAGAS, L. D. Efetividade do processo de comunicação com base na teoria do comportamento informacional: o caso de um organismo internacional da área da saúde pública sediada 
no Brasil. 2006. Dissertação (Mestrado) Programa de pós-graduação em Ciência da Informação, Departamento de Ciência da Informação e Documentação, Universidade de Brasília. Brasília, 2006.

CHOO, C. W. A organização do conhecimento. Tradução de Eliana Rocha. São Paulo: SENAC, 2003. 425 p.

COSTA, S. M. Ciclo da comunicação. 2/2005. Notas de aula (Tópicos especiais em Ciência da Informação). Departamento de Ciência da Informação e Documentação, Universidade de Brasília, 2007.

CRESWELL, J. W.; CLARK. V. L. Designing and conducting mixed methods research. USA: SAGE, 2007. 275 p.

DAMÁSIO, E. O profissional da informação na indústria: habilidades e competências. 200. Dissertação (Mestrado) Programa de pós-graduação em Biblioteconomia e Ciência da Informação, Pontifícia Universidade Católica de Campinas. Campinas, 2001. Disponível em:< http://www.ufpe. br/snbu/docs/41.a.pdf >. Acesso em: 15 fev. 2017.

DENZIN, N. K.; LINCOLN, Y. S. Handbook of research qualitative. 2. ed. Califórnia. SAGE, 2000. 1064 p.

FERREIRA, J. M. C.; [et al.]. Psicossociologia das Organizações. Alfragide, McGraw-Hill, Portugal, 1998.

FREITAS, L. Comunicação interpessoal face-a-face: uma forma de poder nas organizações privadas. Monografia apresentada ao Departamento de Relações Públicas, Propaganda e Turismo da escola de Comunicações e Artes da Universidade de São Paulo. São Paulo, 2006. Disponível em: http://gestcorp.incubadora.fapesp.br/portal/monografias/pdf/Leandro\%20Freitas.pdf/. Acesso em: 10 jun. 2007.

GASQUE, K. C. G. D. Comportamento dos professores da Educação Básica na busca de informação para a formação continuada: estudo de caso dos Colégios Maristas. 2003. Dissertação (Mestrado) Departamento de Ciência da Informação e Documentação, , Universidade de Brasília. Brasília, 2006.

KUHLTHAU, C. C. Inside de Search Process: information seeking from the user's perspective. Journal of the American Society for Information Science, Washington, D.C, v. 42, n. 5, p. 361-371, 1991.

KUNSCH, M. M. K. Planejamento de relações públicas na comunicação integrada. $4^{\mathrm{a}}$ ed. São Paulo: Summus, 2003. 417 p. 
MEADOWS, A. J. Comunicação. Revista da biblioteconomia de Brasília, v. 25, nº. 2, p. 239-254, jul./dez. 2001.

PINHEIRO, L. V. R. Usuário $\rightarrow$ Informação: o contexto da ciência e da tecnologia. Rio de Janeiro, LTC - Editores S. A. 1982. 45 p.

SOARES, J. B. Comportamento de gestores de empresas de base tecnológica na busca e uso de informação. 2003. Dissertação (Mestrado) Programa de pós-graduação em Ciência da Informação, Departamento de Ciência da Informação e Documentação, Universidade de Brasília. Brasília, 2003.

THAYER, L. Princípios de comunicação administrativa.[S.l.]: Ed. Atlas, 1972.

THIOLLENT, M. Metodologia da pesquisa ação. 5. ed.. São Paulo. Ed. Cortez. 1992. 110 p.

TORQUATO, G. Comunicação empresarial, comunicação institucional. São Paulo: Summus, 1986. 179 p.

TORQUATO, G. Tratado de comunicação organizacional e política. São Paulo: Pioneira Thomson Learning, 2002. 304 p.

TUBBS, S. L.; MOSS, S. Organizational communication. In: TUBBS, S. L.; MOSS, S . Human communication: principles and contexts. 9. ed. Boston: MCGraw-Hill, 2003.

WILSON, T. D. On user studies and information needs. Journal of Documentation, v.37, n. 1, p. 3-15, 1981.

WILSON, T. D. Information behavior: an interdisciplinary perspective. Information Processing and Management, v. 33, n 4, p. 551-572, 1997.

WILSON, T. D. Models in information behavior research. Journal of Documentation, v. 55, no 3, p. 249-270, 1999.

WILSON, T. D. Human information behavior. Informing Science Research, Colorado, v. 3, n ${ }^{\circ}$ 2, 2000 .

WILSON, T. D. Evolution in information behavior modelling: Wilson's model. In: FISHER, K. E., ERDELEZ, S., MCKECHNIE, L. (Eds.). Theories of information behavior. Medford, N.J.: Published for the American Society for Information Science and Technology by Information Today, 2005, p. 31-36. 


\section{CAPÍTULO 3}

0

0
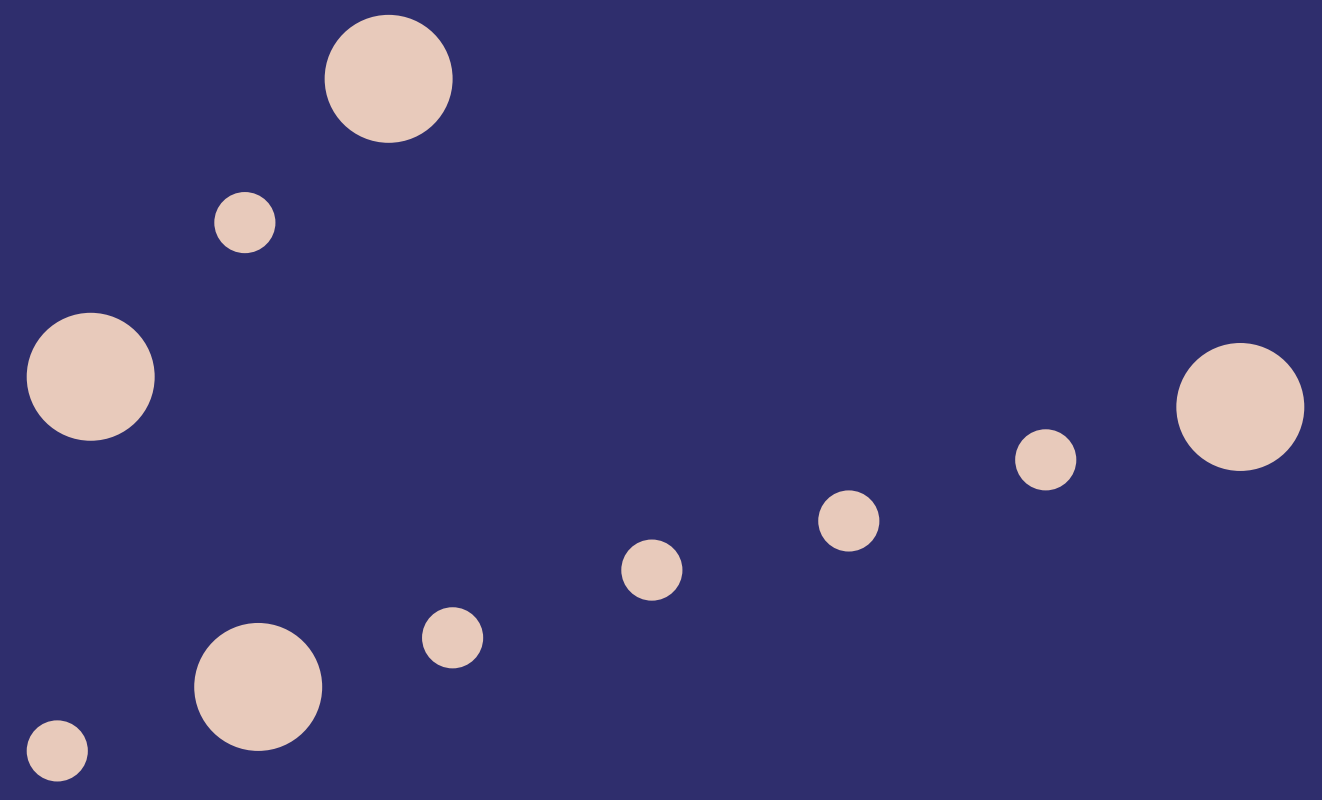

- 00 


\section{O PROCESSO DE COMUNICAÇÃO ENTRE USUÁRIOS E ANALISTAS DE SISTEMAS NO CONTEXTO DAS ORGANIZAÇÕES}

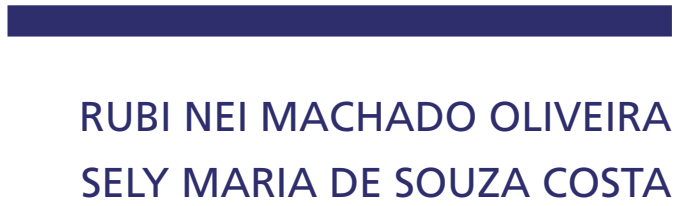

\section{INTRODUÇÃO}

Estudos realizados com bastante frequência pela área da Computação tentam identificar o processo de comunicação entre usuários e analistas de sistemas, durante a fase de levantamento de requisitos no processo de desenvolvimento de software, sob a ótica da Engenharia de Software. A grande maioria foca na proposição de metodologias e ferramentas para automação da análise dos requisitos necessários ao desenvolvimento de produtos de software.

Porém, uma observação mais cuidadosa da questão aponta para a necessidade de que o problema seja estudado por meio de abordagens e métodos das Ciências Sociais e Humanas. Pinto Filho (2005) estudou as etapas dos processos comunicacionais, visando à formulação de um modelo de análise de requisitos que considerasse as questões comunicacionais no âmbito da Ciência da Informação. Sua motivação foi o fato de que, tanto na Ciência da Informação quanto na Ciência da Computação, o assunto era pouco estudado.

No entanto, a dificuldade de profissionais de informática para entender claramente as necessidades dos usuários de sistemas de informação, especialmente na fase de levantamento de requisitos para o desenvolvimento de novos produtos de software, é um problema já identificado nos estudos de comunicação organizacional. Sobre isso, Xexéo (2007, p. 38), autor da área da Computação, afirma que, "na prática do desenvolvimento de software, percebemos que na grande maioria dos casos o usuário tem dificuldade de expressar suas necessidades". $\mathrm{O}$ autor acrescenta que a dificuldade que usuários e analistas enfrentam para encontrar uma linguagem comum e o foco específico nas técnicas de solução (responsabilidade do analista, e não do usuário) é o principal motivo que leva à dificuldade de comunicação. 
Com o propósito de contribuir para a melhoria da comunicação entre usuários e analistas de sistemas, o presente estudo visou a identificar, na literatura e em trabalho de campo, questões relacionadas à análise de requisitos, à comunicação organizacional e à gestão da informação e do conhecimento. Para tal, propõe um modelo do processo de comunicação entre usuários e analistas de sistemas que enfatiza o compartilhamento de conhecimento durante a fase de levantamento de requisitos dentro do processo de desenvolvimento de software.

\section{FUNDAMENTAÇÃO TEÓRICA}

A análise da literatura não permitiu encontrar muitos trabalhos que tenham o intuito de identificar a lacuna existente entre o que é solicitado pelo usuário e o que é entregue pelo analista, sob a ótica da comunicação organizacional (PINTO FILHO, 2005). Nesse contexto, Rezende (2002, p. 6) observa que o analista de sistemas deve possuir um conjunto de habilidades, em especial a de comunicação interpessoal, tanto oral quanto escrita, que é crucial para o desempenho de suas atividades. Gillard (2005, p. 39) acrescenta que as dificuldades ou obstáculos existentes na comunicação devem ser sanados por meio da prática, o que leva a crer que é necessário investir em atividades que promovam e enriqueçam a comunicação.

Kotonya e Sommerville (1998) já alertavam que os sistemas entregues por analistas aos usuários não faziam o que o usuário realmente queria que fizessem e, muitas vezes, não eram usados de maneira efetiva pelas pessoas que pagavam por eles. Constata-se, assim, que o problema de comunicação que impede os analistas de conseguirem capturar as reais necessidades dos usuários é antigo e permanecia até o momento de realização do presente estudo. Algumas vezes, isso ocorre porque os usuários têm dificuldade de transmitir aos analistas suas necessidades (XEXÉO, 2007). Em outras situações, isso decorre do fato de os analistas não conseguirem identificar os reais requisitos dos usuários para o desenvolvimento do produto de software (CHENG; ATLEE, 2007). Na presente pesquisa, portanto, mostrou-se necessário o estudo dessa questão à luz das teorias da comunicação organizacional e da gestão da informação e do conhecimento. Esses temas, sem dúvida alguma, fornecem o embasamento teórico necessário, contribuindo para o melhor entendimento da questão no contexto da Ciência da Informação, mais especificamente no que concerne à comunicação organizacional.

Nesse contexto, Kotonya e Sommerville (1998, p. 55) enumeram o que consideram as quatro dimensões que devem ser dominadas pelo profissional na hora de identificar os requisitos do sistema: 1) entender o domínio da aplicação; 2) entender o problema a ser resolvido; 3 ) entender o contexto do negócio (regras do negócio); 4) entender as necessidades e restrições de todos os interessados no sistema. Observa-se, então, que compreender as necessidades do usuário e todo o contexto que o envolve deve ser uma rotina para analistas. $\mathrm{Na}$ área de Engenharia de Requisitos, Cheng e Atlee (2007) chegaram às mesmas conclusões, afirmando que o conjunto 
das necessidades dos usuários corresponde aos requisitos do software. Semelhantemente a Kotonva e Sommerville, as autoras consideram que a Engenharia de Requisitos terá sucesso se envolver corretamente três atividades distintas. A primeira corresponde ao correto entendimento das necessidades dos usuários, dos clientes e de outros stakeholders. A segunda refere-se ao perfeito entendimento do contexto no qual o software será utilizado. Finalmente, a terceira atividade compreende modelar, analisar, negociar e documentar os requisitos identificados.

Pelo que se observa no contexto em estudo, a gestão da informação com foco específico na necessidade de informação de usuários é input para o processo de comunicação. Este, por sua vez, é veículo do processo de socialização do conhecimento no âmbito organizacional. É esse, portanto, o foco deste estudo.

Creswell (2007, p. 59) observa que a revisão da literatura deve fornecer a fundamentação teórica de uma pesquisa, explorando "aspectos do fenômeno central que está sendo abordado". Nesse sentido, a fundamentação teórica do presente estudo inclui questões relevantes para a discussão a respeito dos aspectos derivados dos objetivos inicialmente definidos. Tópicos sobre o processo de comunicação nas organizações, aspectos ligados à Engenharia de Software, principalmente no que concerne à Engenharia de Requisitos, e gestão da informação e do conhecimento estão compreendidas no arcabouço literário revisado. Servem, portanto, de base para o entendimento de aspectos relacionados com as interações e com o compartilhamento de conhecimento na fase de levantamento de requisitos dentro de um processo de desenvolvimento de software.

No que concerne à comunicação, Meadows (2001, p. 239) chama a atenção para o fato de que a comunicação, palavra com diversos significados e fundamental para a atividade social, é alvo de estudos em diversas disciplinas, tanto nas Ciências Exatas quanto nas Ciências Sociais e nas Humanidades. De forma análoga a Meadows (2001), Berlo (2003, p. 15) alega que a "comunicação humana compreende a produção da mensagem por alguém, e a recepção dessa mensagem por alguém”. Berlo (2003, p. 42) ainda acrescenta que, para existir fidelidade na comunicação, existe a necessidade de que emissor e receptor possuam três habilidades para tratar com a mensagem. A primeira diz respeito à escrita e à fala, para a codificação. A segunda refere-se à leitura e à audição, para a decodificação. A terceira está relacionada ao pensamento ou raciocínio, utilizado tanto para codificar quanto para decodificar a mensagem recebida. Em complemento, Curral e Chambel (2001, p. 358) consideram que a comunicação interpessoal se caracteriza pela ação humana de enviar e receber mensagens. Entretanto, é necessário que a mensagem enviada pela fonte seja codificada pelo uso de um conjunto de símbolos que possuam significado para o receptor. Desse modo, a comunicação só ocorrerá se o receptor for capaz de entender o significado da informação recebida, decodificando a mensagem e respondendo ao estímulo recebido. Esse processo é incremental, pois, a cada nova mensagem, novos estímulos são produzidos de forma que a capacidade do receptor para responder a novos estímulos é ampliada. 


\section{$92 \mid 93$}

Considerando a importância da comunicação em todos os contextos, processos de comunicação têm sido estudados por inúmeros autores, que estabeleceram modelos para ilustrá-los. Para McQuail e Windahl (1993, p. 5), por exemplo, a comunicação envolve, em termos gerais, um emissor, um canal, uma mensagem transmitida, um receptor, uma relação entre emissor e receptor, um efeito da mensagem, um contexto em que ocorre a comunicação e um conjunto de coisas ao qual a mensagem se refere. Chagas e Costa (2007, p. 40) consideram que o modelo apresentado por Tubbs e Moss (2003) é um dos que melhor representa o processo de comunicação, pela riqueza dos elementos considerados (figura 1), mostrando a natureza cíclica e crescente da comunicação. Isso ocorre porque Tubbs e Moss incorporam ao processo filtros individuais que interferem na interpretação das mensagens por ambos os comunicadores (emissor e receptor), refletindo a relevância dos modelos mentais desses atores nas intenções de comunicação da mensagem.

Figura 1 - Modelo de Tubbs

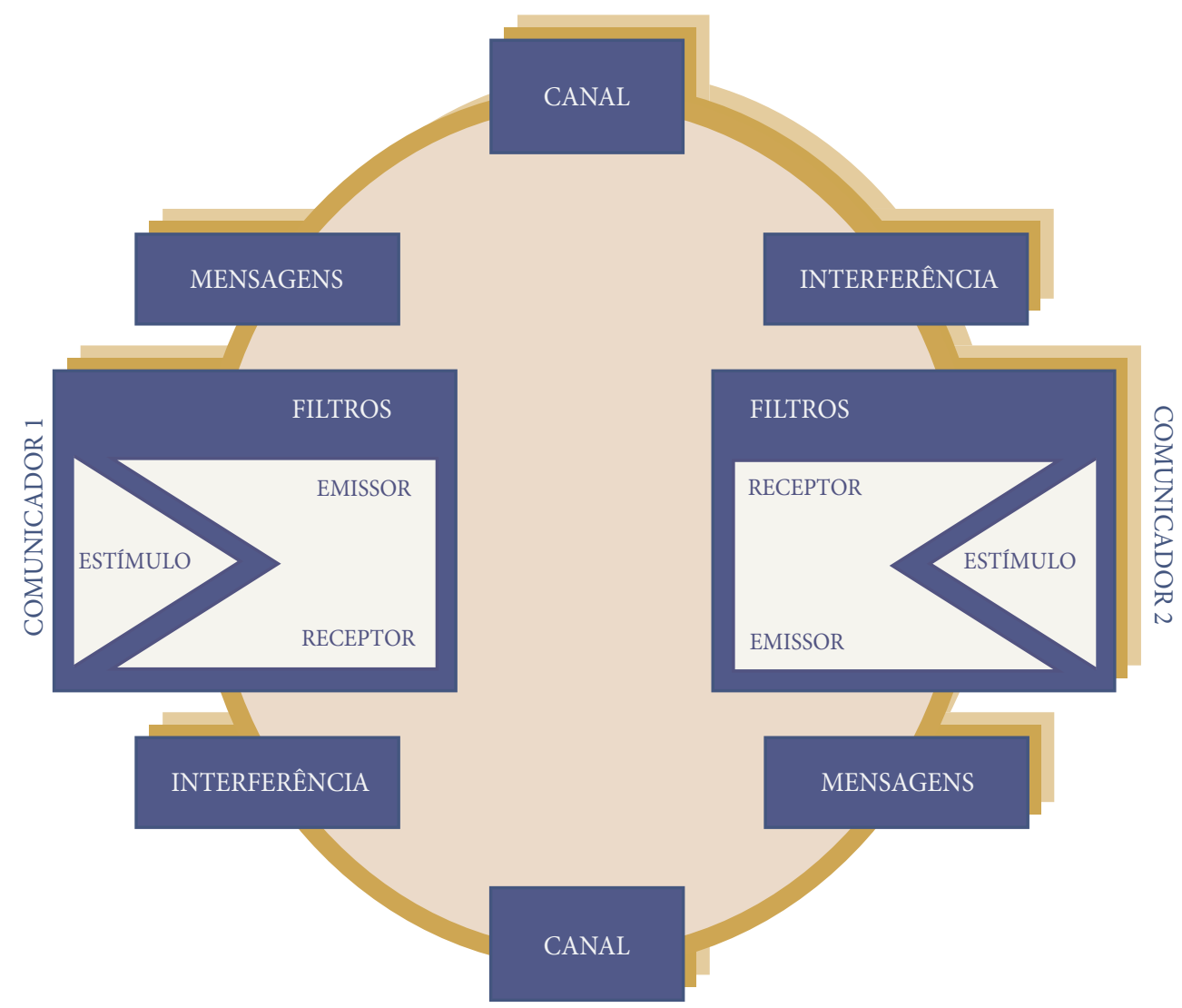

Fonte: Traduzido de Tubbs e Moss (2003, p. 9). 
É essencial observar que as questões envolvidas nas discussões sobre a comunicação dependem tanto do contexto quanto da abordagem adotada. Marchiori (2005), por exemplo, considerando o ambiente das organizações, ressalta a necessidade de gerenciar a informação, elemento básico dentro de uma organização. A autora (Op. Cit., p. 112) acrescenta que "se a comunicação em uma perspectiva individual é enviar mensagens com significado para outros [...], em um contexto organizacional as implicações entre informação e comunicação se alteram".

Miller (2006, p. 1) lembra que a comunicação organizacional está localizada na intersecção entre a organização e a comunicação. Barker e Gaut (2001, p. 172) acrescentam que "a efetividade da comunicação é a chave para o sucesso de qualquer organização". A essa discussão, Meadows (2001, p. 239) acrescenta que, para um estudo mais detalhado, a comunicação pode ser reduzida a duas entidades. A primeira refere-se ao "processo de comunicação", enquanto a segunda diz respeito à "mensagem comunicada". Organização, por sua vez, de acordo com o entendimento de Tubbs e Moss (2003, p. 448), pode ser considerada como um conjunto de indivíduos, pessoas, que, utilizando uma divisão de trabalho, buscam atingir um objetivo comum.

Como visto, a comunicação no ambiente organizacional proporciona a troca de mensagens entre os diversos setores da organização, e é esse trâmite que garante seu funcionamento. No contexto do desenvolvimento de sistemas, especificamente na Engenharia de Requisitos, a comunicação caracteriza-se pela troca de informações sobre as necessidades dos usuários e ocorre entre estes e os membros da equipe de desenvolvimento.

Poucos estudos a respeito da comunicação no contexto da Engenharia de Requisitos foram identificados, entre os quais se destaca o de Saiedian e Dale (2000, p. 423), que apresenta sugestões para melhorar o diálogo entre clientes e desenvolvedores de software. Apoiando-se em trabalho anterior de Holzblatt e Beyer (1995, p. 31), os autores confirmam a visão de que "clientes e desenvolvedores de software devem criar uma compreensão comum dos problemas do trabalho e do impacto das soluções técnicas sobre os trabalhos". No mesmo sentido, Wahono (2002, p. 70) lista alguns dos problemas mais comuns no que se refere aos aspectos relacionados com a comunicação entre usuários e analistas, enfatizando quatro deles: 1) usuários e analistas falam línguas diferentes; 2 ) analistas têm conhecimento pobre a respeito do domínio do problema do usuário; 3 ) informações óbvias são facilmente omitidas; 4) usuários diferentes possuem visões conflitantes sobre o mesmo assunto.

Durante o desenvolvimento de produtos de software a fase de levantamento de requisitos é uma atividade social e comunicativa (COUGHLAN; MACREDIE, 2002, p. 49). De forma semelhante àquela identificada por Wahono (2002, p. 70), os autores observam que existem causas que podem determinar falhas no entendimento dos requisitos do software, entre as quais se encontra comunicação pobre entre as pessoas, o que dificulta o processo de comunicação entre usuários e analistas. 
Como indicado anteriormente, a comunicação e a gestão da informação e do conhecimento possuem imbricações relevantes tanto nas relações intraorganizacionais como nas interorganizacionais. No que concerne à gestão da informação, Cianconi (2001, p. 33) a define como um conjunto de atividades compreendidas por planejar, selecionar, coletar, analisar, organizar, otimizar os fluxos, normalizar, tornar disponível para uso e avaliar informações, disseminando-as em sistemas e serviços. A disseminação em sistemas e serviços, por seu turno, compreende a capacidade da organização em prover o compartilhamento das informações necessárias à operacionalização de suas atividades e à tomada de decisão.

Sobre a gestão do conhecimento, uma das mais conhecidas teorias é a de Nonaka e Takeuchi (1997, p. 68), a qual afirma que o conhecimento é obtido "por meio da interação entre o conhecimento tácito e o conhecimento explícito", passando, posteriormente, por processos de conversão. De acordo com os autores, a conversão do conhecimento ocorre por quatro modos distintos. No primeiro, a externalização, o conhecimento é convertido de tácito para explícito. No segundo, a combinação, o conhecimento é convertido de explícito para explícito. No terceiro, a internalização, o conhecimento é convertido de explícito para tácito. Finalmente, no quarto e último modo, a socialização, o conhecimento é convertido de tácito para tácito. Davenport e Prusak (1998, p. 5) afirmam que o conhecimento “origina-se e é aplicado na mente dos conhecedores", demonstrando, mais uma vez, que o conhecimento é algo interno e próprio do ser humano. Para Jashapara (2005, p. 138), o conhecimento tácito "está embutido no sistema, nos processos e no contexto de uma organização", mesclando-se com o ambiente organizacional onde está inserido, contribuindo para construção do conhecimento organizacional.

A gestão da informação e do conhecimento no processo de desenvolvimento de software e, mais especificamente, na Engenharia de Requisitos tem sido abordada por diferentes autores. No trabalho de Espindola et al. (2005), o foco foi a gestão do conhecimento útil para armazenar e disseminar, entre os integrantes das equipes de desenvolvimento, o conhecimento obtido em projetos nos quais a organização esteve envolvida. Não se refere, portanto, ao compartilhamento de conhecimento entre usuários e analistas.

Oliveira, Araújo e Borges (2007) identificaram que o uso de narrativas sobre os sistemas que precisavam de manutenção auxiliava na captura do conhecimento tácito dos usuários, proporcionando melhoria na comunicação e no compartilhamento do conhecimento entre usuários e analistas. Finalmente, Tiwana (2004) observou que a integração do conhecimento na performance do desenvolvimento de software melhora o seu desenvolvimento. Constata-se, assim, que as práticas atuais de gestão do conhecimento na Engenharia de Requisitos, com exceção do trabalho apresentado por Oliveira, Araújo e Borges (2007), não têm levado em consideração, de forma clara, o conhecimento tácito de usuários. Narrativas também foram 
empregadas na gestão do conhecimento para favorecer o compartilhamento de experiências no ambiente organizacional (BRUSAMOLIN; MORESI, 2008).

Autores como Rezende (2002), Sommerville (2007) e Xexéo (2007) estudaram questões relacionadas à Engenharia de Software, uma atividade de transformação de necessidades (do cliente) em produtos de software (análise, projeto, protótipos e manuais), que culminam em um programa de computador, como parte de um sistema de informação mais amplo e complexo. Diferentes modelos dos processos de desenvolvimento de software também foram objeto de estudos de vários autores, entre eles Booch, Rumbaugh e Jacobson (2000) e Pressman (2006). O conjunto de métodos, técnicas e procedimentos utilizados nesses processos é denominado de Engenharia de Requisitos, por meio da qual se identifica o que o cliente ou o usuário da aplicação precisa que seja feito, tratando-se, portanto, de uma fase importante. Em razão disso, a Engenharia de Requisitos é uma atividade crítica no processo de desenvolvimento de software, estudada por autores como Pressman (2006), Sommerville (2007), Pfleeger e Atlee (2006), Cheng e Atlee (2007) e Ormandjieva, Hussain e Kosseim (2007), entre outros, os quais a ressaltam como cerne do processo de desenvolvimento de software. Faz parte da Engenharia de Requisitos uma profunda interação entre usuários e analistas de sistemas, o que destaca a importância da comunicação efetiva entre eles.

\section{METODOLOGIA}

Verifica-se, com base no que aponta Saracevic (1996, p. 50), uma inter-relação entre a Ciência da Computação e a Ciência da Informação. A primeira encarrega-se de tratar "de algoritmos que transformam informações", enquanto a segunda "trata da natureza da informação e sua comunicação para uso pelos humanos". Assim, faz-se pertinente analisar, sob o ponto de vista da Ciência da Informação, a questão comunicacional do processo que envolve as interações entre usuários e analistas de sistemas. Levando-se em conta as abordagens aqui discutidas, considerou-se necessária, dentro da Engenharia de Requisitos, a construção de um modelo do processo de comunicação (figura 2) que leve em consideração o compartilhamento de conhecimento tácito entre usuários de produtos de software e analistas de sistemas. O modelo determina que a prática de socialização do conhecimento tácito entre usuários e analistas proporcionaria melhoria na comunicação. Dessa forma, o uso de mecanismos de gestão do conhecimento, por sua vez, permitiria maior efetividade na comunicação.

Adotou-se, para a representação básica do processo de comunicação, o modelo proposto por Osgood e Schramm (McQUAIL; WINDAHL, 1993, p. 19), visto ter se mostrado apropriado e suficiente para explicar o processo de comunicação entre usuários e analistas de sistemas. Acrescentaram-se, ao modelo dos autores, os elementos da gestão do conhecimento, especificamente no que concerne ao processo de socialização. O modelo indica que o levantamento 
de requisitos no desenvolvimento de software consiste em um processo de comunicação. A efetividade da comunicação, por sua vez, depende do grau de conhecimento que analistas de sistemas obtêm a respeito das características do ambiente e das necessidades do usuário, assim como o grau de conhecimento dos usuários sobre o trabalho dos analistas. Nesse sentido, a socialização do conhecimento, como processo de gestão do conhecimento entre esses dois grupos de atores, impacta a efetividade da comunicação e vice-versa.

Figura 2 - Modelo conceptual da pesquisa

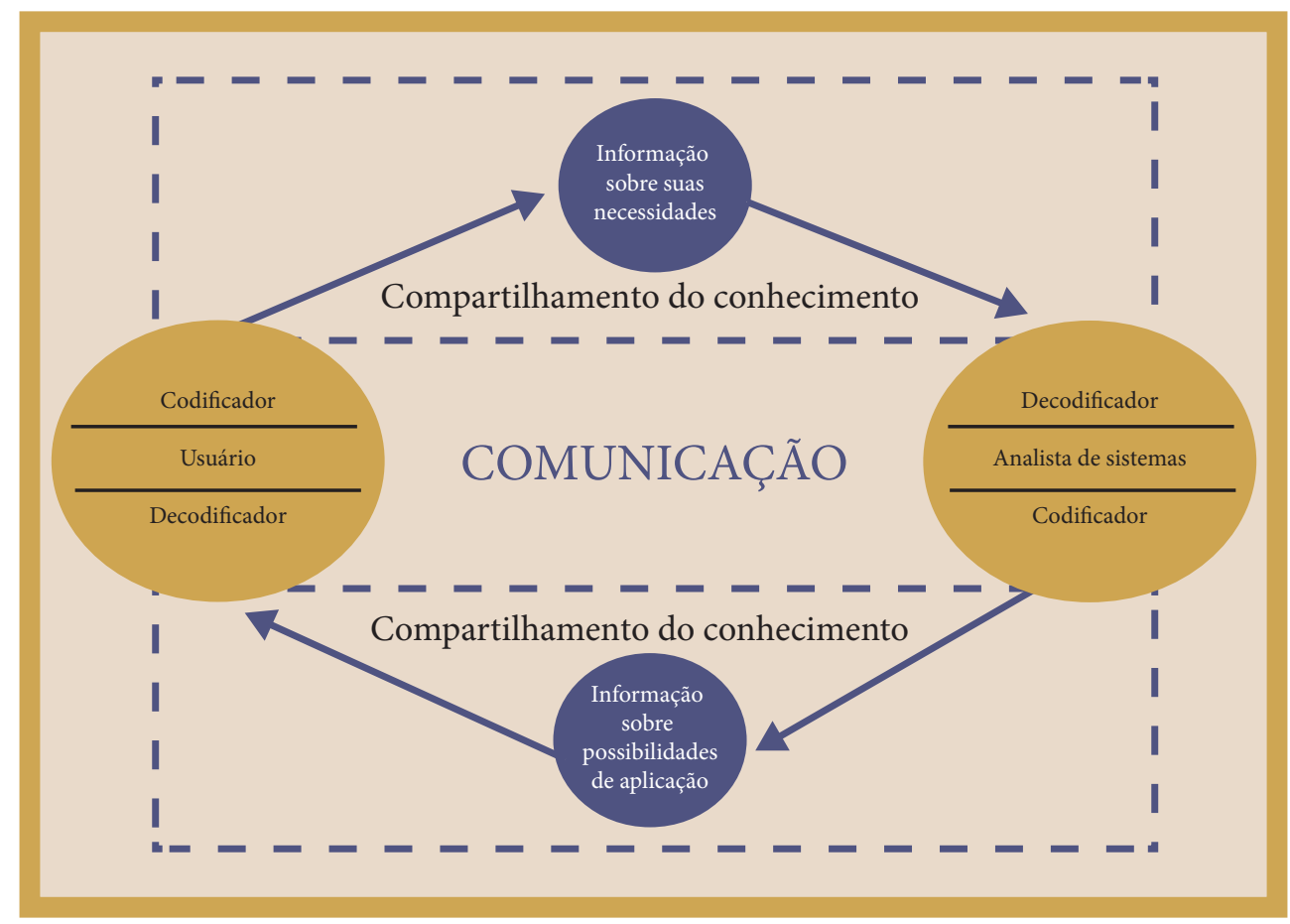

Fonte: Adaptado de Osgood e Schramm (MCQUAIL; WINDAHL, 1993).

O referencial teórico e o modelo conceptual que o ilustra apontaram a necessidade do estabelecimento de um método de pesquisa apropriado que, por meio da coleta de dados, permitisse atingir os objetivos propostos. Assim, identificou-se a necessidade de um enfoque metodológico voltado para a utilização de pesquisa bibliográfica combinada com um levantamento (survey), o qual foi realizado por meio de entrevista semiestruturada. Os dois métodos foram considerados adequados à posterior análise dos dados coletados. Tratou-se de uma pesquisa descritiva em que, conforme argumentam Cervo, Bervian e Silva (2007, p. 61), o pesquisador deve observar, registrar, analisar e correlacionar os fatos ou fenômenos estudados sem, no entanto, interferir no ambiente estudado. Semelhantemente, Rudio (2007, p. 69) é enfático ao afirmar que, na pesquisa descritiva, o pesquisador procura "conhecer e 
interpretar a realidade, sem nela interferir para modificá-la”. No presente contexto, durante a fase de levantamento e análise de requisitos, descrever as interações entre usuários e analistas constituiu procedimento necessário para aplicar os elementos próprios do modelo de processo de comunicação proposto.

Para realização do levantamento, definiu-se como adequada a amostra composta de 12 usuários de produtos de software e 12 analistas de sistemas que atuam em órgãos da administração federal situados no Plano-Piloto do Distrito Federal. Porém, dos 12 usuários e 15 analistas consultados sobre a possibilidade de participarem da pesquisa, apenas 6 usuários e 12 analistas aceitaram o convite. $\mathrm{O}$ roteiro da entrevista foi dividido em duas partes. A primeira visou à identificação de características demográficas do universo pesquisado, enquanto a segunda objetivou obter informações para que se identificassem aspectos do processo de comunicação que pudessem favorecer o compartilhamento do conhecimento entre usuários e analistas de sistemas.

Os analistas entrevistados trabalhavam em setores específicos de desenvolvimento de software, enquanto os usuários participantes foram selecionados intencionalmente (com base na acessibilidade e conveniência), entre aqueles que tivessem participado efetivamente do desenvolvimento de algum produto de software. Embora Creswell (2007, p. 164) considere pouco desejável que sejam utilizadas amostras não probabilísticas, é usual em pesquisas qualitativas dentro das Ciências Sociais, a utilização de amostras definidas intencionalmente por acessibilidade, por conveniência ou por seleção racional (RICHARDSON, 1999, p. 161; GIL, 2007, p. 104).

\section{ANÁLISE E DISCUSSÃO DOS RESULTADOS}

Creswell (2007, p. 194) considera que "o processo de análise de dados consiste em extrair sentido dos dados". Assim, os dados obtidos por meio das entrevistas foram organizados de acordo com os grupos que responderam as questões formuladas. Além da análise de conteúdo para as respostas obtidas pelos entrevistados (interação usuário-analista), foi realizada uma análise bibliográfica dos aspectos referentes aos processos de comunicação que melhor ilustrassem a comunicação entre usuários e analistas de sistemas e as técnicas mais utilizadas para o levantamento de requisitos. Como destacado por Richardson (1999, p. 228), a análise documental e a análise de conteúdo podem ser realizadas em conjunto. $\mathrm{O}$ autor acrescenta que a análise de conteúdo é utilizada em grupos restritos para a análise de dados obtidos por meio de discussões, entrevistas ou conversas grupais em que se utiliza a linguagem oral.

Os resultados da pesquisa bibliográfica foram incorporados na fundamentação teórica do trabalho, levando em conta, principalmente, que colaboravam, de fato, para a discussão no campo teórico. No entanto, três trabalhos são destacados nesta análise quanto aos aspectos 
relevantes na identificação e no relato de técnicas e métodos para levantamento de requisitos: Rezende (2002), Pressman (2006) e Pfleeger e Atlee (2006). Segundo Rezende (2002, p. 185), são seis as principais técnicas utilizadas para o levantamento de dados como base para que o analista identifique os requisitos do software: observação pessoal, questionário, entrevista, seminário, pesquisa e técnica mista. Pressman (2006, p. 124), por sua vez, propõe a utilização da "coleta colaborativa de requisitos", em que um grupo formado por usuários e analistas trabalha somando esforços, com o objetivo de propor soluções para os problemas existentes. Pfleeger e Atlee (2006, p. 146), considerando que cada stakeholder possui uma visão particular do sistema e de como ele deve funcionar, apontam que todos os envolvidos devem ser ouvidos durante a fase de levantamento de requisitos, por meio de técnicas de elicitação de requisitos, tais como: revisão da documentação disponível, observação do sistema em uso, entrevista em grupo e brainstorming. Observa-se, portanto, que todas as técnicas empregadas por analistas de sistemas para o levantamento de requisitos de software envolvem a interação entre usuários e analistas, a qual está inserida em um processo de comunicação em que os atores precisam compartilhar conhecimento intensa e continuamente.

No que concerne ao processo de comunicação envolvido nessa interação, seu estudo em diferentes contextos estão representados e discutidos por meio de uma variedade de modelos identificados na literatura. No contexto organizacional, em particular, os modelos estudados mostram-se úteis à discussão do tema, constituindo, na verdade, seu foco central.

Resultados obtidos por meio de entrevistas sobre o processo de comunicação mostram que tanto analistas quanto usuários acreditam que, para o desenvolvimento de um bom produto de software, é necessário que ambos falem a mesma língua (uma linguagem comum), sem jargões técnicos de ambos os lados. Isso, na percepção dos dois grupos, requer maior clareza, visando à eficiência tanto do processo de desenvolvimento de software quanto da própria comunicação. É, portanto, de extrema importância, a existência de maior aproximação entre os dois grupos, o que poderia trazer benefícios para o processo de comunicação durante o levantamento de requisitos. Na visão de Pfleeger e Atlee (2006, p. 141), analisar requisitos envolve muito mais do que simplesmente escrever o que o usuário quer, pois envolve a expressão de um comportamento desejado e deve definir os estados que podem ser assumidos por objetos ou entidades. Adicionalmente, deve indicar as funções que precisam ser executadas para alterar os estados ou as características desses objetos ou entidades, o que certamente possibilita o sucesso das interações.

A despeito de relatos de sucesso nesse processo por parte de alguns entrevistados, identificou-se que existem muitos problemas de comunicação ainda não resolvidos. Analistas destacaram a importância de que o usuário seja um bom conhecedor do negócio que será 
informatizado, enquanto usuários consideraram que os analistas deviam ter uma visão mais detalhada daquilo que estão analisando.

Solicitados a discorrer sobre um exemplo de sucesso no levantamento de requisitos, parte dos analistas considerou que, para que isso ocorra, é preciso que as necessidades dos usuários sejam interpretadas corretamente. Essa interpretação, associada à reunião de toda a documentação produzida em encontros de usuários e analistas nos casos em que obtiveram sucesso, proporcionou a implementação correta da solicitação. Ou seja, as ações de interpretar e implementar corretamente as necessidades dos usuários e reunir com eles a documentação sobre o sistema atual estão diretamente ligadas aos aspectos já mencionados pelos entrevistados, tais como: linguagem comum, clareza na identificação das solicitações, aproximação entre analistas e usuários e conhecimento sobre o que o usuário quer. Mais que isso, tanto analistas quanto usuários destacaram a necessidade de contato direto e contínuo além de maior comprometimento para melhorar a comunicação.

Com relação aos conhecimentos que seriam importantes para que analistas e usuários desempenhem a contento seus trabalhos, os resultados indicaram, de uma maneira geral, que tanto usuários quanto analistas sentem a necessidade de que conhecimentos específicos sobre o papel desempenhado pelos usuários em suas organizações sejam compartilhados com os analistas. O objetivo é apresentar subsídios que embasem os analistas sobre o processo que deverá ser informatizado. Nesse sentido, o compartilhamento do conhecimento entre usuários e analistas foi uma questão unânime, que foi considerada relevante pela totalidade dos entrevistados para o sucesso da comunicação. Somente essa atuação conjunta e a cooperação entre os dois tipos de atores garantem a socialização do conhecimento.

Após a análise do resultado das entrevistas, chegou-se à conclusão que tanto usuários quanto analistas concordaram que, para um processo de comunicação efetivo, há a necessidade da ocorrência de um compartilhamento do conhecimento entre ambos. De maneira geral, verificou-se que a maioria dos analistas entrevistados adota uma ou mais técnicas indicadas pela literatura e cada um deles possui uma forma particular de encarar o processo de levantamento de requisitos.

Os usuários, por sua vez, também de uma forma geral, tinham consciência de que o sistema resultante das solicitações feitas dependeria de como os requisitos seriam apresentados aos analistas. Nesse ponto, verifica-se a assertiva de Xexéo (2007, p. 35), que é enfático ao afirmar que, antes de iniciado o processo de desenvolvimento, nem mesmo o cliente sabe o que ele realmente quer. É provável que isso aconteça porque os usuários, ao verem as primeiras telas de um novo aplicativo começam a identificar a necessidade de novas funcionalidades que, até aquele momento, não eram nem mesmo imaginadas. Mesmo 
assim, os usuários entrevistados afirmaram que o produto dependeria em muito da maneira pela qual eles transmitem aos analistas as suas solicitações.

Berlo (2003, p. 41) ressalta a necessidade de fidelidade na comunicação, o que requer que o decodificador tenha a capacidade de traduzir a mensagem de forma exata e que o codificador tenha capacidade de codificar a mensagem em uma linguagem composta por códigos conhecidos pelo decodificador. No caso dos resultados da presente pesquisa, ao estabelecer uma linguagem comum entre usuários e analistas, obtém-se um canal de comunicação capaz de transmitir as mensagens com fidelidade entre emissor e receptor.

Seguindo as indicações de Nonaka e Takeuchi (1997, p. 68), em uma abordagem diferente da adotada por Berlo, verifica-se que a socialização entre usuários e analistas no levantamento de requisitos pressupõe a existência de contato mais próximo entre eles, como já dito anteriormente. Michelis (2000, p. 126) acrescenta que a socialização "exige a criação de um espaço virtual comum para os atores de um processo de cooperação”. Para que essa socialização ocorra, mostra-se indispensável a aproximação considerada pelos entrevistados, pois é por meio dessa aproximação que ocorre a socialização e é com a socialização que o conhecimento tácito é transmitido entre os indivíduos (NONAKA; TAKEUSHI, 2008, p. 60). Os entrevistados consideraram ideal a socialização que permite existir a troca recíproca de conhecimento, por meio de uma atuação conjunta e da cooperação de todos. Para tanto, ressaltaram a necessidade de reuniões frequentes. Sobre isso, tanto Pressman (2006, p. 125), ao indicar diretrizes para uma "coleta colaborativa de requisitos", quanto Rezende (2002, p. 191), ao definir "seminário", argumentam a respeito da importância de reuniões planejadas, conduzidas e assistidas por analistas e usuários com o objetivo de captar ideias e obter uma visão mais completa dos problemas da organização.

Verifica-se que, embora tenham um modo particular de trabalhar, todos os analistas seguem passos semelhantes quanto ao levantamento de requisitos. Os usuários, por sua vez, de maneira geral, têm consciência de que o sistema resultante das solicitações feitas aos analistas dependerá de como os requisitos são apresentados a estes. Reafirmase, assim, que, somente com a maior integração entre os dois grupos, os produtos de software serão desenvolvidos com menor probabilidade de erros e em maior conformidade com as necessidades dos usuários. A partir dessas constatações, foi possível elaborar um modelo (figura 3) ao qual foram adicionados três elementos necessários à melhoria da comunicação entre usuários e analistas de sistemas, nomeadamente clareza, comprometimento e cooperação. Optou-se, ademais, por acrescentar a abordagem de Tubbs e Moss (2002), que indica a retroalimentação do processo, visto que a cada nova mensagem o processo se amplia e o feedback obtido influencia mensagens subsequentes de forma crescente. 
Figura 3 - Modelo do processo de comunicação entre usuários e analistas de sistemas

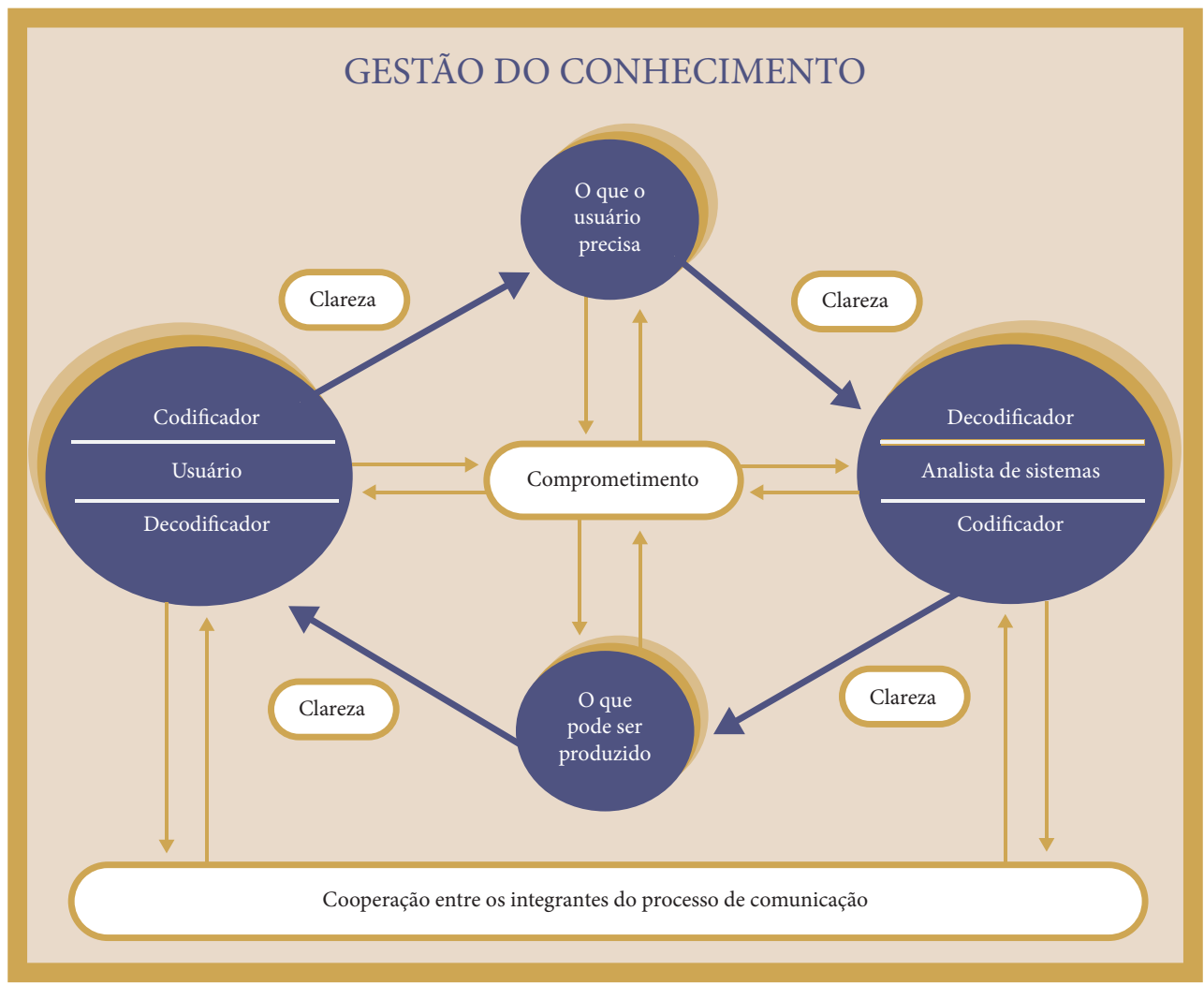

Fonte: Adaptado de Osgood e Schramm (McQuail; Windahl, 1993, p. 19), com adições de Tubbs e Moss, 2002.

Acredita-se que o modelo proposto represente corretamente a comunicação entre usuários e analistas, na medida em que agrega os elementos clareza, comprometimento e cooperação, com o intuito de ser fiel à realidade do processo de comunicação específico entre esses atores. Tais elementos são considerados como componentes próprios da gestão do conhecimento, que os mantêm "encapsulados", pois é necessário que, por intermédio da gestão do conhecimento no processo de comunicação entre usuários e analistas, esses elementos sejam inseridos e gerenciados.

\section{CONCLUSÕES}

O objetivo geral desta pesquisa foi propor um modelo de processo de comunicação entre usuários e analistas de sistemas que enfatizasse o compartilhamento do conhecimento durante a fase de levantamento de requisitos dentro de um processo de desenvolvimento de software. 
Nesse modelo, identificou-se que o sucesso na comunicação entre os indivíduos pode ser alcançado se, à luz da gestão do conhecimento, o processo de comunicação for realizado com clareza, comprometimento e cooperação.

Em suma, para haver comunicação eficiente, é necessário clareza nessa comunicação (ausência de ruído). Para haver compartilhamento do conhecimento, é necessário o comprometimento entre emissor e receptor em relação às metas que se almeja alcançar. Por sua vez, para que as metas sejam alcançadas, é necessário cooperação entre os envolvidos.

\section{REFERÊNCIAS}

BARDIN, L. Análise de conteúdo. 4. ed. Lisboa: Edições 70, 2009.

BARKER, L. L.; GAUT, D. R. Communication. 8. ed. Boston: Allyn \& Bacon, 2001.

BERLO, D. K. O processo da comunicação: introdução à teoria e à prática. 10. ed. São Paulo: Martins Fontes, 2003.

BOOCH, G.; RUMBAUGH, J.; JACOBSON, I. UML: guia do usuário. Rio de Janeiro: Campus, 2000.

BRUSAMOLIN, V.; MORESI, E. Narrativas de histórias é uma técnica de gestão do conhecimento para compartilhamento de experiências, pensamentos e valores no ambiente organizacional. Ciência da Informação, Brasília, v. 37, n. 1, p. 37-52, jan./abr. 2008. Disponível em: $<$ http://revista.ibict.br/index.php/ciinf/article/download/1005/747 >. Acesso em: 21 nov. 2009.

CERVO, A. L.; BERVIAN, P. A.; SILVA, R. da. Metodologia científica. 6. ed. São Paulo: Pearson Prentice Hall, 2007.

CHAGAS, L. de D.; COSTA, S. de S. Efetividade do processo de comunicação com base na abordagem do comportamento informacional: o caso de um organismo internacional da área da saúde pública sediado no Brasil. Ciência da Informação, Brasília, v. 36, n. 3, p. 39-50, set./dez. 2007. Disponível em: <http://revista.ibict.br/index.php/ciinf/article/view/947/742 >. Acesso em: 26 mai. 2009. 
CHENG, B. H. C.; ATLEE, J. M. Research directions in requirements engineering. In: INTERNATIONAL CONFERENCE ON SOFTWARE ENGINEERING. CONFERENCE ON THE FUTURE OF SOFTWARE ENGINEERING, 2007, Washington, USA. Proceedings... Washington: IEEE Computer Society, 2007. p 285-303. Disponível em: <http://portal.acm. org/citation.cfm?id=1254725>. Acesso em: 06 maio 2009.

CIANCONI, R. Gestão da informação na sociedade do conhecimento. 2. ed. Brasília: SENAI/ DN, 2001.

COUGHLAN, J.; LYCETT, Mark; MACREDIE, Robert D. Communication issues in requirements elicitation: a content analysis of stakeholder experiences. Information and Software Technology. Amsterdam, v. 45, n. 8, p 525-537, jun. 2003. Disponível em: < http://bura.brunel. ac.uk/handle/2438/396>. Acesso em: 06 set. 2009.

COUGHLAN, J.; MACREDIE, R. D. Effective communication in requirements ilicitation: a comparison of methodologies. Requirements Engineering. Londres, v. 7, n. 2, p. 47-60, jun. 2002. Disponível em: <http://bura.brunel.ac.uk/handle/2438/389>. Acesso em 06 set. 2009.

CRESWELL, J. W. Projeto de pesquisa: método qualitativo, quantitativo e misto. 2. ed. Porto Alegre: Artmed, 2007.

CURRAL, L.; CHAMBEL, M. J. Processos de comunicação nas organizações. In: FERREIRA, J. M. Carvalho; NEVES, José; CAETANO, António. Manual de psicossociologia das organizações. Lisboa: Mc Graw Hill, 2001.

DAVENPORT, T. H; PRUSAK, L. Working knowledge: how organizations manage what they know. Boston: Harvard Business School, 1998.

DINGSØYR, T.; DJARRAYA, H. K.; RØYRVIK, E. Practical knowledge management tool use in a software consulting company. Communications of the ACM, New York, USA, v. 48, n. 12, p. 97-100, dez. 2005. Disponível em: <http://portal.acm.org/citation.cfm?id=1101779. 1101783 >. Acesso em: 06 set. 2009.

ESPINDOLA, R. et al. Uma abordagem baseada em gestão do conhecimento para gerência de requisitos em desenvolvimento distribuído de software. In: WORKSHOP EM ENGENHARIA DE REQUISITOS, 8, 2005, Porto. Anais... Porto: FEUP, p. 87-99, 2005. Disponível em: <http:// wer.inf.puc-rio.br/WERpapers/artigos/artigos_WER05/rodrigo_espindola.pdf >. Acesso em: 06 maio 2009.

GIL, A. C. Métodos e Técnicas de Pesquisa social. 5. ed. 8. reimpr. São Paulo: Atlas, 2007. 
GILLARD, S. Managing IT projects: communication pitfalls and bridges. Journal of Information Science, Londres, v. 31, n. 1, p. 37-43, fev. 2005. Disponível em: <http://jis. sagepub.com/cgi/reprint/31/1/37 >. Acesso em: 06 set. 2009.

HOLZBLATT, K.; BEYER, H. R. Requirements gathering: the human factor. Communications of the ACM, New York, v. 38, n. 5, p. 31-32, mai. 1995. Disponível em: < http://portal.acm. org/citation.cfm?id=203356.203361>. Acesso em: 06 set. 2009.

JASHAPARA, A.. The emerging discourse of knowledge management: a new dawn for information science research? Journal of Information Science, Londres, v. 31, n. 2, p. 136-148, abr. 2005. Disponível em: < http://jis.sagepub.com/cgi/reprint/31/2/136 >. Acesso em: 06 set. 2009.

KOTONYA, G.; SOMMERVILLE, I. Requirements engineering: processes and techniques. Chichester: John Wiley \& Sons, 1998.

MARCHIORI, M. R. Cultura e comunicação interna: idealizar e comunicar. In: NASSAR, Paulo. Comunicação interna: a força das empresas. São Paulo: Associação Brasileira de Comunicação Empresarial, 2005. p. 109-116.

McQUAIL, D.; WINDAHL, S. Communication models for the study of mass communications. 2. ed. London: Longman, 1993.

MEADOWS, J. Comunicação. Trad. Sely Maria de Souza Costa. Revista de Biblioteconomia de Brasília, Brasília, v. 25, n. 2, p. 239-254, jul/dez. 2001.

MICHELIS, G. de. Cooperation and Knowledge Creation. In: NONAKA, I.; NISHIGUCHI, T.. Knowledge Emergence: social, technical, and evolutionary dimensions of knowledge creation. New York: Oxford Press, 2000. p. 124-144.

MILLER, K. Organization communication: approaches and processes. Belmont: Thomson Wadsworth, 2006.

MINAYO, M. C. de S. (Org.). Pesquisa social: teoria, método e criatividade. 26. ed. Petrópolis: Vozes, 2007.

NONAKA, I.; KONNO, Noboru; TOYAMA, Ryoko. Emergence of "BA": a conceptual framework for the continuous and self-transcending process of knowledge creation. In: NONAKA, I.; NISHIGUCHI, T. Knowledge Emergence: social, technical, and evolutionary dimensions of knowledge creation. New York: Oxford Press, 2000. p. 13-52. 
NONAKA, I.; TAKEUCHI, H. Criação de conhecimento na empresa: como as empresas japonesas geram a dinâmica da inovação. 17. ed. Rio de Janeiro: Elsevier, 1997.

NONAKA, I.; TAKEUCHI, H. Teoria da criação do conhecimento organizacional. In: TAKEUCHI, H.; NONAKA, I. Gestão do conhecimento. Porto Alegre: Bookman, 2008. p. 54-90.

OLIVEIRA, A. C. de; ARAUJO, R. M. de; BORGES, M. R. da S. Telling stories about system use: capturing collective tacit knowledge for system maintenance. In: INTERNATIONAL CONFERENCE ON SOFTWARE ENGINEERING AND KNOWLEDGE ENGINEERING, 2007, Boston. Anais... Boston: Koeldege Systems Institute Graduate School, 2007. p. 337-342. Disponível em: < http://www.ksi.edu/seke/seke07.html >. Acesso em: 06 set. 2009.

ORMANDJIEVA, O.; HUSSAIN, I.; KOSSEIM, L. Toward a text classification system for the quality assessment of software requirements written in natural language. In: FOURTH INTERNATIONAL WORKSHOP ON SOFTWARE QUALITY ASSURANCE. 2007, Dubrovnik, Croácia. Anais... Dubrovnik, 2007. p 39-45. Disponível em: < http://portal. acm.org/citation.cfm?id=1295082 >. Acesso em: 06 set. 2009.

PFLEEGER, S. L.; ATLEE, J. M. E. Software engineering: Theory and Practice. 3. ed. Upper Saddle River: Pearson Prentice Hall, 2006.

PINTO FILHO, A. T. T. de O. As contribuições da comunicação e do conhecimento da ciência da informação para a análise de requisitos no desenvolvimento de software. Campinas. 2005. 119 f. Dissertação (Mestrado em Ciência da Informação) - Pontifícia Universidade Católica de Campinas, Campinas, 2005.

PRESSMAN, R. S. Engenharia de software. 6. ed. Rio de Janeiro: McGraw-Hill, 2006.

REZENDE, D. A. Engenharia de software e sistemas de informação. 2. ed. Rio de Janeiro: Brasport, 2002.

RICHARDSON, R. J. Pesquisa social: métodos e técnicas. 3. ed. Santos: Atlas, 1999.

RUDIO, F. V. Introdução ao projeto de pesquisa científica. 34. ed. Petrópolis: Vozes, 2007.

SAIEDIAN, H.; DALE, R. Requirements engineering: making the connection between the software developer and customer. Information and Software Technology. Amsterdam, v. 42, n. 6, p. 419-428, abr. 2000. Disponível em: <http://dx.doi.org/10.1016/S0950-5849(99)001019>. Acesso em: 06 set. 2009. 
SARACEVIC, T. Ciência da Informação: origem, evolução e relações. Trad. Ana Maria P. Cardoso. Perspectivas em Ciência da Informação, Belo Horizonte, v. 1, n. 1, p. 41-62, jan./ jun. 1996. Disponível em: <http://www.eci.ufmg.br/pcionline/index.php/pci/article/viewFile/235/22>. Acesso em: 28 Jun. 2008.

SOMMERVILLE, I. Engenharia de software. 8. ed. São Paulo: Pearson Addison-Wesley, 2007.

TAKEUCHI, H.; NONAKA, I. Classic work: theory of organizational knowledge creation. In: MOREY, D.; MAYBURY, M.; THURAISINGHAM, B. Knowledge management: classic and contemporary works. Cambridge: MIT Press, 2001. p. 139-182.

TIWANA, A. An empirical study of the effect of knowledge integration on software development performance. Information and Software Technology. Amsterdam, v. 46, n. 13, p. 899906, out. 2004. Disponível em: <http://www.bus.iastate.edu/tiwana/pdfs/j/ TiwanaIST2004. pdf $>$. Acesso em: 06 set. 2009.

TUBBS, S. L.; MOSS, S. Human communication: principles and contexts. 9. ed. New York: Mc Graw Hill, 2003.

WAHONO, R. S. Toward a method for eliciting software requirements using constraint natural language. IECI Chapter Japan Series. Tóquio, v. 4, n. 1, p. 69-71, mar. 2002. Disponível em: $<$ http://romisatriawahono.net/publications/2002/romi-ijw2002.pdf>. Acesso em: 06 set. 2009.

XEXÉO, G. Modelagem de sistemas de informação: da análise de requisitos ao modelo de interface. On-line, 2007. Disponível em: <http://wiki.xexeo.org>. Acesso em: 30 out. 2007. 


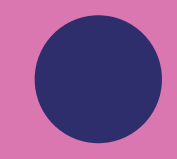

○

○

-

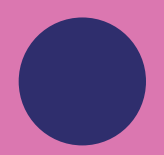

-

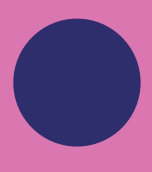

○

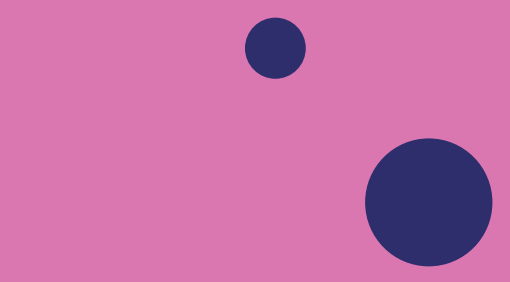

○

○

- 0

○
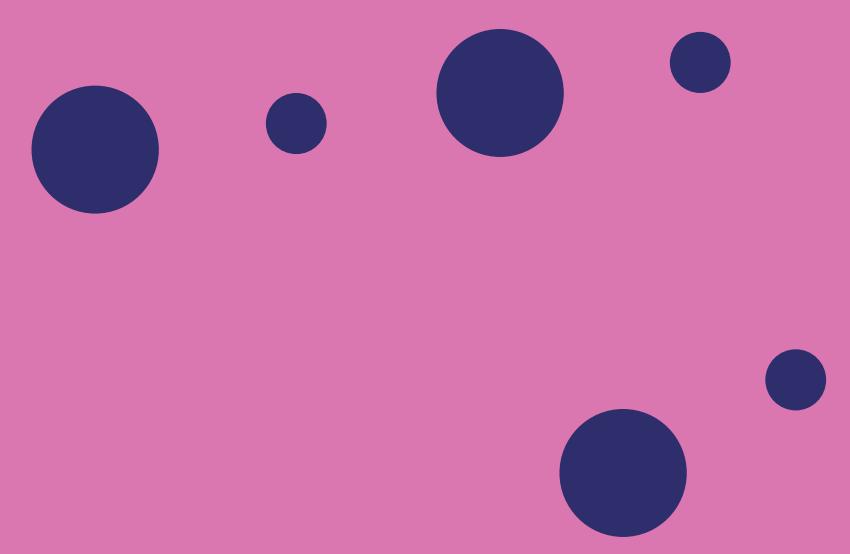


\section{CAPÍTULO 4}

○

0

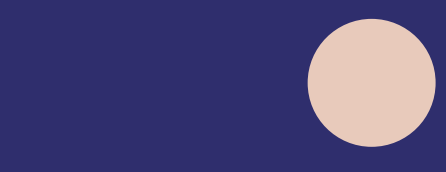

○
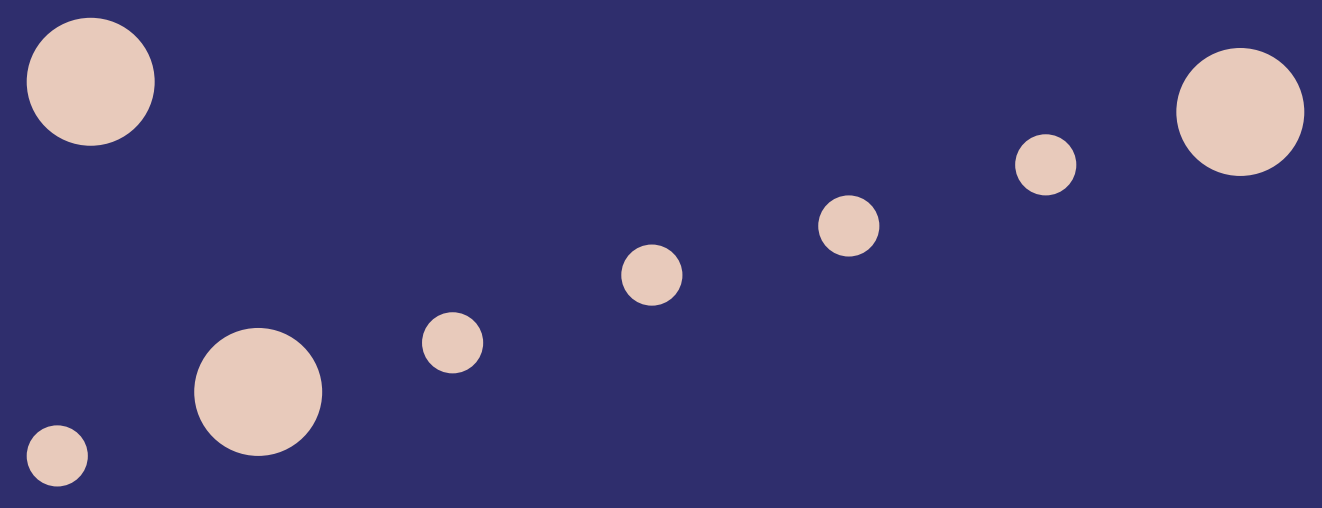

- 00

0 


\section{MÉTODO DE AVALIAÇÃO DE PROGRAMAS DE GOVERNO ELETRÔNICO SOB A ÓTICA DO CIDADÃO-CLIENTE

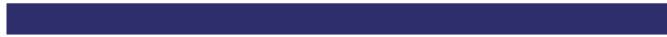

\author{
CLÁUDIA AUGUSTO DIAS \\ SELY MARIA DE SOUZA COSTA
}

\section{INTRODUÇÃO}

Por ser uma área de estudo ainda recente, e pelo fato de o governo eletrônico ter adquirido em tão pouco tempo importância significativa, propondo-se a promover a cidadania, a transparência administrativa e a gestão de informações governamentais, verificou-se a necessidade de identificar e validar métricas para avaliar os resultados de programas de governo eletrônico. Mesmo com a proliferação de levantamentos realizados por órgãos públicos, instituições de pesquisa e empresas de consultoria a respeito do progresso do governo eletrônico em diversos países, constata-se que seus resultados, classificações e procedimentos metodológicos diferem entre si. As estratégias de avaliação de e-gov devem se basear na quantificação do real valor dessa iniciativa para cidadãos, empresas e para o próprio governo.

Em 2003, a International Organization of Supreme Audit Institutions realizou levantamento sobre auditorias de governo eletrônico conduzidas pelas entidades fiscalizadoras superiores de 180 países (57 responderam). Constatou-se que algumas entidades já haviam realizado auditorias de e-gov sob a ótica da auditoria de Tecnologia da Informação (TI) ou da usabilidade de portais web, porém nenhuma delas analisou o real valor da implementação do e-gov seja para o cidadão seja para o próprio governo, pela falta de métodos de auditoria e métricas adequadas.

Do ponto de vista teórico, na Ciência da Informação, ao se pesquisar a literatura sobre comunicação da informação, percebe-se a supremacia de estudos sobre comunicação científica, realizados desde os anos 1950, quando o intuito da área era promover a troca de informação de valor científico entre pesquisadores. Observa-se, também, uma quantidade de estudos mais recentes sobre comunicação de informação tecnológica e organizacional. Poucas são 
as pesquisas em Ciência da Informação que versam sobre comunicação de outros tipos de informação, além do âmbito científico, tecnológico, organizacional e de negócios.

A carência de aprofundamento teórico sobre governo eletrônico e de estudos em Ciência da Informação sobre comunicação para o cidadão; a variedade de métodos de avaliação de governo eletrônico com enfoques diversos; e a necessidade de medir efetivamente o sucesso, sob o ponto de vista do cidadão-cliente, das iniciativas de governo eletrônico, como alternativa de canal de comunicação do governo com a sociedade na prestação de serviços públicos, deram origem ao problema de pesquisa da tese de doutorado em Ciência da Informação (Dias, 2006), o qual pode ser expresso em duas questões: Como avaliar os resultados de programas de governo eletrônico sob a ótica do cidadão-cliente? Há relação direta entre o atendimento aos padrões de qualidade adotados e a satisfação do cidadão-cliente com os serviços de governo eletrônico? Para responder às questões, a pesquisa ora relatada teve como objetivo definir e validar método de avaliação dos resultados de programas de governo eletrônico sob a ótica dos cidadãos-clientes.

\section{FUNDAMENTAÇÃO TEÓRICA E METODOLOGIA}

Por se tratar de sistema informatizado de comunicação de massa entre governo e cidadão, por meio da internet, foi preciso definir os conceitos relevantes para a pesquisa e a relação entre eles. Como resultado desse esforço, foi elaborado o modelo conceitual da pesquisa, que consiste em recurso teórico-metodológico, cuja função foi nortear tanto o desenho da pesquisa quanto a análise e discussão dos resultados.

\subsection{Modelo conceitual da pesquisa}

A figura 1 representa o modelo que exprime o ângulo pelo qual o problema da pesquisa foi estudado, relacionando conceitos das áreas exploradas na revisão de literatura. Esse modelo contém a teoria que embasa a explicação dos resultados e norteia o desenho do estudo, ou seja, a construção do referencial teórico da pesquisa.

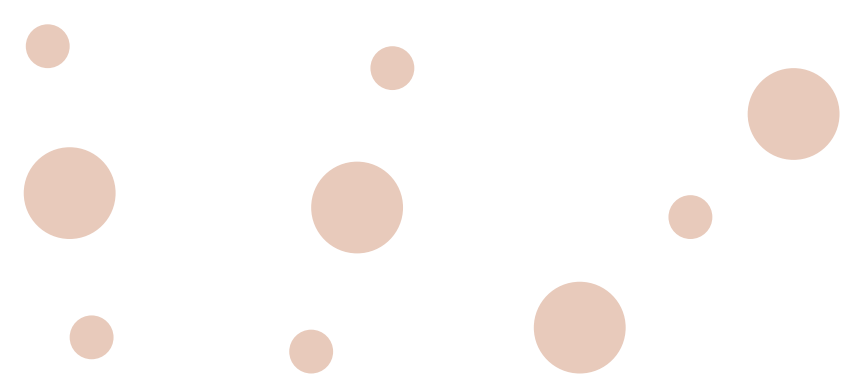


Figura 1 - Comunicação eletrônica entre governo e cidadão-cliente de serviços públicos

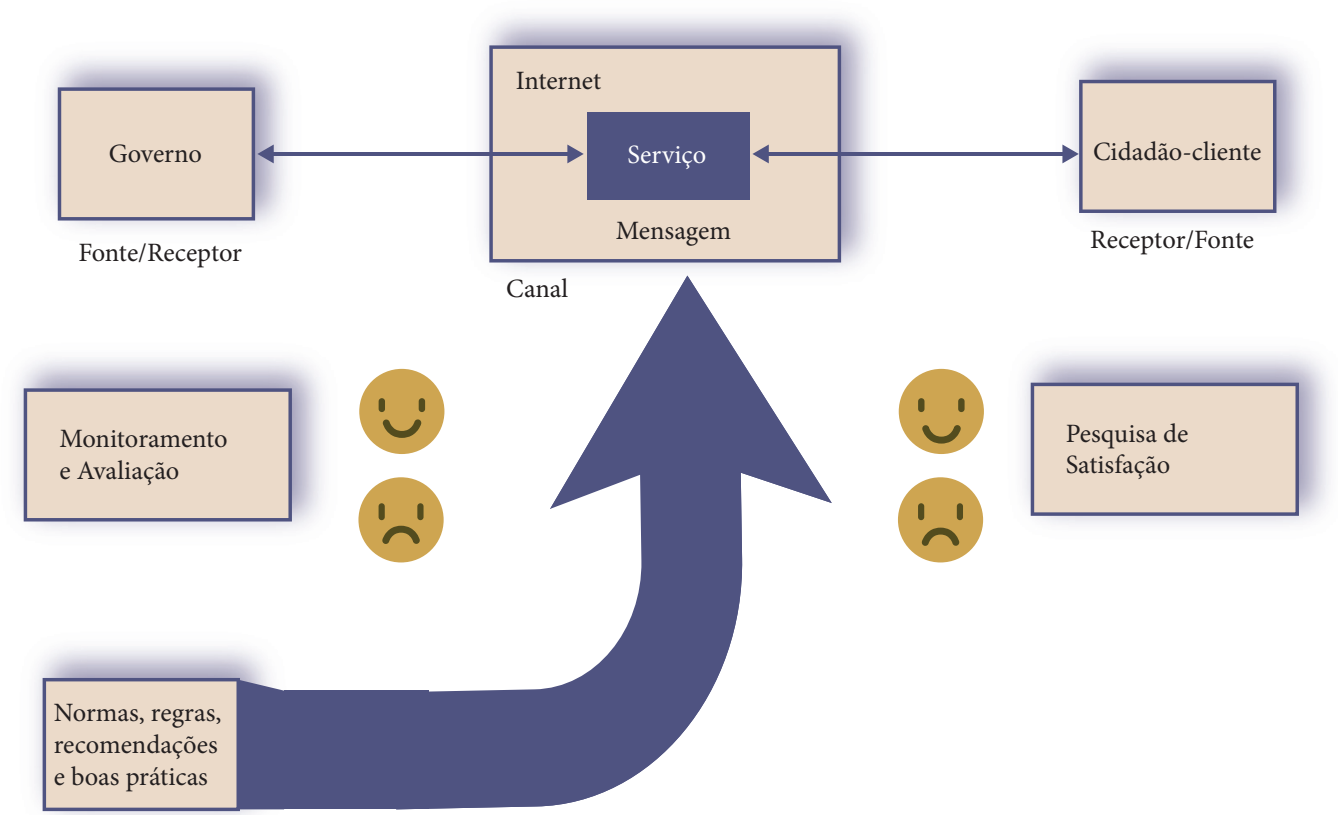

Fonte: Elaboração dos autores (2018).

A prestação de serviços via internet foi considerada, nesta pesquisa, comunicação de massa, do governo para o cidadão, já que o conteúdo selecionado pelo governo para veiculação na internet, na verdade, é uma amostra do total disponível, criado por um grupo de pessoas que trabalha para o governo, para disseminação rápida por meio de artefatos tecnológicos, a uma grande audiência, heterogênea, amplamente dispersa e anônima, concordando, assim, com as características típicas da comunicação de massa. Por ser um membro anônimo do público, o cidadão-cliente não tem o compromisso de responder ou reagir, como acontece na comunicação interpessoal. A credibilidade do canal internet, como já constatado em algumas avaliações de governo eletrônico, influencia a maneira como o cidadão-cliente se relaciona com ele e é afetado pelo conteúdo nele transmitido.

Por sua vez, ao relacionar a prestação de serviços de governo eletrônico com o processo de comunicação tradicional, é possível afirmar que o governo e o cidadão-cliente são ambos emissores e receptores, já que tal comunicação se dá de forma bidirecional - ora é o governo que comunica informações sobre a prestação do serviço (mensagem), ora é o cidadão-cliente que transfere, ao governo, as informações necessárias (mensagem) à conclusão dessa prestação de serviços on-line, por meio do canal internet. 
Ao traçar um paralelo entre fidelidade do processo de comunicação e qualidade de serviços públicos, vê-se que, em ambos os casos, o importante é determinar o que aumenta ou reduz tal fidelidade ou qualidade. Comparando o conceito de que a comunicação é efetiva quando a forma pela qual o estímulo foi iniciado e pretendido pelo emissor, ou fonte, corresponde, o mais próximo possível, à forma com que é percebido e respondido pelo receptor, com o conceito de qualidade percebida como julgamento do cliente sobre a superioridade ou excelência de um serviço, fruto da comparação entre os serviços esperados e a percepção dos serviços recebidos, observa-se que ambos tratam do mesmo tema.

A ausência de recursos de comunicação, a presunção não enunciada, a distração e a apresentação confusa, destacadas na literatura como barreiras à comunicação humana, são também consideradas problemas de disponibilidade (ausência de recursos de comunicação), usabilidade (qualidade de uso) e/ou acessibilidade de interfaces web na prestação de serviços públicos eletrônicos. As agências governamentais, por sinal, são conhecidas por suas comunicações frequentemente incompreensíveis.

A fidelidade do processo de comunicação na prestação de serviços públicos eletrônicos está, então, relacionada com os conceitos de acessibilidade e usabilidade de interfaces web, duas das dimensões da qualidade de serviços públicos eletrônicos examinadas nesta pesquisa. De certa forma, outras dimensões da qualidade também se ligam à fidelidade do processo de comunicação eletrônica: facilidade de localização do portal web da instituição, facilidade de localização do serviço de governo eletrônico e sua disponibilidade.

A qualidade de serviços públicos eletrônicos, de uma maneira geral, pode ser medida pela conformidade com padrões, normas, recomendações e boas práticas, e inferida pela satisfação geral de seus usuários, cidadãos e clientes desses serviços. Do lado do cidadão-cliente, o método mais empregado para medir sua satisfação é a pesquisa de satisfação de clientes, motivo pelo qual esse foi um dos métodos escolhidos neste estudo. Do lado do governo, para checar a conformidade com padrões de qualidade, e ainda o sucesso das iniciativas de e-gov, o método de aferição mais adequado parece ser o monitoramento e a avaliação de indicadores de desempenho, mais especificamente, de eficácia. Para complementar essa visão que relaciona fidelidade do processo de comunicação eletrônica entre governo e cidadão-cliente e qualidade dos serviços públicos eletrônicos, construiu-se o modelo de avaliação de governo eletrônico, descrito a seguir.

\subsection{Modelo de avaliação de governo eletrônico}

O modelo de avaliação de governo eletrônico, aqui proposto e representado de forma gráfica na figura 2, sintetiza os aspectos abordados na revisão de literatura da tese. 
Ao observar os elementos da figura 2, é possível visualizar as características (canais eletrônicos de comunicação, foco no cliente, processamento em tempo real, ambiente sem papel, processos automáticos, integração linha de frente-retaguarda, dependência da tecnologia) e os potenciais benefícios do governo eletrônico (melhores serviços, governo mais eficiente e novas relações entre governo e sociedade), assim como os três setores envolvidos nas interações de e-gov (G2B - Government to Business, G2C - Government to Citizen e G2G - Government to Government), os cinco estágios evolutivos (apresentação de informações, busca de informações, interatividade limitada, transação eletrônica e integração e-gov) e os vários tipos de avaliação de governo eletrônico: sob a perspectiva institucional (classificação em estágios evolutivos, benchmarking, comparação da situação alcançada com seus objetivos estratégicos, prestação de contas ao governo central e avaliação de programas de governo); e avaliação de aplicações específicas e seus principais indicadores (uso, produtividade, satisfação de clientes, custos e retorno de investimento). 
Figura 2 - Modelo de avaliação de governo eletrônico

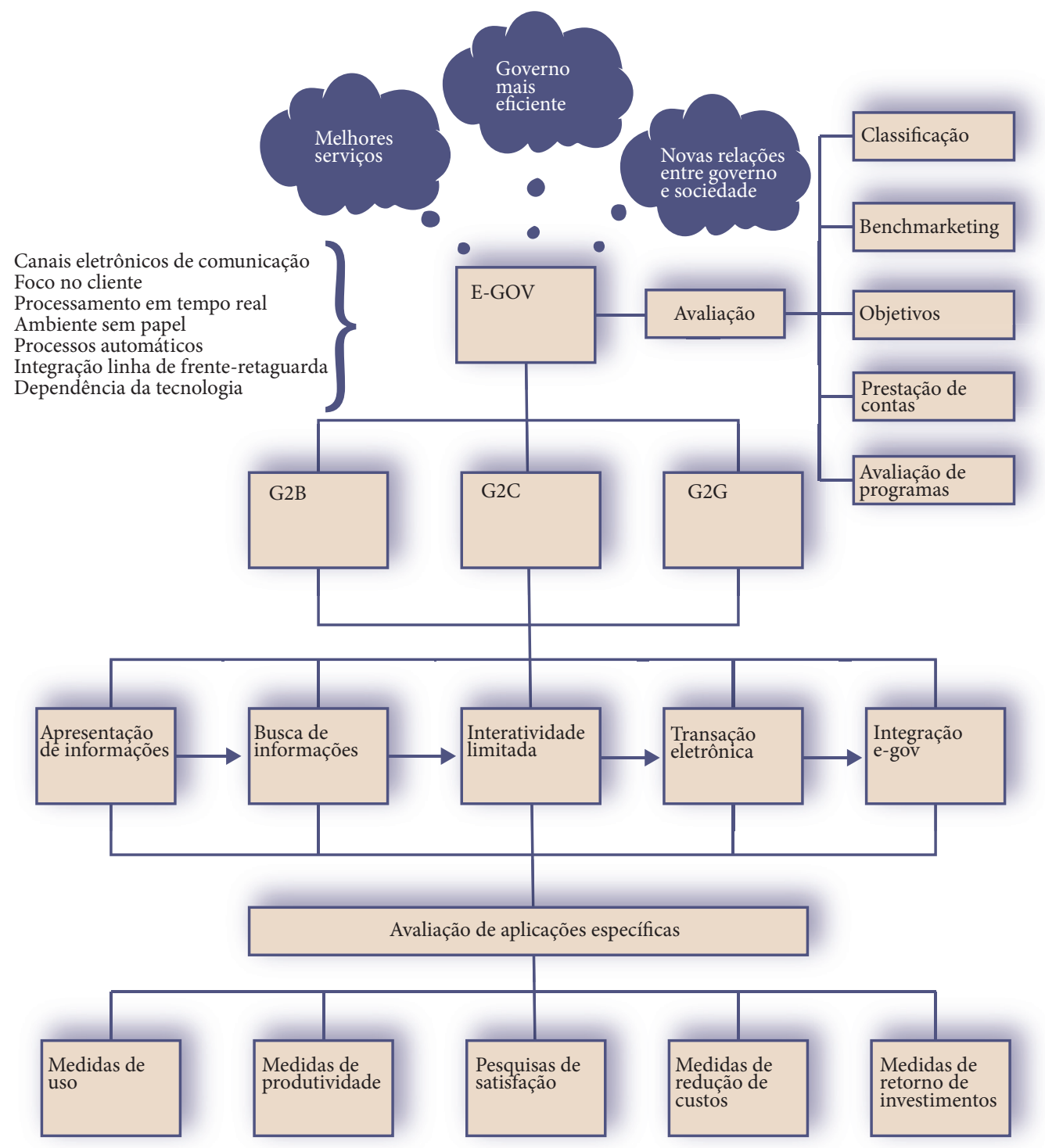

Fonte: Elaboração dos autores (2018).

A partir desse modelo de avaliação de e-gov aqui proposto, é possível ter uma visão didática, ao mesmo tempo geral e sintética, das características e potenciais benefícios do governo eletrônico, assim como dos setores envolvidos nas interações de e-gov, estágios evolutivos e tipos de avaliação. Tal modelo pode ser aplicado como ponto de partida tanto em estudos acadêmicos sobre governo eletrônico com foco específico em um ou mais aspectos nele representados, quanto em trabalhos de avaliação sob perspectiva institucional ou de aplicações específicas. Na pesquisa realizada, esse modelo foi particularmente 
importante na seleção dos métodos de avaliação que seriam mais adequados à pesquisa e dos tipos de serviços e estágios de e-gov objetos de análise no estudo de caso.

\subsection{Seleção dos tipos de serviços, estágios de e-gov e métodos de avaliação}

Como o tema da pesquisa trata da prestação de serviços públicos eletrônicos sob a ótica do cidadão-cliente, e o objetivo do Programa de Governo Eletrônico brasileiro é "ampliar a oferta e melhorar a qualidade da prestação de serviços e informações públicas por meios eletrônicos”, foram enfocados, na pesquisa, como benefício potencial do e-gov, o de "melhores serviços", e como contexto, serviços G2C, para atendimento direto ao cidadão. Por serem os estágios iniciais de apresentação e busca de informações, no governo eletrônico, menos significativos quanto à prestação de serviços públicos eletrônicos, foram escolhidos, inicialmente, os estágios de interatividade limitada, transação eletrônica e integração e-gov, como critérios para seleção dos serviços e-gov do estudo.

Entre os métodos de avaliação do e-gov como estratégia do governo central, foi escolhida a avaliação de programas, por sua abrangência, pois possibilita diferentes enfoques de análise (insumos, processos, produtos, impactos) e ainda diferentes critérios de avaliação (eficiência, eficácia, efetividade, impacto). Os outros tipos de avaliação (classificação em estágios evolutivos, avaliação da prestação de contas e avaliação dos objetivos estratégicos) foram descartados por tratarem de aspectos limitados de implementação e controle não diretamente voltados ao foco da pesquisa. O benchmarking foi descartado por ser mais indicado em etapas posteriores de avaliação. Comparar iniciativas de e-gov antes de realizar autoavaliações parece inverter a ordem natural das coisas.

Como o foco da pesquisa foi a avaliação dos serviços e-gov sob a ótica do cidadão-cliente na comunicação com o governo via internet, nada melhor do que utilizar métodos que tenham como fontes de informação os próprios cidadãos-clientes, como é o caso da pesquisa de satisfação. Para representar o que se pretendia avaliar na pesquisa de satisfação, foi construído um modelo gráfico que relaciona as diversas variáveis estudadas.

\subsection{Modelo de avaliação da satisfação}

A partir dos conceitos e modelos da revisão de literatura, propôs-se para o ambiente eletrônico, de forma resumida e contextualizada, um modelo para medir a satisfação dos clientes de serviços de governo eletrônico (figura 3). Tal modelo inclui, como variáveis latentes (ou construtos) que influenciam a satisfação geral, as expectativas dos cidadãos-clientes, a qualidade e o valor por eles percebidos, bem como os padrões de qualidade relacionados especificamente com esse canal de comunicação, subdivididos em dez dimensões: facilidade de localização do portal web; facilidade de localização do serviço; acessibilidade; usabilidade; disponibilidade; confiabilidade; privacidade de dados pessoais e 
segurança de informações; conveniência; capacidade de resposta a dúvidas e reclamações; e tempo de atendimento. Todos os elementos do modelo de avaliação da satisfação encontram-se minuciosamente definidos em Dias (2006).

Figura 3 - Modelo para medir a satisfação do cliente de serviços de governo eletrônico

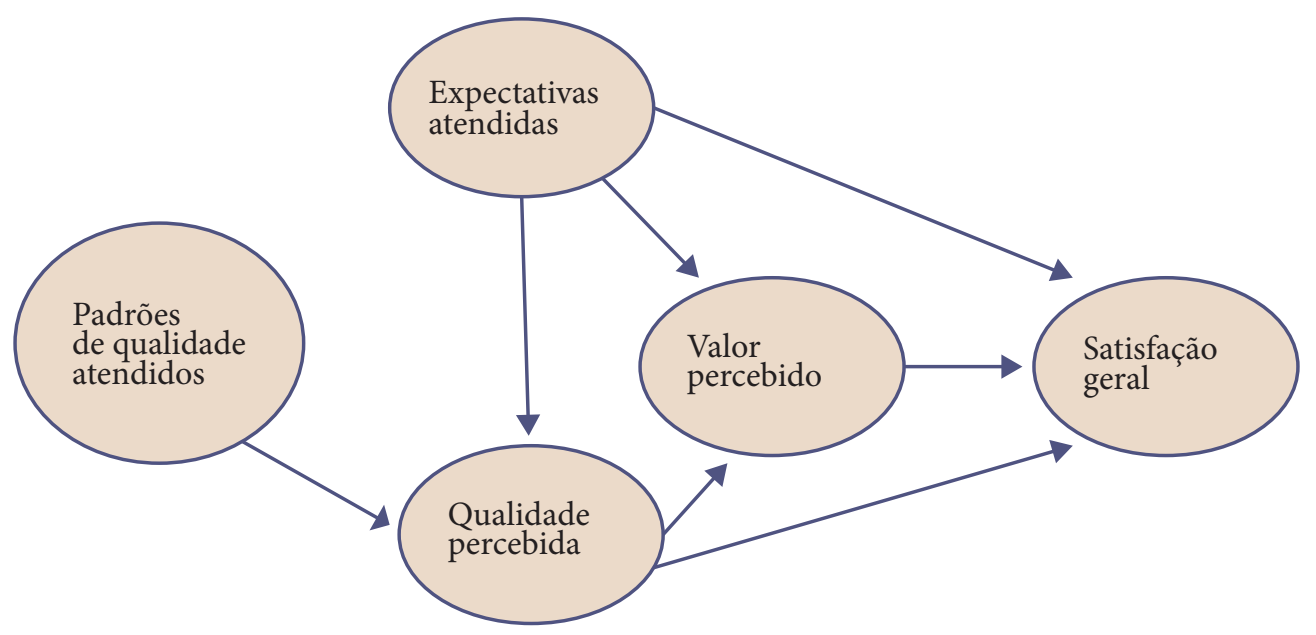

\section{DIMENSÕES}

Facilidade de localização do portal web da instituição

Facilidade de localização do serviço de governo eletrônico

Acessibilidade

Usabilidade

Disponibilidade

Confiabilidade

Privacidade de dados pessoais e segurança de informações

Conveniência

Capacidade de resposta a dúvidas e reclamações

Tempo de atendimento

Fonte: Elaboração dos autores (2018). 
Como variáveis latentes, tais construtos não podem ser medidos diretamente e necessitam de indicadores, ou variáveis observáveis, para sua mensuração. O Quadro 1 apresenta um possível conjunto de variáveis latentes e observáveis, derivadas do modelo proposto.

Quadro 1 - Conjunto de variáveis latentes e observáveis

\begin{tabular}{|c|c|}
\hline $\begin{array}{c}\text { VARIÁVEIS } \\
\text { LATENTES } \\
\text { (CONSTRUTOS) }\end{array}$ & VARIÁVEIS OBSERVÁVEIS \\
\hline Expectativas atendidas & Var. 1 - Expectativa geral da qualidade do serviço de governo eletrônico. \\
\hline $\begin{array}{l}\text { Padrões de qualidade } \\
\text { atendidos }\end{array}$ & $\begin{array}{c}\text { Var. } 2 \text { - Porcentagem de normas, regras, recomendações ou boas práticas atendidas pelo } \\
\text { serviço de governo eletrônico, sob o ponto de vista de especialistas. }\end{array}$ \\
\hline \multirow{12}{*}{ Qualidade percebida } & $\begin{array}{c}\text { Var. } 3 \text { - Avaliação geral da adequação do serviço de governo eletrônico às exigências } \\
\text { pessoais. }\end{array}$ \\
\hline & $\begin{array}{l}\text { Var. } 4 \text { - Avaliação geral da adequação do serviço de governo eletrônico às expectativas } \\
\text { pessoais. }\end{array}$ \\
\hline & $\begin{array}{l}\text { Var. } 5 \text { - Avaliação quanto à facilidade de localização do portal web em que o serviço de } \\
\text { governo eletrônico é prestado. }\end{array}$ \\
\hline & $\begin{array}{l}\text { Var. } 6 \text { - Avaliação quanto à facilidade de localização do serviço de governo eletrônico } \\
\text { no portal web da instituição. }\end{array}$ \\
\hline & Var. 7 - Avaliação quanto à acessibilidade do serviço de governo eletrônico. \\
\hline & Var. 8 - Avaliação quanto à usabilidade do serviço de governo eletrônico. \\
\hline & Var. 9 - Avaliação quanto à disponibilidade do serviço de governo eletrônico. \\
\hline & Var. 10 - Avaliação quanto à confiabilidade do serviço de governo eletrônico. \\
\hline & $\begin{array}{c}\text { Var. } 11 \text { - Avaliação quanto à privacidade de dados pessoais e segurança de informações } \\
\text { do serviço de governo eletrônico. }\end{array}$ \\
\hline & Var. 12 - Avaliação quanto à conveniência do serviço de governo eletrônico. \\
\hline & $\begin{array}{c}\text { Var. } 13 \text { - Avaliação quanto à capacidade de resposta a dúvidas e reclamações do serviço } \\
\text { de governo eletrônico. }\end{array}$ \\
\hline & Var. 14 - Avaliação quanto ao tempo de atendimento do serviço de governo eletrônico. \\
\hline
\end{tabular}




\begin{tabular}{|c|c|}
\hline $\begin{array}{c}\text { VARIÁVEIS } \\
\text { LATENTES } \\
\text { (CONSTRUTOS) }\end{array}$ & VARIÁVEIS OBSERVÁVEIS \\
\hline \multirow{10}{*}{ Valor percebido } & $\begin{array}{c}\text { Var. } 15 \text { - Avaliação geral da qualidade do serviço de governo eletrônico em relação aos } \\
\text { outros canais de prestação do serviço. }\end{array}$ \\
\hline & $\begin{array}{l}\text { Var. } 16 \text { - Avaliação quanto à facilidade de localização do serviço de governo eletrônico, } \\
\text { em relação aos outros canais de prestação do serviço. }\end{array}$ \\
\hline & $\begin{array}{c}\text { Var. } 17 \text { - Avaliação quanto à acessibilidade do serviço de governo eletrônico, em relação } \\
\text { aos outros canais de prestação do serviço. }\end{array}$ \\
\hline & $\begin{array}{l}\text { Var. } 18 \text { - Avaliação quanto à usabilidade do serviço de governo eletrônico, em relação } \\
\text { aos outros canais de prestação do serviço. }\end{array}$ \\
\hline & $\begin{array}{c}\text { Var. } 19 \text { - Avaliação quanto à disponibilidade do serviço de governo eletrônico, em } \\
\text { relação aos outros canais de prestação do serviço. }\end{array}$ \\
\hline & $\begin{array}{c}\text { Var. } 20 \text { - Avaliação quanto à confiabilidade do serviço de governo eletrônico, em relação } \\
\text { aos outros canais de prestação do serviço. }\end{array}$ \\
\hline & $\begin{array}{l}\text { Var. } 21 \text { - Avaliação quanto à privacidade de dados pessoais e segurança de informações } \\
\text { do serviço de governo eletrônico, em relação aos outros canais de prestação do serviço. }\end{array}$ \\
\hline & $\begin{array}{c}\text { Var. } 22 \text { - Avaliação quanto à conveniência do serviço de governo eletrônico, em relação } \\
\text { aos outros canais de prestação do serviço. }\end{array}$ \\
\hline & $\begin{array}{c}\text { Var. } 23 \text { - Avaliação quanto à capacidade de resposta a dúvidas e reclamações do serviço } \\
\text { de governo eletrônico, em relação aos outros canais de prestação do serviço. }\end{array}$ \\
\hline & $\begin{array}{l}\text { Var. } 24 \text { - Avaliação quanto ao tempo de atendimento do serviço de governo eletrônico, } \\
\text { em relação aos outros canais de prestação do serviço. }\end{array}$ \\
\hline Satisfação geral & Var. 25 - Avaliação da satisfação geral com o serviço de governo eletrônico. \\
\hline
\end{tabular}

Fonte: Elaboração dos autores (2018).

A partir do modelo para medir a satisfação do cliente de serviços de governo eletrônico, foi possível obter uma visão geral das dimensões a serem consideradas nesse tipo de avaliação. Tal modelo, após as devidas adaptações e testes de validade e confiabilidade, poderá ser aplicado tanto em estudos acadêmicos sobre governo eletrônico, quanto em trabalhos de avaliação sob a perspectiva institucional ou de aplicações específicas. Do lado da avaliação de programas, também foi construído um modelo que extrai, da revisão de literatura sobre o assunto, os elementos relevantes para a pesquisa.

\subsection{Modelo de avaliação de programas de governo eletrônico}

O modelo de avaliação de programas da pesquisa, representado graficamente pela figura 4, destaca as questões de auditoria identificadas como mais relevantes, de acordo com a temática deste estudo. Tais questões estão relacionadas à eficácia do Programa Governo Eletrônico, comparando seu objetivo de oferecer melhores serviços aos cidadãos-clientes com os resultados 
pretendidos relativos à qualidade desses serviços, monitorada e avaliada por meio de comparações com padrões de qualidade previamente definidos e de pesquisas de satisfação de clientes. O modelo ainda representa os dois níveis do governo que seriam responsáveis por essas atividades e as ferramentas e técnicas capazes de obter respostas a tais questões. O objetivo dessa avaliação, em especial, é identificar padrões de qualidade, indicadores adotados e possíveis boas práticas que possam ser reproduzidas por outras instituições do governo. Para ser considerado um modelo de avaliação, é preciso selecionar e definir construtos, contexto, critérios, métricas e metodologia. Os construtos necessários para compreender e delimitar bem o modelo de avaliação proposto encontram-se detalhadamente definidos em Dias (2006). 
Figura 4 - Modelo de avaliação de programas desta pesquisa

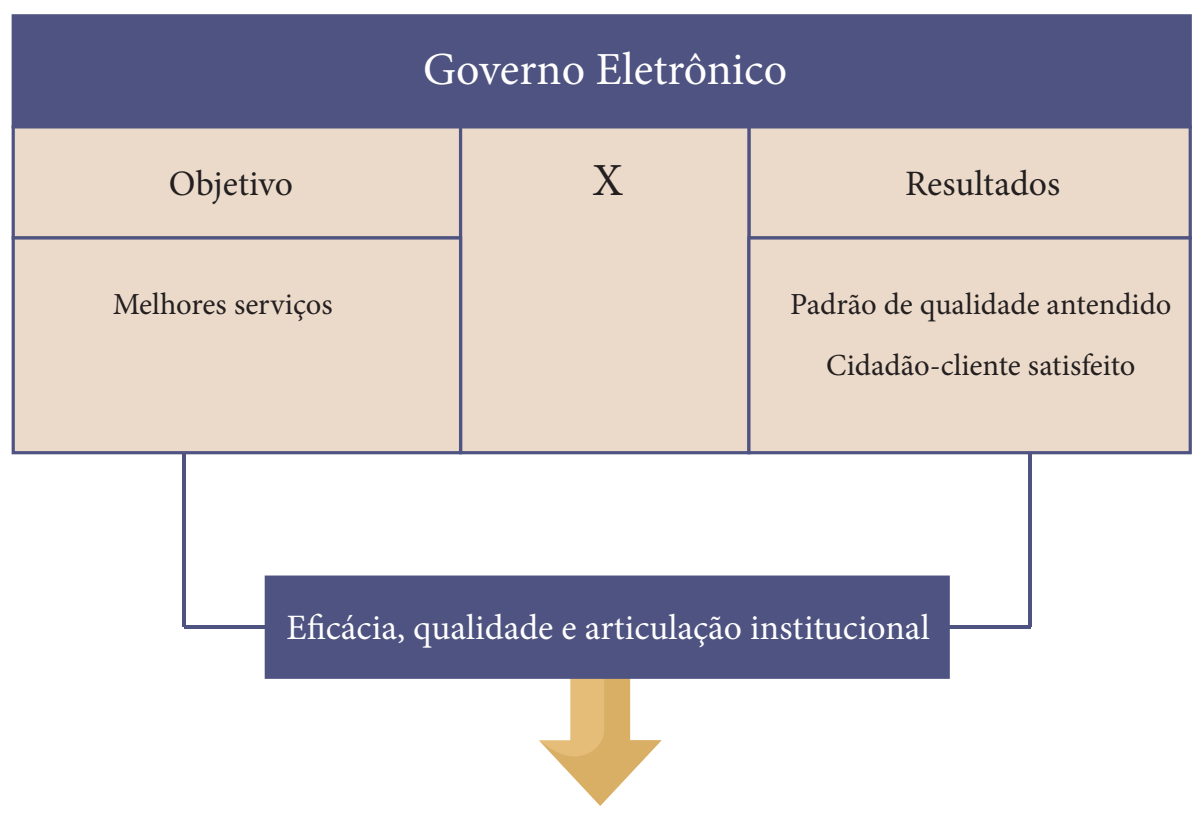

\section{Questões de auditoria}

Como é feito o monitoramento e a avaliação da eficácia do Programa Governo Eletrônico?

Os padrões definidos para os serviços e-gov são atendidos?

Os cidadãos-clientes estão satisfeitos ou insatisfeitos com os serviços e-gov?

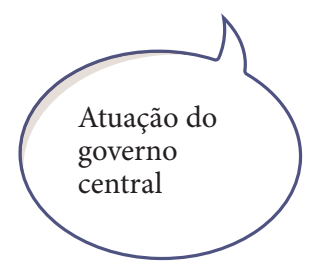

Ferramentas

Análise do grupo de interesse

Análise SWOT

Diagrama de verificação de risco

Matriz de planejamento

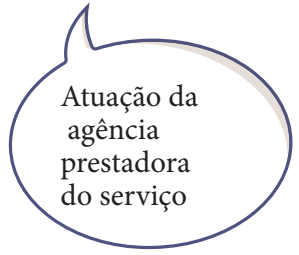

Técnicas de coletas de dados

Pesquisa documental

Entrevista individual

Grupo focal

Levantamento (survey)

Avaliação heurística e testes

Fonte: Elaboração dos autores (2018). 
Por fim, para completar os requisitos do modelo de avaliação de Saracevic (2000), a metodologia adotada, composta de métodos de pesquisa e técnicas de coleta e análise de dados, está descrita no próximo item. A figura 5 representa o contexto definido para esta pesquisa, destacando os aspectos e as dimensões selecionados.

Figura 5 - Aspectos e dimensões selecionados para esta pesquisa

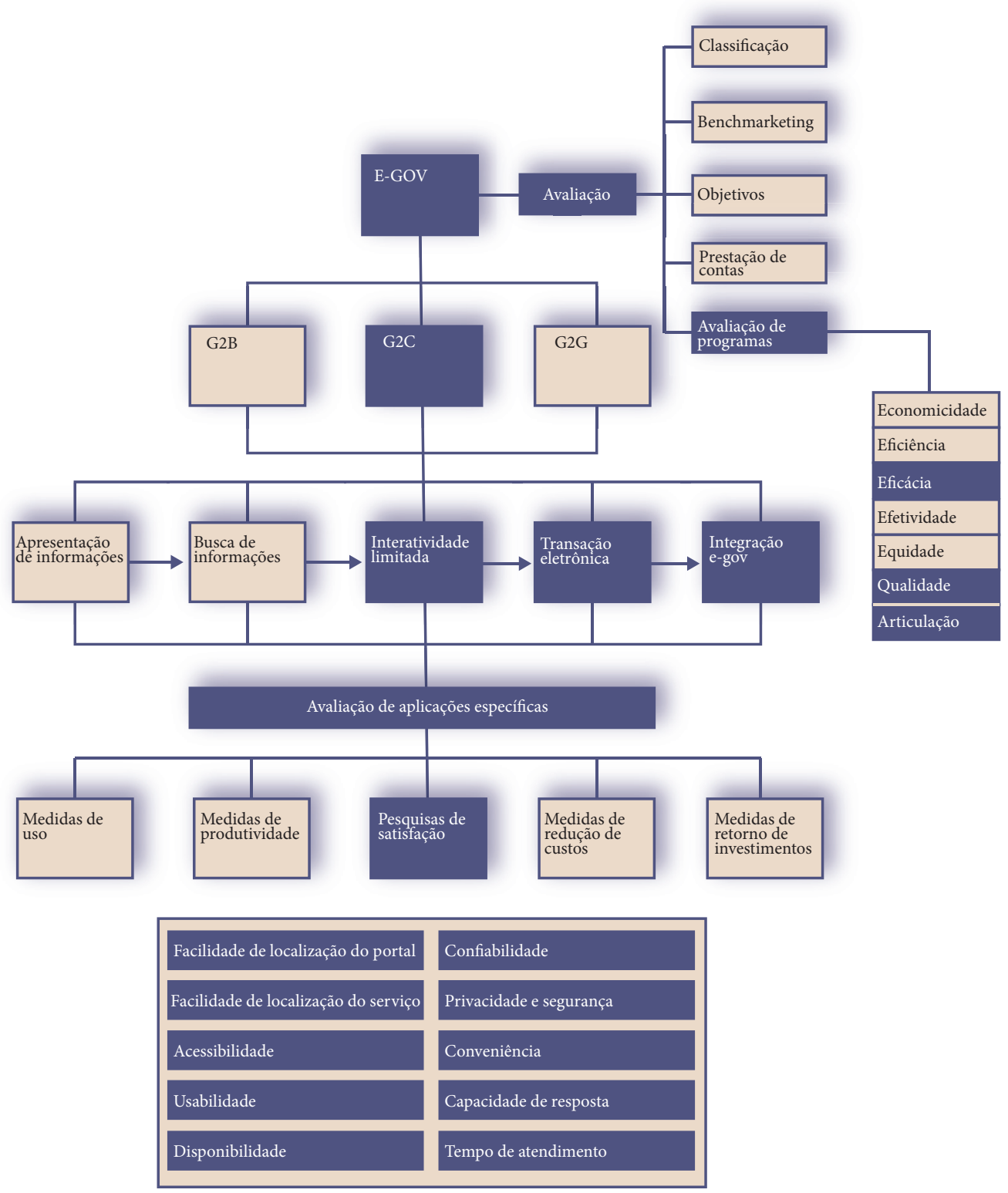

Fonte: Elaboração dos autores (2018). 


\subsection{Métodos e procedimentos de pesquisa}

Em razão do caráter exploratório desta pesquisa aplicada, em tema cujo corpo de conhecimento ainda não está consolidado, a abordagem adotada foi o estudo de caso. Para aumentar a confiabilidade dos resultados da pesquisa, foram selecionados cinco serviços de governo eletrônico, de atendimento direto a qualquer cidadão brasileiro com acesso à internet, e empregados vários métodos para coleta dos mesmos dados e comparados seus resultados. Essa técnica, conhecida como triangulação, é recomendada por diversos autores.

Para atingir o objetivo geral da pesquisa, que foi definir e validar método de avaliação dos resultados de programas de governo eletrônico sob a ótica dos cidadãos-clientes, foram adotadas as seguintes etapas metodológicas: identificação, na literatura, de documentação sobre programas de governo eletrônico, métodos e métricas para sua avaliação; elaboração de modelo de avaliação de governo eletrônico; seleção de métodos de avaliação identificados na literatura; elaboração de modelos de avaliação baseados nos métodos selecionados; seleção do Programa E-Gov brasileiro e dos serviços públicos eletrônicos a serem avaliados; proposta de método de avaliação de programas de governo eletrônico; aplicação e validação do método elaborado no Programa de Governo Eletrônico brasileiro e nos serviços públicos eletrônicos selecionados.

Por meio de pesquisas na internet, realizou-se o mapeamento dos serviços e-gov disponíveis na alta esfera da Administração Pública Federal (APF). Entre as 45 instituições examinadas, dos Poderes Executivo, Legislativo e Judiciário, foram escolhidos os Ministérios da Educação, da Previdência Social, da Saúde e do Trabalho e Emprego como possíveis contextos de casos típicos a serem estudados, por sua importância e relevância social no cenário nacional quanto à prestação de serviços públicos para a melhoria das condições de vida da população brasileira como um todo.

Tomando como base as características das diversas estratégias de amostragem, foi escolhida, para a seleção dos serviços eletrônicos específicos da pesquisa, a amostragem direcionada de casos típicos, por ser uma estratégia capaz de aumentar a utilidade da informação obtida a partir de amostras pequenas e proporcionar a reprodução direta dos procedimentos metodológicos e resultados desta pesquisa em outros casos similares.

Apesar das especificidades de cada área de atuação desses ministérios, há forte similaridade em seus objetivos sociais e no tratamento equitativo oferecido aos beneficiários de seus serviços, ainda mais quando essa prestação de serviços é feita pela internet, contexto em que todos, a partir do momento em que obtêm acesso a esse canal de comunicação, são tratados como membros anônimos de uma "audiência" heterogênea, como na comunicação 
de massa tradicional. Por isso, não foi considerado um fator limitante, para a análise dos resultados da pesquisa, a escolha de serviços em áreas diversas. Pelo contrário, tal fato reforça ainda mais seus resultados.

Com intuito de verificar a viabilidade da pesquisa no Programa de Governo Eletrônico Brasileiro, realizou-se estudo preliminar, na Secretaria-Executiva do Comitê Executivo de Governo Eletrônico - Secretaria de Logística e Tecnologia da Informação (SLTI), do Ministério de Planejamento, Desenvolvimento e Gestão (MP). Esse estudo concluiu, a partir das fraquezas e ameaças identificadas em conjunto com os gestores do programa, na análise SWOT, que seria oportuna uma avaliação pormenorizada do alcance dos objetivos do e-gov brasileiro, em relação à melhoria da qualidade da prestação de serviços públicos eletrônicos.

Os primeiros contatos com os responsáveis pelos portais e-gov dos ministérios selecionados como possíveis casos típicos revelaram o interesse dessas instituições em participar do estudo de caso, não só para avaliar a conformidade de seu portal em relação aos padrões e critérios nacionais e internacionais, mas também para conhecer a opinião de seus clientes, visando a uma possível remodelagem do portal web, em razão dos problemas identificados por meio deste estudo. Na literatura sobre estudos de caso, esse interesse das instituições em participar é considerado como um fator significativo para o sucesso da pesquisa, pois facilita a interação do pesquisador e, consequentemente, seu entendimento a respeito dos contextos estudados.

A fim de identificar os serviços eletrônicos prioritários e mais adequados ao estudo de caso, foram realizadas entrevistas com os gestores das áreas sociais já mencionadas. Nessas entrevistas, entre outros aspectos, foram solicitadas listas dos serviços eletrônicos prestados, com informações tais como: nome e descrição do serviço; prioridade em relação aos demais serviços; estágio de evolução como portal de governo eletrônico (interatividade limitada, transação eletrônica ou integração e-gov); orçamento (se possível); disponibilidade on-line (se permanente ou sazonal); responsáveis e executores; público-alvo; se existe cadastro/registro dos beneficiários atendidos; taxa de utilização em relação ao público-alvo; se foi realizada análise de necessidades do público-alvo antes de sua implementação; se foi realizada avaliação posterior (pesquisa de satisfação; controle de qualidade; análise de reclamações, sugestões e críticas recebidas); se foram definidos indicadores de acompanhamento do serviço.

Essas informações constituíram, na verdade, critérios para a seleção dos serviços eletrônicos desta pesquisa. Nas listas de serviços públicos eletrônicos enviadas pelos gestores, não foi fornecida qualquer informação sobre cadastro/registro de beneficiários atendidos nem indicadores de acompanhamento. Em nenhum serviço, realizou-se análise de 
necessidades do público-alvo antes de sua implementação. Alguns deles foram avaliados por meio de análise de reclamações, sugestões e críticas recebidas. Também não foi possível determinar os valores orçamentários alocados para essas atividades de governo eletrônico por dificuldades técnicas decorrentes da forma como o orçamento público brasileiro é estruturado. Nenhum serviço foi classificado no último estágio de integração e-gov, o que já era esperado. Percebeu-se também que tal classificação em estágios evolutivos de e-gov não era do conhecimento dos gestores, causando certa confusão de interpretação. Foi necessário acessar os serviços eletrônicos na internet para corrigir eventuais erros de classificação cometidos pelos gestores.

Optou-se, então, por selecionar, em cada área social, um serviço diretamente relacionado à missão das agências governamentais, considerado prioritário pelos próprios gestores. No caso de serviços com mais de uma opção de interação com o cidadão, ou seja, serviços subdivididos em outros, tomou-se, para classificá-los, o estágio mais avançado entre todas as opções de serviços. Por sugestão do coordenador do Comitê Técnico de Inclusão Digital, do Programa de Governo Eletrônico, e pelo fato de ser um serviço público eletrônico utilizado pelas classes sociais menos favorecidas, apesar de não ser um benefício, mas uma obrigação do cidadão, foi incluída, nesta pesquisa, a Declaração Anual de Isento 2005 (DAI), da Receita Federal.

O Quadro 2 mostra os serviços públicos eletrônicos escolhidos como casos típicos para este estudo, todos classificados no estágio de transação eletrônica, e suas breves descrições, extraídas dos portais web das respectivas instituições. 
Quadro 2 - Serviços e-gov selecionados para este estudo

\begin{tabular}{|c|c|c|}
\hline MINISTÉRIO & SERVIÇO & DESCRIÇÃO \\
\hline Fazenda - Receita Federal & $\begin{array}{c}\text { Declaração Anual de Isento } 2005 \\
\text { (DAI) }\end{array}$ & $\begin{array}{l}\text { O público-alvo da Declaração Anual } \\
\text { de Isento é composto por pessoas } \\
\text { físicas que receberam rendimentos } \\
\text { tributáveis, no ano de 2004, cuja } \\
\text { soma foi inferior ou igual a R } \$ \\
\text { 12.696,00, desde que não estejam } \\
\text { inseridas nas demais condições que } \\
\text { as obriguem à Declaração de Ajuste } \\
\text { Anual, como a participação em } \\
\text { empresas. }\end{array}$ \\
\hline \multirow{3}{*}{ Previdência Social } & Requerimento de auxílio-doença & $\begin{array}{l}\text { Por meio deste serviço, pode-se } \\
\text { requerer o auxílio-doença e escolher } \\
\text { a Agência da Previdência Social } \\
\text { onde se deve comparecer para fazer a } \\
\text { avaliação médico-pericial. }\end{array}$ \\
\hline & Requerimento de pensão por morte & $\begin{array}{l}\text { Por meio desse serviço, o dependente } \\
\text { poderá cadastrar, requerer a pensão } \\
\text { e escolher a Agência da Previdência } \\
\text { Social para onde se deve encaminhar } \\
\text { a certidão de óbito e os demais } \\
\text { documentos solicitados para a } \\
\text { liberação do pagamento, de acordo } \\
\text { com a condição de dependente. }\end{array}$ \\
\hline & $\begin{array}{l}\text { Requerimento do benefício } \\
\text { salário- maternidade }\end{array}$ & $\begin{array}{l}\text { O requerimento do salário- } \\
\text { maternidade pela internet é uma } \\
\text { facilidade criada pela Previdência } \\
\text { Social para a segurada contribuinte } \\
\text { individual, facultativa, empregada, } \\
\text { em caso de adoção ou guarda } \\
\text { judicial para fins de adoção, e para } \\
\text { a empregada doméstica (babá, } \\
\text { cozinheira, governanta), em qualquer } \\
\text { situação (parto, adoção ou guarda } \\
\text { judicial), podendo ser feito por esta } \\
\text { ou por seu empregador, nos casos de } \\
\text { empregada ou empregada doméstica. }\end{array}$ \\
\hline Trabalho & $\begin{array}{l}\text { Programa Nacional de Estímulo ao } \\
\text { Primeiro Emprego (PNPE) }\end{array}$ & $\begin{array}{l}\text { O PNPE tem como objetivo } \\
\text { contribuir para a geração de } \\
\text { oportunidades de trabalho decente } \\
\text { para a juventude brasileira, } \\
\text { mobilizando o governo e a sociedade } \\
\text { para a construção conjunta de } \\
\text { uma Política Nacional de Trabalho } \\
\text { Decente para a Juventude. }\end{array}$ \\
\hline
\end{tabular}

Fonte: Elaboração dos autores (2018).

A relação de serviços públicos eletrônicos enviada pela Previdência Social foi a que apresentou maior quantidade de serviços interativos e transacionais com foco no cidadão, motivo pelo qual foram escolhidos três serviços eletrônicos dessa área. Os serviços de requerimento de 
auxílio-doença e de pensão por morte foram escolhidos por serem os serviços públicos eletrônicos mais acessados, enquanto a escolha do serviço de requisição do benefício de salário-maternidade pautou-se pelo fato de ter sido esse um serviço que apresentou aumento acentuado na sua taxa de uso no período da greve dos servidores da Previdência Social, em 2005, o que demonstra o potencial do e-gov como alternativa real de canal de comunicação e prestação de serviços públicos à sociedade. No período dessa greve, a requisição do salário-maternidade foi feita exclusivamente pela internet. $\mathrm{O}$ serviço eletrônico PREVcidadão, inicialmente selecionado para avaliação, foi descartado por estar em manutenção no período da pesquisa.

O Programa Nacional de Estímulo ao Primeiro Emprego (PNPE), selecionado como serviço público eletrônico prestado pelo Ministério do Trabalho e Emprego, foi incluído nesta pesquisa apesar de estar em processo de internalização, segundo o Coordenador-Geral de Modernização e Informática desse ministério. Como os serviços, com foco no cidadão, relacionados pelo Ministério da Saúde, foram classificados nos estágios de e-gov iniciais de apresentação e busca de informações, nenhum serviço dessa área foi selecionado para a pesquisa. Os serviços mais avançados do portal web desse ministério, classificados como serviços de interatividade limitada e transações eletrônicas, têm, como público-alvo, os gestores da área de Saúde e não propriamente o cidadão.

\subsubsection{Proposta de método de avaliação de programas de governo eletrônico}

A proposta de um método de avaliação de resultados de programas de governo eletrônico sob a ótica do cidadão, como instrumento para melhoria da comunicação eletrônica entre governo e sociedade, baseou-se nos modelos definidos e na abordagem escolhida, e tal fato deve ser observado na sua aplicação. Certamente outros conjuntos de procedimentos, técnicas e ferramentas seriam mais adequados a estudos que optarem por outros objetivos do e-gov, outras abordagens, outros enfoques, outras delimitações de pesquisa. Cada método, por definição, tem vantagens e desvantagens. Não há um método perfeito para todos os propósitos de pesquisa em ambientes complexos, como é o caso do governo eletrônico. $\mathrm{O}$ método proposto é constituído das etapas seguintes: pesquisa documental sobre o Programa E-Gov, além da análise de normas, manuais e recomendações utilizados pelas prestadoras dos serviços selecionados; análise do contexto com auxílio de técnicas e ferramentas de avaliação de programas; entrevistas presenciais com gestores do Programa E-Gov e gestores de portais e serviços e-gov; avaliação heurística e testes nos portais dos serviços e-gov selecionados; grupos focais com coordenadores de Comitês Técnicos do Programa E-Gov e gestores de serviços e-gov (selecionados e não selecionados); levantamentos on-line (questionários) com gestores de portais e-gov não 
selecionados e cidadãos-clientes dos serviços selecionados; entrevista, via telefone, com cidadãos-clientes dos serviços selecionados.

\subsubsection{Aplicação e validação do método elaborado}

As etapas mencionadas foram aplicadas ao Programa de Governo Eletrônico brasileiro e nos serviços e-gov selecionados, de agosto a dezembro de 2005, e seus procedimentos validados a partir de análises estatísticas e de confrontação das mesmas informações obtidas de diferentes fontes e com diferentes técnicas de coleta.

A técnica quantitativa adotada na pesquisa, mais especificamente no levantamento feito com gestores de portais e-gov da Administração Pública Federal, sobre monitoramento e avaliação dos serviços e-gov, e na avaliação da satisfação dos clientes dos serviços públicos eletrônicos selecionados, foi a do tipo survey, com questionários autoadministrados, cujos resultados são inferidos a partir da opinião de uma amostra representativa da população estudada. O estudo agregado das opiniões dos integrantes da amostra permite conhecer o comportamento da população a partir de análises estatísticas.

A coleta de dados com os usuários ocorreu de 21 de outubro a 19 de novembro de 2005, conforme acordos feitos com cada uma das instituições cujos serviços foram selecionados para esta pesquisa. O questionário respondido pelos gestores ficou disponível na internet de 25 de outubro a 18 de novembro do mesmo ano.

Em ambos os levantamentos, a principal técnica de análise de dados utilizada, com auxílio dos softwares Microsoft Excel 97, Statistical Package for the Social Sciences (SPSS) e Sphinx, foi estatística (distribuição de frequências, medidas de tendência central e dispersão, cruzamento de variáveis, correlações, regressão múltipla), dada a natureza dos dados coletados. No caso dos dados qualitativos coletados em resposta a perguntas abertas, foi realizada análise de conteúdo com auxílio do software Sphinx, o qual também foi utilizado na produção de todos os questionários deste estudo.

Para a construção do instrumento utilizado na coleta de dados da etapa quantitativa relacionada à pesquisa de satisfação dos clientes dos serviços públicos eletrônicos selecionados, foram consultados documentos sobre pesquisas on-line e levadas em consideração as dimensões apresentadas na figura3. Tais dimensões se transformaram nas variáveis propostas no Quadro 1. Após sua elaboração, o questionário-piloto foi submetido à revisão de seis doutorandos e de uma professora do Departamento de Ciência da Informação e Documentação, da Universidade de Brasília (UnB), bem como de dois especialistas, professores do Instituto de Psicologia da UnB. Após as devidas alterações, sugeridas pelos 
revisores, o questionário-piloto revisado no formato em papel foi adaptado para a web, considerando-se as vantagens e desvantagens de sua aplicação nesse ambiente.

Em seguida, foi realizada a análise de juízes do questionário on-line por três auditores, uma psicóloga e atendentes da central de atendimento da Previdência Social, além de pré-teste, durante uma semana, com usuários de todos os serviços. O questionário definitivo foi atualizado de acordo com estas últimas análises e adaptado para cada serviço avaliado. Para não desestimular os beneficiários dos serviços selecionados no preenchimento de questionário tão extenso, e ainda assim obter respostas para todas as suas perguntas, optou-se por subdividir as questões em dois tipos de questionários diferentes preenchidos por parcelas do universo.

O questionário 1 foi respondido por 2.086 pessoas; o questionário 2, por 2.419, totalizando 4.505 participantes da pesquisa de satisfação on-line, já descontados os questionários descartados por duplicidade ou por terem excedido o limite preestabelecido de três questões sem respostas.

A consistência interna dos questionários respondidos pelos usuários dos serviços públicos eletrônicos selecionados, ou seja, sua confiabilidade, foi medida pelo Alfa de Cronbach.

A técnica estatística de regressão múltipla, cujo objetivo principal é predizer o valor da variável dependente, dados os valores de variáveis independentes associadas, a partir de fórmula algébrica denominada equação de regressão, foi utilizada para identificar as dimensões que mais significativamente contribuíram para a "qualidade percebida" e para o "valor percebido", assim como os construtos que mais contribuíram para a "satisfação geral". Além disso, a partir dessa técnica, identificou-se o poder de explicação dos construtos antecedentes da satisfação e sua validade convergente.

A validade convergente do construto "satisfação geral" foi medida pela comparação das respostas à pergunta específica sobre satisfação geral e do conjunto das perguntas relacionadas aos construtos "qualidade percebida", "valor percebido" e "expectativas atendidas", seus antecedentes, expresso pela equação de regressão. A partir de correlações entre itens dos questionários de satisfação relacionados a construtos diferentes, verificou-se sua validade discriminante. Já a validade nomológica foi observada com a comparação dos resultados deste estudo com outros anteriores realizados por outros pesquisadores.

As técnicas qualitativas adotadas foram as seguintes: pesquisa documental, entrevista individual (incluindo entrevista telefônica), análise de contexto, testes automáticos e 
manuais com os portais web dos serviços públicos eletrônicos selecionados, avaliação heurística e grupo focal.

A técnica de entrevista individual foi adotada com quatro fontes de informação diferentes e com propósitos diferentes. A entrevista com os gestores do Programa E-Gov teve, como objetivo, entender o contexto e a forma como o programa funciona. Foram entrevistados o Secretário de Logística e Tecnologia da Informação, a Diretora do Departamento de Governo Eletrônico, e o Coordenador do Comitê Técnico de Gestão de Sítios On-Line, Secretário de Comunicações da Presidência da República, por ser esse comitê o que mais se aproxima da temática desta pesquisa.

A entrevista com os gestores de portais e-gov das áreas de Educação, Previdência Social, Saúde e Trabalho e Emprego teve, como propósito, compreender a estratégia adotada por cada ministério na implementação de seus portais web e ainda solicitar, a cada um, lista de serviços públicos eletrônicos por eles prestados, para atendimento direto ao cidadão. Tal lista foi utilizada na seleção dos serviços do estudo de caso.

As entrevistas individuais com os gestores dos serviços públicos eletrônicos selecionados, responsáveis tanto pelo conteúdo quanto pela implementação eletrônica dos serviços de Declaração Anual de Isento, requisições de auxílio-doença, pensão por morte, salário-maternidade e PNPE, possibilitaram a coleta de informações tais como: público-alvo, universo atendido, disponibilidade do serviço, técnicas de análise de necessidades, monitoramento e avaliação adotadas, entre outras. Os resultados dessas entrevistas foram utilizados como subsídios para a elaboração do instrumento de coleta de dados quantitativo enviado aos gestores de portais e-gov não selecionados para a pesquisa qualitativa.

Nessas entrevistas, também foram apresentados aos gestores o questionário sobre medidas adotadas em relação à segurança de dados, baseadas na Resolução nº 7 , de 29 de julho de 2002, e os questionários da pesquisa de satisfação, correspondente ao seu serviço, para que indicassem que respostas esperavam receber de seus clientes. A confrontação das respostas dos gestores e dos clientes dos serviços ao mesmo questionário permite mostrar até que ponto a percepção do gestor quanto à qualidade do serviço prestado se compara à percepção dos clientes do serviço.

As entrevistas telefônicas, por sua vez, foram feitas com 142 usuários dos serviços DAI, PNPE e Auxílio-doença, em um universo de 2.301 pessoas que se prontificaram a participar, estratificados por serviço e selecionados aleatoriamente, com o objetivo de identificar os pontos positivos e negativos desses serviços, na opinião desses usuários. O tamanho da amostra, representando 1/16 do universo, foi calculado com 
nível de confiança de 95\%, +/- 8\% de erro amostral e proporção, mais conservadora, de 50/50 do universo em questões com duas opções de resposta. As entrevistas foram realizadas em dezembro de 2005 , gravadas e transcritas.

$\mathrm{Na}$ análise do contexto, foram utilizadas ferramentas típicas de diagnóstico em avaliação de programas: análise de grupo de interesse (stakeholder), análise SWOT, painel de referência, diagrama de verificação de riscos (DVR) e matrizes de planejamento e de achados de auditoria, que auxiliaram na compreensão do contexto estudado. Para o painel de referência, foram convidados dois especialistas em governo eletrônico, três auditores e um especialista em avaliação de programas de governo para debater a matriz de planejamento do estudo.

Para a avaliação da interface web dos serviços selecionados, foram realizados testes automáticos de acessibilidade - ferramentas automáticas, disponíveis gratuitamente na web, que avaliam a acessibilidade de páginas web, por meio de análise estática dessas páginas. Como essas ferramentas automáticas só conseguem detectar um número limitado de problemas potenciais, foram utilizados outros métodos complementares, manuais, de avaliação de acessibilidade: teste com diferentes tipos de navegadores web, em condições variadas (com figuras e sons habilitados; figuras desabilitadas; sons desabilitados; sem utilizar o mouse; e com diferentes resoluções de vídeo). Essas condições simulam restrições de navegação a que alguns usuários estariam submetidos, seja por estarem usando tecnologias assistivas, hardware e software mais antigos ou mais modernos, seja por terem limitações físicas ou mentais.

Outra técnica adotada para avaliação da interface dos serviços selecionados foi a avaliação heurística - método de inspeção sistemático da usabilidade de sistemas interativos, cujo objetivo é identificar problemas de usabilidade de sistemas informatizados. Esse método envolve a participação de um pequeno grupo de avaliadores na análise do fluxo de interação necessário para iniciar e completar tarefas reais, bem como no julgamento dos elementos interativos do sistema, em relação a princípios reconhecidos de usabilidade, designados também como "heurísticos". Essa avaliação complementa os testes automáticos em pontos passíveis de verificação apenas manual, como, por exemplo, o contraste de cores e a adequação do texto de um link ao conteúdo por ele apontado.

Neste estudo de caso, foram analisados, por um especialista em usabilidade e um analista de sistemas, separadamente, os cinco serviços públicos eletrônicos selecionados, comparando suas características com as recomendações, princípios e/ou heurísticas previamente escolhidos.

Essa avaliação considerou dez dimensões, ponderadas de acordo com sua importância, sob o ponto de vista da maioria dos 4.505 usuários pesquisados no levantamento on-line (Quadro 3). Os itens da lista de verificação, gerada a partir de normas e recomendações produzidas pelo governo brasileiro (Resolução n 7, Modelo e Cartilha Técnica de Acessibilidade e Cartilha 
de Usabilidade para sítios e portais) e por pesquisadores independentes, foram ponderados de acordo com a seguinte escala: Peso 3 - artigos, incisos e alíneas da Resolução no 7/2002; Peso 2 - recomendações de prioridade 1 da Cartilha Técnica de Acessibilidade (Brasil - MP, 2005) e parâmetros mínimos da Cartilha de Usabilidade (Brasil. Governo Eletrônico, 2004); Peso 1 - recomendações de alta prioridade de Vilella (2003), heurísticas de Dias (2001) e recomendações do manual do governo alemão (Stutz et al., 2002).

Quadro 3 - Pesos das dimensões - grau de importância indicado pelos usuários pesquisados

\begin{tabular}{|c|c|}
\hline DIMENSÃo & PESO \\
\hline Privacidade e segurança de dados & 3 \\
\hline Disponibilidade & 3 \\
\hline Tempo de atendimento & 3 \\
\hline Acessibilidade & 2 \\
\hline Capacidade de resposta a dúvidas & 2 \\
\hline Confiabilidade & 2 \\
\hline Facilidade de localização do portal da instituição & 1 \\
\hline Usabilidade & 1 \\
\hline Conveniência & 1 \\
\hline
\end{tabular}

Fonte: Elaboração dos autores (2018).

Tal ponderação considerou o fato de a Resolução $n^{\circ} 7$, deliberada pelo Comitê Executivo do Governo Eletrônico (Cege) e, portanto, norma a ser cumprida, e as Cartilhas Técnica de Acessibilidade e de Usabilidade serem documentos do governo brasileiro, mesmo que não coercitivos, mas certamente mais significativos para os gestores de portais da Administração Pública Federal do que as recomendações de pesquisadores independentes.

Os avaliadores especialistas efetuaram também a classificação dos serviços oferecidos no portal da Previdência, tomando como base o conteúdo disponível no período de 16 a 18 de novembro de 2005. O objetivo desse levantamento foi identificar a taxa de serviços interativos colocados à disposição do cidadão. Foram pesquisados links para informações e serviços existentes até o terceiro nível de navegação (acessando até três páginas a partir da página inicial do portal, considerada ponto zero). O conteúdo foi classificado como serviço quando havia alguma interação do portal com o usuário, como preencher campos, fornecer senha, acessar dados, e como informação, quando o portal apenas fornecia qualquer informação oficial ao usuário. 
Para confirmar, refutar ou compreender melhor os resultados do levantamento quantitativo realizado com os gestores de serviços e-gov, foram realizados três grupos focais com gestores, nos dias 9, 11 e 17 de novembro de 2005, dos quais participaram 23 representantes de dez ministérios, cinco agências reguladoras e oito unidades vinculadas à Presidência da República, empresas públicas, autarquias ou fundações, selecionados aleatoriamente entre aqueles residentes em Brasília que se identificaram como interessados em participar desse tipo de entrevista. Nesses grupos focais, participaram ainda um moderador e três observadores para registrar as discussões, já que, para esse grupo de pessoas, talvez fosse constrangedor gravar suas intervenções. Os temas discutidos foram os mesmos da etapa quantitativa: planejamento, gerência, monitoramento e avaliação dos serviços públicos eletrônicos por parte dos próprios órgãos prestadores dos serviços e atuação da coordenação do Programa de Governo Eletrônico.

Para promover a discussão sobre a atuação da coordenação do programa no monitoramento e avaliação da qualidade dos serviços públicos prestados via internet, realizou-se, no dia 3 de novembro de 2005, grupo focal com os oito coordenadores de Comitês Técnicos de Governo Eletrônico. Dada a quantidade reduzida de coordenadores, não houve alternativa a não ser realizar apenas um encontro com todos eles, mesmo contrariando a recomendação de realizar vários grupos focais para que se possa chegar a uma conclusão mais próxima da realidade, sobre o tema discutido. Nesse grupo focal, também participaram um moderador e três observadores, sem gravação de áudio ou vídeo.

O uso de grupos focais na pesquisa teve como intenção provocar o confronto de opiniões, percepções, sentimentos, atitudes e ideias dos participantes a respeito desses temas. Os usuários dessa técnica partem do pressuposto de que a energia gerada pelo grupo resulta em maior diversidade e profundidade de respostas, isto é, o esforço combinado do grupo produz mais informações, e com maior riqueza de detalhes, do que o somatório das respostas individuais. Em suma, a sinergia entre os participantes leva a resultados que ultrapassam a soma das partes individuais.

A análise dos resultados obtidos foi essencialmente baseada em técnicas qualitativas (análise de conteúdo, sumarização, interpretação de opiniões e atitudes), apesar de terem sido contabilizados, estatisticamente, os resultados dos testes automáticos, manuais e da avaliação heurística das interfaces dos serviços públicos eletrônicos examinados.

\section{ANÁLISE E DISCUSSÃO DOS RESULTADOS}

Como contribuições significativas dos resultados da pesquisa que responde à questão "Como avaliar os resultados de programas de governo eletrônico sob a ótica do cidadão-cliente?”, destacam-se três aspectos: 1) os modelos de avaliação de governo eletrônico, de avaliação da 
satisfação e de avaliação de programas de governo eletrônico; 2) os instrumentos de coleta de dados relacionados aos objetivos da pesquisa, disponíveis como apêndices deste documento; 3) os resultados da aplicação do método proposto na avaliação do Programa E-Gov brasileiro e de cinco serviços públicos eletrônicos selecionados, quanto ao monitoramento e à avaliação de sua eficácia, os quais foram incorporados a um relatório de auditoria do Tribunal de Contas da União com recomendações para sua melhoria.

O conjunto de técnicas que compôs o método de avaliação englobou, além do grupo focal e da avaliação heurística, várias das técnicas e ferramentas de coleta, análise de dados e de controle de qualidade geralmente utilizadas em avaliações de programa: pesquisa documental, entrevista (inclusive por telefone), levantamento (survey), análise de grupo de interesse, análise SWOT, diagrama de verificação de risco, matriz de planejamento, matriz de achados e painel de referência. No que se refere às técnicas utilizadas na pesquisa, podem-se destacar os seguintes pontos.

Diferentemente da maioria das avaliações de resultados sociais de políticas e serviços públicos, geralmente feitas por meio de indicadores quantitativos (número de pessoas atingidas, quantidade de recursos aplicados), o método de avaliação de e-gov proposto permite avaliação mais ampla e consistente, já que alia técnicas estatísticas a outras que possibilitam análise em profundidade das informações coletadas.

A técnica de entrevistas por telefone, única técnica usada para coletar informações de usuários no cálculo do índice ACSI (2004), que incluiu a avaliação de portais web do governo eletrônico americano, pela primeira vez, em 2002, foi uma entre várias técnicas utilizadas por esta pesquisa, propiciando, assim, triangulação de resultados e, consequentemente, maior validade.

A análise de conteúdo web realizada nesta pesquisa, por sua vez, constitui outro aspecto relevante. Isso porque foi além da verificação da disponibilidade de serviços úteis ao cidadão comum e da classificação em estágios evolutivos, como a de estudos comparativos das Nações Unidas e de firmas de consultoria, pois englobou elaboração de lista de verificação, a partir de normas e padrões de qualidade nacionais e internacionais, e posterior avaliação heurística por especialistas, complementada por testes automáticos e manuais.

O uso de grupos focais nesta pesquisa teve como intenção provocar o confronto de opiniões, percepções, sentimentos, atitudes e ideias dos participantes. Os gestores de portais da APF que integraram três grupos focais receberam muito bem a técnica a ponto de se expressarem naturalmente, aparentemente sem reservas, aproveitando a oportunidade para trocar experiências entre si. Muitos saíram dali com a intenção de entrar em contato com outros participantes para estender a discussão após a entrevista em grupo. Observou-se que o esforço combinado do grupo produziu mais informações, e com maior riqueza de detalhes, do que o somatório das respostas individuais. 
A alta taxa de resposta da pesquisa de satisfação realizada com 4.505 usuários de serviços e-gov brasileiros consiste em aspecto que merece destaque. O resultado contrariou o que a literatura afirma sobre baixas taxas de resposta em pesquisas na internet. O motivo que levou os usuários dos serviços e-gov a participarem desta pesquisa talvez tenha sido a carência de canais de comunicação do governo com os cidadãos, que viram, na pesquisa, uma oportunidade para reivindicar, reclamar, elogiar. Outra razão talvez tenha sido a oportunidade que o questionário de satisfação on-line lhes proporcionou de expressar suas opiniões, com facilidade e rapidez, acerca dos serviços do governo, visando a sua melhoria, fazendo com que se sentissem prestigiados por estarem sendo "ouvidos" (senso de inclusão e importância).

O fato de parte desta pesquisa ter sido apoiada pelo Tribunal de Contas da União pode ter lhe conferido maior seriedade, aos olhos da coordenação do programa, dos gestores de portais e dos usuários dos serviços públicos eletrônicos avaliados. Isso, por sua vez, pode ter influenciado positivamente sua predisposição e compromisso no fornecimento de dados e na participação nas entrevistas individuais, grupos focais e levantamentos (questionários).

É importante destacar também que a técnica de levantamento on-line (questionário) desta pesquisa sobre serviços e-gov foi aplicada com clientes que haviam utilizado recentemente os serviços, isto é, em um período menor que seis meses, para que tivessem mais condições de lembrar e opinar sobre seus aspectos positivos e negativos. Esse levantamento teve ainda a vantagem de alcançar, em curto espaço de tempo e com baixo custo, populações grandes e diversas, no que se refere a perfis e localização geográfica.

A incorporação de técnicas de prospecção realizada com os cidadãos-clientes (survey e entrevistas telefônicas), nesta pesquisa, está de acordo com o documento brasileiro Padrões de qualidade do atendimento ao cidadão: estabelecendo padrões de qualidade do atendimento (Brasil - MP, 2000), que recomenda monitorar sistematicamente o desempenho das instituições governamentais em relação a padrões, a partir, por exemplo, do levantamento da opinião dos usuários por meio de pesquisas de satisfação e entrevistas. Além disso, considerou-se que apenas os consumidores podem julgar a qualidade; todos os demais julgamentos são irrelevantes. Apesar de existir norma brasileira que determina a realização de avaliação de satisfação do usuário, pelo menos anualmente, os resultados desta pesquisa indicaram que esse não é um procedimento usual na Administração Pública Federal.

O grau de triangulação das técnicas utilizadas nesta pesquisa, por seu turno, foi expressivo, tanto que as ferramentas de análise e controle de qualidade de avaliação de programas percorreram todos os achados de auditoria em ações do Programa E-Gov, enquanto as entrevistas, os grupos focais e os questionários contribuíram para a identificação de quase todos eles. A pesquisa documental e a avaliação heurística (incluindo os testes de interface) foram mais significativas em determinados temas. De uma maneira geral, os 
achados foram subsidiados por mais de uma técnica, o que demonstra um ponto forte do método de avaliação proposto.

O fato de apresentar os resultados de testes de confiabilidade e validade dos questionários de satisfação, propiciando, assim, a outros pesquisadores, sua aplicação e confirmação, torna esta pesquisa distinta da maioria das pesquisas de marketing, área que costuma aplicar questionários de satisfação com clientes de produtos e serviços. Também, diferentemente da maioria desses estudos, que utilizam, preferencialmente, estatísticas descritivas, como frequência e média, esta pesquisa utilizou, além desses, outros tipos de análise estatística de dados, tais como moda, mediana, desvio-padrão, correlação, regressão múltipla, cruzamento de variáveis e fatorial.

Como contribuições significativas dos resultados da pesquisa que pretendeu responder a questão "Há relação direta entre o atendimento aos padrões de qualidade adotados e a satisfação do cidadão-cliente com os serviços de governo eletrônico?”, é importante destacar três aspectos: 1) a elaboração da lista de verificação para portais e serviços e-gov; 2) a confrontação do modelo de avaliação da satisfação com modelos similares de outros estudos, demonstrando sua validade nomológica; 3) os próprios resultados da aplicação do método na avaliação do Programa E-Gov brasileiro e de cinco serviços públicos eletrônicos selecionados, também incorporados a um relatório de auditoria do Tribunal de Contas da União encaminhado aos coordenadores do programa e gestores dos serviços participantes.

A avaliação do atendimento aos padrões de usabilidade e acessibilidade realizada nesta pesquisa demonstrou que mesmo os portais que atenderam a maiores porcentagens de padrões de qualidade precisam dar mais atenção às necessidades dos usuários e à acessibilidade de seu conteúdo; fornecer informações sobre questões ligadas à privacidade e segurança; facilitar a comunicação entre governo e cidadãos; e incluir os usuários no processo de seu desenvolvimento. Imagina-se que a probabilidade de um portal ou serviço web ser mais acessível e amigável seja maior quando seu desenvolvimento é pautado em padrões de qualidade derivados de consultas a seus usuários. Em relação aos resultados desta parte da pesquisa, podem-se destacar cinco pontos. No primeiro ponto, foram observadas as relações entre os construtos "expectativas", "qualidade percebida", "valor percebido" e "satisfação geral", originalmente definidas no modelo americano ACSI, e foi confirmado o maior impacto da "qualidade percebida" sobre a satisfação do cliente. No segundo, a relação entre os construtos "expectativas" e "satisfação geral" $(\beta=0,089)$ demonstrou que as expectativas dos usuários não influenciam a satisfação nem a percepção da qualidade do serviço. No terceiro ponto, quanto ao poder de explicação dos construtos "expectativas", "qualidade percebida" e "valor percebido" sobre a variação total do construto "satisfação geral", esta pesquisa no âmbito do governo federal brasileiro, com 74\%, nivelou-se a outros estudos em empresas brasileiras e americanas, mesmo com diferenças de contextos e de tipos de objetos avaliados (produtos ou serviços). No quarto, os resultados 
desta pesquisa, em relação ao modelo de avaliação da satisfação, por serem compatíveis aos previstos na teoria e aos de outros estudos de validação do ACSI, tomado como base para a construção do modelo desta pesquisa, demonstram validade nomológica dos construtos que o compõem, complementando, assim, os testes de confiabilidade e validades convergente e discriminante. Por fim, dada a dependência do tipo de dimensão avaliada no relacionamento entre "padrão de qualidade atendido" e "satisfação geral", e por não ter sido encontrado, na literatura, estudo com essa mesma questão de pesquisa, não foi possível comparar os resultados desta pesquisa com outros, nem dar resposta a essa questão que fosse válida para todas as dimensões sob avaliação, razão pela qual esse assunto foi incorporado à lista de sugestões para pesquisas futuras.

Também foi possível chegar a outras conclusões não associadas diretamente a questões de pesquisa. Após a aplicação do método de avaliação proposto, observou-se que, de uma maneira geral, os usuários participantes desta pesquisa estão satisfeitos com a qualidade dos serviços públicos eletrônicos selecionados (36\% estão satisfeitos e $21 \%$ muito satisfeitos, totalizando $57 \%$ com avaliação positiva).

Em relação às dimensões apontadas como mais importantes pelos usuários de serviços e-gov, pode-se dizer que os resultados desta pesquisa apontaram que a confiabilidade é a dimensão mais importante para os consumidores dos serviços, enquanto a aparência das instalações (análoga à usabilidade da interface web) é a menos valorizada - e, paradoxalmente, aquela em que os serviços tendem a ser mais bem avaliados, como aconteceu nesta pesquisa. A dimensão "privacidade e segurança" foi identificada como a mais importante para os usuários desta pesquisa e representou motivo de preocupação de $40 \%$ dos respondentes ( 834 pessoas). Essa preocupação com a privacidade e a segurança corrobora a hipótese de que aumentar a percepção dos usuários quanto à segurança e à privacidade de informações e inspirar sua confiança são fatos decisivos para a sustentação do comércio e do governo eletrônicos.

Esta pesquisa identificou como dimensões mais importantes a privacidade e segurança, a disponibilidade e o tempo de atendimento. A economia de tempo e a conveniência de escolha do canal de comunicação com o governo também foram bem cotadas nesta pesquisa.

Por meio de cruzamentos de variáveis, observou-se que os usuários que mais valorizaram a prestação de serviços públicos via internet, em comparação com os outros canais de atendimento, foram os com ensino superior completo, com boa habilidade no uso de computadores e que utilizam a internet mais de três vezes por semana. Entre aqueles que apontaram a privacidade de dados pessoais e a disponibilidade como as dimensões mais importantes na prestação de serviços públicos eletrônicos, destacaram-se os especialistas na área de informática com curso de pós-graduação completo e que utilizam a Internet pelo menos três vezes por semana. Valorizaram mais a usabilidade as pessoas menores de 18 anos e que estavam utilizando a internet pela primeira vez. 
Ao confrontar as respostas dos gestores e dos clientes dos serviços ao mesmo questionário, esta pesquisa evidenciou que gestores e clientes tiveram opiniões diferentes quanto ao grau de importância das dimensões sob avaliação, provavelmente pelo fato de os gestores não conhecerem as necessidades e expectativas de seus clientes, já que, para os usuários, as técnicas de prospecção não são usuais. É provável que a aplicação mais frequente de pesquisas de satisfação, análise de demanda (expectativas, necessidades) e análise de reclamações, sugestões e críticas diminua as diferenças de opinião ou percepção entre gestores e clientes de serviços e-gov.

A carência de estudos sobre oferta versus demanda previamente à implementação de serviços públicos eletrônicos e de monitoramento contínuo e avaliação, além do parâmetro "quantidade de acessos", é a causa mais provável do desconhecimento do público-alvo por parte dos gestores de portais e serviços públicos eletrônicos. Tal fato pode levar à implementação de serviços que não atendem às necessidades e expectativas desse público, e, sob o ponto de vista administrativo, à implementação de serviços sem que se saiba, previamente, se a demanda justifica seus custos.

Compreender quão importantes são as características da prestação do serviço para seus clientes ajuda a organização a escolher áreas de melhoria que sejam significativas para eles. As características da prestação de serviços com menores índices de satisfação (as maiores lacunas) não serão necessariamente aquelas eleitas pelos clientes como prioritárias para melhoria. Dados sobre a importância, combinados com avaliações de satisfação, fornecem à organização informações para a tomada de decisão. Se a organização medir apenas os níveis de satisfação e priorizar suas ações com base nos índices mais baixos de satisfação, seus esforços para melhoria de desempenho poderão ser em vão se as dimensões escolhidas tiverem pouca importância para os cidadãos-clientes.

Na dimensão "usabilidade", estão inseridas as principais barreiras à comunicação: presunção enunciada, distração (excesso de informações, poluição visual, apresentação de conteúdo supérfluo), apresentação confusa de conteúdo (linguagem complexa, siglas, jargões técnicos). Todas essas barreiras foram constatadas, em maior ou menor grau, na avaliação heurística dos serviços e-gov selecionados para esta pesquisa, o que confirma a opinião de alguns autores de que as agências governamentais são conhecidas por suas comunicações frequentemente incompreensíveis. Porém, tais aspectos parecem não ter atrapalhado a interação dos usuários com os serviços na internet, já que foram bem avaliados nesse quesito na pesquisa de satisfação.

O fato de vários usuários terem comentado, em pergunta aberta do questionário de satisfação, sobre o processo de prestação do serviço fora do ambiente eletrônico, confirma que os consumidores de serviços não avaliam sua qualidade apenas com base no produto final. Sua avaliação incorpora, também, sua opinião sobre o processo de fornecimento do serviço. 
Quanto ao estágio de e-gov preponderante, esta pesquisa identificou maior quantidade de serviços no estágio inicial de apresentação de informações e baixa quantidade de transações on-line. Além da dificuldade de integração dos sistemas legados e plataformas tecnológicas heterogêneas, e do fato de a internet ainda não ser vista, pelos dirigentes da Administração Pública Federal (APF), como canal estratégico de prestação de serviços ao cidadão, outras prováveis causas da baixa porcentagem de serviços transacionais são as seguintes: maior prioridade dada aos serviços eletrônicos internos do governo voltados aos gestores; necessidade de reestruturação dos processos de prestação dos serviços; e falta de cultura de e-gov e de foco no cidadão na APF.

O fato de a certificação digital ainda ser incipiente na APF e a inexistência de plano de ação do Programa de Governo Eletrônico para priorizar o desenvolvimento de novos serviços pelos órgãos da APF também podem ser considerados fatores que levam à baixa porcentagem de serviços com foco no cidadão. O grupo focal de coordenadores destacou, ainda, que "nem todas as pessoas têm condições de acessar a internet. Logo, nem tudo pode ser feito integralmente pela internet”.

Como possíveis efeitos dessa baixa porcentagem de serviços transacionais, citam-se as seguintes: a falta de ações concretas para implementar diretrizes do programa que tenham foco no cidadão, a sobrecarga dos canais tradicionais de prestação de serviços ao cidadão, o não atendimento das expectativas do público-alvo e a consequente imagem negativa do governo quanto ao uso incipiente da tecnologia para beneficiar o cidadão. Esta pesquisa identificou, como principais serviços públicos eletrônicos acessados, além daqueles selecionados, a consulta ao CPF e serviços da Receita Federal.

\section{CONCLUSÕES}

Esta pesquisa teve a pretensão de contribuir para o avanço da atividade prática de avaliação de governo eletrônico, porém com bases científicas, ao identificar e validar procedimentos, critérios de avaliação, padrões de qualidade e indicadores em um determinado contexto. Além disso, fornece novo enfoque para a área de Comunicação da Informação, ao traçar, em seu marco teórico, um paralelo entre fidelidade do processo de comunicação e qualidade de serviços públicos.

O modelo de avaliação de governo eletrônico, derivado da revisão de literatura e do poder de abstração e síntese do pesquisador, contribui para o entendimento teórico sobre governo eletrônico, tendo sido reconhecido pela comunidade acadêmica, na II Conferência Sul-Americana em Ciência e Tecnologia Aplicada ao Governo Eletrônico - Conegov 2005, pela premiação do artigo que o apresenta (DIAS, 2005).

O modelo para medir a satisfação do cliente de serviços de governo eletrônico expande o modelo ACSI americano para o contexto de e-gov, ao definir claramente as dimensões de avaliação desse ambiente. Já o modelo de avaliação de programas desta pesquisa associa elementos da avaliação 
de programas da área de Administração Pública ao contexto de e-gov, trazendo, para o campo teórico, uma visão prática de avaliação.

Apesar de esta pesquisa diferir, em vários aspectos, de estudos anteriores sobre satisfação, seus resultados reforçam os achados anteriores no que se refere ao forte impacto da percepção da qualidade sobre a satisfação também na prestação de serviços públicos eletrônicos, demonstrando aos gestores que investimentos na qualidade produzem efeitos sobre a satisfação dos cidadãos-clientes.

Pode-se dizer que o método de avaliação proposto apresenta maior variedade de técnicas de coleta de dados do que os estudos identificados na revisão de literatura, além de demonstrar a confiabilidade e a validade de seus instrumentos, seja por testes estatísticos, seja por triangulação. As dimensões de avaliação desta pesquisa, por sua vez, são ora adaptações de dimensões do meio físico para o ambiente eletrônico, ora reunião de aspectos avaliados em estudos diversos, reclassificados de acordo com a experiência do pesquisador.

Como os serviços e-gov selecionados para esta pesquisa pertencem a setores distintos do governo brasileiro, é de se esperar que os instrumentos e procedimentos aqui utilizados possam ser aplicados em outros setores sem qualquer comprometimento de seus resultados. Além disso, a repetição da avaliação desses mesmos serviços públicos eletrônicos pode traduzir-se em oportunidade para análise de tendências e séries temporais, a fim de determinar mudanças de longo prazo e padrões cíclicos nos dados coletados.

A partir da análise das técnicas, da descrição dos procedimentos metodológicos adotados pelo pesquisador, e tendo em mãos vários dos instrumentos utilizados nesta pesquisa, outros pesquisadores, auditores e gestores de portais e serviços web poderão lançar mão deste método para avaliação, sob a mesma ótica adotada nesta pesquisa, de serviços e-gov e programas de governo de qualquer esfera (municipal, estadual, federal) ou país. É importante dizer que a concepção, a formatação gráfica, os métodos de coleta e análise de dados da pesquisa de satisfação on-line desenvolvidos nesta pesquisa, além do subconjunto de suas perguntas, foram adotados posteriormente a esta pesquisa por equipe da Diretoria de Auditoria de Tecnologia da Informação do Tribunal de Contas da União, em auditoria de conformidade com o Sistema Nacional de Integração de Informações em Justiça e Segurança Pública (Infoseg), tendo atingido bons resultados no que concerne à confiabilidade interna do instrumento, e à participação, acima do esperado, dos usuários desse sistema.

O método de avaliação de programas de governo eletrônico, que combina uma variedade de técnicas de coleta e análise de dados, quantitativas e qualitativas, aplicadas tradicionalmente em diferentes áreas do conhecimento, com a participação de gestores públicos e cidadãos, poderá ser aplicado por auditores internos e externos de qualquer país com programa de governo eletrônico instituído. Os padrões de qualidade reunidos em uma única lista de verificação para portais e 
serviços e-gov poderão também ser utilizados por projetistas de portais de governo eletrônico preocupados com a acessibilidade e a usabilidade de sua interface, assim como com outros aspectos de qualidade e segurança de sistemas de tecnologia da informação.

O modelo para medir a satisfação do cliente de serviços de governo eletrônico, com a definição clara de dimensões e os questionários dele derivados, apresenta critérios e instrumentos validados estatisticamente, passíveis de aplicação em outros serviços de governo eletrônico, e não só naqueles selecionados para esta pesquisa. Tal modelo serve para determinar não só os níveis correntes de satisfação, mas também as expectativas e prioridades de melhoria dos clientes relacionados a cada um dos serviços públicos identificados. Os questionários desenvolvidos e validados nesta pesquisa, por sua vez, podem se tornar também instrumentos padronizados de pesquisa para facilitar tanto comparações confiáveis entre serviços similares ou do mesmo serviço ao longo do tempo, quanto o desenvolvimento de parâmetros normativos, sem necessidade de conversão de pesquisas em uma métrica comum.

A análise das dimensões mais importantes para a satisfação com os serviços e-gov provê, aos tomadores de decisão, uma ferramenta para priorizar ações entre tantas necessárias para melhorar seus serviços. Essa análise permite identificar quais dimensões necessitam de mais atenção por parte dos gestores públicos para que sejam atendidas as expectativas e necessidades dos cidadãos-clientes.

Em suma, para a academia, esta tese de doutorado em Ciência da Informação (Dias, 2006) permite analisar, sob um novo ângulo, a fidelidade do processo de comunicação entre governo e sociedade e a qualidade de serviços públicos. Além disso, serve como fonte de consulta bibliográfica sobre o estado da arte de avaliação de e-gov sob a ótica do cidadão-cliente; como referência para a construção de novos instrumentos de coleta de dados; e como fonte de inspiração para outras pesquisas complementares a esta. Para a comunidade técnica, esta pesquisa oferece método de avaliação de governo eletrônico, com lista de verificação para portais e serviços e-gov, instrumentos de coleta de dados validados e procedimentos detalhados, com análise crítica de vantagens e desvantagens de cada técnica, para sua aplicação prática em avaliação de programas e serviços públicos eletrônicos, visando a uma tomada de decisão abalizada para a melhoria desses programas e serviços. A aplicação periódica desse método permitirá o acompanhamento e o controle da qualidade dos serviços e-gov oferecidos à população.

\section{REFERÊNCIAS}

ACSI - American Customer Satisfaction Index. ACSI Model. [on-line], novembro de 2004. http://www. theacsi.org/model.htm. 
BRASIL. Governo Eletrônico. Cartilha de Usabilidade para Sítios e Portais do Governo Federal. Versão 01. Brasília: Comitê Técnico de Gestão de Sítios e Serviços On-line, 2004. 11p.

BRASIL. Ministério do Planejamento, Orçamento e Gestão - MP. Primeira pesquisa nacional de avaliação da satisfação dos usuários dos serviços públicos: uma nova relação do setor público com o cidadão. Brasília: MP, Secretaria de Gestão, 2000. 41p.

BRASIL. Recomendações de Acessibilidade para a Construção e Adaptação de Conteúdos do Governo Brasileiro na Internet: cartilha técnica. Brasília: MP, Departamento de Governo Eletrônico - DGE, 2005.41p.

BRASIL. Tribunal de Contas da União. Governo eletrônico no Brasil: mapeamento. Brasília: TCU, Secretaria Adjunta de Fiscalização - Adfis, 2004. 87p.

DIAS, C. A. Métodos de avaliação de usabilidade de portais corporativos: um estudo de caso no Senado Federal. Brasília: Universidade de Brasília, 2001. 229p. (Dissertação de mestrado em Ciência da Informação).

DIAS, C. A. Método de avaliação de programas de governo eletrônico sob a ótica do cidadão-cliente: uma aplicação no contexto brasileiro. 2006. 298 f. Tese (Doutorado em Ciência da Informação) -Universidade de Brasília, Brasília, 2006.

DIAS, C. A. Governo eletrônico: definições, características, potenciais benefícios, desafios e tipos de avaliação. In: CONFERÊNCIA SUL-AMERICANA EM CIÊNCIA E TECNOLOGIA APLICADA AO GOVERNO ELETRÔNICO, 2. , 2005, Florianópolis, Anais...Florianópolis: Conegov 2005.p. 101-114.

DIAS, C. A. Método de avaliação de programas de governo eletrônico sob a ótica do cidadão-cliente: uma aplicação no contexto brasileiro. Brasília: Universidade de Brasília, 2006. (Tese de doutorado em Ciência da Informação).

SARACEVIC, T. Digital library evaluation: toward an evolution of concepts. Library Trends, v. 49, n. 2, p. 350-369, Fall 2000.

STUTZ, O. et al. Quality criteria for a public-user-friendly and secure website. In: GERMANY. Bundesamt für Sicherheit in der Informationstechnik - BSI. E-government manual. Bonn: BSI, 2002. 106p.

VILLELA, R. M. Conteúdo, usabilidade e funcionalidade: três dimensões para avaliação de portais estaduais de governo eletrônico na Web. 2003.262 f. Dissertação (Mestrado) - Programa de Pós-graduação em Ciência da Informação, Escola de Ciência da Informação, Universidade Federal de Minas Gerais, Belo Horizonte, 2003 


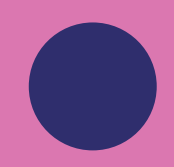

$\bullet$

○

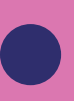

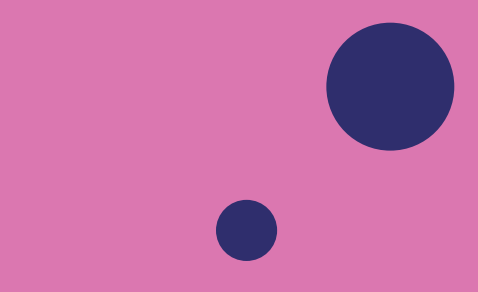

0

$.0^{\circ} \cdot \bullet$

$\cdot 0 \cdot 0$

0

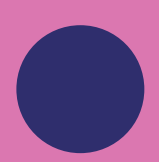

0

○

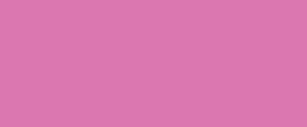

$$
.
$$

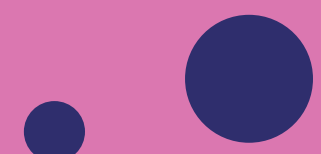$$
\text { . }
$$

$$
\text { . }
$$

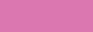

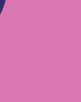




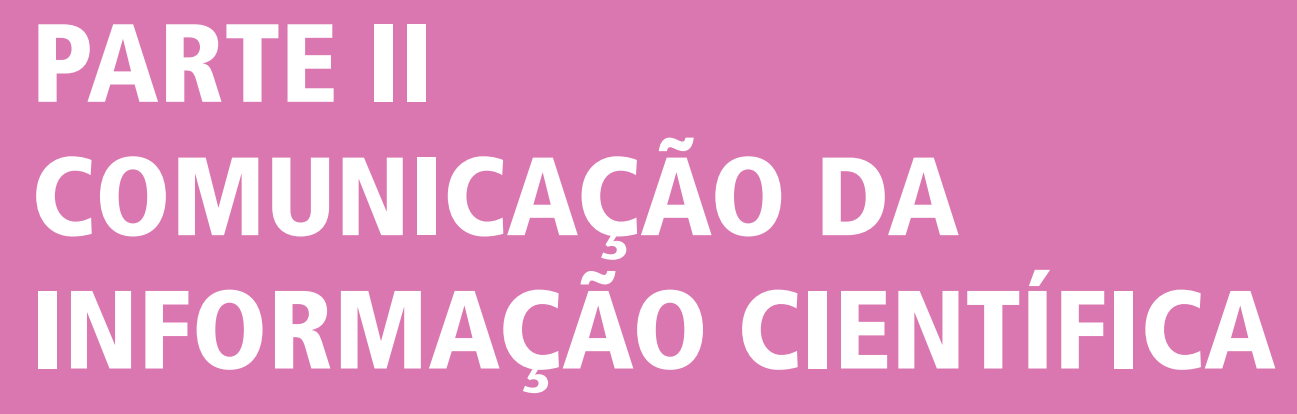




\section{CAPÍTULO 5}

0

0
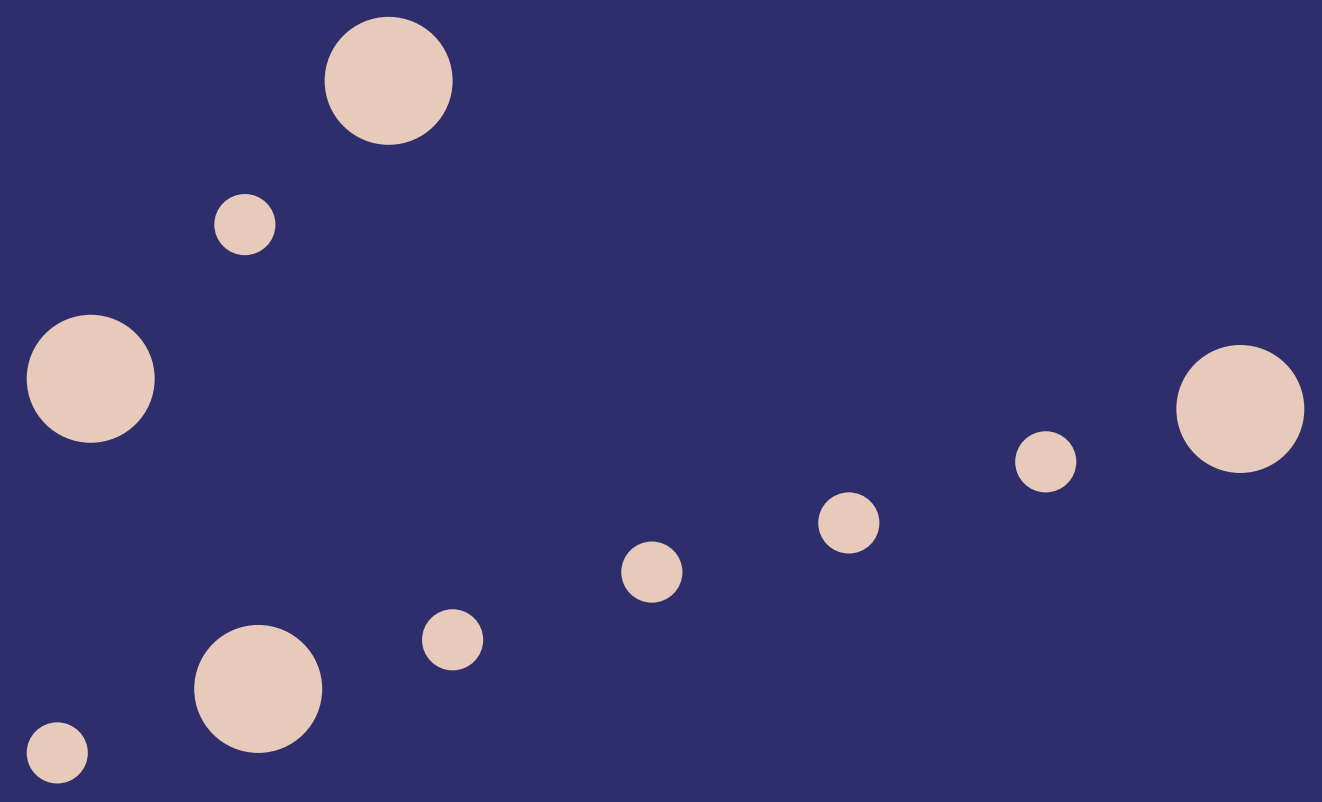

- 00 


\section{PADRÕES DE COMUNICAÇÃO EM DIFERENTES COMUNIDADES CIENTÍFICAS}

CARLOS SOUSA PINTO JOAQUIM LUÍS COSTA

\section{INTRODUÇÃO}

Para que a Ciência cumpra o seu papel na sociedade, seus resultados têm de ser disseminados, e, ao longo dos tempos, os cientistas recorreram a diversas formas de comunicação para atingir esse fim. Nesse contexto, a forma de comunicar Ciência tem sido abordada ao longo dos tempos por vários teóricos. As características de cada disciplina, o uso das tecnologias, as formas de produzir e comunicar conhecimento e os consequentes modelos de comunicação científica são alguns dos aspectos investigados. Esses estudos permitem analisar os padrões entre as várias disciplinas, sendo consensual considerar que existem diferenças entre as Ciências Exatas, Naturais, Sociais e Humanas, Artes e Humanidades.

Dentro dessas disciplinas, as que se inserem no âmbito das Ciências Sociais e Humanas fizeram uso tardio das tecnologias de informação e comunicação (TICs), como o correio eletrônico e os chats para contatos informais, e pouco uso dos meios eletrônicos de divulgação científica (como livros e revistas em formato eletrônico) para a comunicação formal. É relevante, nesse contexto, destacar as questões intrínsecas inerentes ao padrão de comunicar as descobertas científicas.

Sendo assim, o presente trabalho propõe identificar padrões de comunicação das Ciências Sociais e Humanas. Procura-se reconhecer os aspectos comuns e os diferenciadores, desejando chegar a um modelo de comunicação científica mais adaptado a essas disciplinas. Paralelamente, procura-se abrir caminho para novas aplicações tecnológicas que se identifiquem com as mesmas disciplinas em estudo.

Este trabalho, portanto, contribuirá para o esclarecimento do processo de comunicação de Ciência, porque ambiciona estudar na íntegra o sistema de produção e divulgação do conhecimento. Ao mesmo tempo, é um estudo atual, se levado em conta que se vive em um clima 
de transição de um modelo impresso para um modelo eletrônico, ao mesmo tempo em que há quem advogue o fim da comunicação impressa. Impõe-se, assim, analisar a forma como as disciplinas têm se adaptado - ou não - aos novos formatos de comunicação.

\section{FUNDAMENTAÇÃO TEÓRICA}

As pesquisas científicas só atingem o seu significado quando comunicadas. Para que isso possa acontecer, as diversas áreas científicas formalizaram as práticas para circulação e troca de informação entre pesquisadores e o público em geral, designando-as de "comunicação científica". Garvey e Griffith (1979) definiram essas práticas como o conjunto de atividades que englobam a produção, a disseminação e o uso, desde o início da criação até o momento da aceitação dos resultados. Consideram, assim, que, como está presente em todas as fases, ela é "um processo fundamental e inseparável da atividade científica" (LEITE, 2006). Esse processo deu origem a vários modelos sobre a comunicação de ciência, os quais podem variar consoante os interlocutores, as características e os meios que estão ao dispor de quem produz conhecimento. O modelo de Garvey e Griffith (figura 1) é um dos pioneiros, embora tenha sido desenvolvido para uma disciplina específica: a Psicologia. Tornou-se, assim, o princípio de uma série de estudos sobre o assunto (COSTA, 1999).

Figura 1 - Modelo do processo de comunicação científica proposto por Garvey e Griffith, de 1979

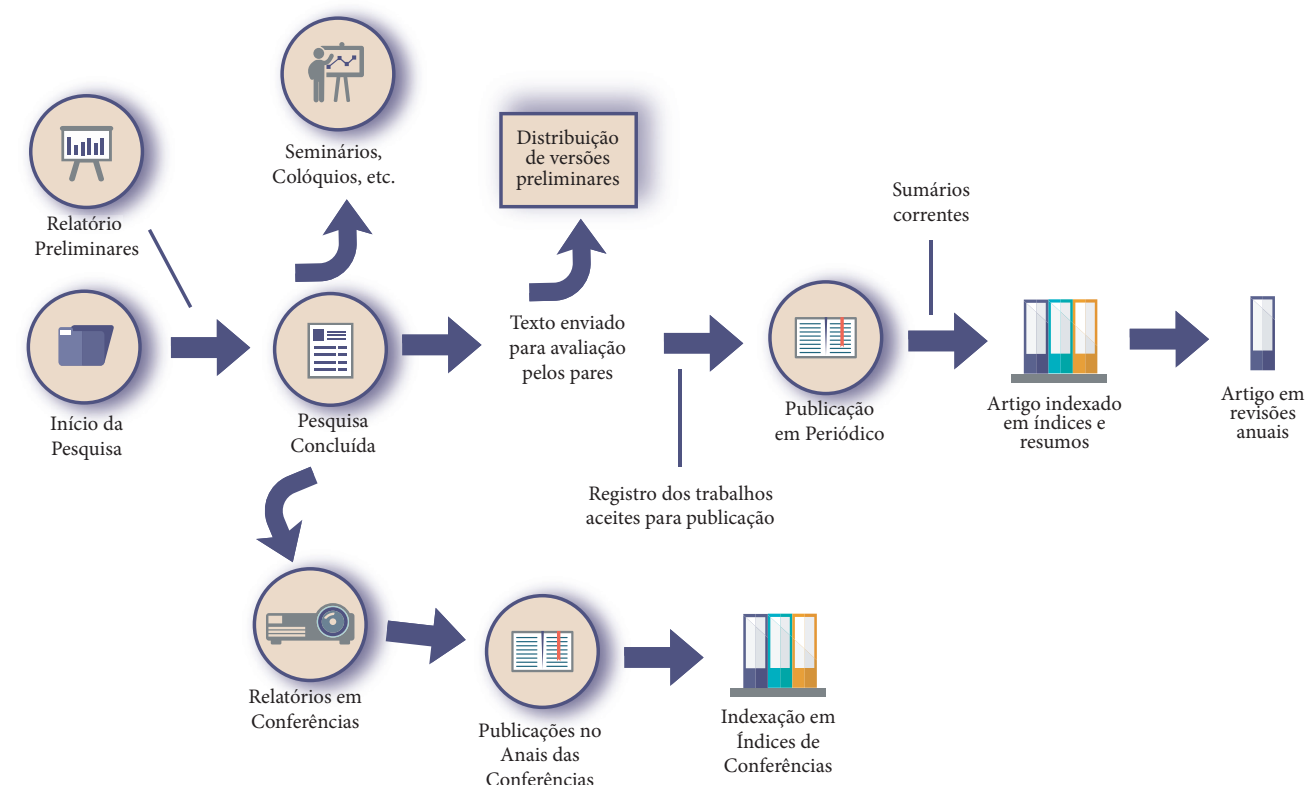

Fonte: Adaptado de Hurd (2000). 
Uma das conclusões evidenciadas pelos autores é a de que, no momento de divulgação da pesquisa, por meio de um canal formal de comunicação, parte significativa da comunidade científica já tem conhecimento dos resultados, por meio dos contatos realizados com seus pares ao longo da investigação. Para isso, utilizam os canais informais de comunicação (COSTA, 1999).

Esse modelo foi essencialmente desenvolvido para a comunicação impressa. No entanto, tendo em atenção os progressos no que se refere à comunicação mediada por computador, a partir de meados da década de 1980, novos modelos foram apresentados, entre os quais uma versão derivada do modelo anterior, desenvolvido por Hurd (1996) e ilustrado na figura 2

Figura 2 - Modelo de comunicação de Hurd, de 1996

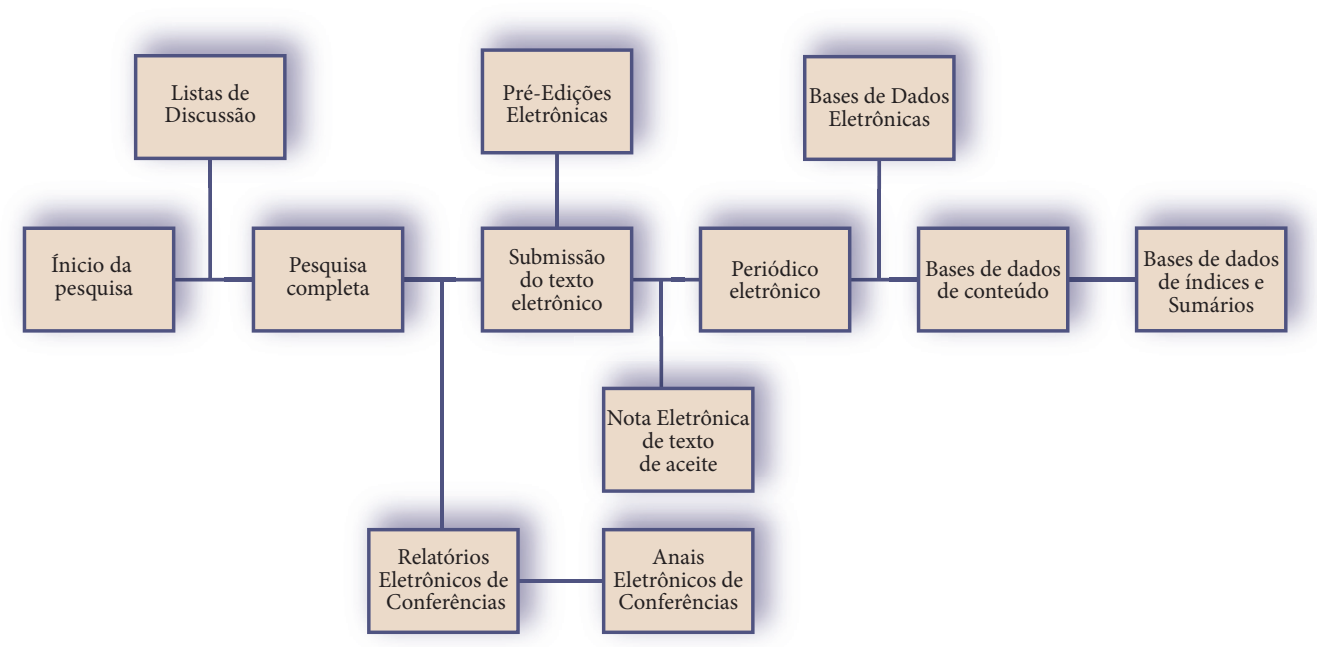

Fonte: Adaptado de Costa (1999).

Ao modelo dos anos 1970 de Garvey e Griffith, Hurd acrescentou o componente eletrônico, em que os canais informais tradicionais, como o telefone e o contato pessoal, são substituídos pelo correio eletrônico ou pelas listas de discussão. Tal substituição justifica-se pelo fato de os canais eletrônicos serem excelentes para contatos entre pesquisadores, quando separados por grandes distâncias (LEITE, 2006). Todavia, passados quatro anos após a apresentação desse modelo, Hurd reformulou-o, apresentando uma nova versão (figura 3). Para fundamentar a reformulação, a autora relatou que a inovação se alastrou de forma rápida, fazendo-se notar na utilização ativa dos computadores pessoais e da web (HURD, 2000). 
Figura 3 - Modelo de Hurd para o ano de 2020

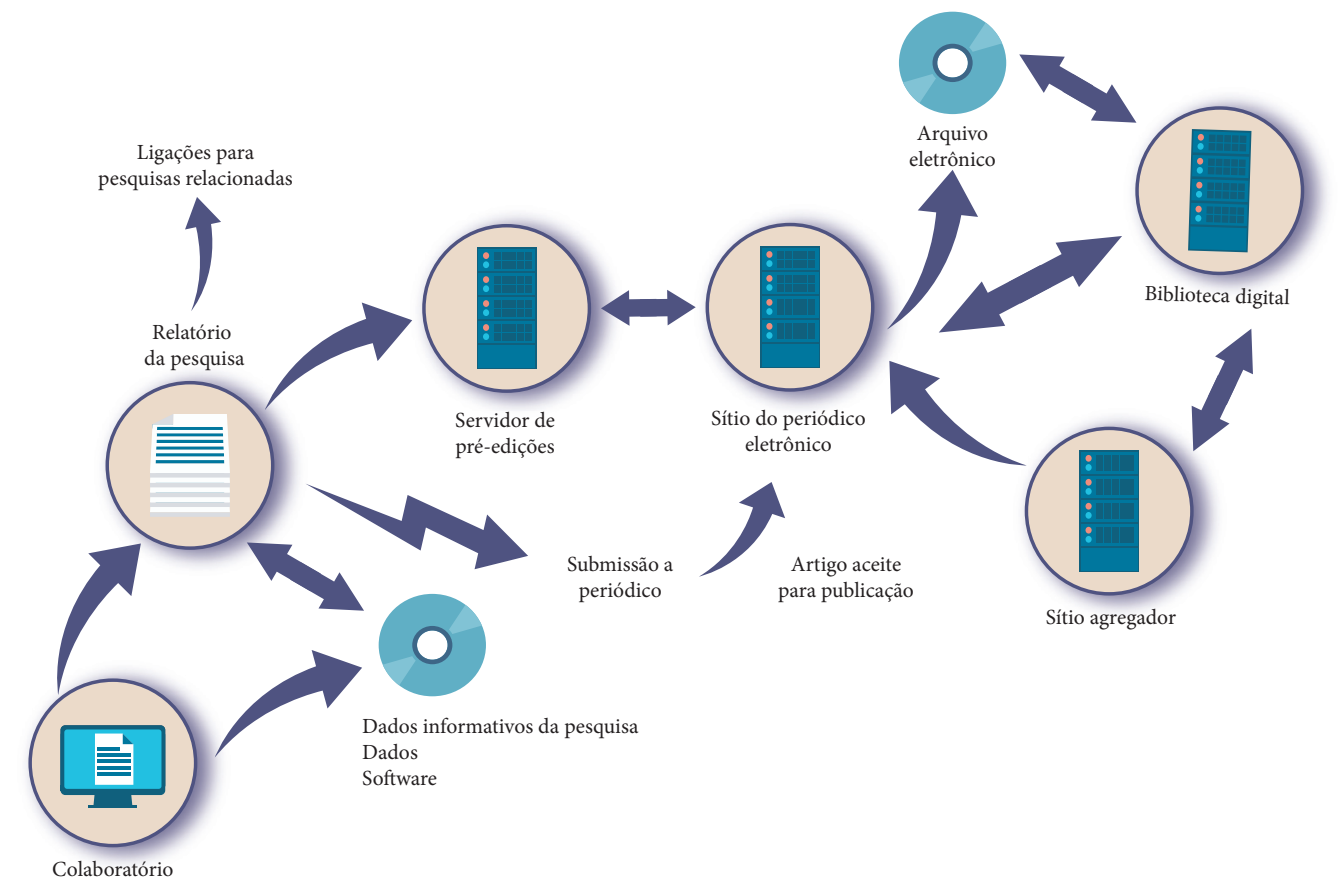

Fonte: Adaptado de Hurd (2000).

Perante esse cenário, em que, de um lado, tem-se um modelo pouco prático e, de outro, os modelos essencialmente eletrônicos, Costa apresentou uma proposta que pretendeu fazer a "ponte" entre o impresso e o digital (COSTA, 1999). Nesse trabalho, e com base em investigações na área das Ciências Sociais, a autora considerava que um sistema totalmente eletrônico de comunicação não existia, afirmando que, nessas ciências, a utilização de serviços digitais era ainda diminuta. Propôs, assim, um modelo híbrido (figura 4), dando atenção aos desenvolvimentos tecnológicos, sem se descuidar das questões tradicionais que caracterizam a comunicação científica. Considerava, então, que, numa fase inicial, o correio eletrônico seria a principal ferramenta de comunicação. Numa segunda fase, quando da submissão dos textos, esses seriam criados com o auxílio do processador de texto, e sua submissão posterior seria feita por meio eletrônico (COSTA, 1999). No entanto, e apesar da preponderância dos meios eletrônicos nas fases consideradas, a comunicação formal ainda era realizada com base no modelo tradicional, em que livros e periódicos impressos se impõem aos novos formatos digitais (COSTA, 1999). 
Figura 4 - Modelo híbrido do processo de comunicação científica proposto por Costa (1999)

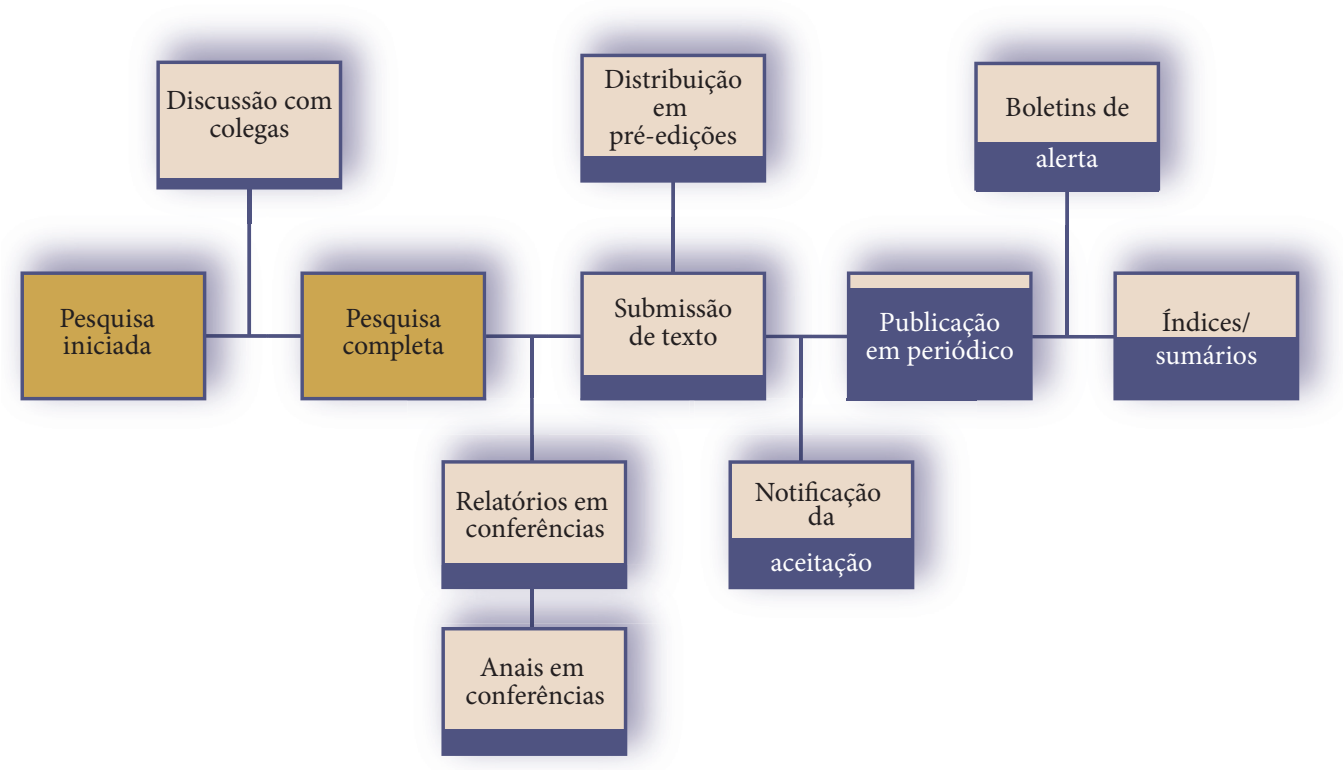

Fonte: Adaptado de Costa (1999).

Foram inúmeros os autores que analisaram o comportamento das áreas do saber em relação às tecnologias, abordando aspectos específicos, em diferentes contextos e regiões geográficas. Estão entre eles Talja, Savolainen e Maula (2004), Bridges e Clement (1997), Barjak (2006) Harrison e Stephen (1996), Mendez e Chapman (2006), Wilson (1997), Bomfá e Castro (2004), Kling e Callahan (2002), entre outros. É importante, portanto, observar que, em razão das suas características e dos modos de produzir e comunicar o saber, as diferentes disciplinas das Ciências adotam formatos que melhor satisfazem suas necessidades.

Analisando essas questões no contexto de Portugal, Borges (2006), com base nos acadêmicos da Universidade de Coimbra, obteve resultados que demonstram que, nas áreas de Humanidades, a monografia era o formato de publicação mais utilizado (93\% de utilização) e que livros e artigos tinham distribuição equitativa (BORGES, 2006). Semelhantemente a Borges, Miranda e Pereira (1996), que se basearam em estatísticas da Unesco, identificaram que monografias e artigos nas Ciências Sociais apresentavam praticamente a mesma expressão quantitativa. Com base nesses estudos, a questão que naturalmente se colocava era saber qual era a atitude dos cientistas sociais na utilização dos livros e revistas em formato eletrônico. Meadows (1999), contudo, realçou o fato de que, na década de 1990, cerca de dois terços dos periódicos eletrônicos seriam dedicados a temas sociais. Embora pareça uma contradição em relação ao que até agora se referiu, para o autor esse 
fato significava um escape (BROOCKMAN et al., 2001), pois, não havendo solução na publicação impressa (alta recusa de artigos e falta de recursos financeiros), as revistas eletrônicas seriam a maneira prática de contornar a situação.

As diferenças disciplinares existem, de fato, no que tange a eventos científicos, para comunicar formalmente a Ciência. Entretanto, parecem esbater-se, pois, para esse tipo de comunicação, as TICs são usadas por todas as áreas disciplinares. A única dissemelhança parece residir no estilo de comunicar. Enquanto nas Humanidades e nas Ciências Sociais as conferências podem ser aproveitadas para longos discursos, nas Ciências Exatas são mais usadas para disseminação de pesquisas recentes (GARVEY; GRIFFITH, 1979).

Voltando à temática da disseminação em formato eletrônico, há quase duas décadas surgiu uma nova forma de comunicação formal, em acesso aberto, por meio dos repositórios institucionais. A despeito das diferenças em relação a sua adoção, Allen (2005), entre inúmeros outros autores, destacou que as plataformas de disseminação do conhecimento científico têm a possibilidade de garantir acesso global, reduzir custos de subscrição e possibilitar mais citações (MEADOWS, 1999). Assim como nas diferenças de comportamento já mencionadas, o estudo de Allen deixa transparecer que humanistas tendem a adotar mais tardiamente os repositórios, enquanto cientistas sociais se colocam numa posição intermédia e investigadores das Ciências Exatas e Naturais aparecem como mais entusiastas. No entanto, como os repositórios são essencialmente utilizados nas universidades, verifica-se uma posição mais favorável ao seu uso para disseminação de teses e dissertações, o que foi constatado no estudo de Borges (2006). Davis e Connolley (2007), que estudaram atitudes e motivações de acadêmicos de diversas Ciências que não depositavam seus trabalhos no repositório da Universidade de Cornell, concluíram que os repositórios eram vistos como uma competição com a forma tradicional de publicar ou como um suplemento à publicação tradicional (DAVIS e CONNOLLEY, 2007). Nesse sentido, é possível concluir que, apesar de os acadêmicos das Humanidades e das Ciências Sociais terem uma visão positiva sobre os repositórios, faziam pouco uso dessas plataformas. Portanto, diferenças disciplinares continuam a ser uma questão invariável da comunicação científica, independentemente do formato utilizado.

\section{METODOLOGIA}

O objetivo principal deste trabalho consistiu na análise da realidade da comunicação científica no que diz respeito às comunidades das Ciências Sociais e das Humanidades. Este estudo foi realizado no contexto do Mestrado em Ciência da Informação do Departamento de Sistemas de Informação da Universidade do Minho, Portugal. Considera-se natural que se tenha escolhido comunidades no seio dessa universidade, até por ser mais fácil o acesso a seus membros participantes. 
A Universidade do Minho foi pioneira em Portugal na criação de repositórios institucionais, com a implementação do RepositoriUM ${ }^{1}$. Na data da realização do presente trabalho, a plataforma contava com a presença de seis dezenas de comunidades, a maioria das áreas das Ciências Exatas, Ciências Naturais e Engenharias.

Após a seleção da instituição e da população-alvo, o passo seguinte consistiu na escolha do método de coleta de dados que melhor se adaptaria aos objetivos do trabalho. Para tal, levou-se em conta argumentos como os de Albarello (1997) sobre a necessidade de selecionar o método mais adequado aos objetivos da investigação, ao tipo de resultados esperados e ao modelo de análises a serem efetuadas. Uma vez ponderadas as diversas opções metodológicas existentes, decidiu-se proceder à coleta de dados dos docentes das seis escolas da Universidade do Minho, utilizando o método de levantamento (survey) por meio da aplicação de questionário.

O estudo contemplou 496 docentes distribuídos pelas seis escolas nas áreas das Ciências Sociais e Humanas, aos quais foi enviado por correio eletrônico um questionário composto por 32 perguntas, entre os meses de novembro de 2007 e março de 2008. A abordagem utilizada para o Instituto de Ciências Sociais (ICS) foi diferente da que foi seguida para as demais escolas em razão das diferenças existentes entre o instituto e as outras comunidades estudadas.

\section{ANÁLISE E DISCUSSÃO DOS RESULTADOS}

Quanto às características demográficas dos participantes da pesquisa, a análise dos dados mostrou que a maior taxa de respostas proveio de docentes do sexo feminino $(63,4 \%)$. A maioria situava-se na faixa etária dos 41 aos 50 anos (41,6\%), seguindo-se os da faixa situada entre os 31 e os 40 anos (com 32,7\%). Isso denota que parte dos estudos e das carreiras da maioria dos respondentes coincidiu com o advento e a adoção das novas tecnologias. Por essa razão, entende-se que os participantes são conhecedores das tecnologias, pelo menos na condição de usuário. No que concerne ao nível da formação acadêmica, 74,3\% eram doutores, e $20,8 \%$ mestres.

1 A ideia da criação de um repositório institucional começou a florescer em 2002 (RODRIGUES; SARAIVA, 2008) e ganhou forma a partir do ano seguinte, com a realização do estudo das plataformas então existentes para a construção e gestão de repositórios (RODRIGUES, et al, 2004). A escolha recaiu sobre a plataforma DSpace (RODRIGUES, et al, 2004). Após a configuração e instalação do sistema com base em quatro comunidades-piloto, o RepositoriUM - assim designado - ficou disponível em 20 de novembro de 2003, carregado com 280 documentos. Em janeiro de 2004, o serviço ficou definitivamente disponível para todas as comunidades da universidade (RODRIGUES; SARAIVA, 2008). 
Quanto às questões diretamente ligadas aos objetivos da investigação, os dados recolhidos revelaram a predominância do acesso a fontes de informação impressas para a criação de conhecimento. Monografias em formato impresso eram a primeira fonte de consulta nas comunidades de Direito, Ciências da Comunicação, Sociologia e Letras. Revistas em formato eletrônico foram apontadas pelas comunidades de Economia, Geografia e Estudos da Criança. Por sua vez, as comunidades de História, Estudos da Criança e Psicologia demonstraram preferência pelas revistas científicas no formato impresso. Observa-se que, no formato eletrônico, somente revistas científicas foram apontadas e nenhuma comunidade optou por monografias eletrônicas. No entanto, o formato eletrônico vinha ganhando mais terreno, fato comprovado pelas três comunidades que utilizavam preferencialmente esse meio. Destaca-se o uso de monografias e de revistas impressas pela comunidade de História, fato que é compatível com o padrão de comunicação da área em vários outros estudos. Entretanto, e apesar do aumento da utilização do formato eletrônico centralizado em periódicos, é possível apontar que o meio impresso é o mais utilizado quando se recorre a fontes de informação para a realização de investigação.

Os resultados mostraram, ainda, que o principal fator que influencia a escolha das fontes de informação é sua credibilidade, o que evidencia a preocupação das comunidades investigadas em aceder a fontes o mais confiáveis possível. O segundo fator mais citado é a disponibilidade do texto integral, seguido da atualidade da fonte. O custo de aquisição ou acesso não se apresentou como relevante no momento de selecionar a fonte de informação, não sendo mencionado por nenhum dos respondentes.

Observa-se, nos resultados sobre fontes de informação, a predominância do formato impresso (mais prestígio e maior durabilidade) sobre o eletrônico (maior acesso, menor tempo de publicação e facilidade em atualizar os conteúdos). Os dados revelam, ainda, que o principal meio de comunicação formal são os artigos impressos. Apesar de Shoham (1998) ter considerado que, no Direito, as monografias eram o principal meio para comunicar ciência, o presente estudo evidenciou que as revistas superam as monografias, que ficaram em posição secundária. Outro aspecto importante é a relevância dada às comunicações em eventos internacionais, as quais foram apontadas pelos pesquisadores das áreas de Ciências da Comunicação, História, Sociologia e Estudos da Criança como principal meio de comunicação. Esse resultado parece contrariar Meadows (1999), que considerava as comunicações em conferências como pouco produtivas e usadas, sobretudo, para estabelecer contatos entre colegas (MEADOWS, 1999). De fato, na literatura analisada, comunicações em conferências não foram apontadas como primeira opção de fonte de informação, como o foram no presente estudo. A questão dos direitos autorais, ressaltada por Meadows (1999), Allen (2005), Davis e Connolley (2007) e Oliveira e Noronha (2005) não foi levada em conta pela maioria das comunidades investigadas, em especial as de Ciências da Comunicação, Geografia e Letras. 
Sobre a comunicação informal, a população investigada centrou o foco no correio eletrônico (rapidez nos contatos e possibilidade de registro tanto da comunicação enviada quanto da recebida), à exceção da comunidade de Direito, que prefere os contatos presenciais. Bridges e Clement (1997) consideravam que o correio eletrônico substituiria de forma eficiente o telefone e as reuniões presenciais (op. cit.). Na época do presente estudo, no entanto, a observação não pareceu pertinente em razão de o meio eletrônico parecer mais coadjuvar do que substituir os outros meios.

No que concerne às tecnologias que melhor se adaptam às necessidades de produção científica, editores de texto se apresentavam como preferencial em todas as áreas em análise, o que parece óbvio no período estudado. Em segundo lugar, foram citados programas de tratamento estatístico de dados e geradores de gráficos.

Na discussão dos padrões de comunicação científica, a análise das autorias reveste se de particular importância para se perceber o padrão corrente em Ciências Sociais e Humanas. Os valores obtidos demonstraram que a maioria das comunidades prefere realizar investigação em fontes de autoria única. Analisados esses valores por áreas científicas, notou-se que as Humanidades (71\%) privilegiavam as autorias únicas, dado não tão significativo nas Ciências Sociais (54,4\%). Tais resultados confirmaram o que se identifica no trabalho de Bridges e Clement (1997).

No âmbito da comunicação, as comunidades de Direito, Sociologia e Letras revelaram abrangência mais nacional, enquanto outras comunidades, como a de Economia, tendiam a alargar seus conteúdos além-fronteiras. Sobre o idioma de comunicação, Humanidades publicavam mais em português (65,6\%), assim como Ciências Sociais $(59,8 \%)$. Tais padrões revelam menos parcerias internacionais, quando comparadas com Ciências Exatas ou Naturais.

Relativamente ao depósito de documentos no RepositoriUM, até a data da realização do trabalho, os resultados indicavam fraca utilização por parte das comunidades estudadas. A comunidade de Ciências da Comunicação apresentava-se, em 2009, como a principal contribuidora para o repositório, ao contrário da comunidade de Direito, em que todos os participantes recusavam o depósito de documentos. Por grupos disciplinares, as comunidades de Ciências Sociais depositavam menos que Humanidades. Para o primeiro grupo, os valores rondavam os $37,8 \%$, ao passo que, para o segundo, os valores subiam para os $43,2 \%$. Por fim, e no que diz respeito ao tipo de documentos depositados, os artigos previamente publicados e as teses de doutoramento surgiam como os mais armazenados, com percentagens de 33,6\% e 30\%, respetivamente. As monografias, os relatórios técnicos e os trabalhos para alunos não tinham grande representatividade. 
Os dados apresentados mostram que os investigadores estavam já razoavelmente familiarizados com os princípios do movimento de acesso aberto ao conhecimento. No entanto, não privilegiavam esse meio para divulgar Ciência. Isso era confirmado até a data da realização deste trabalho pela reduzida utilização do repositório da Universidade do Minho.

\section{CONCLUSÕES}

Este foi um trabalho que passou por diversas vicissitudes, das quais se destacam duas. A primeira se refere ao formato do questionário que, com 32 questões, provocou reações pouco favoráveis por parte dos potenciais respondentes, que o consideraram extenso e demorado no seu preenchimento. A segunda, relacionada com a primeira, materializou-se na dificuldade de obtenção dos questionários preenchidos, resultado de uma fraca adesão por parte dos investigadores contatados. Essas duas situações levaram a uma baixa taxa de questionários respondidos e, por conseguinte, com poucos dados para generalizações, o que levou a considerar que as conclusões do estudo teriam que ser relativizadas, servindo como indicadoras de tendência. As conclusões a que foi possível chegar dizem respeito a uma série de aspectos, compatíveis com o período de realização do estudo, como descrito a seguir.

O formato impresso continuava a predominar, apesar de o formato eletrônico denotar tendência de crescimento inegável, tanto em Ciências Sociais quanto em Humanidades.

$\mathrm{Na}$ comunicação formal científica, privilegiam-se os artigos em revistas científicas impressas e as comunicações em conferências. O formato eletrônico, no contexto das Ciências Sociais e Humanas, é sinônimo de artigos em revistas científicas, em detrimento de outros meios como as monografias eletrônicas.

A credibilidade e o prestígio das publicações constituem os fatores principais para que o impresso seja o preferido quando da seleção do meio de comunicação formal, e a opção pelos formatos eletrônicos não tem relação com qualidade ou prestígio, mas com acesso rápido à informação.

Comunicações em eventos constituem importante meio de divulgação da pesquisa, em especial nas áreas de Ciências da Comunicação, História, Sociologia e Estudos da Criança.

Direitos autorais não são considerados um problema para a escolha do formato de comunicação, ao contrário do que a literatura referia.

Quanto ao tipo de autoria, os resultados apontam para a preferência de autorias únicas na produção de conhecimento, particularmente em Humanidades, quando comparadas com Ciências 
Sociais. No que se refere ao alcance dos trabalhos e à língua de comunicação, há predomínio para o âmbito nacional e para o uso predominante da língua portuguesa.

Comunidades sociais e humanísticas da Universidade do Minho, de forma geral, mostraram-se conhecedoras dos princípios e meios da comunicação eletrônica, com destaque para os repositórios institucionais. Nesse contexto, é possível reconhecer a existência de uma evolução da utilização dos meios tecnológicos ao longo da produção e divulgação de conhecimento para as comunidades analisadas.

O uso da web tende a ser mais frequente para pesquisa de fontes de informação, mas diminui durante a produção do conhecimento e volta a crescer quando da disponibilização formal. Por sua vez, o correio eletrônico e os editores de texto são mais utilizados quando da produção do conhecimento.

Relativamente aos modelos de comunicação, o modelo híbrido de Costa demonstrou ser o que mais se aproxima da realidade. Todavia, requereu alterações, em razão dos resultados do presente estudo (figura 5). Tais alterações estão relacionadas à etapa de produção de conhecimento, em que se evidenciam três aspectos: o recurso às fontes de informação (impressas e eletrônicas); os contatos informais com colegas, com ênfase no uso do correio eletrônico; e, por último, a investigação em si. Comunicações em conferências e publicações em periódicos constituem outra diferença em relação ao modelo de Costa, que considerou unicamente as publicações em periódicos.

Figura 5 - Modelo de comunicação científica para as comunidades de Ciências Sociais e Humanas

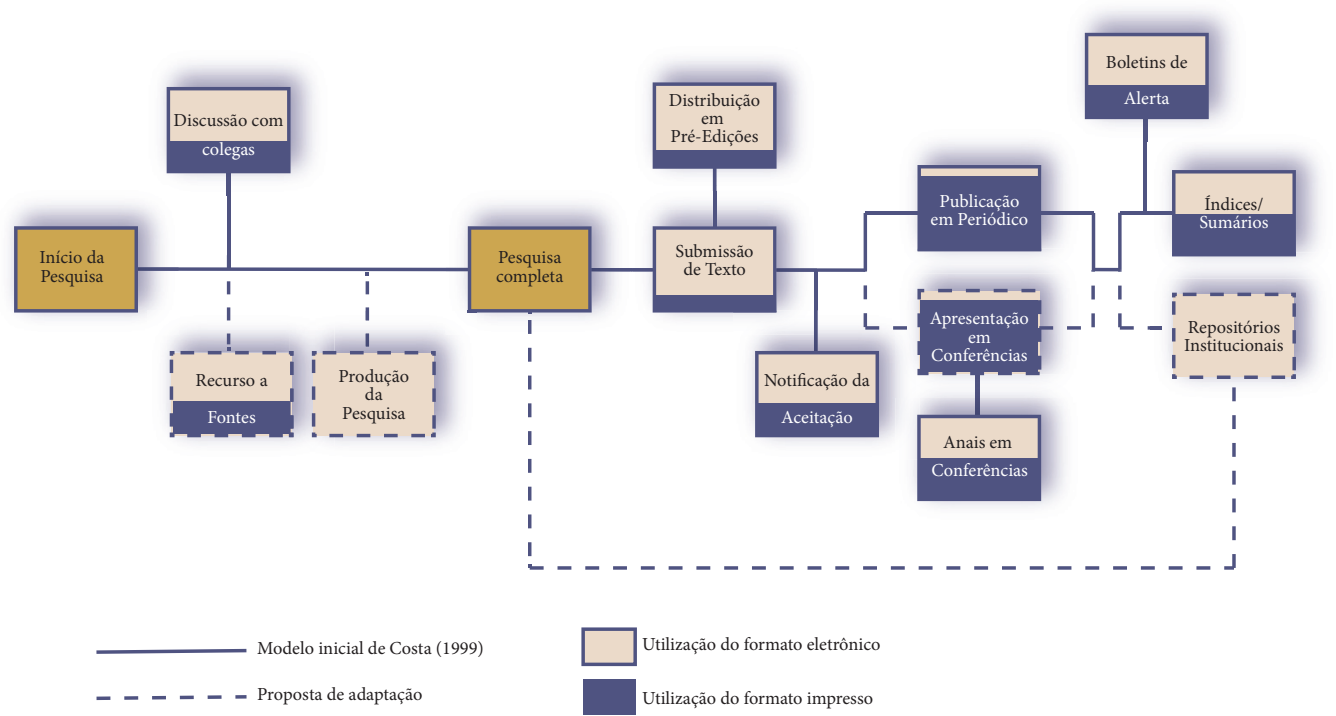

Fonte: com alterações no modelo apresentado por Costa (1999). 
Uma vez publicado formalmente, os investigadores têm a possibilidade de depositar suas publicações em repositórios em acesso aberto, aspecto não explorado no modelo de Costa, pois repositórios institucionais são posteriores a sua pesquisa. $\mathrm{O}$ modelo proposto, portanto, enfatiza o componente eletrônico na produção do conhecimento e no depósito final em repositórios.

Há dois tipos de padrões de comunicação. O primeiro, tradicionalista, engloba todas as comunidades em que os novos formatos de comunicação, formal ou informal, são pouco explorados. O segundo, híbrido, conjuga aspectos tradicionais com aspectos mais recentes da comunicação científica. As Ciências Humanas tendem a ser mais tradicionalistas em todo o processo da comunicação científica, ao contrário das Ciências Sociais, que têm a tendência a aplicar novos formatos de comunicação.

O novo modelo proposto, portanto, parece ser o indicado para a situação atual da comunicação científica. Estudos futuros são necessários para confirmação ou não das conclusões do presente trabalho, em relação a pelo menos (mas não somente) três aspectos. O primeiro refere-se à ampliação da população investigada, envolvendo investigadores demais áreas do conhecimento. O segundo remete a uma possível relação entre a língua de publicação e o âmbito das investigações, permitindo um conhecimento mais rico sobre o fenômeno de produção, comunicação e depósito do conhecimento científico. Por fim, o terceiro relaciona-se à concepção de uma solução tecnológica capaz de melhor satisfazer as necessidades das comunidades.

\section{REFERÊNCIAS}

ALBARELLO, L. Recolha e tratamentos quantitativos dos dados de inquéritos. In ALBARELLO, L et al. Práticas e métodos de investigação em Ciências Sociais. Lisboa: Gradiva; 1997.

ALLEN, J. Interdisciplinary differences in attitudes towards deposit in institutional repositories. Dissertação (Mestrado) Manchester Metropolitan University, Department of Information and Communications, Manchester, 2005. Disponível em: <http://eprints. rclis.org/archive/00005180/01/FULLTEXT.pdf > Acesso em 3 fev. 2008.

BARJAK, F. The role of the Internet in informal scholarly communication. Journal of the American Society for Information Science and Technology, v. 57, n. 10, p. 13501367, aug. 2006. 
BOMFÁ, C. R. Z, CASTRO, J. E. Desenvolvimento de revistas científicas em mídia digital: o caso da Revista Produção Online. Ci. Inf., Brasília, v. 33, n. 2, p. 39-48, maio/ago. 2004. Disponível em:< http://revista.ibict.br/index.php/ciinf/article/view/209/186 > Acesso em 22 set. 2008

BORGES, M. M. A esfera: comunicação académica e novos média. 2006. xi, 787 f. Tese (Doutorado em Letras) Universidade Coimbra, Coimbra, 2006. Disponível em: <http://hdl. handle.net/10316/8557> Acesso 13 jul. 2018.

BRIDGES, A. E., CLEMENT, R. T. Crossing the threshold of rocket mail: e-mail use by U. S. humanities faculty. The Journal of Academic Librarianship, v. 23, n. 2, p. 109-117, mar. 1997. Disponível em: < https://www.sciencedirect.com/science/article/abs/pii/S0099133397900069> Acesso em: 13 jul. 2018

BROCKMAN, W. S. et al . Scholarly work in the Humanities and the evolving information environment. Council on Library and Information Resources: reports, pub. 104, 2001. Disponível em:< http://www.clir.org/pubs/reports/pub104/contents.html > Acesso em 14 fev. 2008.

COSTA, Sely M. S. The impact of computer usage on scholarly communication amongst academic social scientists. 1999. 318 f. Tese (Doutorado) - Curso em Ciência da Informação, Loughborough University, Inglaterra, 1999. Disponível em: < http://repositorio.unb.br/handle/10482/2025> Acesso 13 jul. 2018.

DALTON, M. S. A system destabilized: scholarly books today. Journal of Scholarly Publishing, v. 37, n. 4, p. 251-269, jul. 2006,. Disponível em:< http://utpjournals.metapress.com/content/ yt6784h200734017/fulltext.pdf> Acesso em 27 fev 2008.

DAVIS, P. M.; CONNOELLY, M. J. L. Institutional repositories: evaluating the Reasons for non-use of Cornell University's Installation of Dspace. D-Lib M, v. 13, n. 3/4, 2007. Disponível em:< http://www.dlib.org/dlib/march07/davis/03davis.html > Acesso em 11 Jun 2007.

GARVEY, W. D.; GRIFFITH, B. C. Scientific communication as a social system. In: GARVEY, W. D.; GRIFFITH, B. C. Communication: the essence of science. London: Pergamon Press, 1979. p. 148-164.

HARRISON, T. M., STEPHEN, T (Eds.). Computer networking and scholarly communication in the twenty-century university. New York: State University of New York Press; 1996. 
HURD, J. M. The transformation of scientific communication: a model for 2020. Journal of the American Society for Information Science, v. 51, n. 14, p. 1279-1283, 2000. Disponível em: <https://www.learntechlib.org/p/90015/>. Acesso em: 13 jul. 2018.

KLING, R., CALLAHAN, E. Electronic journals, the internet, and scholarly communication. Annual Review of Information Science and Technology, v. 37, n. 2, 2005. Disponível em: $<$ https://doi.org/10.1002/aris.1440370105> Acesso em: 13 jul. 2018

LEITE, F. C. L. Gestão do conhecimento científico no contexto acadêmico: proposta de um modelo conceitual. 2006. xiii, 240 f. Dissertação (Mestrado) -Programa de pós-graduação em Ciência da Informação, Departamento de Ciência da Informação e Documentação, Universidade de Brasília, Brasília, 2006. Disponível em: <http://repositorio.unb.br/handle/10482/3975> Acesso 13 jul. 2018.

MEADOWS, A. J. Comunicação científica. Brasília: Briquet de Lemos, 1999.

MENDEZ, M., CHAPMAN, K. The use of scholarly monographs in the journal literature of Latin American history. Journal Literature of Latin American History, v. 7, n. 3, 2006. Disponível em: < http://southernlibrarianship.icaap.org/content/v07n03/mendez_m01.htm $>$ Acesso em: 13 jul. 2018

MIRANDA, D. B, PEREIRA, M. N. F. O periódico científico como veículo de comunicação: uma revisão de literatura. Ci. Inf., Brasília, v. 25, n. 3, p. 375-382, 1996. Disponível em: <http:// www.brapci.inf.br/v/a/866 > Acesso em 22 maio 2007.

OLIVEIRA, R. B. P. M.; NORONHA, D. P. A comunicação científica e o meio digital. Informação \& Sociedade: Estudos, v. 15, n. 1, p. 75-92, 2005. Disponível em: <http://www. brapci.inf.br/v/a/3114>. Acesso em: 13 jul. 2018.

RODRIGUES, E.; SARAIVA, R. RepositoriUM case history. Repositories Support Project, 2008. Disponível em: <http://www.rsp.ac.uk/repos/casestudies/pdfs/minho.pdf > Acesso em 10 set. 2008

RODRIGUES, E. et al. RepositóriUM: criação e desenvolvimento do Repositório Institucional da Universidade do Minho. In CONGRESSO NACIONAL DE BIBLIOTECÁRIOS, ARQUIVISTAS E DOCUMENTALISTAS, 8, Estoril, 2004 - "Nas encruzilhadas da informação e da cultura : (re)inventar a profissão" : Actas. [CD-ROM]. Lisboa : Associação Portuguesa de Bibliotecários, Arquivistas e Documentalistas, 2004. ISBN 972-9067-36-8 
SHOHAM, S. Scholarly communication: a study of Israeli academic researchers. JLIS; v. 30, n. 2, 1998, p. 113-121.

TALJA, S.; SAVOLAINEN, R.; MAULA, H. Field differences in the use and perceived usefulness of scholarly mailing lists. IR: information research, v. 10, n. 1, Oct. 2004. Disponível em: <http://InformationR.net/ir/10-1/paper200.html> Acesso em: 13 jul. 2018

WILSON, T. Electronic publishing and the future of the book. IR, v. 3 n. 2, 1997. Disponível em:< http://informationr.net/ir/3-2/paper39.html > Acesso em: 13 jul. 2018. 


\section{CAPÍTULO 6}

0

O

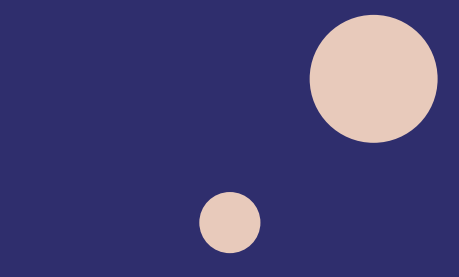

0

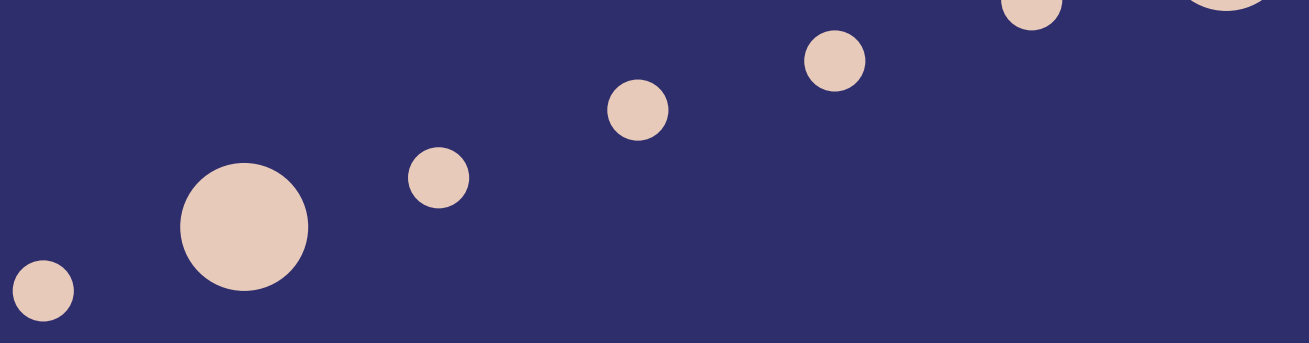

- 00

0 


\section{A COMUNICAÇÃO CIENTÍFICA ENTRE PESQUISADORES DA SURDEZ DO PONTO DE VISTA DA LINGUAGEM}

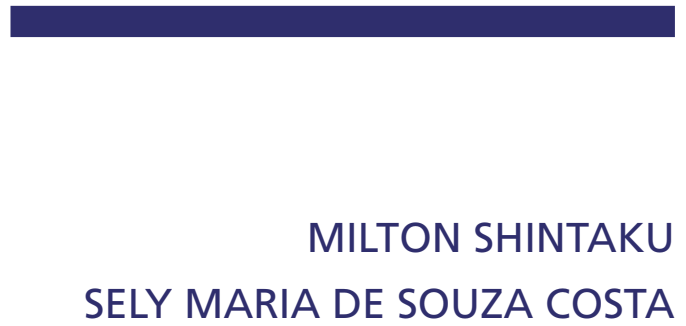

SELY MARIA DE SOUZA COSTA

\section{INTRODUÇÃO}

Tanto a interdisciplinaridade quanto a multidisciplinaridade tendem a constituir características comuns aos fenômenos estudados pelas Ciências Humanas e Sociais. Revelam, assim, a complexidade dos fenômenos que envolvem o homem. Entre tantos outros tópicos de estudo, é na multidisciplinaridade que estão situadas as questões relacionadas à surdez, do ponto de vista da linguagem, justamente por se tratar de tópico que apresenta múltiplas facetas.

Nesse contexto, a surdez, de forma geral, apresenta-se como um tópico amplo, estudado no âmbito de diferentes disciplinas (Gráfico 1), nas quais tem sido abordada sob diferentes enfoques. Por exemplo, somente disciplinas como a medicina focam o tema como deficiência, congênita ou adquirida, ou, ainda, como sequela de doenças, de medicamentos ou da senilidade. Já em relação às Ciências Sociais e Humanas, é possível focar a surdez sob variados aspectos, tais como inclusão social, mercado de trabalho, linguagem e educação, entre tantos outros.

É, portanto, a possibilidade de estudar a surdez sob múltiplas abordagens que a revela como tópico multidisciplinar. A presente pesquisa, por conseguinte, teve como principal objetivo averiguar se as características de estudos da surdez como tópico de estudo multidisciplinar influenciam os padrões de comunicação científica dos pesquisadores que a estudam do ponto de vista da linguagem. 
Gráfico 1 - Grupos de pesquisa sobre a surdez, por disciplina, no Brasil

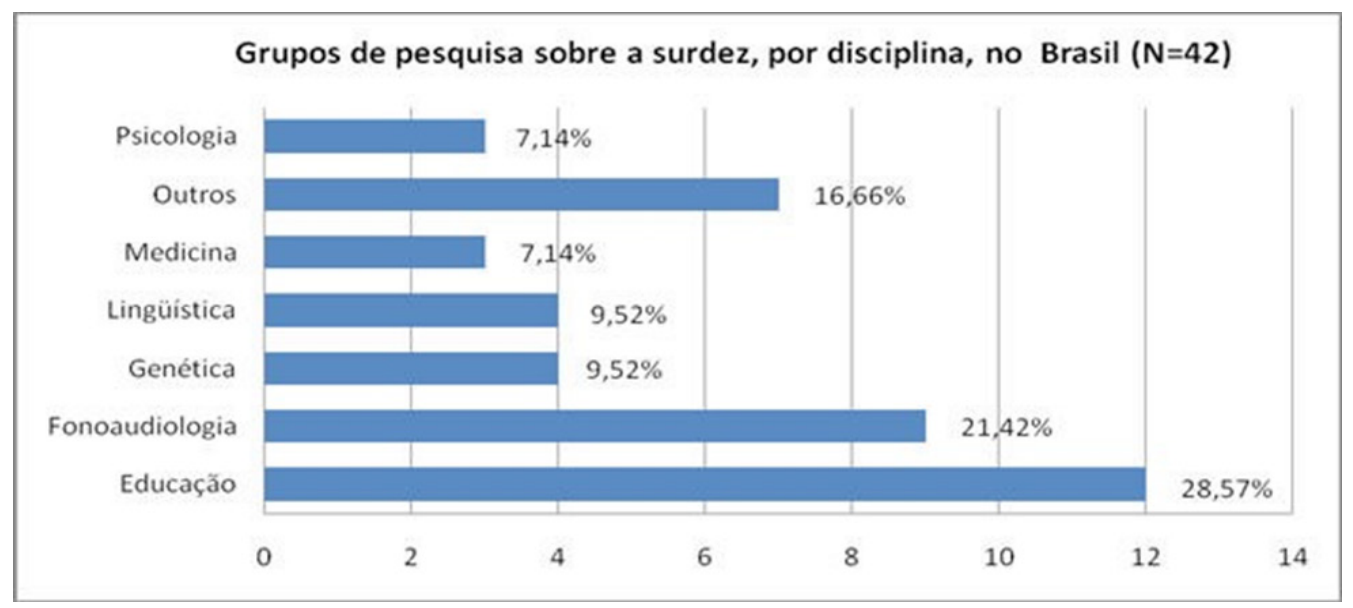

Fonte: Diretório de grupos de pesquisa do CNPq/2008.

\section{FUNDAMENTAÇÃO TEÓRICA: ABORDAGENS REFERENTES À SURDEZ, À DISCIPLINARI- DADE E À COMUNICAÇÃO}

Do ponto de vista da linguagem, Ferreira Brito (1993) revela que, na maioria dos países, surdos fazem uso de uma língua gestual visual. No caso do Brasil, tal linguagem - denominada Língua Brasileira de Sinais (Libras) - é legalmente considerada como a forma de expressão dos surdos (BRASIL, 2000). Observe-se que estudos sobre a surdez com ênfase na linguagem envolvem questões de comunicação nos mais diversos contextos, em especial seus aspectos cognitivos e sociais, como considerado por Saussure (2003). É importante notar que a comunicação está presente em quase todos os momentos da vida do homem, tornando possível a interação dos seres humanos com o meio em que vivem. Apesar da complexidade que a envolve, tem na transmissão de conhecimento um dos papéis mais importantes na sociedade, pois permite o avanço do saber.

A linguagem, por sua vez, do mesmo modo estudada por várias disciplinas, envolve desde a expressão gráfica, por meio da arte e da literatura, até as engenharias, com seus processos técnicos e informatizados. De fato, por possuir formas de expressão variadas, as quais permitem a percepção por todos os sentidos, a linguagem constitui um tópico de estudo que abrange várias disciplinas nas quais a comunicação está sempre relacionada.

Não apenas por ter dificuldades em ouvir, mas, principalmente, por viver em um mundo de ouvintes, o indivíduo surdo acaba por se tornar um estrangeiro em seu próprio país 
(SWAANS-JOHA, 1993, p. 47). Essa abordagem sociológica da surdez, compartilhada por vários pesquisadores, encontra-se no centro das dificuldades enfrentadas pelos surdos na vida cotidiana, que é, na verdade, adequada aos ouvintes. Em aeroportos, por exemplo, os avisos e chamadas efetuados por companhias aéreas ou agências governamentais são apenas no formato oral, apesar da existência de painéis de aviso em forma escrita. Entretanto, essa forma sonorizada dos aeroportos ilustra como alguns serviços prestados à sociedade estão adequados apenas aos ouvintes, impondo grandes dificuldades aos surdos.

Há, ainda, um grande equívoco por grande parte da sociedade sobre o domínio da forma escrita da língua. Por causa das várias graduações de surdez e pela diferenciação do conhecimento da língua oral, tem-se a ideia de que todos os surdos são alfabetizados. No entanto, somente indivíduos que adquirem a surdez após a alfabetização ou que tenham surdez moderada conseguem fazer a ligação entre letras e sons. Isso porque, para as línguas que possuem escrita baseada em alfabetos, as letras representam sons, algo inteiramente indefinido aos surdos profundos.

Outro ponto de equívocos ocorre na premissa de que todo surdo tem a capacidade de leitura labial (BOTELHO, 1999, p. 2). Ocorre que muitos sons distintos possuem a mesma articulação externa, ou seja, a boca move-se igualmente. Por essa razão, surdos profundos possuem dificuldades em relacionar movimentos labiais com fonemas. Perguntas, por exemplo, no português, ocorrem por entonação, sendo entendida apenas pelo som.

Ferreira Brito (1993) lembra que a Libras é a forma plena de expressão de surdos. No entanto, para interagir com os conhecedores dessa língua, que é ágrafa, torna-se necessária a complementação na forma escrita do português. Em outras palavras, embora a Libras tenha assegurado seu status de língua, o uso do português escrito ainda é obrigatório, a despeito das iniciativas de escrita de línguas de sinais.

Nesse contexto, destaca-se a importância da comunicação para o ser humano, visto que pode ser mensurada pela impossibilidade de sobrevivência, em sociedade, sem sua utilização. É importante notar, nesse sentido, que a ausência da audição, visão ou fala não impede a comunicação. De fato, a criação de códigos que suprem essas deficiências demonstra quão importante é a comunicação na criação das relações humanas. Isso porque, como já enfatizado, a sociedade não existe sem a comunicação entre seus membros (COHEN, 1985, p. 28).

É importante chamar a atenção para o fato de que o estudo da surdez não parece ter sido foco de estudos na Ciência da Informação, como identificado no Quadro 1, tampouco o tema parece ter sido estudado no contexto da comunicação científica. Considerando que, na ciência, o conhecimento é criado a partir do conhecimento anterior, a comunicação científica tem, de fato, um papel primordial no desenvolvimento do conhecimento. Foi esse papel que 
a tornou parte importante nos estudos da Ciência da Informação (BATISTA et al., 2007, p. 2), dado o interesse da área nos fluxos da informação científica.

Definida como os processos envolvidos desde a geração do conhecimento científico até a sua popularização (LIEVROUW, 1990, p. 3), a comunicação científica possui características diferenciadoras em relação a outros processos comunicativos. Isso ocorre porque trata não apenas do conhecimento científico, mas de normas e padrões aceitos na comunidade científica. Mais que isso, diferenças intrínsecas entre as diversas áreas do conhecimento influenciam na forma de produção, disseminação e uso do conhecimento e, desse modo, nos padrões de comunicação. O presente estudo, com base nas diferenças disciplinares em relação aos padrões de comunicação no contexto científico, levanta a questão da relação entre a surdez e os padrões de comunicação científica, no intuito de identificar indícios de sua influência nesses padrões.

Os espaços do conhecimento científico são compartilhados com outros tipos de conhecimentos da vida cotidiana, mas possui padrões próprios de comunicação no contexto da ciência. Nesse sentido, tem sido abordado por diferentes pesquisadores, os quais têm proposto variados modelos para ilustrar os aspectos pertinentes ao processo de comunicação da ciência em diferentes comunidades. Tais modelos retratam as diferentes etapas do processo de comunicação, os diferentes canais de comunicação, as diversificadas comunidades de pesquisadores, além de questões relacionadas aos padrões de cada disciplina ou de grupos científicos, tais como Ciências Exatas e Naturais, Tecnologia e Medicina, Ciências Sociais e Humanas e Artes e Humanidades.

Regras de conduta ou normas sociais são pontos de caracterização de comunidades científicas (MEADOWS, 1999). Por essa razão, membros de comunidades científicas seguem um conjunto de normas, regras e padrões que orientam suas ações dentro do grupo (BOUDON, 1995). Cabe lembrar que comunidades científicas são formadas por indivíduos que podem pertencer a mais de uma disciplina ou grupo de disciplinas (HARRISON; STEPHEN, 1995) e que os níveis de interação entre as disciplinas geram a multidisciplinaridade, a pluridisciplinaridade, a interdisciplinaridade ou a transdisciplinaridade. (Japiassu, 1976, p. 73-75).

A multidisciplinaridade envolve a total independência entre as disciplinas que estudam um determinado fenômeno, não ocorrendo cooperação, mas tão somente a superposição de conhecimentos (JAPIASSU, 1976). A independência das disciplinas na multidisciplinaridade ocorre mesmo que as fronteiras sejam ultrapassadas (NICOLESCU, 1997, p. 1-4).

A pluridisciplinaridade, por sua vez, caracteriza-se pelo compartilhamento de estudo por disciplinas correlatas que possuam áreas de intersecção. Nesse caso, para Japiassu 
(1976), apesar de manter a individualidade disciplinar, os objetivos se tornam mais próximos, embora distintos.

Quanto à interdisciplinaridade, a relação disciplinar não se reduz a um denominador comum entre as disciplinas, mas à possibilidade de expandir ao máximo as potencialidades de cada disciplina (ETGES, 1995). Ao compreender mais de uma disciplina, faz a mediação entre as diferenças e permite expandir o conhecimento para além dos limites das disciplinas envolvidas no sistema, necessitando de interação de conceitos ou métodos.

Finalmente, a transdisciplinaridade, termo cunhado por Jean Piaget (biólogo, psicólogo e educador suíço), visa a designar uma etapa que supere a interdisciplinaridade (JAPIASSU, 1976). Constitui, portanto, um processo que transcende as interações ou reciprocidades, formando-se nas ligações internas de um sistema constituído por disciplinas distintas. A transdisciplinaridade permite, assim, um conhecimento consolidado interdisciplinar.

O tipo de abordagem, portanto, no que concerne aos níveis de interações entre as disciplinas, pode determinar como estudar a surdez. Dessa forma, o estudo identificou desde as disciplinas que possuem estudo sobre o tópico até os padrões de comunicação científica. Nesse sentido, a pesquisa analisou estudos da Educação, da Fonoaudiologia, da Linguística e da Psicologia. A depender da disciplina, há diferentes terminologias para designar a surdez. Na presente pesquisa, optou-se pelos termos utilizados na autodenominação, que, para Adams e Rohring (2004), além de constituir a forma mais polida de denominação de minorias sociais é também a abordagem amplamente aceita pela comunidade surda e por estudiosos dessa comunidade em relação à linguagem, como Skliar e Quadros (2000) e a FENEIS (2006). Assim, surdez e surdo são termos mais aceitos que deficiência auditiva e deficiente auditivo, por destacarem a noção de deficiência, embora sejam esses os termos mais aceitos nos estudos relacionados às ciências da saúde.

No que concerne aos estudos da comunicação, são muitos os estudiosos que a consideram responsável pelo bem-estar físico ou psíquico do indivíduo (TUBBS; MOSS, 2006, p. 7). Um exercício de estender os estudos da relação de dependência entre informação e mensagem permite adotar pelo menos três abordagens, nomeadamente física, cognitiva e social (Quadro 1). Tais abordagens podem, por generalização, ser utilizadas para os estudos da comunicação, sendo, então, reflexos da visão da informação na comunicação. 
Quadro 1 - Abordagens da informação na comunicação, sob diferentes enfoques

\begin{tabular}{|c|c|c|c|}
\hline $\begin{array}{l}\text { ABORDAGEM / } \\
\text { FENÔMENO }\end{array}$ & FÍSICA & COGNITIVA & SOCIAL \\
\hline Informação & $\begin{array}{l}\text { Mensagens codificadas em } \\
\text { forma de sinais elétricos }\end{array}$ & $\begin{array}{c}\text { Mensagens codificadas, } \\
\text { interpretadas e } \\
\text { decodificadas }\end{array}$ & $\begin{array}{l}\text { Mensagem compartilhada } \\
\text { entre comunicadores } 1 \text { e } 2 \\
\text { (emissor X receptor) }\end{array}$ \\
\hline Comunicação & $\begin{array}{c}\text { Unidirecional, ocorre } \\
\text { entre um emissor e um } \\
\text { transmissor, por meio de } \\
\text { um canal físico } \\
\text { Autores seminais: Shannon } \\
\text { (1948) e Shannon; Weaver } \\
\text { (1949) }\end{array}$ & $\begin{array}{c}\text { Bidirecional (fonte e } \\
\text { destinatário; codificador e } \\
\text { decodificador) } \\
\text { Feedback: essencial, dado } \\
\text { o caráter cíclico e crescente } \\
\text { do processo } \\
\text { Interpretação: função } \\
\text { cognitiva entre codificação } \\
\text { e decodificação } \\
\text { Autores seminais: Defleur } \\
\text { (1970, in McQuail e } \\
\text { Windhal, 1993, p. 18); } \\
\text { Osgood e Schramm (1954, } \\
\text { in McQuail e Windahl, } \\
\text { 1993, p. 19) }\end{array}$ & $\begin{array}{l}\text { Bidirecional, comunicador } \\
1 \text { e comunicador } 2 \text { nos } \\
\text { papeis (compartilhados) } \\
\text { entre emissor e receptor. } \\
\text { Introduz os conceitos de } \\
\text { interferência (externo } \\
\text { aos comunicadores) } \\
\text { e filtro (interno dos } \\
\text { comunicadores) } \\
\text { Autores seminais: Tubbs e } \\
\text { Moss (2006) }\end{array}$ \\
\hline
\end{tabular}

Fonte: Elaboração dos autores (2018).

Questão relevante a se considerar nessa discussão está relacionada ao fato de a sociedade estar organizada em diferentes tipos de comunidades, todas com seus próprios limites, padrões e símbolos, entre outros aspectos que lhes são inerentes. Tais questões, por seu turno, tanto requerem dessas comunidades quanto lhes apontam o próprio padrão de comunicação, isto é, cada tipo de comunidade na sociedade tem seus próprios padrões de comunicação. Esses padrões resultam do contexto em que estão inseridas, das questões culturais e sociais que as permeiam, como, por exemplo, os papéis desempenhados por seus membros e os símbolos por eles compartilhados, entre outros aspectos.

Pesquisadores acadêmicos constituem um desses tipos de comunidade. Por conseguinte, a comunicação entre eles revela aspectos importantes a serem considerados na discussão a respeito da comunicação humana. No caso da presente pesquisa, que foca os pesquisadores da surdez, o contexto específico da comunicação é o acadêmico, no qual se estudam as questões relacionadas à comunicação científica.

Ziman (1984, p. 58-67) considera que a comunicação científica é a instituição social principal da ciência, pois, ao reconhecer o conhecimento científico, atua pela preservação da própria ciência. Em relação a essa questão, Meadows (1999, p. 3-5) observa que pesquisa e comunicação andam juntas para gerar o conhecimento científico. O conhecimento resultante de pesquisa, portanto, ganha status de conhecimento científico ao ser posto à prova, por meio da comunicação. Destarte, a tríade conhecimento 
científico-pesquisa-comunicação científica possui interdependência funcional em que uma não existe sem a outra.

Um dos primeiros e mais citados modelos de representação do processo de comunicação científica, proposto por Garvey e Griffith (1979, p. 127-147), esquematiza a comunicação com foco na questão da disseminação científica ao longo do tempo. Posteriormente, o modelo dos autores motivou sua adaptação por vários outros pesquisadores, incluindo a ilustração publicada por Hurd (1996), em que as etapas originalmente propostas por eles são sintetizadas, como observado na figura 1.

Figura 1 - Modelo do processo de comunicação de Garvey e Grifith (1979, adaptado por Hurd, 1996)

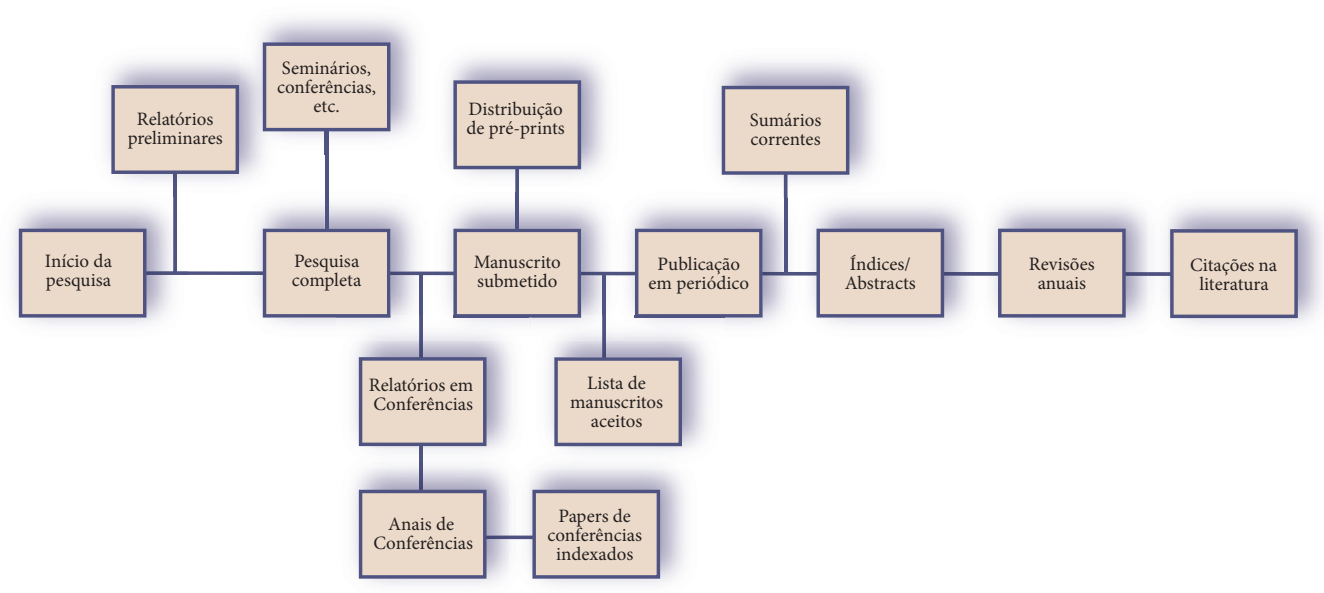

Fonte: Garvey e Grifith (1979, adaptado por Hurd, 1996.

Hurd, baseada em Garvey e Griffith, propôs um novo modelo, que leva em conta somente a comunicação baseada no computador. Assim, em seu modelo, as etapas propostas por Garvey e Grifith são todas consideradas como ocorrendo inteiramente no meio eletrônico, não levando em conta, portanto, o ambiente baseado no meio impresso (figura 2). 
Figura 2 - Modelo do processo de comunicação de Hurd (1996)

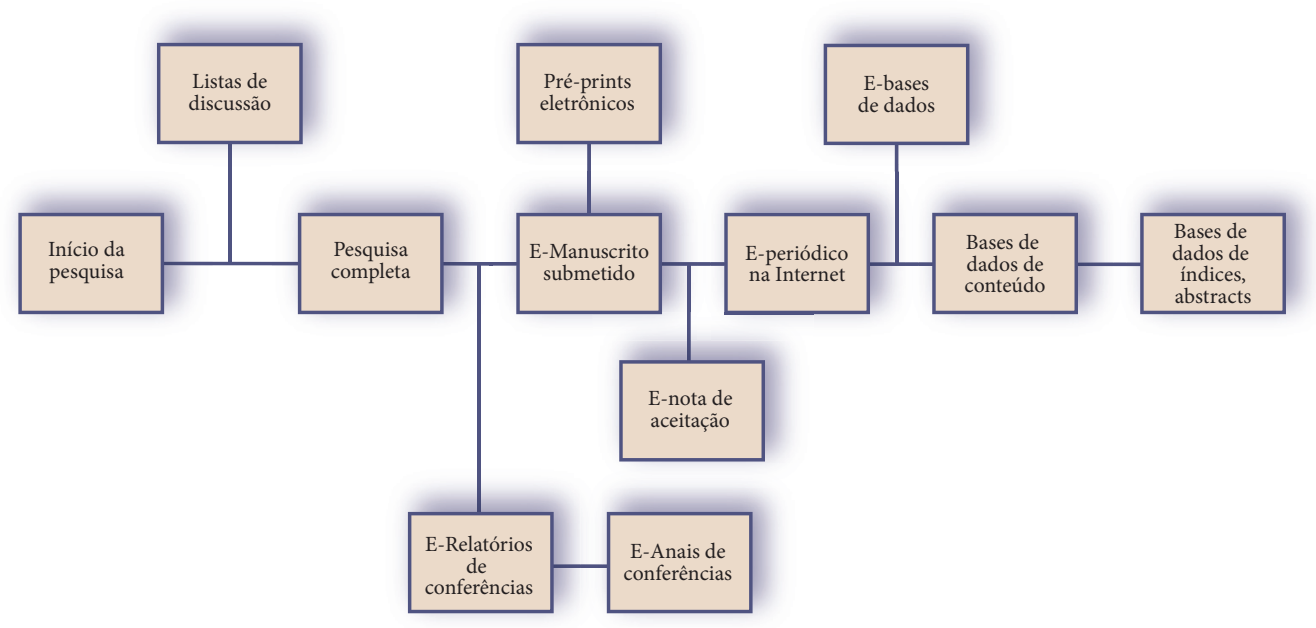

Fonte: Hurd (1996).

Björk (2005), por sua vez, ilustra o modelo de comunicação científica em sete níveis hierárquicos e 26 diagramas, que focam aspectos específicos do processo. A figura 3 apresenta o primeiro e mais abrangente nível de detalhamento de seu modelo (executar a pesquisa, comunicar e implementar os resultados), em uma abordagem diferenciada dos autores que o antecederam. 
Figura 3 - Primeiro nível de detalhamento do modelo do processo de comunicação de Björk (2005)

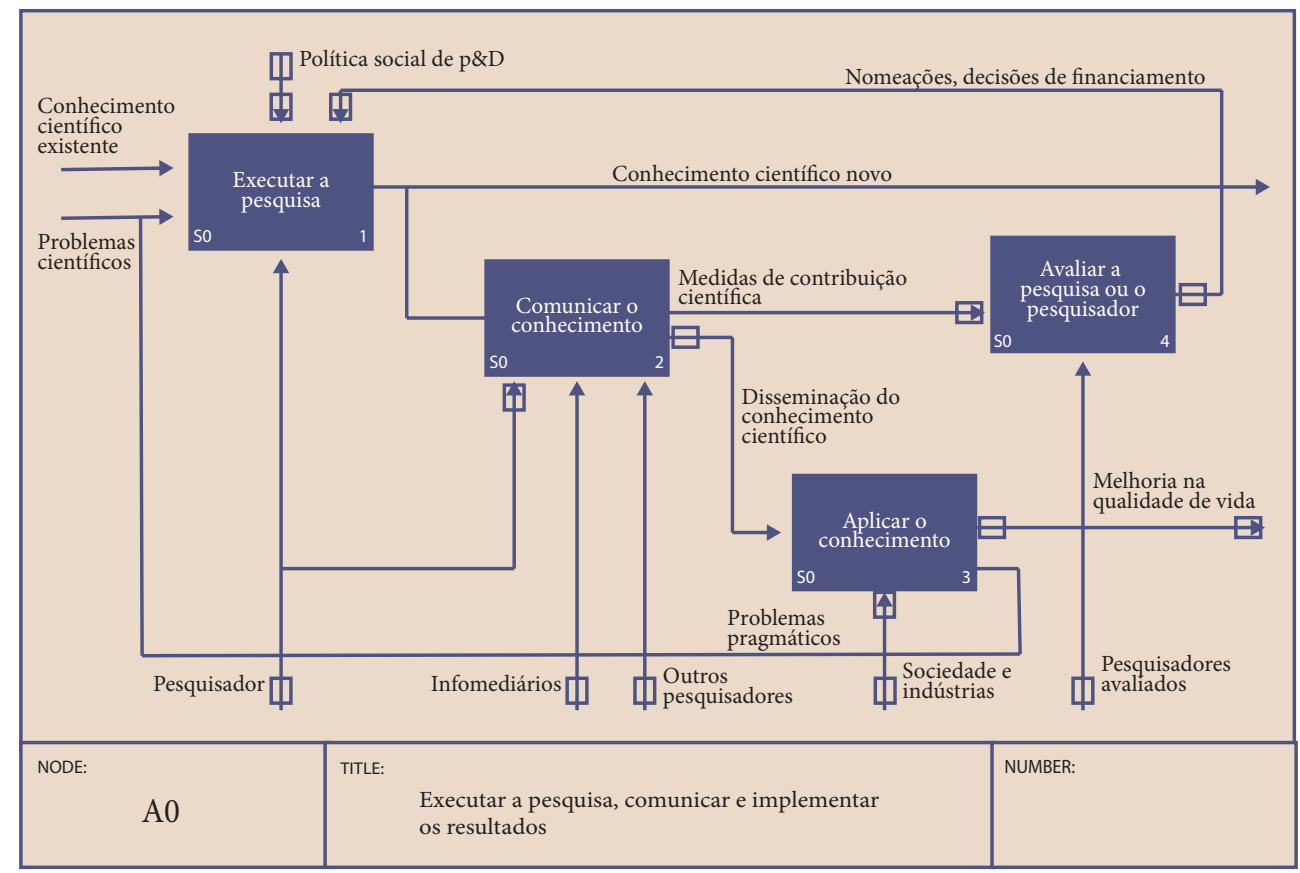

Fonte: Björk (2005).

Um retorno às adaptações do modelo de Garvey e Griffth (1979) conduz à pesquisa realizada por Costa (1999), em que a autora estudou o impacto do uso do computador na comunicação científica, incluindo, no modelo dos autores, aspectos do modelo de Hurd (1996). Nesse sentido, a autora propõe um modelo híbrido do processo de comunicação que não se baseia totalmente no meio impresso nem no meio eletrônico, portanto mais apropriado à realidade da época. Adaptou-o, uma década depois, ilustrando o crescimento dos aspectos eletrônicos (figura 4) no processo (COSTA, 2008). 
Figura 4 - Modelo do processo de comunicação científica de Costa (2008)

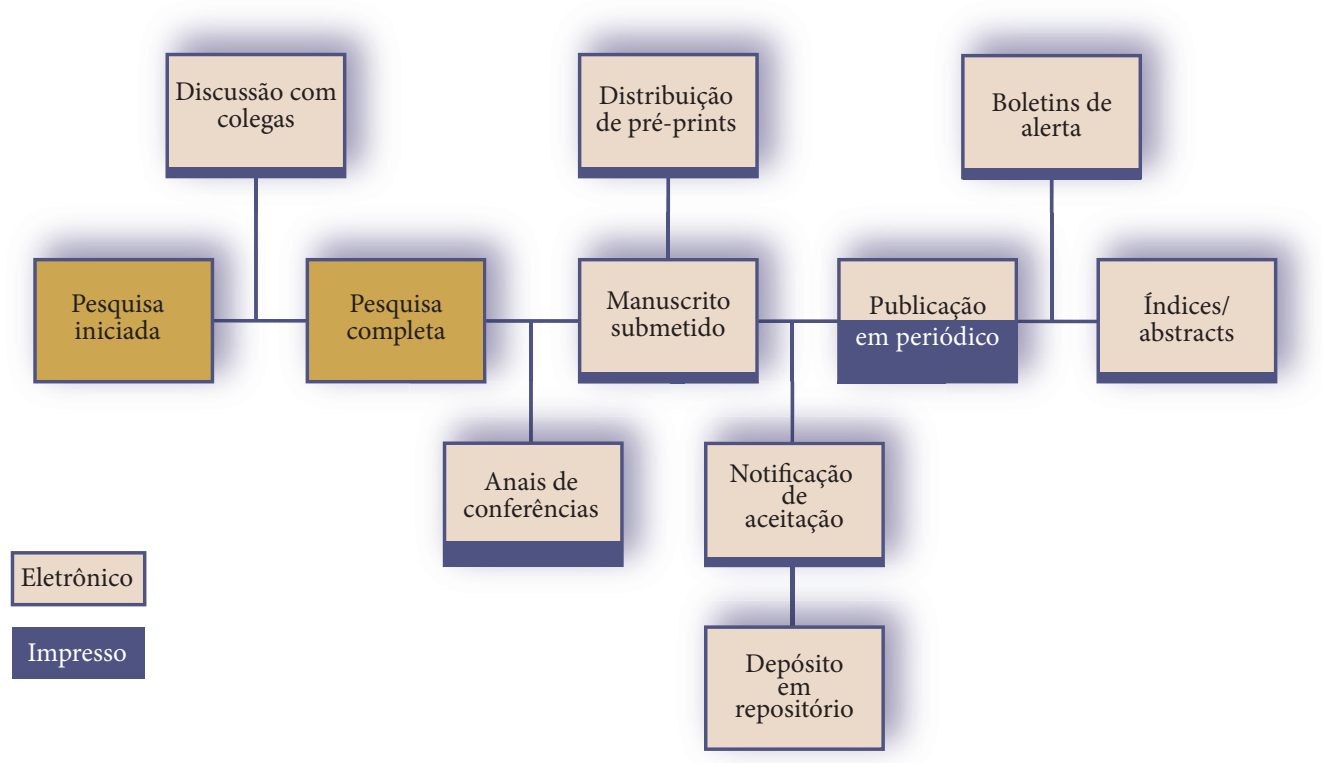

Fonte: Costa (2008).

\section{ABORDAGEM METODOLÓGICA}

Para o embasamento teórico do presente estudo, foram propostas questões relacionadas aos padrões de comunicação científica e ao estudo da surdez com foco na linguagem. Essas questões, discutidas por meio da análise da literatura relevante, permitiram a construção de um referencial teórico, que orientou os aspectos metodológicos da pesquisa. Nesse sentido, a abordagem metodológica adotada para o estudo levou em conta dois conjuntos de conceitos. O primeiro conjunto é composto pelos conceitos fundamentais da Ciência da Informação, apresentados por Meadows (1999), Garvey (1979) e Ziman (1984), e pelos modelos do processo de comunicação científica formulados por Garvey e Griffith (1979), Hurd (1996, 2000), Bjork (2005) e Costa (2008). O segundo é formado por conceitos sobre as relações disciplinares discutidos por Japiassu (1976).

Os aspectos epistemológicos visaram à orientação do estudo para a discussão de resultados. Os aspectos metodológicos foram fundamentados em uma abordagem mista, pelo uso de dois métodos de coleta de dados: levantamento (survey) e análise documental. O uso de abordagem mista permitiu associar a precisão quantitativa (diminui a distorção dos dados, segundo Richardsom, 2008) à profundidade qualitativa, (DENZIN; LINCOLN, 2006, p. 23), por considerá-las adequadas às ferramentas para coleta de dados utilizada no estudo. 
Com vistas a atender os objetivos propostos, a presente pesquisa foi dividida em etapas necessárias para analisar o estudo da surdez do ponto de vista da linguagem, no que tange à comunicação científica. Inicialmente, foram levantadas quais disciplinas estudam a surdez com ênfase na linguagem, caracterizando seus estudos e seus pesquisadores. Em seguida, foram identificados os pesquisadores e seus padrões de comunicação científica.

\section{ANÁLISE E DISCUSSÃO DOS RESULTADOS}

No que concerne às disciplinas que estudam a surdez do ponto de vista da linguagem, a análise de conteúdo das teses e dissertações disponíveis na Biblioteca Digital de Teses e Dissertações (BDTD) revelou que estudiosos no tópico em questão estão mais presentes em disciplinas como Educação, Fonoaudiologia, Linguística e Psicologia. Por esta razão, são essas as disciplinas que fizeram parte do presente estudo. Delimitam, nesse caso, as disciplinas focadas no presente estudo.

Do total de 67 teses e dissertações analisadas, a Linguística demonstrou possuir um quantitativo maior de estudos, tanto em mestrado, com 19 dissertações, quanto em doutoramento, com 10 teses. Cabe notar que a Fonoaudiologia não possui teses nesse assunto, provavelmente em razão de os programas de pós-graduação nessa disciplina serem ainda recentes (iniciados em 2004). As palavras-chave utilizadas pelos autores das 67 teses e dissertações revelaram aspectos que diferenciam os estudos nas diferentes disciplinas em questão. Enquanto a Educação tem preocupação com estudos ligados à educação especial (GONZALES SOTO, 2002), a Fonoaudiologia trata de reabilitação e problemas com a escrita (AMORIM, 1982), por exemplo. Somente os termos "surdez" e "Libras" são comuns a todos esses estudos.

Os dados revelam, também, certa preferência pelo método qualitativo, pois $78 \%$ dos trabalhos indicaram a escolha desse tipo de abordagem. Esse indício é condizente com aspectos discutidos por estudiosos dos modelos de comunicação, nos quais as disciplinas dos estudos que adotam abordagem qualitativa pertencem, na maioria, às Ciências Sociais e Humanas. Da mesma forma, 16 desses estudos consistem em pesquisas etnográficas, com uma grande variedade de métodos de coleta de dados, destacando-se a entrevista (31\%), a análise documental (16\%) e a observação (11\%).

Outro ponto apresentado nos estudos analisados refere-se à distribuição espaço-temporal. Os metadados revelaram que esses estudos ocorreram em Instituições de Ensino Superior (IES) de vários estados brasileiros e com interesse relativamente maior nos últimos anos. Nesse caso, a concentração maior de estudos nas regiões Sul e Sudeste reflete a distribuição de instituições acadêmicas brasileiras. $\mathrm{O}$ interesse mais recente pelo tópico pode indicar influência da Lei de Libras, promulgada em 2002. 
A coleta realizada nos registros do Diretório de Grupos de Pesquisa do CNPq, por sua vez, ratificou, quase que totalmente, os resultados obtidos na BDTD, no que se refere às disciplinas que estudam a surdez com ênfase na linguagem. A análise baseada nos campos de metadados de descrição e de linha de pesquisa revelou que apenas a Psicologia não vinculou grupos de pesquisa nessa base de dados, mesmo que psicólogos integrem grupos de outras disciplinas. Esses dados podem revelar dificuldades da Psicologia em institucionalizar grupos de pesquisas nesse tópico, mas não descarta seu interesse pelos estudos da surdez do ponto de vista da linguagem.

É interessante ressaltar uma observação decorrente do estudo em relação às razões pelas quais as disciplinas estudam o tópico. Trata-se da coincidência entre os achados da presente pesquisa e o Decreto $\mathrm{n}^{\circ}$ 5.626, de 22 de dezembro de 2005 (BRASIL, 2005). No que concerne à formação de grupos de pesquisa, verificou-se vinculação às disciplinas de Educação, Fonoaudiologia e Linguística, que, por sua vez, inserem-se no que determinam os artigos 3 o e 40 do Decreto, que tratam da inclusão da Libras nos parâmetros curriculares dos cursos superiores de formação de professores, nas três disciplinas.

Em relação aos participantes desses grupos de pesquisa, os dados revelaram algumas particularidades relacionadas às suas composições. Com 92\% de integrantes femininos, o estudo da surdez com ênfase na linguagem reflete a composição de grupos de estudiosos das disciplinas que estudam o tópico. Essa composição é identificada em estudos como os de Rosemberg (2001), Santos et al. (2003), Kernbichler (2005) e Melo e Oliveira (2006), que estudaram a composição de pesquisadores em grupos de estudo da Educação, da Fonoaudiologia, da Linguística e da Psicologia, respectivamente. Outro aspecto identificado foi que 38 dos 62 pesquisadores possuíam doutoramento entre os anos 2000 e 2008, o que, evidentemente, está relacionado ao fato de que a surdez, do ponto de vista da linguagem, é um tópico de estudo igualmente recente, como discutido anteriormente.

Os resultados da pesquisa levantaram três características relacionadas aos padrões de comunicação científica. O primeiro diz respeito ao uso de fontes de informação para pesquisa. O segundo refere-se aos veículos para publicação de resultados da pesquisa. No terceiro, finalmente, são abordadas as modalidades de autoria na publicação dos resultados.

Sobre o uso de fontes de informação, a maior utilização de artigos de periódicos, padrão típico das ciências rígidas ou de divisões disciplinares mais próximas a elas, está em conformidade com os resultados da pesquisa feita por Zwan e Nederhof (1990) sobre estudiosos da Linguística. O equilíbrio entre o uso de fontes impressas e digitais como subsídio à pesquisa, revelado no presente estudo, é resultado das diferenças entre o uso de livros e comunicações em eventos científicos. Os primeiros são mais utilizados na 
forma impressa, enquanto os últimos são mais utilizados no formato digital. Mais que isso, artigos de periódicos são quase igualmente utilizados nos formatos digital e impresso. Essa convivência entre o impresso e eletrônico está de acordo com o modelo híbrido proposto por Costa (2008).

Quanto ao aspecto de disseminação de resultados de pesquisa, os veículos para publicação identificados nos resultados do presente estudo estão em consonância com o processo "publicar resultados", discutido por Björk (2005). Assim, os resultados das pesquisas sobre surdez realizadas por linguistas, fonoaudiólogos, educadores e psicólogos são publicados tanto em livros, quanto em artigos de periódicos e comunicação em eventos. Essa diversidade de veículos pode ser ilustrada por meio da adaptação do modelo de Costa (2008) tal como se apresenta na figura 5. De fato, o modelo da autora parece apropriado para representar a comunicação científica dessa comunidade por representar os veículos utilizados nas formas digital e impressa, característica ausente no modelo de Björk (2015).

Figura 5 - Processo de comunicação científica na comunidade que estuda a surdez do ponto de vista da linguagem

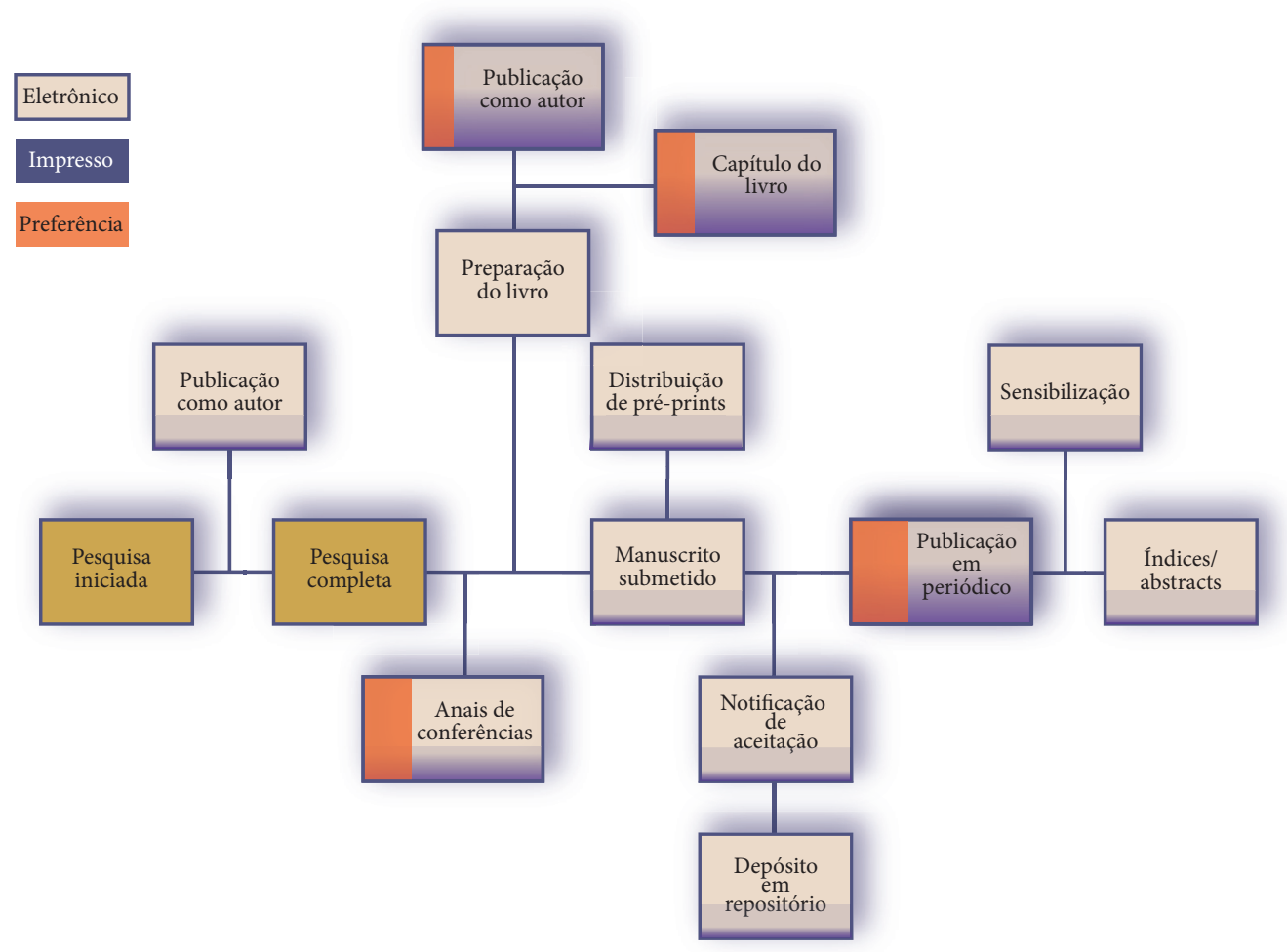

Fonte: Elaboração dos autores (2018). 
As modalidades de autoria foram tratadas no presente estudo como autoria individual ou múltipla e como autoria entre pares da mesma disciplina ou de outra. De acordo com os resultados obtidos, a incidência de publicação colaborativa na mesma área mostrou interação importante dos pesquisadores no seio de suas disciplinas, o que revela o caráter multidisciplinar do tópico. Corrobora essa noção a incidência mais baixa de colaboração entre autores de disciplinas distintas. Como observa Japiassu (1976), uma integração maior entre autores de diferentes disciplinas apontaria para o caráter interdisciplinar, que não parece ser o caso. O estudo confirma as previsões de Hurd (2000) de que a comunicação científica no início do século XXI revelaria aumento da colaboração entre pesquisadores, visto que identificou maioria de autoria múltipla.

\section{CONCLUSÕES}

A surdez do ponto de vista da linguagem como tópico de estudo pesquisado está presente principalmente em quatro disciplinas, nomeadamente Educação, Fonoaudiologia, Linguística e Psicologia, distribuídas, assim, desde as Ciências da Saúde (Fonoaudiologia), até as Humanidades (Linguística e Educação), passando pelas Ciências Sociais e Humanas (Psicologia). Tal distribuição revela a complexidade do tópico estudado, o qual tem influência, embora aparentemente parcial, na comunicação científica entre seus pesquisadores.

A variedade de fontes de informação e de veículos de publicação revelam padrões compatíveis com aqueles das três principais divisões do conhecimento, a despeito do tópico constituir um fenômeno social e humano cuja abordagem seria própria das Ciências Sociais e Humanas, inseridas em um continuum que se estende desde as Humanidades até as Ciências Exatas e Naturais.

O interesse pelo tópico da surdez do ponto de vista da linguagem por parte da Educação, da Fonoaudiologia e da Linguística tem motivação relacionada a ações governamentais de inclusão dos surdos, sendo maior nos últimos anos.

O uso de fontes de informação para pesquisa, a despeito de apontar para os três principais tipos de publicação acadêmica, nomeadamente livros, artigos e comunicações em eventos, há utilização maior de artigos de periódicos. O mesmo padrão se aplica aos tipos de publicação em que divulgam seus resultados. Observa-se preferência, por parte dos pesquisadores da surdez do ponto de vista da linguagem, pela publicação em coautoria entre pesquisadores da mesma disciplina.

Padrões de comunicação de pesquisadores da surdez constitui um tema complexo, possibilitando pesquisas em diferentes disciplinas, entre elas a Ciência da Informação. Nessa, em 
especial, a questão da comunicação científica tende a ser uma das abordagens que oferecem resultados úteis para a ampliação dos horizontes dos estudos sobre o tópico.

\section{REFERÊNCIAS}

ADAMS, W.; ROHRING, P. S. Handbook to service the deaf and hard of hearing: JA Bridge to Accessibility. San Diego: Elsevier Academic Press, 2004.

AMORIM, A. Fonoaudiologia geral. Rio de Janeiro: Enelivros, 1982.

BATISTA, A. A. et al. Comunicação científica: o papel da Open Archives Initiative no contexto do Acesso Livre. Encontros Bibli: revista eletrônica de Biblioteconomia e Ciência da Informação, Florianópolis, n. esp., 1º sem. 2007.

BJÖRK, B. C. Scientific communication life-cycle model. 2005. Disponível em: <http://oacs. shh.fi/publications/Model35explanation2.pdf >. Acesso em: 20 abr. 2014.

BOTELHO, P. Educação inclusiva para surdos: desmistificando pressupostos. In. Anais do I SEMINÁRIO INTERNACIONAL SOCIEDADE INCLUSIVA, 1., 1999, Belo Horizonte. Anais eletrônicos. Belo Horizonte: PUC-Minas, 1999. Disponível em: <http://www.sociedadeinclusiva.pucminas.br/anaispdf/educsurdos.pdf>. Acesso em: 20 abr. 2014.

BOUDON, R. The analysis of ideology. Chicago: University of Chicago Press, 1995.

BRASIL. Decreto-lei no 5.626, de 22 de dezembro de 2005. Regulamenta a Lei no 10.436 , de 24 de abril de 2002, que dispõe sobre a Língua Brasileira de Sinais-Libras. Diário Oficial [da] República Federativa do Brasil, Brasília, DF, 23 abr. 2005. Disponível em: <https:// http:// www.planalto.gov.br/ccivil/_Ato2004-2006/2005/Decreto/D5626.htm>. Acesso em: 20 abr. 2014.

BRASIL. 10.098, de 19 de dezembro de 2000. Dispõe sobre a acessibilidade. Diário Oficial [da] República Federativa do Brasil, Brasília, DF, 20 dez. 2000. Disponível em: <https:// http://www.planalto.gov.br/ccivil/_Ato2004-2006/2005/Decreto/D5626.htm>. Acesso em: 20 abr. 2014.

COHEN, A. P. The symbolic construction of community. Londres: Routledge, 1985. 
COSTA, S. M. S. The impact of computer usage on scholarly communication amongst academic social scientists. 1999. 302 p. Tese (Doutorado) - Programa de pós-graduação em Ciência da informação, Loughborough University, Department of Information Science, Loughborough, Inglaterra, 1999.

COSTA, S. M. S. Abordagens, estratégias e ferramentas para o acesso aberto via periódicos e repositórios institucionais em instituições acadêmicas brasileiras. Liinc em Revista, 2008, v. 4, n. 2. Disponível em: <http://revista.ibict.br/liinc/index.php/liinc/article/ view/281> Acesso em: 20 abr. 2014.

DENZIN, N. K.; LINCOLN, Y. S. et al. O planejamento da pesquisa qualitativa: Teorias e abordagens. 2. ed. Tradução de Sandra Regina Netz. Porto Alegre: Artmed, 2006.

ETGES, N. J. Produção do conhecimento e interdisciplinaridade. In: JANTSCH, A. P; BIANCHETTI (Orgs). Interdisciplinalidade. Petrópolis: Vozes, 1995. p. 51-84.

FENEIS. Federação Nacional de Educação e Integração dos Surdos. Relatório de atividades de 2006. São Paulo, 2006. Disponível em: < http://www.feneis.com.br >. Acesso em: 20 abr. 2014.

FERREIRA BRITO, L. Integração social e educação dos surdos. Rio de janeiro: Babel Editora, 1993.

GARVEY, D. W. Communication: The Essence of Science. Oxford: Pergamon Press, 1979.

GARVEY, D. W.; GRIFFITH, B. C. Communication and information processing within scientific disciplines: empirical findings for Psychology. In: GARVEY, D. W.; GRIFFITH, B. C. Communication: the essence of science. Oxford: Pergamon Press, 1979. p. 127-147.

GONZALES SOTO, A. P. Apresentação, In: TORRES GONZÁLEZ, J.A. Educação e diversidade: bases didáticas e organizativas. Porto Alegre: Artmed Editora, 2002.

HARRISON, T. M.; STEPHEN, T. D. The electronic journal as the heart of the online scholarly community. Baltimore: Library Trends, 1995.

HURD, J. Models of scientific communications system. In: CRAWFORD, S. et al. (Eds). From print to electronic: the transformation of scientific communication. Medford, NJ: Information Today Inc, 1996. p. 9-33 
HURD, J. The transformation of scientific communication: A model for 2020. Journal of the Americam Society for Information Science, New York, v. 51, n. 14, p. 1279$1283,2000$.

JAPIASSU, H. Interdisciplinaridade e patologia do saber. Rio de Janeiro: Imago editora Ltda., 1976.

KERNBICHLER, Maria Alice Borin Sanchez. O processo de profissionalização de uma ocupação feminina: a fonoaudiologia em São Paulo. 2005. 148 f. Dissertação (Mestrado) Programa de Pós-graduação em Ciências Sociais, Centro de Educação e Ciências Humanas, Universidade Federal de São Carlos, São Carlos,, 2005. Disponível em: <https://repositorio. ufscar.br/handle/ufscar/1442>. Acesso em: 17 ago. 2018.

LIEVROUW, L. A. Communication and the social representation of scientific knowledge. Critical studies in mass communication, New Jersey, v. 7, n. 1, p. 1-10 mar. 1990. Disponível em: <http://polaris.gseis.ucla.edu/llievrou/csmc90.pdf>. Acesso em: 20 abr. 2014.

MEADOWS, A. J. A comunicação científica. Tradução de Briquet de Lemos e A.A. Briquet de Lemos. Brasília: Livros, 1999

MELO, H. P. de; OlIVEIRA, A. B. A produção científica brasileira no feminino. Cadernos Pagu, UNICAMP, v. 27, p. 301-332, 2006. Disponível em: < http://www.scielo.br/pdf/cpa/n27 /32146.pdf >. Acesso em: 20 abr. 2014.

NICOLESCU, B. Em busca de uma evolução transdisciplinar para a universidade. In:CONGRESSO INTERNACIONAL QUE UNIVERSIDADE PARA O AMANHÃ? 1997, Chulalongkorn University. Anais eletrônicos. Bangkok: Congresso Internacional Que Universidade para o Amanhã, 1997. Disponível em: <www. cetrans.futuro.usp.br>. Acesso em: 20 abr. 2014.

RICHARDSON, J. R. Pesquisa social: métodos e técnicas. 3. ed. São Paulo: Atlas, 2008.

ROSEMBERG, F.. Caminhos cruzados: educação e gênero na produção acadêmica. EducPesq, v. 27, n. 1, p. $47-68,2001$.

SANTOS, A. A. A. dos et al. I Congresso Nacional de Psicologia - Ciência e Profissão: o que tem sido feito na Psicologia Educacional. Psicol. Esc. Educ., 2003, v. 7, n. 2, p. 135-144, 2001.

SAUSSURE, F. Curso de lingüística geral. Tradução de Antônio Chelini, José Paulo Paes e Izidoro Blikstein. 23.ed. São Paulo: Cultrix, 2003. 
SHANNON, C. A mathematical theory of communication. The Bell System Technical Journal, Willey, v. 57, n. 6, p. 379-423, 623-656, Jul./Out., 1948.

SHANNON, C.; WEAVER, W. The mathematical theory of communication. Urbana: University of Illinois, 1949,

SKLIAR, C.; QUADROS, R. M. Invertendo epstemologicamente o problema da inclusão: os ouvintes no mundo dos surdos. São Paulo: Estilo das Clinicas, v. 5, n. 9, p. 33-51, 2000. Disponível em: <ttp://www.sj.cefetsc.edu.br/ nepes/docs/midiateca_artigos/inclusao_educacao_ssurdos/texto27.pdf >. Acesso em: 20 abr. 2014.

SWAANS-JOHA, B. C. Mental health problems among deaf people and mental health care. In: FRACCHIA, G. N.; THEFILATOU, M. (Org). Health Services Research. Amsterdan: IOS Press, 1993. p. 42-50.

TUBBS, S. T.; MOSS, S. Human communication. 10. ed. Nova Iorque: McGraw Hill, 2006.

ZIMAN, J. M. An introduction of science studies: the philosophical and social aspects of science and technology. Cambridge: Cambridge University Press, 1984.

ZWAAN, R. A.; NEDERHOF, A. J. Some aspect $\mathrm{f}$ scholarly communication in linguistic: an empirical study language. The Journal of Linguistic Society of America.Washington, Linguistic Society of America, v. 66, n. 3, p. 55. 


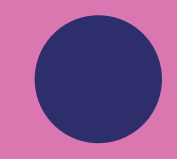

○

○

-

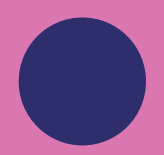

-

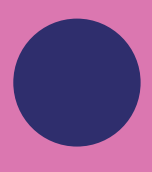

○

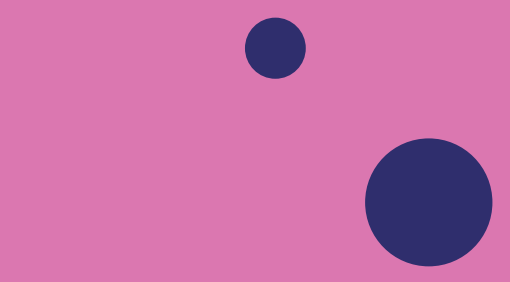

○

○

- 0

○
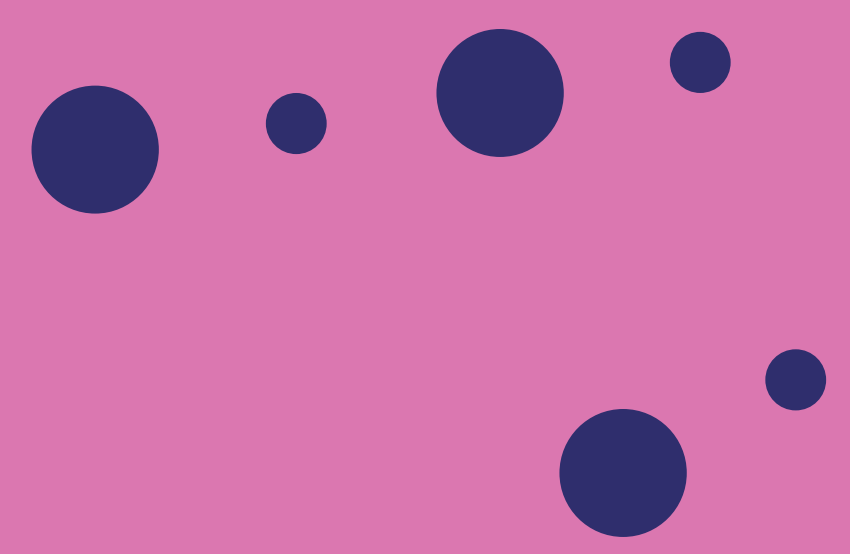


\section{CAPÍTULO 7}

0

0
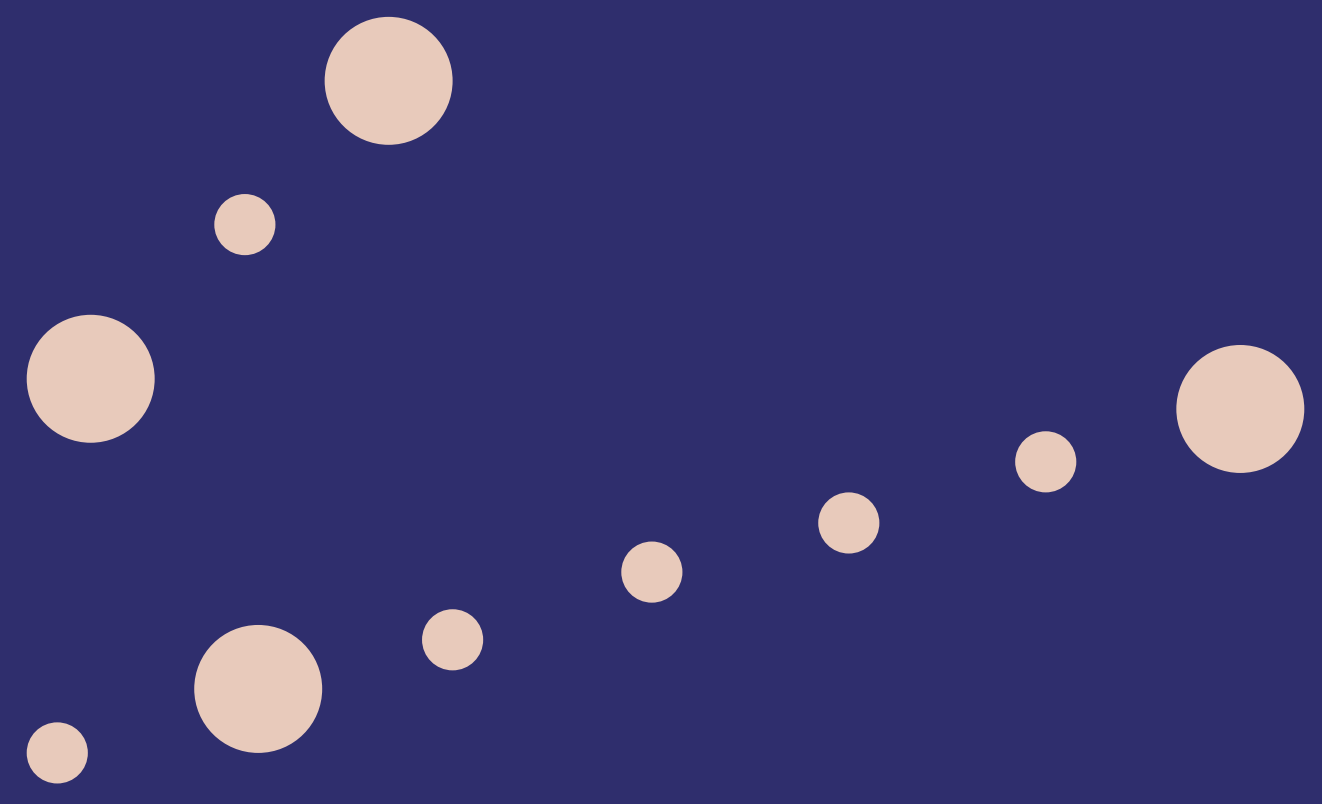

- 00 


\section{O PENSAMENTO REFLEXIVO NO LETRAMENTO INFORMACIONAL NAS PESQUISAS DE PÓS-GRADUAÇÃO}

KELLEY CRISTINE GONÇALVES DIAS GASQUE SELY MARIA DE SOUZA COSTA

\section{INTRODUÇÃ̃O}

Produzir pesquisas no mestrado e no doutorado exige desenvolver a capacidade de buscar e usar adequadamente a informação. Os estudantes de pós-graduação, ao reconhecerem as necessidades de informação, devem buscá-la e apreendê-la para transformá-la em conhecimento, processo que integra habilidades intelectuais, como decodificação, interpretação, organização e comunicação do conhecimento.

Essas competências abrangem, além dos procedimentos técnicos e intelectuais, valores pessoais, motivações, crenças, visão crítica e atitudes, como responsabilidade, ética e, ainda, a capacidade de o indivíduo refletir sobre os próprios processos de busca e de uso da informação, assumindo o controle e o monitoramento desses processos. Portanto, as atividades de busca e de uso da informação implicam, quase sempre, a aprendizagem de conceitos procedimentos e atitudes, o que, por sua vez, pode resultar em aumento do conhecimento pessoal.

Ao considerar a aprendizagem para pesquisar como atividade crucial para a produção de conhecimento de qualidade, apresenta-se resultado de pesquisa de doutorado realizada com o objetivo de identificar o tipo de relação entre o pensamento reflexivo e as competências empregadas na busca e no uso da informação por pesquisadores em formação, estudantes de mestrado e de doutorado.

\section{FUNDAMENTAÇÃO TEÓRICA E METODOLOGIA}

Nesta investigação, partiu-se do pressuposto de que os pesquisadores em formação necessitam de informações para a obtenção e produção de conhecimento no decorrer de suas atividades 
de pesquisa. Por essa razão, para buscar e usar informações, pesquisadores precisam construir e desenvolver competências informacionais que possam ser mais eficazes mediante o emprego do pensamento reflexivo. Nesse contexto, os conceitos de comportamento informacional e pensamento reflexivo são fundamentais e tratados nas seções subsequentes.

\subsection{Comportamento informacional}

A literatura sobre busca e uso da informação é vasta. Observa-se que esses conceitos se inserem em uma abordagem mais ampla, denominada por Wilson (1997) de "comportamento informacional". O autor inclui, como parte desse tópico, os conceitos de necessidades de informação; as variáveis intervenientes no comportamento de busca da informação (como características pessoais e barreiras econômicas); o comportamento de busca e aquisição; o processamento e uso da informação (por exemplo, aprendizagem); e a transferência da informação.

Embora se reconheça a inter-relação dos conceitos que compõem o comportamento informacional, optou-se nesta seção por definir os principais conceitos tratados na pesquisa aqui relatada. As questões sobre fatores intervenientes, transferência de informação e métodos de pesquisa estão subjacentes à discussão dos conceitos, mas não são objetos específicos de investigação. Além dos conceitos tradicionais relacionados com o comportamento informacional, foram incluídos como relevantes a esta discussão os conceitos de aprendizagem e de letramento informacional. No primeiro caso, a inclusão se justifica em razão do fato de a aprendizagem permear todas as atividades de busca e de uso da informação. No segundo, a inclusão é justificada pela crença de que a eficácia da busca e do uso da informação depende da apreensão e do desenvolvimento de competências que constituem o letramento informacional. Nesse sentido, foram definidos cinco conceitos relevantes. O primeiro conceito, necessidades de informação, vincula-se ao estado mental de um indivíduo (WILSON, 1997), entendido como um déficit de informação a ser preenchido. Na abordagem do autor, necessidades de informação podem estar relacionadas aos motivos psicológicos, afetivos e cognitivos, assim como ao papel que a pessoa desempenha e aos contextos político, social e econômico do ambiente em que habita. O segundo conceito, busca da informação, é composto por um conjunto de atividades que, de acordo com Wilson (1997), inclui conhecimentos e competências, os quais possibilitam aos indivíduos identificar as necessidades informacionais e a natureza da informação, elaborar planejamento de busca da informação, determinar os tipos e formatos de fontes potenciais de informação, estratégias para utilização das tecnologias da informação e comunicação, entre outras. Essas atividades requerem também visão crítica, responsabilidade e ética. O terceiro conceito, uso da informação, refere-se às atividades em que o indivíduo se engaja para apreender a informação e transformá-la em conhecimento. Envolve habilidades intelectuais, como decodificação, interpretação, organização e avaliação do conhecimento. A decodificação e a interpretação incluem atividades de leitura, estabelecimento de relações 
entre o conhecimento prévio e as novas informações, comparação entre vários pontos de vista e avaliação. A organização e a avaliação relacionam-se com a própria organização, elaboração de textos por meio de resumos, esquemas e julgamento do conhecimento produzido a partir de critérios definidos claramente. O uso da informação abrange, também, os valores pessoais, motivações, crenças, visão crítica e atitudes, como responsabilidade, ética e também a capacidade do indivíduo de refletir sobre os próprios processos de uso da informação, bem como controlar e monitorar esses processos. Usar a informação implica a aprendizagem de um conteúdo que pode ser conceitual, procedimental ou atitudinal, podendo resultar em aumento do conhecimento pessoal (WILSON, 1997). O quarto conceito, que é o de aprendizagem, compreende o processo de aquisição do conhecimento inerente ao ser humano que perpassa as várias atividades do comportamento informacional. Segundo Dewey (1979a), é o processo de aprender a pensar, considerando as experiências e informações, que abrange as atitudes, as disposições morais e o cultivo das apreciações estéticas. Nesta pesquisa, compreende-se a aprendizagem como o conjunto das mudanças relativamente permanentes resultantes das inter-relações entre a reflexão e a experiência. Finalmente, o último conceito, letramento informacional, consiste em um processo de aquisição e desenvolvimento de competências informacionais, as quais possibilitam localizar, selecionar, acessar, organizar e avaliar as informações para o uso e a geração de conhecimento, incluindo as questões éticas, legais e socioeconômicas da informação, bem como a reflexão crítica sobre a produção informacional. A aprendizagem das competências visa à tomada de decisão, à resolução de problemas e à realização de pesquisas.

\subsection{Pensamento reflexivo}

Pesquisadores precisam buscar e usar informações para levantar hipóteses, construir teorias e socializar os resultados da pesquisa. As atividades de busca e de uso da informação podem ser mais eficazes com o emprego do pensamento reflexivo, o qual se refere a uma cadeia de ideias interligadas entre si, firmada em base sólida e em evidências, aspirando chegar a uma conclusão por meio de um esforço consciente e voluntário. Schön (1992) diferenciou três momentos do processo de reflexão: a reflexão na ação, a reflexão sobre a ação e a reflexão sobre a reflexão na ação. O primeiro refere-se aos processos de pensamento que ocorrem durante a ação, permitindo a reformulação das ações no decurso do processo. O segundo relaciona-se à análise que o sujeito faz dos processos e das características da sua própria ação no momento em que ele se distancia da prática do cotidiano. E o terceiro vincula-se à análise sobre o fato ocorrido, o que o sujeito observou, o significado atribuído e os outros significados que podem ser atribuídos ao ocorrido. Orienta-se para a ação futura a partir da compreensão dos contextos políticos, sociais, culturais e pessoais em que ocorreu, para olhar os novos problemas e descobrir soluções. Neste trabalho, o foco não está centrado no momento da ação, mas após a ação, especificamente tratando da reflexão sobre a reflexão na ação. 
Parece não constar na literatura da área da Ciência da Informação estudos que permitam que se visualize a priori como esses conceitos estão relacionados. Em razão disso, este estudo propõe a abordagem denominada teoria fundamentada (grounded theory), de Glaser e Strauss (1967), uma metodologia de natureza exploratória, orientada para os dados, considerando que esses são coletados sem a preocupação de testar uma teoria. Pelo contrário, o objetivo é construir a teoria a partir do que os dados revelam.

\section{METODOLOGIA}

A pesquisa realizada adotou a abordagem qualitativa. Tal abordagem tem sido utilizada para compreender o problema e os fatores subjacentes ao objeto pesquisado, mediante estudos de pequenas amostras (MALHOTRA, 2001) e a atribuição de sentido pelos próprios sujeitos, uma vez que os pesquisadores podem interagir com os sujeitos estudados.

A população estudada abrange os alunos dos cursos selecionados da pós-graduação stricto sensu da Universidade de Brasília (UnB) e da Universidade de São Paulo (USP). Para a seleção, foram considerados alunos dos cursos de pós-graduação avaliados pela Capes com notas 6 ou 7 indicadoras de excelência acadêmica e inserção internacional.

Entre os programas de pós-graduação da UnB e da USP, avaliados com notas 6 e 7, foram selecionados com a intenção de cobrir as diversas áreas de conhecimento, nomeadamente, Ciências Exatas e Naturais, Ciências Sociais, Artes e Humanidades, tanto cursos de natureza mais flexíveis, conceituais, quanto os mais rígidos, factuais, quais sejam: Matemática, Geologia, Nefrologia, Sociologia, Antropologia e Educação. Posteriormente, houve a inclusão do curso de Educação da UnB e também do curso de educação da Pontifícia Universidade Católica do Paraná (PUCPR). Os dois cursos não foram definidos a priori por não preencherem os critérios de seleção da pesquisa. Contudo, após as entrevistas de pré-testes, realizadas com um pós-graduando de cada curso, os relatos foram incorporados na amostra final, devido ao grau de contribuição das reflexões apresentadas.

Para a coleta de dados, utilizou-se a entrevista semiestruturada. Esse tipo de entrevista é constituído de perguntas abertas e organizadas em determinada ordem, podendo o entrevistador acrescentar perguntas para esclarecimentos (LAVILLE; DIONNE, 1999). Uma das características desse instrumento é a flexibilidade. As perguntas são previamente definidas, mas o pesquisador tem a liberdade de buscar esclarecimentos ou elaborar as respostas dadas (MAY, 2004).

Para a elaboração das questões da entrevista, foram utilizados dois indicadores: os objetivos da pesquisa e os padrões de letramento informacional para identificar as competências 
empregadas na busca e no uso da informação pelos pesquisadores em formação no processo de comunicação científica. Tais padrões foram aprovados pelo comitê diretor da Association of College and Research Libraries (ACRL), órgão vinculado à American Library Association $(A L A)$. As entrevistas foram aplicadas após o exame de qualificação, entre o período de maio de 2007 a janeiro de 2008.

O tratamento dos dados foi realizado ao longo do processo de coleta. Após a primeira entrevista, eles foram analisados com o objetivo de verificar a qualidade do pensamento produzido e expresso, isto é, a ocorrência do pensamento reflexivo nos relatos dos sujeitos. Para tanto, foi utilizado o indicador de ensino reflexivo, proposto por Zeichner e Liston (1985), que permite a análise de acordo com quatro categorias principais: discurso factual, discurso prudencial, discurso justificativo e discurso crítico.

O discurso factual é caracterizado pela descrição dos fenômenos ocorridos em situações de busca e de uso da informação, isto é, o que ocorre, o que ocorreu ou deveria ter ocorrido. Nessa categoria, distinguem-se quatro subcategorias: discurso descritivo, discurso informativo, discurso hermenêutico e discurso explicativo/hipotético. Somente a subcategoria de discurso explicativo/hipotético indica pensamento reflexivo. O discurso descritivo descreve os detalhes ou características dos fenômenos observados. O discurso informativo identifica a informação relevante para o fenômeno, embora esta não seja verificável por observação direta da atividade. O discurso hermenêutico foca nos significados atribuídos pelo sujeito aos acontecimentos e nas atividades em análise. O discurso explicativo/hipotético identifica as relações de causa e efeito na ocorrência dos eventos.

O discurso prudencial é caracterizado por sugestões e conselhos referentes às ações e avaliações sobre a atividade ou qualidade das ações desenvolvidas pelo sujeito, classificando-se em quatro subcategorias. A primeira, denominada instrução, caracteriza-se por sugestões para que o sujeito tente um determinado procedimento ou perspectiva, sem que seja fornecida justificação para tal. A segunda, denominada conselho/opinião, consiste em sugestão para que o sujeito considere dois ou mais cursos de ação, sem proporcionar justificação para as ações sugeridas. A terceira, denominada avaliação, consiste em julgamento - positivo ou negativo - sobre o valor, trabalho ou qualidade de uma ação sem que seja fornecido suporte justificativo. O quarto, denominado apoio, caracteriza-se por expressões de empatia, de encorajamento emotivo, relativas a uma ação passada, presente ou futura. De acordo com os autores, entretanto, nenhuma das subcategorias revela pensamento reflexivo.

O discurso justificativo caracteriza-se por identificar os motivos e a racionalidade subjacentes às condutas do sujeito, ao considerar as questões do tipo: o que fundamenta esta ação ou decisão? Divide-se em três subcategorias classificadas de acordo com o tipo de racionalidade que justifica a ação desenvolvida. A primeira consiste na racionalidade pragmática, a qual 
emprega critérios que indicam o que é efetivo ou eficiente numa situação. A ação é justificada com base na sua eficácia para assegurar um resultado pretendido. A segunda compreende racionalidade intrínseca que justifica a ação com base no conhecimento e nos valores universais. A terceira, racionalidade extrínseca, justifica a ação com base em critérios externos à situação em análise e à ação presente. Todas as subcategorias são consideradas como indicadoras de pensamento reflexivo.

O discurso crítico avalia a adequação das razões oferecidas no domínio do discurso justificativo, assim como valores intrínsecos inerentes à estrutura e aos conteúdos. São quatro as subcategorias do discurso crítico, das quais três correspondem às subcategorias do discurso justificativo, pragmático, intrínseco e extrínseco. A quarta subcategoria relaciona-se à prática curricular (ex.: currículo oculto). Nesse caso, considera-se a avaliação do sujeito em relação à adequação do currículo para o desenvolvimento da capacidade de buscar e usar a informação. Todas as quatro subcategorias deste tipo de discurso são indicadoras de atividade reflexiva.

Em linhas gerais, quando foi possível identificar as categorias principais e a subcategoria explicativo/hipotética no discurso dos pesquisadores em formação, contabilizou-se uma unidade de pensamento (UP) e a sua classificação na respectiva categoria. Em seguida, contabilizaram-se as unidades de pensamento identificadas em cada uma das categorias, agrupando-as em dois tipos de discurso que atendem a sua natureza: discurso reflexivo e não reflexivo.

Após a identificação do tipo do pensamento, os dados foram tratados e codificados de acordo com os procedimentos propostos pela teoria fundamentada para o desenvolvimento da teoria sobre a busca e o uso da informação pelos pesquisadores em formação. Tal abordagem analítica constitui "um método geral de análise comparativa [constante]" (GLASSER; STRAUSS, 1967, p. viii). Por isso, é frequentemente citada como método comparativo constante, com três objetivos definidos: 1) proporcionar uma base lógica para a teoria com a intenção de contribuir para "fechar a lacuna entre teoria e pesquisa empírica" (p. vii); 2) propor padrões e procedimentos mais adequados para descoberta da teoria; 3 ) validar a pesquisa qualitativa como método adequado e específico designado para gerar uma teoria.

A análise comparativa dos dados consistiu de três momentos, como preconiza a teoria fundamentada: codificação aberta, codificação axial e codificação seletiva. Na codificação aberta, os dados (textos das entrevistas) foram analisados, frase a frase, e rotulados com códigos que representavam a sua essência, isto é, o que possuíam de mais relevante em termos de significação. Nesse processo, foram gerados inúmeros códigos, categorizados por meio de análise comparativa, em que os incidentes e fenômenos registrados eram confrontados para as relações entre eles fossem verificadas. Trata-se de um processo contínuo e evolutivo no qual as comparações são realizadas até que comecem a emergir as categorias iniciais e suas propriedades. A cada nova entrevista eram incluídos novos dados e, quando necessário, reorganizadas as 
categorias, o que, por sua vez, requeria aglutiná-las ou incluí-las. O objetivo foi categorizar os dados e reuni-los em torno dos fenômenos relevantes neles descobertos.

A etapa seguinte consistiu na codificação axial. A partir da categorização obtida como resultado da codificação aberta, buscou-se estabelecer as relações entre as categorias. Para essa análise, utilizou-se o paradigma de codificação, que envolve condições, contexto, estratégias de ação/interação e consequências. Ressalte-se que, após a primeira entrevista, foi possível montar um esboço dessas relações. Entretanto, nem sempre novas categorias resultantes da codificação aberta eram inseridas imediatamente na codificação axial. Esse procedimento ocorria somente quando a categoria era consolidada pela agregação de códigos, deixando-a mais consistente. Na prática, as novas categorias que surgiam ficavam "reservadas" até que adquirissem consistência para que fossem integradas à codificação axial.

Após a finalização das entrevistas, as categorias foram novamente comparadas, analisadas e reorganizadas. Algumas categorias foram aglutinadas e outras, com pouca consistência, excluídas. Também nessa fase, após a reorganização das categorias, os fenômenos e eventos afins foram agrupados, permitindo a definição de quais constituíam categorias propriamente ditas e quais constituíam, de fato, subcategorias delas. Nesse sentido, as categorias foram definidas como aquelas que apresentaram maior grau de abstração. Aquelas com menor grau de abstração constituíram as subcategorias, observadas as suas relações com as categorias de nível mais alto.

Passou-se, então, à codificação seletiva, o que requereu retomar os diagramas elaborados na codificação axial. A intenção foi revisar as relações à luz das categorias definitivas. Os diagramas e memorandos possibilitaram o desenvolvimento da codificação seletiva, isto é, o registro escrito dos significados obtidos.

Posteriormente, após a análise das entrevistas e do tratamento dos dados, obteve-se o mapeamento das competências empregadas pelos pesquisadores em formação na busca e no uso da informação. Realizou-se um paralelo entre as competências informacionais dos pesquisadores em formação e o padrão de letramento informacional, proposto pelo ACRL (2000), que provê uma estrutura de cinco padrões e 22 indicadores de performance para avaliar as habilidades individuais dos estudantes do ensino superior em todos os níveis.

\section{ANÁLISE E DISCUSSÃO DOS RESULTADOS}

O objetivo da teoria fundamentada (grounded theory) é construir uma teoria sustentada pelos dados coletados ao longo da pesquisa. Por sua vez, o objetivo da pesquisa foi gerar um modelo teórico sobre as relações entre o pensamento reflexivo e as competências para buscar e usar 
a informação na comunicação científica. O modelo gerado pela pesquisa consiste em estágios processuais que compõem a categoria central "o pensamento reflexivo na busca e no uso da informação na comunicação científica", os quais, por sua vez, relacionam-se aos objetivos específicos da pesquisa.

\section{Estágio 1 - Experiências e sentimentos: a pesquisa na educação básica e na graduação}

A investigação sobre as experiências dos pesquisadores em formação com pesquisas da educação básica à graduação mostra que os resultados dessa aprendizagem influenciam a maneira como os pesquisadores em formação, mestrandos e doutorandos, buscam e usam as informações. Os resultados mostram que a vivência com pesquisas na educação básica consistia essencialmente em levantamento bibliográfico, experimentos em laboratórios de química, física ou biologia, ou, às vezes, tarefas a serem realizadas em casa. As bibliotecas e os livros eram utilizados como os principais canais e fontes para a busca de informações. Os sujeitos relataram sobre a pouca frequência e sistematização das atividades, uma vez que as pesquisas provavelmente não constavam no projeto político-pedagógico dessas escolas; mais ainda, poucos professores se envolviam nessas atividades.

Os dados condizem com a maioria dos trabalhos revisados, sendo identificados quatro que relatam problemas relacionados ao tópico estudado. O primeiro reporta problemas como temática muito ampla solicitada aos estudantes, falta de roteiros ou orientação adequada, pouca indicação de materiais de pesquisa e desconhecimento dos alunos em relação aos recursos da biblioteca (MACHADO, 1989). O segundo estudo destaca as questões sobre trabalhos de pesquisas solicitados como tarefas de casa e desvinculados do processo pedagógico (NEVES, 2000). Visão reducionista do professor e compreensão da pesquisa como cópia, síntese ou repasse de conteúdos foram problemas identificados no estudo de Rocha e Brito (2007). A visão reducionista da pesquisa, o quarto trabalho, foi apontada por Amaral (2000) como a causa de quatro tipos de consequências. A primeira relaciona-se ao entendimento errôneo sobre a questão curricular, interpretada como a ruptura com o conhecimento formal. A segunda apresenta o entendimento de projetos como a única maneira de se conduzir o ensino. A terceira destaca a preocupação em inserir os conteúdos de todas as disciplinas no interior dos projetos de pesquisa. E, por fim, a quarta reconhece a crença dos professores na defasagem de conteúdo a partir do uso dos projetos.

Os dados evidenciam que o ensino brasileiro parece ser muito conservador, isto é, as aulas são mais expositivas e o foco parece ainda estar no ensino (transmissão de conhecimento) e no professor. Apesar do reconhecimento da importância da pesquisa como ferramenta de aprendizagem, os problemas identificados neste estudo, no que diz respeito à sua 
implementação efetiva, podem estar relacionados ao sistema educacional e aos fatores vinculados a ele.

Por sua vez, os resultados dos relatos relacionados à vivência com pesquisas na graduação mostram não haver diferenças expressivas entre as atividades de pesquisa na educação básica e na graduação, pois ambas demonstraram ser superficiais e pouco orientadas. Entretanto, aquelas proporcionadas pelos programas de iniciação científica confirmam ser significativas por favorecerem uma compreensão melhor dos instrumentos e métodos de trabalho investigativo, principalmente quando as atividades são bem orientadas. Esse resultado corrobora o de Morosini (1996), que estudou as experiências com pesquisa por bolsistas de iniciação científica inscritos no IV Salão de Iniciação Científica, promovido pela Universidade Federal do Rio Grande do Sul (UFRGS). Os resultados mostram que $80 \%$ dos bolsistas avaliaram positivamente a experiência, pretendendo continuar a aprendizagem de pesquisador na pós-graduação.

Fava-de-Moraes e Fava (2000) citam que as vantagens do programa de iniciação científica são as seguintes: a possibilidade de transcender a rotina e estrutura curricular, o desenvolvimento de competências e habilidades para enfrentar fatos novos, melhor desempenho dos bolsistas nas seleções para a pós-graduação, período mais breve na obtenção da titulação, além de maior facilidade de falar em público e de se adaptar às atividades didáticas futuras. Segundo os autores, há evidências suficientes para se afirmar que muitas ideias inovadoras das teses são provenientes da iniciação científica.

Considerando os benefícios que proporciona, recomenda-se que a iniciação científica, como projeto básico de formação do universitário, constitua uma prerrogativa de todos os estudantes. Por sua vez, a bolsa de iniciação científica deveria ser vista como um incentivo individual aos estudantes que demonstram potencial e vocação para a carreira acadêmica. Além disso, torna-se importante destacar que a orientação para a pesquisa deve contemplar as atividades de busca e de uso da informação, que, por sua vez, evocam outras questões relacionadas à seleção de fontes relevantes e à aprendizagem de idiomas estrangeiros.

Os pesquisadores relataram que os sentimentos decorrentes das experiências com pesquisas na educação básica e na graduação eram de prazer e interesse, e que as experiências foram importantes e significativas. Uma hipótese considerada com maior poder explicativo para explicar o fato é a que relaciona a liberdade, a autonomia e a criatividade com a pesquisa (compreendida como projetos). Essa forma de aprender se opõe radicalmente àquela que ensina "um produto acabado, sem maior atenção quanto aos modos e meios por que originalmente assim se fez, nem também quanto às mudanças que seguramente irá sofrer no futuro" (DEWEY, 1979b, p. 6). Nesse sentido, não se pode desconsiderar, como 
destaca o modelo do processo de pesquisa de informações, de Kuhlthau (1989), que os componentes cognitivos e afetivos influenciam o comportamento informacional humano.

\section{Estágio 2 - Competências empregadas na busca da informação por pesquisadores em formação no processo de comunicação científica}

As competências para a busca de informação envolvem conhecimentos e experiências que possibilitam encontrar informação relevante e pertinente. Para tanto, a consciência da necessidade de informação e a identificação prévia de como e onde encontrá-la são fases importantes do processo de busca. As necessidades informacionais surgem quando os indivíduos reconhecem a existência de uma lacuna no conhecimento e na capacidade de dar sentido à sua vivência. Contudo, nem sempre essa necessidade está claramente definida, articulada e delimitada. Observou-se, neste estudo, que pesquisadores em formação, ao se depararem com a necessidade de informação, vão diretamente aos canais e fontes sem pensar previamente no tipo de informação necessária ou nas estratégias mais adequadas para buscá-las. São três os recursos mais utilizados para isso, nomeadamente, a Internet, os colegas e o mapeamento de citações.

O primeiro recurso mais empregado na busca da informação para pesquisa, por pesquisadores em formação, é a internet. O motivo principal de seu uso relaciona-se à facilidade de acesso, como critério de seleção das fontes e canais de informações, fato recorrente na literatura da Ciência da Informação, como verificado por Gasque e Costa (2003), Figueiredo (1994) e Giacometti (1990).

A aprendizagem referente à busca de informação na internet por pesquisadores em formação ocorre pela própria experiência, observação e adaptação aos sistemas. Assim, a falta de orientação adequada pode ocasionar lacunas no conhecimento desses pesquisadores, como diagnosticado nesta pesquisa. Essas lacunas podem acarretar problemas diversos, tal como ressalta Targino (2002). Entre outros, a autora enumera: inconsistência, instantaneidade e efemeridade das informações, banalização da autoria e desrespeito à propriedade intelectual, além de uso aético da informação.

O segundo recurso mencionado pelos pesquisadores em formação como mais utilizado é a interação com os colegas e grupos de pesquisa para obtenção de informações, o que parece confirmar a ideia da pesquisa como um processo dialógico intra e interpessoal. As redes informais foram instâncias utilizadas como canal e instrumento de disseminação de informações, como relatados por Gasque e Costa (2003) e Macedo (1999). Um ponto importante desses grupos é que seus membros parecem agregar valor à informação por meio das interpretações das informações e de suas experiências compartilhadas com os colegas. 
O mapeamento de citações ou "encadeamento" foi o terceiro recurso citado, sendo usual entre os pesquisadores, como se pode observar pelo modelo proposto por Ellis (1989). O encadeamento pode ocorrer para trás, forma mais tradicional, e para frente, forma mais inovadora de buscar informação. No caso da pesquisa, foram citados encadeamentos para trás. O encadeamento é uma estratégia que aparece no estudo de Caregnato (2003) com alunos do Programa de Pós-graduação em Comunicação e Informação da Universidade Federal do Rio Grande do Sul (UFRGS). Esse tipo de estratégia caracteriza-se por ser uma forma rápida de obtenção de fontes de informação.

A escolha dos canais e fontes de informações está atrelada aos custos dos produtos, serviços e deslocamentos para obtenção da informação, os quais, muitas vezes, impedem que os pesquisadores adquiram as fontes ou limitam sua utilização. Obviamente, eles buscam reduzir os custos com a utilização de várias estratégias, como busca de materiais na biblioteca, fotocópias, solicitação de informações aos amigos e orientador, pesquisas na internet por informações sem custos ou contatos diretos com os autores. Alguns pesquisadores consideraram que as tecnologias têm diminuído os custos, especialmente de deslocamento. Então, provavelmente, além do fácil acesso, a utilização maior da internet relaciona-se com essa questão.

\section{Estágio 3 - Competências empregadas no uso da informação por pesquisadores em formação no processo de comunicação científica}

Usar a informação é uma competência complexa que congrega várias outras. Wilson (2000) define "uso da informação" como o conjunto dos atos físicos e mentais que envolvem a incorporação da nova informação aos conhecimentos prévios do indivíduo. Dessa forma, envolve processos de aprendizagem, tais como critérios de avaliação da informação, organização, procedimentos de aprendizagem, questões éticas, legais e socioeconômicas e socialização da pesquisa.

Em relação à avaliação e à seleção da informação, os pesquisadores em formação selecionam textos e obras de autores com comprovado domínio em determinada área do conhecimento. O reconhecimento da autoridade relaciona-se ao autor clássico, pioneiro, e também àqueles que o seguirem desde que acrescentem contribuição crítica ou reflexiva de caráter teórico no âmbito da doutrina original. A avaliação pela coerência da abordagem sustenta-se na verificação do nexo entre as articulações textuais, na abordagem escolhida e no uso adequado da terminologia da área para compor a estrutura conceitual.

Na pesquisa de Campello et al. (2000), a avaliação pela autoridade foi apontada como o segundo critério mais usado por estudantes da educação básica, sendo o próprio conteúdo o primeiro critério. Wilson (1997) cita a exposição seletiva como barreira para buscar a 
informação, em que as pessoas tendem a se expor às ideias que estão em conformidade com os seus interesses, necessidades ou atitudes. Ou seja, a tendência é buscar informação que não entre em conflito com suas predisposições.

Sobre a organização da informação, pesquisadores em formação relataram que classificam as informações encontradas por temas e as sintetizam por meio de resumos, fichamentos e marcação de textos. Utilizam, portanto, procedimentos básicos de organização, conhecendo poucas técnicas. Por conseguinte, aproximadamente metade dos entrevistados relatou dificuldades na recuperação, o que requer um tempo maior para essa tarefa. Essas dificuldades ocasionam sentimentos desagradáveis, como angústia, por exemplo.

Outro tópico relacionado ao uso da informação refere-se à percepção da aprendizagem. Os resultados mostram a leitura e a escrita, seguida da participação em eventos e cursos, como as principais estratégias de aprendizagem mencionadas por pesquisadores em formação. Eles estão em consonância com os de Rosemberg (2000), que apresenta a leitura como o canal mais utilizado por professores universitários (95,7\%), seguida dos eventos técnico-científicos (84,1\%).

Quando abordadas as questões éticas, legais e socioeconômicas relacionadas à informação e à tecnologia da informação na pesquisa, as principais preocupações dos pesquisadores em formação centraram-se em três aspectos: preservação da autoria - especificamente o plágio; preservação do nome da instituição e dos indivíduos pesquisados, particularmente a não exposição dos sujeitos; e , por fim, a veracidade e a confiabilidade da informação, no que diz respeito ao cuidado para não distorcer o sentido da informação.

A falta de conhecimento sobre as questões éticas, legais e socioeconômicas da informação e da tecnologia da informação pôde ser observada pelas dificuldades dos pesquisadores em formação em discorrer sobre essas questões no processo de pesquisa. Os depoimentos colhidos significam, de fato, uma preocupação, especialmente nos dias atuais, com o uso intensivo da internet.

A pesquisa de Madray (2007), motivada por ações recorrentes de plágio na Universidade de Long Island, foi uma das poucas encontradas que tratam do assunto. A suposição da autora, confirmada na pesquisa, é de que muitas fraudes ocorrem de maneira não intencional, isto é, por falta de informação sobre a ética na pesquisa. Por sua vez, Goldim (2002) enumera uma variedade de fraudes que podem ocorrer nas diferentes etapas da pesquisa, entre as quais se destacam a autoria indevida, a não citação de fontes, a coleta inadequada e o tratamento de dados feito de forma incorreta. $\mathrm{O}$ autor distingue o erro, fruto do acaso, da fraude, ação que contém uma intencionalidade, embora ambos gerem resultados incorretos.

Essa discussão parece ser relevante para o desenvolvimento de uma ciência mais ética. Entretanto, ela deve ser tão abrangente que assegure sua transposição com o devido aprofundamento para 
todas as etapas de estudo, da educação básica ao ensino superior, em todos os níveis, para que as pessoas tenham consciência dos seus atos, não os cometendo por falta de conhecimento.

Os pesquisadores em formação relataram sobre o processo de socialização da pesquisa. Nessa etapa, foi possível observar algumas diferenças entre os pesquisadores em formação das áreas de naturais e exatas e aqueles de humanas e sociais. Os pesquisadores das áreas duras não são tão suscetíveis à influência da revisão de literatura e contatos com colegas, tendo um projeto menos flexível. Ao contrário, os demais pesquisadores são mais flexíveis, estruturando melhor o trabalho ao longo do processo por meio das leituras e discussões com colegas. Essas diferenças são recorrentes na literatura da Ciência da Informação. Meadows (1999) ressalta as diferenças que ocorrem em vários aspectos das disciplinas no que se refere à comunicação.

Em se tratando da estruturação da pesquisa, a forma de apresentação do trabalho constitui a principal preocupação dos pesquisadores em formação. Isso inclui, entre outras questões, a importância das normas técnicas de pesquisa sobre as quais eles possuem pouco conhecimento, conforme observado. Para sanar essas dificuldades, recorrem aos colegas e aos orientadores.

Os trabalhos apresentados em eventos são a forma mais comum utilizada para socializar a pesquisa durante o curso de pós-graduação, com menor ocorrência de submissão de artigos. A publicação de artigos e livros está, na verdade, no plano da expectativa, com exceção daqueles que obrigatoriamente devem submeter artigos como requisito para conclusão do curso. Na medida em que artigos e livros são, via de regra, resultado de pesquisas concluídas, é natural que seja assim.

Meadows (1999) define congressos e conferências como o protótipo da interação informal. A participação em eventos, como congressos, grupos de estudos e reuniões departamentais, provavelmente são o meio recorrente de disseminação da informação, pela atualidade das informações e pelas possibilidades de interação proporcionando feedback imediato dos pares. Além disso, o autor considera que os pesquisadores jovens são os que mais usufruem desse tipo de comunicação por terem menos probabilidade de possuir conhecimento prévio da pesquisa. Exemplifica que um levantamento sobre cientistas britânicos constatou que $90 \%$ deles haviam obtido informações úteis à pesquisa ao assistirem congressos e conferências.

\section{Estágio 4 - Habilidades para buscar e usar a informação na pós-graduação}

A pesquisa em questão tratou da busca e do uso da informação por pesquisadores em formação na comunicação científica. Nesse contexto, discutem-se conhecimentos, competências e habilidades para o engajamento nos processos necessários à produção do conhecimento científico. Por conseguinte, discute-se também como os pesquisadores em formação aperfeiçoam essas competências. 
Competências informacionais, de acordo com os resultados desta pesquisa, estão relacionadas a, pelo menos, cinco fatores: saber buscar bem a informação; manter o trabalho organizado; ter facilidade de articular informações e construir arcabouço conceitual; ter capacidade de leitura rápida; e, finalmente, ter boa formação na área de pesquisa.

Diferentemente dos aspectos positivos, em que as respostas foram dispersas, obteve-se certo consenso entre os pontos mais frequentemente citados que deveriam ser melhorados. Entre esses, o planejamento da busca da informação foi o mais citado, seguido da fluência na leitura em língua estrangeira e da compreensão dos sistemas de buscas.

Os dados obtidos apresentam pontos interessantes a serem discutidos. O primeiro é que a autoavaliação mostra claramente que a busca da informação por estudantes da pós-graduação não tem se constituído em um conteúdo de aprendizagem. Entretanto, Ivanitskaya, O’Boyle e Casey (2006) mencionam que a autopercepção das competências dos estudantes tende a aumentar com o nível educacional. A pesquisa dos autores sobre as competências informacionais dos estudantes universitários da área de saúde mostrou que, embora a maioria (84\%) tenha se autoavaliado competente na busca da informação, não foi capaz de realizar pesquisas mais complexas, diferenciar fontes de informação ou fazer juízo de fidedignidade dos web sites e artigos.

Apesar da ressalva sobre a autopercepção da competência e sua relação com o nível educacional, os dados dos autores estão em consonância com relatos dos pesquisadores em formação investigados, sobre a forma como buscam e usam a informação. Compõem, portanto, um mapeamento das competências informacionais dos pesquisadores em formação, como descrito anteriormente.

\subsection{Considerações sobre o paralelo entre competências de busca e de uso de infor- mação de pesquisadores em formação e os padrões da ACRL}

A pesquisa partiu do pressuposto de que o desenvolvimento de competências informacionais é crucial para pesquisadores em formação. Tais competências devem ser construídas ao longo do processo educacional, de forma contextualizada e sistematizada, mediante o uso do pensamento reflexivo. Esse, por sua vez, possibilita ampliar a consciência a respeito dos elementos, das relações e da funcionalidade desses processos, com a finalidade de produzir conhecimentos de forma eficaz.

O objetivo desse tópico é sistematizar os principais resultados decorrentes do mapeamento das competências informacionais dos pesquisadores em formação, em comparação com os padrões de competência dos alunos do ensino superior, propostos pela ACRL (2000), considerando o uso do pensamento reflexivo. 
O mapeamento das competências informacionais dos pesquisadores em formação investigados evidencia que eles utilizam recursos básicos para buscar e usar a informação, nem sempre da forma mais eficiente, demonstrando pouco conhecimento e pouca consciência a respeito desses processos. Destacam-se os quatro aspectos mais significativos em relação aos padrões propostos pela ACRL (2000). Primeiramente, a partir da definição da necessidade informacional, pesquisadores em formação não planejam como buscar a informação. Agem, na verdade, de forma quase sempre impulsiva, isto é, a partir de uma força psíquica espontânea que leva a uma ação. Nesses termos, não existe identificação a priori de fontes e recursos informacionais. Em segundo lugar, pesquisadores demonstram pouco conhecimento a respeito das diversas fontes que podem ser usadas para buscar informações, adotando um método de busca mais restrito no que concerne aos canais utilizados. Além disso, em relação ao uso da internet, principal canal de acesso à informação, demonstram pouca compreensão dos sistemas de informação e das estratégias de busca da informação. Em terceiro lugar, os principais problemas em relação ao uso da informação referem-se à organização da informação e à percepção da própria aprendizagem. Em quarto lugar, pesquisadores possuem compreensão precária acerca dos aspectos socioeconômicos, legais e sociais do acesso e do uso da informação.

Os fenômenos e os processos que influenciam o desenvolvimento e o grau de competência informacional dos pesquisadores, constituintes do modelo "o pensamento reflexivo na busca e no uso da informação no processo de comunicação científica” são descritos em três pontos. No primeiro, a maior parte do pensamento empregado na busca e no uso da informação é do tipo não reflexivo. No segundo, o letramento informacional na pós-graduação é influenciado pelas experiências e sentimentos com pesquisa na educação básica, na graduação e na participação em projetos de iniciação científica. No terceiro, o letramento informacional na pós-graduação sofre influência de outros fatores, como a cultura acadêmica, a atitude dos professores em relação à busca e ao uso da informação, a concepção de ensino e aprendizagem, a infraestrutura e os custos da informação e a consciência do grau de competência informacional.

\subsection{Modelo teórico do pensamento reflexivo e as competências empregadas na busca e no uso da informação para pesquisa}

A pesquisa permitiu a elaboração de um modelo teórico a partir da análise dos dados coletados, visando a identificar as relações entre o pensamento reflexivo empregado na busca e no uso da informação no processo de comunicação científica por pesquisadores em formação e o letramento informacional. O foco nas interações dos aspectos sociais, cognitivos, educacionais e ambientais permitiu a compreensão do desenvolvimento do processo de letramento informacional na pós-graduação, pela metodologia selecionada. A descrição da categoria central e das categorias e processos emergentes coincide com o que Glaser (1978) denomina processo social básico, por contemplar a ação de forma integral e demonstrar as inter-relações entre elas. 
A identificação dessa inter-relação requeria explorar o percurso dos pesquisadores em formação, considerando seis aspectos: a experiência e as vivências com o trabalho de pesquisa na educação básica e na graduação; a construção do conceito de pesquisa; os sentimentos extraídos das experiências com pesquisas; o mapeamento das competências empregadas na busca e no uso da informação na pesquisa; a autoavaliação das competências informacionais; e o papel das relações sociais no processo do conhecimento.

Tal relação demonstrou ter natureza multirreferencial, o que se caracteriza pela pluralidade tanto dos fenômenos envolvidos quanto das relações entre eles. A multirreferencialidade é uma abordagem epistemológica que preconiza a leitura do fenômeno sob vários ângulos e sistemas de referência distintos (ARDOINO, 1995).

O modelo teórico obtido na presente pesquisa, representado na figura 1, evidencia que os pesquisadores em formação, ao se depararem com uma necessidade informacional, engajam-se em atividades de busca e de uso da informação, que requerem competências desenvolvidas por meio do letramento informacional. Esse, por sua vez, é influenciado pelas experiências e reflexões sobre a busca e o uso da informação ocorridas na educação básica e na graduação, bem como os sentimentos extraídos dessas experiências.

Adicionalmente, os fatores relacionados ao processo de letramento informacional que ocorre na pós-graduação são os seguintes: cultura acadêmica, atitude do professor em relação à busca e ao uso da informação, concepção de ensino e aprendizagem, infraestrutura e custos da informação e consciência do grau de competência informacional. Esses fatores são interdependentes e refletem-se na eficácia e na qualidade da busca e do uso da informação e, consequentemente, na produção do conhecimento. Considerando que os pesquisadores em formação serão responsáveis pela formação de novos profissionais, os quais poderão atuar como professores e/ou pesquisadores, então as experiências e sentimentos dos aprendizes na educação básica e na graduação são influenciadas por esses profissionais. 
Figura 1 - Modelo teórico do pensamento reflexivo empregado na busca e no uso da informação no processo de comunicação científica

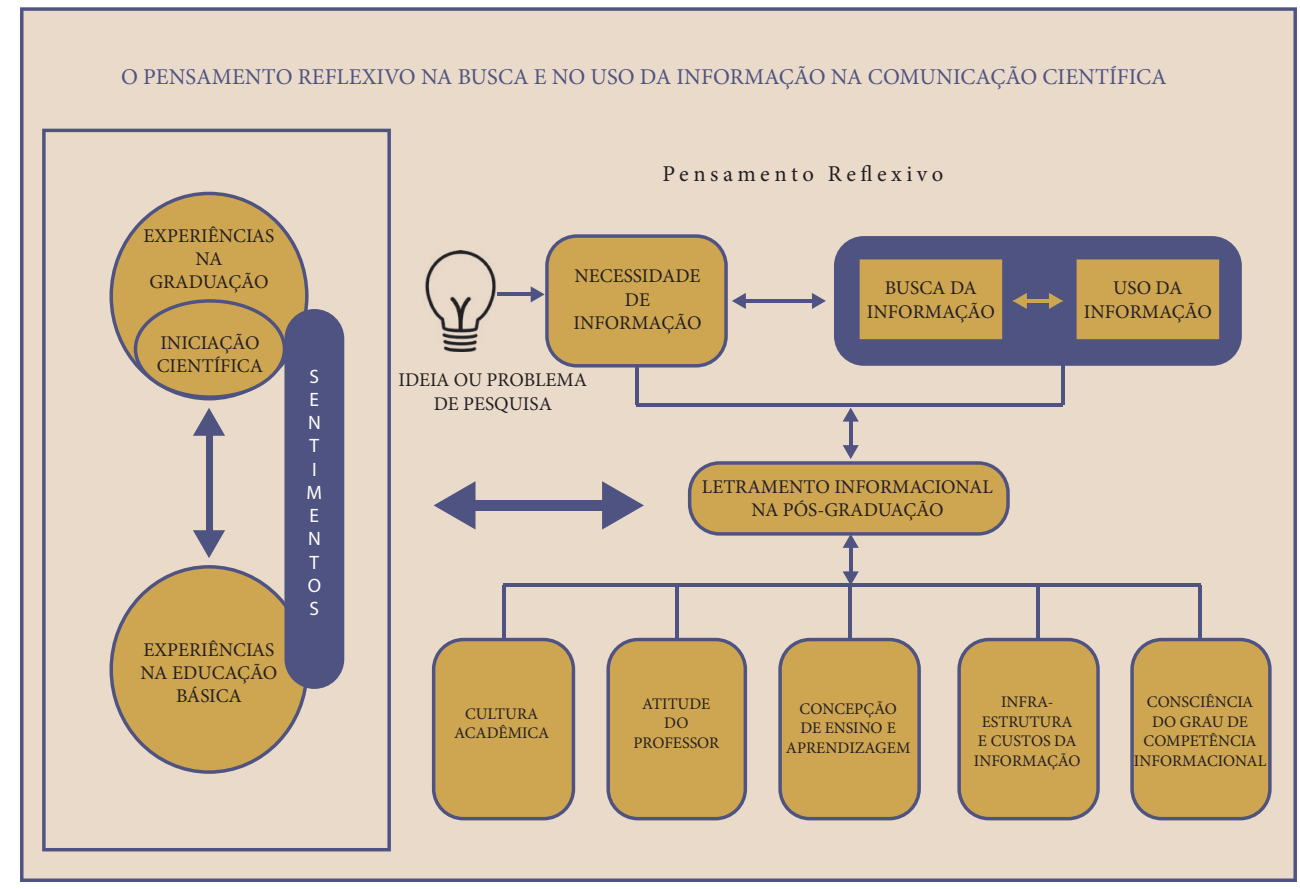

Fonte: Elaboração dos autores (2018).

\section{CONCLUSÕES}

Os resultados da pesquisa evidenciam problemas relacionados à produção de conhecimento nos cursos avaliados em sua maioria com as notas 6 e 7 pela Capes, além dos cursos que foram agregados após o pré-teste e avaliados com nota 4 pela referida instituição. Observou-se que os pesquisadores em formação precisam desenvolver competências de busca e uso da informação que possibilitem realizar pesquisas de forma eficaz e eficiente. Nesse sentido, há necessidade de considerar seis recomendações oriundas dos resultados da pesquisa. Primeiramente, é necessária a conscientização dos atores atuantes na educação, envolvendo tanto docentes quanto profissionais da informação, sobre a importância do letramento informacional como processo inerente à formação do pesquisador. A segunda recomendação diz respeito à necessidade de desenvolvimento de processos de letramento informacional mediante o uso do pensamento reflexivo, o que requer a formação do pesquisador desde a educação básica, ocasião em que deve ter contato de forma mais sistematizada e contextualizada com as situações de pesquisas. Em terceiro lugar, verifica-se a necessidade de aprendizagem dos processos de busca e de uso da informação, e não somente do assunto diretamente vinculado à pesquisa. 
Ou seja, a busca e o uso de informação devem ser conteúdos de aprendizagem e de avaliação vinculados à experiência de sala de aula. Tal aprendizagem exige revisão da concepção de ensino e aprendizagem de forma a privilegiar o desenvolvimento do pensamento reflexivo. Em quarto lugar, recomenda-se um aumento significativo do envolvimento de estudantes da graduação em projetos de pesquisa, e não somente de bolsistas de iniciação científica, de maneira que seja possível aprofundar os conhecimentos adquiridos na educação básica. Em quinto lugar, deve-se reconhecer a necessidade de discussão ampla sobre questões como cultura acadêmica, concepção de ensino e aprendizagem, formação do professor, infraestrutura de informação e conscientização do grau de competência informacional. Por fim, sugere-se que haja avaliação da infraestrutura de informação nos ambientes educacionais, a fim de proporcionar acervo atualizado e serviços de qualidade, assim como serviços de treinamento contínuo na área de recuperação da informação e de tradução.

\section{REFERÊNCIAS}

AMARAL, A. L. Conflito conteúdo/forma em pedagogias inovadoras: a pedagogia de projetos na implantação da escola plural. In: REUNIÃO DA ANPED, 23a, 2000. Anais eletrônicos... Disponível em:< http://23reuniao.anped.org.br/textos/0403t.PDF $>$. Acesso em: 20 ago. 2014.

ARDOINO, J. L'Analyse Multiréférentielle: multiréférentielle (analyse). Portail de l'APP, 1986. Disponível em: <http://jardoino.club.fr/pdf/ana_multi.pdf >. Acesso em: 20 ago. 2014.

ASSOCIATION OF COLLEGE AND RESEARCH LIBRARY (EUA). Information literacy competency for higher education. Chicago: ALA, 2000.

CAMPELLO, B. S. et al. A Internet na pesquisa escolar: um panorama do uso da Web por alunos do ensino fundamental. In: CONGRESSO BRASILEIRO DE BIBLIOTECONOMIA E DOCUMENTAÇÃO, 19., 2000, Porto Alegre. Proceedings... Porto Alegre: Pontifícia Universidade Católica do Rio Grande do Sul, 2000. Disponível em: < http://dici.ibict.br/ view/year/2000.html>. Acesso em: 11 jun. 2006.

CAREGNATO, S. E. Busca e uso de informações por alunos de pós-graduação: implicações para o desenvolvimento de habilidades informacionais na área de comunicação. In: CONGRESSO BRASILEIRO DE CIÊNCIAS DA COMUNICAÇÃO, 26., 2003, Belo Horizonte. Anais... Belo Horizonte: Intercom, 2003.

DEWEY, J. Como pensamos: como se relaciona o pensamento reflexivo com o processo educativo, uma reexposição. 4.ed. São Paulo: Nacional, 1979a. 
DEWEY, J. Experiência e educação. São Paulo: Nacional, 1979 b.

ELLIS, D. A behavioral model for information retrieval system design. Journal of Information Science, Cambridge, n. 15, p. 237-247, 1989.

FAVA-DE-MORAES, Flávio; FAVA, Marcelo. A iniciação científica: muitas vantagens e poucos riscos. São Paulo em Perspectiva, São Paulo, v. 14, n. 1, p. 73-77, jan./mar. 2000. Disponível em:<http://www.scielo.br/pdf/spp/v14n1/9803.pdf >. Acesso em: 25 jul. 2014.

FIGUEIREDO, N. M. de. Estudos de uso e usuários da informação. Brasília: IBICT, 1994.

GASQUE, K. C. G. D.; COSTA, S. M. de S.. Comportamento dos professores da educação básica na busca da informação para formação continuada. Ciência da Informação, v. 32, n. 3, dez. 2003, p. 54-61. Disponível em:< http://www.scielo.br/pdf/ci/v32n3/19024.pdf >. Acesso em: 8 ago. 2014.

GIACOMETTI, M. M.. Motivação e busca da informação pelo docente-professor. Ciência da Informação, Brasília, v. 19, n. 1, p. 12-20, jan./jun. 1990.

GLASER, B.G. Theoretical sensitivity. Chicago: Sociology Press, 1978.

GLASER, B. G.; STRAUSS, A. L. The discovery of grounded theory: strategies for qualitative research. New York: Aldine de Gruyter, 1967.

GOLDIM, J. R.. Fraude em pesquisa científica. Bioética e Ética na Ciência. Porto Alegre, 2002. Disponível em:< http://www. ufrgs.br/bioetica/fraude.htm>. Acesso em: 8 mar. 2008.

IVANITSKAYA, L.; O'BOYLE, I.; CASEY, A. M.. Health information literacy and competencies of information age students: results from the interactive on-line research readiness self- assessment (RRSA). Journal of Medical Internet Research, v. 8, n. 2, 2006.

KUHLTHAU, C. C. Information search process: a summary of research and implications for school library media programs. School Library Media Research, v. 18, n.1, 1989. Disponível em: $<$ http://www.ala.org/aasl/sites/ala.org.aasl/files/content/aaslpubsandjournals/slr/edchoice/SLMQ_InformationSearchProcess_InfoPower.pdf $>$. Acesso em: 4 de jan. 2007.

LAVILLE, C.; DIONNE, J. A construção do saber: manual de metodologia da pesquisa em ciências humanas. Porto Alegre: Artmed, 1999. 
MACEDO, T. M. B. Redes informais nas organizações: a co-gestão do conhecimento. Ciência da Informação, Brasília, v. 28, n. 1, p. 94-100, 1999. Disponível em: < http:// revista.ibict.br/ciinf/index.php/ciinf/article/viewArticle/332:. Acesso em: 22 ago. 2014.

MACHADO, A. M. N. Pesquisa escolar: uma questão para resolver. 1989. $92 \mathrm{f}$. Dissertação (Mestrado em Biblioteconomia) - Pontifícia Universidade Católica de Campinas, Campinas.

MADRAY, A.. Developing students' awareness of plagiarism: crisis and opportunities. Library Philosophy and Practice, jun. 2007. Disponível em:< http://digitalcommons. unl.edu/libphilprac/134/ Acesso em: 20 de fev. 2008.

MALHOTRA, N. K. Pesquisa de marketing: uma orientação aplicada. 3.ed. Porto Alegre: Bookman, 2001.

MAY, T. Pesquisa social: questões, métodos e processos. 3. ed. Porto Alegre: Artmed, 2004.

MEADOWS, A.J. A comunicação científica. Brasília, DF: Briquet de Lemos, 1999.

MOROSINI, M. C.. Os aprendizes de cientista: quem são e como avaliam o seu aprendizado. IC on-line, Porto Alegre, v.1, n.3, dez. 1996. Disponível em: < http://www. portalanpedsul.com.br/admin/uploads/2008/Educacao_Superior/Trabalho/02_17_20_ Politicas_de_Iniciacao_Cientifica.pdf >. Acesso em: 26 de jul.. 2014

NEVES, I. C.. Pesquisa escolar nas séries iniciais do ensino fundamental em Porto Alegre, RS: bases para um desempenho interativo entre a sala de aula e biblioteca escolar. 2000. 177 p. Tese (Doutorado em Ciência da Informação e Documentação) Escola de Comunicação e Artes, Departamento de Biblioteconomia e Documentação, Universidade de São Paulo, São Paulo.

ROCHA, L. R.; BRITO, G. da S.. Professor e Internet: a concepção de pesquisa em ambientes informatizados. Teias, Rio de Janeiro, v. 8, n. 15-16, jan/dez, 2007.

ROSEMBERG, D. S. A Leitura e os canais intermediários de informação na formação continuada de professores universitários. Encontros Bibli (UFSC), Florianópolis - SC, v. 10, n. 10, p. 1-9, 2000.

SCHÖN, D.. Formar professores como profissionais reflexivos. In: NÓVOA (Org.). Os professores e a sua formação. Lisboa: Dom Quixote, 1992. 
TARGINO, M. das G. Novas Tecnologias e Produção Cientifica: uma relação de causa e efeito ou uma relação de muitos efeitos? DataGramaZero, Rio de Janeiro, v. 3, n. 6, dez. 2002. Disponível em:< http://www.dgz.org.br/dez02/Art_01.htm>. Acesso em: 15 jun. 2004.

WILSON, T.D. Human Information Behavior. Informing Science Research, v. 3, n. 2, p. 49-55, 2000.

WILSON, T.D. Information behaviour: an interdisciplinary perspective. Information Processing \& Management, v. 33, n. 4, p. 551-572, 1997.

ZEICHNER, K.; LISTON, D. Varieties of discours in supervisory conferences. Teaching and Teacher Education, v. 1, n. 2, p. 155-174, 1985. 


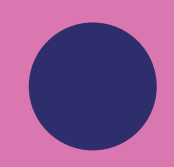

$\bullet$

○

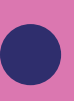

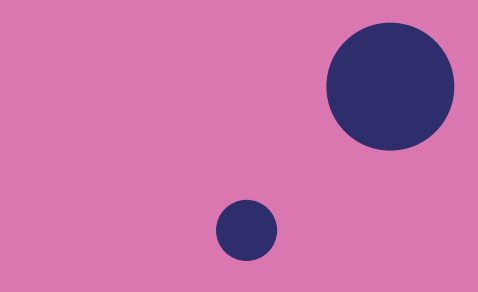

0

$.0^{\circ} \cdot \bullet$

$\cdot 0 \cdot 0$

0

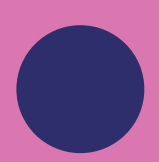

0

○

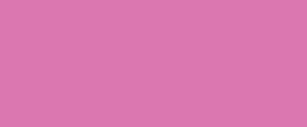

$$
.
$$

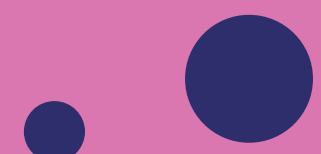$$
\text { . }
$$

$$
\text { . }
$$

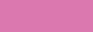

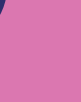




\section{PARTE III COMUNICAÇÃO DA INFORMAÇÃ̈O EM COMUNIDADES}




\section{CAPÍTULO 8}

○

0

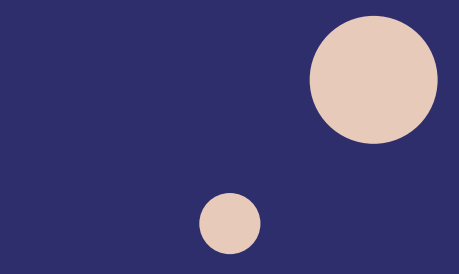

0

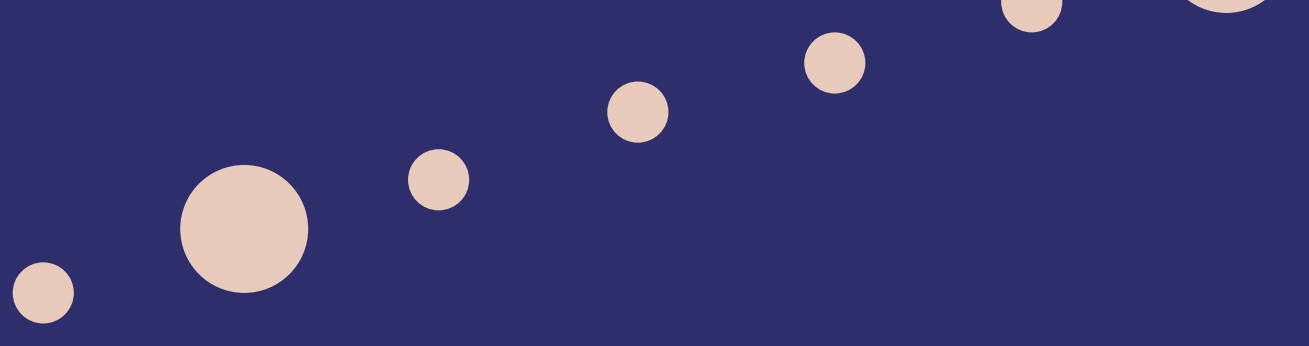

- 00

0 


\title{
PESQUISA E AÇÃO PARTICIPATÓRIA COM FOCO EM LETRAMENTO INFORMACIONAL E TRABALHO COLABORATIVO PARA DESENVOLVIMENTO DE CIDADANIA ${ }^{1}$
}

\author{
- (20) \\ ROSEMEIRE BARBOSA TAVARES \\ SELY MARIA DE SOUZA COSTA \\ MARK HEPWORTH (IN MEMORIAN)
}

\section{INTRODUÇÃ̃O}

O estudo da literatura relacionado ao tema cidadão e cidadania apresenta uma séria discussão sobre desenvolvimento social, como requisito básico e essencial para o desenvolvimento econômico de qualquer nação. Cidadania está relacionada ao exercício pleno de direitos civis, políticos e sociais. Informação para cidadania, por sua vez, contempla aquela informação que irá formar e informar o cidadão e contribuirá para garantir sua emancipação, autonomia e dignidade. Assim, informação para cidadania diminui a desigualdade de oportunidade e a exclusão social por duas razões. Em primeiro lugar, porque amplia as oportunidades de inserção do cidadão no mercado de trabalho; e, em segundo lugar, porque dá condições ao cidadão de participar, de forma consciente e efetiva, do processo de gestão pública.

Autores como Calabrese e Burgelman (1999) e Demo (2002) argumentam que é necessário restabelecer os direitos sociais do cidadão, por meio do acesso à informação, a qual tem o

1 Versão modificada do artigo publicado em: TAVARES, R. T.; COSTA, S. M. S.; HEPWORTH, M.. Pesquisa e ação participativa com foco em letramento informacional e trabalho colaborativo para desenvolvimento de cidadania. In: ENCONTRO NACIONAL DE PESQUISA EM CIÊNCIA DA INFORMAÇÃO, 13., 2012, Rio de Janeiro. Anais... Rio de Janeiro: Ancib, 2012. 
poder de instruir o cidadão, dando a ele condições para argumentar e discutir criticamente. Adicionalmente, Apple (2008) assevera que educação tem um papel fundamental no processo de inserção crítica do cidadão na sociedade. É necessário desenvolver, no cidadão, habilidades para usar os instrumentos que lhes darão acesso ao conhecimento, à inovação e a novas competências. É importante, ainda, desenvolver no cidadão habilidades morais e intelectuais para que ele se torne capaz de formar julgamentos reflexivos e de colocar em equilíbrio convicções pessoais e princípios impessoais de justiça (DEMO, 2002).

Nesse sentido, inúmeros autores têm indicado a gestão participativa ou os processos de participação popular. Eles defendem que a participação leva ao engajamento e ao comprometimento, além de promover aprendizagem, por meio do compartilhamento de informação e conhecimento. Segundo Cogo e Maia (2006), os processos de participação popular tendem a observar as propriedades do processo de argumentação - publicidade, igualdade de direitos, ausência de coação e de tentativas para ludibriar - e, assim, pode evitar que a deliberação popular não caia no domínio da retórica.

Essa pesquisa partiu da premissa de que é importante inserir os membros da comunidade na sociedade da informação e do conhecimento. Assim, fundamentou-se na construção do modelo de gestão da informação que utiliza técnicas de pesquisas participatórias como foco em letramento informacional e trabalho colaborativo. O objetivo é demonstrar que pesquisa participatória contribui para o desenvolvimento da cidadania no momento em que habilita o cidadão a gerenciar informações e a trabalhar colaborativamente no seio de sua comunidade.

\section{FUNDAMENTAÇÃO TEÓRICA}

O estudo teórico sobre letramento informacional mostra que existe uma preocupação adicional em habilitar o cidadão para manusear criticamente a informação. Isso compreende os processos de identificar necessidades de informação, de buscar informação nos repositórios informacionais, de usar informação para tomar decisão e solucionar problemas e de contribuir para alimentar os repositórios com novas informações e conhecimentos. Para Belkin e Vickery (1989), a necessidade de informação é identificada quando a pessoa reconhece um gap em seu estado de conhecimento. Assim, o indivíduo busca informação para suprir essa falta de conhecimento identificada. Nicholas e Herman (2009, p. 18, tradução nossa) adicionam:

Necessidade é identificada quando indivíduos precisam fazer seus trabalhos efetivamente, resolver problemas satisfatoriamente ou investir em algum hobby que lhes dê prazer. A palavra-chave aqui é "precisar", que assume a conotação de que as pessoas, para desempenhar suas atividades de forma eficiente, efetiva, segura e feliz, precisam estar bem informados, ou seja, suas necessidades de informação precisam ser identificadas e sanadas. 
Estar bem informado não tem o mesmo significado para todas as pessoas. Cada uma tem diferentes necessidades básicas e, portanto, diferente gap de conhecimento. Adicionalmente, as pessoas não têm claro quais são suas necessidades básicas, por si só, e consequentemente não conseguem identificar de que informação elas precisam. Nicholas e Herman (2009) afirmam que isso começa a se tornar claro quando elas experimentam um problema ou dificuldade, ou estão sob algum tipo de pressão. Nesse momento, elas podem identificar necessidades cognitivas e emocionais facilmente, principalmente porque a necessidade de informação surge dentro de um contexto. Diante desses preceitos, para identificar a necessidade de informação dos cidadãos (necessidade secundária), é importante identificar uma situação ou problema comum aos membros da comunidade (necessidade básica) que os motive a acessar e usar informação para tomar decisões e solucionar problemas conjunta e colaborativamente.

A busca e o uso de informação, por sua vez, constituem um processo humano fundamental muito próximo da aprendizagem, mas também relacionado à solução de problemas (MARCHIONINI, 1998). A necessidade de informação, como já foi dito, está relacionada à falta de conhecimento e torna-se latente quando as pessoas têm de gerenciar algum problema ou dificuldade. Por sua vez, a busca e o uso de informação representam a habilidade de localizar e aplicar informação para suprir uma necessidade identificada ou uma falta de conhecimento.

\subsection{Informação e cidadania}

No contexto da informação para comunidades, o acesso e o uso de informação não devem estar vinculados a pessoas alfabetizadas ou fisicamente habilitadas. É importante estruturar a informação em um formato que todas as pessoas possam acessar, como, por exemplo, vídeos para pessoas cegas ou analfabetas e áudio para pessoas surdas. De acordo com Hepworth e Walton (2009), as habilidades de ler e escrever, embora sejam importantes, não são essenciais para habilitar pessoas ao acesso e ao uso de informação. Não devem, portanto, ser o fator que impede o cidadão de engajar-se criticamente à sociedade. Bates (2002, p. 128, tradução nossa) afirma que "nós absorvemos talvez $80 \%$ de todo o conhecimento simplesmente estando atentos, conscientes e cientes nosso do contexto social e do ambiente físico" (traduzido pela autora, ibid, p. 128).

A interação crítica dos cidadãos com a comunidade pode ajudar no processo de aprendizagem, tanto quanto pode contribuir para a inserção do cidadão na era da informação. Eles aprendem a identificar problemas/situações sociais, a discutir e analisar conjuntamente, a compartilhar experiências e conhecimentos, a tomar decisões e a solucionar problemas. Mais importante do que isso, eles vão agir na comunidade com o objetivo de aprender a identificar, acessar e usar informações, a fim de se tornarem cidadãos bem-informados, críticos e conscientes. 
Partindo da premissa de que cada membro da comunidade tem um papel significante em seu contexto social, o processo de participação popular que leva a uma interação crítica deve ser amplo. Isso quer dizer que não deve prescindir de nenhum membro da comunidade e precisa ser o mais representativo possível, porque os membros da comunidade possuem conhecimento e experiências importantes que precisam ser compartilhados (sobre contexto, cultura, história, por exemplo). Além disso, é necessário o engajamento e o comprometimento de todos para que o problema seja solucionado, e só há engajamento com participação efetiva. As pessoas precisam estar convencidas de que elas contribuíram para apontar a solução do problema, pois, somente assim, vão sentir-se responsáveis pelo sucesso (ou fracasso) do projeto.

O primeiro passo para que se construa um bom modelo de comunicação da informação em comunidades é transformar o cidadão em usuário efetivo de informação. Em seguida, é necessário que comunidades e/ou organizações disponibilizem estrutura física e logística para que os membros da comunidade possam interagir criticamente, acessando informação e solucionando problemas sociais. Além do mais, deve-se reestruturar o processo de gestão da informação das organizações, notadamente as públicas, para que essas forneçam informação útil e relevante ao cidadão, no intuito de promover o aprendizado.

Em outras palavras, as comunidades devem transformar-se em organizações do conhecimento. Nesses espaços, pessoas são estimuladas a usar informação para criação de significado, construção do conhecimento e tomada de decisões (CHOO, 2006).

\subsection{Comunicação e cidadania}

Dois aspectos são essenciais na comunicação da informação para a comunidade. Primeiramente, as variáveis biológicas, culturais, educacionais e socioeconômicas devem ser levadas em conta no momento de se disponibilizar informação para os cidadãos. Tais variáveis influenciam na forma com que cada cidadão recebe a informação e constrói sua realidade. Ao considerar essas variáveis, é possível assegurar o uso efetivo da informação no processo de análise e busca de solução.

Outro aspecto importante é tentar neutralizar, ou pelo menos minimizar, a influência de variáveis como valor da liberdade e igualdade, discursos e práticas dos líderes políticos e concentração de poder promovido pela mídia. Se houver grande discrepância entre elas a comunicação não irá fluir efetivamente. Os mais fortes tendem a oprimir e sobrepor-se aos mais fracos, e a experiência e o conhecimento destes não serão compartilhados ou disseminados por causa da opressão daqueles. 
Assim, um modelo de comunicação da informação para cidadãos, no contexto de suas comunidades, deve promover a autonomia do cidadão como comunicador - transmissores e receptores simultaneamente - e não como mero receptor. Um ambiente deve ser idealizado de modo que os cidadãos possam criar e disseminar mensagens sempre a partir da necessidade de informação motivada pela busca de solução de problemas sociais. Ao solucionar problemas sociais de forma integrada e participativa, as comunidades estarão promovendo seu crescimento, por meio do desenvolvimento, engajamento e comprometimento de seus cidadãos.

Por fim, um modelo de comunicação da informação para cidadãos, no contexto de suas comunidades, deve ser transacional. Isso significa dizer que a comunicação é multidirecional, de muitos para muitos. Assim, o ambiente onde os cidadãos irão comunicar-se, a fim de acessar e usar informação e compartilhar experiência e conhecimento, deve consistir em um ambiente de aprendizagem. Habilidades como trabalhar em equipe, aprender a discutir, falar e ouvir, respeitar diferenças, analisar problemas e tomar decisão são exemplos de tópicos a serem explorados nessas comunidades de aprendizagem.

\subsection{Letramento informacional e cidadania}

O fim do segundo milênio foi marcado por uma transformação histórica na sociedade humana. A evolução tecnológica, um fenômeno centrado em informação, tem redefinido a sociedade. Castells (2003) chama essa nova sociedade de "informacional, global e em rede". A nova sociedade tem dado particular importância para informação e conhecimento como recursos valorizadíssimos tanto para organizações como para as pessoas.

A sociedade informacional começa a adotar uma abordagem baseada em questão (inquiry-based) para aprendizagem, porque a nova ordem é exigir que as pessoas desenvolvam habilidades para aprender continuamente em vez de permanecerem como receptores passivos de informação (HEPWORTH; WATSON, 2009). Como consequência, uma atenção particular é dada para capacidades informacionais do indivíduo, isto é, seu letramento informacional, que pode ser definido como:

Um complexo conjunto de habilidades, que capacita o indivíduo a compreender e engajar-se criticamente no mundo em que vive e no ambiente informacional e de conhecimentos, para que este possa participar efetivamente nos processos de aprendizagem, tanto fazendo uso da informação existentes no ambiente informacional quanto contribuindo com novas informações para atualizar e incrementar esse ambiente (HEPWORTH; WATSON, 2009, p. 10, tradução nossa). 
Hepworth e Walton (2009) enfatizam que letramento informacional é uma importante habilidade para promover o fortalecimento do indivíduo (empowerment) e habilitá-lo a trabalhar de forma participativa. Eles asseveram que:

O fortalecimento do indivíduo é sustentado pelo letramento informacional. A habilidade para aprender efetivamente e independentemente e, ainda, usar conhecimentos, dados e informações do ambiente informacional, irá provavelmente resultar em pessoas com mais poder de escolha. Se as pessoas têm poder de escolha, significa dizer que elas estão bem informadas sobre suas situações, podem ver alternativas de forma crítica e sustentável e são capazes de escolher ou criar uma variedade de soluções e estratégias. Isso pode levar as pessoas a ter mais opções para decidir como participar e interagir socialmente e como usar efetivamente os recursos e serviços informacionais disponíveis ou contribuir para incrementar esses recursos e serviços (traduzido pela autora, Ibid, p. 3).

Assim, pessoas precisam conscientizar-se do papel da informação na nova sociedade e das habilidades que elas precisam desenvolver para acessar, estocar, recuperar e usar a informação que irá promover bem-estar e qualidade de vida. No entanto, os autores asseveram que muitas pessoas acham difícil acessar e usar as informações que estão armazenadas nos diversos repositórios informacionais (Ibid, 2009). Esse é especialmente o caso observado em países em desenvolvimento, onde existe significativa carência de tempo, de recursos e de educação apropriada.

Desenvolver essas habilidades individualmente é uma possibilidade. Entretanto, na perspectiva construtivista social de aprendizagem (MACKERACHER, 2004), letramento informacional que leva ao desenvolvimento da comunidade é uma situação diferente e, provavelmente, muito mais efetiva. Lloyd (2007), por exemplo, remodela a natureza do letramento informacional, da esfera do indivíduo para uma esfera maior, da comunidade, como uma abordagem inserida no contexto sociocultural. Adicionalmente, abordagens participativas para solução de problemas têm sido identificadas como formas efetivas de engajamento dos membros das comunidades. A participação leva pessoas a desenvolver soluções sustentáveis que genuinamente expressam as necessidades da comunidade (mais que aquelas soluções insustentáveis que são impostas por especialistas de fora). Usando métodos participatórios, pode-se presumir que a pesquisa irá atuar também como um mecanismo que ajuda no intuito de desenvolver novos insights e capacidades nas pessoas. Essa é uma das características próprias apontada por Chambers (2005) para Participative Research and Action (PRA).

Da perspectiva do comportamento informacional do cidadão, novamente é reconhecida a significância do tema "necessidade de informação no contexto do comportamento informacional". Esse tema tem sustentado pesquisas nos últimos 20 anos, o que pode ser comprovado pelos artigos e apresentações feitos no Information Seeking in Context Conference. Assim, pesquisadores dessa área estão evitando abordagens de levantamento tradicionais e buscando 
alternativas que levem a explorar melhor o comportamento informacional das pessoas. A tendência é seguir por uma perspectiva mais etnográfica ou interpretativista, nas quais as necessidades (básicas e de informação) possam ser contextualizadas.

\subsection{0 modelo conceitual da pesquisa}

A combinação desses fundamentos teóricos tem influenciado e sustentado esta pesquisa. Assim, a pesquisa visa desenvolver, no cidadão, habilidades de letramento informacional e de trabalho colaborativo para atuarem em suas comunidades de forma consciente e proativa. Além disso, o estudo capacita cidadãos a identificar problemas sociais, buscar e usar informações para estudar o problema e propor soluções que, quando bem endereçadas, podem melhorar o bem-estar e a qualidade de vida dos participantes.

Os conceitos que formaram a base conceitual da pesquisa, construídos com base no que se identificou na literatura, estão destacados na figura 1, que ilustra o modelo conceitual da pesquisa, destacando não somente esses conceitos, mas, principalmente, suas relações.

Figura 1 - Modelo conceitual da pesquisa

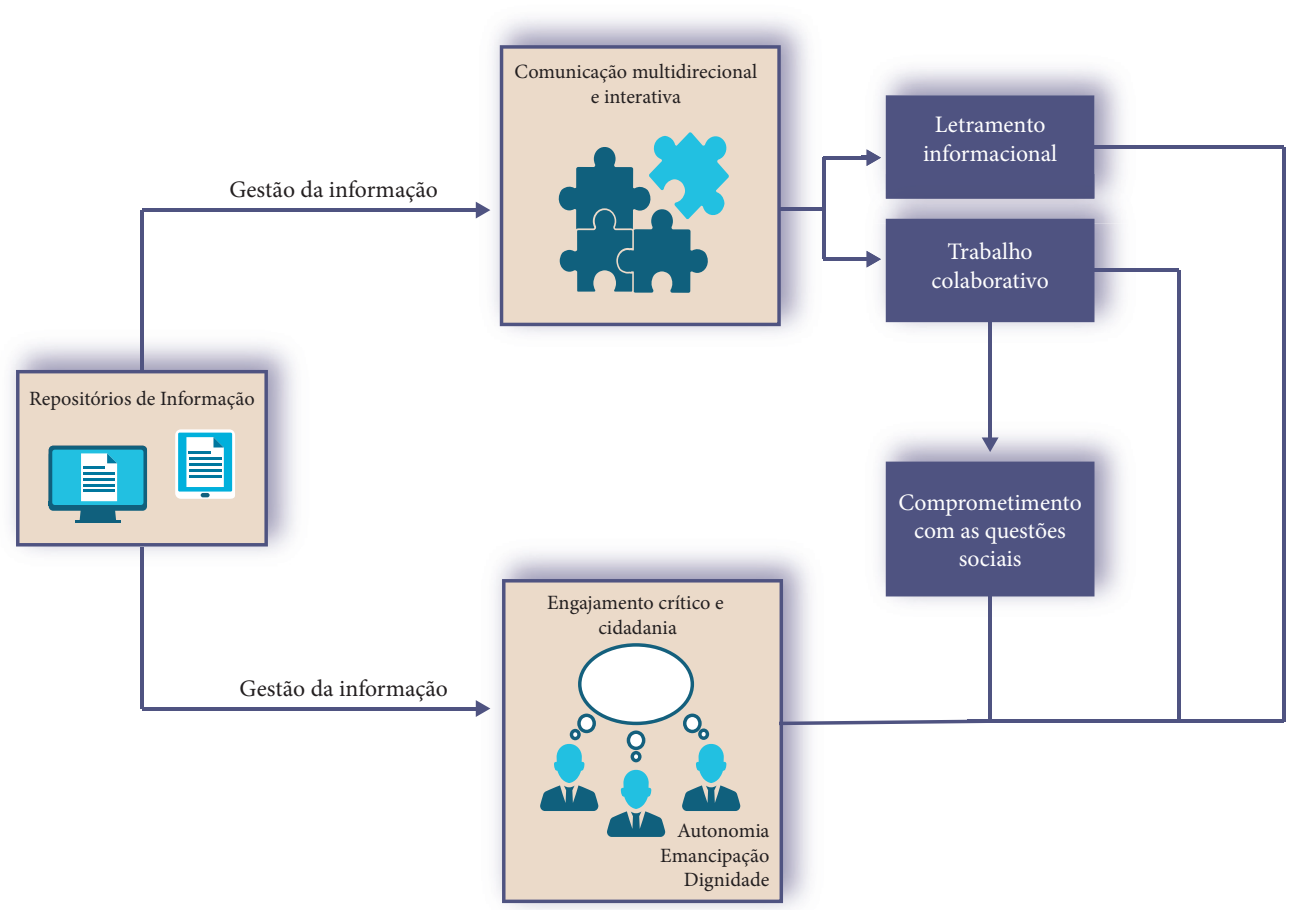

Fonte: Elaboração dos autores (2018). 
O modelo conceitual traz os conceitos de pesquisa participatória como base do processo de comunicação efetiva entre cidadãos moradores de uma mesma comunidade, que visa desenvolver habilidades direcionadas ao letramento informacional e ao trabalho colaborativo. Tem-se como premissa que técnicas de pesquisa participatória conjugadas ao letramento informacional constituem requisitos essenciais para que a comunicação seja processada de forma interativa e multidirecional. Aliado a isso, um canal de comunicação entre os membros da comunidade nesses termos contribui para o desenvolvimento crítico e técnico do cidadão, possibilitando que ele próprio possa conquistar sua autonomia, emancipação e dignidade. Finalmente, ao estimular pessoas a discutirem e proporem soluções para problemas sociais que eles vivenciam na comunidade onde vivem, a metodologia contribui para o desenvolvimento da própria comunidade mediante a conscientização crítica de seus membros, o comprometimento e a responsabilidade social.

O modelo teórico provê elementos que sugerem ser possível desenvolver consciência crítica e cidadania por meio de uma abordagem de investigação participativa. Nesse contexto, cidadania significa melhor comunicação entre os membros da comunidade, engajamento, comprometimento e conquista de direitos sociais a partir da inserção do cidadão na era da informação. O modelo de investigação participativa é capaz de habilitar pessoas a manusear informações sempre que se depararem com algum problema ou situação que precisam ser solucionados ou mudados. Adicionalmente, a metodologia participatória permite que as pessoas possam trabalhar juntas, dentro de sua comunidade, compartilhando experiências e conhecimentos.

\section{A PESQUISA PARTICIPATÓRIA: INSTRUMENTOS E PROCEDIMENTOS METODOLÓGICOS}

Essa pesquisa foi estruturada tomando-se por base a abordagem epistemológica interpretativista e adota a metodologia Participative Research and Action (PRA) dentro da perspectiva teórica de pensamento crítico. $\mathrm{O}$ foco da pesquisa é letramento informacional, trabalho colaborativo e cidadania. A ênfase está na própria interpretação e percepção que as pessoas têm de um determinado contexto. As questões e os problemas que foram investigados originaram-se dos participantes e de suas reflexões acerca da realidade.

Coerente com a perspectiva teórica do pensamento crítico, esta pesquisa está preocupada mais com o desenvolvimento da consciência crítica do que com a solução do problema propriamente dito. De fato, Brookfield (1987) afirma que a situação, o fenômeno, a questão ou o problema proveem apenas motivação para que os participantes possam trabalhar juntos e de forma colaborativa. Nessa perspectiva, o aprendizado emerge por meio do compartilhamento de conhecimento e experiências. A intenção é habilitar os participantes a analisar informações e refletir, desenvolvendo assim consciência crítica. 
A perspectiva teórica de pensamento crítico compartilha muitas características com a metodologia PRA, as quais proveram a estrutura metodológica e influenciaram as intervenções. A PRA tem sido muito aplicada nos países em desenvolvimento, inicialmente com a denominação Participatory Rural Appraisal. Chambers (2005, p. 3, tradução nossa) assevera que a PRA é "um conjunto de abordagens, comportamentos e métodos para habilitar as pessoas a fazerem seus próprios planejamentos, análise e avaliações, implementarem suas próprias ações e atuarem, eles próprios, no monitoramento e controle dessas ações”.

Muitos métodos e instrumentos têm sido desenvolvidos para investigar o comportamento informacional, como grupos focais, questionários e entrevistas, embora todos pareçam inapropriados no contexto desta pesquisa. Os questionários, por exemplo, tendem a predefinir a natureza dos tópicos da investigação e, para algumas extensões, determina o grau de significância que pode ser dado a cada tópico. Nesta pesquisa, ao contrário, não houve ideias preconcebidas sobre a necessidade de informação dos participantes, e a parte fundamental da pesquisa foi verificar se a abordagem participativa seria capaz de habilitar as pessoas a explorar e identificar suas próprias necessidades de informações. Entrevistas, embora forneçam mais oportunidades para o inesperado, também se mostraram inapropriadas por não serem participativas ou por não habilitarem os membros da comunidade a explorar suas próprias necessidades de informação e, juntos, chegarem a um consenso sobre o que é importante. Em outro sentido, as reuniões de grupo poderiam ser grosseiramente descritas como seções de grupo focal. Entretanto, a abordagem participativa não é normalmente considerada quando se conduzem grupos focais. Usando uma abordagem participativa, determinado número de tópicos pode ser discutido nos grupos, mas a discussão está fortemente estruturada em regras participativas. Assim, o aspecto-chave da PRA é o desenvolvimento de capacidades, isto é, habilidades, competências e atitudes.

Freire (2007) garante que o trabalho participativo é uma excelente alternativa para a educação e o envolvimento das pessoas na sociedade. Habilidades, competências e atitudes podem ser desenvolvidas mediante o uso da PRA, com fortes tendências para promover interação e engajamento das pessoas com suas comunidades. A PRA é uma metodologia que permite a participação de todos no processo de investigação, além de desenvolver habilidades de pesquisa e reflexão no uso da informação, a partir do compartilhamento de dois referenciais teóricos: letramento informacional e solução de problemas. Em parte, é dada ênfase à reflexão, uma importante abordagem do processo de aprendizagem.

Cohen e Uphoff (1980) defendem a ideia de que governos precisam adotar a participação popular como diretriz e base para o desenvolvimento. Reforçam o argumento de que a participação é, por si só, uma necessidade básica e citam alguns exemplos. O Conselho Econômico e Social das Nações Unidas (Unesco) tem aconselhado os países a incluírem propostas de participação popular em seus programas de governo. Já a Conferência de Empregabilidade 
Mundial (World Employment Conference) possui um programa que tem como ação "a participação das pessoas no processo de tomada de decisão que os afetam, por meio de organizações de suas escolhas" (COHEN; UPHOFF, 1980, p.18, tradução nossa). A Conferência Mundial de Reforma Agrária e Desenvolvimento Rural (WCCARD) afirma que a participação das pessoas em instituições ou sistemas que governam suas vidas é um direito humano básico e, ainda, é essencial para o realinhamento dos poderes políticos em favor dos grupos marginalizados e para o desenvolvimento econômico e social (COHEN; UPHOFF, 1980, p. 18, tradução nossa).

Cornwall (2009) observa que a PRA pode mobilizar a população, dando suporte para incrementar mudanças. Adicionalmente, a participação popular, como política de governo, promove eficiência, eficácia e efetividade, além de estimular a realização de trabalhos voluntários, o que seguramente melhora a qualidade e a quantidade de serviços públicos disponibilizados à população, sem onerar o caixa do governo. Por meio da participação popular, as ações do governo podem ser monitoradas e controladas mais efetivamente, o que o leva a um melhor desempenho da administração pública. Além disso, ela promove maior conscientização do cidadão em relação à manutenção e preservação dos bens públicos. Os projetos governamentais têm mais chances de sucesso quando os membros da comunidade estão mais envolvidos, uma vez que há engajamento e comprometimento e, portanto, muito mais energia voltada para a ação.

Muitas organizações concordam com o fato de que não existe desenvolvimento sustentável e duradouro sem participação popular, que, de acordo com Kumar (2008), constitui peça central dos processos de desenvolvimento. A PRA carrega a ideia de que uma crescente participação irá significar maior democracia, igualdade e justiça social, além de promover a autonomia, emancipação e dignidade dos cidadãos - desenvolve consciência crítica em relação a direitos e deveres do cidadão e melhora a aplicação e distribuição dos recursos públicos, o que irá, por sua vez, motivar pessoas a participar das decisões que afetam suas vidas, em outras palavras, permite o exercício da cidadania.

A primeira intervenção foi caracterizada como uma investigação-piloto, na qual técnicas foram aplicadas e questões foram formuladas, as quais permitiram ao pesquisador refletir sobre a adequabilidade da metodologia e, ainda, sobre como melhorar os instrumentos de pesquisa. A investigação-piloto foi feita em Brasília, DF, Brasil. Três comunidades foram eleitas preliminarmente: a Associação dos Moradores do Varjão, a Associação de Mulheres de Negócio e Profissionais do Brasil e Comunidade de Moradores da Candangolândia. Esta última (figura 2) foi selecionada por apresentar vantagens específicas: fácil contato com os membros da comunidade, espaço disponível para realização das reuniões e grande diversidade em relação à amostra de pessoas, incluindo homens e mulheres, jovens e pessoas mais velhas, solteiros e casados, empregados, autônomos e desempregados, estudantes, donas de casa e aposentados. 
Figura 2 - Lotes da comunidade da pesquisa na Candangolândia
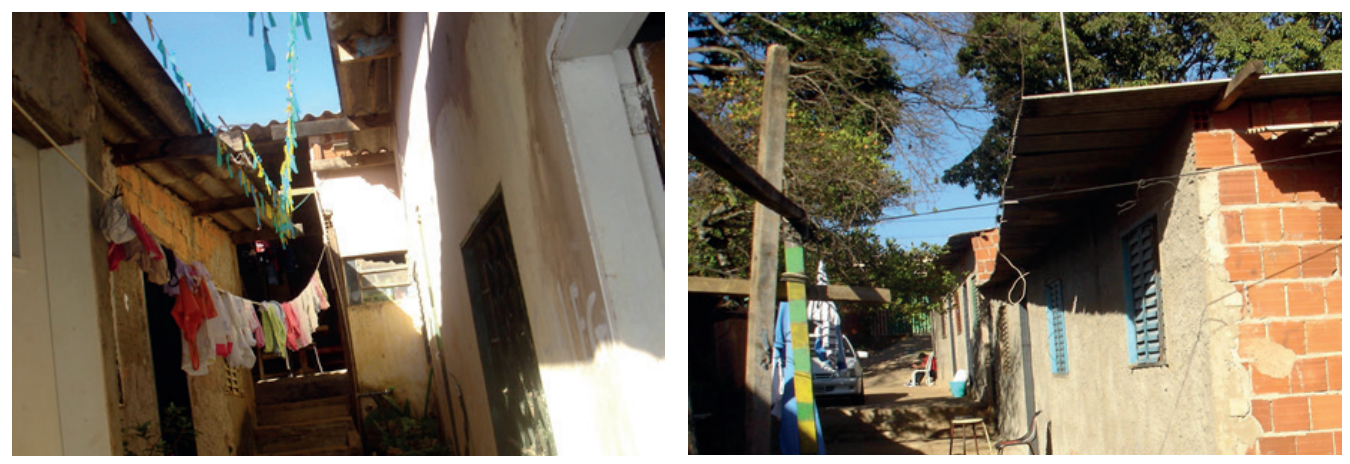

Fonte: Capturada pelos autores (2012).

Cinco reuniões foram planejadas para implementar essa investigação-piloto, cada uma com duração, em média, de 2 a 3 horas. Na primeira reunião, foram realizadas as apresentações pessoais e a seleção do problema social a ser estudado. A segunda teve como objetivo o levantamento da necessidade de informação. A terceira visou à classificação e categorização das informações. Na quarta, realizaram-se a classificação das informações e o levantamento do comportamento de busca e uso de informação dos participantes. Por fim, a quinta teve como objetivo o uso da informação na sugestão de soluções para o problema social selecionado.

A partir do resultado das avaliações do projeto-piloto, a investigação propriamente dita contou com uma reunião a mais. A sugestão dos participantes foi separar o conteúdo da quinta reunião a fim de que eles tivessem mais tempo para analisar os conteúdos informacionais (quinta reunião) e propor soluções para o problema selecionado (sexta reunião).

Foram selecionadas técnicas para conduzir as reuniões. O objetivo foi explorar atividades de trabalho colaborativo e de acesso e uso de informações para entender e analisar problemas e/ ou situações e apontar soluções. As técnicas incluem: dinâmica de apresentações, discussões, exposições de trabalhos, tempestade de ideias (brainstorming), cartões coloridos para as pessoas expressarem ideias, diagrama de causa e efeito e trabalhos em grupo.

Essa variedade de técnicas foi necessária por três razões principalmente: 1) algumas técnicas mostraram-se mais apropriadas para a exploração de tópicos específicos (por exemplo, o brainstorming permitiu levantar o máximo de informações possíveis); 2) ao usar uma variedade de técnicas, é possível obter maior engajamento, tendo em mente que a maioria dos participantes chegava às reuniões após um longo dia de trabalho; 3 ) essas técnicas estiveram distribuídas em diversas reuniões, dando a ideia exata de que o trabalho evolui a cada atividade. 


\section{Primeira reunião}

A primeira reunião envolveu um conjunto de seis atividades e contou com a presença de 20 participantes. Na primeira atividade, o pesquisador apresentou-se e expôs o trabalho que seria desenvolvido ao longo das reuniões. O objetivo foi explicar aspectos da pesquisa e da metodologia de investigação participatória. Esses esclarecimentos foram muito importantes para buscar mais comprometimento e não gerar expectativas frustradas.

Na segunda atividade, os participantes se apresentaram, falando resumidamente de si mesmo, e opinaram sobre o trabalho e sobre como contribuir. $\mathrm{O}$ objetivo foi promover interação e permitir aos participantes que conhecessem um pouco de cada um.

A terceira atividade serviu para definir regras e valores para o grupo. Os participantes citaram livremente valores e regras de comportamento, os quais foram anotados em uma grande folha de papel (brainstorming). Em seguida, eles votaram nos três valores ou regras que julgavam mais importantes. Os três mais votados passaram a ser os valores do grupo. O respeito foi o primeiro valor definido, significando que eles iriam ouvir os outros, aceitar opiniões diferentes e contribuir. O trabalho em equipe foi o segundo, significando que eles iriam participar das discussões e buscariam consenso em todas as atividades. $\mathrm{O}$ terceiro valor foi a honestidade, que significou que eles assumiriam suas posições com integridade.

A quarta atividade foi concebida para que os participantes discutissem e enumerassem todos os problemas que eles tinham naquela comunidade. Os participantes escreveram em cartões os problemas sociais com os quais tinham que conviver diariamente (cada problema foi escrito em um cartão, separadamente). Os cartões foram fixados em uma grande folha de papel. O problema mais ressaltado seria selecionado para ser estudado. $\mathrm{Na}$ intervenção-piloto, o problema relacionado às deficiências do sistema de saúde pública foi o eleito. $\mathrm{Na}$ intervenção propriamente dita, foi escolhido o transporte coletivo.

A quinta atividade foi concebida para análise do problema social selecionado. Novamente foi proposto um brainstorming, por meio do qual os participantes puderam identificar a causa e o efeito do problema social escolhido.

Por fim, a última atividade destinou-se à avaliação, o que se repetiu nas demais reuniões. Os participantes, sem se identificarem, escreveram suas avaliações em cartões, fixando-os em uma grande folha de papel, e discutiram a avaliação em grupo. O objetivo foi estimular o participante a criticar as atividades, os comportamentos e as estruturas do trabalho que estava sendo desenvolvido. Esse processo de avaliação constituiu uma ferramenta importante para desenvolvimento de consciência crítica. 


\section{Segunda reunião}

A segunda reunião envolveu 20 participantes e um conjunto de três atividades, cujo principal objetivo foi lhes dar suporte para que pudessem identificar as informações das quais eles precisariam para analisar o problema e sugerir soluções. Iniciou-se com uma atividade de reflexão que foi repetida em todas as reuniões subsequentes. Tal reflexão consistiu em promover discussões, estimulando os participantes a falarem acerca do que aprenderam, do que não entenderam e do que precisaria ser melhorado. O objetivo dessa reflexão foi estimular os participantes a perceberem como se dá o processo de aprendizagem.

A segunda atividade foi concebida para levantamento de necessidades de informação. Por meio de um brainstorming, os participantes puderam identificar, a partir do diagrama de causa e efeito, as informações que eles precisariam para entender o problema e apontar soluções, registradas em uma grande folha de papel (figura 3).

Figura 3 - Necessidade de informação levantada pelos participantes da pesquisa.
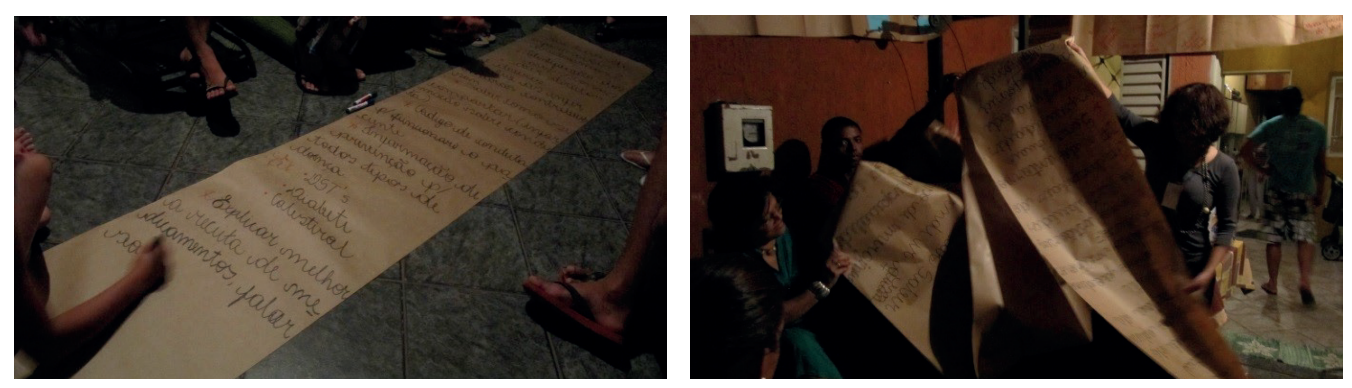

Fonte: Capturada pelos autores (2012).

Com auxílio do diagrama de causa e efeito, os participantes foram capazes de explorar e compartilhar suas visões sobre o problema, as quais foram construídas mediante contribuições de todos, refletindo seus entendimentos sobre o sistema público de saúde (investigação-piloto) e sobre o transporte coletivo (investigação propriamente dita). Cada item do diagrama indicou uma ou mais informações que julgaram importante explorar. Por exemplo: no estudo sobre o sistema público de saúde, ao indicarem a corrupção como problema, identificaram informações que os ajudariam a entender melhor a questão (informações sobre recursos financeiros, dinheiro que é gasto no sistema de saúde pública, quem são os gestores da saúde, quem fiscaliza o sistema de saúde e como eles podem denunciar e reclamar). 


\section{Terceira reunião}

A terceira reunião, na qual estiveram presentes 18 pessoas, contou com três atividades. Considerando que a primeira atividade de cada reunião é sempre destinada à reflexão sobre o aprendizado e a última à avaliação do trabalho desenvolvido, a atividade principal no meio consistiu em categorizar as informações, preparando-as para serem acessadas e usadas (figura 4).

Figura 4 - Atividade destinada a classificar e categorizar informações
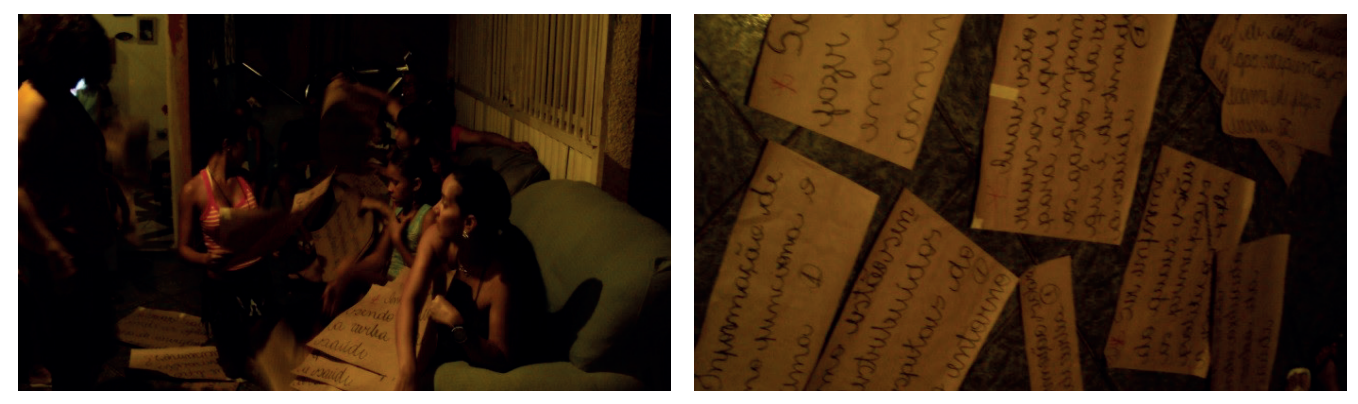

Fonte: Capturada pelos autores (2012).

A categorização foi importante para organizar a informação de acordo com as indicações de acesso nos repositórios institucionais. Na investigação-piloto, por exemplo, os participantes definiram quatro categorias nas quais seriam agrupadas as informações: hospitais e especialidades; medicamentos, efeitos e contraindicações; profissionais da saúde e paciente; e sistema público de saúde.

A preparação para acesso e uso das informações ajudou os participantes a entender o ambiente informacional, uma vez que permitiu identificar as fontes relevantes dessa informação. Desse modo, foi possível identificar que as informações inseridas na primeira categoria estavam disponíveis, em sua maioria, na Secretaria de Saúde do Distrito Federal, enquanto as da segunda, prioritariamente, na Agência Nacional de Vigilância Sanitária (Anvisa). As informações inseridas na terceira categoria poderiam ser encontradas nos conselhos dos profissionais de saúde; e, por fim, as da quarta categoria, na Secretaria de Planejamento do Distrito Federal.

\section{Quarta reunião}

A quarta reunião contou com quatro atividades e teve dois objetivos principais: classificar as informações em ordem de importância e acessibilidade e levantar o comportamento informacional dos participantes. Vinte e três pessoas compareceram a essa reunião. 
Após a atividade de reflexão, foram realizadas duas atividades-meio. Na primeira, os participantes reuniram-se em pequenos grupos, classificaram a informação por importância e facilidade de acesso, eliminaram redundâncias, selecionando as informações importantes e de fácil acesso que seriam prioritariamente recuperadas (figura 5). A segunda teve como objetivo levantar o comportamento informacional dos participantes, por meio da aplicação de um questionário, cujas respostas sobre como acessam e usam informações foram anotadas em uma folha de papel. A atividade culminou na identificação dos comportamentos de busca e uso da informação.

Figura 5 - Classificação das informações por importância e facilidade de acesso
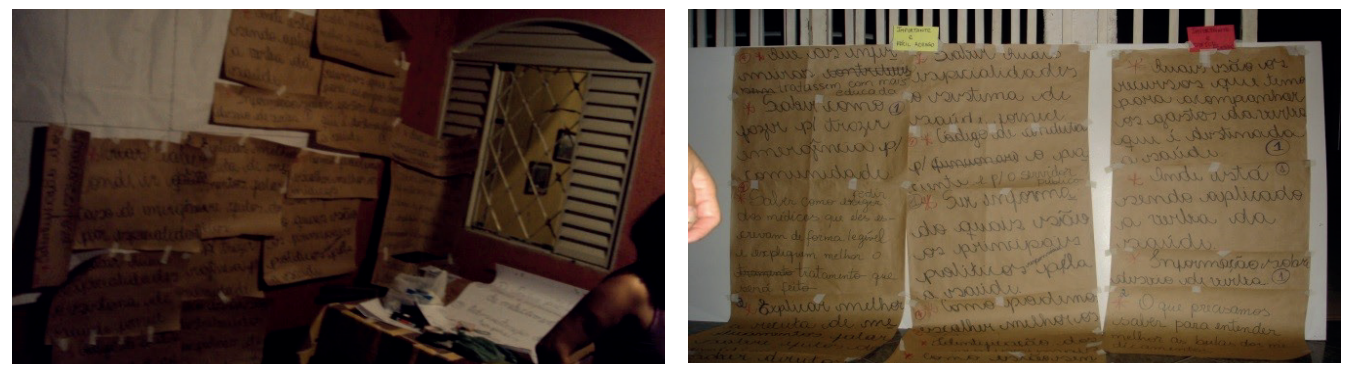

Fonte: Capturada pelos autores (2012).

Nessa atividade, é natural que os participantes classifiquem todas as informações como importantes, o que aconteceu, de fato, na investigação-piloto. Isso ocorreu porque não quiseram correr o risco de eliminar alguma informação sem antes analisá-la e compreender o seu conteúdo. Após uma classificação rigorosa relacionada ao acesso - fácil ou difícil - e outra para eliminar redundâncias, foi possível obter um conjunto de informações consistente e racional.

\section{Quinta reunião}

Após uma pausa de uma semana, na qual os participantes coletaram as informações, a quinta reunião contou com três atividades. Além das reuniões de reflexão e avaliação, o principal objetivo foi reunir as informações e analisar seus conteúdos. Dezoito pessoas estiveram presentes nessa reunião.

Para analisar as informações, os participantes reuniram-se em pequenos grupos e cada um analisou e discutiu uma categoria. Depois disso, fizeram uma apresentação para que os outros pudessem ter conhecimento sobres aquelas informações. Desse modo, todos discutiram sobre o conteúdo de todas as informações que foram coletadas. 
Os participantes demonstraram entender o conteúdo da informação e, mais importante, compartilharam esse conteúdo com os outros grupos. O resultado dessa atividade evidenciou que houve aprendizado em relação ao letramento informacional (levantamento de necessidade de informação, busca e uso de informação) e ao trabalho conjunto e colaborativo.

\section{Sexta reunião}

A sexta e última reunião contou com três atividades. Seu principal objetivo foi analisar o problema social selecionado e sugerir soluções. Visto que se tratava da última reunião, a avaliação foi mais criteriosa, a fim de contemplar aspectos gerais da investigação como um todo. Dezoito pessoas estiveram presentes nessa reunião.

Para analisar o problema social, os participantes reuniram-se em pequenos grupos e analisaram e discutiram o problema com base nas informações acessadas e usadas. Depois disso, elencaram uma série de propostas de soluções que foram expostas e discutidas no grande grupo. Desse modo, todos tiveram acesso e discutiram acerca das soluções para o problema social selecionado.

Os participantes propuseram soluções para o problema social selecionado e, mais importante, foram capazes de discutir essas propostas para os outros grupos. Evidenciou-se que uma investigação que utiliza a comunicação multidirecional e interativa, aplicando técnicas de pesquisa participatória, pode contribuir para desenvolver habilidades direcionadas ao letramento informacional e atitudes voltadas para o trabalho colaborativo que, juntas, promovem o desenvolvimento de cidadania.

\section{ANÁLISE E DISCUSSÃO DOS RESULTADOS}

A análise dos resultados consistiu na transcrição e codificação dos dados, bem como na descrição dos principais achados da investigação e dos aportes fornecidos por autores relevantes, cujas abordagens fundamentam a discussão das questões desta pesquisa. A discussão, por sua vez, consiste nas interpretações e comentários da própria pesquisadora em relação às questões e aos objetivos da pesquisa.

É importante lembrar que todas as atividades desenvolvidas nas reuniões utilizaram técnicas de comunicação multidirecional e interativa, o que resultou em grande massa de dados brutos. Após a transcrição bruta, os dados foram codificados de forma a classificar e categorizar as atividades, associando códigos aos conceitos do modelo teórico da pesquisa. Esse método de análise dos dados está abalizado nos pressupostos da teoria fundamentada (grounded theory), 
tal como sugerido por Bryman (2008). O autor observa que a teoria fundamentada tornou-se uma metodologia largamente utilizada para analisar dados qualitativos.

Teoria fundamentada tem sido definida como a teoria derivada da coleta e da análise sistemática dos dados durante o processo de pesquisa. Nesse método, dados coletados, análise e uma eventual teoria anterior possuem relações próximas entre si. Desse modo, duas características da teoria fundamentada são: está preocupada com o desenvolvimento da teoria proveniente dos dados coletados e é uma abordagem interativa e recursiva (BRYMAN, 2008, p. 541). ${ }^{2}$

Na teoria fundamentada, os dados são repetidamente confrontados com a teoria (resultado de uma teoria anterior), até que se obtenha a teoria proveniente desse confronto sistemático. O presente estudo não adotou rigorosamente a metodologia da teoria fundamentada, visto que a coleta de dados implicou efetiva participação dos sujeitos sem confrontação de resultados intermediários. Entretanto, princípios da teoria fundamentada foram considerados durante o trabalho de análise, notadamente em relação a dados recorrentemente analisados e codificados, permitindo alcançar um nível de agregação que aproximou dados a conceitos do modelo teórico da pesquisa (figura 1). Tudo isso - dados coletados, dados codificados e modelo teórico anterior - serviu de base para se chegar ao modelo de análise adotado por este estudo, representado na figura 6.

2 Tradução livre da autora. 
Figura 6 - Critérios para análise dos dados

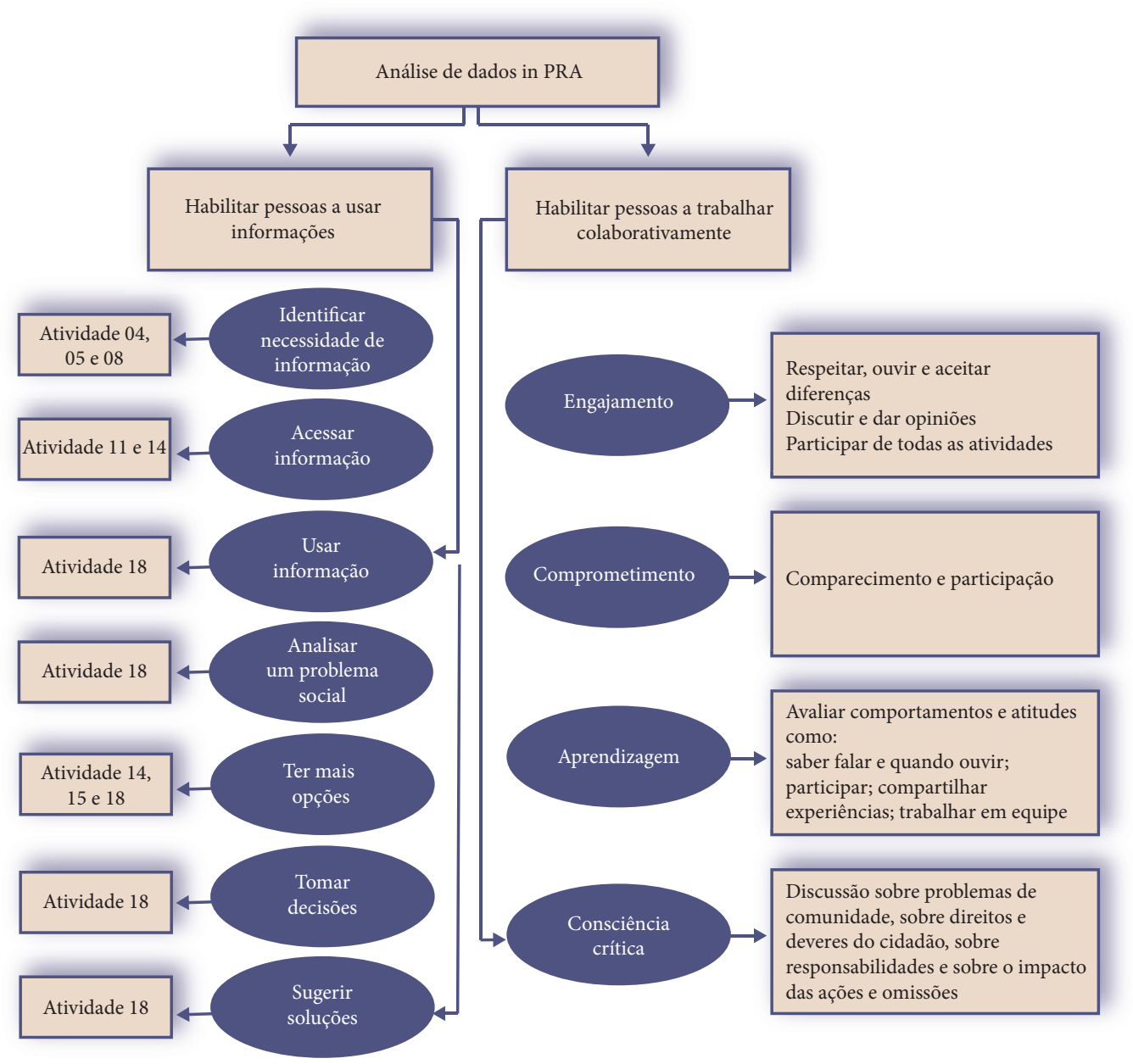

Fonte: Elaborado pelos autores.

A partir da produção escrita decorrente das atividades, foi possível constatar as necessidades de informação, os comportamentos de busca e uso de informações e a solução de problemas. A aprendizagem e o trabalho em equipe, por sua vez, foram observados pelo pesquisador durante as reuniões, à medida que os participantes foram melhorando suas capacidades de ouvir os outros, de apresentar suas opiniões, de compartilhar aprendizado e experiência, de ajudar os outros e respeitar diferenças. O comprometimento foi observado pelo comparecimento e pela motivação na realização das atividades. Por sua vez, a consciência crítica e a cidadania foram evidenciadas nos dados verbais, quando os participantes discorreram sobre os problemas da comunidade, suas responsabilidades e seus direitos. Além disso, destaca-se que eles foram capazes de analisar o impacto potencial de suas ações e omissões. 
Pesquisa e ação participatória podem ser usadas para investigar a necessidade de informação dos cidadãos?

A investigação demonstrou que a metodologia participatória, associada a atividades e técnicas de trabalhos em grupo, é suficiente para levantar a necessidade de informação dos membros de uma comunidade. Na primeira reunião (projeto-piloto), foi selecionado um problema social a ser estudado, que, no caso, foi a deficiência do sistema de saúde pública. Realizou-se a análise desse problema para identificar as razões dessa deficiência e suas causas e efeitos. Após análise e discussão, os participantes apontaram razões para essa deficiência do sistema, comentando, por exemplo, o não funcionamento dos centros de saúde à noite e a falta de hospital na comunidade. Ressaltaram, ainda, que os postos e hospitais não estão equipados adequadamente, faltam fisioterapeutas, psicólogos, nutricionistas e outras especialidades. Reclamaram das filas e afirmaram que as pessoas gastam muito tempo esperando para ser atendidas.

O levantamento das necessidades de informação baseou-se no diagrama de causa e consequência, a partir do qual os participantes identificaram 29 tipos de informação que julgaram necessárias para entender o problema e apontar soluções. Nicholas e Herman (2009) asseveram que a necessidade de informação é secundária e decorre de uma necessidade básica anterior. A partir de um problema social selecionado (necessidade básica), os participantes identificaram necessidades (secundárias) da informação útil à proposição de solução para o problema. As atividades desenvolvidas mediante o emprego de técnicas participatórias proveram uma efetiva ferramenta para explorar a necessidade de informação em uma comunidade.

\section{Pesquisa e ação participatória podem ser usadas para desenvolver no cidadão habilidades de letramento informacional e de trabalho colaborativo?}

Foi possível comprovar que o uso de técnicas participatórias pode habilitar as pessoas a aprenderem colaborativamente e que intervenções podem conduzir ao desenvolvimento de letramento informacional, quando combina necessidade, busca e uso efetivo da informação para analisar e solucionar problemas sociais. As atividades nesta pesquisa participatória tiveram, em parte, a intenção de desenvolver habilidades de letramento informacional nos participantes, tanto quanto conduzir ao aperfeiçoamento de suas capacidades para, colaborativamente, solucionar problemas. De fato, ao serem capazes de identificar e categorizar suas necessidades de informação, os participantes aprenderam a usar técnicas participatórias, tornando-se cientes dos recursos de informação que podem ajudá-los a suprir suas necessidades básicas. Isso é, em síntese, letramento informacional, desenvolvido a partir de uma abordagem baseada na solução de problemas. 
Os participantes desenvolveram habilidades de trabalho em equipe, revelando-se capazes de manipular e usar, colaborativamente, informações na análise de problemas e sugestão de soluções. Entre as soluções apontadas, destacam-se cinco. A primeira refere-se ao conhecimento sobre a disponibilidade de apoio especializado, considerando importante saber como estão distribuídos os hospitais e centros de saúde no Distrito Federal e, ainda, quais especialidades médicas e terapêuticas estão disponibilizadas em cada um. A segunda solução diz respeito à melhor apresentação da bula dos medicamentos, visto que consideravam impossível para o cidadão comum entender as informações impressas em razão de conterem termos muito técnicos. A terceira ressalta a importância de receberem, via folhetos ou por e-mail, informações sobre saúde e sobre como evitar doenças. Na quarta, conhecerem e exercerem seus direitos e deveres como cidadão, notadamente em relação à saúde pública, sabendo como agir no caso de esses direitos serem negligenciados. Por fim, a quinta solução refere-se ao conhecimento sobre órgãos de fiscalização e controle de gasto público e de ações administrativas, sabendo como estabelecer contato com esses órgãos.

Chambers (2002) afirma que as pessoas, mesmo pobres e marginalizadas, são capazes de analisar suas realidades, enquanto Rey (2005) acrescenta que essas realidades podem ser entendidas mediante discussão e negociação. Esse processo de pensamento (ou questionamento) crítico está, per se, conectado com o desenvolvimento de consciência crítica, que surge a partir da prática da solução de problemas de forma colaborativa (BROOKFIELD, 1987).

\section{Pesquisa e ação participatória conduzem ao maior senso de cidadania?}

As reflexões e avaliações foram usadas para melhorar o processo de investigação e, mais importante, para avaliar a aprendizagem e o desenvolvimento de consciência crítica em relação à informação e às situações que os participantes vivenciaram. No que concerne a melhorias no processo de investigação, as deficiências identificadas no estudo-piloto puderam ser corrigidas na investigação propriamente dita, como, por exemplo, o aumento do número de reuniões necessárias para a realização da pesquisa e a criação de dinâmicas no início da reunião. Sobre a aprendizagem, é possível afirmar que, na investigação propriamente dita, os participantes se mostraram capazes de conduzir as atividades com maior independência (em relação ao pesquisador) do que na investigação-piloto. Em relação ao desenvolvimento de consciência crítica, os participantes tornaram-se mais críticos quanto aos seus próprios papeis e ao papel do Estado na sociedade, em relação a direitos, deveres, ações, entre outras questões evidenciadas nas soluções apontadas na seção anterior.

As soluções propostas pelos participantes e transcritas a seguir indicam um senso de cidadania. Isso porque os participantes puderam perceber quais seriam seus novos papéis, mais ativos, na implementação de mudanças e como poderiam exigir que essas mudanças fossem 
executadas. Nesse sentido, sugeriram, entre outros aspectos, quatro soluções dentro do contexto da saúde pública: 1) mais dinheiro para a saúde pública; 2) controle efetivo do sistema de saúde pública para evitar corrupção, fraudes e apropriações indevidas (mais rigor nas leis e mais agilidade do poder judiciário); 3 ) ampla discussão e divulgação de direitos e responsabilidades dos cidadãos; 4) fortalecimento do sistema público de saúde do Distrito Federal e dos sistemas de outras cidades que estão sediadas ao redor da capital. Como é possível notar, o uso de técnicas participatórias na presente pesquisa permitiu o envolvimento do cidadão com a comunidade, o seu comprometimento com a solução de problemas e o reconhecimento de seus direitos e deveres.

\section{CONCLUSÃO}

Comportamento informacional e metodologias participatórias não são conceitos novos, mas o uso das últimas para descrever o primeiro é relativamente inovador. Esta pesquisa demonstrou que a PRA é um método que pode ser usado para explorar o comportamento informacional. Mais que isso, é indicado para habilitar pessoas a focar em suas necessidades de informação e no papel da informação para ajudar a solucionar problemas. Em outras palavras, a PRA pode desenvolver o letramento informacional. Adicionalmente, a intervenção parece ter aumentado a habilidade das pessoas em trabalhar colaborativamente para solucionar problemas sociais, tanto quanto despertou nelas o desejo de assumir um papel mais ativo na busca de soluções para os problemas da comunidade.

O objetivo geral da pesquisa foi demonstrar que uma investigação que utiliza a comunicação multidirecional e interativa, aplicando técnicas de pesquisa participatória, pode contribuir para desenvolver habilidades direcionadas ao letramento informacional e às atitudes voltadas para o trabalho colaborativo que, juntas, promovem o desenvolvimento de cidadania. $\mathrm{O}$ uso da PRA permite que os sujeitos de uma pesquisa trabalhem com o pesquisador, desenhando o projeto, coletando e analisando dados e utilizando os resultados em seus próprios benefícios. Permite ainda que permaneçam juntos, em pequenos grupos, e discutam e compartilhem experiências, sugerindo soluções para situações e problemas sociais.

A intervenção participatória é uma ferramenta de aprendizagem que, pela via do letramento informacional e do trabalho colaborativo, contribui para o envolvimento de todos na implementação das propostas de soluções, as quais seguramente promoverão mudanças que trarão benefícios para todos. Portanto, o processo de desenvolvimento do trabalho em si é tão relevante quanto os resultados alcançados.

Desenvolver habilidades de letramento informacional de forma individual é uma possibilidade. Entretanto, na perspectiva construtivista social de aprendizagem apresentada por 
Mackeracher (2004), letramento informacional que leva ao desenvolvimento da comunidade é uma situação diferente e, provavelmente, muito mais efetiva. Essa é a grande contribuição da presente pesquisa.

\section{REFERÊNCIAS}

APPLE, M. W. Can schooling contribute to a more Just society? Journal of Education, Citizenship and Social Justice, v.. 3, n. 3, p. 239-261, 2008.

BATES, M. Toward an integrated model of information seeking and searching. New Review of Information Behavior Research, v. 3, 2002, p.1-16.

BELKIN, N. e VICKERY, A. Interaction in Information Systems: A Review of Research from Document Retrieval to Knowledge-Based System. London: British Library, 1989.

BROOKFIELD, S. Developing Critical Thinkers. San Francisco: Jossey-Bass, 1987.

BRYMAN, A.. Social Research Methods. 3. ed.. New York: Oxford University Press, 2008.

CAlabrese, A.; BUrgelman, J.-C.(Orgs.) Communication, Citizenship, and Social Policy: rethinking the limits of the welfare state. England: Rowman \& Littlefield Publishers, 1999.

CASTELLS, M. A sociedade em rede - A era da informação: economia, sociedade e cultura. Vol. 1. Tradução de Roneide Venâncio Majer. 6. ed. Rio de Janeiro: Paz e Terra, 2003.

CHAMBERS, R. Participatory Workshops: a Sourcebook of 21 Sets of Ideas and Activities. 4. ed.. London: Earthscan, 2005.

CHOO, C-W. A organização do conhecimento: como as organizações usam a informação para criar significado, construir conhecimento e tomar decisões. Tradução de Eliana Rocha. 2. ed. São Paulo: Senac, 2006.

COGO, D.; MAIA, J. (Orgs.). Comunicação para a cidadania. Rio de Janeiro: EDUERJ, 2006.

COHEN, J.; UPHOFF, N. Participation's place in rural development: seeking clarity through specificity. World Development, v. 8, 1980, p. 213-235. 
CORNWALL, A.. Beneficiary, Consumer, Citizen: Perspective on Participation for Poverty Reduction. Sidastudies, n. 2, 2009.

DEMO, P.. Introdução à sociologia: complexidade, interdisciplinaridade e desigualdade social. São Paulo: Atlas, 2002.

FREIRE, P. Pedagogia da autonomia: saberes necessários à prática educativa. Special Edition. São Paulo/Brazil: Paz e Terra, 2007.

HEPWORTH, M.; WALTON, G. Teaching Information Literacy for Inquiry-Based Learning. Cambridge: Woodhead Publishing, 2009.

KUMAR, S. Methods for community participation: a complete guide for practitioners. 5. ed. Warwickshire: Practical Action Publishing, 2008.

LLOYD, A. Recasting information literacy as a sociocultural practice: implications for library and information science researchers. Information Research. v.12, n. 4, 2007. Disponível em: <http://InformationR.net/ir/12-4/colis34.html.>

MACKERACHER, D. Making sense of adult learning. 2. ed. Toronto: University of Toronto Press Incorporated, 2004.

MARCHIONINI, G. Information Seeking in Electronic Environments. Cambridge: Cambridge University Press, 1988.

NICHOLAS, D.; HERMAN, E. Assessing Information Needs in the Age of the Digital Consumer. 3. ed. London: Routledge, 2009.

REY,G. Pesquisa qualitativa e subjetividade: os processos de construção da informação. São Paulo-Brasil: Pioneira Thomson Learning, 2005. 


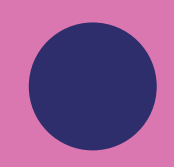

$\bullet$

○

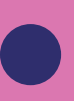

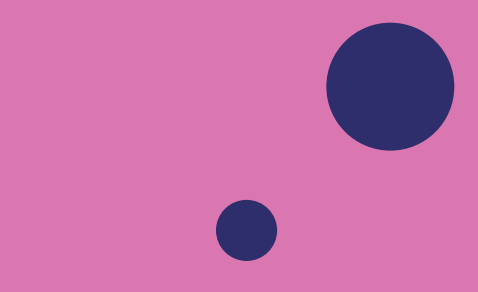

0

$.0^{\circ} \cdot \bullet$

$\cdot 0 \cdot 0$

0

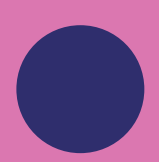

0

○

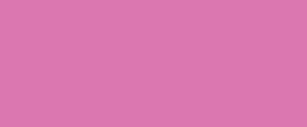

$$
.
$$

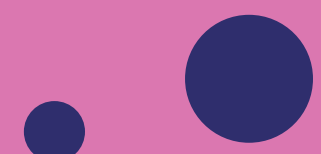$$
\text { . }
$$

$$
\text { . }
$$

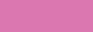

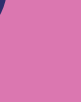




\section{PARTE IV GESTÃO DA INFORMAÇÃO E GESTÃO DO CONHECIMENTO}




\section{CAPÍTULO 9}

0

O

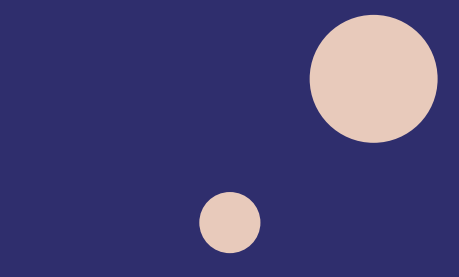

0

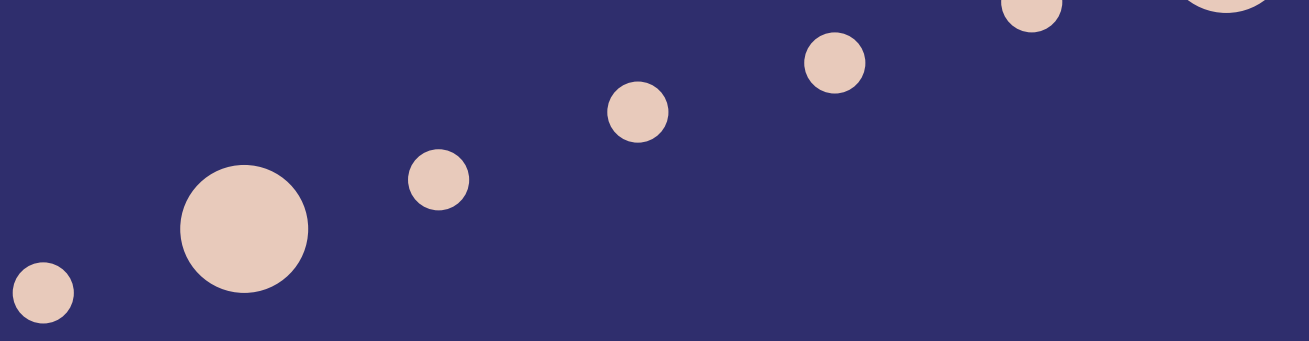

- 00

0 


\section{COMPORTAMENTO DE GESTORES DE EMPRESAS DE BASE TECNOLÓGICA NA BUSCA E NO USO DE INFORMAÇÕES}

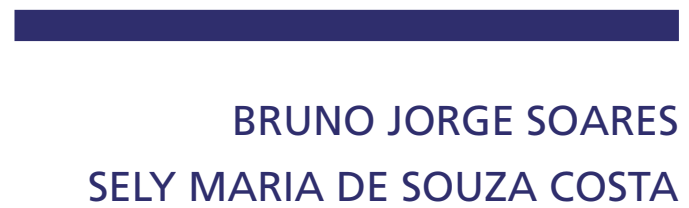

\section{INTRODUÇÃO}

A denominação "era da informação" tem sido adotada a partir da eclosão de novas tecnologias de produção, armazenamento e distribuição da informação e de seu uso crescente e intensivo pela sociedade. Um dos setores envolvidos de forma intensa com essa revolução é o setor empresarial. Nesse contexto, há maior quantidade e qualidade de informações a respeito dos atores desse mercado (clientes, concorrentes, fornecedores, parceiros, etc.), como também novas tecnologias que possibilitam às empresas coletar, armazenar e utilizar as informações sobre o mercado em que atuam de um modo mais amplo e intenso. Entretanto, a conjunção da complexidade do ambiente e a intensidade da disseminação de informações gerou certo paradoxo para os decisores das organizações. Berstein (1997, p. 202) definiu quatro desses paradoxos. O primeiro estabelece que a informação que se tem não é a informação que se quer. O segundo, argumenta o autor, estabelece que a informação que se quer não é a informação da qual se precisa. O terceiro aponta para a questão concernente à informação da qual se precisa, mas que não é a informação que se pode obter. Finalmente, o autor afirma que a informação que se pode obter custa mais do que se quer pagar.

Com efeito, as novas tecnologias de informação provocaram muitas mudanças na sociedade principalmente no setor empresarial. Tais mudanças refletem-se na maneira pela qual os indivíduos lidam com a informação, que, no caso das empresas, afeta o modo como é usada pelos gestores no seu processo de tomada de decisão e também na aquisição e incorporação do conhecimento. Essas mudanças parecem ser mais visíveis em setores empresariais que têm um relacionamento intenso com a tecnologia, sendo o segmento de empresas de base tecnológica um caso muito representativo de todo esse contexto. Portanto, o fenômeno investigado nesta 
pesquisa compreendeu a utilização de informações para negócios (representando a relação com a tomada de decisão) e de informações tecnológicas (representando a relação com a transferência de conhecimento) por parte de gestores de empresas de base tecnológica, no papel de usuários de informação. Nesse sentido, a pergunta que a pesquisa visou a responder foi: Como os gestores de empresas de base tecnológica comportam-se na busca e no uso de informações tecnológicas e para negócios?

Dentro dessa questão, foram investigados dois aspectos do comportamento informacional dos gestores de organizações de base tecnológica: a maneira pela qual se dá a busca desse tipo de informação e o modo como as informações são utilizadas pelos gestores desse tipo de empresa.

Para tanto, adotou-se como metodologia a teoria fundamentada ou grounded theory, que é apresentada como uma metodologia capaz de desenvolver modelos teóricos na área de estudos do comportamento de indivíduos em relação à informação. Tal atividade é importante na medida em que auxilia no aperfeiçoamento de processos de geração de novos conceitos teóricos. Weick (1989, p. 516) enfatiza a ideia quando ressalta que “[...] a teoria não pode ser melhorada a menos que melhoremos o processo de desenvolvimento da teoria, e nós não podemos melhorar o processo de desenvolvimento até que os descrevamos mais precisamente [...]". Nesse contexto, como esperado pelo estudo, a investigação do comportamento informacional de gestores de empresas de base tecnológica, mais especificamente empresas de software, permite uma compreensão real das atitudes dos gestores diante de vários meios e fontes de informação.

Considerando-se as questões levantadas pelo problema da pesquisa, objetivaram-se basicamente quatro tipos de ações. A primeira consiste na identificação do perfil das empresas de base tecnológica situadas no Brasil em relação a questões próprias destas. A segunda diz respeito à identificação do perfil de gestores e tomadores de decisão. A terceira relaciona-se à identificação de fontes de informação utilizadas por gestores de empresas de base tecnológica. Finalmente, a quarta ação refere-se à análise dos comportamentos dos tomadores de decisão em empresas de base tecnológica em relação à busca e ao uso de informações tecnológicas e para negócios.

As empresas de desenvolvimento e comercialização de software foram escolhidas como representantes da categoria "base tecnológica" na presente pesquisa. A escolha justifica-se pelo papel importante da informação na constituição desse tipo de empresa. De fato, a informação é um aspecto presente tanto como matéria-prima quanto como produto, pois o produto ou serviço desenvolvido pela empresa consiste essencialmente em um conhecimento específico obtido pelo processamento de informações. Nesse sentido, as empresas de desenvolvimento e comercialização de software (EDCS) tendem a utilizar intensamente tanto a tecnologia quanto a informação na produção de seus produtos e serviços. 


\section{METODOLOGIA}

Uma grande parte dos estudos de usuários está baseada em levantamentos realizados por meio de questionários estruturados e análises estatísticas simples. Esses levantamentos geralmente são feitos com usuários de centros de informação/bibliotecas específicos e têm o objetivo de identificar as necessidades e o uso da informação por parte desses indivíduos.

A contribuição dos estudos quantitativos para o conhecimento do comportamento de indivíduos em relação à informação tem sido questionada quanto à generalização dos resultados e sua aplicação no planejamento de serviços de informação. A análise de Wilson (1981, p. 12) corrobora essa posição, quando o autor pondera que:

A grande maioria dos estudos de "necessidades de informação" foi conduzida sob uma concepção relativamente grosseira do "método científico", usando questionários autopreenchidos como o principal instrumento de coleta de dados. Pesquisadores sociais de muitos tipos se desencantaram com este modelo de pesquisa e estão se voltando cada vez mais para a consideração de "pesquisa qualitativa" como alternativa completa à pesquisa quantitativa ou, pelo menos, como preliminar [...] A pesquisa qualitativa parece particularmente apropriada ao estudo das necessidades subjacentes ao comportamento de busca de informação.

Em relação aos estudos de usuários, a preocupação com o método qualitativo é o desenvolvimento de conceitos teóricos em vez de uma aplicação de conceitos preexistentes. Nesse sentido, uma das abordagens qualitativas mais importantes é a teoria fundamentada, desenvolvida por Glaser e Strauss (1967), que tem como objetivo principal o descobrimento da teoria a partir dos dados coletados. A utilização desse tipo de abordagem pode ser verificada nas pesquisas de Ellis et al. (1993) e Ellis e Haugan (1997), nas quais os autores estudaram o comportamento de pesquisadores (desde engenheiros a cientistas sociais) em relação à busca de informações. Tais pesquisas sustentaram a formulação de um modelo de comportamento dos sujeitos pesquisados. Ellis (1993, p. 484) também indica que essa abordagem é recomendada quando o objetivo da pesquisa é desenvolver uma consciência das percepções que indivíduos e grupos têm do seu ambiente de informação e o papel da informação em suas atividades.

Além disso, segundo Ellis (1993, p. 483), a teoria fundamentada tem sido aplicada em estudos empíricos nas atividades de informação e comunicação de vários outros grupos, como, por exemplo, estudos referentes à comunicação sobre poluição para fazendeiros da Dinamarca, ao uso da informação em decisões tomadas por gerentes de médias empresas e até aos padrões de comunicação de dentistas. 
A teoria fundamentada consiste em uma abordagem relativamente nova na área de Ciência da Informação. Barney Glaser e Anselm Strauss foram os precursores dessa abordagem teórica com o livro The Discovery of Grounded Theory: Strategies for Qualitative Research, publicado no ano de 1967. A partir do lançamento do livro, a abordagem que se originou na área de saúde difundiu-se também nas Ciências Sociais e na Ciência da Informação.

No Brasil, a teoria fundamentada tem sido aplicada em várias áreas do conhecimento. Há trabalhos nas disciplinas da saúde, como Enfermagem, área de origem da teoria fundamentada (SANTOS, 1997; OLIVEIRA, 1998; KIMURA, 1999; GOMES, 2000; ALVAREZ, 2001), e na Psicologia (SILVA, 1998; MARTINS, 1999; BERTHOUD, 2000). Nas disciplinas sociais, há os trabalhos na área de Administração (VERLE, 1999), Comunicação (FOSSATI, 1998) e Ciência da Informação (SIMÕES, 1997).

Glaser e Strauss (1967, p. 34) argumentam que normalmente há crenças de que a aplicação das teorias formais (com maior grau de generalidade) em uma determinada área específica irá fornecer a maioria ou a totalidade de conceitos e hipóteses necessários para a explicação de um determinado fenômeno. Como consequência disso, o pesquisador tende a "forçar" os dados para se adequarem aos pressupostos teóricos e também a negligenciar conceitos e hipóteses que possam surgir. Na opinião desses autores, a teoria fundamentada permite que os conceitos substantivos e as hipóteses surjam primeiro, dentro deles próprios, e não como resultado de uma formulação teórica preestabelecida. $\mathrm{O}$ trabalho do pesquisador ao analisar determinado fenômeno social é gerar uma teoria a partir da observação específica desse fenômeno e não a aplicação de uma teoria preestabelecida para explicá-lo.

Primeiramente, a visão da teoria como um processo e não um produto final é mais coerente com a realidade da interação social e seu contexto estrutural (GLASER; STRAUSS, 1967, p. 32). Uma teoria deve ser encarada como somente uma etapa de um processo explanatório de determinado fenômeno social. No caso da presente pesquisa, não se pretende "esgotar" a discussão do comportamento humano relacionado à busca e ao uso de informações. Ao contrário, a investigação aqui apresentada visa a contribuir para maior entendimento do comportamento informacional humano: estudando outra comunidade de usuários de informação (gestores de empresas de base tecnológica) na busca e no uso de informações tecnológicas e para negócios.

Outro ponto a ser destacado é a relação entre os dados ${ }^{1}$, os conceitos e a teoria. Na teoria fundamentada, as atividades de coleta de dados, elaboração de conceitos e formulação de

1 Dados são entendidos nesta pesquisa como o resultado da observação de um determinado fenômeno social. Podem assumir a forma das declarações em uma entrevista ou até diários, cartas e documentos de dado ator do fenômeno social. 
teoria são realizadas de forma simultânea. Também em relação à formulação de hipóteses de pesquisa, essa atividade é precedida pela análise dos dados.

Um último aspecto da metodologia proposta pela teoria fundamentada indica a "ignorância" de teorias existentes como um modo de evitar pressupostos na análise do fenômeno. Este parece, talvez, ser um dos pontos importantes da teoria fundamentada: a partir da não utilização prévia de conceitos teóricos existentes acerca do fenômeno social a ser investigado, pode-se alcançar um novo entendimento.

No que diz respeito à presente pesquisa, o processo de coleta de dados não foi executado à luz dos modelos teóricos das Ciências da Informação ou da Administração. Isso se justifica pela intenção de permitir que os conceitos explicativos do comportamento de gestores na busca e no uso de informações fossem gerados a partir da sua investigação. Procurou-se utilizar, por conseguinte, modelos teóricos explicativos do comportamento informacional do indivíduo na etapa de discussão dos dados. Essa contribuição ocorre dentro do modelo da teoria fundamentada em dois níveis teóricos (GLASER; STRAUSS, 1967, p. 33). O primeiro é composto pelas teorias substantivas, as quais são mais empíricas e têm um intenso vínculo com o fenômeno social observado em uma determinada pesquisa. O segundo é composto pelas teorias formais, as quais são mais conceituais, na medida em que não se restringem a um determinado objeto de investigação. De fato, os autores apontam que as teorias substantivas e formais existem em níveis distinguíveis de generalidade, enquanto a teoria formal difere somente em termos de gradação. No caso deste estudo, a teoria desenvolvida é substantiva. Isso significa que se buscou criar um modelo teórico do comportamento de gestores de EDCS na busca e no uso de informações tecnológicas e para negócios.

Charmaz (2000, p. 515) pergunta: “Como fazemos a teoria fundamentada?”. A própria autora responde, afirmando que a análise começa cedo: "nós os teoristas fundamentados codificamos os dados assim que coletamos”. Isso explica a realização da análise de dados desde o começo das entrevistas.

A aplicação da teoria fundamentada pode ser dividida em três grandes atividades - a coleta, a codificação e a análise dos dados -, com um estreito relacionamento entre essas fases. De fato, essas atividades ocorrem de maneira simultânea, isto é, na primeira observação de uma determinada realidade social, há a coleta de dados, os quais são codificados e também analisados. A figura 1 demonstra a relação entre esses processos ao longo da realização de uma pesquisa. 
Figura 1 - Etapas de coleta, codificação e análise dos dados na realização de uma pesquisa

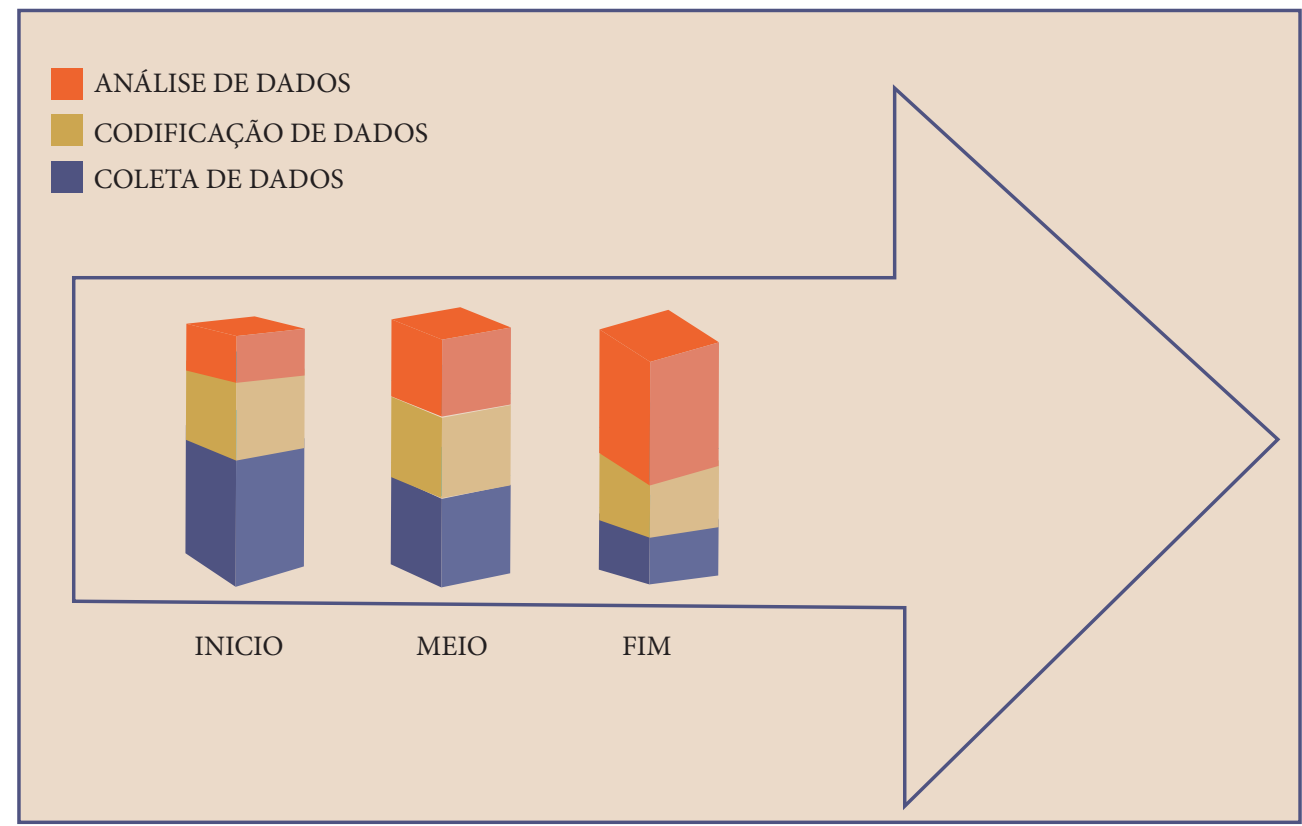

Fonte: Adaptado de Glaser e Strauss (1967).

Com base na figura 1, percebe-se a relação entre a coleta, a codificação e a análise de dados sob dois enfoques. Primeiramente, as três atividades ocorrem do início ao fim do projeto de pesquisa. Em segundo lugar, nota-se uma variação no tempo destinado à execução de cada atividade: no início do processo de pesquisa, a coleta de dados prepondera sobre as outras atividades, alterando-se no final, quando a preponderância é da análise dos dados.

A seguir, é detalhada cada atividade realizada neste estudo de acordo com as orientações metodológicas da teoria fundamentada.

\subsection{Coleta de dados}

As fontes que geram os dados em uma pesquisa assumem grande importância na aplicação da teoria fundamentada. Glaser e Strauss (1967) indicam duas grandes fontes de dados para o desenvolvimento de pesquisa que envolva a teoria fundamentada: a pesquisa bibliográfica e o trabalho de campo. Os dados resultantes da primeira fonte de dados, a pesquisa bibliográfica, estão presentes no item anterior do presente trabalho (análise de literatura). Neste item, será apresentado um método específico para a coleta de dados: a entrevista pessoal. 
Para Kvale (1996, p. 29), a entrevista tem como propósito obter descrições do mundo real (world life) do entrevistado, visando a interpretar o significado do fenômeno estudado. Para o autor, um dos aspectos importantes da entrevista ${ }^{2}$ em uma pesquisa qualitativa é a investigação do dia a dia dos entrevistados e a sua relação com essa questão. No caso do presente trabalho, buscou-se na entrevista levantar informações a respeito do comportamento dos gerentes de empresas de base tecnológica na busca e no uso de informações tecnológicas e para negócios. Neste estudo, a entrevista visou identificar tanto as práticas desses atores no fenômeno social investigado quanto os significados que eles atribuem a essas práticas. Em outras palavras, investigam-se tanto os comportamentos dos gerentes em relação à busca e ao uso da informação como também os significados atribuídos por eles a esses comportamentos.

\subsection{Codificação dos dados}

A codificação é uma das principais atividades no uso da teoria fundamentada como abordagem metodológica. Strauss e Corbin (1998, p. 13) observam que os procedimentos de codificação têm os seguintes propósitos:

- Construir/gerar ao invés de testar/verificar a teoria.

- Prover ferramentas analíticas aos pesquisadores para lidar com grandes massas de dados.

- Auxiliar os pesquisadores a considerar significados diferentes para o fenômeno investigado.

- Ser ao mesmo tempo sistemático e criativo.

- Identificar, desenvolver e relacionar os conceitos que são os blocos que auxiliam na construção da teoria.

Segundo Strauss e Corbin (1998), os procedimentos de codificação dividem-se em: codificação aberta, codificação axial e codificação seletiva. Essa classificação tem o propósito de acentuar aspectos muito significativos no processo de codificação.

A codificação aberta pode ser descrita como "o processo analítico pelo qual conceitos são identificados e suas propriedades e dimensões são descobertos nos dados" (STRAUSS; CORBIN, 1998, p. 101). Um exemplo disso é a codificação aberta da transcrição da gravação de uma

2 A partir desse ponto da pesquisa, o simples termo "entrevista" corresponderá a essa concepção de entrevista em profundidade ou não/semiestruturada. 
entrevista pessoal, quando o pesquisador examina minuciosamente, linha por linha, a massa qualitativa de dados. Nesse exame, deve-se assegurar que o pesquisador codifique de maneira irrestrita todos os dados disponíveis e nomeie com um rótulo conceitual e representativo cada incidente presente no fenômeno investigado. Assim, o objetivo da codificação aberta é "descobrir, nomear e caracterizar o fenômeno de acordo com suas propriedades e dimensões" (STRAUSS; CORBIN, 1998, p. 206).

A codificação axial é definida como o processo de relacionar as categorias às suas subcategorias. Esse processo é assim definido porque a codificação ocorre ao redor dos eixos da categoria, conectando-a ao nível de propriedades e dimensões (STRAUSS; CORBIN, 1998, p. 123). Desse modo, o relacionamento das categorias com as respectivas subcategorias permite o início de explicações mais precisas e completas do fenômeno investigado.

$\mathrm{Na}$ especificação de uma categoria, a codificação axial envolve os seguintes passos:

- Delinear as propriedades de uma categoria e suas dimensões.

- Identificar a variedade de condições, ações/interações e consequências associadas com o fenômeno.

- Relacionar a categoria com suas subcategorias por meio de enunciados que denotam essa relação.

- Procurar nos dados indícios que denotem como as categorias mais importantes podem estar relacionadas entre si.

Como último processo da codificação, tem-se a codificação seletiva, que corresponde ao "processo de integrar e refinar a teoria”. Nas palavras de Strauss e Corbin (1998, p. 43):

Na codificação aberta, o analista está interessado na geração de categorias e suas propriedades e então procura determinar como as categorias variam dimensionalmente. Na codificação axial, as categorias são sistematicamente desenvolvidas e ligadas a subcategorias. No entanto, isso não é feito até que as categorias principais sejam finalmente integradas para formar um amplo esquema teórico, em que as descobertas da pesquisa tomam a forma da teoria. Codificação seletiva é o processo de integrar e refinar categorias.

A integração corresponde à organização das categorias em torno de um conceito central para a explicação do fenômeno. Com a obtenção desse conceito central, há o refinamento quando o pesquisador "apara" os excessos e suplementa as categorias pouco desenvolvidas. Na figura 2, apresenta-se uma ilustração a respeito da codificação. 
Figura 2 - Etapas da codificação: aberta, axial e seletiva
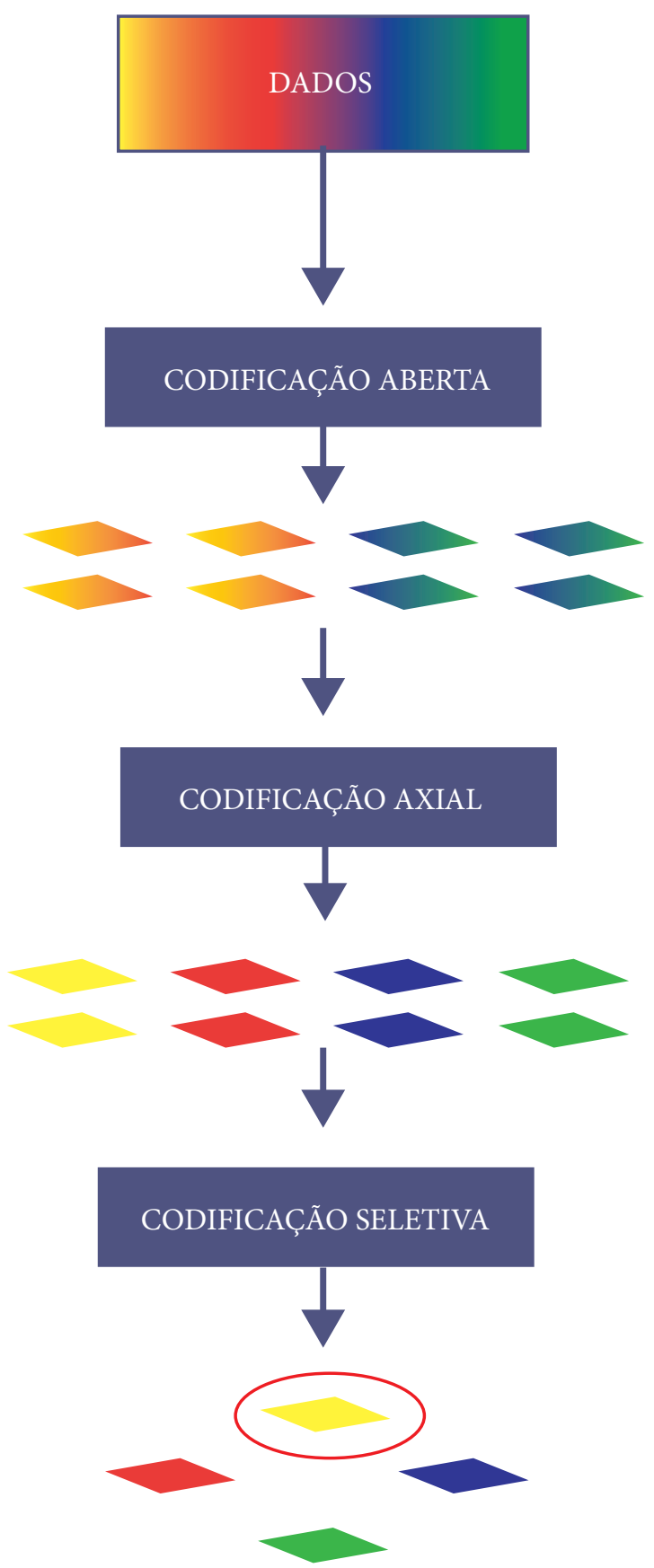

Fonte: Adaptado de Strauss e Corbin (1998). 


\subsection{Análise dos dados}

Glaser e Strauss (1967, p. 101) apresentam duas posturas tradicionais de análise de dados qualitativos em pesquisas sociais. Na primeira, o pesquisador, antes de analisar os dados qualitativos, tenta convertê-los em quantitativos. A outra postura tradicional de análise, por sua vez, implica em uma atitude relapsa do pesquisador em relação ao processo de codificação. Nesse caso, o pesquisador visa à geração de novos conceitos e ideias e, assim, não se entrega à pré-tarefa de codificação para analisar os dados. Glaser e Strauss (1967, p. 102) recomendam a união entre essas duas posturas de análise, tal como está representado na figura 3.

Figura 3 - Modelos tradicionais de análise

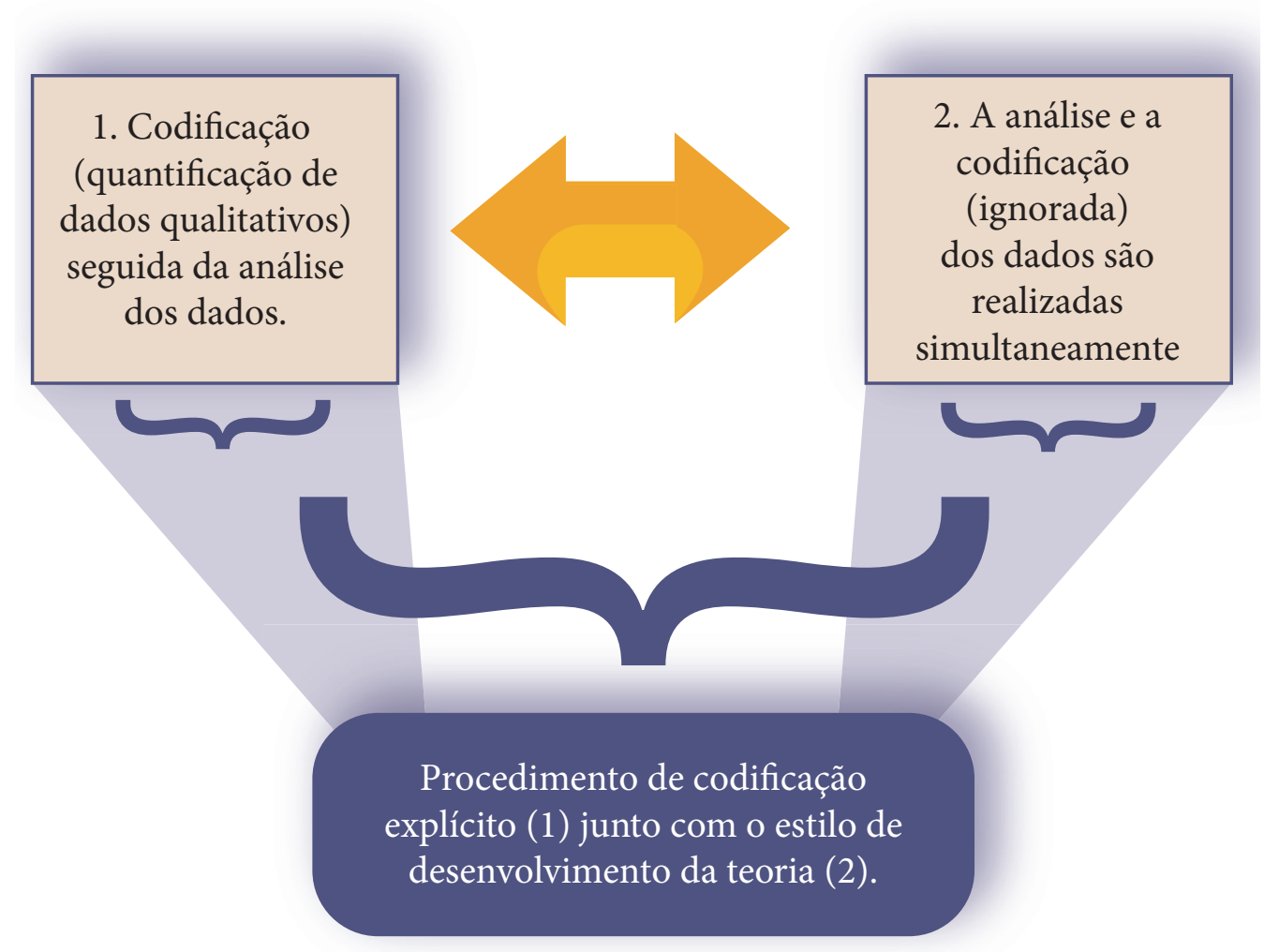

Fonte: Adaptado de Glaser e Strauss (1967).

Como pode ser observado, a proposta de modelo analítico da teoria fundamentada é a integração das posturas analíticas tradicionais de dados qualitativos, constituída de uma fase explícita de codificação dos dados que ocorre simultaneamente com a elaboração de categorias e conceitos e, finalmente, da teoria. 
O intercâmbio equilibrado entre essas etapas é obtido pelo emprego de duas atividades primordiais na análise dos dados: memoing ou ato de escrever notas e amostragem teórica. Essas duas atividades estão presentes na maioria das reflexões sobre a teoria fundamentada e assim constituem um ponto comum para os pesquisadores que adotam essa metodologia.

Para Strauss e Corbin (1998, p. 217-218), os memos são os registros do pesquisador, de sua análise, pensamentos, interpretações, questões e direções para a coleta de dados. Os autores caracterizam a produção desses memos em três momentos: codificação, elaboração teórica e procedimentos operacionais. Nota-se que essa divisão tem somente a finalidade de destacar essas atividades e a necessidade de registrá-las em memos. Tanto Strauss e Corbin (1998) quanto Glaser (1998) ressaltam a liberdade do pesquisador ao escrever suas notas.

Outra atividade importante na análise dos dados e na construção da teoria é a amostragem teórica. Glaser e Strauss (1967, p. 45) a definem como o processo por meio do qual o pesquisador realiza simultaneamente a coleta, a codificação e a análise dos resultados e decide quais são os próximos dados a serem coletados. A amostragem teórica segue os critérios de propósito teórico e relevância (GLASER e STRAUSS, 1967, p. 48). Esses critérios tendem a criar um controle mais sistemático, relevante e impessoal sobre os dados do que os controles pré-planejados, rotinizados e arbitrários dos estudos projetados para obtenção de fatos e testes de hipóteses.

Strauss e Corbin (1998, p. 201) definem a amostragem teórica como o processo de obtenção dos dados conduzido pelos conceitos derivados da teoria em desenvolvimento. Esses conceitos estão baseados no ato constante de fazer comparações que irão proporcionar oportunidades de descobrir variações entre os conceitos e dar densidade às categorias em termos de suas propriedades e dimensões. Durante esse processo, o pesquisador procura indicadores (eventos ou acontecimentos) representativos dos conceitos teóricos relevantes.

Para Charmaz (2000, p. 219), os pesquisadores usam a amostragem teórica para desenvolver as categorias e torná-las mais definitivas e úteis. Assim, o objetivo da amostragem é refinar ideias, e não aumentar o número da amostra original. A amostragem teórica nos ajuda a encontrar os limites de nossas categorias, detalhar exatamente seu ajuste e relevância. Glaser (1998, p. 157) postula que a amostragem teórica tanto é dirigida pela teoria construída quanto também direciona a emergência de novos conceitos teóricos.

No caso da presente pesquisa, a amostragem teórica foi realizada da seguinte forma:

- Entrevistas iniciais: o pesquisador obtém descrições gerais dos entrevistados, tendo em vista o seu interesse em gerar o maior número de categorias possíveis. 
- Entrevistas finais: o pesquisador direciona a entrevista para o desenvolvimento e a saturação das categorias provenientes dos conceitos obtidos nas primeiras entrevistas.

Como se pode observar, nas primeiras entrevistas o pesquisador adquire conceitos explicativos iniciais para o fenômeno que está sendo investigado. De posse desses conceitos, o pesquisador realiza uma segunda rodada de entrevistas, tentando averiguar e comparar os conceitos obtidos nas primeiras entrevistas. Assim, para as entrevistas seguintes, o pesquisador condensa novamente os dados obtidos nas entrevistas anteriores, com o intuito de averiguá-los e compará-los.

Para encerrar a amostragem teórica, utiliza-se como parâmetro a saturação teórica, na qual são exauridas as categorias pertinentes ao fenômeno investigado. Glaser e Strauss (1967, p. 61) observam que isso ocorre somente quando nenhuma categoria nova parece emergir, isto é, quando a categoria já está bem desenvolvida no que se refere a suas dimensões e relacionamentos.

Para o presente estudo, foram entrevistados 15 gestores de empresas de desenvolvimento e comercialização de software associadas ao núcleo TecSoft. A interação entre coleta e análise dos dados proposta pela teoria fundamentada possibilitou a alteração do instrumento de coleta ao longo do processo de obtenção dos dados. A primeira modificação ocorreu após a realização de duas entrevistas nas quais se alterou a ordem das questões iniciais, proporcionando maior fluência às entrevistas. Além disso, foram incluídas subquestões a algumas questões gerais com o intuito de detalhar de maneira mais adequada os tópicos abordados.

A outra modificação ocorreu após a realização da sexta entrevista, na qual as declarações do entrevistado foram muito "ricas" para a explanação do comportamento de busca e uso de informações. Nesse sentido, foram incluídas outras subquestões que detalhavam as respostas às questões gerais elaboradas no roteiro inicial. Com essa reformulação, o roteiro não sofreu mais modificações e foi utilizado até a conclusão da $15^{\mathrm{a}}$ entrevista.

A orientação para tais modificações surgiu da própria codificação e análise dos dados obtidos nas entrevistas, isto é, os dados obtidos nas entrevistas iniciais foram codificados e analisados, estruturando uma série de relacionamentos entre as categorias obtidas que foram especificadas nas entrevistas seguintes. Desse modo, conforme orientação da metodologia, os critérios para alterações surgiram a partir da codificação e da análise das próprias entrevistas, ou seja, dos próprios dados.

No caso do presente estudo, após a realização de cada entrevista, houve o processo de transcrição, no qual a entrevista gravada foi transformada em um arquivo de texto que foi submetido a um exame minucioso linha a linha, no qual eram atribuídos rótulos conceituais aos dados obtidos. Todo esse processo de codificação foi sustentado pela utilização de um software de 
tratamento e análise de dados qualitativo, o Nudist (Non-numeric Unstructured Data, Index Searching and Theorizing), que permitiu a seleção de trechos específicos das entrevistas, os quais eram transformados em categorias. Essa categorização foi realizada durante o processo de coleta e análise de dados.

Assim, o processo de codificação deu-se da seguinte forma:

- Codificação livre: os códigos/rótulos foram atribuídos aos dados de cada entrevista individualmente.

- Codificação estruturada: todos os códigos criados foram organizados em uma árvore de codificação que foi se estruturando a partir da realização das entrevistas e do acúmulo de códigos.

Em suma, todo o processo de codificação proporcionou um total de 1.080 códigos organizados dentro da estrutura de codificação axial. A codificação seletiva, que constitui o terceiro passo e compreende o processo de desenvolver e refinar essa grande massa de categorias, foi guiada pelo objetivo geral da pesquisa, que é a elaboração do modelo de comportamento informacional dos gestores.

\section{RESULTADOS}

Conforme as prescrições da teoria fundamentada, o processo de análise teve início com a realização da primeira entrevista, sua transcrição e codificação. A utilização de memos, isto é, anotações do pesquisador com suas reflexões e considerações a respeito dos dados coletados, iniciaram o processo de análise na presente pesquisa. Os memos foram criados e armazenados junto às categorias elaboradas durante o processo de codificação no Nudist.

Outro ponto interessante diz respeito à amostragem teórica, na qual os dados coletados, codificados e analisados eram os guias para as etapas seguintes na coleta de dados. Isso foi feito a partir da escolha dos entrevistados. As primeiras quatro entrevistas foram realizadas com gestores das áreas técnica, comercial, administrativa e da direção-geral das empresas. Com base nos resultados dessas entrevistas, nos objetivos da pesquisa e nas características da amostra, optou-se por concentrar as entrevistas nos gestores da área de desenvolvimento e, principalmente, nos gestores responsáveis pela direção-geral das empresas.

Observe-se que as quatro classes de tamanhos de empresas foram incluídas na amostra: duas microempresas, sete empresas pequenas, três médias empresas e três grandes empresas. As atividades das empresas visitadas estão ligadas fundamentalmente ao desenvolvimento e 
à comercialização de softwares próprios e de terceiros. Também há empresas que incluem hardware no desenvolvimento e comercialização de software (próprio ou de terceiros).

Os cargos ocupados pelos gestores entrevistados podem ser divididos em cinco áreas: desenvolvimento de software, gerência de tecnologia, comercialização de software, administração e finanças e direção-geral da empresa. Do total de gestores, foram entrevistados quatro diretores de desenvolvimento, um gerente de tecnologia, dois gestores da área comercial, dois gestores administrativo-financeiros e seis diretores-executivos.

Tendo por base a metáfora cognitiva das organizações como processadoras de informação, o ambiente informacional do gestor das EDCS é composto de quatro principais fontes produtoras de informação, formadas por atores que produzem/emitem informação. A primeira fonte conceituada como produtora de informação é constituída de clientes. A segunda fonte de informação é composta de fabricantes (fornecedores e parceiros). A terceira, os concorrentes, são representados por outras empresas ou indivíduos que desenvolvem e comercializam software, atendendo o mesmo tipo de clientes. A quarta fonte de informação é representada por produtores profissionais, tais como universidades, institutos de pesquisa do mercado de TI e associações de classe. Embora diferenciados desses quatro tipos de fontes produtoras de informação, foram incluídas, ainda, outras fontes, tais como livros, revistas e jornais. A ordem de apresentação por parte dos atores está baseada em um continuum que se estende desde o marco de um processo não intencional de produção de informação até o marco de um processo intencional de produção de informação. A figura 4 ilustra a questão da ordem de apresentação da informação.
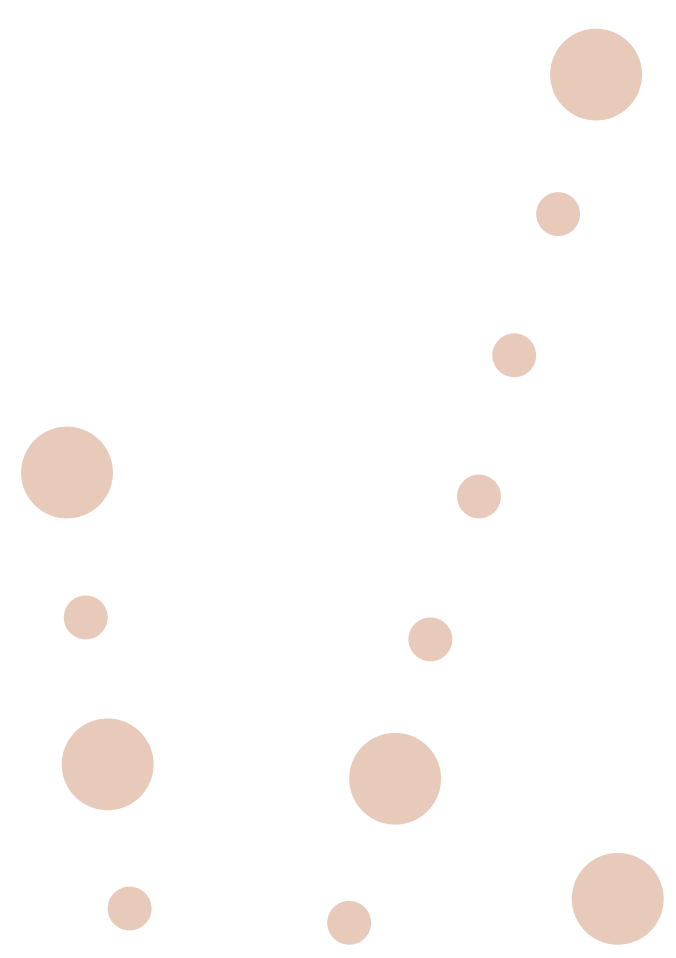
Figura 4 - Intervalo de produção de informações

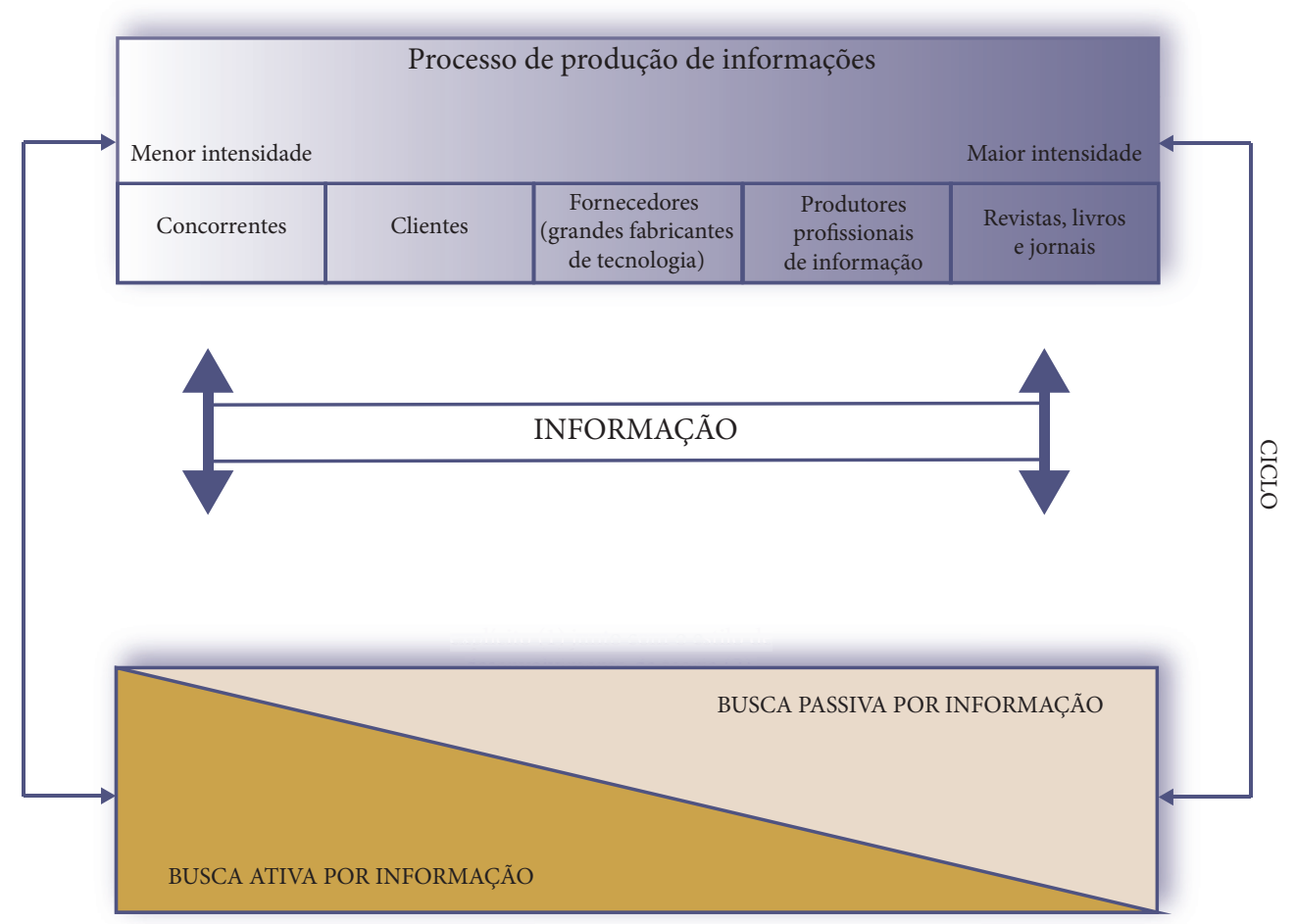

Fonte: Elaboração dos autores (2018).

A seguir, serão apresentados detalhes da produção ou emissão de informações desses atores que participaram da formação de um ambiente de uso de informação para os gestores das EDCS. 
A figura 5 ilustra o fluxo de informação entre os clientes e as EDCS. Esse fluxo pode ser discutido de acordo com a aquisição de soluções de software

Figura 5 - Fluxo de informação empresa versus cliente.

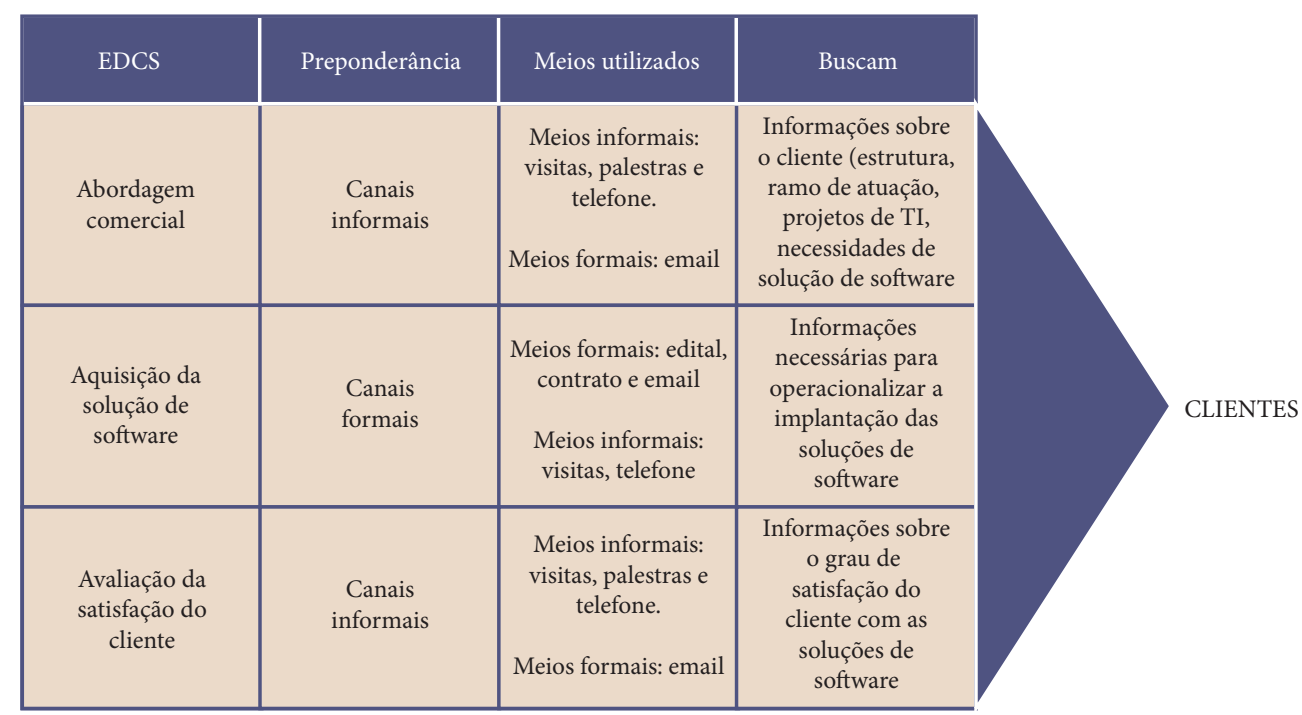

Fonte: Elaboração dos autores (2018).

O detalhamento das informações produzidas por esses atores é fundamental para a compreensão do comportamento dos gestores, visto que o fluxo dessas informações em direção ao gestor pode ser considerado como busca passiva ou aquisição não intencional de informação. O Quadro 1 representa uma matriz de relacionamento entre as quatro categorias de atores produtores informacionais discutidas anteriormente e a empresa de comercialização e desenvolvimento de software. 
Quadro 1 - Relação entre os produtores informacionais e a empresa

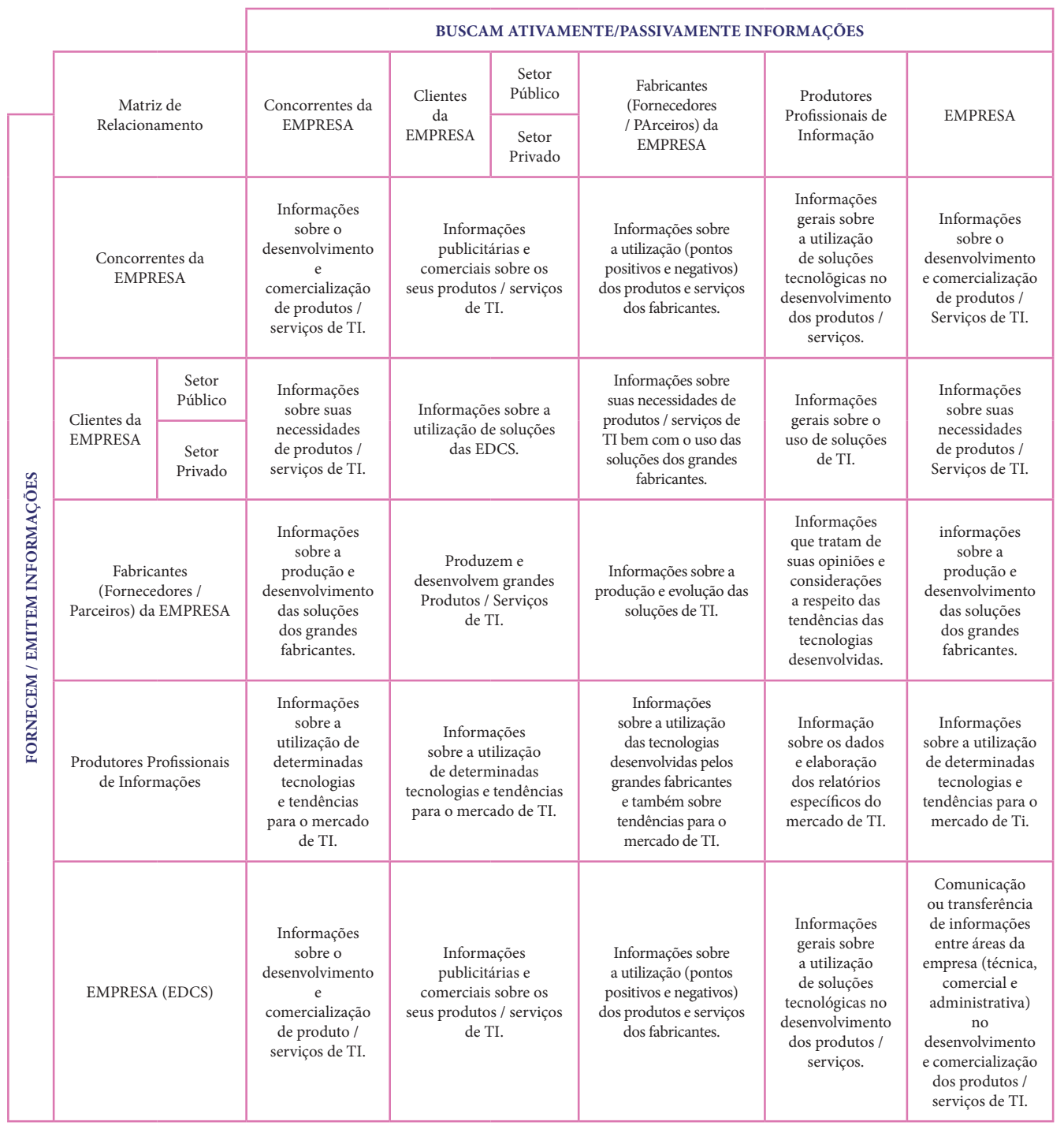

Fonte: Elaboração dos autores (2018).

A discussão das fontes de informação mostrou-se questão relevante na explanação do comportamento informacional do gestor, principalmente no que diz respeito ao fluxo de informação entre fontes produtoras de informação, nomeadamente clientes, concorrentes, fornecedores, parceiros/produtores e as EDCS. Tal fluxo constitui o ambiente informacional no qual gestores buscam e usam informações para o desempenho de suas funções. Canais de acesso à informação e comportamento na busca e no uso da informação completaram as análises, que 
permitiram a proposição do modelo resultante do trabalho de pesquisa relatado aqui, a partir da aplicação da teoria fundamentada. É o que se apresenta na seção de conclusão a seguir.

\section{CONCLUSÃO}

A presente pesquisa visou à proposição de um modelo geral de comportamento informacional de gestores de empresas de base tecnológica na busca e no uso de informações tecnológicas e para negócios no ambiente informacional em que atuam (figura 6). Nesse sentido, as atividades desenvolvidas por gestores de EDCS, o contexto e os papeis por eles exercidos e o próprio processo de comunicação nas EDCS influenciam o comportamento desses na busca e no uso de informação.

Os principais elementos do modelo resultante da pesquisa são: fontes de informação, canais de acesso à informação e comportamento do gestor na busca e no uso de informação. Importante notar variações das possibilidades de manifestação do comportamento informacional à medida que se altera a função e a EDCS em que atua. No modelo geral, as funções dos gestores não estão mostradas porque um modelo único não é suficiente para ilustrar a influência dessas no comportamento informacional dos gestores.

A abordagem metodológica com base na teoria fundamentada assegura análise rigorosa e abrangente de resultados obtidos em pesquisas, principalmente em virtude do tipo de codificação utilizada na análise dos dados obtidos. De fato, o uso da teoria fundamentada 
proporciona nova perspectiva aos estudos de usuários de informação na Ciência da Informação. Ademais, a integração de conceitos da Ciência da Informação e da Administração fornece aporte teórico importante para outros estudos do comportamento informacional de gestores.

Figura 6 - Modelo de comportamento do gestor em relação à busca e ao uso de informações

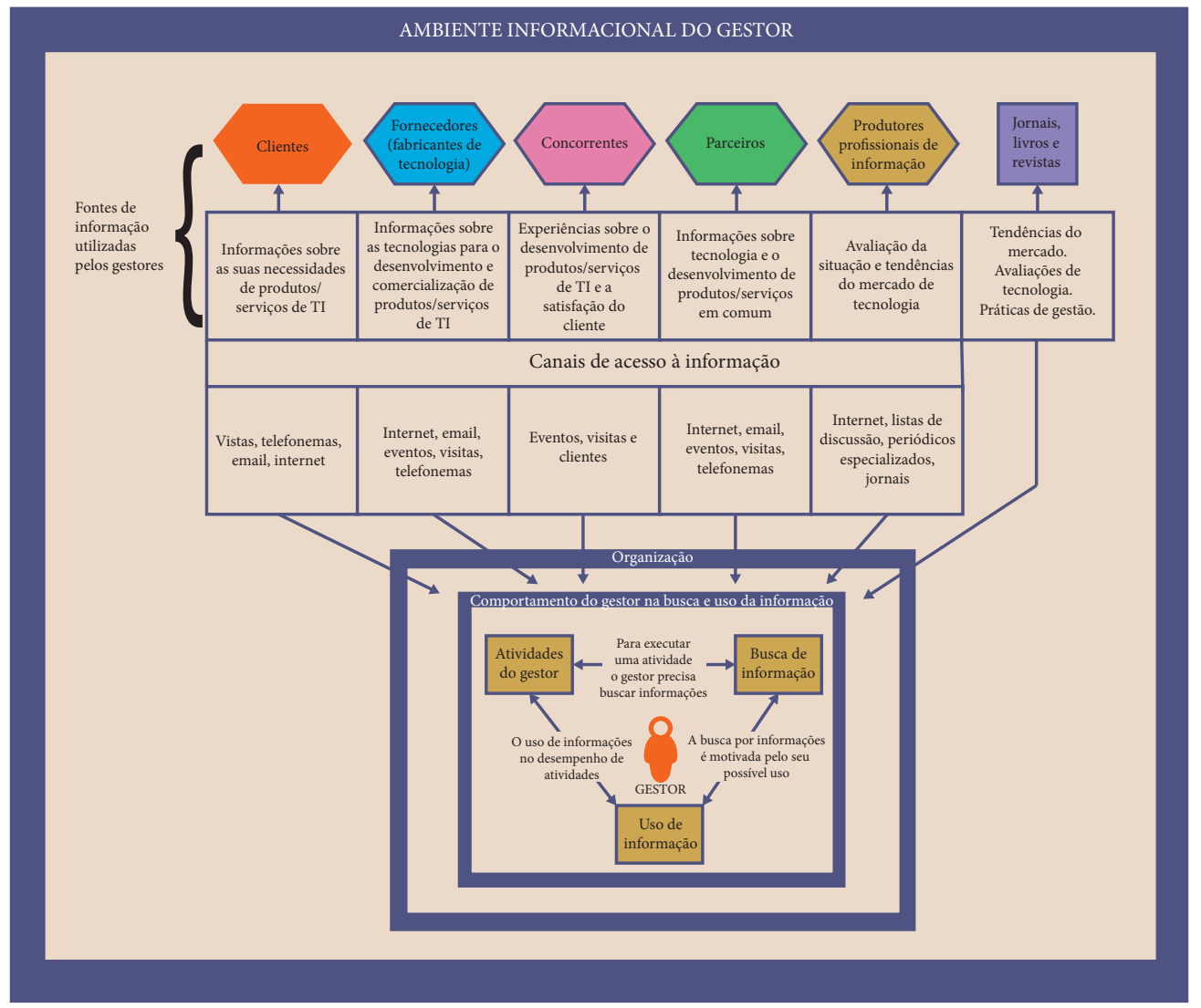

Fonte: Elaboração dos autores (2018).

\section{REFERÊNCIAS}

ALVAREZ, A. M. Tendo que cuidar: a vivência do idoso e de sua família cuidadora no processo de cuidar e ser cuidado em contexto familiar. 2001. $186 \mathrm{f}$. Tese (Doutorado) - Curso do Programa de Pós-graduação em Enfermagem, Centro de Ciências da Saúde, Universidade Federal de Santa Catarina, Florianópolis, 2001. Disponível em: <http://repositorio.ufsc.br/xmlui/handle/123456789/81693>. Acesso em: 16 jul. 2018. 
BERSTEIN, P. Desafio aos deuses: a fascinante história do risco. Rio de Janeiro: Campus, 1997. $390 \mathrm{p}$.

BERTHOUD, C. M. Re-significando a parentalidade: desafio para toda uma vida. 2000. 368 f. Tese (Doutorado) - Curso de Programa de Pós-graduação Psicologia, Pontifícia Universidade Católica de São Paulo, São Paulo, 2000.

CHARMAZ, Kathy. Grounded theory: objectivist and contructivist methods. In: DENZIN, N. K.; LINCOLN, Y. (Ed.). The handbook of qualitative research. 2. ed. Thousand Oaks, Ca: Sage Publications, 2000. p. 509-535. Disponível em: <http:/qualquant.org/wp-content/uploads/text/ Charmaz\%202000.pdf>. Acesso em: 16 jul. 2018.

ELLIS, D. Modeling the information-seeking patterns of academic researchers: a grounded theory approach. Library Quarterly, The University of Chicago Press, v. 63, n. 4, p.469-486, Oct. 1993. Disponível em: <https://www.jstor.org/stable/4308867>. Acesso em: 16 jul. 2018.

ELLIS, D.; COX, D.; HALL, K. A comparison of the information seeking patterns of researchers in the physical and social sciences. Journal of Documentation, v. 49, n. 4, p. 356-369, 1993.

ELLIS, D.; HAUGAN, M. Modeling the information-seeking patterns of engineers and research scientists in an industrial environment. Journal of Documentation, v. 53, n. 4, p. 384-403, 1997.

FOSSATI, P. M. Comunicação persuasiva na Internet: o caso do Jurerê Praia Hotel. 1998. 178 f. Dissertação (Mestrado), Pontifícia Universidade Católica de Porto Alegre, Porto Alegre, 1998. Disponível em: <http://repositorio.ufsc.br/xmlui/handle/123456789/81693>. Acesso em: 16 jul. 2018.

GLASER, B. G. Doing grounded theory: issues and discussions. Mill Valey, Ca: Sociology Press, 1998.

GLASER, B. G.; STRAUSS, A. L. The discovery of grounded theory: strategies for qualitative research. New York: Aldine, 1967.

GLAZER, R. Marketing in an information-intensive environment: strategic implications of knowledge as an asset. Journal of Marketing, v. 55, p. 1-19, 1991.

GOMES, L. C. Tendo que vencer o próprio preconceito: a mulher enfermeira cuidando da mulher que provoca aborto. 2000. 93 f. Dissertação (Mestrado), Universidade do Estado do Rio de Janeiro, Faculdade de Enfermagem, Rio de Janeiro, 2000.

KIMURA, A.F. Enfrentando desafios de transformações para vir a ser mãe e profissional. 1999. $202 \mathrm{f}$. Tese (Doutorado), Universidade de São Paulo, Escola de Enfermagem, São Paulo, 1999. 
KVALE, S. Interviews: an introduction to qualitative research interviewing. Thousand Oaks CA : Sage, 1996.344 p.

MARTINS, M. M. Tempo e trabalho: um estudo psicossocial com trabalhadores que têm horário fixo e flexível em uma empresa industrial de médio porte. 1999. 280 f. Dissertação (Mestrado), Pontifícia Universidade Católica de São Paulo, Programa de pós-graduação em Psicologia Social, São Paulo, 1999.

OLIVEIRA, I. Vivenciando com o filho uma passagem difícil e reveladora: a experiência da mãe acompanhante. 1998. 162 f. Tese (Doutorado), Universidade de Säo Paulo, Escola de Enfermagem, São Paulo, 1998.

SANTOS, L. H. P. Vivendo em constante conflito: o significado da prática docente no ensino médio de enfermagem. 127 f. 1997. Dissertação (Mestrado), Programa de Pós-Graduação em Enfermagem Fundamental, Universidade de São Paulo, Escola de Enfermagem de Ribeirão Preto da Universidade de São Paulo, 1997.

SILVA, C. R. Aspectos psicossociais do processo de participação em entidades não-governamentais: um estudo de caso de uma organização que atua no campo da Aids. 1998. 171 f. Dissertação (Mestrado). Pontifícia Universidade Católica de São Paulo, 1998.

SIMÕES, A. M. A representação social da aids construída a partir das informações veiculadas nos jornais diários: análise da cobertura sobre aids no jornal “Estado de Minas”. 1997. 195 p. Dissertação (Mestrado), Curso de Mestrado em Ciência da Informação, Universidade Federal de Minas Gerais, Escola de Biblioteconomia da UFMG, 1997.

STRAUSS, A.; CORBIN, J. Basics of qualitative research: techniques and procedures for developing grounded theory. 2. ed. Thousand Oaks, California : Sage, 1998. 312 p.

VERLE, L. I. Novas imagens para um novo meio: um estudo de caso do website de arte interativa SITO. 1999. 225 f. Dissertação (Mestrado), Curso de Pós-graduação em Comunicação Social, Pontifícia Universidade Católica do Rio Grande do Sul, Faculdade dos Meios de Comunicação Social, 1999.

WEICK, K. Theory construction as disciplined imagination. Academy of Management Review, v. 14, n. 4, p. 516-531, 1989.

WILSON, T.D. On user studies and information needs. Journal of Documentation, v. 37, n. 1, p. 3-15, 1981. 


\section{CAPÍTULO 10}

0

O

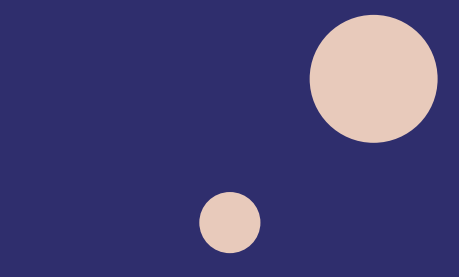

0

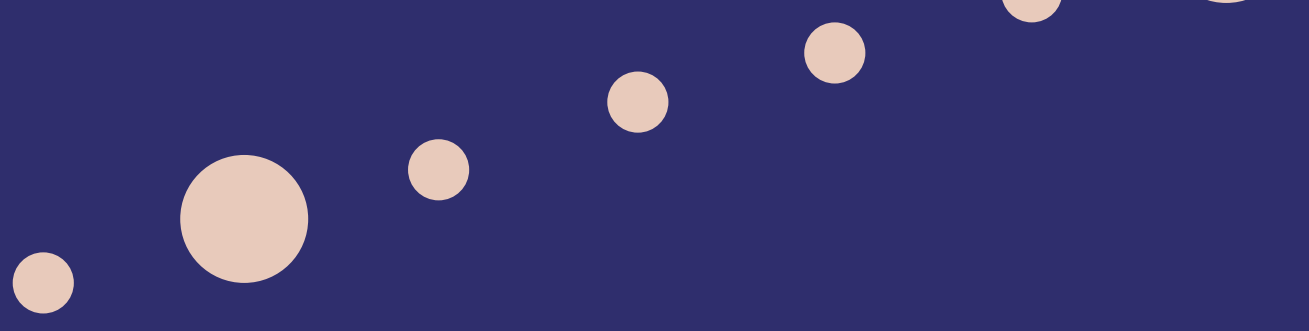

- 00

0 


\section{SISTEMATIZAÇÃO DO FLUXO DE INFORMAÇÃO TECNOLÓGICA NO ATENDIMENTO AO CLIENTE DA EMBRAPA HORTALIÇAS'}

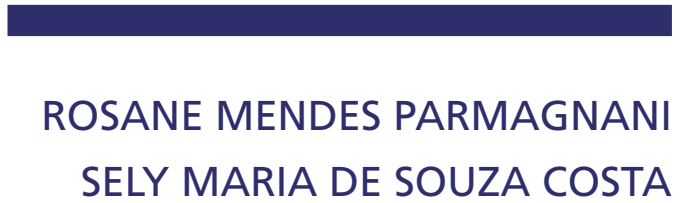

\section{INTRODUÇÃO}

No início da década de 1990, Figueiredo (1990) chamou a atenção para o fato de que a área de Ciências Agronômicas estava se desenvolvendo no País com relação à organização e disseminação da informação, e isso se devia, entre outros fatores, à execução de programas e projetos em âmbito nacional e internacional. Observa-se que, a partir desse desenvolvimento, as atividades de processamento de informação se revestiram de importância fundamental no contexto de qualquer organização, o que tornou a informação, de fato, um recurso essencial para segurança, sobrevivência e desenvolvimento das instituições em todos os níveis.

Maia et al. (1991) propõem um processo cíclico em que a informação gera conhecimento. Este, por sua vez, possibilita a produção científica e tecnológica, a qual modifica a geração de bens e serviços, que são incorporados ao mercado internacional. A internacionalização dos bens e serviços com forte componente de ciência e tecnologia proporciona maiores investimentos, os quais, se reutilizados ou incorporados ao setor de informações, permitem recomeçar o processo. Essas considerações são particularmente importantes para as instituições governamentais, nas quais a sistematização, a utilização racional e a segurança da informação assumem papel estratégico.

1 Versão modificada do artigo publicado em: PARMAGNANI, R. M.; COSTA, S. M. S. Sistematização do fluxo de informação tecnológica no atendimento ao cliente da Embrapa Hortaliças. In: CONGRESSO BRASILEIRO DE GESTÃO DO CONHECIMENTO, 2, 2003, São Paulo. Anais... São Paulo: SBGC, 2003 
Na década de 1970, para que os níveis de produtividade e competitividade desejáveis para o País fossem atingidos, o governo federal criou a Empresa Brasileira de Pesquisa Agropecuária (Embrapa), com uma infraestrutura de pesquisa com forte incentivo à produção intelectual e à formação profissional, além de um sistema de informação que permite a formação de acervos, bem como o processamento, o armazenamento e a recuperação dos conhecimentos resultantes da pesquisa na área agrícola. É importante ressaltar que a informação, que constitui tanto o insumo, quanto o produto final da empresa, tem alta relevância na gestão e na operação da Embrapa, cujo objetivo principal de negócios é a pesquisa e o desenvolvimento.

Na Embrapa Hortaliças, o estudo e o conhecimento do sistema de informação tecnológica nela instalado poderá contribuir tanto para detectar os pontos fortes e fracos do processo de comunicação e transferência da informação tecnológica, quanto para planejar o melhor desempenho dos elementos que compõem o sistema. Nesse contexto, a informação tecnológica surge como peça fundamental, inserindo-se no fluxo de comunicação que deve existir entre pesquisador, profissionais da informação e produtor rural.

Na comunicação interna da Embrapa Hortaliças, observa-se que, no processo de atendimento ao cliente na busca por informação tecnológica, o fluxo se processa no Setor de Informação (SIN) e na Área de Comunicação e Negócios (ACN). Entretanto, a empresa se ressente da falta de uma maior e melhor comunicação e integração entre os profissionais que trabalham nesses setores - agrônomos, bibliotecários e auxiliares de operações -, bem como de uma infraestrutura básica comum. Os procedimentos realizados no atendimento variam de acordo com o setor e com o profissional da informação envolvido. Essa diversidade em relação a processar os pedidos dificulta a otimização do processo de atendimento, uma melhor comunicação e integração, a redução na duplicidade de esforços e investimentos, além de interferir na qualidade de prestação do serviço ao cliente. Assim, a presente pesquisa visa a propor um modelo de fluxo de informação tecnológica no atendimento ao cliente da Embrapa Hortaliças, de forma que o trabalho entre os setores envolvidos no processo seja unificado, otimizado e sistematizado.

\section{METODOLOGIA}

\subsection{Pesquisa qualitativa}

A pesquisa qualitativa de natureza fenomenológica surgiu nas primeiras décadas do século $\mathrm{XX}$, como forte reação ao enfoque positivista nas Ciências Sociais. Na verdade, a pesquisa qualitativa responde questões muito particulares. Como destaca Minayo (1994), a pesquisa qualitativa nas Ciências Sociais se preocupa com uma realidade que não pode ser somente 
quantificada. Assim, a abordagem qualitativa aprofunda-se no mundo dos significados das ações e das relações humanas, um lado não perceptível e não captável nas equações, médias e estatísticas. Um dos métodos de pesquisa que normalmente utiliza a abordagem qualitativa é o da pesquisa-ação, adotado nesta pesquisa por ser o mais apropriado ao estudo do problema investigado. Isso porque o método da pesquisa-ação permite ao pesquisador desempenhar papel ativo na coleta, análise e interpretação dos dados.

\subsection{Método pesquisa-ação}

A pesquisa-ação pode ser definida, segundo Thiollent (1996), como um tipo de pesquisa com base empírica que é concebida e realizada em estreita associação com uma ação ou com a resolução de um problema coletivo. Na pesquisa-ação, os pesquisadores e os participantes representativos da situação ou do problema estão envolvidos de modo cooperativo ou participativo. De acordo com Wilson (2000), o processo da pesquisa-ação pode ser entendido quando visto como um ciclo de aprendizagem que se inicia pela existência de situações não comuns em uma organização, percebidas como problemáticas. A fim de estudar a situação-problema, o analista deve avaliar ou desenvolver formas de descrevê-la utilizando modelos e linguagem de modelagem. O ciclo se completa na aplicação do desenvolvimento de metodologias apropriadas de solução de problemas para situações-problema específicas. Na pesquisa-ação, é necessário produzir conhecimentos, adquirir experiência, contribuir para a discussão ou fazer avançar o debate acerca das questões abordadas. $\mathrm{O}$ uso desse método para a realização do estudo aqui proposto é, sem dúvida, o mais indicado, especialmente no que concerne à abordagem sistêmica adotada.

\subsection{Abordagem sistêmica: a metodologia de sistemas flexíveis}

Neste estudo, é adotado o conceito de sistema de atividade humana, tal como proposto por Wilson (2000), que classifica sistemas em quatro tipos: sistemas naturais, sistemas projetados, sistemas de atividade humana e sistemas sociais e culturais. O conceito de sistemas de atividade humana é o mais apropriado para uso na metodologia de sistemas flexíveis (Soft Systems Methodology-SSM).

\subsubsection{Sistemas de Atividade Humana}

O Sistema de Atividade Humana (SAH) pode ser descrito como uma interação dentro do conjunto de subsistemas ou dentro do conjunto de atividades. A palavra "atividade" implica ação e, desse modo, a linguagem em SAH é modelada em termos de verbos. Os SAHs são 
formados por dois outros sistemas: um sistema de atividade e um sistema social, cujo limite é coincidente com o limite do SAH. O sistema de atividades define "o que" mudar, e o sistema social define "como" tais mudanças podem ser implementadas ou se essas mudanças são ou não aceitáveis.

\subsubsection{Metodologia de sistemas flexíveis}

O surgimento da SSM foi uma tentativa de resolver problemas mal estruturados e encontrados em organizações, os quais podem ser classificados como SAHs. Nesse sentido, a finalidade da metodologia é permitir às pessoas compreender os sistemas sociais explícitos e aprimorá-los, da mesma forma pela qual as pessoas podem usar os princípios da Engenharia para aperfeiçoar e explicitar seu entendimento sobre sistemas mecânicos (ARONSON, 2001). A SSM foi desenvolvida por Peter Checkland, no final da década de 1960 e durante década de 1970, por meio de um variado número de projetos de pesquisa-ação na indústria e sua aplicação e refinamento ao longo dos anos.

Segundo Checkland e Scholes (1999), a SSM tem como um dos objetivos principais a melhoria nas áreas de interesse sociais pela participação dos sujeitos envolvidos na situação, em um ciclo de aprendizagem contínuo. A aprendizagem ocorre com o processo iterativo, por meio de conceitos de sistemas usados para refletir e debater as percepções do mundo real. A reflexão e o debate são estruturados por um variado número de modelos sistêmicos, concebidos como tipos holísticos ideais de determinados aspectos da situação-problema. Essa metodologia tem por substrato situações-problema, as quais são entendidas como uma questão que não apresenta solução exata e inequívoca, mas varia de acordo com o ponto de vista do analista envolvido, com a visão dos clientes, proprietários e membros arrolados na discussão, bem como com o ambiente.

O estudo dos problemas relacionados ao fluxo de informação tecnológica no atendimento ao cliente da Embrapa Hortaliças aponta para sua definição e análise como sendo um SAH. Desse modo, para estudar a sua sistematização, é necessária sua descrição dentro dos três requisitos fundamentais para a caracterização desse problema como um SAH. O primeiro requisito é nocional, baseado em noções (visões) que tanto o analista quanto os sujeitos da pesquisa têm da situação-problema, não sendo, portanto, uma descrição "objetiva" dessa realidade. $\mathrm{O}$ segundo é intencional (visa a um propósito específico). O terceiro é a propriedade emergente (característica sem a qual o sistema não existiria).

Embora seja possível a aplicação de apenas algumas fases da SSM, o processo completo envolve sete estágios, detalhados a seguir. A sequência lógica ilustrada pela figura 1 - Estágios da metodologia de sistemas flexíveis figura 1 é uma forma clara de descrever a metodologia, 
mas não representa necessariamente a sequência na qual a SSM deva ser usada. Na realidade, representa um modelo de atividades. $\mathrm{O}$ analista pode começar com qualquer atividade, progredir em qualquer direção, e usar uma iteração significativa em qualquer estágio. As seções a seguir descrevem com mais detalhes cada estágio da metodologia.

Figura 1 - Estágios da metodologia de sistemas flexíveis

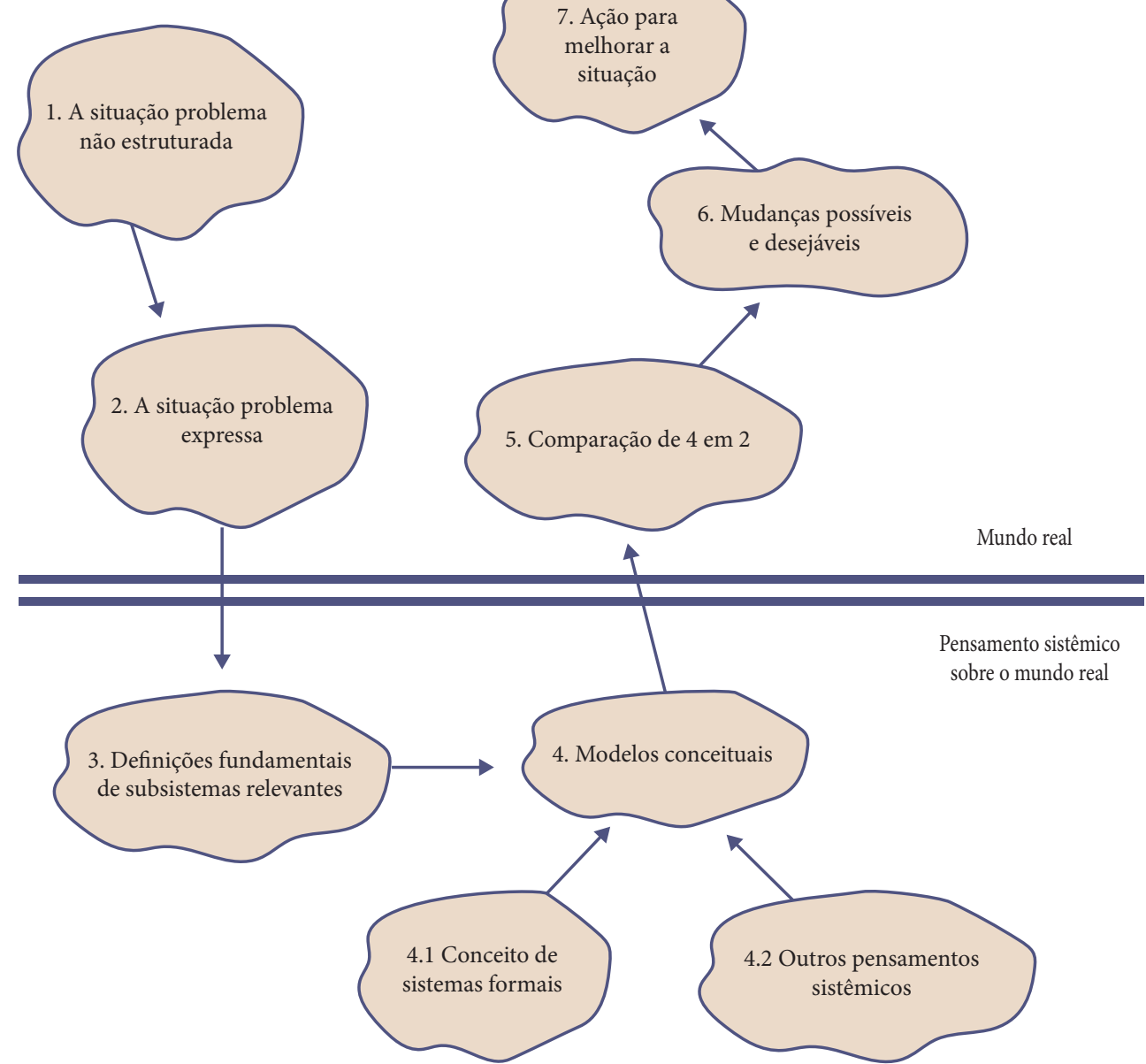

Fonte: Adaptado de Checkland (1981).

\subsection{Universo da pesquisa}

A população - sujeitos da pesquisa - é constituída pela totalidade dos profissionais de informação distribuídos em dois setores que realizam o atendimento ao cliente da Embrapa 
Hortaliças, no que concerne a informação tecnológica, sob a coordenação de uma chefia. Participaram da pesquisa nove profissionais de nível superior das áreas de Biblioteconomia e Agronomia e dois profissionais de nível médio.

\subsection{Técnica de coleta de dados}

A coleta de dados qualitativos não é um processo acumulativo e linear cuja frequência, controlada e mensurada, autoriza o pesquisador a estabelecer leis e prever fatos. Os dados são colhidos, iterativamente, num processo de idas e voltas, nas diversas etapas e na interação com seus sujeitos. Os aspectos particulares novos descobertos no processo de análise são investigados para orientar uma ação que modifique a condição e a circunstância indesejada (CHIZZOTTI, 2000).

Os dados da pesquisa em estudo foram obtidos por meio de entrevista e análise documental realizada nos documentos existentes na biblioteca, nas bases de dados de respostas técnicas da ACN e nos relatórios anuais dos setores envolvidos. A entrevista seguiu um roteiro que consta de uma lista de pontos previamente estabelecidos, destinados a atingir o máximo de clareza nas descrições do fenômeno em estudo. Foram coletadas informações a respeito de cinco aspectos: 1) características das informações; 2) canais e fontes de informação; 3) fluxo da informação tecnológica; 4) tecnologias da informação; 5) profissionais da informação. Foi aplicado um pré-teste com o propósito de validar a clareza, objetividade e pertinência das questões contidas em um dos instrumentos de coleta de dados utilizado, a entrevista. Na ocasião, realizou-se uma explicação sobre os objetivos da pesquisa.

\section{ANÁLISE DOS DADOS POR MEIO DA SSM}

A análise dos dados coletados na pesquisa é apresentada de acordo com as rotinas próprias da SSM, como se descreve a seguir.

\section{Estágio 1: situação-problema mal estruturada}

É o estágio inicial, no qual a situação-problema precisa ser examinada. A situação-problema, objeto do estudo aqui proposto, é descrita com base nos processos, atores, relacionamentos e estruturas envolvidos no ambiente pesquisado a partir do que foi coletado nas entrevistas e na análise documental. 
A Embrapa Hortaliças, que tem um papel muito importante a desempenhar no desenvolvimento do País, não pode prescindir de mecanismos que agilizam o processo de pesquisa como um todo. Um dos recursos vitais para as áreas técnica e administrativa é a informação. As demandas que chegam à Embrapa Hortaliças são trazidas por produtores rurais, empresários do agronegócio de hortaliças e setores governamentais. Para que o produto final - a tecnologia - chegue ao cliente, é necessário estabelecer uma perfeita comunicação entre os profissionais que realizam o atendimento. Para tanto, a Embrapa Hortaliças possui o Setor de Informação e Informática (SIN) e a Área de Comunicação e Negócios (ACN).

Os pedidos chegam de forma direta à $\mathrm{ACN}$ e ao $\mathrm{SIN}$, ou de forma indireta por meio dos setores de protocolo, telefonia, informática (Webmaster) e vendas, que repassam as solicitações aos setores de atendimento. Entretanto, observa-se que o fluxo de informação opera de forma desestruturada, variando de acordo com o setor atendente e com o profissional da informação envolvido no atendimento.

\section{Estágio 2: situação-problema estruturada - rich picture}

A análise dos dados coletados por meio de entrevista, observação do analista e análise documental permitiu identificar seis aspectos a serem considerados. O primeiro refere-se às questões preocupantes mais relevantes para entendimento da situação-problema investigada. O segundo diz respeito às estruturas hierárquicas existentes nos diversos setores envolvidos no fluxo de informação objeto desta análise. O terceiro constitui os atores envolvidos nas diversas atividades realizadas no campo da situação-problema investigada. O quarto está relacionado com os organismos internos e externos ao sistema que representa a situação-problema. O quinto é constituído dos relacionamentos entre os diversos atores, organismos, entidades, etc. $\mathrm{O}$ último aspecto relaciona-se aos conflitos resultantes de superposições, duplicações e diferentes pontos de vista. 
O resultado do processo de estruturação da situação-problema (envolvido na análise cultural e na análise lógica) é registrado por meio de rich picture (ilustração rica). A rich picture que representa o SAH objeto desta pesquisa é apresentada na figura 2.

Figura 2 - Detalhamento da rich picture - questões relevantes

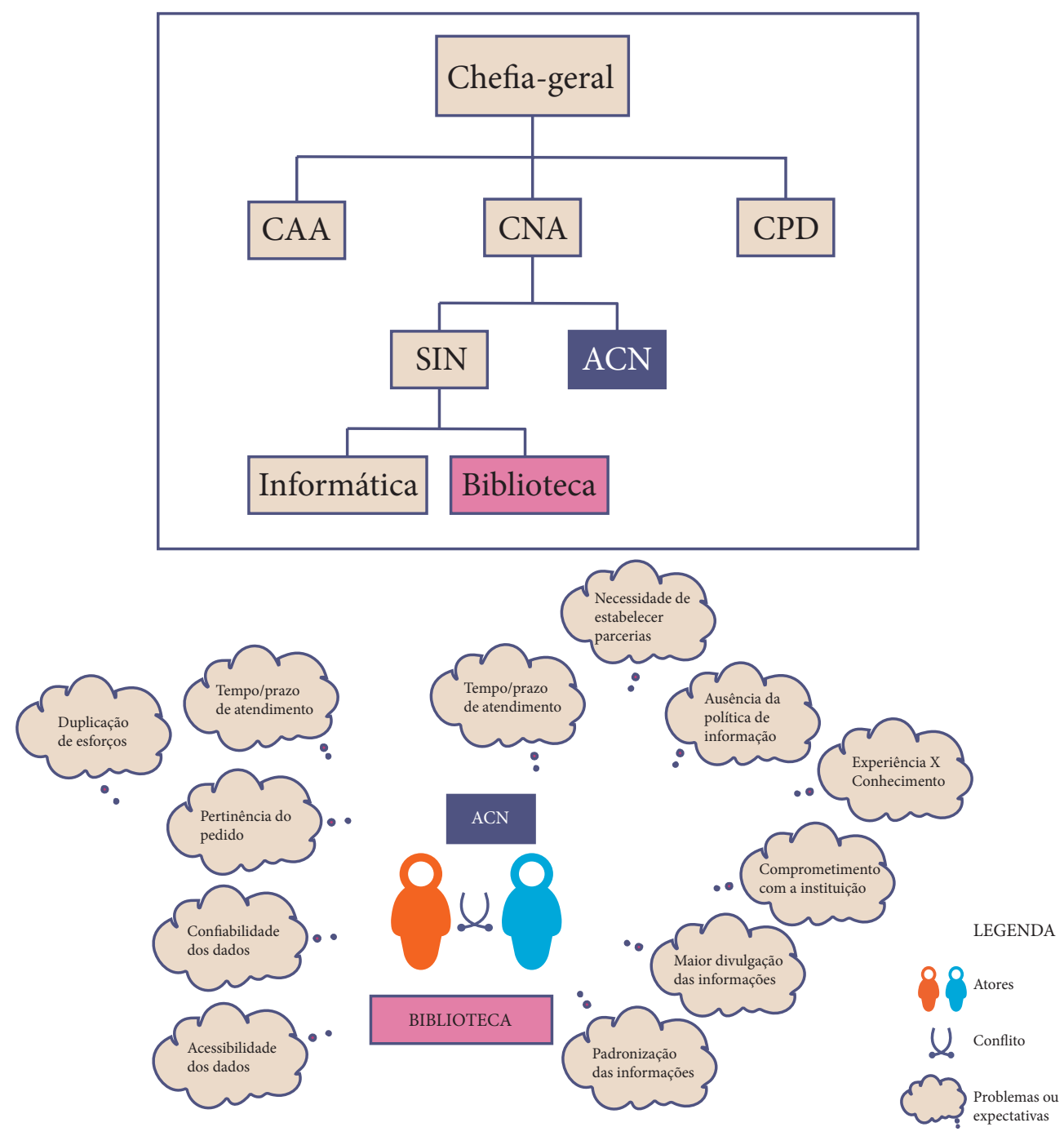

Fonte: Elaboração dos autores (2018).

O processo de acomodação das preocupações dos autores (multiplicidade de visões) e dos conflitos de opinião ilustrado na rich picture em forma de "nuvens de pensamento" e "espadas cruzadas", respectivamente, vai determinar quais são os subsistemas relevantes que irão realizar os processos de transformação necessários ao melhoramento da situação-problema. 


\section{Estágio 3: definições fundamentais de subsistemas relevantes}

Até aqui o estudo da situação-problema envolveu a análise de fatos do mundo real. A partir do estágio 3, o analista ingressa no mundo sistêmico: o pensar sistemicamente sobre o mundo real. Nesse sentido, o conceito de nocional, próprio da metodologia, vai direcionar o trabalho do analista, pois os subsistemas relevantes definidos vão representar a noção que ele tem da situação-problema e que, por sua vez, baseia-se na sua própria reflexão sobre as "visões de mundo" (weltanschauung) dos atores envolvidos.

Na sistematização do fluxo de informação tecnológica no atendimento ao cliente da Embrapa Hortaliças, foram definidos quatro subsistemas relevantes: padronização das informações prestadas e dos procedimentos, acesso amplo e irrestrito às informações, divulgação das informações e capacitação dos profissionais de informação e dos usuários do sistema.

Vistos como sistema, cada um desses processos envolve uma entrada (uma questão relevante da situação-problema mal estruturada), uma transformação (procedimentos que possibilitam o melhoramento da situação-problema) e uma saída (a situação-problema melhorada). Além disso, envolve atores (pessoas responsáveis pela transformação), proprietários (decisores com poder de interromper, suspender ou parar o sistema) e clientes (beneficiários ou vítimas do sistema). O sistema opera em um ambiente sobre o qual normalmente não é possível intervir. Nesse sentido, os fatores do ambiente são considerados restrições. Desse modo, a identificação dos sistemas relevantes do fluxo de informação tecnológica no atendimento ao cliente na busca por informações na Embrapa Hortaliças permitiu a elaboração de uma definição fundamental, no nível mais alto de complexidade:

Um sistema de propriedade da Embrapa Hortaliças, que transforma o fluxo desordenado e diversificado de informação tecnológica no atendimento ao cliente (produtores, técnicos rurais, extensionistas, etc.), realizado pelos setores ACN, SIN, SSA e SPM, em um fluxo de informação tecnológica otimizado, sistematizado e unificado, a ser realizado pelos setores SIN e ACN, de acordo com as políticas de atuação da chefia da Embrapa Hortaliças, de informação do DTI e de atendimento ao cliente do SAC - Sede.

\section{Estágio 4: modelos conceituais}

O estágio de construção dos modelos conceituais começa com as definições fundamentais elaboradas no estágio anterior e com a seguinte questão: que atividades teriam lugar no sistema e que vêm ao encontro dos requisitos presentes na definição fundamental? 
O modelo conceitual embute um conjunto de atividades interconectadas e definidas em um nível específico de detalhes (nível de resolução) para que o sistema seja aquele descrito na definição fundamental. É importante incluir todas as atividades envolvidas na definição e construir um modelo de atividades de "como" o sistema deverá realizá-las. Desse modo, o primeiro nível de modelagem é mostrado na figura 3, que ilustra o mínimo de atividades necessárias ao fluxo de atendimento ao cliente da Embrapa Hortaliças.

Figura 3 - Estágio inicial do desenvolvimento da modelagem

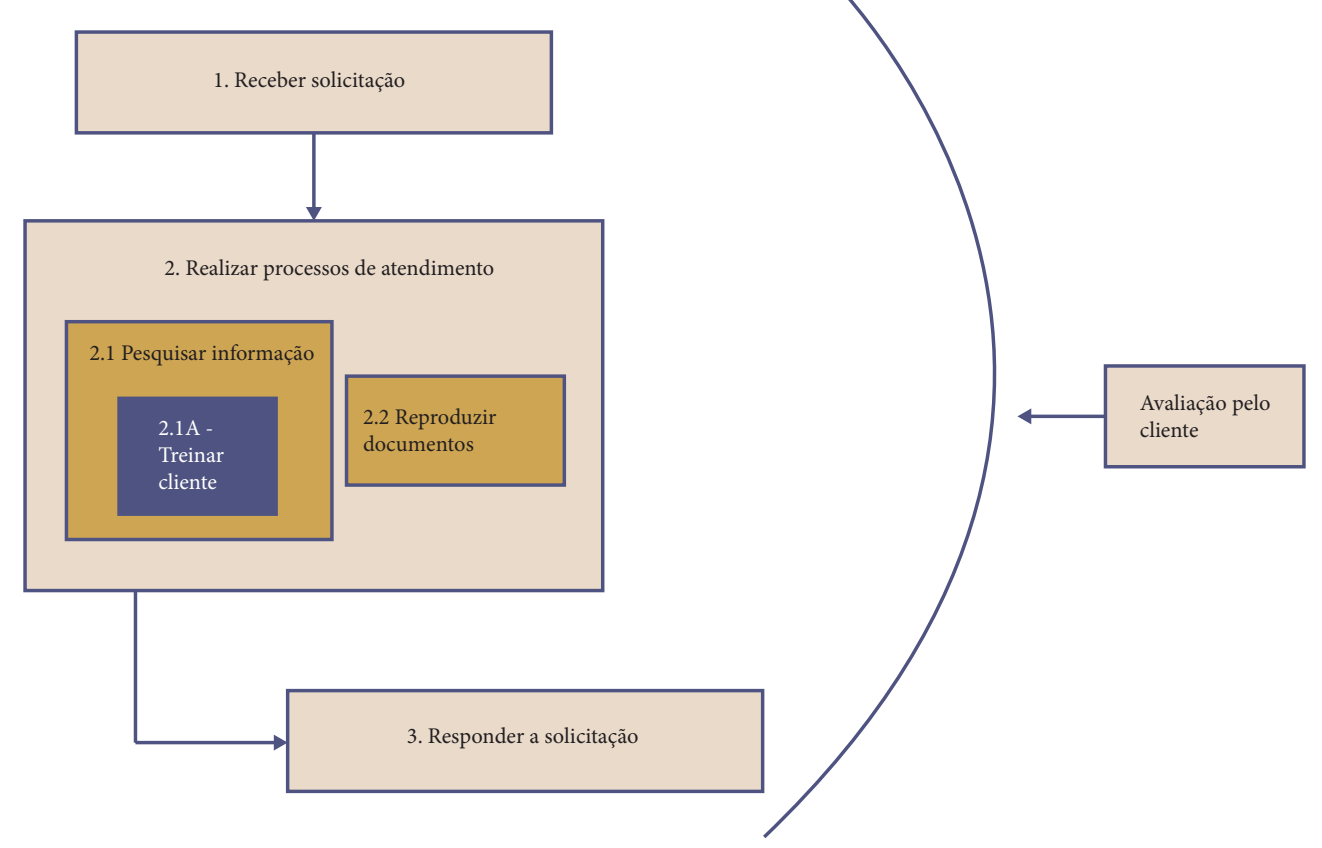

Fonte: Elaboração dos autores (2018).

O modelo ilustrado na figura 3 corresponde ao primeiro nível de resolução na definição do $\mathrm{SAH}$, que representa o fluxo de informação tecnológica no atendimento ao cliente da Embrapa Hortaliças. No entanto, a análise revelou que, dada a sua complexidade, era necessário defini-lo em um nível mais detalhado, obtendo assim a expansão do modelo de primeiro nível. A iteratividade própria da metodologia apontou, neste momento da análise, para um retorno ao estágio 3 e para a consequente elaboração das definições fundamentais dos subsistemas relevantes do sistema fluxo. A primeira diz respeito à padronização das informações prestadas e dos procedimentos. A segunda consiste no acesso amplo e irrestrito às informações. A terceira refere-se à divulgação das informações. A quarta e última constitui a capacitação dos profissionais de informação e dos usuários do sistema. 
Destarte, é modelado e descrito a seguir o subsistema Padronização das Informações Prestadas e dos Procedimentos - por ter sido considerado, na análise, o mais relevante e mais viável de ser de fato implementado. As melhorias resultantes das transformações realizadas por esse sistema terão reflexo nos outros três subsistemas, facilitando, por conseguinte, sua definição posterior. Desse modo, é necessário elaborar a definição fundamental e o modelo conceitual (figura 4) do subsistema Padronização das Informações Prestadas e dos Procedimentos:

Um sistema de propriedade da Embrapa Hortaliças, que transforma informações prestadas aos clientes (produtores, técnicos rurais, extensionistas, etc.) e procedimentos não padronizados realizados pelos setores ACN, SIN, SSA e SPM em informações prestadas e procedimentos padronizados, a serem realizadas pelos setores SIN e ACN, de acordo com as políticas de atuação da chefia da Embrapa Hortaliças, de informação do DTI e de atendimento ao cliente do SAC-Sede. 
Figura 4 - Modelo conceitual do subsistema Padronização das Informações Prestadas e dos Procedimentos

1. Estabelecer uma infraestrutura física, computacional, informativa e pessoal básica

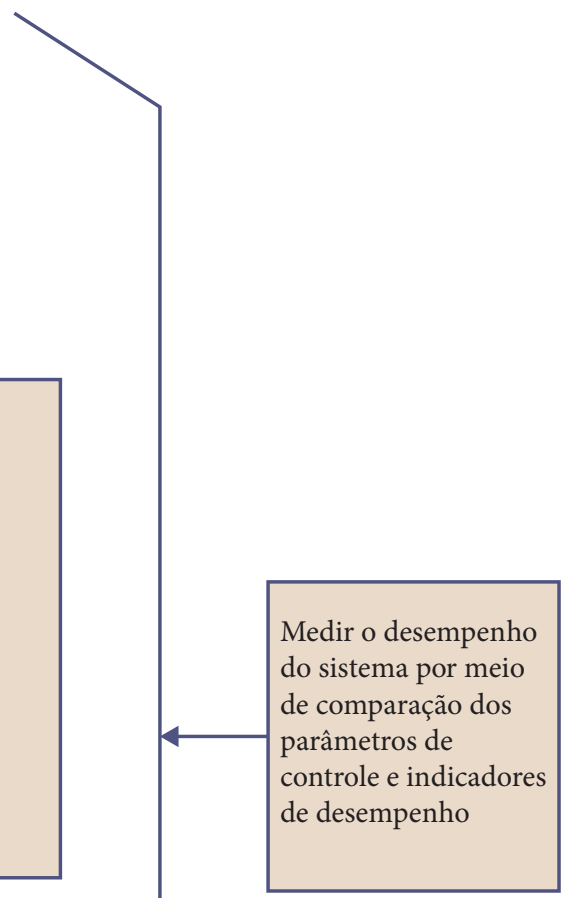

2. Elaborar procedimentos e ferramentas de trabalho

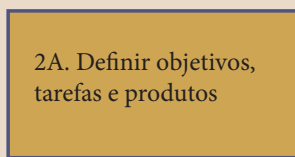

2C. Definir ferramentas que agilizem, controlem e padronizem o trabalho e o resultado
2B. Definir parâmetros de controle e indicadores de desempenho

2D. Elaborar manuais de procedimentos operacionais

3. Reelaborar o cadastro de instituições e pesquisadores

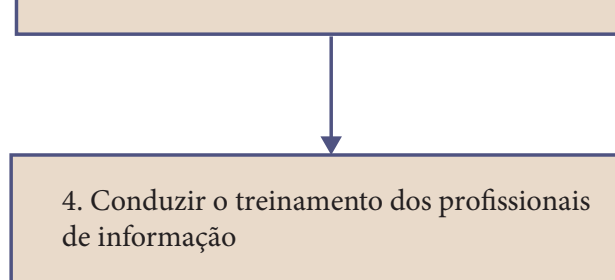

\section{Estágio 5: comparação do mundo real x modelo conceitual}

Este é o estágio no qual o analista compara o modelo conceitual que descreve as ações a serem implementadas com as questões relevantes constantes na rich picture que 
descreve a situação-problema encontrada no mundo real. Considerando que se optou pela utilização de uma agenda para fundamentar a comparação, são usadas as ações especificadas no modelo como roteiro para elaboração da agenda com as questões a serem discutidas para decisão sobre que mudanças implementar.

Cada ação definida no modelo conceitual foi avaliada para ver se era sistemicamente desejável e culturalmente possível. Sistemicamente desejável na medida em que deveria constituir um elemento fundamental tanto na constituição quanto no bom desempenho do sistema, e culturalmente possível na medida em que respondia positivamente aos papéis, valores e normas observados na situação-problema estudada Costa (2003). A agenda, portanto, constitui o produto deste estágio. A aceitação da agenda fornecerá uma série de tópicos para o próximo estágio. O que não foi considerado possível nem desejável foi, então, deixado fora do processo de transformação.

Nesta pesquisa, a discussão da agenda com os atores da situação-problema foi substituída por um processo de reflexão do analista, com base nas opiniões daqueles atores. Isso porque, como exercício acadêmico, a discussão propriamente dita não era crucial para a tomada de decisão sobre as mudanças a serem implementadas no fluxo de informação tecnológica no atendimento ao cliente da Embrapa Hortaliças.

\section{Estágio 6: proposição de mudanças possíveis e desejáveis}

Ao se definir um modelo sistêmico padronizado para o fluxo de informação tecnológica no atendimento ao cliente da Embrapa Hortaliças, o sistema resultante deverá sanar as dificuldades decorrentes da grande diversidade de situações, multiplicidade de funções e pulverização das solicitações. A efetividade no desenvolvimento das atividades em todo o sistema garantirá a quantidade e a qualidade de produtos e serviços necessários ao atendimento das necessidades dos clientes, reduzindo o número de demandas diretas.

A padronização deverá permitir mensurar o desempenho e a qualidade dos produtos/serviços, podendo ser certificada pela conformidade às normas estabelecidas, e/ou avaliada pela presença de critérios especificados. As mudanças definidas no subsistema Padronização das Informações Prestadas e dos Procedimentos incluem as cinco ações: 1) estabelecer uma infraestrutura básica; 2) elaborar procedimentos e ferramentas de trabalho; 3 ) reelaborar cadastro de instituições e pesquisadores; 4) conduzir o treinamento dos profissionais da informação; 5) medir o desempenho do sistema por meio de comparação dos parâmetros de controle e indicadores de desempenho. 
A implementação das ações propostas neste estágio quanto às mudanças culturalmente possíveis e sistemicamente desejáveis deve promover a efetiva transformação de informações prestadas e procedimentos não padronizados em informações prestadas e procedimentos padronizados. Isso, por sua vez, deverá adicionar uma parcela significativa ao melhoramento do fluxo de informação tecnológica no atendimento ao cliente da Embrapa Hortaliças.

\section{CONCLUSÃO: IMPLEMENTAÇÃO - ESTÁGIO 7}

O sétimo estágio consiste na efetiva implementação das mudanças definidas no sexto estágio como resultado do processo de decisão realizado quando da comparação dos modelos conceituais com a rich picture. Neste estágio, portanto, ocorre a execução do sistema relevante responsável pelo melhoramento da situação-problema.

No presente estudo, o primeiro sistema a ser implementado consiste, como ficou identificado no estágio 4 (modelo conceitual), o Sistema de Padronização das Informações Prestadas e dos Procedimentos. Conforme detalhado no estágio 6 (Proposição de mudanças possíveis e desejáveis), as mudanças envolvem o total de procedimentos e recursos necessários à transformação de um fluxo de informação tecnológica desordenado e diversificado em um fluxo de informação tecnológica otimizado, sistematizado e unificado.

É importante observar que, quando as mudanças são implementadas, os problemas percebidos inicialmente tendem a desaparecer. No entanto, é sempre possível que novos problemas emerjam, o que provoca o reinício do processo de investigação. Esse eterno recomeçar do processo investigativo alimenta, em última análise, o desenvolvimento da Ciência.

\section{REFERÊNCIAS}

ARONSON, D. Introduction to systems thinking. Disponível em: <http://www. thinking.net/Systems_Thinking/> Acesso em: 24 abr. 2001.

CHECKLAND, P.; SCHOLES, J. Soft systems methodology in action. New York: John Wiley \& Sons, 1999.

CHIZZOTTI, A. Pesquisa em ciências humanas e sociais. 4. ed. São Paulo: Cortez, 2000 . 
COSTA, S. M. S. A Metodologia de Sistemas Flexíveis. Revista de Biblioteconomia de Brasília, Brasília, v. 27, n. 1, jan./jun. 2003 (no prelo).

FIGUEIREDO, N. M. de. Metodologias para promoção do uso da informação: técnicas aplicadas particularmente em bibliotecas universitárias e especializadas. São Paulo: Novel, 1990.

MAIA, C. A.; PASSOS, E. J. L.; COSTA, S. M. S Informação cientifica e tecnológica e desenvolvimento econômico e social: contribuição da biblioteca especializada. In: CONGRESSO BRASILEIRO DE BIBLIOTECONOMIA E DOCUMENTAÇÃO, 16., 1991, local. Anais... Salvador: APBEB, 1991. v. 2, p. 683-691.

MINAYO, M. C. de S. Pesquisa social: teoria, método e criatividade. 3. ed. Petrópolis: Vozes, 1994.

THIOLlENT, M. Metodologia da pesquisa-ação. 7. ed. São Paulo: Cortez, 1996.

WILSON, B. Systems: concepts, methodologies and applications. 2. ed. Chichester: John Wiley \& Sons, 2000. 


\section{CAPÍTULO 11}

0

O

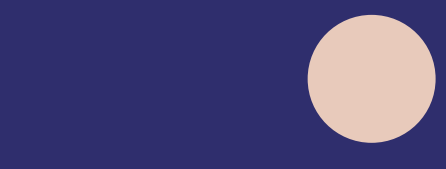

O
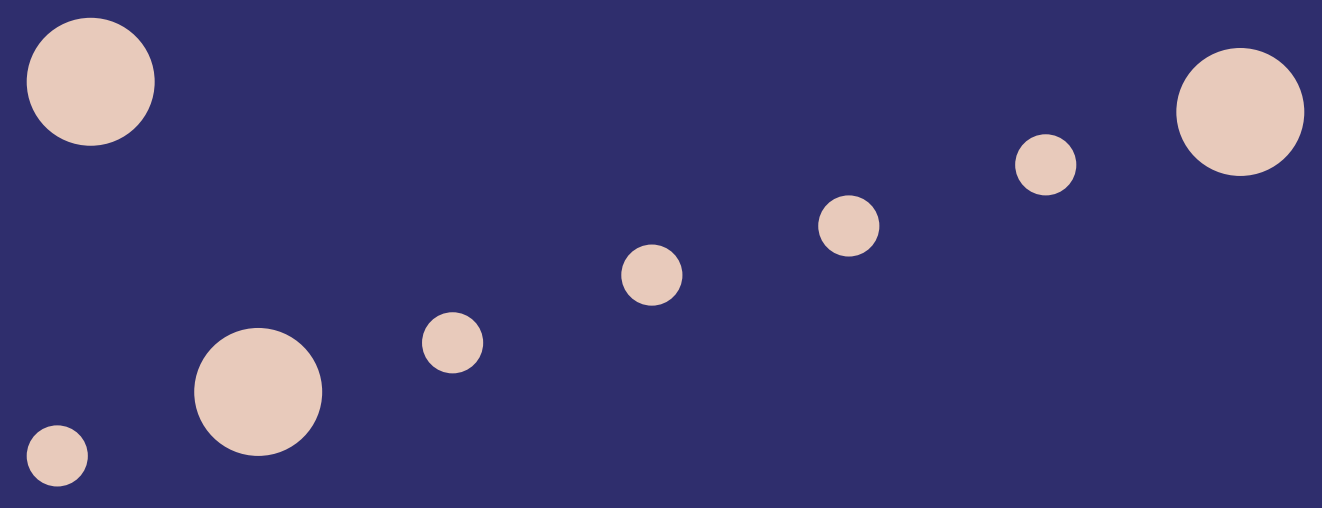

- 00

0 


\section{CONSTRUÇÃO E IMPLEMENTAÇÃO DE MODELO PARA AVALIAR A QUALIDADE DA INFORMAÇÃO ESTRATÉGICA BANCÁRIA}

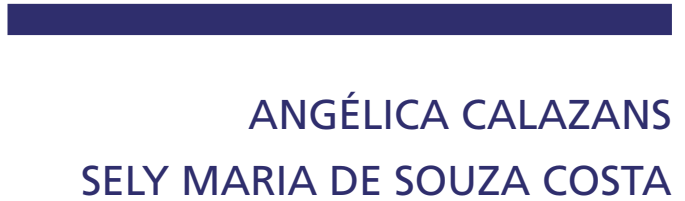

\section{INTRODUÇÃO}

O reconhecimento da informação como um dos recursos mais importantes da sociedade tem ressaltado a necessidade de seu gerenciamento de forma a possibilitar sua aquisição, interpretação e utilização de modo mais eficiente e eficaz. No setor bancário, no qual a gestão da informação pode ser descrita como a base dos negócios, os problemas inerentes ao uso da informação são especialmente críticos. No Brasil, o segmento bancário é o segundo setor em participação no PIB nacional (PIRES; MARCONDES, 2004). Mais que isso, as instituições bancárias são as principais peças do Sistema Financeiro Nacional e, na última década, segundo Fortuna (2005), necessitaram reestruturar-se e mudar as estratégias de atendimento, aumentando a oferta de produtos e serviços, a fim de garantir a competitividade.

A melhoria da competitividade nesse setor envolve o conhecimento, a inovação e as competências essenciais (PIRES; MARCONDES, 2004). Davenport e Prusak (1998) acrescentam que o conhecimento "corresponde à informação com um contexto, um significado, uma interpretação". Considerando o inter-relacionamento informação-conhecimento-inovação é possível inferir que o gerenciamento aperfeiçoado de uma informação com mais qualidade e difundida por toda a organização possibilitará a melhoria da inovação e, consequentemente, da eficiência e eficácia organizacional.

1 Versão modificada do artigo publicado: CALAZANS, A. T. S.; COSTA, S. M. S.. Modelo de avaliação da qualidade da informação estratégica bancária. Ciência da Informação, Brasília, v. 38, n. 3, p. 21-39, 2009. 
Na última década, as atividades voltadas para a qualidade da informação têm aumentado significativamente, promovendo até mesmo a necessidade de as organizações medirem e aumentarem a qualidade das informações utilizadas e disponibilizadas. Para isso, faz-se necessário analisar a gestão da informação organizacional, objetivando identificar aspectos que impactam a qualidade da informação e, dessa forma, possibilitar sua melhoria contínua.

A gestão da informação pode ser conceituada como a gestão de uma rede de processos correlatos que adquirem, criam, organizam, distribuem e usam a informação (CHOO, 2003a). Para o contexto das organizações, Mcgee e Prusak (1994) observam que a capacidade de adquirir, interpretar e utilizar a informação de forma eficaz poderá garantir, na economia da informação, o diferencial competitivo. Assim sendo, a gestão da informação com qualidade será, cada vez mais, a base para o melhor desempenho organizacional.

Neste capítulo, apresenta-se um modelo para mensurar a qualidade da informação estratégica no contexto bancário, identificando-se os aspectos da gestão da informação que podem influenciar essa qualidade. Compõe-se, portanto, de quatro seções. Na primeira, descreve-se o ambiente da pesquisa (segmento bancário). A segunda, fundamentação teórica, é composta dos tópicos sobre gestão da informação, qualidade da informação e informação estratégica. $\mathrm{Na}$ terceira, apresentam-se os resultados da aplicação do modelo proposto para avaliar a qualidade da informação, considerando-se a percepção dos usuários de informação estratégica de uma instituição financeira governamental. A última seção apresenta as conclusões do estudo.

\subsection{Ambiente bancário brasileiro (contexto da pesquisa)}

Os bancos são instituições financeiras monetárias que exercem como atividades básicas, entre outras, a captação de depósitos à vista ou a prazo por meio de movimentação de contas correntes, realização de operações de crédito e desconto de títulos (FORTUNA, 2005). Para Tachibana (2004), nos últimos anos, a indústria bancária brasileira passou por significativas modificações devido ao fim da hiperinflação, à entrada de bancos estrangeiros, às privatizações, entre outros fatores. Botelho (2007, p. 13) identifica, ainda, na última década, uma série de ações responsáveis pelas modificações do setor financeiro, entre elas: a implementação do Plano Real; os programas de recuperação dos bancos, que impediram um colapso do sistema e trouxeram grande mudança para o ambiente de competição; o aumento da concorrência estrangeira; e a consolidação do setor (diminuição do número de bancos). De acordo com o mesmo autor, o momento atual vivido pelo setor bancário brasileiro é de grande competição.

Na concepção de Kuljis e Scoble (1997), o trabalho com a informação ocupa importante papel nas instituições financeiras, que dependem totalmente de informação acurada, corrente e acessível. Os problemas inerentes ao uso da informação são especialmente críticos 
nesse setor, cujo gerenciamento pode ser descrito como a base dos negócios. BroadyPreston e Hayward (1998, p. 395) afirmam que a empresa com vantagens informacionais tem a habilidade de armazenar e recuperar a informação, definindo-a e utilizando-a em processos estratégicos específicos.

Sem dúvida, as organizações necessitam implementar ações que agreguem qualidade às informações, na medida em que "a informação é um ativo que precisa ser gerenciado, da mesma maneira que os ativos representados pelos seres humanos, capital, propriedades e bens materiais" (MCGEE; PRUSAK, 1994). O que possibilita tal gerenciamento são as técnicas e os processos utilizados para gestão da informação. Segundo Wilson (1997), a gestão da informação é o gerenciamento dos princípios administrativos ou sua aplicação aos processos de aquisição, organização, controle, disseminação e uso da informação para operacionalização das organizações. Essa é a questão que se discute, sucintamente, na fundamentação teórica a seguir.

\section{FUNDAMENTAÇÃO TEÓRICA}

O modelo conceitual para esta pesquisa representa a síntese da fundamentação teórica construída a partir da análise da literatura. Com base nesta fundamentação teórica, optou-se pela realização de um estudo fundamentado nos conceitos de gestão da informação, qualidade da informação e informação estratégica, bem como na percepção dos atores envolvidos no processo de gestão de informação estratégica de uma instituição financeira governamental.

\subsection{Gestão da informação}

A quantidade de informações disponíveis tem forçado as organizações a empreenderem ações para a otimização da coleta, do tratamento, da localização e da análise das informações (QUEYRAS; QUONIAM, 2006, p. 81). Nesse contexto, um dos desafios das organizações é compreender o valor estratégico da informação para potencializar sua utilização correta. Segundo Santos e Beraquet (2001), diversos estudos sobre as causas das falências das organizações apontam que boa parte dos problemas resulta de um conhecimento incompleto do seu ambiente: clientes, concorrentes, fornecedores, regulamentos. De fato, na maioria dos casos, essas informações estão disponibilizadas nas próprias organizações, sem que tenham sido organizadas e gerenciadas, de forma a permitir seu aproveitamento adequado.

Para controlar o processo de gestão da informação, Choo (2003a, p. 404) sugere, com base nos trabalhos de Davenport (1993) e McGee e Prusak (1994), um conjunto de sete processos inter-relacionados (figura 1): a identificação das necessidades informacionais; a aquisição 
da informação; a organização e o armazenamento da informação; o desenvolvimento de produtos e serviços informacionais; a distribuição; o uso da informação; e o comportamento adaptativo do usuário. O autor acrescenta, ainda, que o último processo - comportamento adaptativo - seria a seleção de novas ações dirigidas para os objetivos, mas considerando também a interação com outras organizações (ambiente externo), ou seja, é a retroalimentação do processo de gestão, gerando novas necessidades informacionais. Para melhorar a qualidade da informação, tópico discutido a seguir, organizações devem promover a compreensão dos processos informacionais e sua interdependência, assim como gerenciar a informação como um valor.

Figura 1 - Modelo de processos da gestão da informação

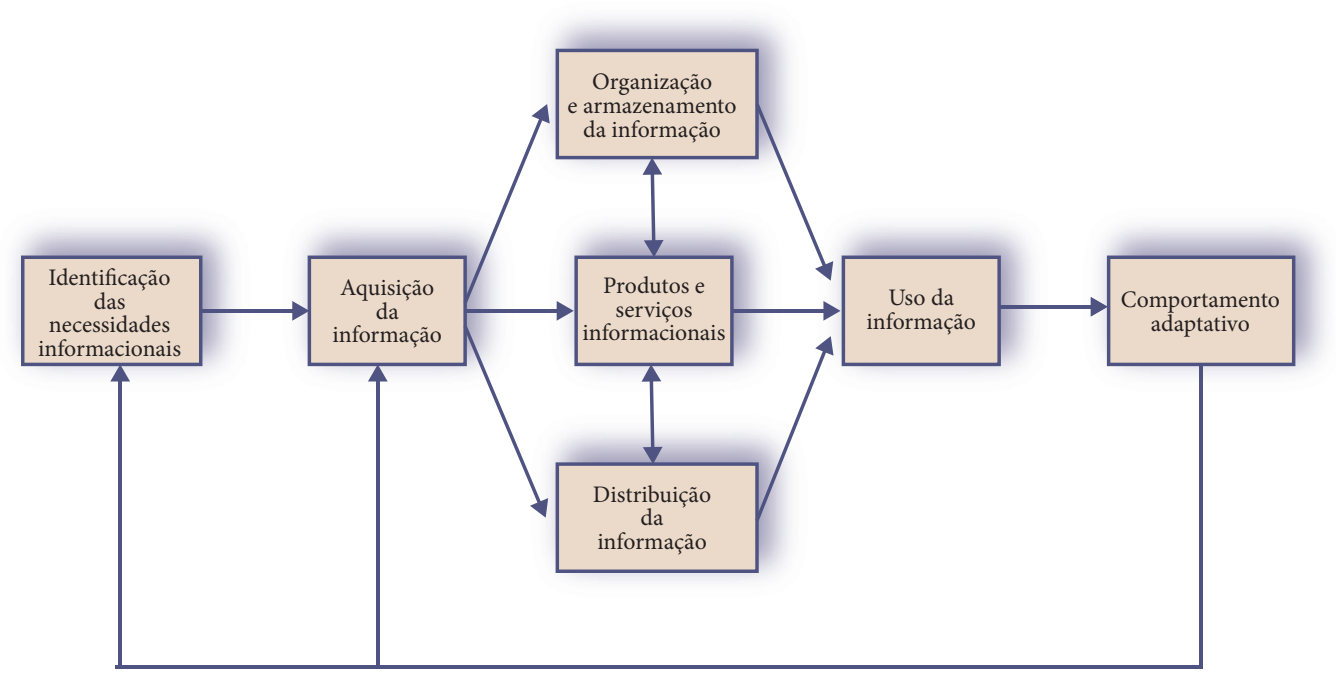

Fonte: Choo (2003a, p. 404).

\subsection{Qualidade da informação}

A preocupação com a qualidade da informação tem aumentado consideravelmente e recebido mais atenção na última década, principalmente após a pesquisa desenvolvida, em 1996, por Wang e Strong. Desde 1996, a cada ano, esse tema tem sido o foco da Conferência Internacional de Qualidade da Informação promovida pelo Massachusetts Institute of Technology (MIT). Apesar de parte dos estudos estar vinculada à qualidade de sistemas de informação, alguns trabalhos têm focado, também, a qualidade da informação como produto. Em 2006, ocorreu, na Austrália, o primeiro Workshop on Information Quality, onde foram apresentados trabalhos voltados para o tema, o que demonstra sua relevância contemporânea. 
Apesar de autores como Nehmy (1996) e Oleto (2006) ressaltarem a dificuldade de mensurar a qualidade da informação, é possível identificar, na literatura, trabalhos que propõem e/ ou validam modelos para avaliar a qualidade da informação nos mais variados contextos organizacionais. Utilizando uma abordagem teórico-ontológica, Wand e Wang (1996) analisam, com base em revisão de literatura, as diversas dimensões de qualidade da informação. Segundo esses autores, existem conceitos (por exemplo, accuracy) com significados diferentes entre diversos autores.

Com foco nos papéis dos participantes do processo, Strong et al. (1997, p. 39) identificam três papéis dentro do sistema de manufatura da informação: os produtores da informação, que geram e fornecem informação; os curadores ou custodiantes da informação, que fornecem e controlam os recursos para armazenar, mantendo e fixando a informação; os consumidores da informação, que a utilizam para executar suas funções. No estudo do processo para qualidade da informação, Albrecht (1999) propõe um processo dividido em quatro etapas: avaliação, priorização da mudança, redesenho e treinamento. Albrecht (1999) afirma que o comprometimento e a conscientização dos líderes são essenciais para que qualquer modelo de qualidade seja implementado.

Já Lee et al. (2002) sugerem a utilização de abordagem empírica e intuitiva e detalham uma metodologia para avaliação da qualidade da informação em organizações. Esses autores desenvolveram e aplicaram, em cinco organizações, a metodologia AIMQ (Methodology for Information Quality Assessment), que constitui um modelo para avaliação da qualidade da informação e sua aplicação nas empresas.

A metodologia AIMQ é constituída de três componentes. O primeiro componente é um modelo de produto, serviço e performance (chamado de PSP/IQ - Performance, Service and Product Model for Information Quality), o qual possui quatro quadrantes baseados no tratamento da informação como produto ou serviço (figura 1). O segundo componente é um instrumento chamado IQ Assessment (IQA), no formato de um questionário, em que são consolidadas as visões acadêmicas de qualidade de informação. Os autores identificaram 12 a 20 critérios ou características de qualidade para cada quadrante de qualidade, os quais foram reduzidos para quatro a cinco critérios após aplicação de um piloto. Foi utilizada a técnica Cronbach Alpha para identificar o relacionamento das medidas de cada dimensão e pontuar pesos para cada item. O terceiro componente baseia-se em duas análises: na análise dos gaps de IQ, que compara a avaliação IQ organizacional com as melhores práticas organizacionais, para cada quadrante do PSP/IQ; e na análise dos gaps de papéis, que estuda a variação entre a avaliação de diferentes stakeholders de sistemas de informação (profissionais de sistemas de informação e os consumidores). Segundo Lee et al. (2002), os consumidores de informação têm o entendimento básico da qualidade da informação necessária para seus trabalhos. 
Diferentemente de Strong; Lee; Wang (1997) e Lee et al. (2002), Liu e Chi (2002) propõem uma abordagem teórica específica evolutiva e sugerem uma avaliação de qualidade para cada uma das fases da construção dos dados (para alguns autores, dado e informação são intercambiáveis): coleta, organização, representação e aplicação. Gackowski (2004), por sua vez, propõe uma abordagem com foco na perspectiva da necessidade de negócio, na qual, considerando a relatividade inerente da percepção de qualidade da informação, sugere um modelo para avaliá-la a partir da análise do impacto do valor dos dados e das informações.

A qualidade de dados em relação aos atores que participam do processo foi analisada por Lee e Strong (2004), os quais demonstraram o relacionamento entre o conhecimento por parte dos atores (produtores, custodiantes e usuários) e a qualidade disponibilizada. Os produtores fornecem a entrada dos dados, os custodiantes seriam os responsáveis pelo armazenamento e distribuição, e os usuários utilizam a informação como suporte para seu trabalho. A pesquisa dos autores sugere que o conhecimento dos atores sobre os processos de produção dos dados e a satisfação da qualidade dos dados, nas suas diferentes dimensões, estão altamente correlacionados.

Quadro 1 - Modelo de produto, serviço e performance (PSP/IQ - Performance, Service and Product Model for Information Quality)

\begin{tabular}{|c|c|c|}
\hline & $\begin{array}{l}\text { CONFORMIDADE COM AS } \\
\text { ESPECIFICAÇÕES }\end{array}$ & $\begin{array}{c}\text { ATENDE OU EXCEDE AS } \\
\text { EXPECTATIVAS DO CONSUMIDOR }\end{array}$ \\
\hline Product quality & $\begin{array}{c}\text { Sound information } \\
\text { (as características da informação fornecida } \\
\text { atendem aos padrões de IQ) } \\
\text { Dimensões da qualidade da informação: } \\
\text { - livre de erro (free of error) } \\
\text { - representação concisa (concise } \\
\text { representation) } \\
\text { - completude (completeness) } \\
\text { - representação consistente (consistent } \\
\text { representation) }\end{array}$ & $\begin{array}{c}\text { Useful information } \\
\text { (a informação fornecida atende as } \\
\text { necessidades de trabalho do consumidor) } \\
\text { Dimensões da qualidade da informação: } \\
\text { - quantidade apropriada (amount of data) } \\
\text { - relevância (relevancy) } \\
\text { - compreensibilidade (understandability) } \\
\text { - interpretabilidade (interpretability) } \\
\text { - objetividade (objectivity) }\end{array}$ \\
\hline Service quality & $\begin{array}{c}\text { Dependable information } \\
\text { (o processo de converter dados em informações } \\
\text { atende aos padrões) } \\
\text { Dimensões da qualidade da informação: } \\
\text { - atualizada (timeliness) } \\
\text { - segura (security) }\end{array}$ & $\begin{array}{c}\text { Usable information } \\
\text { (o processo de converter dado em informação } \\
\text { excede as necessidades dos consumidores) } \\
\text { Dimensões da qualidade da informação: } \\
\text { - credibilidade (believability) } \\
\text { - acessibilidade (accessibility) } \\
\text { - facilidade de manipulação (easy of } \\
\text { manipulation) } \\
\text { - fidedignidade (reputation) } \\
\text { - valor agregado }\end{array}$ \\
\hline
\end{tabular}

Fonte: Adaptado de Lee et al. (2002). 
Lima e Maçada (2007) utilizaram as dimensões (ou características) de Pipino, Lee e Wang (2002) para criar um modelo de avaliação da qualidade da informação em três bancos públicos, com base na visão dos gerentes de agências. No estudo, os autores identificaram algumas dimensões com pouca diferenciação semântica, dimensões essas que ficaram fora do modelo. Em seu trabalho, sugerem que, no contexto das instituições pesquisadas, algumas características (dimensões) de qualidade ficaram fora do modelo proposto, entre elas "livre de erro", "segurança" e "facilidade de uso". Tais dimensões, segundo esses autores, não foram consideradas importantes pelos respondentes, pois já fazem parte da cultura informacional dos bancos.

A análise da literatura revela que qualidade da informação é um tema multidimensional, com um vasto campo para experimentação e aplicação. Existem, no entanto, inúmeras propostas e poucas aplicações em organizações. É importante ressaltar que, qualquer que seja o modelo ou ferramenta a ser utilizado/a ou adaptado/a, faz-se necessário inicialmente identificar o domínio a ser analisado, ou seja, definir o contexto da informação organizacional a ser avaliado, de forma a permitir um mapeamento do nível de qualidade naquele escopo específico, possibilitando delimitar até mesmo os usuários dessa informação. No caso do presente trabalho, definiu-se o escopo como a informação estratégica de uma instituição bancária governamental.

\subsection{Informação estratégica}

A informação é criada, tratada e transferida nas organizações, e é a eficiência desse processo que vai garantir o bom desempenho e o deslocamento da organização para patamares mais elevados de competitividade. A informação organizacional possui características e dimensões específicas. Um de seus segmentos é a informação estratégica, ou seja, a informação que subsidia o processo de tomada de decisão estratégica, permitindo à organização aprender e adaptar-se às mudanças ambientais internas e externas.

Para Frishammar (2003), informação estratégica é a informação adquirida e utilizada para fundamentar as tomadas de decisões estratégicas. Segundo Vaitsman (2001), as tomadas de decisões apoiam-se nas informações disponíveis para a solução de um problema, de forma a proporcionar ao decisor um razoável número de alternativas, possibilitando a escolha da mais favorável. Essas decisões, por sua vez, são compostas de um conjunto de ações e fatores, que direcionam a organização a fim de reduzir a incerteza e os riscos, identificar oportunidades e proporcionar vantagens competitivas. Existem, segundo McNeilly (2002), três passos básicos no processo de tomada de decisões estratégicas, nomeadamente obter a informação correta, tomar uma boa decisão e implementar essa decisão. Além disso, o sucesso para obtenção de informação correta passa necessariamente pelo conhecimento dos tipos de informações necessárias para a tomada de decisão, a forma de encontrá-las e transmiti-las em tempo. 
Alguns autores classificam a informação organizacional sob as mais variadas dimensões. Choo (2003b) considera o critério de fontes e, nessa perspectiva, inclui fontes humanas (internas e externas), textuais (publicadas e documentos internos) e fontes em linha (bases de dados e recursos da internet). Frishammar (2003) utiliza o critério de obtenção: informação estratégica obtida de forma solicitada e informação estratégica obtida de forma não solicitada. Informação solicitada inclui toda a informação explicitamente solicitada pelos usuários e, também, a informação fornecida por conta de solicitações organizacionais. Informação não solicitada inclui informação obtida sem ser demandada. Frishammar (2003) acrescenta que a obtenção da informação para uso estratégico também ocorre a partir de fontes internas e/ou externas, e que essas origens podem ser divididas em fontes pessoais referentes ao contato humano e fontes impessoais relativas a processos escritos e não verbais.

A importância da informação para as organizações, portanto, já é universalmente aceita e considerada como recurso relevante para o sucesso. No entanto, ela alcançará o máximo de eficácia quando bem gerenciada. Somente uma gestão competente da informação possibilitará identificar a informação que a organização precisa obter, como, quando e onde obtê-la e a melhor forma de utilizá-la. Porém é importante notar que a complexidade que envolve a informação estratégica e a dificuldade de sua gestão decorrem dos vários níveis envolvidos para sua obtenção - do nível individual ao interorganizacional (MCGEE; PRUSAK, 1994). O principal objetivo da gestão da informação é, portanto, identificar e potencializar os recursos informacionais de uma organização, ensinando-a a aprender e a adaptar-se às mudanças ambientais (TARAPANOFF, 2001). Isso permite inferir que somente a gestão da informação estratégica pode proporcionar maior qualidade, eficiência e eficácia na criação, na distribuição e no uso desse tipo de informação no contexto organizacional. Considerando esses aspectos, a pesquisa respondeu duas questões principais. A primeira diz respeito à forma de avaliar a qualidade da informação estratégica. A segunda refere-se à identificação dos aspectos de gestão que influenciam essa qualidade no contexto de organizações bancárias.

\subsection{Modelo teórico da pesquisa}

Considerando-se o exposto, a presente pesquisa teve como objetivo construir e validar um modelo para avaliação da qualidade da informação estratégica organizacional no contexto de organizações bancárias, identificando aspectos da gestão da informação que influenciam essa qualidade.

Com base na análise da literatura, foram selecionados conceitos e modelos teóricos que fundamentaram a construção de um modelo conceitual (figura 2) que aponta as questões 
necessárias para avaliar a qualidade da informação estratégica organizacional no contexto de uma organização bancária. Para tal, identifica os aspectos da gestão da informação que influenciam positivamente e negativamente essa qualidade. A construção desse modelo resultou da análise dos trabalhos de vários autores e envolveu três aspectos. O primeiro refere-se à classificação da informação, quanto à dimensão, aos objetivos, às fontes e à abrangência (DIAS; BELLUZZO, 2003, MORESI, 2001, FRISHAMMAR, 2003, e CHOO, 2003b). O segundo relaciona-se a sua avaliação, que é realizada por meio da perspectiva ontológica do usuário (LEE et al., 2002; GACKOWSKI GACKOWSKI, 2005). O terceiro consiste na identificação dos aspectos que impactam essa qualidade por meio da análise da gestão da informação, em que participam produtores, custodiantes e consumidores/ usuários (CHOO, 2003a; STRONG; LEE; WANG, 1997).

Figura 2 - Modelo conceitual da pesquisa

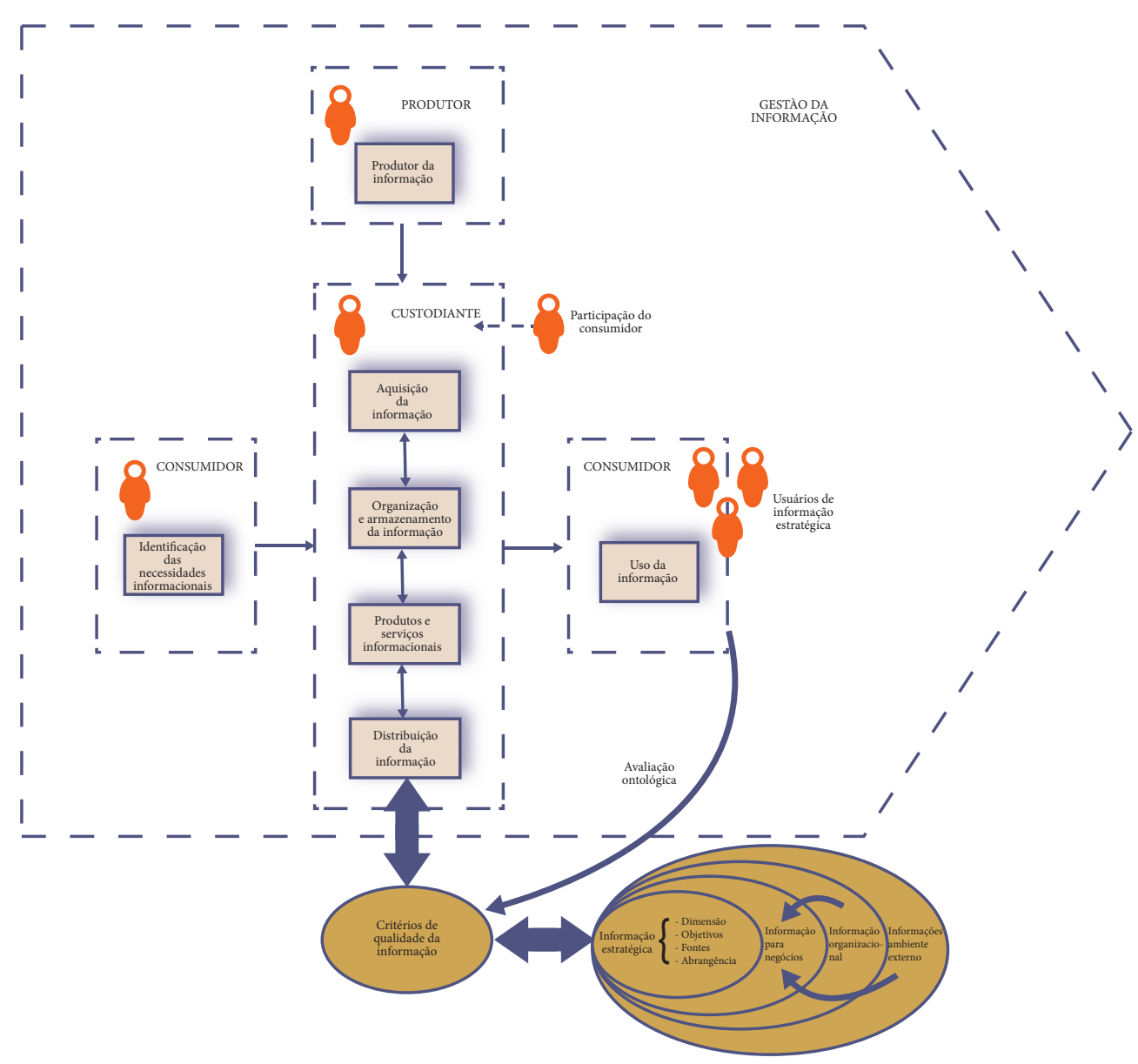

Fonte: Elaboração dos autores (2018). 


\section{PLANO DA PESQUISA}

Levando em conta o referencial teórico construído para o estudo, essa investigação utilizou as abordagens qualitativa e quantitativa.

A abordagem qualitativa se deve ao caráter de complexidade que envolve os dados evidenciados nesta investigação. Deve, ainda, proporcionar maior conhecimento acerca de conceitos sobre a informação estratégica e a gestão da informação existente nas organizações pesquisadas. Segundo Strauss e Corbin (1998), métodos qualitativos podem ser utilizados para explorar áreas em que o conhecimento é pequeno ou áreas de grande conhecimento, sobre as quais se deseja obter um novo entendimento. Podem, assim, ser utilizados para obter detalhes sobre um fenômeno, tal como uma impressão, processos, valores e emoções que são difíceis de extrair ou entender, por meio da utilização de métodos de pesquisa tradicionais. A pesquisa qualitativa é uma abordagem utilizada para estudar o mundo social, para descrever e analisar as ações, os valores, a cultura e o comportamento humano e de grupos na perspectiva dos indivíduos estudados (BRYMAN, 1996). Além disso, é mais indutiva e seu objeto de estudo é a palavra. Busca descobrir e não testar, tendo como meta a penetração no problema, com ênfase nos significados e nas representações que as coisas têm para as pessoas (CASTRO, 2006).

Já a abordagem quantitativa é considerada por Collis e Hussey (2005) como focada na mensuração dos fenômenos, envolvendo coletar e analisar dados numéricos. A abordagem quantitativa é aplicável, nesta investigação, principalmente com relação ao emprego da quantificação no tratamento dos dados referentes às características de qualidade da informação. É interessante destacar que os estudos de Lee et al. (2002) e Huang et al. (1999) sobre qualidade da informação utilizaram a abordagem quantitativa para mensurar as características de qualidade da informação.

Considerando-se essas duas abordagens, o propósito deste estudo é tanto descritivo quanto explicativo. A pesquisa descritiva, na concepção de Collis e Hussey (2005), preocupa-se com a caracterização do comportamento dos fenômenos e é utilizada para identificar e obter informações sobre as características de um determinado problema. Em concordância com Collis e Hussey (2005), Trivinos (1987) e Gil (1999) consideram que o foco essencial desses estudos é a descrição das características de determinada população ou fenômeno. Algumas pesquisas descritivas buscam, além da descrição do fenômeno, identificar os fatores que determinam ou contribuem para a ocorrência dos fenômenos e, nesse caso, tem-se uma pesquisa descritiva que se aproxima da explicativa. Gil (1999) define como pesquisa explicativa aquela que permite o aprofundamento do conhecimento da realidade, pois tenta explicar a razão e o porquê das coisas. Alguns autores como Collis e Hussey (2005) chamam a pesquisa explicativa, proposta por Gil (1999), de analítica ou explanatória, que seria a continuação da pesquisa descritiva por meio da análise e explicação do motivo pelo qual os fatos estão ocorrendo. Portanto, os 
fenômenos da qualidade da informação estratégica relacionam-se ao propósito descritivo da pesquisa, enquanto os aspectos da gestão da informação que podem influenciar essa qualidade referem-se ao propósito explicativo.

No que tange ao alcance temporal, a pesquisa se caracteriza como uma pesquisa interseccional, uma vez que investiga a informação estratégica e a qualidade da informação em determinado período e em determinado contexto organizacional. O estudo baseou-se nas percepções de profissionais que utilizam essa informação e/ou participam do seu processo de gestão, ou seja, usuários e custodiantes da informação estratégica.

O método adotado para realização do estudo, portanto, é o estudo de caso, o qual foi escolhido pela relação observada entre o objeto desta pesquisa e as características básicas do estudo de caso, descritas por Benbasat et al. (1987) e Yin (2001), conforme Quadro 2. Na coluna da direita, são identificadas as características desta pesquisa.

Quadro 2 - Características básicas do estudo de caso

\begin{tabular}{|c|c|}
\hline CARACTERÍSTICAS DO ESTUDO DE CASO & $\begin{array}{c}\text { ESTA } \\
\text { PESQUISA }\end{array}$ \\
\hline Fenômeno observado em seu ambiente natural & $\sqrt{ }$ \\
\hline Dados coletados por diversos meios & $\sqrt{ }$ \\
\hline Estudo exploratório, descritivo ou explanatório & $\sqrt{ }$ \\
\hline Uma ou mais entidades (pessoa, grupo, organização) são examinadas & $\sqrt{ }$ \\
\hline A complexidade da unidade é estudada intensamente & $\sqrt{ }$ \\
\hline Pesquisa dirigida aos estágios de exploração, classificação e desenvolvimento de hipóteses do \\
processo de construção do conhecimento & $\sqrt{ }$ \\
\hline Não são utilizados controles experimentais ou manipulações & \\
\hline Podem ser feitas mudanças na seleção do caso ou dos métodos de coleta à medida que o \\
pesquisador desenvolve novas hipóteses & \\
\hline Pesquisa envolvida com questões do tipo "como" e "por que", em vez de frequências ou \\
incidências & \\
\hline Enfoque em eventos contemporâneos & $\sqrt{ }$ \\
\hline
\end{tabular}

Fonte: Adaptado de Benbasat et al. (1987) e Yin (2001).

Os problemas e objetivos da pesquisa também se alinham à definição de estudo de caso de Goldenberg (2001), o qual afirma que essa estratégia reúne um grande número de informações detalhadas, por meio de diferentes técnicas de pesquisa, com o objetivo de apreender a totalidade de uma situação, por meio de um mergulho profundo e exaustivo no problema da pesquisa. Estudos de casos múltiplos são utilizados em mais de uma unidade de análise, e os resultados desses estudos possuem maior grau de robustez. Estudos de casos 
múltiplos utilizam a lógica da replicação e é importante verificar se o número de casos selecionados é importante para o estudo (YIN, 2001). Como a presente pesquisa foi aplicada em organizações bancárias governamentais (instituição 1) e em parte governamentais (instituição 2), esse requisito está atendido, considerando que, no Brasil, existem somente essas duas instituições com esse perfil.

Os instrumentos de coleta de dados aplicados foram entrevistas semiestruturadas, questionários e pesquisa em documentos organizacionais. Para as entrevistas, foi utilizada amostra não probabilística intencional com base nos critérios "tempo" (experiência dos sujeitos com informação estratégica) e "função gerencial". Para análise dos dados coletados via questionários, utilizaram-se técnicas estatísticas (Qui-quadrado) e de mineração de dados (algoritmos Apriori). Para análise dos dados das entrevistas e da pesquisa documental, utilizou-se a técnica de análise de conteúdo.

Foram aplicados 173 questionários, os quais foram enviados, por e-mail, para a população de usuários (questionários completos). Para a população de custodiantes, foram aplicados 27 questionários, também enviados por e-mail (questionário resumido). Do total de questionários enviados aos usuários, retornaram $139(80,34 \%)$ e, do total de questionários enviados aos custodiantes, retornaram $21(77,77 \%)$. Com relação à entrevista, foram selecionadas nove sujeitos (5,6\% da amostra) entre usuários e custodiantes, considerando-se os critérios adotados.

\section{RESULTADOS}

Os resultados da pesquisa são mostrados de acordo com os objetivos específicos propostos. Por conseguinte, descrevem: o perfil da população, a informação estratégica, os elementos constitutivos da qualidade da informação, o processo de gestão, os aspectos da gestão que mais influenciam a qualidade e a avaliação da qualidade da informação.

No que concerne à caracterização do perfil da população na instituição financeira investigada, usuários e custodiantes de informação estratégica são descritos com base em cinco características: 1) formação especializada: 77\% dos usuários e 61,9\% dos custodiantes possuem especialização (pós-graduação lato sensu completa); 2 ) distribuição regular pelas três faixas de tempo de experiência ( 0 a 5, 6 a 10 e acima de 11 anos inclusive), ficando, cada faixa, entre $30 \%$ e $36 \%$; 3 ) grau de conhecimento sobre informação estratégica entre bom e ótimo $(87,77 \%$ de usuários e 76,19\% de custodiantes); 4) gastam de $50 \%$ a $75 \%$ do seu tempo lidando com informação 
estratégica (69,78\% dos usuários e 71,43\% dos custodiantes); 5) usuários inserem-se no nível estratégico e tático $(83,45 \%)$, e custodiantes estão alocados no nível tático e operacional $(95,23 \%)$.

A caracterização da informação estratégica permitiu sua conceptualização no contexto da instituição bancária investigada, sendo quatro as principais características ou dimensões dessa informação. A primeira diz respeito à obtenção da informação por solicitação $(84,18 \%$ dos participantes) e formal (registrada em formato de documentos, de acordo com $91,73 \%$ dos participantes). A segunda é composta de informações internas $(90 \%)$ e tratadas (73\%). Sobre a terceira, há pouca utilização de tecnologias de Data Warehouse ou Data Mart para esse tipo de informação. Finalmente, a informação estratégica provoca diferentes necessidades com relação aos tipos de informação (clientes, concorrentes, produtos, entre outros).

A definição de qualidade da informação adotada nesta pesquisa é a seguinte: "qualidade da informação consiste da totalidade das características de uma informação que confere a capacidade de satisfazer os seus usuários, sendo mensuráveis e quantificáveis". As características de qualidade (elementos constitutivos da qualidade da informação) foram avaliadas ontologicamente e com relação à percepção do grau de importância pelos usuários. Destarte, foram consideradas como compondo três conjuntos. O primeiro aponta que a maior parte dos conceitos adotados na pesquisa para as características de qualidade é apropriada, visto que foram ratificados pelas respostas favoráveis obtidas nos questionários ou entrevistas, sendo irrisório o número de respondentes que divergiram dos conceitos adotados. O segundo revela que as características "livre de erro" e "fidedigna" foram apontadas pela maior parte dos participantes como as mais importantes no contexto da instituição estudada. Finalmente, o terceiro mostra que a percepção do grau de importância de cada característica apresenta padrões diferenciados, dependendo do objetivo e do produto da área que trabalha com informação estratégica (figura 3 e figura 4 ).

Esses resultados foram obtidos por meio da classificação das respostas das quatro áreas com maior quantitativo de respondentes (financeira, TI, operações e planejamento), visando a uma possível comparação. As características de qualidade de informação "livre de erro" e "fidedigna", nas quatro áreas consultadas, foram aquelas consideradas como "muito importante", com percentuais que variaram de $53,85 \%$ a $83,33 \%$ e de $50 \%$ a $69,23 \%$, respectivamente. Tal resultado foi também identificado na aplicação dos algoritmos de mineração, não sendo encontrados padrões de resposta para as áreas, exceto a área de planejamento estratégico. 
Figura 3 - Grau de importância "muito importante" por característica de qualidade e por área (percentual)

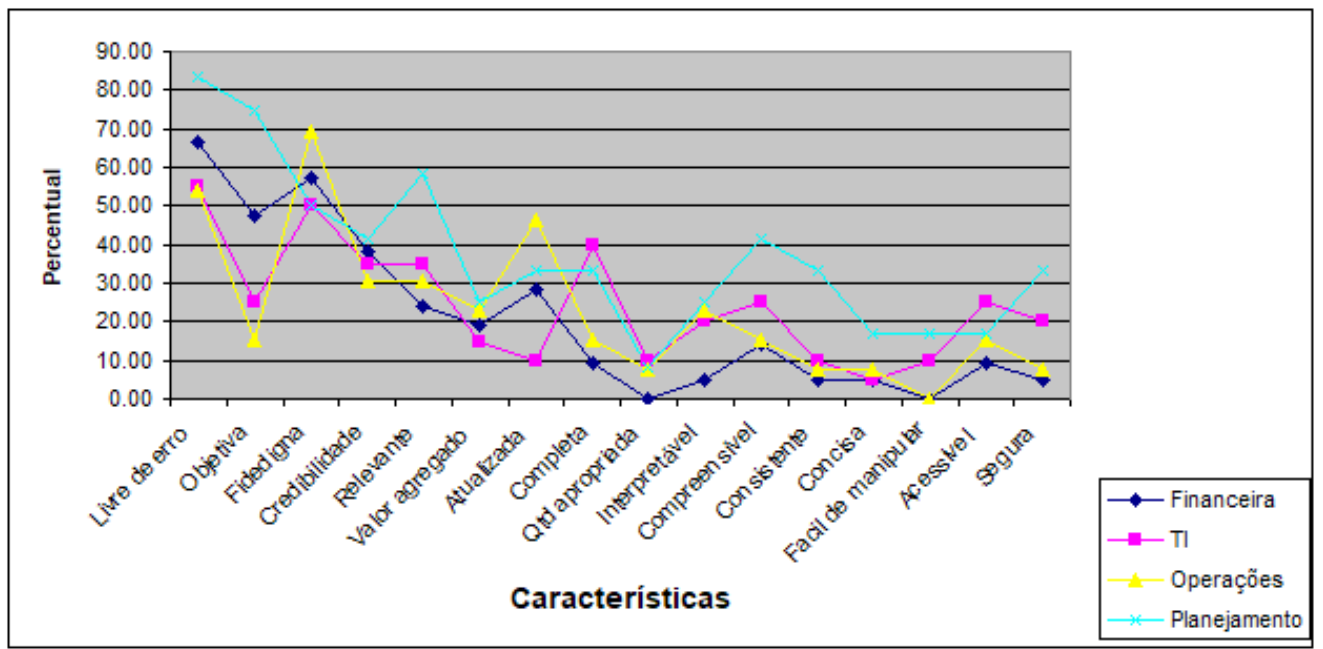

Fonte: Elaboração dos autores (2018).

Figura 4 - Grau de importância “importante” por característica de qualidade e por área (percentual)

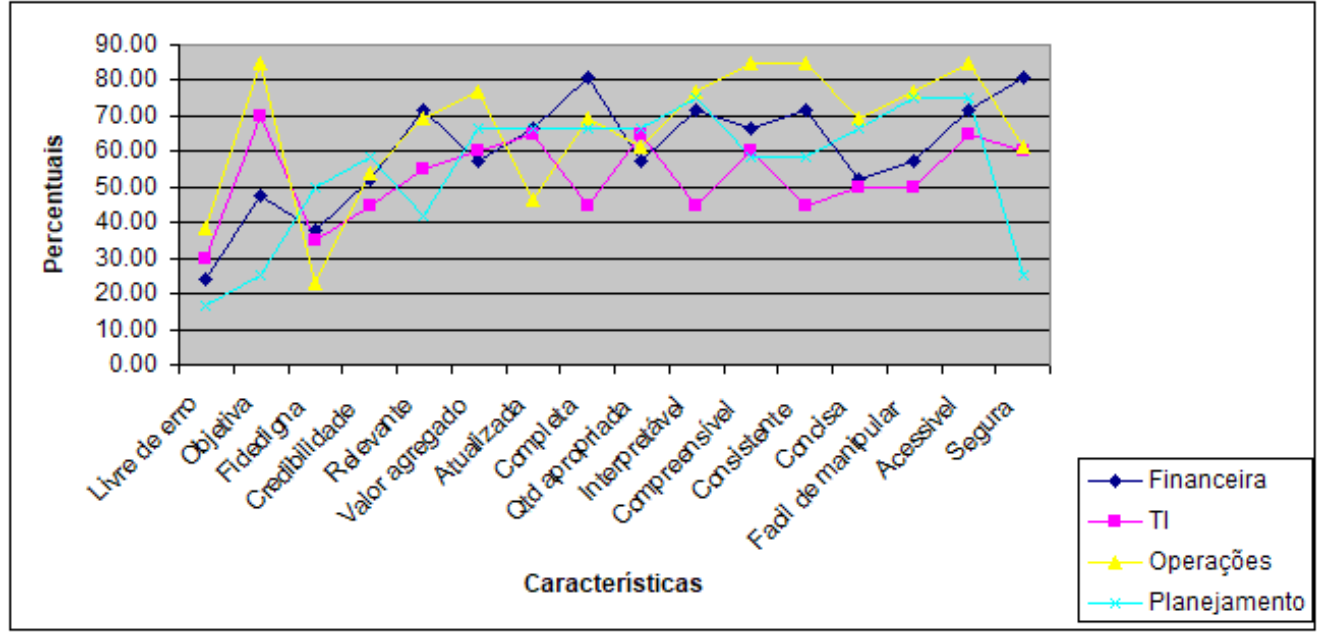

Fonte: Elaboração dos autores (2018).

A análise dos processos de gestão da informação permitiu identificar que possuem alto grau de diferenciação. Porém, todos os participantes identificaram com facilidade os responsáveis pelo processo de gestão em suas ou em outras áreas. No entanto, dependendo da área de atuação, as responsabilidades e atividades relativas a cada fase de gestão da informação são diferenciadas. 
A identificação dos aspectos da gestão da informação estratégica que influenciam a qualidade possibilitou visualizar que todas as fases do processo de gestão são consideradas importantes. Entretanto, a fase "distribuição/disseminação da informação no momento, local e forma adequados" é considerada mais significativa para a qualidade da informação estratégica. A fase menos significativa é a "definição de como e onde guardar a informação".

Além das fases da gestão da informação que mais influenciam a qualidade, a pesquisa identificou as características mais significativas, por fases, na visão de usuários e custodiantes (Quadro 3).

Quadro 3 - Fases de gestão e características mais representativas na percepção de usuários e custodiantes

\begin{tabular}{|c|c|c|c|}
\hline \multirow{2}{*}{ FASES DE GESTÃO } & \multirow{2}{*}{$\begin{array}{c}\text { CARACTERÍSTICAS } \\
\text { DE QUALIDADE } \\
\text { MAIS } \\
\text { SIGNIFICATIVAS }\end{array}$} & \multicolumn{2}{|c|}{ PERCEPÇÃO } \\
\hline & & USUÁRIOS & CUSTODIANTES \\
\hline \multirow{3}{*}{ Identificação das necessidades de informação } & Objetiva & $\sqrt{ }$ & \\
\hline & Completa & $\sqrt{ }$ & \\
\hline & Relevante & $\sqrt{ }$ & $\sqrt{ }$ \\
\hline Planejamento e seleção das fontes de informação & Fidedigna & $\sqrt{ }$ & $\sqrt{ }$ \\
\hline \multirow{2}{*}{ Obtenção da informação, coleta de dados } & Livre de erro & $\sqrt{ }$ & \\
\hline & Atualizada & $\sqrt{ }$ & \\
\hline \multirow{2}{*}{$\begin{array}{l}\text { Definição de como e onde guardar (formas de } \\
\text { armazenamento) }\end{array}$} & Acessível & $\sqrt{ }$ & $\sqrt{ }$ \\
\hline & Segura & $\sqrt{ }$ & \\
\hline Tratamento/transformação da informação & Livre de erro & $\sqrt{ }$ & $\sqrt{ }$ \\
\hline \multirow{2}{*}{$\begin{array}{l}\text { Distribuição/disseminação da informação no } \\
\text { momento, local e forma adequados }\end{array}$} & Segura & $\sqrt{ }$ & \\
\hline & Acessível & $\sqrt{ }$ & $\sqrt{ }$ \\
\hline
\end{tabular}

Fonte: Elaboração dos autores (2018).

Usuários e custodiantes têm, em sua maioria, a mesma percepção do impacto das fases nas características. Esse resultado foi obtido após a aplicação do Qui-quadrado, em que foram definidas duas hipóteses: $\mathrm{H} 0$ - a percepção com relação às fases que impactam determinada característica de qualidade é independente dos usuários e custodiantes; $\mathrm{Hl}$ - a percepção com relação às fases que impactam determinada característica de qualidade depende de cada grupo (usuários e custodiantes). Para todas as características (exceto a característica "objetiva"), os valores obtidos estão na região de aceitação. O estudo indica que as percepções dos usuários e 
custodiantes são comparáveis no que diz respeito à percepção do impacto das fases de gestão nessas características (figura 5).

Figura 5 - Qui-quadrado: percepção dos usuários e custodiantes a respeito do impacto das fases de gestão em cada característica de qualidade da informação

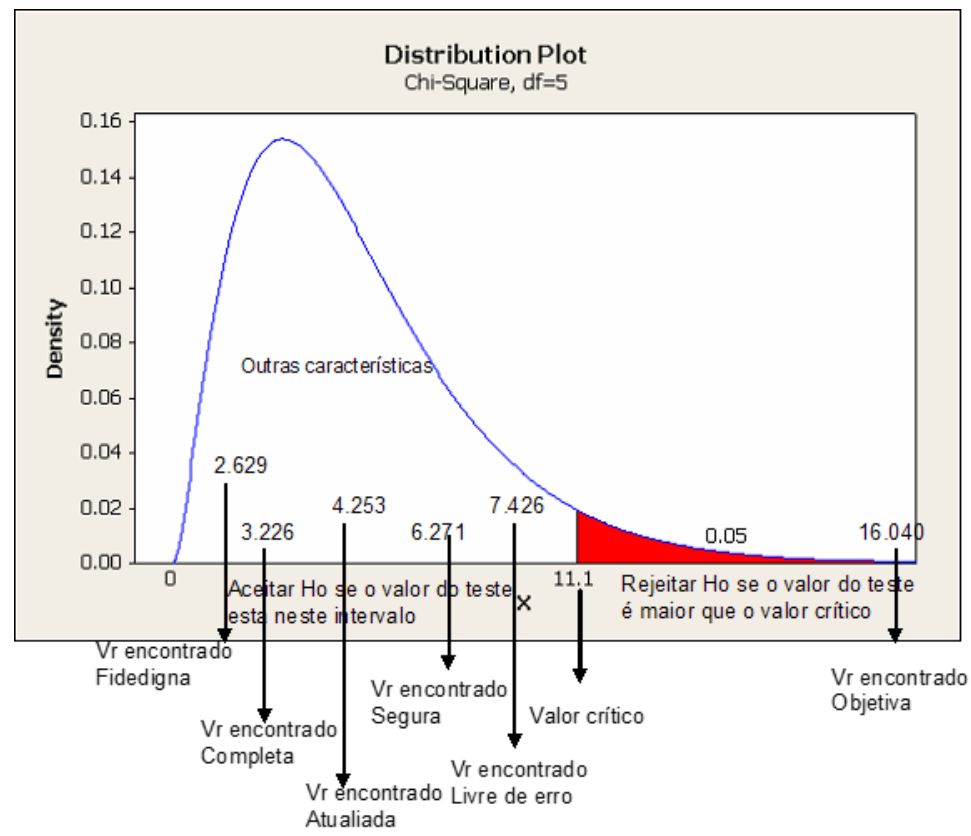

Fonte: Elaboração dos autores (2018).

Com relação à percepção da qualidade da informação na instituição estudada, o valor total identificado foi de 3,2. A maior parte dos respondentes qualificou a informação entre $2 \mathrm{e}$ 4 em uma escala de 0 (menor qualidade) a 5 (maior qualidade), como ilustrado na figura 6. Foram analisadas as respostas correspondentes às quatro áreas que participaram da pesquisa com maior quantidade de respondentes. Para essas, os resultados mostraram os seguintes valores: área financeira, 3,51; área de TI, 3,17; área de operações, 3,36; área de planejamento estratégico, 3,22. 
Figura 6 - Percepção de qualidade da informação por respondente da instituição

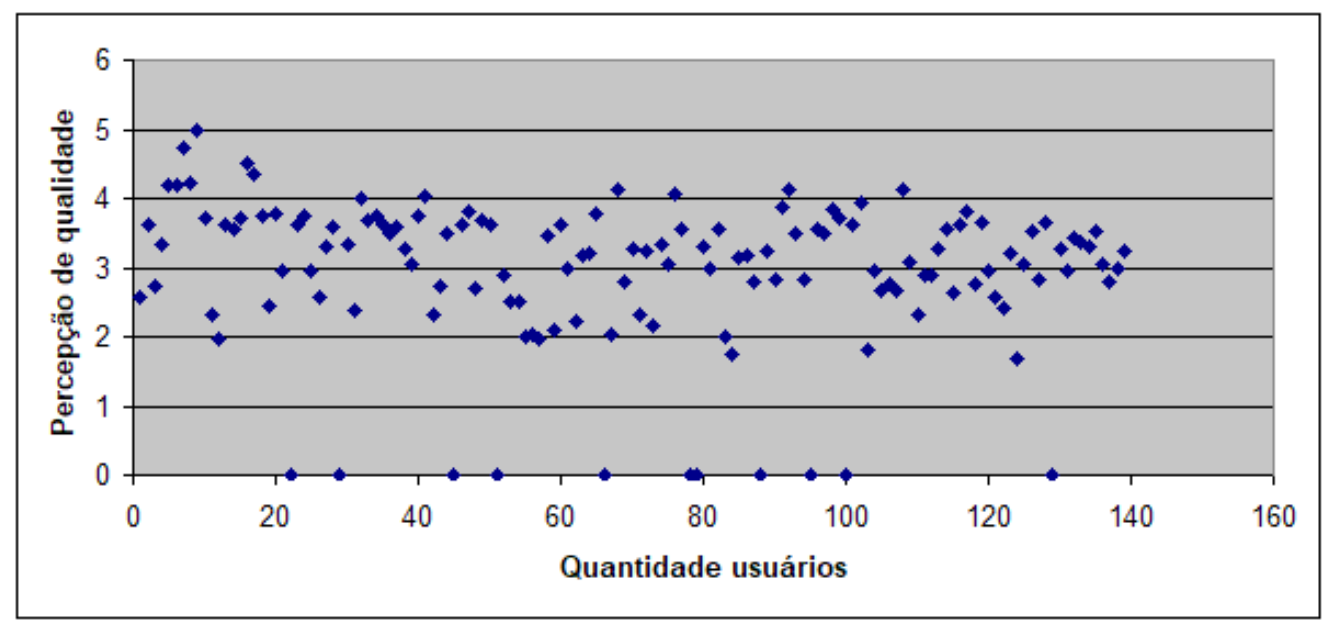

Fonte: Elaboração dos autores (2018).

Entre $32,37 \%$ e $46,76 \%$ dos usuários "concordam" ou "concordam plenamente" que a informação que recebem é "relevante". Entre 20,86\% e 30,22\% dos usuários "discordam parcialmente" ou "concordam parcialmente" que a informação que recebem é "livre de erro", "completa" e possui "quantidade apropriada".

A percepção das características que possuem mais ou menos qualidade depende de cada área. Esse resultado foi obtido após a aplicação do Qui-quadrado, cuja finalidade foi verificar se existe variação nas opiniões dos usuários de áreas distintas, que, nesse caso, são as áreas financeira, de TI, de planejamento estratégico, de operações, acerca da qualidade percebida. Se a hipótese nula é aceita, isso sugere que a percepção do nível de qualidade é independente da área. Sendo aceita a hipótese alternativa, a percepção de qualidade está vinculada a cada área.

Realizaram-se os cálculos utilizando a ferramenta SAS. Na figura 7, apresentam-se os resultados dos cálculos, considerando o grau de liberdade (df) de 15 e o valor 93.41. O valor crítico correspondente ao grau de liberdade de 15 e ao nível de significância de $5 \%$ na tabela de distribuições Qui-quadrado (STEVENSON, 2001) é de 25.0. Como o valor obtido (93.41) está na região de rejeição, pode-se inferir que as áreas não são comparáveis no que se refere à percepção da qualidade da informação, quando analisadas considerando suas respostas por características de qualidade. 
Figura 7 - Qui-quadrado: percepção dos participantes com relação à qualidade da informação recebida por característica de qualidade

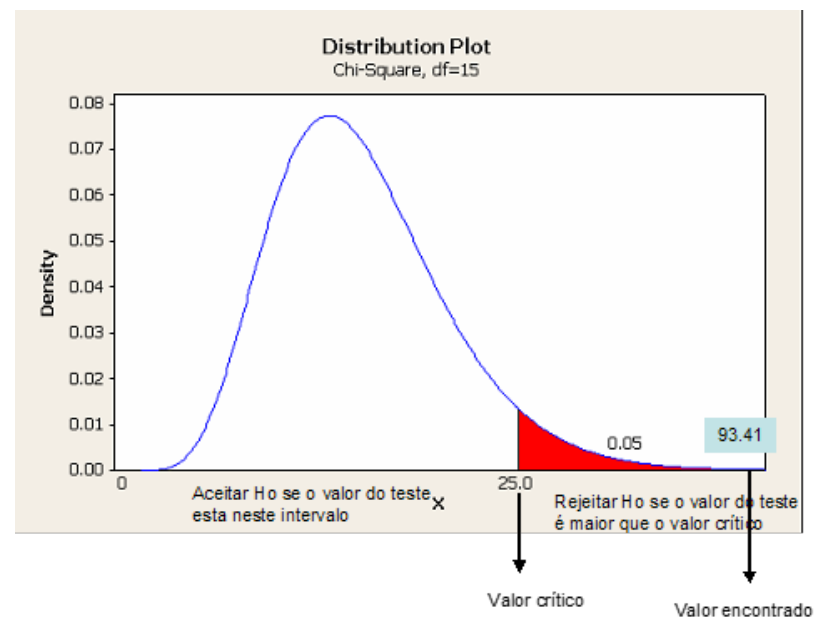

Fonte: Elaboração dos autores (2018).

\section{CONCLUSÕES E RECOMENDAÇÕES}

Esta pesquisa teve por objetivo construir e validar um modelo para avaliação da qualidade da informação estratégica no contexto de organizações bancárias, identificando aspectos da gestão da informação que influenciam essa qualidade. Para atingir esse objetivo, foi construído o modelo conceitual que norteou o desenho da pesquisa e a discussão dos resultados obtidos. Com base no modelo proposto, foi possível não somente levantar os dados necessários ao atingimento dos objetivos, mas também obter conclusões que refletem a teoria embutida no modelo adotado.

A avaliação da qualidade da informação estratégica em contextos organizacionais consolida a possibilidade de se avaliar e mensurar esse elemento estratégico. Além disso, o modelo permite a identificação das fases de gestão da informação que devem ser mais bem trabalhadas para a melhoria dessa qualidade. Permite, ainda, a melhoria contínua desse processo. Mais do que isso, o modelo proposto ressalta a necessidade de as organizações investirem nesse tópico, de forma a agregar cada vez mais valor a esse tipo de informação.

A importância de se buscar a completude de uma pesquisa envolve não somente definir ou adaptar modelos, mas aplicá-los ao mundo real e, dessa forma, mapear o nível de qualidade da informação, identificando aspectos que podem ser melhorados. 
Os resultados da pesquisa sobre o perfil da população na instituição financeira permitem concluir que usuários e custodiantes de informação estratégica apresentam três características. Em relação à primeira, têm um bom nível de capacitação profissional. No que concerne à segunda, dedicam, em quase sua totalidade, de 50\% a 100\% do seu tempo trabalhando com informação estratégica e têm, em sua maioria, percepção entre boa e ótima do seu nível de conhecimento para lidar com ela. Sobre a terceira, inserem-se - particularmente usuários nos níveis estratégico e tático das instituições.

No contexto da instituição financeira pesquisada, a informação estratégica caracteriza-se por ser a informação que subsidia o processo decisório estratégico nas organizações, auxiliando-a a obter vantagens competitivas, reduzir riscos e incertezas e identificar oportunidades. Nesse sentido, chegou-se a três conclusões. A primeira é que grande parte dessa informação é obtida por solicitação e é formal, sendo a maior parte interna e tratada. A segunda mostra que a informação estratégica requer o uso de tecnologias avançadas (Data Warehouse/Data Mart) para seu tratamento, embora, em sua maior parte, esse uso venha ocorrendo em baixa quantidade. A terceira mostra que diferentes necessidades são geradas com relação aos tipos de informação (clientes, concorrentes, produtos, entre outros), mesmo considerando o foco da pesquisa (informação estratégica em organização bancária).

Com relação aos elementos constitutivos da qualidade da informação estratégica no contexto bancário, conclui-se que a maior parte dos conceitos adotados na pesquisa para as características de qualidade é apropriada. Mais que isso, as características "livre de erro" e "fidedigna" são as mais importantes no contexto da instituição estudada, e a percepção do grau de importância de cada característica apresenta padrões diferenciados, dependendo do objetivo e do produto da área que trabalha com informação estratégica.

Considerando a caracterização dos processos de gestão da informação estratégica, foi possível concluir que os processos de gestão possuem alto grau de diferenciação. Isso se deve, principalmente, à estrutura organizacional e à forma diferenciada de lidar com a informação estratégica. Por sua vez, todos os participantes identificaram com facilidade os responsáveis pelo processo de gestão em suas ou em outras áreas. No entanto, dependendo da área de atuação, as responsabilidades e atividades relativas a cada fase de gestão da informação são diferenciadas. É comum a participação de usuários na fase de tratamento/transformação da informação, porque é necessário manipular a informação antes de utilizá-la.

Sobre os aspectos da gestão da informação estratégica que influenciam a sua qualidade no contexto bancário, e considerando as fases de gestão que mais influenciam as características de qualidade, todas as fases do processo de gestão são consideradas importantes. Entretanto, a fase "distribuição/disseminação da informação no momento, local e forma adequados" é 
considerada mais significativa para a qualidade da informação estratégica, enquanto a fase menos significativa foi a "definição de como e onde guardar a informação".

Além das fases da gestão da informação que mais influenciam a qualidade, a pesquisa identificou as características mais significativas por fases. Isso, por sua vez, permitiu concluir que a característica "relevante" é mais importante para a fase "identificação das necessidades de informação", enquanto a característica "fidedigna" é a mais representativa para a fase "planejamento e seleção das fontes de informação". A característica "acessível” é a mais representativa para as fases "definição de como e onde guardar a informação (formas de armazenamento)" e "distribuição/disseminação da informação no momento, local e forma adequados". Já a característica "livre de erro" é a mais importante para a fase "tratamento/ transformação da informação".

A característica "relevante" é aquela com maior nível de qualidade da informação, enquanto a característica com menor nível de qualidade da informação é a "livre de erro". Porém a percepção dos usuários está acima da média com relação à qualidade da informação $(3,2$ em uma escala de 0 a 5). A percepção das características que possuem mais ou menos qualidade depende de cada área.

Os resultados obtidos neste estudo sugerem futuros estudos em outros contextos organizacionais, que procurem identificar a aplicabilidade do modelo construído com relação à informação estratégica, verificando, até mesmo, sua aplicabilidade para outros tipos de informação. Sendo assim, serão necessárias três ações. Primeiramente, é preciso identificar ontologicamente os conceitos e as relações que existem no domínio escolhido ou no contexto de interesse, para que os usuários tenham o mesmo entendimento sobre as características de qualidade que estão sendo avaliadas, e que a pesquisa seja realizada considerando os mesmos significados. Em segundo lugar, é necessário mapear as informações relevantes dentro do domínio estudado, que é o do contexto organizacional, de forma a priorizar a qualidade deste escopo de informações, garantindo, assim, uma ação mais efetiva para melhoria da qualidade. Finalmente, é essencial que se busque a completude da pesquisa, não somente definindo ou adaptando um modelo, mas aplicando-o ao mundo real, mapeando a percepção de qualidade, a fim de identificar, no processo informacional organizacional, os aspectos que influenciam positivamente ou negativamente essa percepção de qualidade.

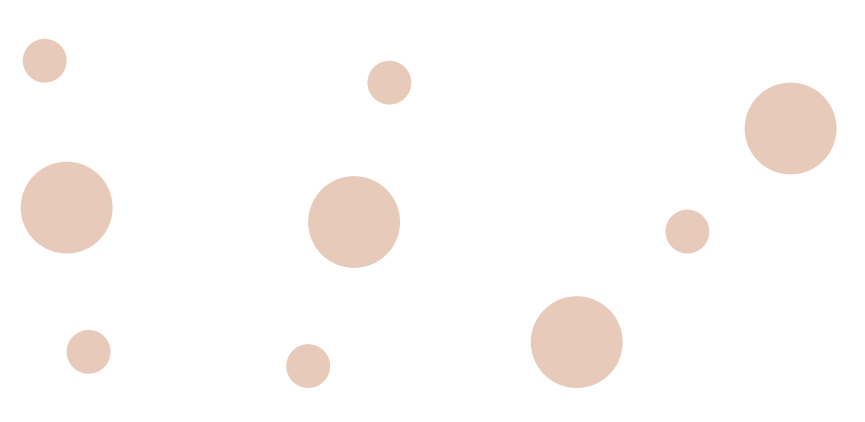




\section{REFERÊNCIAS}

ALBRECHT, K.. Information: the next quality revolution? Quality digest, 1999. Disponível em: <http://www.qualitydigest.com/june99/html/info.html>. Acesso em: 24 nov. 2007.

BENBASAT, I., GOLDSTEIN, D. K. \& MEAD, M. The case research strategy in studies of information systems. MIS quarterly, v. 11, n.3, p. 368-386, Set, 1987.

BOTELHO, L. M. A. Análise do Posicionamento Estratégico na Indústria Bancária Brasileira à Luz da tipologia de Porter, 2007. Dissertação (Mestrado), Faculdade de Administração, Pontifícia Universidade Católica (PUC), Rio de Janeiro, 2007.

BROADY-PRESTON, J.; HAYWARD, T. Turbulent change: strategy and information flow in UK retail banks. Journal of Information Science, v. 24, n. 6, p. 395-408, 1998.

BRYMAN, A. Quantity and Quality in social Research. Canada: Routledge, 1996.

CASTRO, C de M. A prática da pesquisa. São Paulo: Pearson Prentice Hall, 2006. 190 p.

CHOO, C. W. A organização do conhecimento. São Paulo: Editora Senac, 2003a. 425 p.

CHOO, C. W. Gestão da informação para a organização inteligente: arte de explorar o meio ambiente. Lisboa: Editorial Caminhos SA, 2003b. 365 p.

COLLIS, J.; HUSSEY, R. Pesquisa em Administração: um guia prático para alunos de graduação e pós-graduação. 2. ed. Porto Alegre: Bookman, 2005. 349 p.

DAVENPORT, T. H. Process Innovation: reengineering work through information technology. Boston, MA: Harvard Business School Press, 1993.

DAVENPORT, T. H.; PRUSAK, L. Conhecimento empresarial: como as organizações gerenciam o seu capital intelectual. Rio de Janeiro: Campus, 1998.

DIAS, M.; BELLUZZO, R. Gestão da Informação em Ciência e Tecnologia sob a ótica do Cliente. Bauru, SP: EDUSC, 2003. 184 p.

FORTUNA, Eduardo. Mercado Financeiro: produtos e serviços, 16. ed., Rio de Janeiro: Qualitymark Ed., 2005, 848 p. 
FRISHAMMAR, Johan. Information use in strategic decision making. Management Decision. v.41, n. 4, p. 318-326, 2003.

GACKOWSKI, Z. J. Logical Interdependence of Data/information Quality dimensions: a purpose-focused view on IQ. In: INTERNATIONAL CONFERENCE ON INFORMATION QUALITY AT MIT, 2004, Cambridge, MA. Proceedings of the International Conference on Information Quality at MIT. Cambridge, MA: Massachusetts Institute of Technology MIT, 2004. p. 126-140.

GACKOWSKI, Z. J. Operations quality of data and information: teleological operations research-bases approach, call for discussion. In: 10th INTERNATIONAL CONFERENCE ON INFORMATION QUALITY AT MIT, 2005, Cambridge, MA. Proceedings of the 10th International Conference on Information Quality at MIT. Cambridge, MA: Massachusetts Institute of Technology - MIT, 2005.

GIL, A. C. Métodos e Técnicas de Pesquisa social. 5. ed. São Paulo: Atlas, 1999. 206 p.

GOLDENBERG, M. A arte de pesquisar: como fazer pesquisa qualitativa em Ciências Sociais. 5. ed. Rio de Janeiro: Record, 2001.

HUANG, K. T.; LEE, Y. W.; WANG, R. Y. Quality Information and Knowledge. New Jersey: Prentice-Hall, 1999.

KULJIS, J.; SCOBLE, C. Problems of Management and decision making in Multinational Banking. IEEE, 1060-3425, p. 398-405, 1997.

LEE, Y. W; STRONG, D. M. Knowing-Why about data process and data Quality. Journal of Management Information Systems v. 20, n.3, p. 13-39, 2004.

LEE, Y. W et al AIMQ: a methodology for information quality assessment. Elsevier Information \& management 40, p. 133-146, 2002.

LIMA, L. F. R.s; MAÇADA, A. C. G.. Modelo para qualidade da informação na indústria bancária. IN: ENCONTRO DA ANPAD, 23, 2007, Rio de Janeiro, RJ. Anais... Rio de Janeiro: Anpad, 2007.

LIMA, L. F. R.; MAÇADA, A. C. G.; VARGAS, L. M.. Research into information Quality: a study of the state of the art in IQ and its consolidation. . IN: INTERNATIONAL CONFERENCE ON INFORMATION QUALITY AT MIT, 11, 2006, Cambridge, MA. Proceeding... Cambridge, MA: Massachusetts Institute of Technology - MIT, 2006. 
LIU, L.; CHI, L. N. Evolutional data quality: a theory specific view. In: 07th INTERNATIONAL CONFERENCE ON INFORMATION QUALITY AT MIT, 2004, Cambridge, MA. Proceedings of the 07th International Conference on Information Quality at MIT. Cambridge, MA: Massachusetts Institute of Technology - MIT, 2002. p. 292-304.

MCGEE, J. V.; PRUSAK, L. Gerenciamento estratégico da informação: aumente a competitividade e a eficiência de sua empresa utilizando a informação como ferramenta estratégica. Rio de Janeiro: Campus, 1994.

MCNEILLY, M. Gathering information for strategic decisions, routinely. Strategy \& Leadership, v. 30, n. 5. p. 29-34, 2002.

MORESI, E. A. D. Gestão da informação e do conhecimento. In: TARAPANOFF, K.(Org.). Inteligência organizacional e competitiva. Brasília: Editora Universidade de Brasília, 2001. p. 111-142.

NEHMY, R. M.. Q. Leitura epistemológico-social da qualidade da informação, 1996. Dissertação (Mestrado), Universidade Federal de Minas Gerais, Belo Horizonte, 1996.

OLETO, R. R. Percepção da qualidade da informação. Ciência da informação, vol. 35, n. 1, p. 57-62, jan.-abr., 2006.

PIPINO, L. L.; LEE, Y. W.; WANG, R. Y. Data Quality Assessment. Communications of the ACM, v. 45, n. 4, apr. 2002.

PIRES, M. G.; MARCONDES, R. C. Conhecimento, Inovação e Competência em Organizações financeiras: uma análise sob o ponto de vista de gestores de bancos. RAC, p. 61-78, Edição Especial, 2004.

QUEYRAS, J.; QUONIAM, L. Inteligência competitiva (IC). In: TARAPANOFF, K.(Org.). Inteligência, informação e conhecimento em corporações. Brasília: IBICT, UNESCO, 2006. p. 73-97.

SANTOS, R. N. M. dos; BERAQUET, V. S. M. Informação estratégica e empresa: um discurso a prova de fatos. Datagramazero, Revista da Ciência da Informação, v. 2, n. 3, jun., 2001.

STEVENSON, W. J. Estatística aplicada à Administração. São Paulo: Harper\&Row do Brasil, 2001. 
STRAUSS, A.; CORBIN, J. Basics of qualitative research - Techniques and procedures for developing grounded theory. 2. ed. California: SAGE publications, 1998. 312 p.

STRONG, D. M; LEE, Y. W.; WANG, R. Y.10 Potholes in the Road to Information. Quality - IEEE Computer, v. 30, p. 8, 1997.

TACHIBANA, L. M. Uma análise do ambiente de negócios da indústria bancária comercial. Contexto, Porto Alegre, v. 4, n. 6, 1º. Semestre, 2004.

TARAPANOFF, K. Referencial teórico: introdução. In: TARAPANOFF, K.(Org.). Inteligência organizacional e competitiva. Brasília: Editora Universidade de Brasília, 2001. p. 33-58.

TRIVINOS, A. N.S. Introdução à pesquisa em ciências sociais: a pesquisa qualitativa na educação. São Paulo: Atlas, 1987.175 p.

VAITSMAN, H. S. Inteligência empresarial: atacando e defendendo. Rio de Janeiro: Interciência, 2001.

WAND, Y.; WANG, R. Y. Anchoring data quality dimensions in ontological foundations. Communications of the ACM, v. 39, n. 11, p. 86-95, 1996.

WILSON, T.D. Information Management. In: International Encyclopedia of information and library Science. London: Routledge, 1997. p. 187-196.

YIN, R. K. Estudo de caso: Planejamento e métodos. 2a . Ed., Porto Alegre: Bookman, 2001. 


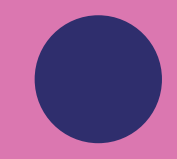

○

○

-

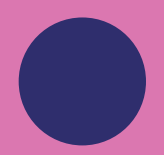

-

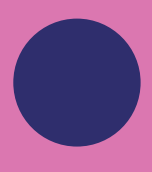

○

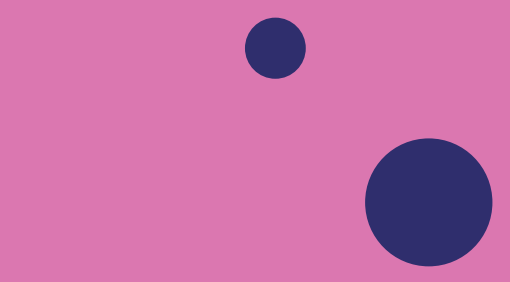

○

○

- 0

○
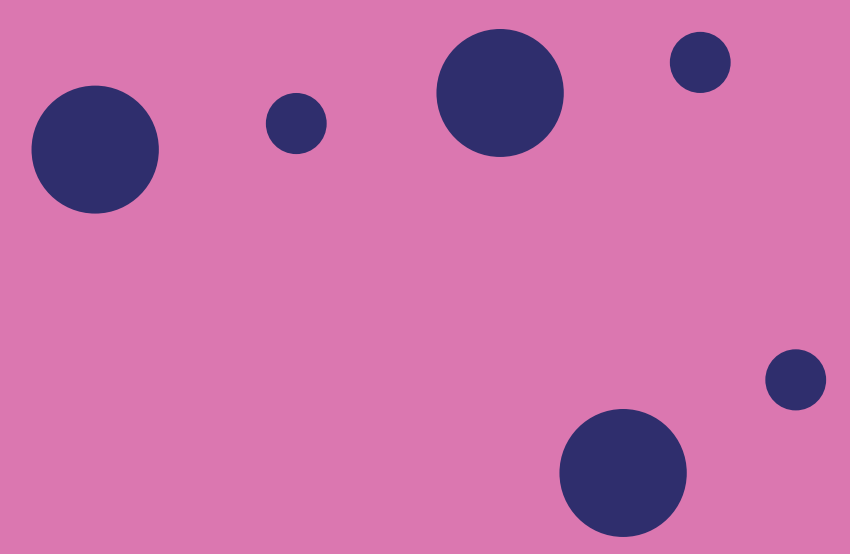


\section{CAPÍTULO 12}

0

0
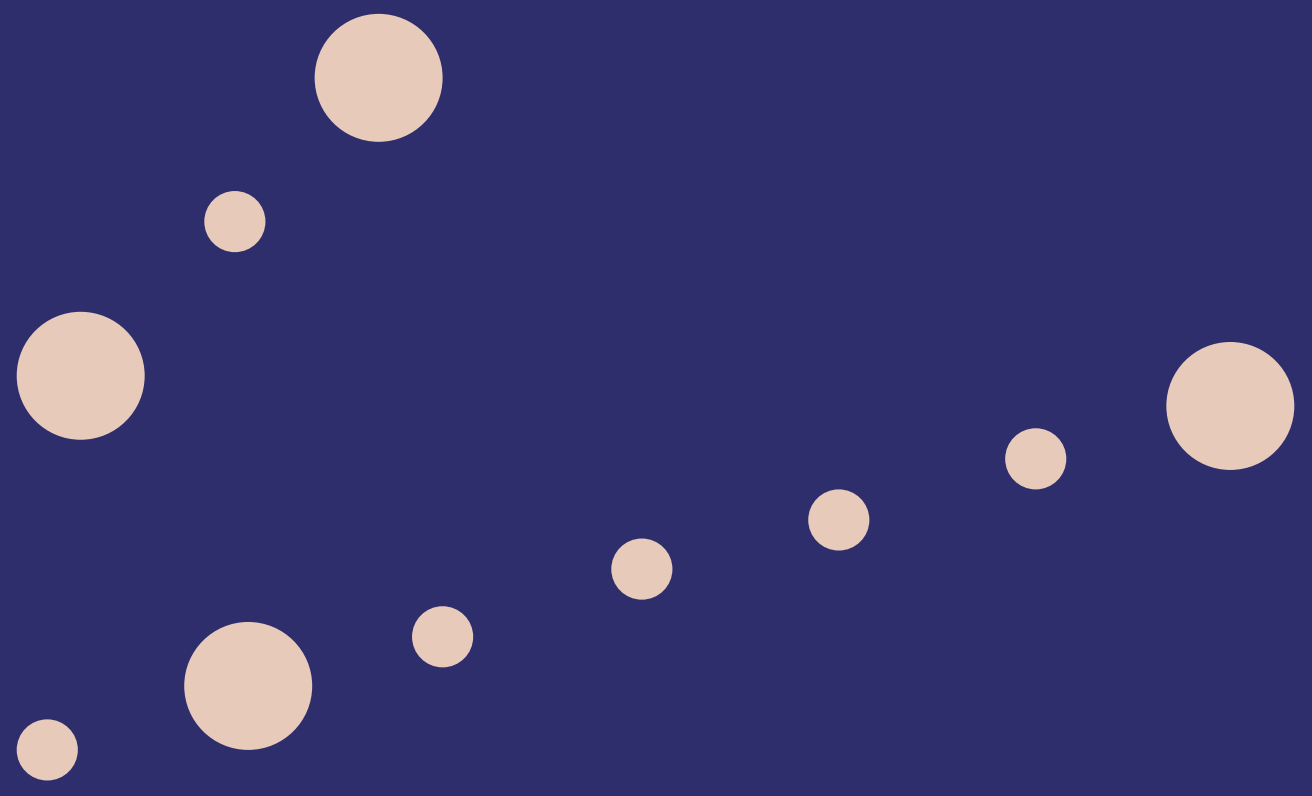

- 00

0 


\title{
GESTÃO DO CONHECIMENTO ESTRATÉGICO: METODOLOGIA E APLICAÇÕES
}

\author{
ROBERTO CAMPOS DA ROCHA MIRANDA \\ SELY MARIA DE SOUZA COSTA
}

\section{INTRODUÇÃO}

Entender o processo de geração de estratégias e a complexidade na tomada de decisão nos níveis superiores de uma organização é preocupação fundamental e contínua de pesquisadores na área de gestão. Agregar a essas questões o entendimento de atores, sistemas e métodos envolvidos aumenta o grau de interação de elementos que navegam entre dados, informações, conhecimentos e inteligências nas esferas pessoais, grupais e organizacionais.

Nesse contexto, propõe-se, neste capítulo, apresentar pesquisa voltada para o entendimento sistêmico da gestão do conhecimento estratégico (GCE), matéria que contempla os saberes da gestão do conhecimento (GC), da gestão da informação (GI), do planejamento estratégico (PE) e da inteligência competitiva (IC). O objetivo é indicar a estrutura metodológica de geração do modelo de GCE e os desdobramentos derivados em estudos posteriores.

Justifica-se a apresentação da pesquisa desenvolvida em 2004 (MIRANDA, 2004) pela atualidade das questões discutidas e pelas possibilidades de aplicação da GCE na atuação das organizações. Ressalta-se que o trabalho ora apresentado é um resgate da pesquisa com indicação de resultados posteriores a sua realização, os quais agregaram maior compreensão ao fenômeno "conhecimento estratégico" em contextos de organizações pública e privadas. 


\section{ABORDAGENS TEÓRICA E METODOLÓGICA}

\subsection{Fundamentação teórica}

A pesquisa concentrou seu escopo no âmbito das organizações, assim entendidas como aquelas com ou sem fins lucrativos, privadas ou públicas. Considerando as duas etapas do trabalho, o universo da pesquisa teórica abrangeu o estudo de modelos de GC delineados por brasileiros e estrangeiros, além de perspectivas e enfoques estratégicos, escolhidos de acordo com quatro critérios. O primeiro diz respeito à atualidade e consistiu em buscar, na literatura, os modelos mais recentes sobre o tema e amplamente conhecidos e aceitos na comunidade que estuda a GC no Brasil. O segundo critério consiste na variabilidade e diz respeito aos modelos que trazem visões diferenciadas em termos de escolas de formação, quer seja a postura oriental-japonesa - modelo de Nonaka e Takeuchi (1997) -, quer seja a ocidental norte-americana - modelo de Davenport e Prusak (1998) - ou, ainda, a ocidental-brasileira - modelos de Terra (2001) e Teixeira Filho (2001). O quarto critério refere-se à similaridade básica, em que os modelos - de forma direta ou indireta - tratam das questões relacionadas à gestão do conhecimento tácito, elemento da GCE que interessa especialmente por influenciar na diferenciação entre novatos e experientes. Finalmente, o último critério consiste nos aspectos cognitivos, que constituem os modelos que apresentam visões cognitivistas do trato com o conhecimento, levando em consideração, principalmente, a questão relacionada ao conhecimento tácito (LAROCHE; NIOCHE, 1994).

A GCE parte do conhecimento estratégico, considerando-o como o tipo de conhecimento gerado no âmbito das organizações pelo acúmulo de saber sobre processos, produtos, serviços, fornecedores, concorrência, etc., no trato com estratégias. Nesse aspecto, a GCE trata a estratégia como um processo construtivo que parte de dados e informações tanto internos - oriundos do acompanhamento da gestão de atividades da organização - quanto externos - oriundos do monitoramento estratégico, de maior dificuldade de captura e coleta, mas eivados de conteúdo fundamental para a alteração dos rumos da organização (MIRANDA, 1999). Voltando-se ainda para a estratégia, consideram-se suas quatro perspectivas de construção (WHITTINGTON, 2002). A primeira perspectiva é a clássica, em que a estratégia é fruto de um processo deliberado de planejamento estratégico. A segunda é a evolucionista, em que a estratégia emerge como resultado de situações - oportunidades ou ameaças - ocorridas no ambiente-tarefa da organização. A terceira é a processual, que se constitui em um processo no qual cada órgão e colaborador participam com informações, trazendo seus conhecimentos e aprendizados. Por último, a quarta perspectiva, sistêmica, envolve todas as demais perspectivas, enfatizando a geração do próprio conhecimento estratégico como resultado e feedback do sistema de geração de estratégias em um contexto social. 
Na questão dos decisores estratégicos, tem-se a própria decisão, que parte da premissa da expectativa de obtenção de algo futuro a partir de opção no momento em que a decisão ocorre. A formulação estratégica parte da premissa de que se deve contemplar todo o conhecimento tácito e explícito dos envolvidos (gestores, assessores, especialistas, etc.) no que se refere à definição de opções estratégicas. Em pequenas organizações, decisores e formuladores se confundem, e os processos de formulação e decisão são mesclados. Reforça-se ainda a diferença entre novatos e experientes - profissionais que detêm pouco e muito conhecimento estratégico, respectivamente - e suas necessidades diferenciadas de informação e de conhecimento. $\mathrm{O}$ referido conhecimento estratégico sofre influência de fatores como contexto, cultura organizacional, etc. Os elementos que descrevem o conhecimento estratégico estão indicados na figura 1.

Figura 1 - Modelo conceitual: conhecimento estratégico

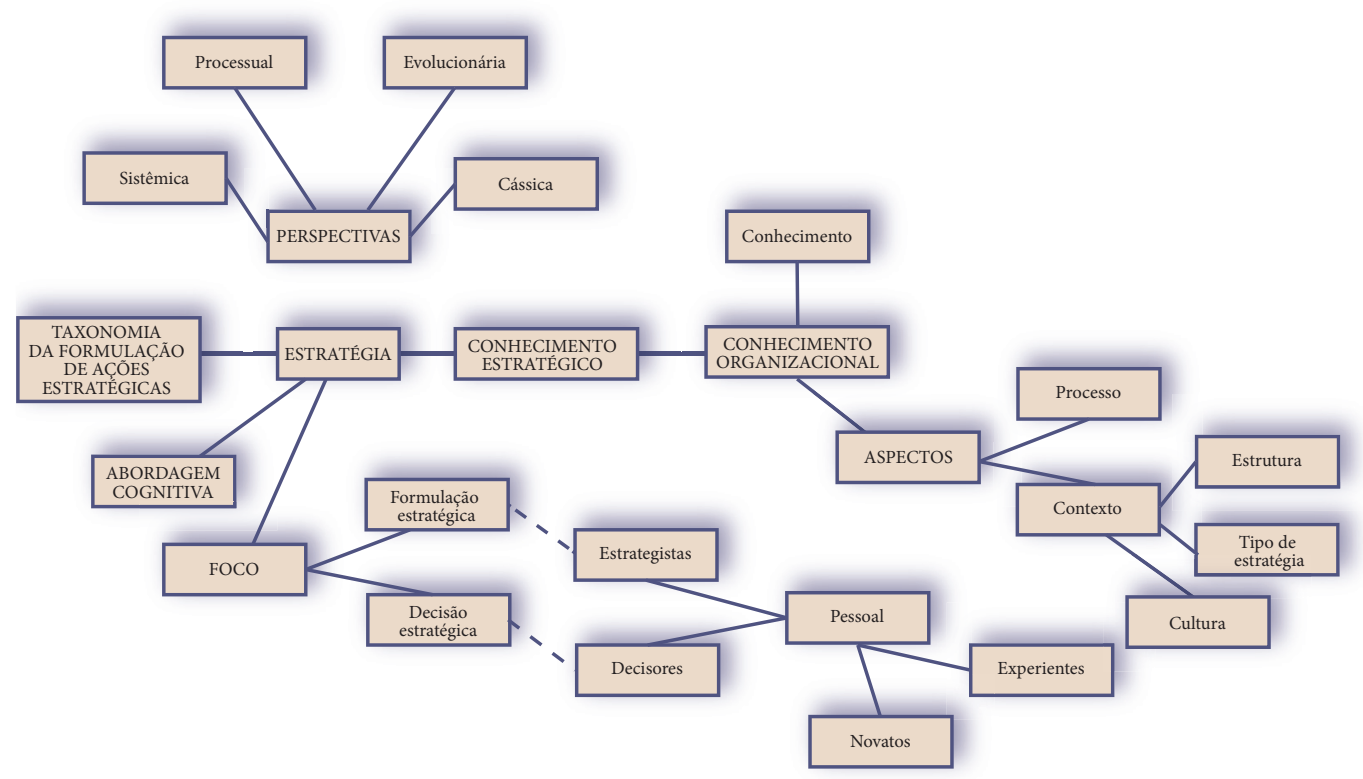

Fonte: Miranda (2004).

Em decorrência dos elementos avaliados, foram definidos conceitos operacionais para a pesqui$\mathrm{sa}$, os quais foram agrupados em categorias. A primeira categoria refere-se ao conhecimento estratégico, que é o tipo de conhecimento organizacional que abarca saberes relacionados ao planejamento, à descrição, ao impacto, à predição, à avaliação e à geração de estratégias, sendo formado pela vertente explícita - as informações estratégicas e as de acompanhamento - e a tácita - o conhecimento acumulado por estrategistas e decisões nos processos de formulação e decisão estratégicas. Inserto nessa categoria está o conhecimento explícito e o conhecimento 
tácito. O primeiro, conhecimento disponível em livros, revistas e outros meios de fácil acesso, é transferível e se aproxima do conhecimento declarativo estudado na psicologia cognitiva. $\mathrm{O}$ segundo, conceituado como o conhecimento próprio das pessoas que o detêm, é representado pelas experiências, habilidades e capacidades do indivíduo, e, com técnicas adequadas, pode ser parcialmente elicitado. Subdivide-se em: 1) conhecimento tácito, tácito elicitável ou tácito extrínseco - conhecimento tácito passível de ser elicitado e convertido em conhecimento explícito, envolvendo especialmente experiências, formas de trabalho, etc.; 2) conhecimento tácito implícito, tácito não elicitável ou tácito intrínseco - conhecimento tácito que não é passível de ser elicitado e, consequentemente, não pode ser convertido em conhecimento explícito, envolvendo especialmente emoções, sentimentos, sensações, etc.

A segunda categoria refere-se à decisão estratégica, que é entendida como a integração entre fins (os objetivos estratégicos) e meios (as ações estratégicas). Caracteriza-se por ser influenciada pelos limites cognitivos do decisor, da complexidade do problema e de conflitos entre os decisores, ou seja, é a tomada de decisão sobre a estratégia a ser adotada, realizada pelo decisor detentor de autoridade formal dentro da organização. Nessa categoria, inclui-se o decisor ou tomador de decisão, que é o dirigente da organização, dotado de competência formal para optar pela estratégia mais adequada a determinado objetivo, exercendo o ato da decisão estratégica.

A terceira categoria, a formulação estratégica, é considerada o processo de desenvolvimento da reflexão estratégica, que resulta de uma elaboração cognitiva (diagnóstico, avaliação das alternativas, escolha e implantação) e sofre influência de fatores como a "a estrutura, a política e o poder, a cultura organizacional e mesmo as emoções", ou seja, trata-se do processo que precede a decisão estratégica e é realizada por estrategistas. Incluem-se na categoria os estrategistas, entendidos como os profissionais da organização, sem poder decisório, que utilizam o conhecimento estratégico para formulação de estratégias.

Ressalta-se, porém que ambos, decisores e estrategistas, são categorias que se subdividem em novatos (estrategistas ou decisores de uma organização que não dispõem de experiência na execução das atividades relacionadas à formulação e à decisão estratégicas respectivamente e, por isso, tendem a utilizar mais a vertente explícita do conhecimento estratégico em seus trabalhos) e experientes (estrategistas ou decisores de uma organização que dispõem de experiência na execução das atividades relacionadas, respectivamente, à formulação e à decisão estratégicas e, por isso, tendem a utilizar mais a vertente tácita do conhecimento estratégico em seus trabalhos).

O estudo teórico permitiu o desenvolvimento de um modelo integrado de GCE, que é constituído de três partes, também designadas como modelos, em virtude de suas características no que diz respeito à abrangência e à completeza quanto ao trato do conhecimento estratégico. 
Os seguintes modelos foram identificados: o modelo conceitual, o modelo matemático e o modelo sistêmico.

\subsubsection{Modelo conceitual}

O modelo conceitual de GCE pode ser tomado como a visão ampla e sinérgica dos diversos fatores, elementos, agentes, processos, que constituem a essência do trabalho com o conhecimento estratégico. Entre os elementos que constituem a CGE distinguem-se os seguintes: a gestão, assim considerando os agentes (estrategistas e decisores, novatos e experientes), os fatores sistêmicos (contexto, cognição, tecnologia, modelo gerencial, cultura organizacional), os tipos de gestão e o processo de gestão; o conhecimento, considerando a formação do conhecimento (conhecimento organizacional e o tipo de conhecimento envolvido - tácito elicitável e explícito); e, finalmente, a estratégia, considerando as ações envolvidas (formulação e decisão), as perspectivas estratégicas (clássica, evolucionista, processual e sistêmica) e a taxonomia da formulação de ações estratégicas (do dado ao conhecimento).

\subsubsection{Modelo matemático}

O modelo matemático aqui descrito busca equacionar a função entre o conhecimento estratégico e os fatores sistêmicos na gestão do conhecimento estratégico, com o intuito de utilizar essa relação no diagnóstico da situação da organização quanto ao processo de implantação ou de desenvolvimento de um programa de GCE. Os fatores sistêmicos identificados incluem seis elementos: 1) a cognição, que está relacionada aos processos mentais, à experiência, à capacidade de julgamento e outras características que venham a caracterizar a forma de atuação individual de estrategistas e decisores no processo de formulação e de decisão estratégica, respectivamente; 2) a tecnologia, que tem relação com as tecnologias da informação e da comunicação aplicadas ao processo de formulação e decisão estratégicas, além da utilização de técnicas e métodos que venham a apoiar esses trabalhos. Trata-se de um fator de influência na infraestrutura dos trabalhos de GCE; 3) a cultura organizacional, que se refere aos valores e crenças compartilhados no seio da organização, os quais fundamentam "o estilo de ser" do grupo organizacional, sendo retratado pela motivação dos colaboradores, pela comunicação formal e informal entre eles, pelas características do ambiente para o aprendizado, pela integração entre as pessoas que participam dos grupos de trabalho, pela experiência partilhada, pela rotatividade (turn over) da equipe, pelo compartilhamento de conhecimento e pelos valores organizacionais; 4) o modelo gerencial, que se refere à liderança empreendida pelos decisores, à estrutura de poder, influência e autoridade e à proposição clara dos valores e objetivos a serem alcançados pela organização; 5) o contexto, que está relacionado às questões voltadas para o ambiente (interno e externo à organização), bem como à tempestividade e à 
oportunidade de adoção de estratégias de acordo com a situação da empresa; 6) a individualidade, que foi identificada por Fujihara (2008) e abarca questões relacionadas à influência e à experiência pessoal, elementos anteriormente incluídos em outros fatores.

O modelo matemático permite que se estabeleça relação entre a perspectiva estratégica, a tendência a ser adotada na formulação e na decisão estratégicas e os fatores que mais contribuem para o processo. No caso, surge uma nova perspectiva, que é a do conhecimento, voltado para o uso intensivo do conhecimento estratégico em organizações que já o possuem de forma mais estruturada, conforme se pode observar no Quadro 1.

Quadro 1 - Relação entre perspectiva estratégica e fatores sistêmicos

\begin{tabular}{|c|c|c|}
\hline PERSPECTIVA ESTRATÉGICA & TENDÊNCIA & FATORES ENVOLVIDOS \\
\hline Clássica & Planejamento & Cognição e modelo gerencial \\
\hline Evolucionária & Mercado & Contexto \\
\hline Processual & Fatores socioculturais & $\begin{array}{c}\text { Modelo gerencial, cultura } \\
\text { organizacional e contexto }\end{array}$ \\
\hline Sistêmica & Integração dos fatores & $\begin{array}{c}\text { Cognição, modelo gerencial, cultura } \\
\text { organizacional e contexto }\end{array}$ \\
\hline
\end{tabular}

Fonte: Miranda (2004).

\subsubsection{Modelo sistêmico}

O modelo sistêmico tem por objetivo estabelecer características, procedimentos e tecnologias envolvidas nas fases da GCE, a fim de sistematizar o processamento do conhecimento explícito associado ao conhecimento tácito. Os subsistemas integrantes do sistema de CGE identificados são seis.

O sistema de monitoramento do conhecimento estratégico é responsável pelo rastreamento do conhecimento existente nos ambientes interno e externo à organização. O sistema busca acompanhar as fontes de conhecimento já identificadas e perscruta novas, por meio do uso de ferramentas de tecnologia da informação e de métodos da inteligência competitiva e de outras áreas.

Já o sistema de aquisição e captura do conhecimento estratégico transforma conhecimento (tácito e explícito) não estruturado, bem como informações dispersas (estratégicas e de acompanhamento), em conhecimento estratégico estruturado. Para isso, são utilizadas técnicas de 
gestão e organização da informação e de elicitação do conhecimento, a fim de gerar insumos para os sistemas de armazenamento e aplicação do conhecimento estratégico, bem como para o sistema de aprimoramento de estrategistas e decisores novatos.

O terceiro é o sistema de armazenamento de conhecimento estratégico explícito, que atua na função de guardar em repositórios adequados o conhecimento explícito adquirido e o conhecimento tácito elicitado (externalizado e codificado). Tal ação se realiza com o uso de tecnologias da informação, a fim de que o conhecimento estratégico explícito seja disponibilizado aos demais sistemas integrantes.

O quarto sistema é o de aprimoramento de estrategistas e decisores novatos e é voltado para o desenvolvimento das competências dos novatos estrategistas e decisores. O sistema utiliza o conhecimento estratégico disponibilizado pelo subsistema de socialização e compartilhamento do conhecimento tácito e pelo sistema de armazenamento do conhecimento estratégico explícito e tem por finalidade reduzir o gap existente entre os experientes e os novatos, no que tange à decisão e à formulação estratégica.

O quinto sistema é o de aplicação do conhecimento estratégico, que desempenha a função precípua do conhecimento estratégico: decisão e formulação estratégicas. O sistema contempla o desenvolvimento de aplicativos específicos que apoiam tanto as decisões, quanto as decisões estratégicas, ao filtrar o conhecimento efetivamente relevante para determinada tomada de decisão ou elaboração no contexto estratégico.

O último sistema é o de avaliação do sistema de GCE, que é responsável pela verificação da eficácia do sistema, realizando a tarefa por meio da medição de parâmetros e critérios de desempenho voltados para a análise qualitativa e quantitativa das ações estratégicas adotadas, a fim de permitir a eliminação de distorções e o aprimoramento do sistema.

Antes de avaliar a metodologia empregada na discussão da GCE, cabe indicar sua interação com outras áreas. Considerando que a GCE está relacionada com temas que são tratados também por outras disciplinas, é interessante apresentar pontos que definem os limites da GCE e sua interação com outros campos da Ciência.

O primeiro fator a ser considerado é a interação entre a GCE e a inteligência competitiva (IC). De acordo com Porter (1985), é necessário haver uma metodologia para capturar e analisar dados cruciais do ambiente externo à organização. Igualmente, Jacobiak (1996) advoga que a IC é uma importante parte da gestão estratégica, que provê informação para que decisores prevejam tendências de mercado e a posição dos competidores. Tyson (1998) completa a ideia assegurando que a IC é a inteligência que transforma informação dispersa em conhecimento estratégico para a organização. Assim, embora a visão da IC seja a de trabalhar com 
o conhecimento estratégico, não há foco nos atores especificamente envolvidos (estrategistas e decisores estratégicos) nem em novatos e experientes, buscando ampliar suas competências, habilidades e atitudes (CHA) como ocorre na GCE. Por sua vez, a GCE busca identificar padrões nos comportamentos de estrategistas e decisores estratégicos, de forma a criar condições para melhor apoiar seus trabalhos voltados para temas estratégicos. Outro ponto a ser considerado é que todos os esforços em GCE estão relacionados à busca de informação estratégica, à aquisição de conhecimento estratégico e à criação de repositórios de dados, informação e conhecimento. Um exemplo disso ocorre quando a GCE busca registrar lições aprendidas, bem como quando práticas são partilhadas entre novatos e experientes. No âmbito do contexto estratégico, o foco está nos estrategistas e nas ações estratégicas que podem ser adotadas pela organização.

Considerando o PE e a GCE, ambos referem-se à previsão de tendências para formular e decidir estrategicamente. Mas, uma vez mais, o foco da GCE está na forma como estrategistas e decisores estratégicos pensam, agem e escolhem a melhor estratégia ou ação estratégica. A ideia é tratar o processo estratégico como um processo de aprendizagem que cresce à medida que uma estratégia é criada e implementada.

O terceiro campo a ser considerado é a gestão da informação e do conhecimento. A GCE utiliza técnicas e métodos de ambos os tipos de "gestão", mas sempre aplicados à formulação e à decisão estratégica. A figura 2 mostra a interação entre a GCE e outros campos.

Figura 2 - Relação entre a GCE, a inteligência competitiva, a gestão do conhecimento e a gestão da informação

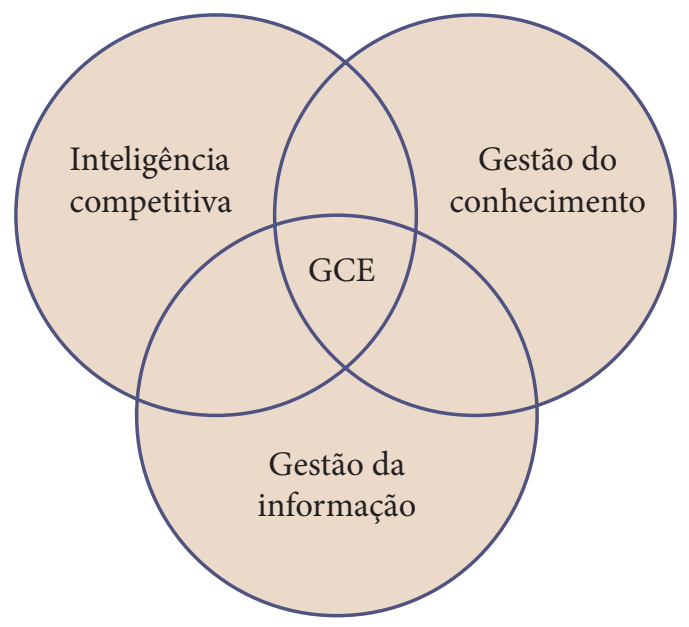

Fonte: Elaboração dos autores (2018). 


\section{ABORDAGEM METODOLÓGICA}

A metodologia empregada para a realização da pesquisa envolveu dois momentos diferenciados. No primeiro, apresentou-se uma discussão teórica sobre o modelo de GCE, a partir do estudo comparado entre os modelos de GC existentes e a caracterização do CE como tema específico de estudo. Dessa discussão, derivou-se o modelo conceitual do sistema de gestão do conhecimento estratégico. O segundo momento consistiu da validação do modelo teórico elaborado, por meio de pesquisa descritiva e de campo realizada com profissionais de GC.

A pesquisa caracterizou-se como teórico-metodológica em uma primeira visão, valendo-se tanto de estudo bibliográfico dos modelos e quanto de abordagens de GC e de enfoque estratégico escolhidos para estudo, comparando-os e identificando elementos pertinentes à derivação do modelo de GCE, conforme ilustra a figura 3.

Figura 3 -Derivação esquemática do modelo de gestão do conhecimento estratégico

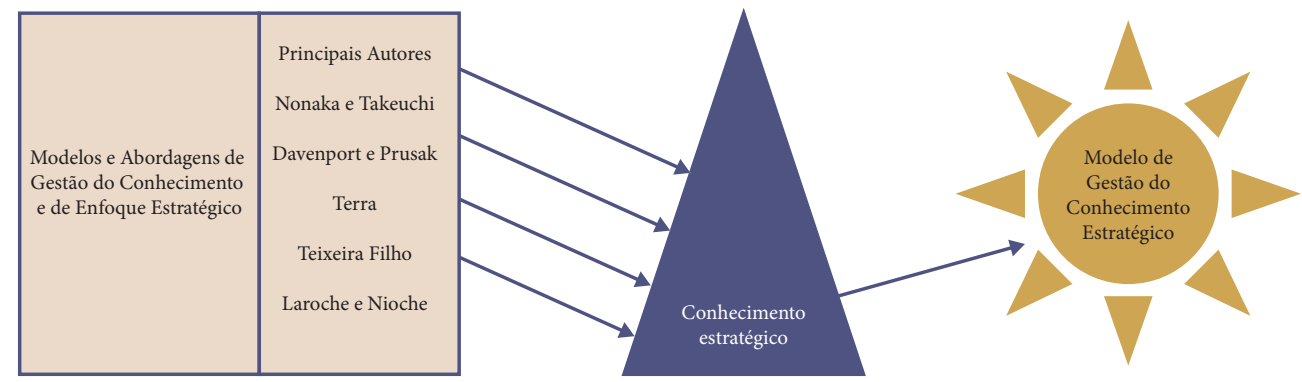

Fonte: Miranda (2004).

A derivação do modelo foi realizada a partir dos modelos já existentes de gestão do conhecimento, levando-se em consideração as perspectivas estratégicas, as abordagens estratégicas (particularmente a cognitiva, por ter relação com o tratamento do conhecimento tácito) e as características do conhecimento estratégico. No caso, foram estabelecidos três modelos. O primeiro, conceitual, situa a GCE diante de outros conceitos envolvidos. O segundo, matemático, estabelece relações entre os fatores sistêmicos na GCE e as perspectivas estratégicas tomadas para estudo. Finalmente, o modelo sistêmico apresenta os elementos básicos que caracterizam o sistema de gestão do conhecimento estratégico.

Já em uma segunda etapa do estudo, realizou-se pesquisa descritiva e de campo com um grupo de respondentes, cuja característica principal era a de estarem envolvidos com GC, com o fito de validar a consistência e o pragmatismo do modelo teórico anteriormente derivado. Nesse caso, a validação do modelo se deu em três níveis: 1) avaliação do modelo matemático, a partir das informações prestadas pelos respondentes; 2) validação do modelo conceitual, 
tomando por referência as posições de respondentes classificados como especialistas (decisores e estrategistas); 3) validação do modelo sistêmico, pelos especialistas respondentes, buscando verificar sua adequabilidade à realidade em que vivem.

Para cada etapa do estudo, foram adotados métodos de abordagem diferenciados. Na primeira etapa, voltada para a modelagem do sistema de GC, utilizou-se o raciocínio abdutivo (ODONE, 1998) como forma de orientação na busca pela solução do problema, valendo-se de pistas e sintomas obtidos a cada passo na evolução do processo de melhor compreender a questão que envolve a GCE. Segundo o raciocínio abdutivo, há utilização concomitante do raciocínio indutivo e do dedutivo ao longo do processo de estudo.

Na segunda etapa, quando da validação do modelo, utilizou-se o método estatístico, com o objetivo de inferir, a partir do posicionamento dos respondentes, se o modelo representa adequadamente a realidade da GCE. Na pesquisa descritiva e de campo, o grupo de respondentes era formado por profissionais especialistas atuantes no mercado e envolvidos com a GC, os quais integram, em sua quase maioria, a Sociedade Brasileira de Gestão do Conhecimento (SBGC). O Quadro 2. apresenta os métodos, técnicas e fontes de coletas de dados de cada etapa da pesquisa.

Quadro 2 - Métodos, técnicas e fontes de coleta de dados

\begin{tabular}{|c|c|c|}
\hline \multirow{2}{*}{ ATRIBUTO } & \multicolumn{2}{|c|}{ MÉTODOS, TÉCNICAS E FONTES DE COLETA DE DADOS } \\
\hline Métodos & $\begin{array}{c}\text { 1a ETAPA } \\
\text { 2a ETAPA } \\
\text { MODELAGM DO SISTEMA DE GCE }\end{array}$ & $\begin{array}{c}\text { VALIDAÇÃo DO MODELO SISTÊMICO } \\
\text { DE GCE }\end{array}$ \\
\hline Técnicas & $\begin{array}{c}\text { Análise bibliográfica } \\
\text { Estudo comparado }\end{array}$ & $\begin{array}{c}\text { Questionários estruturados, utilizando a de campo } \\
\text { escala de Likert para avaliar a percepção dos } \\
\text { profissionais de GC quanto ao modelo }\end{array}$ \\
\hline Fontes & $\begin{array}{c}\text { Livros e artigos que retratem os focos da } \\
\text { pesquisa: estratégia, gestão do conhecimento e e } \\
\text { conhecimento estratégico }\end{array}$ & Profissionais que atuam na área de GC \\
\hline
\end{tabular}

Fonte: Miranda (2004).

Há que se ressaltar a utilização de recursos de correio eletrônico para envio e recebimento dos questionários, buscando acelerar a consolidação e minimizar os custos da pesquisa. Além disso, avaliou-se a possibilidade de utilização de um aplicativo web - o Quest Mail - destinado à criação, ao gerenciamento e à publicação de pesquisas direcionadas e respondidas no corpo da própria mensagem de e-mail (USGI, 2002). O Quadro 3. apresenta os métodos, as técnicas e os resultados do tratamento dos dados de cada etapa da pesquisa. 
Quadro 3 - Métodos, técnicas e resultados do tratamento dos dados

\begin{tabular}{|c|c|c|}
\hline \multirow{2}{*}{ MTRIBUTO } & $\begin{array}{c}\text { 1a ETAPA } \\
\text { 1át }\end{array}$ & $\begin{array}{c}2^{\text {a ETAPA }} \\
\text { MODELAGEM DO SISTEMA DE GCE } \\
\text { DE GCE }\end{array}$ \\
\hline Métodos & Análise bibliográfica & Estatístico \\
\hline Técnicas & Estudo comparado & $\begin{array}{c}\text { Estatística descritiva, com ênfase nas medidas } \\
\text { de posição: moda e percentis }\end{array}$ \\
\hline Resultados & Modelo esquemático e descritivo & Gráficos e tabelas \\
\hline
\end{tabular}

Fonte: Miranda (2004).

\section{ANÁLISE E DISCUSSÃO DOS RESULTADOS}

A análise dos avanços e dos resultados da pesquisa indicaram pontos interessantes e esclarecedores quanto ao conhecimento estratégico.

Primeiramente observou-se que o conhecimento estratégico tem diferentes composições quanto ao conhecimento explícito e tácito, cujas proporções variam de acordo com o nível de expertise do decisor ou do formulador de estratégias, bem como com a complexidade da estratégia adotada. Agrega-se que nem todo conhecimento tácito pode ser elicitado; portanto, o papel do profissional da informação é buscar registrar o conhecimento tácito elicitável, como forma de objetivá-lo e proporcionar o seu reuso.

O conhecimento estratégico tem como foco a formulação e a decisão estratégicas. Portanto, nem todo conhecimento organizacional é estratégico, porque vai atender a necessidades gerenciais ou operacionais que não definem os rumos da organização, mas tão somente o seu funcionamento.

Outro ponto refere-se à necessidade de serem considerados os aspectos cognitivos nos processos de formulação e de decisão estratégicas. Talvez esses aspectos venham a apontar as causas de sucesso da geração e implementação de estratégias em organizações similares e em contextos próximos. Porém, não se pode abdicar das perspectivas estratégicas - clássica, evolucionária, sistêmica, processual e de conhecimento. Os processos de decisão e formulação são complexos e devem valorar todo tipo de fator que venha a levar ao sucesso na implantação da ação estratégica.

Há que se considerar como diferenciados os papéis de estrategistas e decisores no processo de formulação e decisão estratégicas, bem como as características que os distinguem entre novatos e experientes. Ainda que, em organizações pequenas, esses processos se confundam, 
é necessário distinguir os momentos em que se procuram elaborar alternativas de estratégias para posterior decisão. A realização simultânea pode levar a decisões equivocadas, pouco estudadas e de resultados não previamente avaliados.

A relação entre ação estratégica e conhecimento estratégico é intermediada pela inteligência estratégica, segundo a proposta do modelo de taxonomia da formulação de ações estratégicas. Ou seja, a formulação e a decisão estratégicas devem ter como desdobramento a implementação de ações que efetivamente coloquem em prática a estratégia escolhida. Para a adoção das ações, necessário se faz trabalho de inteligência que agregue ao conhecimento estratégico informações pragmáticas sobre a ação adotada, condições reais de implantação, riscos financeiros e outros.

O conceito de GCE situa-se tanto no âmbito da gestão da informação, quanto da gestão do conhecimento, uma vez que se vale do suporte de ambas as gestões (por exemplo, de informação objetivada e de conhecimento, respectivamente) para poder capturar conhecimento tácito, coletar informação, organizar e disponibilizar para uso. Em decorrência disso, indicadores de GC recaem, em sua maior quantidade, em indicadores de eficiência, e, no modelo de GCE, em efetividade (eficiência e eficácia). Ressalta-se ainda a diferença entre gestão estratégica do conhecimento (que se aproxima da GC, por tratar todo o conhecimento gerado na organização) e gestão do conhecimento estratégico (voltado especificamente para a formulação e a decisão estratégicas).

\section{ESTUDOS DECORRENTES DA PESQUISA}

Os estudos que se apresentam neste item referem-se a pesquisas desenvolvidas posteriormente à publicação da tese em 2014. São, em sua maioria, dissertações que trataram de pontos da GCE não discutidos na pesquisa inicial, ou que ampliaram seu campo de entendimento. Os trabalhos se revestiram principalmente do caráter pragmático de aplicação da GCE em organizações públicas e privadas e em contextos diversos, a fim de reforçar a universalidade do modelo.

\subsection{Atuação de estrategistas e decisores}

A pesquisa desenvolvida por Pimenta (2007) teve por objetivo avaliar os possíveis impactos da assimetria da informação na atuação de estrategistas e decisores no procedimento de revisão tarifária das distribuidoras de energia elétrica adotado pela Agência Nacional de Energia Elétrica (Aneel). O estudo foi realizado sob a perspectiva da gestão do conhecimento estratégico e observou-se que os estrategistas e decisores reconhecem a existência de assimetria de informação no procedimento de revisão tarifária. Os decisores, principalmente, procuram 
resguardar-se do problema fazendo uso de expertise e experiência, buscando por informações que complementem aquelas dispostas formal e explicitamente nos processos de revisão. A metodologia de pesquisa utilizou dois modelos de questionários, que foram aplicados aos formuladores da proposta de revisão e à diretoria colegiada - estrategistas e decisores -, e foram realizadas duas entrevistas com um ex-estrategista e um ex-decisor. Os resultados apontaram inadequações e inconsistências em alguns dos mecanismos adotados, a fim de minimizar a assimetria de informação. Observou-se também que a Aneel não tem considerado alguns fatores sistêmicos da gestão do conhecimento, ao passo que outros fatores estão bastante desenvolvidos. Verificou-se que há necessidade de desenvolvimento e manutenção de expertise (PIMENTA, 2007).

\subsection{Fatores sistêmicos da GCE ampliados e aplicados a uma empresa pública}

Fujihara (2008) teve como principal objetivo de pesquisa avaliar o comportamento dos subfatores que influenciam a GCE na Empresa Brasileira de Correios e Telégrafos (ECT), a qual possui uma hierarquia organizacional bem estruturada, cujas ações no campo estratégico permitem avaliar a GCE sob o ponto de vista dos subfatores do estudo. A metodologia aplicada foi a da pesquisa de campo, do tipo quantitativo e descritivo, que permitiu avaliar hipóteses vinculadas aos objetivos traçados. O referencial teórico e a aplicação de análise estatística descritiva e multivariada contribuíram para o alcance dos objetivos. Ficou caracterizada a existência de um inter-relacionamento dos subfatores da GCE, principalmente entre "contexto" e "motivação", "experiência e liderança” e "integração e estrutura de poder". Percebeu-se também que os subfatores se agrupam em fatores comparáveis ao estabelecido no modelo da GCE proposto por Miranda (2004). Foram três as principais contribuições da pesquisa para a Ciência da Informação: a constatação do caráter interdisciplinar da GCE; o aprofundamento do estudo da GCE; e a avaliação do comportamento dos subfatores aplicados em um estudo de caso (FUJIHARA, 2008). Da pesquisa, resultou o surgimento de um novo subfator a ser considerado na GCE: a individualidade.

\subsection{Aprimoramento de estrategistas e decisores novatos}

O trabalho de Martins (2010) teve como foco o aprimoramento de estrategistas e decisores novatos, por meio da transmissão do conhecimento por parte dos estrategistas e decisores experientes no âmbito do Centro de Apoio ao Desenvolvimento Tecnológico (CDT). Adotouse como referencial metodológico o sistema de aprimoramento de estrategistas e decisores novatos, o qual faz parte do modelo sistêmico de GCE. A justificativa para o estudo está na necessidade de aprimoramento dos estrategistas e decisores novatos existentes no CDT. A pesquisa visou propor, como principal resultado, iniciativas que possibilitem a existência 
de um ambiente propício à transferência de conhecimento entre os estrategistas e decisores experientes e novatos existentes no CDT. Concentrando-se no resultado mencionado anteriormente, buscou-se realizar a triangulação do sistema de aprimoramento com as metodologias Learning Style Inventory e Janela de Johari. Os resultados da pesquisa indicaram que o aprendizado organizacional requer a transferência e o compartilhamento do conhecimento entre os profissionais envolvidos no processo, bem como o seu registro.

Concluiu-se que, para a efetiva implementação da GCE, devem-se considerar fatores críticos, tais como: cultura organizacional, apoio da direção da empresa e existência dos sistemas constituintes do sistema de aprimoramento, ou seja, a socialização e a existência de uma base de conhecimento explícito que possa ser acessível aos profissionais (MARTINS, 2010).

\subsection{A GCE aplicada a escritórios de projetos}

O premiado trabalho de Casaes (2012) - Prêmio Candango de Gerenciamento de Projetos, PMI-DF, 2012 - trata da aplicabilidade da gestão do conhecimento estratégico em escritórios de projetos corporativos (EPC) de empresas do Distrito Federal. Nesse contexto, buscou identificar o uso do EPC como instrumento de apoio à GCE e sua influência sobre estrategistas e decisores. Mais que isso, indicou as melhores práticas de gestão da informação (GI) e gestão do conhecimento (GC) a serem incorporadas a um EPC. A abordagem da pesquisa foi multidisciplinar, procurando aproximar as áreas de Ciência, GI, GC e gestão de projetos.

A metodologia utilizada foi a hipotético-dedutiva, realizada com uma pesquisa de campo, do tipo quantitativa e qualitativa, as quais permitiram avaliar as hipóteses vinculadas aos objetivos traçados. Como resultados, verificou-se que os EPC realizam a GCE por meio da utilização do sistema de aplicação do conhecimento estratégico e do sistema de aquisição e captura do conhecimento estratégico, ambos integrantes do modelo sistêmico da GCE, além de serem influenciados pelos fatores sistêmicos: Tecnologias de Informação e Comunicação (TIC), cultura, organização e individualidade. Verificou-se também que o portal corporativo, a memória organizacional e o coaching são as práticas de GI e GC mais aplicadas nos EPC. No entanto, os gestores dos EPC apontam que mineração textual e de dados, raciocínio baseado em casos e educação corporativa são práticas necessárias aos EPC (CASAES, 2012).

\subsection{A GCE aplicada a uma instituição do legislativo brasileiro}

O estudo apresenta reflexão teórica acerca do delineamento sistêmico da gestão do conhecimento estratégico na Câmara dos Deputados (CD), indicando os sistemas relevantes a partir do estabelecimento dos limites, dos atores e das principais questões envolvidas dentro de 
contexto técnico-organizacional e técnico-político. Utilizando-se da situação-problema não estruturada e da situação-problema expressa, fases iniciais da metodologia de sistemas flexíveis (SSM), os fatores sistêmicos da GCE, nomeadamente cognição, modelo gerencial, tecnologia, contexto, cultura organizacional e individualidade, foram discutidos no escopo da CD como ferramentas para auxiliar no processo de reflexão. Os resultados apontaram para a adoção de três sistemas relevantes: sistema de gestão da informação e do conhecimento estratégico institucional, sistema integrado de informação de apoio à atividade legislativa e administrativa da CD e sistema de inteligência antecipativa para a CD (MIRANDA, 2012).

\section{CONSIDERAÇÕES FINAIS}

As possibilidades de estudo na área de GCE são inúmeras, o que gera inquietações de profissionais envolvidos com a pesquisa na área. Tais inquietações, como não poderia deixar de ser, resultaram em estudos outros e apontam para a possibilidade de novos estudos, como discutido a seguir.

O primeiro estudo refere-se à avaliação dos fatores que facilitam ou dificultam o partilhamento de conhecimento estratégico entre decisores e estrategistas. Variáveis como confiança, segurança, garantia de emprego e outras se inserem na hipótese de que são norteadoras da decisão de compartilhamento. Nesse caso, há que se considerar também quais as técnicas adequadas ao registro do conhecimento tácito elicitado de estrategistas e decisores estratégicos e quais são seus comportamentos informacionais e de conhecimento.

Outro estudo que se apresenta refere-se à discussão de como o conhecimento estratégico é constituído, buscando-se identificar e, até mesmo, quantificar o volume de informação e de conhecimento requerido para tipos parametrizados de estratégia. A inquietação advém da dificuldade de prover estrategistas e decisores de informação e/ou conhecimento, de acordo com suas necessidades e com o problema estratégico envolvido. Em geral, há uma sobrecarga de informação sem efetiva disseminação seletiva e apurada, mais objetivada. Tem-se por hipótese, nesse caso, que a tecnologia poderia ser o fator de auxílio na compatibilização entre necessidades/demandas e ofertas de informação e de conhecimento.

A forma de aproveitamento de dados, informações, percepções, etc., partilhados em software sociais (redes sociais, blogs, etc.) na GCE é outra inquietação que vem crescendo em razão do uso desses meios como formas de comunicação entre pares (P2P - peer to peer) e entre clientes e organizações (C2B - costumer to business).

Os fatores "individualidade" e "modelo gerencial" tendem a ser intrinsecamente subjetivos. Avaliar como esses fatores podem ser potencializados, no intuito de aprimorar a formulação 
e a decisão estratégicas vem a ser interessante área de estudo e pesquisa. Por hipótese, a busca pode estar na avaliação cognitiva de formulação e decisão estratégicas, associada ao comportamento informacional dos agentes, suas fontes e a forma como distinguem "o outro do pedregulho" informacional.

As questões de GCE, além de características de fundo (qualidade da informação, volume de conhecimento partilhado, etc.), parecem envolver também a forma como são repassadas e geridas, a fim de que sejam bem utilizadas por decisores, principalmente. A inquietação surge quando se tem a constatação de que decisores estratégicos têm pouco tempo para acessar informações e decidir.

Já no contexto de aprendizado, parece relevante identificar formas efetivas de aprimoramento de novatos e decisores novatos, ampliando os estudos de Martins (2010), a fim de agregar modernas teorias de gestão de pessoas, tais como o uso da investigação apreciativa e da teoria U.

Dentro ainda da visão de gestão de pessoas, pode-se buscar identificar se há uma quantidade ótima de estrategistas e decisores estratégicos novatos e experientes dentro de uma organização, que venham a potencializar a formulação e decisão estratégicas que promovam bom curso à organização. Nesse caso, os estudos se caracterizariam pela avaliação histórica de implementação de estratégias e estrategistas envolvidos. A dificuldade está no registro histórico desses processos como fonte primária de dados para estudo.

Além disso, estudos mais aprofundados poderiam levar ao entendimento de pelo menos quatro pontos. O primeiro refere-se a como definir padrões de desempenho para avaliar a efetividade do sistema de aprimoramento de estrategistas e decisores estratégicos novatos. O segundo relaciona-se a como avaliar as condições (contexto) para que estrategistas e decisores estratégicos novatos compartilhem conhecimento no ambiente organizacional. O terceiro diz respeito a como propor meios que facilitem o acesso ao conhecimento disponível aos estrategistas e decisores estratégicos novatos. Finalmente, o quarto ponto consiste em como estabelecer um processo de monitoramento entre estrategistas e decisores estratégicos experientes e novatos.

Conclui-se, portanto, que o campo da GCE é espaço amplo e aberto a novos estudos e abre caminho para tornar a estratégia organizacional um processo de aprendizado contínuo. 


\section{REFERÊNCIAS}

CASAES, J. C. C. Gestão do conhecimento estratégico aplicada a escritórios de projetos corporativos do Distrito Federal. Dissertação (Mestrado) Curso de Mestrado em Ciência da Informação, Departamento de Ciência da Informação e da Documentação. Brasília, Universidade de Brasília. 2012.

DAVENPORT, T. H.; PRUSAK, L. Conhecimento empresarial: como as organizações gerenciam o seu capital intelectual. 6. ed. Trad. Lenke Peres. Rio de Janeiro: Campus, 1998.

FUJIHARA, R. K. Gestão do Conhecimento Estratégico: estudo dos subfatores sistêmicos aplicados à ECT. 2008. 179 f. Dissertação (Mestrado) - Curso de Mestrado em Ciência da Informação. Departamento de Ciência da Informação e da Documentação. Brasília, Universidade de Brasília. 2010.

JACOBIAK, F. Pratique de la veille technologique. Paris: Éditions d'Organization, 1996.

LAROCHE, H.; NIOCHE, J.-P.. L'approche cognitive de la stratégie d’emprise. Revue Française de Gestion. juin/juil./aôut. 1994.

MARTINS, J. B. Aprimoramento de estrategistas e decisores novatos: a gestão do conhecimento estratégico aplicada ao Centro de Apoio ao Desenvolvimento Tecnológico da Universidade de Brasília. 2010. 158 f., il. Dissertação (Mestrado) - Curso de Mestrado em Ciência da Informação, Departamento de Ciência da Informação e da Documentação. Brasília, Universidade de Brasília. 2010.

MIRANDA, R. C. R. Gestão do conhecimento estratégico na Câmara dos Deputados: uma avaliação teórico-sistêmica. In: MIRANDA, R. C. R. (Org.). Informação e Conhecimento no Legislativo. 1 ed. Brasília: Edições Câmara, 2012, v. 1, p. 141-162.

MIRANDA, R. C. R. Gestão do conhecimento estratégico: uma proposta de modelo integrado. 2004. 289 f., il. Tese (Doutorado) - Curso de Doutorado em Ciência da Informação, Departamento de Ciência da Informação e da Documentação. Brasília, Universidade de Brasília, 2004.

MIRANDA, R. C. R. O uso da informação na formulação de ações estratégicas pelas empresas. Ciência da Informação (Impresso), Brasília, v. 28, n.3, p. 286-292, 1999.

NONAKA, I; TAKEUCHI, H. Criação de conhecimento na empresa: como as empresas japonesas geram a dinâmica da inovação. 2.ed. Rio de Janeiro: Campus, 1997. 
ODDONE, N E. Atividade editorial \& ciência da informação: convergência epistemológica. 1998. 136 f. Dissertação (Mestrado) - Curso de Mestrado em Ciência da Informação, Departamento de Ciência da Informação e da Documentação, Universidade de Brasília, 1998.

PIMENTA, S. G. Impacto da assimetria da informação na atuação de estrategistas e decisores nos procedimentos de revisão tarifária das distribuidoras de energia elétrica. 2007. 127 f. Dissertação (Mestrado) - Curso de Mestrado em Ciência da Informação, Departamento de Ciência da Informação e da Documentação, Universidade de Brasília, Brasília, 2007.

PORTER, M. Competitive Advantage. New York: Free Press. 1985.

TEIXEIRA FILHO, J. Gerenciando conhecimento. 2 ed. Rio de Janeiro: SENAC, 2001.

TERRA, J. C. C. Gestão do conhecimento: o grande desafio empresarial. 2 ed. São Paulo: Negócio Editora, 2001.

TYSON, K. W. M. The complete guide to competitive intelligence: gathering, analyzing and using competitive intelligence. Chicago: Kirk Tyson International. 1998.

USGI: UNIVERSO SOLUÇÕES INTERNET. Questmail. Disponível em: <http://www.questmail.com.br/>. Acesso em: 25 out. 2002.

WHITTINGTON, R. O que é estratégia. Trad. Maria Lúcia G. L. Rosa, Martha Malvezzi Leal. Rev. Técnica Flávio Carvalho de Vasconcelos. São Paulo: Pioneira Thomson Learning, 2002. 


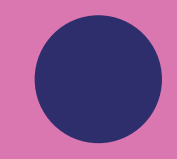

○

○

-

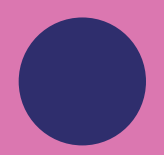

-

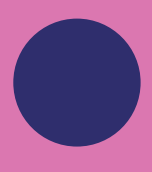

○

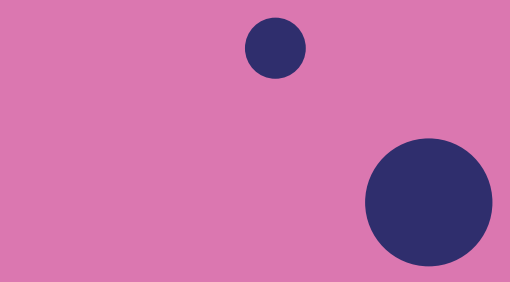

○

○

- 0

○
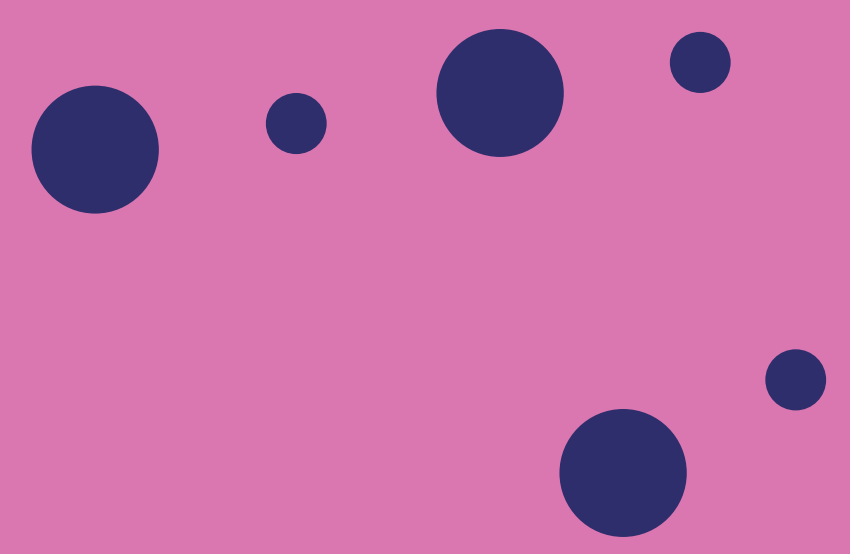


\section{CAPÍTULO 13}

0

O
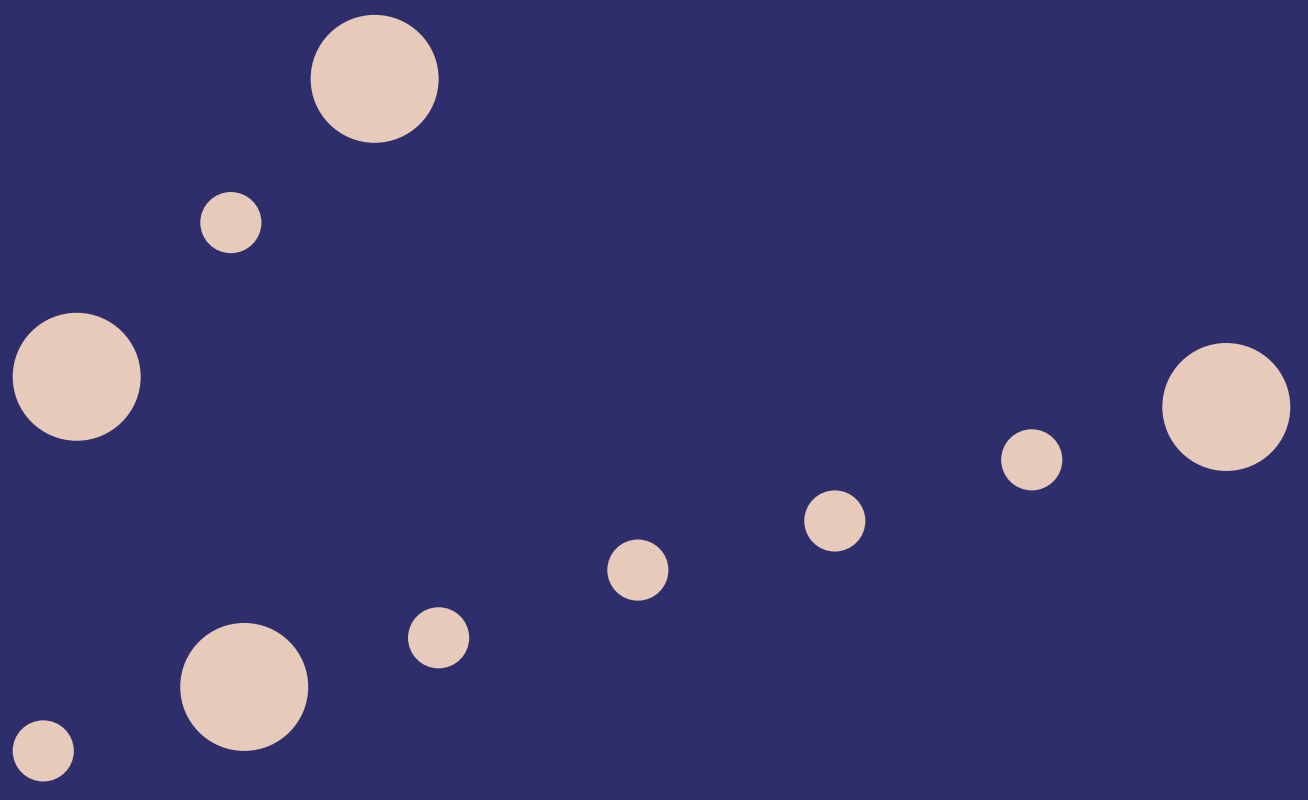

- 00

0 


\section{GESTÃO DO CONHECIMENTO CIENTÍFICO: PROPOSTA DE UM MODELO CONCEITUAL COM BASE EM PROCESSOS DE COMUNICAÇÃO CIENTÍFICA \\ FERNANDO CÉSAR LIMA LEITE SELY MARIA DE SOUZA COSTA}

\section{INTRODUÇÃO}

Iniciativas de gestão do conhecimento devem necessariamente considerar as características do ambiente no qual são implementadas. Tais características dizem respeito, principalmente, à natureza do conhecimento - bem como às forças que condicionam sua criação -, à cultura que envolve os indivíduos e ao seu comportamento em relação à informação e ao conhecimento. Além disso, devem levar em conta, sobretudo, as peculiaridades dos processos de comunicação próprios do ambiente no qual as iniciativas serão implementadas. Desse modo, é imprescindível observar que comunidades de naturezas distintas requerem modelos de gestão do conhecimento que atentem para as suas especificidades. Portanto, a partir das características do contexto no qual se pretende desenvolver a gestão do conhecimento - organizações empresariais, administração pública, o ambiente acadêmico ou outros -, deverão ser delineados modelos de gestão do conhecimento apropriados a cada um deles.

Especificamente em relação ao ambiente acadêmico, corporificado principalmente pelas universidades, parecem ser poucas as iniciativas, os estudos ou os modelos de gestão do conhecimento que, de fato, consideram as suas particularidades. Entre tais particularidades

1 Versão modificada do artigo publicado: LEITE, F. C. L.; COSTA, S. M. S. Gestão do conhecimento científico: proposta de um modelo conceitual com base em processos de comunicação científica. Ciência da Informação, v. 36, n. 1, dez. 2007. 
destacam-se os processos de comunicação científica, a natureza da produção do conhecimento científico, a estrutura e o comportamento de comunidades científicas, além da cultura que envolve o ambiente acadêmico.

Este artigo apresenta resultados de pesquisa teórica que teve por objetivo propor um modelo conceitual de gestão do conhecimento científico, considerando o contexto do ambiente acadêmico e suas particularidades. O objetivo foi, portanto, investigar a relação, em nível conceitual, entre a gestão do conhecimento e os processos de comunicação científica, tendo em vista as peculiaridades do contexto acadêmico e do conhecimento científico.

\section{REFERENCIAL TEÓRICO}

O referencial teórico explicita as relações entre os elementos que, com base em análise crítica da literatura, foram identificados como importantes para a construção do modelo conceitual de gestão do conhecimento científico. Assim, o referencial teórico constitui a lente por meio da qual o problema da pesquisa foi compreendido e investigado. Devido à dificuldade de encontrar estudos sobre gestão do conhecimento que observassem a natureza do ambiente acadêmico, do conhecimento científico e os processos de comunicação científica, um dos principais esforços da pesquisa foi a sinalização de questões que envolvessem a gestão desse tipo particular de conhecimento, bem como as implicações do seu ambiente, das características particulares do conhecimento e da comunicação científica.

Tendo em vista o problema proposto na pesquisa - a representação, por meio de um modelo conceitual, da gestão do conhecimento científico em sua vertente tácita e explícita, no contexto acadêmico -, apresenta-se, a seguir, de maneira breve, a discussão de conceitos e abordagens pertinentes ao estudo sobre as seguintes questões: 1) comunicação científica; 2) aspectos da informação e do conhecimento científico; 3) contexto/cultura científica; e 4) gestão do conhecimento.

\subsection{Comunicação científica}

O estudo da comunicação científica envolve um amplo leque de tópicos e questões complexas. Muitas dessas questões referem-se aos fatores condicionantes do fluxo da informação e do conhecimento, ao comportamento informacional dos atores e suas interações no seio de comunidades científicas, ao impacto de tecnologias, entre outros. A comunicação do conhecimento científico abrange os fenômenos compreendidos entre a fase mais incipiente da pesquisa científica - como a identificação do problema a ser estudado - até o momento em que o conhecimento produzido é internalizado por outros cientistas (GARVEY; GRIFFITH, 
1979). Portanto, a comunicação científica pode ser entendida como o conjunto de esforços, facilidades, processos dinâmicos e complexos, consensual e socialmente compartilhados, por meio dos quais o conhecimento científico - em sua vertente tácita e explícita - é criado, compartilhado e utilizado. Tais processos oferecem, também, meios e condições para a interação social entre membros de comunidades científicas, contribuindo, portanto, para produção, disseminação e uso do conhecimento e, consequentemente, para o avanço da ciência.

Naturalmente, é possível afirmar que há uma relação indissociável entre a produção do conhecimento científico e o processo de comunicação a ela subjacente (GARVEY; GRIFFITH, 1979; ZIMAN, 1981; MEADOWS, 1999). Dessa maneira, no contexto das instituições acadêmicas e das comunidades científicas, a criação do conhecimento não pode prescindir da comunicação científica. Nesse sentido, Meadows (1999) ressalta a importância da comunicação para a construção do conhecimento científico, ao salientar que a comunicação encontra-se no próprio coração da ciência, sendo ela tão vital quanto a própria pesquisa. Meadows enfatiza que todo esforço é desperdiçado se não forem divulgados os resultados das pesquisas. Destarte, a comunicação científica constitui parte essencial do processo de criação do conhecimento científico.

A criação do conhecimento científico ocorre essencialmente por meio de pesquisas científicas realizadas por pesquisadores docentes. Durante a realização desses estudos, o pesquisador, um dos atores do processo de comunicação, faz uso do sistema de comunicação em diversos momentos, uma vez que, à medida que ele produz conhecimento, ele necessariamente o consome. Logo, no início da criação de um novo conhecimento, o esforço de um pesquisador parte daquilo que foi construído anteriormente por outros pesquisadores. Ou seja, o pesquisador nunca parte do marco inicial, pois, no princípio e durante o processo de criação, ele recorre à literatura de sua especialidade e aos seus pares, e, ao fim, divulga os resultados de sua pesquisa por meio dos veículos de comunicação apropriados a sua área de conhecimento. Torna-se evidente, portanto, que um pesquisador utiliza os canais de comunicação em todo o ciclo do conhecimento - desde a sua criação até a sua divulgação -, o que nos permite afirmar que existe um complexo sistema de comunicação científica que permeia as comunidades científicas e instituições acadêmicas.

Pesquisadores dedicados ao estudo da comunicação científica geralmente dividem os canais de comunicação científica em formais e informais. Embora, hoje, o desenvolvimento e a aplicação de tecnologias no processo de comunicação na ciência tenham tornado o limite entre o formal e o informal cada vez mais nebuloso, essa divisão parece ainda ser pertinente. Sobre a relação dos canais formais e informais do processo de criação, estudos revelam indícios de que a comunicação informal é que mais contribui para o fluxo de informação e conhecimento no mundo acadêmico. Braga (1985) ressalta que a comunicação formal é responsável por apenas $20 \%$ de todas as comunicações no processo de geração do conhecimento. Por sua vez, as comunicações que utilizam os canais informais representam $80 \%$ de toda a comunicação 
nesse processo. Garvey e Griffith (1979) destacam que, pelas suas características, os meios informais são restritos a uma pequena audiência. Entretanto, proporcionam maior interação entre os membros da comunidade, já que pesquisadores de uma mesma área criam teias de comunicação a partir de encontros periódicos e trocas de informações, constituindo assim os colégios invisíveis, os quais podem ser entendidos como uma rede de interações informais entre os membros de uma mesma área de atividade científica.

É importante destacar que o uso da internet e de tecnologias emergentes no contexto da comunicação científica tem proporcionado e ampliado, ao longo do tempo, uma série de novas possibilidades e oportunidades de inovação nesse campo. Lagoze e van de Sompel (2001) corroboram essa ideia ao afirmarem que a introdução em grande escala das tecnologias de comunicação e informação gerou demanda para o uso da web no que diz respeito à disseminação dos resultados de pesquisas. Isso fez surgir modelos alternativos para comunicação científica, tais como repositórios institucionais e temáticos, periódicos de acesso aberto, constituindo hoje o Movimento pelo Acesso Aberto à Informação Científica. É importante dar destaque ao seu caráter revolucionário, visto que, além de questionar, tem causado transformações paradigmáticas com significado econômico, tecnológico, político, cultural e social, ocasionando consequências, tais como: a quebra do monopólio de grandes editores científicos, a criação de canais alternativos de veiculação de literatura científica validada ou não (repositórios institucionais ou temáticos), o aumento da visibilidade da produção científica e o autoarquivamento por parte dos próprios pesquisadores. Essas transformações incidem diretamente no modo como os indivíduos em uma comunidade científica criam, compartilham e utilizam o conhecimento.

Por fim, com base em Garvey e Griffith (1979), Crane (1972), Meadows (1999), Costa (1999) e outros, entende-se, portanto, que o sistema de comunicação científica exerce importante papel para criação, compartilhamento e uso do conhecimento científico. Mesmo diante da estreita e cada vez mais frágil divisão entre meios formais de comunicação, é possível ainda sugerir que os formais são mais aptos a compartilhar conhecimento científico em sua vertente explícita. Por sua vez, o compartilhamento do conhecimento científico tácito requer necessariamente meios informais de comunicação.

\subsection{Informação e conhecimento científico}

O conhecimento científico explícito pode ser definido como toda a forma de conhecimento codificado, facilmente estruturável, que tem possibilidade de ser comunicado por sistemas estruturados ou meios formais de comunicação. Compreende, então, todas as formas de literatura científica, avaliadas ou não. O conhecimento científico tácito, por sua vez, refere-se 
ao que pode ser entendido como o conhecimento ou habilidade que pode ser passado entre cientistas por contatos pessoais, mas que não pode ser exposto ou passado em fórmulas, diagramas, descrições verbais ou instruções para ação (COLLINS, 2001). Nesse sentido, é o conhecimento baseado também na informação científica, embora esteja relacionado com a experiência e a competência do pesquisador, caracterizando-se, portanto, por ser de difícil sistematização e representação. Diz respeito àquele conhecimento que é mais bem transferido e assimilado informalmente. Somente parte do conhecimento científico tácito é possível ser formalizada. Quando há o compartilhamento do conhecimento científico tácito, há necessariamente a utilização da comunicação informal. Talvez por essa razão, seja atribuída à comunicação científica informal grande importância no que se refere à produção do conhecimento científico. A relação entre conhecimento científico tácito e comunicação informal é explorada com maior profundidade em Leite (2006).

A partir da interação entre conhecimento científico explícito - o conhecimento científico registrado, a literatura científica - e conhecimento científico tácito - aquilo que os pesquisadores sabem, aprenderam e é comunicado por meios impessoais e não estruturados -, torna-se viável a criação de um novo conhecimento científico. A díade conhecimento tácito-conhecimento explícito nos remete inicialmente a Michael Polanyi (1966), referindo-se inicialmente ao próprio conhecimento científico. Entretanto, a teoria de criação do conhecimento a partir das duas dimensões diz respeito ao modelo construído por Nonaka e Takeuchi (1997), responsáveis pela ampla disseminação dos conceitos de conhecimento tácito e explícito, por meio da abordagem de gestão do conhecimento.

\subsection{Comunidades científicas e acadêmicas}

É importante ressaltar que universidades, como comunidades acadêmicas, constituem elementos do sistema científico. Consideradas ainda como o cerne da produção do conhecimento, os processos de comunicação científica permeiam boa parte de suas atividades, o que permite tanto as trocas internas de conhecimento quanto as externas, em interação com comunidades científicas, as quais, por sua vez, podem ser entendidas como o agrupamento de pares que compartilham um tópico de estudo, desenvolvem pesquisas e dominam um campo de conhecimento específico, em âmbito internacional (COSTA, 1999). Tais comunidades, de caráter disciplinar, influenciam fortemente os processos de comunicação científica em uma universidade. Como as atividades de ensino e pesquisa realizadas por pesquisadores docentes de uma universidade são comumente organizadas em áreas do conhecimento, tem-se que, por consequência, comunidades científicas de diferentes áreas do conhecimento estão representadas em uma universidade. Assim, os processos de comunicação científica, a própria produção do conhecimento científico, bem como a cultura de uma universidade são diretamente influenciados por diferentes comunidades científicas. 


\subsection{Contexto e cultura científica}

Tanto os processos de comunicação científica, quanto o próprio conhecimento científico - e mesmo a gestão do conhecimento - estão necessariamente relacionados e envolvidos por um determinado contexto - no caso, o ambiente acadêmico e a cultura do meio científico. O ambiente científico possui características culturais próprias que o difere de outros contextos, como, por exemplo, do empresarial, do comunitário ou do governamental. Essas características culturais estão relacionadas aos valores, pressupostos e crenças que são partilhados entre os indivíduos que vivem no ambiente e são reafirmados cotidianamente por estarem embrenhados em suas atividades e relações sociais. Especificamente, a cultura e o contexto da ciência e do conhecimento científico moldam as dinâmicas das interações dentro das comunidades, sejam elas científicas ou acadêmicas, e legitimam comportamentos, práticas e processos. Assim, tanto os processos relacionados à criação do conhecimento científico, quanto os processos voltados para a sua comunicação, por exemplo, são moldados e adequados à cultura proveniente do ambiente científico. Sobre essa questão, Meadows (1999, p. 245) destaca que pesquisadores trabalham muitas vezes de modo inconsciente, com base nas práticas instituídas da comunidade científica, as quais, por sua vez, são determinadas por sua história e normas sociais. Por essa razão, a gestão do conhecimento científico deve também levar em consideração as características culturais próprias desse ambiente.

No contexto da ciência, pode-se mencionar que os pressupostos da cientificidade, bem como os aspectos da visão metorniana da ciência, as concepções do campo científico de Bourdieu e os aspectos do novo modo de produção do conhecimento de Gibbons, por exemplo, constituem modelos que contribuem para o entendimento da formação de uma cultura científica. Essa cultura científica, no âmbito das instituições acadêmicas - especialmente as universidades -, certamente é refletida na cultura da organização universitária. Assim, a cultura organizacional, entendida com base no conceito de Schein (2001, p. 10), relaciona-se ao padrão de pressupostos básicos partilhados e aprendidos por membros de uma comunidade, à medida que é capaz de solucionar seus problemas, que têm funcionado bem o suficiente para que sejam considerados válidos. Por essa razão, segundo o autor, são ensinados aos novos membros como sendo o modo correto de perceber, pensar e sentir em relação àqueles problemas. Isso significa dizer, em outras palavras, que a cultura organizacional de uma universidade reflete aspectos de uma cultura científica - os quais são partilhados entre os membros das comunidades científicas -, visto que está inserida em um sistema científico maior. Essa cultura científica/organizacional regula as interações, influencia a percepção e contribui para a formação dos valores próprios de uma instituição acadêmica. 


\subsection{Gestão do conhecimento}

A gestão do conhecimento é um processo complexo e intimamente relacionado com o processo de comunicação nas organizações (SMOLIAR, 2003; IVES ET AL., 1998; THEUNISSEN, 2004). As duas abordagens - gestão do conhecimento e processos de comunicação - possuem princípios compatíveis e objetivos convergentes em diversos momentos, sobretudo durante a fase de compartilhamento ou disseminação de conhecimento. A gestão do conhecimento, de forma abrangente, refere-se ao planejamento e ao controle de ações (políticas, mecanismos, ferramentas, estratégias, entre outras) que governam o fluxo do conhecimento, tanto em sua vertente explícita - e para isso englobam práticas da gestão da informação - quanto na tácita. O planejamento e o controle de ações pressupõem a identificação, a aquisição, a armazenagem, o compartilhamento, a criação e o uso do conhecimento tácito e explícito, com o fim de maximizar os processos organizacionais em qualquer contexto. Todo esse processo viabiliza-se mediante o substrato comunicacional.

É importante destacar o entendimento dos autores sobre a relação entre a gestão do conhecimento e a gestão da informação. Com base na definição anterior, entende-se que a gestão do conhecimento engloba as práticas e metodologias da gestão da informação quando diz respeito principalmente aos processos relacionados à captura, ao armazenamento, à recuperação de uma parcela do conhecimento tácito, o qual, neste momento, é reduzido a estruturas de informação. Muito embora isso aconteça, a gestão do conhecimento não pode ser reduzida à gestão da informação, tampouco confundida, mesmo que aquela se aproprie desta. No momento em que, por exemplo, o tipo de compartilhamento do conhecimento exige que ele seja veiculado por meio de sistemas formais (que permitem o seu "armazenamento e recuperação"), o conhecimento é reduzido a estruturas de informação, que, por sua vez, poderá vir a disparar ou desencadear o processo de geração do conhecimento no indivíduo.

A maioria dos autores estudiosos da Ciência da Informação considera que a área deve se ocupar do que Le Coadic (2004), entre outros autores, chama de conhecimento registrado. Críticos da gestão do conhecimento, portanto, costumam considerar que o conhecimento, uma vez registrado, é informação. Bouthillier e Shearer (2002), no entanto, consideram o argumento de que conhecimento registrado (ou explícito) é informação como uma "avaliação inadequada das dimensões qualitativas dos vários tipos de informação e de conhecimento criados, usados e transferidos". 
Sobre os estudos da gestão do conhecimento na Ciência da Informação, vale a pena retomar as abordagens de Belkin (1978) e Brookes (1981) para a informação e a Ciência da Informação, respectivamente. No trabalho de Belkin, o conceito de informação é expresso tanto no plano cognitivo quanto no plano linguístico, assim representado (BELKIN, 1978, P. 81):

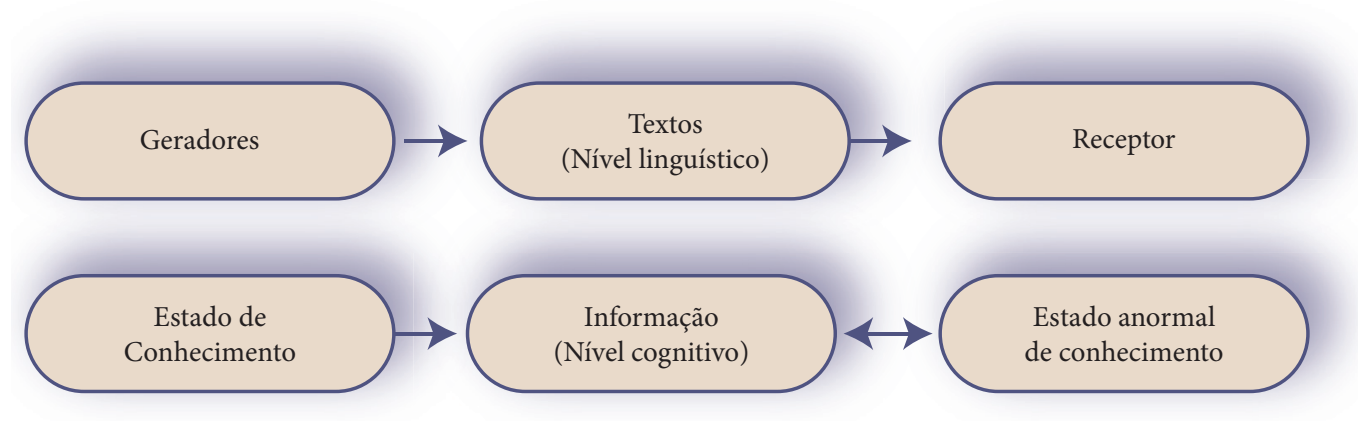

No plano linguístico, o autor insere a informação em um processo de comunicação entre seres humanos. No plano cognitivo, a abordagem de Belkin centra-se nas transformações ocorridas nos estados de conhecimento do indivíduo, quando este recebe a informação capaz de preencher uma necessidade ou lacuna. Um esforço maior permite ver, nos dois níveis em que é expresso o conceito de informação de Belkin, a comunicação como parte da gestão.

A abordagem de Brookes (1980) e a análise que o autor faz sobre os campos de atuação da Ciência da Informação e - como se percebe atualmente - da gestão do conhecimento, complementam a abordagem de Belkin. Batista et al. (2007) estudaram essas questões, destacando que Brookes (1980)

considera que, embora a coleta, a organização e o acesso às fontes de informação sejam essenciais para a prática profissional nas bibliotecas, o foco da prática profissional deveria ser a transformação da informação em conhecimento pessoal (grifo dos autores). Por isso, argumenta que o mundo da Ciência da Informação deve ser visto como um mundo mais amplo e distinto do mundo da documentação e biblioteconomia.

Esse mundo mais amplo e distinto, na visão de Brookes, está situado nas interações entre os Mundos 2 e 3 de Popper (1975). Como é possível notar, Brookes, com base na abordagem dos Três Mundos de Popper, propõe uma relação entre informação e conhecimento nos estudos da Ciência da Informação, baseada, principalmente, na noção de "espaços mentais únicos". O autor chama a atenção para o fato de que os eventos do Mundo 2 - individualidades mentais - ocorrem em espaços individuais privados sendo, portanto, subjetivos. Para objetivá-los, é necessário expressá-los e depositar os registros no Mundo 3, onde são acessíveis a outros e podem, portanto, ser criticamente considerados. 
Brookes explora o Mundo 3 de Popper como o da Biblioteconomia e da Ciência da Informação, ressaltando, entretanto, que o trabalho prático dos profissionais da área é coletar e organizar para uso os registros do Mundo 3. Suas atribuições teóricas são o estudo das interações entre o Mundo 2 e o Mundo 3, "para os descrever e explicar, se puderem, e, então, ajudar na organização do conhecimento, mais do que de documentos, para o uso mais efetivo" BROOKES, 1980, p. 128).

Uma observação importante de Brookes (1980, p. 128) para os estudos da gestão do conhecimento na Ciência da Informação, a partir das abordagens dos três mundos de Popper, é a de que:

[...] essa abordagem, portanto, permite-nos escapar das subjetividades da velha abordagem de 2000 anos para as teorias do conhecimento e da psicologia subjetiva, assim como da filosofia tradicional. Mais que isso, ao adotar a interação entre os Mundos 2 e 3 como nosso campo de estudos, nós estamos reivindicando a propriedade de uma disciplina que nenhuma outra disciplina já reivindicou.

O argumento de Brookes, como pode ser notado, o qual está explícito em seu texto, é de que a Ciência da Informação não deveria ser uma combinação de abordagens de várias disciplinas, como a Linguística, a Ciência da Computação, entre outras. Isso ocorre porque, segundo o autor, a área tem, na verdade, seu próprio território, seus próprios problemas e sua visão própria dos problemas humanos.

Observe-se que o que Brookes chama de "espaços mentais únicos" pode perfeitamente ser considerado como o que Nonaka e Takeuchi (1997) chamam de "conhecimento tácito". Assim, o que Brookes chama de "objetivação" dos espaços individuais fornece a base para os processos de conversão do conhecimento de Nonaka e Takeuchi, mais especificamente, os processos de socialização, internalização e externalização. Conforme concluem Batista et al. (2007),

a análise do modelo de Nonaka e Takeuchi [...] mostra que é a Gestão do Conhecimento que, ao se preocupar em descrever e analisar os processos de conversão das duas formas de conhecimento (tácito ou subjetivo e explícito ou objetivo) realiza a segunda proposta feita por Brookes aos cientistas da informação, isto é, estudar as interações entre os Mundos 2 e 3 de Popper.

São vários os modelos identificados na literatura para o estudo da gestão do conhecimento. A análise desses vários modelos ao longo do estudo fundamentou a consideração de que a gestão do conhecimento engloba práticas da gestão da informação, muito embora não possa ser confundida nem tão pouco reduzida a ela. Assim, a gestão da informação é aplicável principalmente aos processos relacionados à captura, ao armazenamento e à recuperação de apenas uma parcela do conhecimento tácito, o qual, neste momento, é necessariamente 
reduzido a estruturas de informação. Desse modo, a gestão do conhecimento possui intenções diferenciadas que se sobrepõem à gestão da informação, uma vez que se volta, também, para criação e agregação de valor ao conhecimento. A gestão da informação, por seu turno, lida com a parcela do conhecimento tácito que foi explicitado e passível de ser comunicado por meio de sistemas formais de comunicação, sendo assim torna-se um dos meios necessários para o alcance das pretensões da gestão do conhecimento.

Por sua vez, quando se tem em questão o conhecimento tácito de fato, a gestão do conhecimento é responsável pela condução dos processos relacionados ao fluxo e à apropriação do conhecimento, o qual, por seu turno, não pode ser manipulado, no sentido estrito da palavra. A “intencionalidade maior" refere-se, em última análise, ao fato de se fazer com que todo tipo de conhecimento seja valorizado, compartilhado, utilizado, retido na organização, a fim de que os indivíduos criem conhecimento, aprendam mais e da melhor forma. Está preocupada com a criação de condições férteis, bem como com a condução de situações ótimas e viabilizadoras para que o conhecimento seja criado, compartilhado, assimilado e convertido em benefícios aplicáveis à consecução dos objetivos de uma determinada organização. Todos esses aspectos pressupõem elementos a mais do que a gestão da informação sozinha pode oferecer. Os argumentos apresentados que ilustram a relação entre a gestão da informação e do conhecimento, resumidos, em última instância, na interação entre conhecimento tácito (subjetivo) e conhecimento explícito (objetivo), podem ser graficamente representados pela figura 1. Portanto, a gestão da informação é um dos componentes da gestão do conhecimento.

Figura 1 - Relação entre gestão do conhecimento e gestão da informação

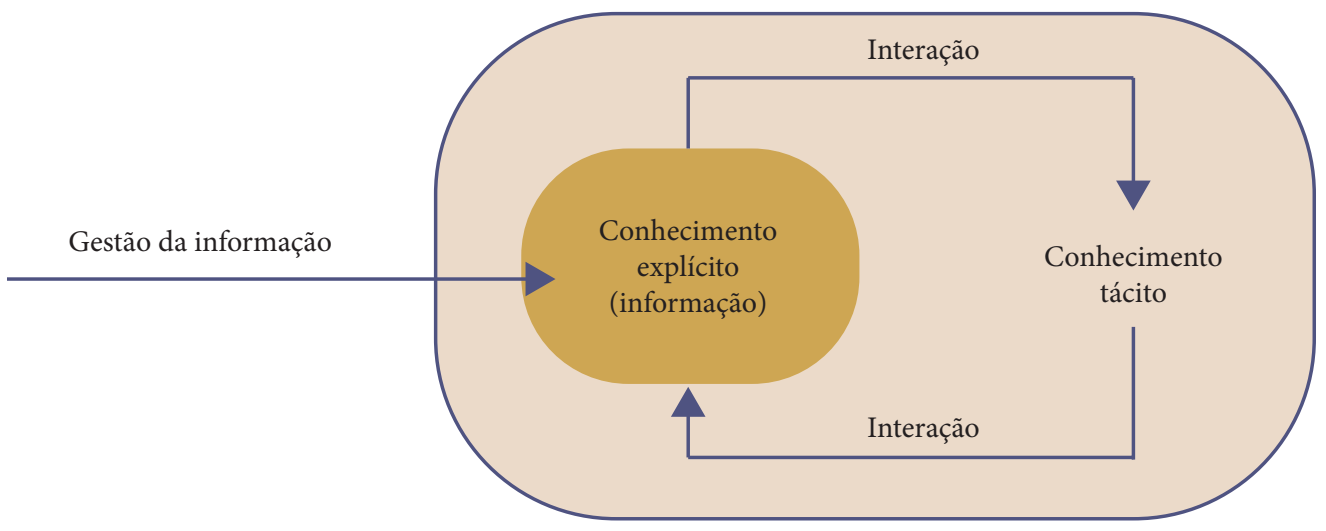

Fonte: Adaptado de Leite (2006).

A literatura sobre a gestão do conhecimento é fortemente influenciada pela teoria de criação do conhecimento organizacional cunhada por Nonaka e Takeuchi (1997), e, embora se deva levar em consideração o contexto cultural específico do desenvolvimento da teoria dos autores 
japoneses - organizações empresariais -, ainda assim seu modelo é uma contribuição sólida ao corpo de conhecimento que fundamenta a gestão do conhecimento. Resumidamente, a construção teórica dos autores é apresentada sob a ótica de duas dimensões. A primeira, ontológica, tem em vista o conhecimento organizacional em oposição à criação do conhecimento individual e relaciona-se aos níveis de entidades criadoras do conhecimento (individual, grupal, organizacional e interorganizacional). Ela parte do entendimento de que o conhecimento só é criado por indivíduos, ou seja, uma organização não pode criar conhecimento por si só, é um processo que amplia organizacionalmente o conhecimento criado pelos indivíduos. A segunda, a dimensão epistemológica, tem como base fundamental a distinção entre conhecimento tácito e explícito, por meio da qual o conhecimento pode ser expresso em palavras e números (explícito), representando apenas a ponta do iceberg do conjunto de conhecimentos como um todo. A partir dessa sistematização, ocorre a espiral da criação do conhecimento, que surge no momento em que "a interação entre conhecimento tácito e conhecimento explícito eleva-se dinamicamente de um nível ontológico inferior até níveis mais altos” (NONAKA; TAKEUCHI, 1997, p. 62). A explicação da espiral de criação do conhecimento organizacional constitui o âmago da teoria dos autores, em que, por meio dos quatro modos de conversão (socialização, externalização, combinação e internalização), que ocorrem a partir da interação entre conhecimento tácito e explícito, é construído um novo conhecimento (NONAKA e TAKEUCHI, 1997, p. 62). A concepção do conhecimento tácito e explícito em uma dinâmica e contínua interação, que torna possível a criação de um novo conhecimento, é a premissa básica da teoria. Os autores ressaltam que o processo de criação do conhecimento é fruto de uma interação constante e dinâmica entre os dois tipos de conhecimento. Tal interação é moldada pelas mudanças entre os diferentes modos de conversão, os quais, por seu turno, sofrem influência de vários outros fatores. Na sua visão, conhecimento explícito e conhecimento tácito são entidades complementares e não excludentes, interagem um com o outro e realizam trocas nas atividades criativas desempenhadas pelos seres humanos. Os autores acrescentam ainda que o modelo dinâmico de criação do conhecimento é fundamentado no pressuposto de que o conhecimento humano é criado e expandido por meio da interação social entre o conhecimento tácito e o conhecimento explícito. A essa interação dão o nome de espiral do conhecimento.

A teoria embutida no referencial teórico sugere, em um primeiro momento, que a comunicação científica é crucial para a gestão do conhecimento científico. Quer se dizer com isso que, de acordo com o referencial desenvolvido, no plano conceitual, a comunicação científica é o substrato fundamental para o desenvolvimento da gestão do conhecimento científico no contexto acadêmico. Atrelados a isso, os pressupostos da gestão do conhecimento, os aspectos relacionados ao conhecimento - e, mais especificamente, ao conhecimento científico -, juntamente com processos de comunicação científica, são elementos que influenciam sistemicamente o desenvolvimento da gestão do conhecimento científico no contexto acadêmico. Da mesma forma, as questões relacionadas com o conhecimento 
e os pressupostos da gestão do conhecimento influenciam e são influenciados pela comunicação científica. Todos esses elementos estão dispostos em um contexto acadêmico, o qual possui características culturais próprias que são influenciadas por uma cultura científica maior. O contexto acadêmico, por sua vez, influencia todos os relacionamentos entre comunicação científica, aspectos do conhecimento e pressupostos da gestão do conhecimento, refletindo, por consequência, na gestão do conhecimento científico. Outra relação que se quer destacar está relacionada ao argumento de que as atividades de ensino e pesquisa realizadas por pesquisadores docentes de uma universidade estão organizadas em diferentes áreas do saber. Por essa razão, as comunidades científicas de diferentes áreas do conhecimento influenciam os processos de comunicação científica, a própria produção do conhecimento científico, assim como a cultura científica/organizacional de uma universidade. Esses seriam os elementos e relacionamentos essenciais, no plano conceitual, de um sistema de gestão do conhecimento científico.

O referencial teórico criado a partir da discussão acerca dos conceitos de conhecimento científico, comunicação científica, gestão do conhecimento, cultura científica/organizacional e suas inter-relações norteou a construção do modelo teórico de gestão do conhecimento científico em sua vertente tácita e explícita, tendo por base os processos de comunicação científica. Essa, por seu turno, está relacionada com o planejamento e controle de ações (políticas, mecanismos, ferramentas, estratégias e outros) que governam o fluxo do conhecimento científico em sua vertente tácita e explícita, tendo como substratos os processos de comunicação científica com o fim de apoiar e maximizar a geração de novos conhecimentos e o ensino.

\section{METODOLOGIA}

A metodologia empregada no estudo envolveu diferentes momentos. Inicialmente, foi construído, com base na análise crítica da literatura e na extração de conceitos, o referencial teórico que constituiu o modelo da pesquisa. Esse ofereceu os fundamentos a partir dos quais o problema da pesquisa foi observado e discutido. Em seguida, norteado pelo referencial teórico, determinou-se a abordagem metodológica e os procedimentos metodológicos propriamente ditos, cujo detalhamento é feito a seguir.

Por se tratar de um tema ainda pouco explorado - a convergência de abordagens da comunicação científica e da gestão do conhecimento -, existe pouco conhecimento a respeito. Dessa maneira, o esforço da pesquisa direcionou-se para a construção teórica de uma base que fundamentasse um modelo conceitual de gestão do conhecimento científico, com aporte na literatura de cada uma das abordagens.

O modelo conceitual de gestão do conhecimento científico proposto foi, portanto, delineado a partir da construção teórica realizada com base na literatura e em entrevistas realizadas com 
pesquisadores docentes de diferentes áreas do conhecimento. A literatura estudada circunscreve principalmente os campos da Ciência da Informação e da Administração. Os textos selecionados são trabalhos científicos relevantes (artigos, teses, dissertações e livros) no que diz respeito aos tópicos relacionados à comunicação científica, ao conhecimento científico e à gestão do conhecimento, cujas temáticas incidem, direta ou indiretamente, sobre o tema proposto, norteando os elementos do referencial teórico desenvolvido para o estudo. A realização das buscas em bases de dados ocorreu no período de julho de 2004 a dezembro de 2005, e não houve restrição de ano das publicações ${ }^{2}$. Os documentos recuperados por meio das buscas foram classificados em três amplas categorias, nomeadamente aspectos conceituais da informação e conhecimento, comunicação científica e gestão do conhecimento.

No que diz respeito às entrevistas com pesquisadores docentes de diferentes áreas do conhecimento, foram adotados os estágios sugeridos por Kvale (1996): tematização, planejamento ou delineamento, entrevista, transcrição, análise e apresentação. O roteiro utilizado no instrumento de coleta de dados foi planejado com base em conceitos e teorias que constituem parte do referencial teórico desenvolvido para o norteamento do estudo, como sugerem Bauer e Gaskell (2002, p. 66). Os autores orientam que, na preparação e no planejamento do instrumento de coleta de dados, é necessário que o pesquisador já tenha desenvolvido um referencial teórico ou conceitual que guie sua investigação, e que tenha identificado os conceitos centrais e os temas que deverão ser vistos na pesquisa. De acordo com isso, o roteiro da entrevista fundamentou-se na combinação de uma análise crítica da literatura pertinente, no reconhecimento do campo - segundo os autores, isso pode incluir observações e/ou algumas conversações preliminares com algumas pessoas relevantes -, nas discussões com colegas experientes e em algum pensamento criativo. Os pesquisadores docentes sujeitos da pesquisa, vinculados à Universidade de Brasília, foram selecionados com base nos seguintes critérios: ser líder de grupo de pesquisa produtivo; ter produção científica recente; orientar alunos de mestrado e doutorado; ter envolvimento com o ensino em níveis de graduação e pós-graduação. A seleção desses sujeitos justifica-se por serem atores que estão diretamente relacionados com a produção e difusão do conhecimento científico. Todas as informações para a seleção do universo foram coletadas na Plataforma Lattes do CNPq. Após o preenchimento dos critérios, 18 pesquisadores foram contatados formalmente via correio eletrônico, dos quais 15 retornaram o contato e dispuseram-se a ser entrevistados, três dos quais constituíram o universo do pré-teste. Na constituição do universo da pesquisa, as áreas do conhecimento foram assim representadas: Ciências da Engenharia (Física, Química, Biologia, Engenharia Mecânica); Ciências Sociais e Humanas (Sociologia, Psicologia, Educação); e Humanidades (Educação, História, Linguística).

2 Os procedimentos de busca e as principais fontes de informação encontram-se descritos em Leite (2006). 


\section{GESTÃO DO CONHECIMENTO CIENTÍFICO: UM MODELO CONCEITUAL}

A gestão do conhecimento científico no contexto acadêmico pode ser estudada a partir de duas perspectivas distintas. A primeira, a vertical, diz respeito ao âmbito das comunidades científicas. Nesse ângulo de análise, essas comunidades, como mencionadas anteriormente, são entendidas como o agrupamento de pares que compartilham um tópico de estudo, desenvolvem pesquisas e dominam um campo de conhecimento específico, em âmbito internacional (COSTA, 1999). A segunda perspectiva, a horizontal, está relacionada às instituições de ensino e pesquisa. Nesse ângulo, adota-se o conceito de comunidades acadêmicas.

A perspectiva da gestão do conhecimento científico no contexto das comunidades científicas, no plano vertical, está relacionada com a gestão do conhecimento produzido por uma disciplina, tópico ou campo específico do saber. Logo, a gestão do conhecimento científico no âmbito de comunidades científicas não possui um caráter institucional, e sim disciplinar. Nesse sentido, a caracterização do conceito de comunidade científica como o conjunto de pesquisadores que compartilham interesse sobre tópicos ou áreas específicas, em âmbito internacional, vem ao encontro daquilo que caracteriza as redes. Probst, Raub e Romhart (2002, p. 82) afirmam que uma rede é caracterizada por um interesse básico comum entre seus membros, além de uma orientação pessoal e participação voluntária, e suas relações estão baseadas no princípio das trocas. As relações de compartilhamento e os fluxos de informação e conhecimento no seio das comunidades científicas ocorrem por meio dos colégios invisíveis. Diferentemente das comunidades acadêmicas, as comunidades científicas não possuem fronteiras nem características organizacionais.

Por sua vez, a perspectiva da gestão do conhecimento científico voltado às instituições de ensino e pesquisa - o plano horizontal, que, neste estudo, corresponde a uma universidade - está relacionada com o conceito de comunidades acadêmicas. Essas comunidades dizem respeito ao agrupamento de membros de uma instituição acadêmica envolvidos com atividades de ensino e pesquisa, cujos recursos humanos são direcionados à pesquisa, os quais compartilham ou não interesses comuns em seus tópicos de estudo. Porém, seus pesquisadores pertencem, individualmente, a grupos de interesse em tópicos específicos sem limites geográficos, denominados anteriormente de comunidades científicas. Nessas comunidades, há um constante e intenso compartilhamento de conhecimento, constituindo, no tópico de interesse específico do pesquisador, o principal locus de comunicação e troca de conhecimentos.

Percebe-se que as duas perspectivas a partir das quais se realiza a abordagem da gestão do conhecimento científico estão inter-relacionadas. Embora seja possível e necessário definir o ângulo de análise, é importante destacar que não é possível uma abordagem excluir a outra. A razão disso está em dois argumentos: 1) membros de comunidades científicas, de uma maneira geral, possuem vínculo com instituições de ensino e pesquisa; 2) pesquisadores membros das 
comunidades acadêmicas pertencem individualmente a comunidades científicas específicas. Assim, a produção científica de uma instituição de ensino e pesquisa, representada pelo conjunto da produção científica dos pesquisadores que mantêm vínculo institucional com ela, constitui, ao mesmo tempo, a produção científica de diferentes comunidades científicas. Por exemplo, a comunidade científica que se dedica ao estudo das publicações eletrônicas, possui uma quantidade $\mathrm{X}$ de membros. Toda a produção científica desses membros constitui o total de conhecimento produzido por essa comunidade. Porém, ao mesmo tempo, cada um dos membros da comunidade científica de publicações eletrônicas possui vínculo com alguma instituição de ensino e/ou pesquisa e, individualmente, contribui para a produção científica total da sua instituição - comunidade acadêmica. O que se quer destacar é que os dois níveis de análise se sobrepõem. Sendo assim, várias comunidades científicas podem "cortar" transversalmente uma determinada comunidade acadêmica. Essa relação pode ser visualizada na figura 2.

Figura 2 - Comunidade acadêmica e comunidades científicas

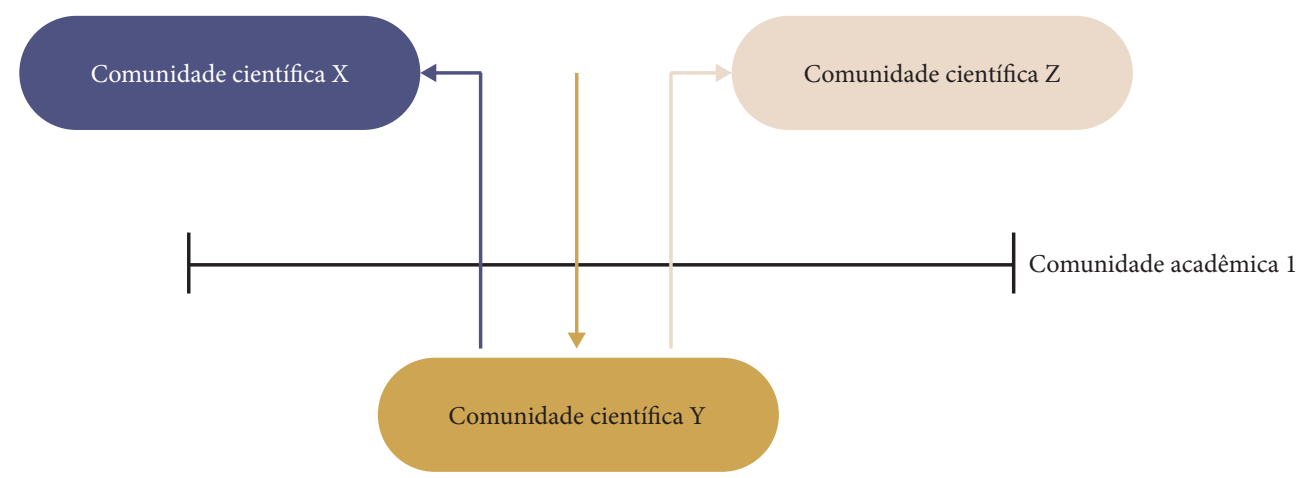

Fonte: Elaboração dos autores (2018).

Neste estudo, a perspectiva adotada é a gestão do conhecimento científico em comunidades acadêmicas - no caso, uma universidade. As implicações das comunidades científicas para esse processo serão exploradas quando da apresentação do modelo conceitual de gestão do conhecimento científico.

Ademais, concorda-se com Wilson (1999, p. 11) ao se conceber um modelo como uma interpretação explícita do entendimento de uma determinada situação, ou simplesmente de ideias a respeito da situação. Segundo o autor, um modelo pode ser expresso por fórmulas matemáticas, símbolos ou palavras, embora seja essencialmente a descrição de entidades, processos ou atributos e as relações entre eles. Pode ser prescritivo ou ilustrativo, mas, acima de tudo, deve ser útil. Wilson põe em relevo a importância de modelos conceituais no estudo de sistemas organizacionais. De acordo com o autor, esses modelos 
são utilizados a fim de clarear uma determinada área de estudo, ilustrar um conceito, determinar a estrutura e a lógica de uma situação qualquer e ser útil como um pré-requisito para o desenho de um sistema ou projeto.

O modelo conceitual de gestão do conhecimento científico, ilustrado na figura 3, bem como os relacionamentos entre seus elementos, é derivado dos seguintes procedimentos: análise da literatura; criação do referencial teórico a partir da análise e discussão da literatura; construção teórica sobre a relação entre gestão do conhecimento e processo de comunicação científica; e análise e discussão das entrevistas realizadas com pesquisadores de diferentes áreas do conhecimento. Os resultados obtidos com o alcance dos objetivos específicos da pesquisa (ver LEITE, 2006) fundamentaram, naturalmente, a construção do modelo conceitual de gestão do conhecimento, contudo, neste artigo, ressalta-se apenas o delineamento do modelo.

Figura 3 - Modelo conceitual de gestão do conhecimento científico no contexto acadêmico

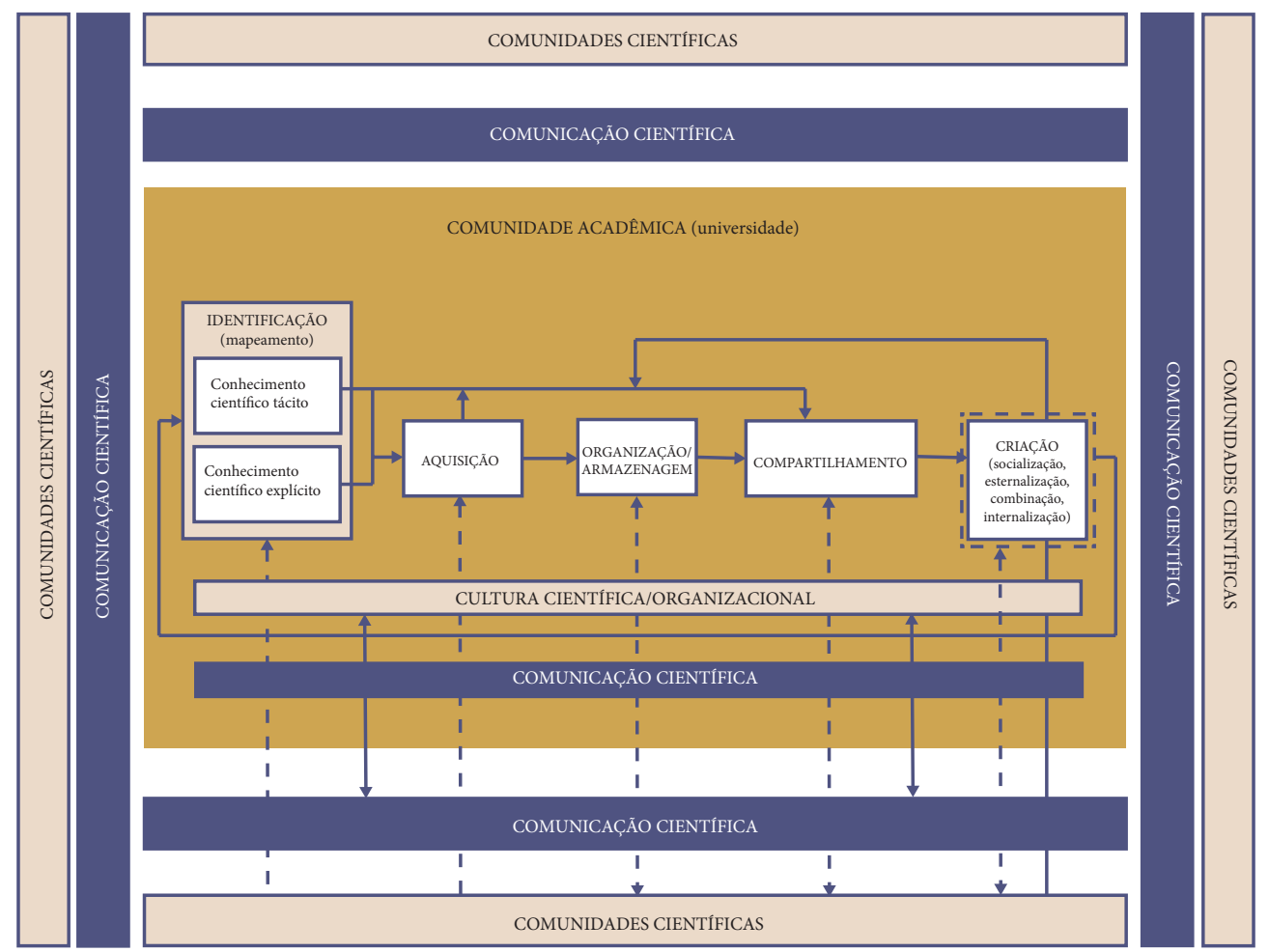

Fonte: Elaboração dos autores (2018).

A versão textual do modelo conceitual de gestão do conhecimento científico encontra-se estruturada em três dimensões: descrição dos elementos macro do modelo e suas relações (comunidades científicas, comunidades acadêmicas, comunicação científica, cultura científica/ 
organizacional e gestão do conhecimento); descrição dos processos constituintes da gestão do conhecimento; descrição e detalhamento dos relacionamentos entre os elementos macro e os processos de gestão do conhecimento.

A relação conceitual entre os principais elementos do modelo fundamenta-se no pressuposto de que a gestão do conhecimento em comunidades acadêmicas - no caso, uma universidade - tem como substrato os processos de comunicação científica e a cultura científica/organizacional. A comunicação científica é subjacente à interação dos membros da comunidade acadêmica em suas respectivas comunidades científicas e, internamente, em sua comunidade acadêmica. A cultura científica/organizacional, por sua vez, influencia e é influenciada pelos processos de comunicação científica. Além disso, é a cultura, tanto científica quanto organizacional, que legitima os meios de comunicação. Da mesma forma, são os processos de comunicação que veiculam os valores e as crenças que influenciam o desenvolvimento de uma cultura, conforme evidenciado nas entrevistas com pesquisadores. Por sua vez, a partir dos processos de comunicação científica, a comunidade acadêmica, por meio de seus pesquisadores, interage com as comunidades científicas, as quais servem de input de conhecimentos para o pesquisador individualmente e para ela própria.

Cabe ressaltar que, no modelo conceitual proposto, a validação não é levada em consideração como processo de gestão do conhecimento, muito embora esteja presente em vários modelos da literatura. No entanto, no contexto da gestão do conhecimento científico, considera-se que o próprio sistema científico exerce naturalmente a função de validação do conhecimento, seja pelo receio do pesquisador em tornar público, mesmo que informalmente, conhecimentos com padrões mínimos de confiabilidade e qualidade, seja pela natural adoção do sistema de peer review por parte das comunidades científicas.

O modelo conceitual de gestão do conhecimento científico proposto apresenta o conjunto de elementos macro, os processos e as relações entre eles. A descrição do modelo limitou-se à caracterização dos principais conceitos e às relações entre eles, bem com aos elementos macro e aos processos de gestão do conhecimento científico propriamente dito. Uma vez que a concepção do modelo baseou-se em conceitos - expressos tanto na análise da literatura quanto na percepção dos entrevistados -, é importante salientar que o modelo não é exaustivo tampouco conclusivo. A intenção foi discutir, estruturar e explorar a relação entre conceitos, no intuito de delinear um arcabouço teórico inicial para a construção de um corpus de conhecimento, uma vez que o tópico "gestão do conhecimento científico" carece de estudos que considerem as especificidades próprias da natureza do conhecimento e do contexto. É importante considerar também que, por uma necessidade de delimitação do objeto de estudo e limitação do tempo disponível para a pesquisa, não foram consideradas, no modelo, outros elementos que exerceriam forte influência sobre a gestão do conhecimento científico no contexto acadêmico. Citam-se como exemplos: a sociedade como um todo e os aspectos da popularização do 
conhecimento científico para segmentos sociais específicos; a influência direta das agências de fomento sobre a criação do conhecimento científico e, por consequência, sua gestão; e a relação entre universidade e indústria, entre outros.

\section{CONSIDERAÇÕES FINAIS}

É importante ressaltar que este estudo, ao combinar duas perspectivas teóricas distintas - a comunicação científica e a gestão do conhecimento -, pretendeu, em última análise, servir à construção de uma base teórica para o desenvolvimento de estudos futuros, uma vez que a literatura de ambos os campos está voltada para os seus próprios núcleos. Portanto, o esforço principal ao propor um modelo conceitual de gestão do conhecimento científico para o ambiente acadêmico, tendo por base os processos de comunicação científica, foi delinear e estabelecer a convergência teórica entre os dois tópicos de estudo visando à constituição de um quadro de referência para estudos nesse tópico. Um dos resultados desse esforço foi a estruturação de conceitos que buscam sustentar a abordagem da gestão do conhecimento científico. A exploração dos aspectos do conhecimento tácito na ciência, por exemplo, tanto com o aporte da literatura quanto nas entrevistas, constitui agora passos já percorridos para o aprofundamento da questão em outros estudos e para a formulação e teste de hipóteses.

A gestão do conhecimento científico, tendo por base a comunicação científica aliada a todas as questões exploradas, difere de estudos tradicionais sobre gestão do conhecimento em universidades. Como ressaltado inicialmente, estudos sobre gestão do conhecimento em universidades geralmente abordam o conhecimento científico do ponto de vista do conhecimento organizacional ou, ainda, enfocam o desenvolvimento de plataformas tecnológicas, fazem gestão de dados e, quando muito, gestão da informação. Portanto, o caráter teórico do trabalho foi conduzido pela necessidade de se compreender os elementos - e as relações entre eles - que influenciam direta ou indiretamente a gestão do conhecimento científico.

Os processos de gestão do conhecimento científico no contexto de uma comunidade acadêmica, mesmo que tenham por objetivo oferecer suporte, potencializar e tornar mais eficientes as atividades de pesquisa e ensino na instituição, bem como a integração entre elas - e por consequência o estímulo à criação de novos conhecimentos -, sofrem influência externa das comunidades científicas, como sugerem os resultados. Por essa e outras razões, a identificação, a aquisição, a organização/armazenagem e, sobretudo, o compartilhamento e a criação do conhecimento científico, como processos de gestão do conhecimento no contexto de uma universidade, não podem desprezar a interferência de várias lateralidades, tanto internas quanto externas, de caráter cultural, tecnológico 
ou social. Dessa maneira, uma instituição acadêmica não pode fechar-se em si, pois está inserida em um complexo sistema científico, no qual a influência mais direta e imediata, no que diz respeito aos fenômenos relacionados com o conhecimento, provém das comunidades científicas.

Por fim, entende-se por gestão do conhecimento científico o planejamento e o controle de ações (políticas, mecanismos, ferramentas, estratégias, entre outras) que governam o fluxo do conhecimento científico em sua vertente tácita e explícita, tendo como substratos os processos de comunicação científica, com o fim de apoiar e maximizar a criação de novos conhecimentos e o ensino.

\section{REFERÊNCIAS}

BATISTA, F. F.; COSTA, S.M.S., ÁLVARES, L. Gestão do conhecimento: a realização da proposta de Brookes para a Ciência da Informação? Encontro Nacional de Pesquisa em Ciência da Informação, 8., Salvador. Anais... Salvador: ANCIB, 2007.

BAUER, M. W.; GASKELL, G. Pesquisa qualitativa com texto, imagem e som: um manual prático. Rio de Janeiro: Vozes, 2002. 516 p.

BELKIN, N. J. Information concepts for information science. Journal of Documentation, v. 34, n. 1, p. 55-85, Mar. 1978.

BOUTHILLIER, F.; SHEARER, K. Understanding knowledge management and information management: the need for an empirical perspective. Information Research, $\mathrm{V}$. 8, n. 1, Oct. 2002.

BRAGA, G. M. Informação, ciência da informação: breves reflexões em três tempos. Ciência da Informação, v. 24, n. 1, p. 84-88, 1985.

BROOKES, B. The foundations of information science. Part I. Philosophical aspects. Journal of Information Science, v. 2, p. 125-133, 1980.

COLLINS, H. M. Tacit knowledge, trust and the Q of sapphire. Social Studies of Science. n. 31, p. 71-85, 2001. 
COSTA, S. M. S. The impact of computer usage on scholarly communication amongst academic social scientists. 1999. 302 p. Tese (Doutorado) - Curso de Doutorado Ciência da Informação Loughborough University, Department of Information Science, Loughborough, Inglaterra, 1999.

CRANE, D. Invisible Colleges: diffusion of knowledge in scientific communities. Chicago, Londres: University of Chicago Press, 1972.

GARVEY, W. D.; GRIFFITH, B. C. Scientific communication as a social system. In: GARVEY, W. D.; GRIFFITH, B. C. Communication: the essence of science. London: Pergamon Press, 1979. p. 148-164.

IVES, W., TORREY, B., GORDON, C. Knowledge management: an emerging discipline with a long history. Journal of Knowledge Management, v. 1, n. 4, 1998. p. 269-274. Disponível em: <http://www.krii.com/downloads/km_emerg_discipl.pdf >. Acesso em: jan. 2006.

KVALE, S. Interviews: an introduction to qualitative research interviewing. Thousand Oaks, Sage Publications, 1996.

LAGOZE, C.; VAN DE SOMPEL, H. The Open Archives Initiative: building a low-barrier interoperability framework. Disponível em: $<$ www.openarchives.org/documents/ jcdl2001-oai.pdf> Acesso em: fev. 2005.

LE COADIC, Y.-F. A ciência da informação. Brasília: Briquet De Lemos, 2004. 124 p.

LEITE, F. C. L. Gestão do conhecimento científico no contexto acadêmico: proposta de um modelo conceitual. Brasília, 2006. 240 p. Dissertação (Mestrado) - Curso de Mestrado em Ciência da Informação, Programa de Pós-Graduação em Ciência da Informação, Universidade de Brasília, Brasília, 2006. Disponível em:< http://eprints. rclis.org/archive/00006259/> Acesso em: fev. 2007.

MEADOWS, A. J. A comunicação científica. Brasília: Briquet de Lemos, 1999. 268 p.

NONAKA, I.; TAKEUCHI, H. Criação do conhecimento na empresa: como as empresas japonesas geram a dinâmica da inovação. Rio de Janeiro: Campus, 1997. 358 p.

POLANYI, M. The tacit dimension. London: Routledge e Kegan Paul, 1966. 
POPPER, K. R. Conhecimento objetivo: uma abordagem evolucionária. Belo Horizonte: Itatiaia, 1975. $394 \mathrm{p}$

PROBST, G., RAUB, S., ROMHART, K. Gestão do conhecimento: os elementos construtivos do sucesso. Porto Alegre: Bookman, 2002. 286 p.

SCHEIN, E. H; CALLAGHAN, D. Guia de sobrevivência da cultura corporativa. Rio de Janeiro: J Olympio, 2001. 191 p.

SMOLIAR, S. W. Interaction management: the next (and necessary) step beyond knowledge management. Business Process Management Journal, v. 9, n. 3, p. 337-353, 2003. Disponível em: http://www.emeraldinsight.com/Insight/ViewContentServlet?Filename=/ published/emeraldfulltextarticle/pdf/1570090305.pdf Acesso em jan. 2006.

THEUNISSEN, P. Communication: The cornerstone of knowledge management. Making a difference: Australian and New Zealand Communication Association Conference, 2004.

WILSON, B. Systems: concepts, methodologies and applications. Lancaster: John Wiley \& Sons, 1990.

ZIMAN, J. M. A força do conhecimento. Belo Horizonte: Itatiaia, 1981, 380 p. 


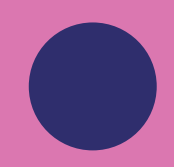

$\bullet$

○

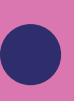

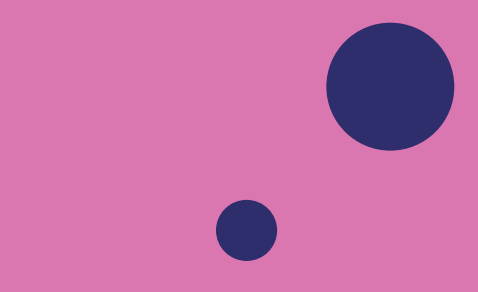

0

$.0^{\circ} \cdot \bullet$

$\cdot 0 \cdot 0$

0

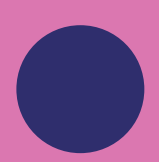

0

○

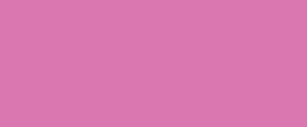

$$
.
$$

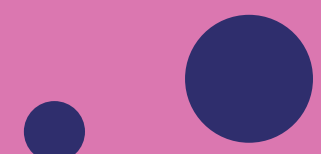$$
\text { . }
$$

$$
\text { . }
$$

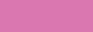

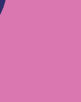


PARTE V

COMUNICAÇÃO E

GESTÃO DA INFORMAÇÃO

E GESTÃO DO

CONHECIMENTO 


\section{CAPÍTULO 14}

0

O

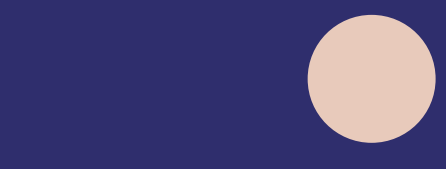

0
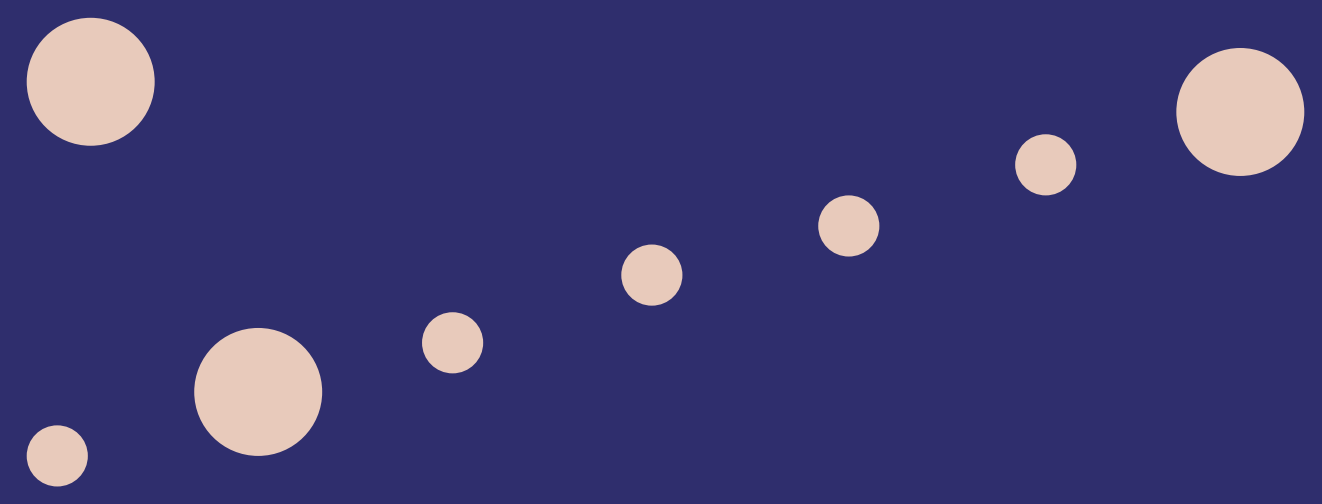

- 00

0 


\section{MODELO GENÉRICO DE GESTÃO DA INFORMAÇÃO CIENTÍFICA DIGITAL PARA INSTITUIÇÕES DE PESQUISA NA PERSPECTIVA DA COMUNICAÇÃO CIENTÍFICA E DO ACESSO ABERTO ${ }^{1}$}

FERNANDO CÉSAR LIMA LEITE SELY MARIA DE SOUZA COSTA

\section{INTRODUÇÃO}

Instituições de pesquisa estão imersas em um cenário de incerteza, cujo ambiente informacional requer transformações concretas, graças a, pelo menos, quatro questões que as têm impactado significativamente. A primeira questão diz respeito às realidades da informação digital em rede. A segunda refere-se às mudanças no modo de produção do conhecimento. A terceira está relacionada às demandas diferenciadas de acesso, uso e disseminação da informação no ambiente científico. A última diz respeito ao crescimento da necessidade de reestruturação do sistema de comunicação científica e reformulação de sua lógica. Consequentemente, práticas e metodologias de gestão da informação científica pautadas na estrutura do modelo tradicional de comunicação da ciência já não são suficientes para atender às expectativas criadas em razão dessas transformações. Mais do que nunca, portanto, é necessário que tais instituições sistematizem processos que otimizem os fluxos da informação que alimenta as atividades de pesquisa e que resultam de tais atividades.

1 Versão modificada do artigo publicado LEITE, F. C. L.; COSTA, S. M. de S. Modelo genérico de gestão da informação científica para instituições de pesquisa na perspectiva da comunicação científica e do acesso aberto. Investigación Bibliotecológica: Archivonomía, Bibliotecología e Información, [s.l.], v. 30, n. 69, p.43-74, maio 2016. Universidad Nacional Autonoma de Mexico. http://dx.doi.org/10.1016/j.ibbai.2016.04.012. 
Considerando que a comunicação da informação científica é um conjunto complexo de processos que envolve toda a cadeia de produção do conhecimento, quanto mais apropriados forem os processos de gestão da informação científica, mais coerentes e fluidos serão os processos de comunicação científica que viabilizam o avanço da ciência e do próprio conhecimento científico. Isso quer dizer que tais processos devem corresponder às expectativas e aos comportamentos dos atores envolvidos, de modo que sejam, ao mesmo tempo, compatíveis com a natureza da informação científica, com sua produção e com as forças e propriedades que governam e influenciam seu fluxo. Por essa razão, assume-se que toda e qualquer influência sofrida pelo sistema de comunicação científica, responsável pela dinâmica informacional presente na cadeia de produção da ciência, deva ser também refletida nas práticas de gestão da informação científica.

Desde o surgimento da internet, o evento que mais transformou, e não apenas modernizou, as bases sobre as quais o sistema de comunicação científica se estruturou foi a emergência de movimento mundialmente conhecido como acesso aberto à informação científica. $\mathrm{O}$ acesso aberto constitui uma reação da comunidade científica à lógica do sistema tradicional de publicação da ciência. Seus pressupostos e estratégias compatibilizam esforços que contribuem para reestruturar/reformar o sistema de comunicação científica de modo que sejam removidas barreiras presentes no fluxo da informação científica publicada, particularmente aquelas relacionadas às tecnologias, aos custos e aos direitos autorais. É importante ressaltar que a motivação primordial do acesso aberto é fazer com que resultados de pesquisa científica estejam pública e permanentemente acessíveis e sem custo a toda a comunidade científica ou a quem possa interessar.

Por promoverem as condições que favorecem um maior e melhor controle institucional da informação científica, as estratégias do acesso aberto - como expressão emergente de fluxos de informação mais democráticos e efetivos - tornam-se aspecto fundamental a ser considerado em iniciativas institucionais de gestão da informação científica em ambiente digital. Levando em conta os desenvolvimentos da última década, é possível considerar que a abordagem do acesso aberto tem se instituído gradativamente como modelo alternativo de comunicação da ciência.

É nesse contexto que se insere o presente artigo, cujo objetivo é apresentar modelo conceitual genérico de gestão da informação científica digital para institutos de pesquisa, tendo por base os fundamentos da comunicação científica na abordagem do acesso aberto. O modelo apresentado resultou de pesquisa que teve como objetivo geral sua construção e proposição, resultantes dos achados de seus quatro objetivos específicos. O primeiro consistiu em descrever, com base na literatura, modelos de gestão da informação e de comunicação científica, incluindo seus elementos e processos. O segundo objetivo foi propor, com base em análise crítica da literatura, relação conceitual entre processos de gestão da informação científica, acesso 
aberto e processos de comunicação científica. O terceiro consistiu em identificar, com base na percepção de pesquisadores, características das atividades de produção do conhecimento científico. Finalmente, o quarto objetivo da pesquisa foi mapear atividades de busca, acesso e uso da informação, assim como hábitos de comunicação científica de pesquisadores de institutos de pesquisa. Em razão da extensão dos resultados de cada um dos objetivos específicos, o relato aqui apresentado se concentra exclusivamente na apresentação do modelo proposto, como resultado do objetivo geral da pesquisa.

Para tal, discutem-se, primeiramente, os conceitos de gestão da informação científica, comunicação científica e acesso aberto, visando à construção do referencial teórico para construção do modelo. Em seguida, é apresentada a metodologia utilizada para desenvolvimento da pesquisa, cujo principal resultado é o modelo apresentado. Finalmente, apresenta-se o modelo teórico proposto, começando por sua versão textual, na qual são discutidos seus elementos (conceitos) constitutivos. Em seguida, apresenta-se sua versão gráfica, na qual as relações entre esses elementos estão ilustradas. Como conclusão, o artigo sumariza a teoria embutida no modelo proposto, acrescida de observações sucintas sobre achados do objetivo geral.

\section{GESTÃO DA INFORMAÇÃO CIENTÍFICA, COMUNICAÇÃO CIENTÍFICA E ACESSO ABERTO: UM REFERENCIAL TEÓRICO}

A fundamentação teórica construída a partir da análise da literatura permitiu apontar relações conceituais entre gestão da informação científica, comunicação científica e acesso aberto. Tais relações são apresentadas a seguir e servem como plataforma teórica sobre a qual se desenvolveu o estudo.

A primeira parte da construção teórica formulada evidencia as relações mais amplas existentes entre gestão da informação científica, comunicação científica e acesso aberto. Nesse sentido, a partir de diferentes perspectivas acerca do entendimento do que constitui a gestão da informação (WHITE, 1985; FAIRER-WESSELS, 1997; CHOO, 1998; DAVENPORT, 1998; MIDDLETON, 2002; WILSON, 2002; JAEGER et al.., 2005; DETLOR 2009;), a gestão da informação científica foi definida como o conjunto de políticas e processos que sistematizam a geração, a coleta/aquisição, a organização, o armazenamento, a preservação, a recuperação, a disseminação e o uso da informação científica no contexto das instituições que têm por finalidade a produção do conhecimento científico. Levando em consideração os níveis de gestão da informação propostos por Rowley (1998) - sobretudo aquele que define os contextos informacionais -, assim como o funcionamento do sistema de comunicação científica e de seus processos (HILLS, 1983; HURD, 1996, 2000, 2004; SHEARER; BIRDSALL, 2002), foi possível definir a finalidade da gestão da informação científica no âmbito de instituições de pesquisa. Tal finalidade diz respeito à promoção de condições para que a informação que 
resulta (produto) das atividades de pesquisa e as alimenta (insumo) esteja disponível e acessível, de modo que pesquisadores gerem novos conhecimentos e, consequentemente, contribuam para o avanço da ciência.

Da definição e da finalidade da gestão da informação, resultou a concepção de que, para que ela ocorra de modo apropriado, é necessário que seja levada em consideração uma série de peculiaridades do ambiente da comunidade científica, sobretudo aquelas que impactam, em qualquer medida, o fluxo da informação na ciência. Ou seja, por impactarem o fluxo da informação, as forças que influenciam o sistema de comunicação científica (BORGMAN, 2007) influenciam, do mesmo modo, os processos de gestão da informação científica (CHOO, 1998; DAVENPORT, 1998). Por sua vez, tendo em vista a inseparabilidade dos processos de comunicação e do fazer científico, conforme ressaltam Goffman e Warren (1980) e Meadows (1999), entre outros autores, a comunicação científica pode ser definida como um complexo sistema que viabiliza os fluxos da informação científica entre pesquisadores, de modo que esses possam, em uma dinâmica cíclica, acessar, usar, gerar e disseminar informação durante a realização de suas atividades como pesquisadores. A partir dessa perspectiva, considera-se que a comunicação científica e a gestão da informação científica estão inexorável e funcionalmente imbricadas. A primeira gera os fluxos de informação enquanto a segunda os sistematiza.

Na relação entre comunicação científica e gestão da informação científica, destaca-se a perspectiva da interdependência e complementaridade. De um lado, a gestão da informação científica pressupõe, além do entendimento do ambiente em que os principais atores da comunidade científica estão inseridos (MIKHAILOV et al., 1984; SHEARER; BIRDSALL, 2002; BIRDSALL, 2005), o envolvimento desses atores com processos e estruturas de comunicação científica. Mais que isso, tais atores promovem, com a legitimidade conferida pela comunidade científica, o fluxo da informação na ciência. Do outro lado, encontra-se a própria comunicação científica, que, per se, não dispõe de estratégias, mecanismos e procedimentos necessários para, sozinha, lidar com a sistematização requerida pela complexidade decorrente das transformações do sistema científico, de modo que suas funções sejam efetivamente desempenhadas.

Parte-se, portanto, do pressuposto de que nenhuma das abordagens é capaz de lidar, isoladamente, com questões estruturais emergentes que envolvam a produção, a distribuição e o uso do conhecimento na comunidade científica. Essas questões surgem exatamente de deficiências ou limitações existentes nas práticas tradicionais tanto de gestão da informação científica quanto de comunicação científica.

Os resultados obtidos da análise da literatura sobre os temas permitiram identificar pelo menos oito questões. A primeira diz respeito às demandas de aumento da visibilidade da instituição, do pesquisador e do impacto dos resultados de suas pesquisas, o que requer enfatizar cada vez mais os mecanismos de disseminação. Tais demandas foram identificadas em Houghton et al. 
(2003), Swan e Brown (2004, 2005), Swan (2004, 2006) e Borgman (2007). A segunda questão relaciona-se à necessidade de desenvolvimento de tecnologias, metodologias e mecanismos que correspondam às especificidades da informação científica, de seu fluxo e do seu contexto de geração e uso. A terceira questão é concernente ao volume crescente da informação científica e o estabelecimento do formato digital como predominante para o acesso e a disseminação da informação científica (BORGMAN, 2007). A quarta refere-se à diversificação de suportes para a veiculação da informação científica (HOUGHTON et al., 2003). A quinta questão relaciona-se com as restrições de acesso e disseminação de resultados de pesquisa publicados em artigos de periódicos científicos, restrições essas impostas pelo modelo de direito de cópia, que preconiza a cessão, por parte do autor, dos direitos patrimoniais exclusivos aos editores. Isso tem conduzido ao monopólio do sistema por editores científicos comerciais, que impõem custos exorbitantes às assinaturas de periódicos ao ponto que nem mesmo instituições de países ricos são capazes de viabilizar a manutenção de suas coleções (DECLARAÇÃO DE BERLIN, 2003; BRODY et al.., 2004; COSTA, 2006; JACOBS, 2006; WILLINSKY, 2006; SUBER, 2007). A sexta questão refere-se às mudanças nas atividades de produção do conhecimento científico, decorrentes, sobretudo, do uso crescente de tecnologias de informação e comunicação. Tais mudanças, além de interferirem nas maneiras como a pesquisa científica é conduzida, requerem transformações nos modos como seus resultados são gerenciados (HOUGHTON et al., 2003). A sétima questão é a demanda crescente do uso de tecnologias de informação e comunicação como suporte ao trabalho colaborativo entre pesquisadores e instituições (HINE, 2006; BORGMAN, 2007; OLSON et al.., 2008; HARIDASAN; KHAN, 2009). A oitava e última questão concerne à necessidade de armazenamento, preservação, acesso, disseminação e reutilização de recursos informacionais não convencionais que, do mesmo modo, resultam das atividades de pesquisas. Conjuntos de dados brutos de pesquisa, simulações, software, objetos multimídia e outros (HOUGHTON et al., 2003; MARON; SMITH, 2008) são exemplos desses recursos.

As oito questões apresentadas figuram entre os principais fatores que se impõem como limitantes para que ambas as abordagens - gestão da informação científica e comunicação científica - a partir de processos, mecanismos e estratégias próprias, respondam de modo satisfatório às necessidades da comunidade científica. Ou seja, nem uma nem outra prática, isoladamente, dispõe de ferramental suficiente para lidar com o cenário atual dos fluxos de informação que alimentam as atividades de pesquisa e que resultam de tais atividades.

O acesso aberto, como abordagem proposta pela própria comunidade científica aos obstáculos que prejudicam o fluxo da informação científica, é responsável pela reestruturação de processos de comunicação científica relacionados com a produção, disseminação e uso do conhecimento. A despeito de suas motivações primárias estarem ligadas a tais aspectos, sua operacionalização é pautada por processos de gestão da informação científica, conforme denotam características e estratégias da via dourada e da via verde, apontadas 
por diversos autores (DECLARAÇÃO DE BERLIM, 2003; BRODY et al., 2004; COSTA, 2006; JACOBS, 2006; WILLINSKY, 2006; SUBER, 2007). Nesse sentido, considerando a vinculação funcional entre comunicação científica, acesso aberto e gestão da informação científica, assume-se que, para otimizar o fluxo da informação científica, reformulando processos de comunicação científica, o acesso aberto recorre a processos sistematizados de gestão da informação científica.

Conforme representado na figura 1, parte-se do pressuposto de que, na abordagem do acesso aberto, a solução de problemas de comunicação científica passa, necessariamente, pela gestão apropriada e efetiva da informação científica. Esta última, por sua vez, deve considerar aspectos próprios da comunicação científica - como é o caso das estratégias de acesso aberto -, como esforço de melhoria dos processos de comunicação da informação no contexto científico. Assim, como já destacado, identifica-se relação tanto de interdependência como de complementaridade entre as duas abordagens, cuja intersecção corresponde ao acesso aberto, conforme ilustrado na figura 2. Portanto, a análise da literatura proveniente das duas abordagens permitiu 
sugerir que, para efeitos da pesquisa realizada e aqui relatada, o acesso aberto pode ser compreendido como a intersecção da gestão da informação científica com a comunicação científica.

Figura 1 - Relacionamento entre gestão da informação científica, comunicação científica e acesso aberto

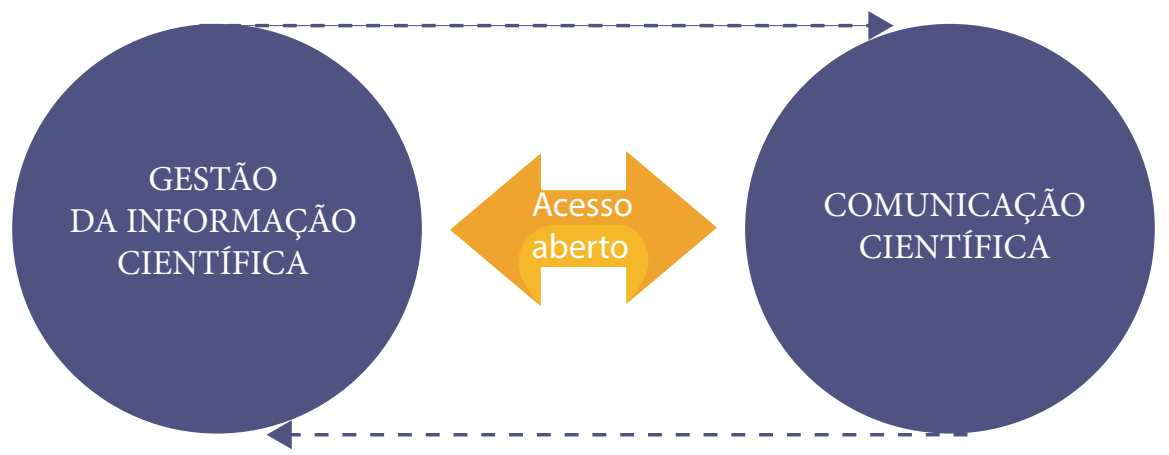

Fonte: Leite (2011).

Figura 2 - Acesso aberto como intersecção entre gestão da informação científica e comunicação científica.

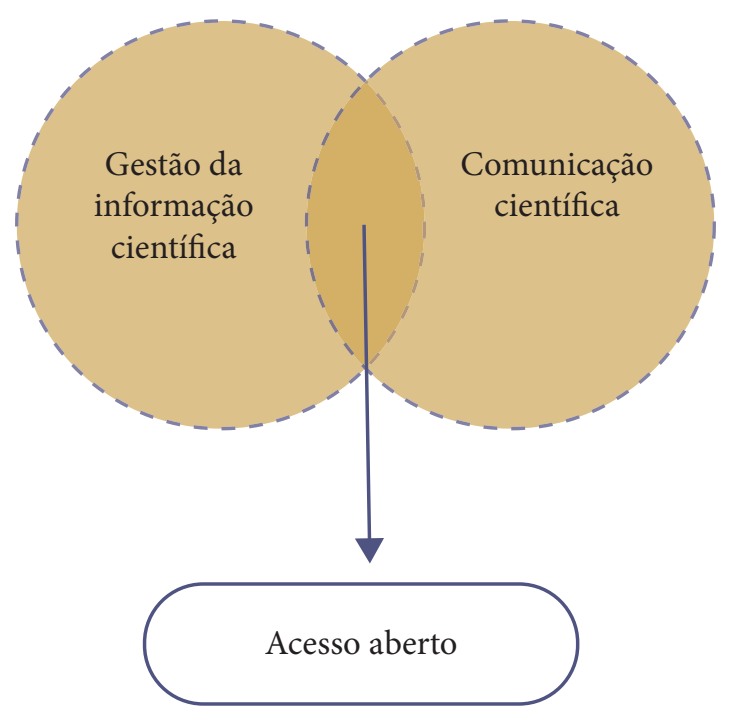

Fonte: Leite (2011).

A partir das conclusões a que se chegou pela análise dessas questões, e visando a identificar as melhores estratégias e os melhores procedimentos para realização da pesquisa tal como apontado por seu referencial teórico, foram tomadas decisões 
sobre a metodologia a ser adotada. É o que se relata na seção a seguir, a qual reflete a relação entre o referencial teórico obtido da literatura e as estratégias necessárias para alcance dos objetivos da pesquisa.

\section{METODOLOGIA}

Tal como requerido pelo problema em estudo e apontado pelo referencial teórico, realizou-se estudo de abordagem mista, operacionalizada com base na combinação de métodos qualitativos e quantitativos para coleta e análise dos dados. Adotou-se, para tal, estratégia de triangulação concomitante, em que dados quantitativos e qualitativos foram coletados simultaneamente e, em seguida, integrados e comparados "lado a lado".

Parte da coleta de dados foi realizada por meio de levantamento que teve como sujeitos pesquisadores vinculados a institutos de pesquisa do Ministério da Ciência, Tecnologia e Inovação (MCTI) do Brasil. Como parâmetro para a escolha de duas instituições, estabeleceu-se a aplicação de dois critérios: produtividade científica e representação das três divisões do conhecimento (Ciências Exatas e Naturais, Ciências Sociais e Humanas, Artes e Humanidades). Para o primeiro critério, adotou-se a quantidade de recursos de informação indexados na plataforma Web of Knowledge. De acordo com a plataforma, entre os institutos de pesquisa vinculados ao MCTI, o Centro Brasileiro de Pesquisas Físicas (CBPF) encabeçava a lista, tendo sido selecionado para o estudo dentro do critério "produtividade". A partir da aplicação do primeiro critério, foi possível aplicar o segundo, que foi a representação de diferentes divisões do conhecimento. Por contemplar tanto disciplinas das Ciências Sociais quanto das Humanidades, o Museu de Astronomia e Ciências Afins (Mast) foi considerado o instituto de pesquisa que mais se diferencia do CBPF, representante das Ciências Exatas. Desse modo, a amostra foi constituída de todos os pesquisadores doutores das duas instituições.

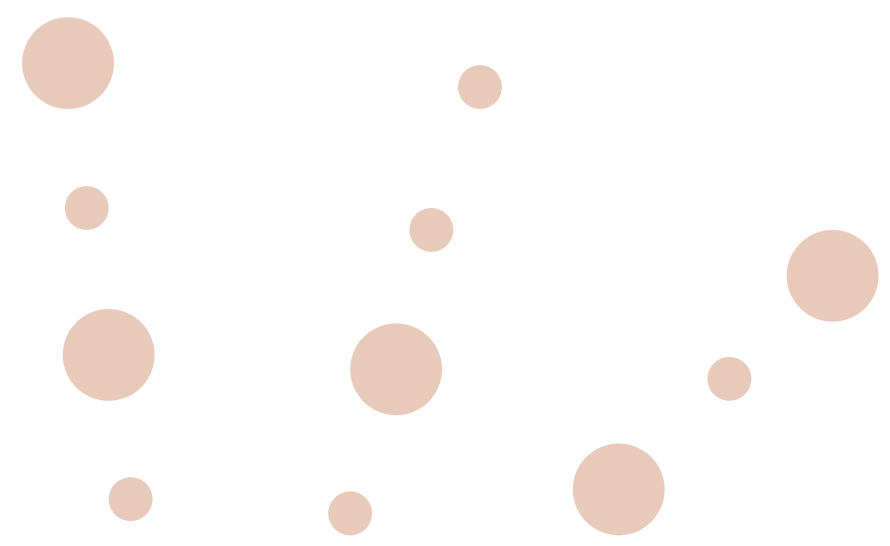


Três estratégias distintas, resumidas na figura 3, foram utilizadas para a coleta de dados feita com os pesquisadores. O resultado dessa coleta permitiu construir o modelo genérico de gestão da informação científica (GIC), fundamentado na perspectiva da comunicação científica e do acesso aberto.

Figura 3 - Procedimentos de coleta de dados para a proposição do modelo de gestão da informação científica (GIC)

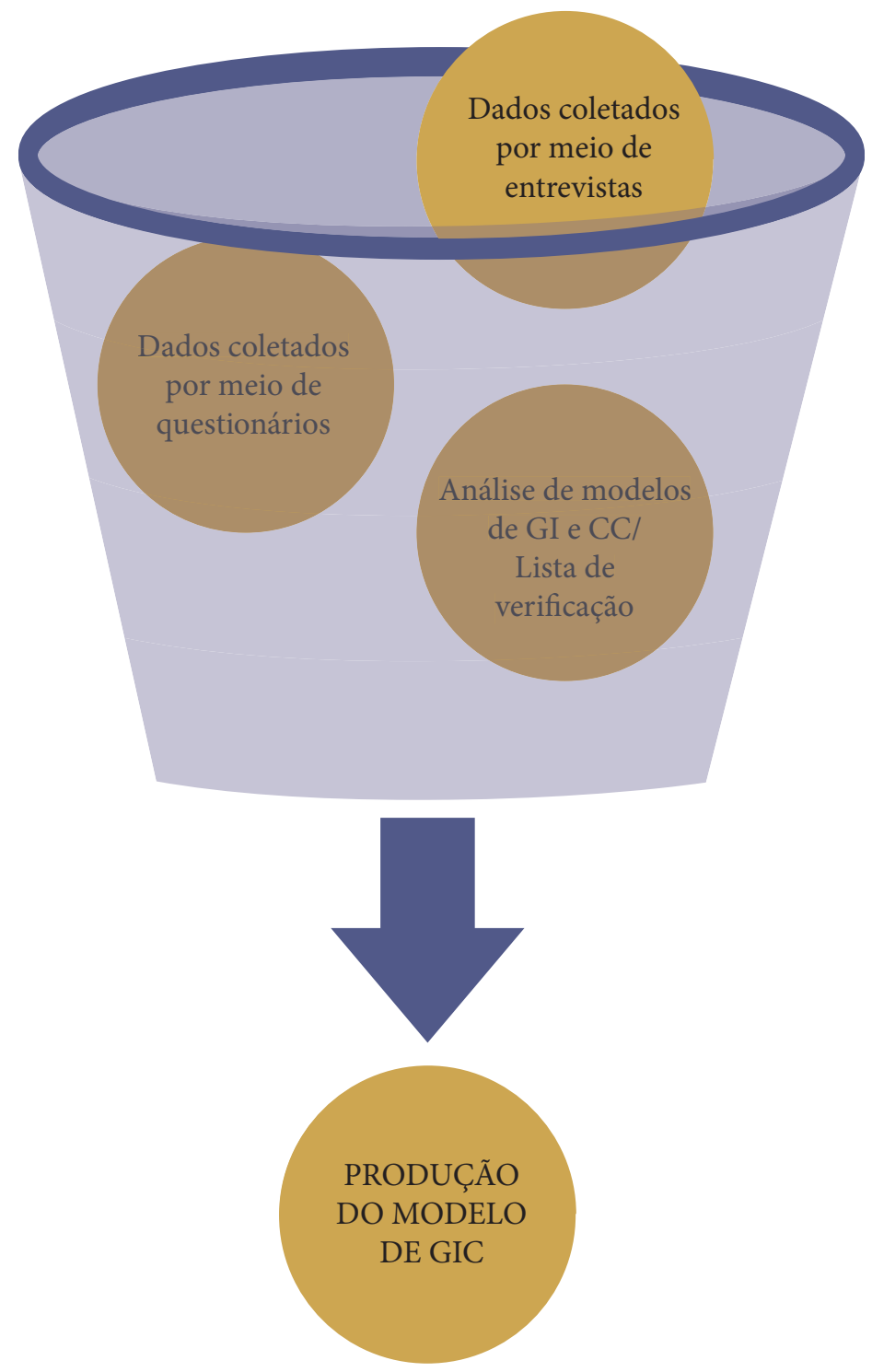

Fonte: Leite (2011). 
As análises da literatura, da percepção de pesquisadores (questionários e entrevistas) e de dados de seus currículos Lattes (lista de verificação) forneceram a base para a proposição do modelo de gestão da informação científica detalhado na seção a seguir. Portanto, os resultados nela apresentados dizem respeito exclusivamente ao modelo proposto como resultado de toda a pesquisa realizada. Resultados mais detalhados ${ }^{2}$ podem ser encontrados em Leite (2011), onde é possível verificar a origem de cada um dos elementos do modelo e das relações entre eles.

\section{MODELO DE GESTÃO DA INFORMAÇÃO CIENTíFICA DIGITAL}

O modelo de gestão da informação científica digital construído e proposto como principal resultado da pesquisa aqui relatada leva em conta processos de gestão da informação, elementos do sistema de comunicação científica, dimensões do acesso aberto, aspectos do ambiente de instituições de pesquisa e forças externas ao ambiente institucional. A explicação de cada um desses elementos (conceitos) que constituem o modelo é apresentada nesta seção, iniciando-se pelo lócus da pesquisa. O objetivo é, além de apresentar a definição dos conceitos, apontar qual a relação entre eles no modelo.

A ordem em que tais conceitos são apresentados resulta do fato de a comunicação ocorrer por meio do fluxo da informação entre pesquisadores, fluxo esse que, nos dias atuais, sofre impactos do acesso aberto em suas várias dimensões. $\mathrm{O}$ acesso aberto, por sua vez, fortaleceu a necessidade de processos de gestão efetiva da informação científica digital. Tudo isso se dá de modo diferenciado, dependendo de aspectos internos às instituições, que conferem flexibilidade aos processos de comunicação e gestão, os quais são também influenciados por atores externos às instituições.

\subsection{Lócus: os institutos de pesquisa}

O modelo proposto tem como lócus institutos de pesquisa (elemento cor-de-rosa da figura 4) considerados sistemas de produção do conhecimento. É importante notar que institutos de pesquisa estão entre os principais atores institucionais do sistema de comunicação científica. Nesse papel, são elementos constitutivos das comunidades científicas, consideradas em seu sentido mais amplo. Institutos de pesquisa interagem e trocam influência com seu ambiente

2 A pesquisa gerou resultados relacionados com a identificação e análise dos modelos de gestão da informação e de comunicação científica, percepção de pesquisadores, características das atividades de produção do conhecimento científico e mapeamento das atividades de busca, acesso e uso da informação, assim como hábitos de comunicação científica de pesquisadores de institutos de pesquisa. A partir desses resultados, o modelo apresentado neste trabalho foi proposto. 
externo, de onde provém a maior parte da informação científica. No modelo, a informação científica constitui, ao mesmo tempo, insumo e produto (entrada e saída) da produção do conhecimento científico.

\subsection{Fluxo da informação científica}

A entrada e a saída de informação científica dos institutos de pesquisa (cujos requisitos foram identificados a partir da análise de necessidades e atividades de busca, acesso e uso da informação e hábitos de disseminação) dependem das relações estabelecidas com o ambiente em que ocorrem. Entre as formas de viabilizar tais relações estão os processos realizados pelo sistema de comunicação científica, responsável por todos os aspectos do fluxo da informação científica. Significa dizer que a informação que resulta das atividades de pesquisa e as alimenta tem seu fluxo nos processos de comunicação científica. Essa concepção presente no modelo proposto foi apropriada de modelos que representam o sistema de comunicação científica (MIKHAILOV et al., 1984; SHEARER; BIRDSALL, 2002; BIRDSALL, 2005), assim como de modelos que representam processos de comunicação científica (UNISIST, 1971; LANCASTER; SMITH, 1978; GARVEY; GRIFFITH, 1979; HILLS, 1983; MIKHAILOV ET AL., 1984; HURD, 1996, 2000, 2004; SØNDERGAARD et al., 2003; HOUGHTON et al., 2009). Tanto o sistema quanto o processo ilustram o aspecto da entrada e da saída de informação científica no contexto de instituições de pesquisa. Combinado a isso, a dinâmica de entrada e saída foi igualmente identificada nos dados obtidos por meio de entrevistas e questionário (busca, acesso, uso e disseminação da informação) e lista de verificação (disseminação da informação). A informação e a comunicação científica estão representadas na versão gráfica do modelo pelas formas alaranjadas (figura 4).

\subsection{Abordagem e dimensões do acesso aberto}

Dados os principais obstáculos que tornaram difícil o alcance das funções da comunicação científica, e em razão da fundamentação teórica adotada, o acesso aberto constitui um imprescindível componente do modelo proposto (forma de cor verde na figura 14 4). Trata-se do componente que contribui para retomada e garantia dos fluxos desimpedidos de informação necessários ao desenvolvimento da ciência, tal como enfatizado pelos pesquisadores respondentes deste estudo e como ressaltam diversos autores na literatura analisada (DECLARAÇÃO DE BERLIN, 2003; BRODY et al., 2004; COSTA, 2006; JACOBS, 2006; WILLINSKY, 2006; SUBER, 2007). Na congregação de suas diferentes dimensões, representadas pelos elementos de cor amarela, os esforços do acesso aberto são úteis e necessários à livre circulação da informação científica, em concordância com as motivações de pesquisadores para disseminar resultados de pesquisa. 
Na perspectiva do modelo proposto, o acesso aberto age sobre duas situações fundamentais para a promoção de fluxos desimpedidos de informação científica. A primeira diz respeito à criação de condições para que pesquisadores possam buscar, acessar e usar toda informação necessária ao desenvolvimento do trabalho de pesquisa - aspectos abordados nas entrevistas e no questionário. A segunda refere-se à garantia de condições para que os resultados das pesquisas realizadas circulem e sejam rapidamente utilizados por outros pesquisadores, favorecendo a geração de novos conhecimentos - aspectos explorados no estudo sobre hábitos de disseminação. Nessas duas situações fundamentais, o acesso aberto contribui para a aceleração da produção de conhecimento e para o aumento do impacto dos resultados de pesquisa, de sua visibilidade e da visibilidade de seus geradores (DECLARAÇÃO DE BERLIN, 2003; BRODY et al., 2004; COSTA, 2006; JACOBS, 2006; WILLINSKY, 2006; SUBER, 2007). Para isso, há que se levar em conta cinco dimensões do acesso aberto, as quais são discutidas a seguir.

\subsubsection{Dimensões do acesso aberto}

Observações derivadas das análises dos dados desta pesquisa indicam que os esforços visando ao acesso aberto devem ser conduzidos tendo em vista cinco dimensões, que, somadas, resultam em ações robustas. A primeira dimensão é a sociocultural, na medida em que requer mudança de comportamento dos atores envolvidos, tais como o surgimento de novas funções e processos (CROW, 2002; HURD, 2004; SUBER, 2010). A segunda é a dimensão gerencial, relacionada ao planejamento, à organização, à direção e ao controle como funções da gestão do sistema de gestão da informação. A ideia da aplicação de funções administrativas em processos de gestão da informação é recorrentemente mencionada na literatura (VICKERS, 1985; DIENER, 1992; FAIRER-WESSELS, 1997; WILSON, 2002). A terceira é a dimensão política, que depende de normas que apoiem institucionalmente as ações do acesso aberto, como a obrigatoriedade do arquivamento da produção científica em repositórios institucionais, prevista em mandatos de depósito e recomendado na literatura (CARR et al., 2006; HARNAD, 2006). A quarta dimensão é a legal e diz respeito, sobretudo, ao estímulo ou às determinações para que pesquisadores disseminem os resultados de suas pesquisas em publicações de acesso aberto (via dourada) ou depositem tais publicações em repositórios (via verde). Mais que isso, prevê que autores retenham seus direitos de cópia e que estes sejam cedidos não exclusivamente à própria instituição (BAILEY, 2006; SUBER, 2010; GALE, 2011). Finalmente, a dimensão tecnológica requer que as iniciativas de acesso aberto acompanhem e se desenvolvam sob a luz da iniciativa de arquivos abertos, primando pelos padrões de interoperabilidade entre sistemas (CROW, 2002; HURD, 2004; COSTA, 2006; SUBER, 2010). Adicionalmente, há a adoção de software livre, que tem ocorrido amplamente em todo o mundo. Juntamente com outros aspectos, as dimensões do acesso aberto são levadas em 
consideração na constituição dos processos de gestão da informação científica digital, discutidas na próxima seção.

\subsection{Processos de gestão da informação científica digital}

Em razão dos desafios em lidar com o ambiente informacional de que fazem parte os institutos de pesquisa, a sistematização e o controle de fluxos de informação científica, que resulta das atividades de pesquisa e as alimenta, requerem o estabelecimento de processos de gestão da informação científica digital. Há, portanto, a necessidade de perspectiva processual, tal como identificado em outros modelos de gestão da informação (CHOO, 1998; DAVENPORT, 1998; DETLOR, 2009) e de comunicação científica (UNISIST, 1971; LANCASTER; SMITH, 1978; GARVEY; GRIFFITH, 1979; HILLS, 1983; MIKHAILOV et al., 1984; HURD, 1996, 2000, 2004; SØNDERGAARD et al., 2003; HOUGHTON et al., 2009). A principal característica da perspectiva processual da gestão da informação científica é sua constituição a partir de um conjunto de fases interconectadas, interdependentes e cíclicas.

Nesse contexto, a gestão da informação científica digital é formada por sete etapas, derivadas das análises da literatura e das entrevistas realizadas com pesquisadores. A primeira etapa é a de geração, que se realiza por meio dos relatos de resultados de pesquisa, os quais passam por processos editoriais responsáveis pela consolidação de publicações científicas. Trata-se de uma etapa constituinte - embora externa ao sistema -, que influencia diretamente sua gestão, pois, tanto o modo como se gera conhecimento em determinadas áreas quanto a negociação de direitos autorais com editoras no momento da publicação impactam as etapas. A segunda etapa é a coleta, que corresponde à aquisição dos recursos de informação científica necessários à realização da pesquisa, mas também resultante delas. Trata-se dos esforços empreendidos na captura da informação científica a ser gerenciada pelo sistema. A terceira etapa refere-se à organização, que corresponde ao desenvolvimento de processos e serviços de informação e à utilização de instrumentos de representação dos recursos de informação científica com vistas à sua posterior recuperação. A quarta etapa é a preservação, que diz respeito ao conjunto de atividades de cunho tecnológico e gerencial que contribuem para garantir o acesso permanente e por longo período à informação em suporte digital. A recuperação da informação corresponde à quinta etapa e trata do processo realizado a partir de interfaces de busca por meio das quais usuários elaboram estratégias de busca que resultam, inicialmente, na apresentação de registros de informação e, em seguida, no seu inteiro teor. A sexta etapa é a disseminação, atividade composta de mecanismos que fazem fluir amplamente recursos de informação científica e facilitam sua descoberta e uso, contribuindo tanto para novos ciclos de geração de conhecimento científico quanto para a visibilidade dos resultados de pesquisa, do pesquisador e da instituição. A última etapa é o uso da informação, o qual, como a geração, é etapa constituinte do sistema de gestão, embora externa a esse. Diz respeito ao consumo da 
informação manifesta na literatura científica de modo que novos conhecimentos possam ser gerados, estando, portanto, intimamente ligado à geração.

Como apontado na representação gráfica do modelo proposto (figura 4), destacados na cor verde, por serem concebidas sob a égide da perspectiva sistêmica da comunicação científica e do acesso aberto, todas as etapas da gestão da informação científica digital são diretamente influenciadas pelo ambiente externo aos institutos de pesquisa. Significa dizer que cada uma das etapas, desde a geração até o uso, é condicionada por forças externas decorrentes do modo como a comunidade científica se comporta em relação às atividades de produção, distribuição e uso do conhecimento científico. As influências que cada uma das etapas da gestão da informação científica digital sofre foram apontadas tanto pela literatura estudada quanto pela pesquisa de campo realizada e encontram-se detalhadamente descritas em Leite (2011). É importante frisar que os processos de coleta, organização, preservação, recuperação e disseminação são conduzidos a partir da implementação de repositórios institucionais (CROW, 2002; COSTA, 2006; SUBER, 2007), que consiste em uma das estratégias para operacionalizar o acesso aberto.

\subsection{Elementos flexíveis do modelo}

Além da influência direta da comunicação científica e do acesso aberto, a gestão da informação científica digital sofre, ainda, influência de um conjunto de elementos internos ao ambiente dos institutos de pesquisa. Tais elementos são partes flexíveis do modelo proposto, uma vez que variam em razão dos ambientes institucionais e das diferenças disciplinares, conforme indicaram os resultados da pesquisa. Os elementos flexíveis correspondem aos círculos na parte interna do instituto de pesquisa (figura 4) e estão definidos a seguir.

O primeiro elemento flexível é a infraestrutura organizacional, tecnológica, política e legal, que aglutina um conjunto de quesitos fundamentais para a gestão da informação científica digital. A infraestrutura organizacional presume a existência de uma estrutura organizacional responsável por atividades informacionais (UNISIST, 1971; FAIRER-WESSELS, 1997; SØNDERGAARD et al., 2003; DETLOR, 2009), normalmente reunidas em bibliotecas de pesquisa ou centros de documentação (LANCASTER; SMITH, 1978; SHEARER; BIRDSALL, 2002; BIRDSALL, 2005). A infraestrutura tecnológica reúne todos os aspectos inerentes à provisão da malha tecnológica (computadores e redes) necessária à implantação do modelo de gestão da informação científica digital (FAIRER-WESSELS, 1997; ROWLEY, 1998; CHOO, 1998; DETLOR, 2009). A infraestrutura política, por seu turno, encerra importante função na governança do sistema de gestão, pois contribui para legitimação institucional dos novos processos ou modificação de processos existentes, por meio de políticas institucionais de acesso aberto que tanto estimulam a publicação de pesquisa em periódicos de acesso aberto quanto 
requerem o depósito dessa produção em repositório institucional de acesso aberto (BAILEY, 2006; CARR et al., 2006; HARNAD, 2006; SUBER, 2010; GALE, 2011). A infraestrutura legal constitui importante condição viabilizadora - ou não - da prática da gestão da informação científica digital. A exigência de que pesquisadores publiquem em periódicos de prestígio publicados por editoras comerciais que exigem a cessão de direitos patrimoniais influencia diretamente o funcionamento do sistema de gestão da informação científica digital. É crucial, nesse contexto, a realização de três ações específicas. A primeira refere-se à conscientização, ao estímulo e à instrumentalização de pesquisadores para a negociação com editores dos direitos de cópia no momento de publicar. A segunda diz respeito à publicação em periódicos de acesso aberto. A terceira trata da adoção, por parte de instituições acadêmicas que publicam periódicos, de licenças e permissões que favoreçam sua livre circulação, como é o caso de algumas combinações de licenças Creative Commons ou similares (SUBER, 2010).

O segundo elemento flexível que influencia a gestão da informação científica digital é o acervo de informação científica institucional. A formação desse acervo baseia-se em dois critérios básicos: a informação necessária à pesquisa e a informação resultante de pesquisa (LANCASTER; SMITH, 1978; ROOSENDAAL; GEURTS, 1997; SHEARER; BIRDSALL, 2002; BIRDSALL, 2005). Bibliotecas e centros de documentação que atuavam principalmente no primeiro momento (UNISIST, 1971; SØNDERGAARD et al., 2003) enfrentavam dificuldade para reunir e permitir acesso à produção científica de autoria de pesquisadores de suas instituições. A emergência do acesso aberto trouxe a possibilidade de melhoria da gestão e da comunicação. No caso da gestão, promove maior e melhor acesso à literatura científica produzida externamente. No que concerne à comunicação, requer a possibilidade de as instituições reunirem, organizarem, armazenarem, preservarem, recuperarem e disseminarem, por meio de repositórios institucionais de acesso aberto, a informação científica que produzem e que é publicada em canais de comunicação científica distribuídos em todo o mundo (LAGOZE; VAN DE SOMPEL, 2001; BRODY et al., 2004; HURD, 2004; COSTA, 2006; JACOBS, 2006; WILLINSKY, 2006; BORGMAN, 2007; SUBER, 2007). Neste elemento flexível do modelo, o repositório institucional, destacado na cor verde, é um sistema de informação responsável pela gestão da informação científica digital cujos autores pertencem ao instituto de pesquisa.

O terceiro elemento flexível consiste nas diferenças disciplinares nos padrões de produção do conhecimento científico. Esse elemento diz respeito ao modo como pesquisadores conduzem suas atividades de pesquisa (KATZ; MARTIN, 1997; HOUGHTON et al., 2003; JAMALI; NICHOLAS, 2008; SWAN, 2008) e à influência que exercem sobre processos de gestão da informação científica. A satisfação de necessidades de informação de pesquisadores cujas atividades de investigação são interdisciplinares exige particularidades dos processos de coleta, recuperação e disseminação da informação científica (HOUGHTON et al., 2003), requerendo sistemas de informação com funcionalidades que permitam acomodar tais demandas. A colaboração, por sua vez, na medida em que envolve pesquisadores de outras áreas, instituições, regiões ou 
países, também influencia determinados processos de gestão da informação científica digital, pois impacta, por exemplo, a geração da informação, e esta, por seu turno, determina o tipo de autoria e as decisões de quando, onde, o que publicar e como disseminar.

Os últimos elementos flexíveis com significativo potencial de influência dizem respeito às diferenças disciplinares nas necessidades, na busca, no acesso, no uso e na disseminação da informação, que formam um conjunto relevante de aspectos a serem considerados na gestão da informação científica digital, pois tais comportamentos são influenciados pelos contextos de atuação dos pesquisadores (GARVEY; GRIFFITH, 1979; CHOO, 1998; DAVENPORT, 1998; ROWLEY, 1998; HURD, 2000; SHEARER; BIRDSALL, 2002; HOUGHTON et al., 2003; HUANG; CHANG, 2008; GORRAIZ et al., 2009). Confirmando esse entendimento, os levantamentos realizados permitiram constatar que físicos e cientistas sociais e humanistas comportam-se de modo distinto quando envolvidos em atividades informacionais. Tais diferenças influenciam diretamente o desenho e o funcionamento de sistemas de informação científica para diferentes áreas.

\subsection{Forças externas: elementos da comunidade científica}

Outro conjunto de elementos que influencia as atividades dos institutos de pesquisa como um todo, bem como os processos de gestão da informação científica digital, são as forças externas formadas por atores ou tendências que impactam as atividades previstas no modelo proposto, principalmente por este ser fundamentado na comunicação científica e no acesso aberto. São seis as forças externas derivadas tanto das entrevistas realizadas quanto de outros modelos identificados na literatura (MIKHAILOV et al., 1984; LAGOZE; VAN DE SOMPEL, 2001; SHEARER; BIRDSALL, 2002; BRODY et al., 2004; HURD, 2004; BIRDSALL, 2005; COSTA, 2006; JACOBS, 2006; WILLINSKY, 2006; BORGMAN, 2007; SUBER, 2007). Cada um dos elementos da comunidade científica e o modo como se relacionam são descritos a seguir.

Universidades e instituições de pesquisa produzem conhecimento e, por essa razão, utilizam informação, por isso são consideradas, ao mesmo tempo, produtoras e usuárias de informação. Comumente assumem papeis de colaboradoras ou competidoras em atividades de geração do conhecimento. Como tal, necessitam manter sistemas de gestão da informação, de modo que possam potencializar suas atividades, o que as torna dependentes umas das outras quando se tem em perspectiva a informação científica necessária à realização de pesquisa. Essa dinâmica revela a necessidade de redes de informação, as quais, para serem constituídas, dependem de acordos que perpassam ações estratégicas e operacionais. Além disso, modelos de gestão da informação científica implementados por determinadas instituições servem de benchmarking para outras. 
Sociedades científicas são entendidas como o agrupamento formal e representativo de pesquisadores que compartilham tópicos de estudo, desenvolvem pesquisas e se reúnem periodicamente, estimulando o compartilhamento de resultados de pesquisas entre pesquisadores. Sua influência sobre o modelo de gestão da informação científica digital reside principalmente no fato de que, além de representarem pesquisadores, catalisando suas aspirações, muitas vezes são responsáveis por publicações científicas, de acesso aberto ou restrito.

Editores científicos são os atores da comunidade científica que mais exercem influência sobre o modelo de gestão da informação científica digital, influenciando diretamente tanto o fluxo da informação que alimenta as atividades de pesquisa quanto o fluxo da informação que resulta de tais atividades. A produção de informação científica depende de processos editoriais, especialmente da avaliação por pares, para que possa se manifestar como literatura científica. Sua incorporação aos fluxos que alimentam as atividades de pesquisa e que resultam delas - na perspectiva do acesso aberto ou não - depende diretamente das funções exercidas por editores científicos, que são responsáveis pela consolidação dos resultados de pesquisa em informação científica. Nesse sentido, políticas editoriais estabelecidas para periódicos científicos são de grande influência, pois exercem influência nos processos compreendidos entre a produção e o uso da informação.

Avanços e desenvolvimentos relacionados com tecnologias de informação e comunicação desafiam a capacidade de reação e adaptação dos sistemas de gestão da informação científica. Além disso, trazem possibilidades e oportunidades de ampliação de funções, desde a geração até o uso da informação científica. De fato, observa-se com certa frequência o surgimento de novas funções, o compartilhamento ou eliminação de outras, assim como a modificação de processos. Por essa razão, as tecnologias de informação e comunicação constituem elemento externo de grande influência no sistema de gestão da informação científica digital, como proposto no modelo, devendo ser levadas em consideração em sua eventual implementação.

É possível que agências de fomento, juntamente com editores científicos, sejam os atores que mais concentram poder de influência sobre o funcionamento efetivo de um sistema de gestão da informação científica digital cuja configuração esteja alinhada com a comunicação científica e o acesso aberto. Em decorrência da função que exercem no sistema de comunicação científica, financiando atividades de pesquisa e participando do estabelecimento de políticas científicas, agências de fomento possuem a prerrogativa de requerer, por meio de mandatos, o depósito da produção científica resultante de pesquisas por elas financiadas em ambientes de acesso aberto, como são os repositórios institucionais. Mandatos de depósito são apontados como estratégias que impulsionam o povoamento de repositórios institucionais e constituem iniciativas frequentes na América do Norte e na Europa. 
Atores responsáveis pela formulação de políticas de informação científica, como é o caso dos formuladores de políticas dos parlamentos e das instituições que atuam no sistema de comunicação científica, constituem o último grupo considerado como de forte influência sobre o sistema de gestão da informação científica digital proposto. Resumidamente, políticas nacionais e institucionais de informação em ciência resultam da articulação entre formuladores de política e variáveis do contexto da produção, da distribuição e do uso da informação científica.

\subsection{Modelo proposto: versão gráfica e textual (proposição de teoria)}

A figura 4 ilustra, em versão gráfica, os elementos constitutivos do modelo de gestão da informação científica digital, definidos resumidamente nesta seção. Mais que isso, revela como estão relacionados tais elementos, na busca por representar a teoria embutida no modelo, que está descrita, em versão textual, em seguida à sua versão gráfica.

figura 4 - Elementos constitutivos do modelo de gestão da informação científica digital

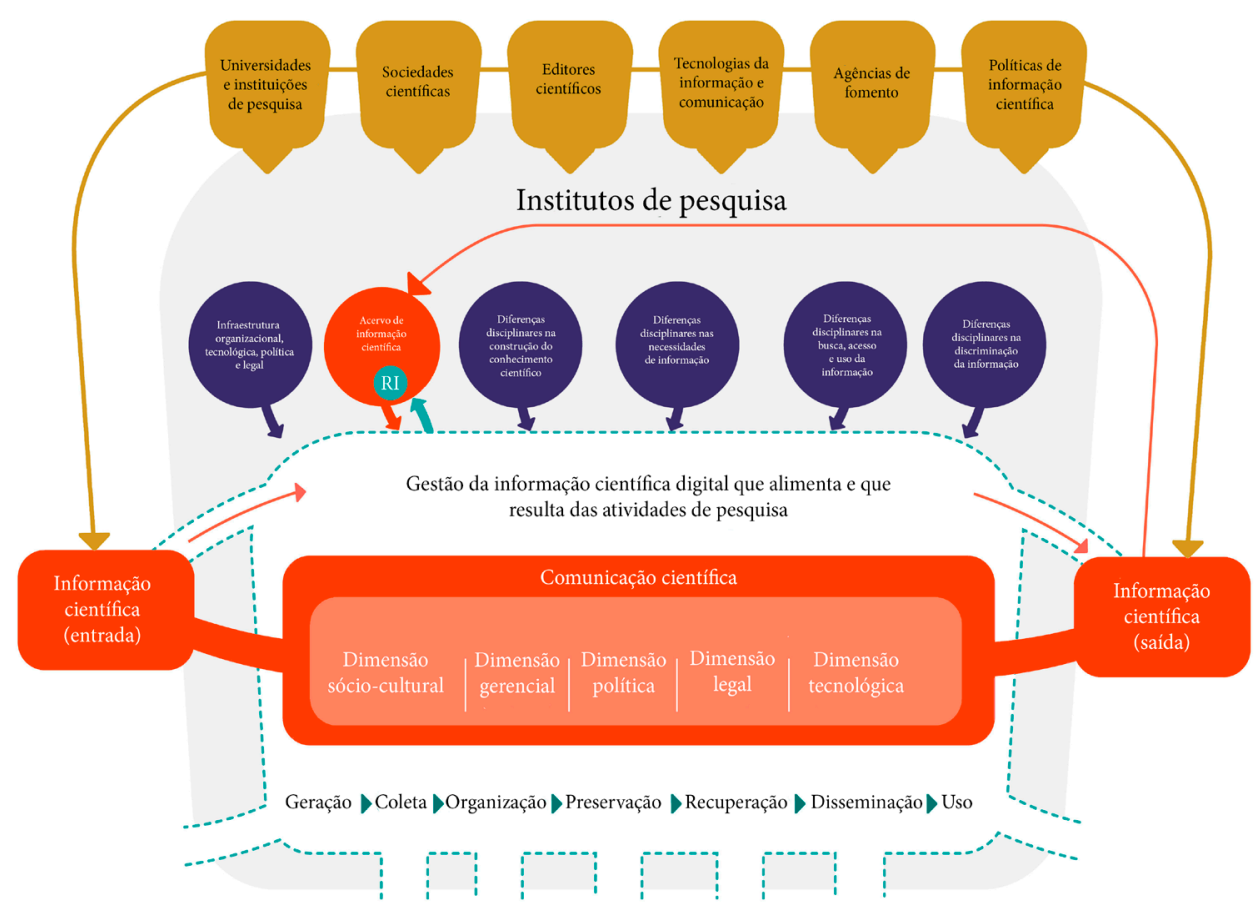

Fonte: Elaboração dos autores (2018). 
Como é possível observar, os elementos constitutivos do modelo conceitual de gestão da informação científica digital, proposto com base nos pressupostos da comunicação científica e do acesso aberto, baseiam-se em abordagem que considera a informação científica o principal ativo do sistema de comunicação científica, uma vez que serve, ao mesmo tempo, como insumo e como produto das atividades de pesquisa. Nesse sentido, a dinâmica do fluxo de entrada e saída da informação científica ocorre por meio do processo de comunicação entre pesquisadores, o qual, em razão de mudanças tecnológicas, sociais e políticas, não corresponde às demandas atuais da produção do conhecimento científico. A principal reação da comunidade científica aos obstáculos impostos ao fluxo da informação na ciência é a abordagem do acesso aberto, constituído das dimensões sociocultural, gerencial, política, legal e tecnológica. Tal condição tornou o processo de comunicação científica dependente de efetiva gestão da informação científica digital, que tanto alimenta a pesquisa quanto resulta dela. Dessa forma, a comunicação e a gestão da informação científica digital em institutos de pesquisa, como lócus relevante de produção do conhecimento científico, devem levar em conta dois grupos de fatores. O primeiro é constituído de aspectos internos, tais como infraestrutura tecnológica, organizacional, política e legal e diferenças disciplinares relacionadas a necessidades, busca, acesso, uso e disseminação da informação, bem como à produção de conhecimento. O segundo corresponde a aspectos externos, tais como atores da comunidade científica como um todo e grupos responsáveis pela geração de tecnologias e formulação de políticas de informação. Portanto, a teoria embutida no modelo proposto estabelece que, para a comunicação científica ser efetiva em institutos de pesquisa, são necessários processos de gestão da informação científica digital que levem em conta dimensões do acesso aberto, aspectos do ambiente informacional da instituição e fatores externos.

\section{CONCLUSÕES}

A comunicação rápida, adequada e eficiente de resultados de pesquisas, transformados em informação científica, influencia diretamente o desempenho de institutos de pesquisa, um dos atores que têm na geração de novos conhecimentos científicos sua principal função. Quanto mais rápida e completa for a informação científica necessária às atividades de pesquisadores, mais produtos científicos eles gerarão, e a custos menores.

Os inúmeros desafios colocados no cenário informacional em que se inserem os institutos de pesquisa requerem modelo de gestão da informação científica que tenha por base a comunicação científica e o acesso aberto. Tal condição os permite responder de modo efetivo demandas emergentes de acesso, circulação e uso da informação científica. 
A intersecção de aspectos da gestão da informação, da comunicação científica e do acesso aberto à informação científica é a solução para as demandas atuais do sistema de comunicação científica. Isso porque nenhuma dessas perspectivas dispõe, isoladamente, de instrumental teórico e metodológico para tratar dos problemas informacionais nos dias atuais.

O modelo proposto neste trabalho representa avanço no reconhecimento de como tais fenômenos podem ser observados e explicados. Mais que isso, constitui conjunto robusto de diretrizes norteadoras para a implementação da gestão da informação científica integrada à comunicação científica e ao acesso aberto. Tem perspectiva genérica, uma vez que seu delineamento considera elementos gerais e necessários a qualquer modelo de gestão da informação científica. Adicionalmente, sua constituição leva em conta elementos flexíveis que acomodam possíveis diferenças contextuais, as quais variam de instituto para instituto ou de instituição para instituição, como no caso das universidades. Fatores externos aos institutos de pesquisa influenciam seus processos tanto de comunicação científica quanto de gestão da informação digital.

\section{REFERÊNCIAS}

BAILEY JR ,Charles. What is open access. In: JACOBS, N. (Ed.) Open Access: key strategic, technical and economic aspects. Oxford: Chandos Publishing, 2006.

BIRDSALL, W. F. Towards an integrated knowledge ecosystem: a Canadian research strategy. Report submitted to the Canadian Association of Research Libraries / L'Association des bibliothèques de recherche du Canada (CARL/ABRC), 2005.

BORGMAN, C. L. Scholarship in the digital age: information, infrastructure, and the internet. Cambridge, Londres: MIT Press, 2007. 336 p.

BRODY, T. et al. The effect of open access on citation impact. In: National Policies on Open Access (OA) Provision for University Research Output: an International meeting. Southampton University, Southampton UK, 2004.

CARR, L. et al. Repositories for institutional open access: mandated deposit policies. 2006.

$\mathrm{CHOO}, \mathrm{C} . \mathrm{W}$. Information management for the intelligent organization: the art of scanning the environment. 2. ed. Medford: ASIS/Information Today, 1998. 272 p. 
COSTA, S. Filosofia aberta, modelos de negócios e agências de fomento: elementos essenciais a uma discussão sobre o Acesso Livre à informação científica. Ciência da Informação, v. 35, n. 2, p. 39-50, 2006.

CROW, R. The case for institutional repositories: a SPARC position paper. ARL Bimonthly Report, n. 223, 2002.

DAVENPORT, T. Ecologia da Informação: por que só a tecnologia não basta para o sucesso na era da informação. São Paulo: Futura, 1998.

DECLARAÇÃO DE BERLIN. Conference on Open Access to Knowledge in the Sciences and Humanities, Berlin, Outubro, 2003.

DETLOR, B. Information management. International Journal of Information Management, v. 30, n. 2, p. 103-108, 2009.

DIENER, R. A. V. Strategic, analytic and operational domains of information management. Bulletin of the American Society for Information Science, v. 19, n. 1, p. 18-19, 1992.

FAIRER-WESSELS, F. A. Information management education: towards a holistic perspective. South African Journal of Library and Information Science, v. 65, n. 2, p. 93-102, 1997.

GALE, M. Survey of University of Toronto faculty awareness, attitudes, and practices regarding scholarly communication: a preliminary report. 2011.

GARVEY, W. D.; GRIFFITH, B. C. Communication and information process within scientific disciplines, empirical findings for psychology. In: GARVEY, W. D. Communication: the essence of science: facilitating information among librarians, scientists, engineers and students. Oxford: Pergamon, 1979, p.127-147.

GOFFMAN, W.; WARREN, K. S. Scientific information systems and the principle of selectivity. New York: Praeger, 1980. 189 p.

GORRAIZ, J. et al. International publication output and research impact in social sciences: comparison of the Universities of Vienna, Zurich and Oslo. Research Evaluation, v. 18, n. 3, 2009, p. 221-232.

HARIDASAN, S.; KHAN, M. Impact and use of e-resources by social scientists in National Social Science Documentation Centre (NASSDOC), India. The Electronic Library, v. 27, n. 1, 2009, p. 117-133. 
HARNAD, S. Optimizing OA self-archiving mandates: what? where? when? why? how? Technical Report, ECS, University of Southampton, 2006.

HINE, C. M. (Ed.). New infrastructure for knowledge production: understanding e-science. Hershey: Information Science Publishing, 2006. 286 p.

HOUGHTON, H. W.; STEELE, C.; HENTY, M. Changing research practices in the digital information and communication environment. Canberra: Department of Education, Science and Training, 2003. $186 \mathrm{p}$.

HOUGHTON, J. et al. Economic implications of alternative scholarly publishing models: exploring the costs and benefits. JISC EI-ASPM project. A report to the joint information systems committee (JISC). London: JISC, 2009. 256 p.

HUANG, M.; CHANG, Y. Characteristics of research output in social sciences and humanities: from a research evaluation perspective. Journal of the American Society for Information Science and Technology, v. 59, n. 11, 2008, p. 1819-1828

HURD, J. M. Models of scientific communication systems. In: CRAWFORD, S. Y.; HURD, H. M.; HURD, J. M. Scientific communication: new roles and new players. Science \& Technology Libraries, v. 25, n. 1, 2004, p. 5-22.

HURD, J. M. The transformation of scientific communication: a model for 2020. Journal of the American Society for Information Science, v. 51, n. 14, 2000, p. 1279-1283.

HURD, J. M. Models of Scientific Communication Systems. In: CRAWFORD, S. W., HURD, J. M., WELLER, A. C. From print to electronic: the transformation of scientific communication. Medford: Information Today, 1996, 117 p.

JACOBS, N. (Ed.). Open access: key strategic, technical and economic aspects. Chandos Publishing: Oxford, 2006.

JAEGER, P. T. et al. Information management. Encyclopedia of Social Measurement, v. 2, 2005.

JAMALI, H. R.; NICHOLAS, D. Information-seeking behavior of physicists and astronomers. Aslib Proceedings: New Information Perspectives, v. 60, n. 5, 2008, p. 444-462.

KATZ, J. S.; MARTIN, B. R. What is research collaboration? Research Policy, v. 26, 1997. 
LAGOZE, C.; VAN DE SOMPEL, H. The open archives initiative: building a low-barrier interoperability framework. In: ACM/IEEE Joint Conference on Digital Libraries, Roanoke, Virginia, 2001, p. 54-62, 2001.

LANCASTER, F. W.; SMITH, L. C. Science, scholarship and the communication of knowledge. Library Trends, v. 27, n. 3, p. 367-387, 1978.

LEITE, F. C. L. Modelo genérico de gestão da informação científica para instituições de pesquisa na perspectiva da comunicação científica e do acesso aberto. 2011. $262 \mathrm{f}$. Tese (Doutorado) - Doutorado em Ciência da Informação, Faculdade de Ciência da Informação, Universidade de Brasília, Brasília, 2011.

MARON, N. L.; SMITH, K. K. Current models of digital scholarly communication. Washington, DC: Association of Research Libraries, 2008. 49 p.

MEADOWS, A. J. A comunicação científica. Brasília: Briquet de Lemos, 1999. 268p.

MIDDLETON, M. R. Information management: a consolidation of operations analysis and strategy. WaggaWagga: Charles Sturt University, 2002. 526 p.

MIKHAILOV, A. I, et al. Scientific communications and informatics. Arlington: Information Resources, 1984. 402 p.

OLSON, G. M., et al. (Ed.). Scientific collaboration on the internet. Cambridge: MIT Press, 2008. $406 \mathrm{p}$.

ROWLEY, J. Towards a framework for information management. International Journal of Information Management, v. 8, n. 5, p. 359-369, 1998.

SHEARER, K.; BIRDSALL, B. The transition of scholarly communication in Canada. 2002.

SØNDERGAARD, T. F. et al. Documents and the communication of scientific and scholarly information: revising and updating the UNISIST model. Journal of Documentation, v. 59, n. 3, p. 278-320, 2003.

SUBER, P. Open access overview: focusing on open access to peer-reviewed research articles and their preprints. 2010 .

SUBER, P. Timeline of the Open Access Movement. 2007. 
SWAN, A. Journal authors survey: report. Cornwall: Key Perspectives, 2004. 77 p.

SWAN, A. Key concerns within the scholarly communication process: report to the JISC Scholarly Communications Group. Truro: Key Perspectives Ltd, 2008. 65 p.

SWAN, A. The culture of open access: researchers' views and responses. In: JACOBS, N. (Ed.) Open access: Key strategic, technical and economic aspects. Oxford: Chandos, 2006.

SWAN, A.; BROWN, S. Authors and open access publishing. Learned Publishing, v. 17, 2004, p. 219-224.

SWAN, A.; BROWN, S. Open access self-archiving: an author study. Cornwall: Key Perspectives, 2005. $97 \mathrm{p}$.

UNISIST. Study report on the feasibility of a world science information system. Paris: UNESCO, 1971. 161 p.

VICKERS, P. Information management: selling a concept. In: CRONIN, B. Information management: from strategies to action. P. 151.160, 1995.

WHITE, M. Intelligence management. In: CRONIN, B. (Ed.). Information management: from strategies to action. Londres: Aslib, 1985. p. 21-35.

WILLINSKY, J. The access principle: the case for open access to research and scholarship. Massachusetts: MIT Press, 2006. 287 p.

WILSON, T. D. Information management. In: FEATHER, J.; STURGES, P. (Eds.). International Encyclopedia of Information and Library Science. Londres: Routleg, 2002. 


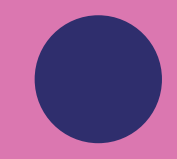

○

○

-

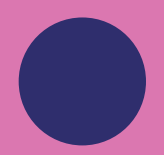

-

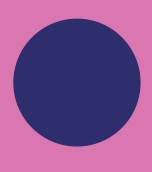

○

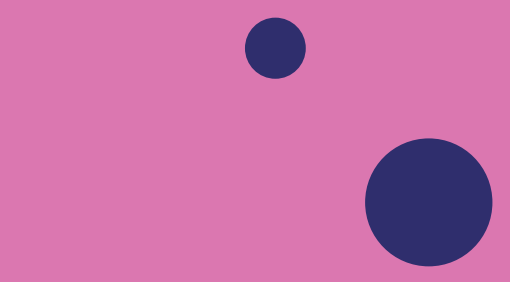

○

○

- 0

○
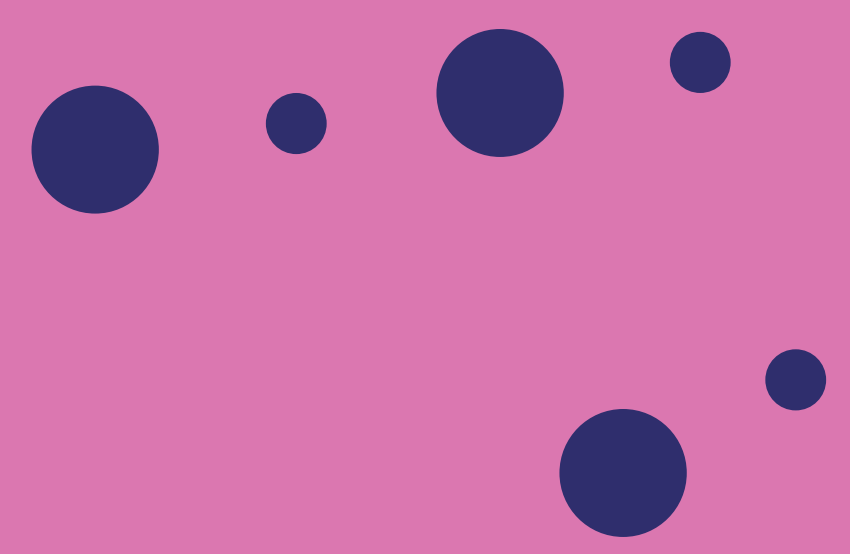


\section{CAPÍTULO 15}

0

O
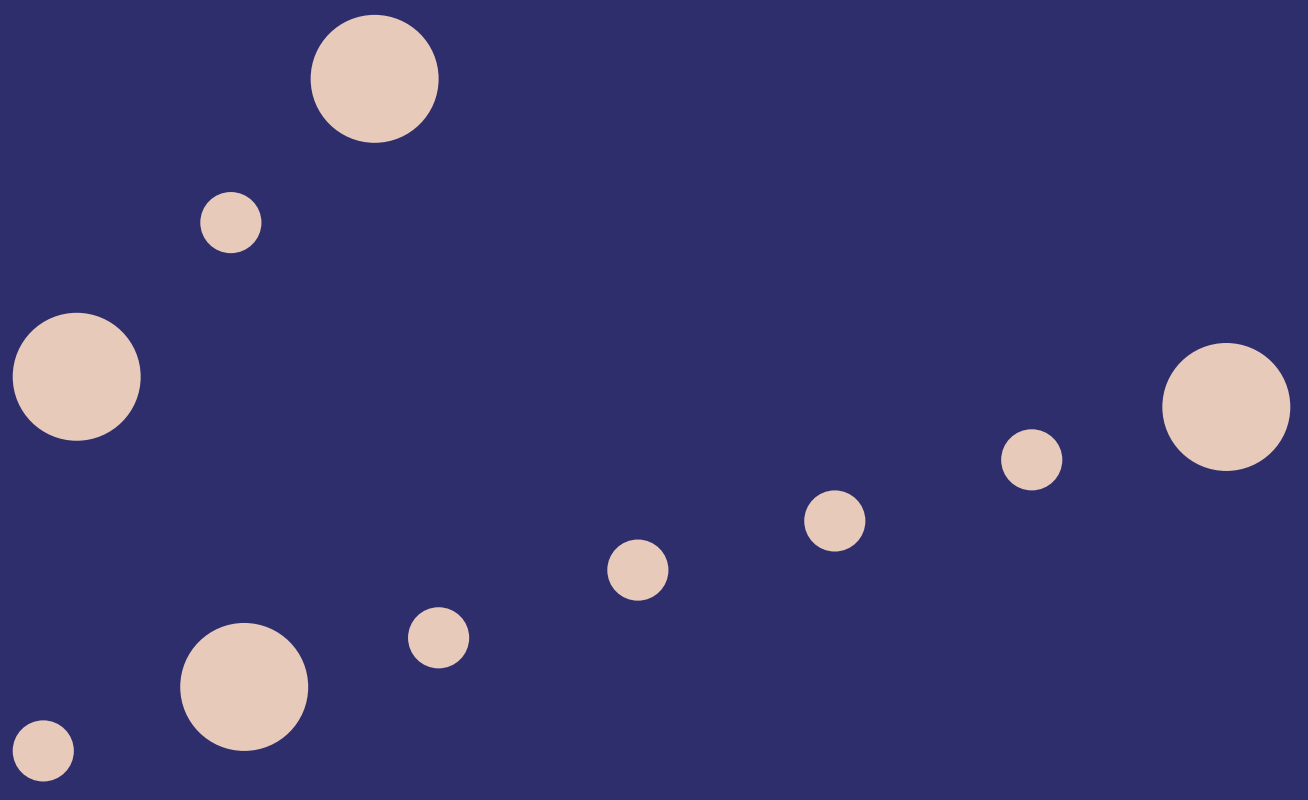

- 00

0 


\title{
PORTAIS CORPORATIVOS COMO FERRAMENTAS DE COMUNICAÇÃO E GESTÃO DO CONHECIMENTO
}

\author{
$\square$ \\ ANDERSON BARROS TORRES \\ SELY MARIA DE SOUZA COSTA
}

\section{INTRODUÇÃ̃O}

Estudos organizacionais têm sido conduzidos a partir de um variado número de abordagens, majoritariamente no âmbito de ciências organizacionais, como a Administração. A abordagem sistêmica, desde o seu surgimento na década de 1960, tem sido adotada de modo crescente nos estudos das organizações, levando em conta que essas podem ser analisadas como sistemas. Outras disciplinas, como a Comunicação, dependendo do problema em estudo, têm, igualmente, contribuído para as discussões das questões organizacionais. Nesse contexto, o presente estudo adotou uma abordagem híbrida, na medida em que lançou mão de questões observadas no âmbito de diferentes disciplinas.

No contexto do presente estudo, objetivou-se comparar as dimensões informal e formal nas organizações. Adicionalmente, no âmbito da organização estudada, a dimensão formal foi percebida como extremamente hierárquica e burocrática, e o fluxo da informação é baseado nas necessidades formalmente determinadas pela organização. No que concerne à dimensão informal, a informação flui no intuito de atender necessidades dos indivíduos, tendo sido observadas questões inerentes à formação de grupos e à cultura organizacional, uma vez que constituem fatores determinantes da comunicação organizacional.

É importante ressaltar que estudos acerca do processo de comunicação no contexto organizacional revelam que o fluxo e o compartilhamento de informação em uma organização estão diretamente relacionados com a estrutura e a cultura organizacionais. A cultura, por sua vez, permeia as ações e decisões das pessoas inseridas na estrutura. Desse modo, é possível inferir que o sucesso de projetos de gestão do conhecimento depende de aspectos comunicacionais, os quais, no entanto, podem tanto facilitar quanto dificultar sua implementação. 
No que concerne à gestão do conhecimento, é de extrema importância que as organizações promovam um ambiente informacional integrado e interdependente, que agregue os subsistemas sociais, culturais e políticos a fim de conduzir a criação, o fluxo e o uso da informação. Espera-se, com isso, chegar ao aprendizado organizacional, o qual implica não só mudança de pensamento, mas também mudança de atitude por parte dos integrantes da organização, e a tecnologia da informação (TI) constitui uma importante ferramenta para auxiliar no processo de criação desse ambiente.

De fato, a partir do estudo da TI verificou-se que o surgimento da internet e, posteriormente, da web trouxe uma série de facilidades para a comunicação entre pontos distintos, tornando-se atraente para as organizações e especialmente útil à gestão da informação e do conhecimento. Nesse sentido, a intranet apresentava uma série de facilidades para a comunicação no ambiente organizacional estudado, mas de forma fragmentada. Acredita-se, portanto, que o portal corporativo constitui um concentrador de tais facilidades, proporcionando um ambiente informacional integrado para o gerenciamento do conhecimento organizacional.

\section{MARCO TEÓRICO-METODOLÓGICO DO ESTUDO}

A abordagem de portais como ferramenta tecnológica surgiu durante o ano de 1998, e esses têm a característica principal de personalizar conteúdos (FRINKELSTEIN, 2003). Segundo o autor, o termo "portal" foi usado para organizações pela primeira vez em um relatório da empresa Merrill Lynch, no qual se identifica o termo Portal de Informação Empresarial (EIP, do inglês Enterprise Information Portal). De acordo com Bolds (2001), portais corporativos possuem características e funcionalidades básicas (Quadro 1), associadas ao benefício trazido para a organização.

Quadro 1 - Características básicas dos portais e seus benefícios

\begin{tabular}{|c|c|}
\hline CARACTERÍSTICAS/FUNCIONALIDADES & BENEFÍCIOS \\
\hline Busca & $\begin{array}{c}\text { Acesso rápido à informação oculta para facilitar os } \\
\text { procedimentos na organização }\end{array}$ \\
\hline Categorização & $\begin{array}{c}\text { Capacidade de organizar as informações por negócio, } \\
\text { grupo ou tarefa, promovendo o acesso à informação } \\
\text { relevante }\end{array}$ \\
\hline Consulta, relatório e análise & $\begin{array}{c}\text { Melhor suporte à decisão, bem como disseminação e } \\
\text { compartilhamento da informação }\end{array}$ \\
\hline Integração da informação e aplicações & $\begin{array}{c}\text { Possibilidade de acessar, por meio de uma única } \\
\text { interface, todas as informações e aplicações necessárias } \\
\text { para aumentar o rendimento do trabalho }\end{array}$ \\
\hline
\end{tabular}




\begin{tabular}{|c|c|}
\hline CARACTERÍSTICAS/FUNCIONALIDADES & BENEFÍCIOS \\
\hline Compartilhamento & $\begin{array}{c}\text { Amadurecimento dos processos organizacionais, pela } \\
\text { colaboração com outras pessoas e o compartilhamento } \\
\text { de informaços, melhorando a performance } \\
\text { organizacional }\end{array}$ \\
\hline Personalização & $\begin{array}{c}\text { Organização da interface para reunir as informações } \\
\text { necessárias e desejáveis para cada pessoa, melhorando a } \\
\text { produtividade }\end{array}$ \\
\hline
\end{tabular}

Fonte: Bolds (2001).

Sharpe et al. (2001) resumem a importância dos portais corporativos ao afirmarem que eles constituem a principal forma de se obter colaboração entre as pessoas, o que é, na verdade, um pré-requisito para o sucesso da gestão do conhecimento organizacional. Os autores afirmam, ainda, que, em sua forma ideal, portais corporativos podem funcionar como uma interface comum para ajudar as pessoas a lidarem com a grande variedade de recursos e serviços oferecidos por meio da rede corporativa. Portanto, conforme ilustrado na figura 1, portais corporativos reúnem, em um só local, conteúdos formalizados de maneira que as informações possam ser reutilizadas. Mais que isso, são mecanismos para a comunicação entre as pessoas para troca de informações e para criação de comunidades virtuais, onde podem colaborar para a solução de um determinado problema por meio do compartilhamento de conhecimento tácito. 
Figura 1 - Portal corporativo como um espaço para conteúdo, comunicação e compartilhamento

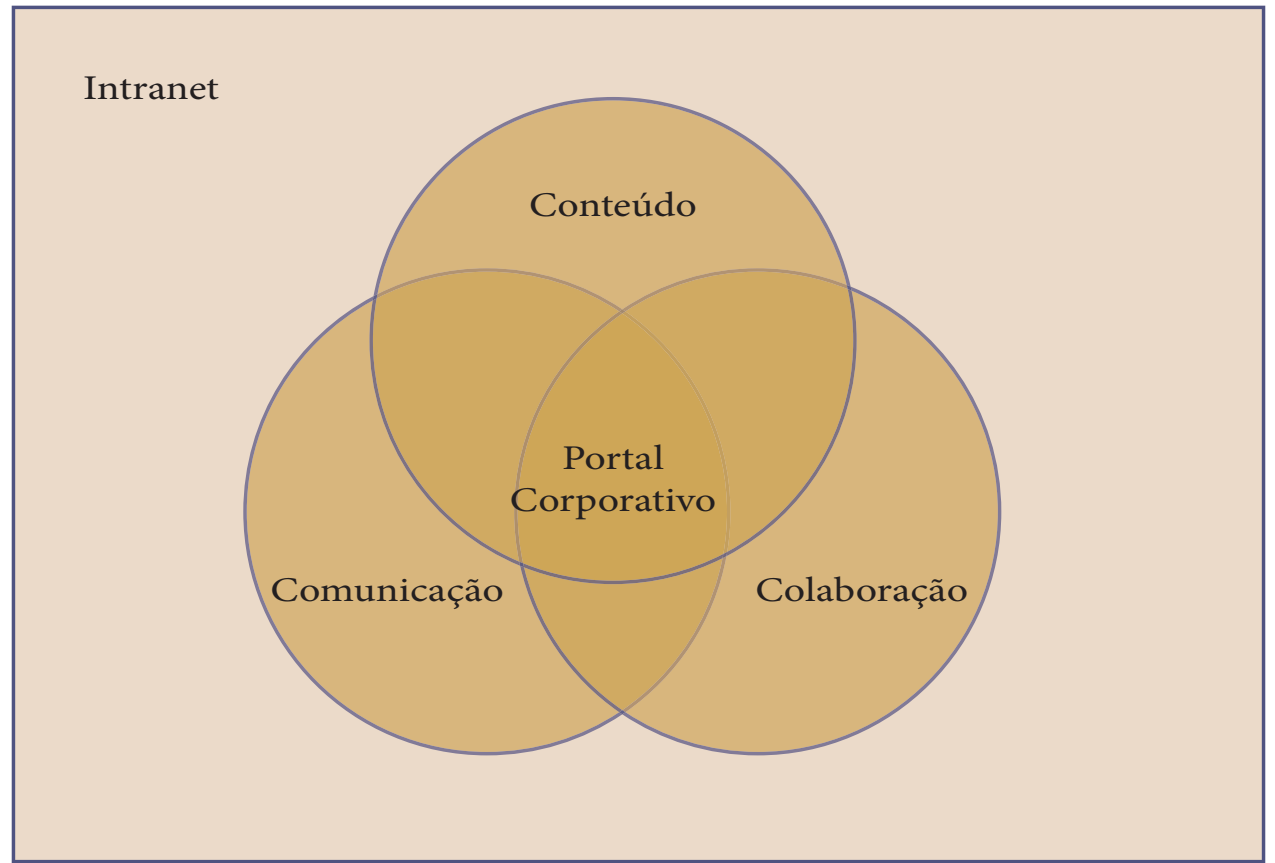

Fonte: Adaptado de Choo (1998).

Nessa perspectiva, a construção do referencial teórico do estudo visou a validar - ou não - o pressuposto de que portais corporativos reúnem as características necessárias à gestão do conhecimento e à comunicação organizacional, conforme ilustra a figura 2. Mais que isso, a construção desse referencial teórico visou a nortear a realização da pesquisa, ou seja, o ângulo pelo qual o problema da audiência do portal corporativo seria estudado. 
Figura 2 - Influência da tecnologia da informação na comunicação organizacional e na gestão do conhecimento

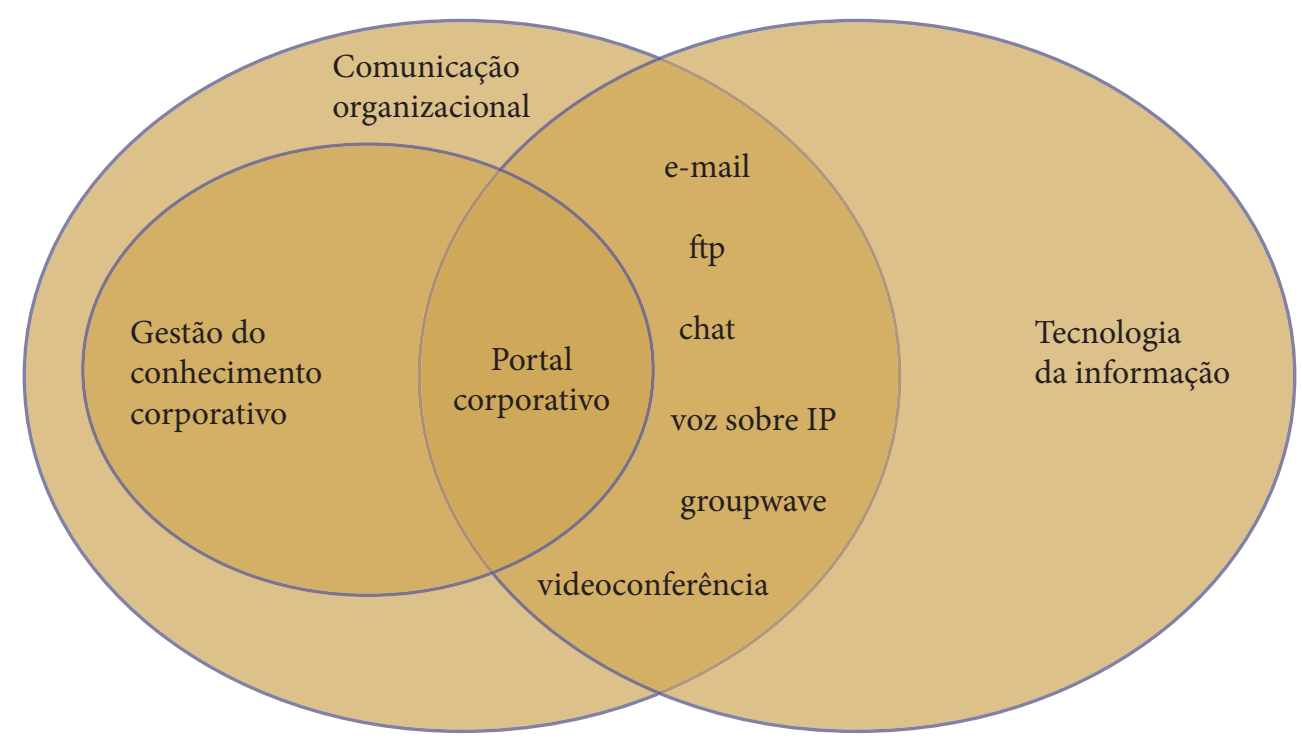

Fonte: Torres (2004).

\section{METODOLOGIA}

Uma vez definido como o problema organizacional objeto do presente estudo deveria ser observado, tornou-se necessário, com base em suas características, escolher a metodologia a ser empregada. Pelo fato de se ter optado pela utilização de enfoque sistêmico na condução do estudo, a Metodologia de Sistemas Flexíveis (SSM, do inglês Soft Systems Methodology), de Checkland (1993), foi considerada a melhor alternativa. Isso porque trata de problemas que, no contexto das organizações, podem ser caracterizados como sistemas de atividade humana ${ }^{1}$, o que implica dizer que não se trata de um simples problema, mas de uma situação-problema² . Desse modo, é possível identificar e observar o comportamento de cada subsistema e como esse subsistema influencia o "todo".

1 O sistema de atividade humana é um sistema nocional. Diz respeito a como os analistas veem e mapeiam o que as pessoas dizem.

2 Conjunto de problemas altamente inter-relacionados, não podendo ser isolados e analisados separadamente. Mais tarde, os autores optaram pelo termo "situação problemática" (Checkland, 1993). 
A SSM, tendo como base a pesquisa-ação, ofereceu as possibilidades necessárias para a identificação de três questões fundamentais da organização estudada. A primeira constitui uma das principais preocupações e conflitos existentes entre os atores do sistema. A segunda diz respeito às restrições impostas pelo ambiente onde o problema está inserido. Finalmente, a terceira está relacionada às mudanças sistemicamente desejadas e culturalmente viáveis para que a situação-problema seja amenizada ou eliminada.

É importante chamar a atenção para características da SSM. Primeiramente, trata-se de uma metodologia aplicável ao estudo de problemas organizacionais. Em segundo lugar, fundamenta-se na abordagem sistêmica, requerendo, portanto, que os problemas estudados possam ser descritos como um sistema. Por fim, ao adotar o método da pesquisa-ação, a SSM requer o envolvimento do pesquisador nas questões organizacionais envolvidas. Permite, portanto, estudar a organização, coletar dados em seu ambiente e intervir nele, obtendo informações que permitam trabalhar tanto de modo interativo quanto, e principalmente, 
iterativo. Para tal, Checkland propõe a utilização da metodologia em até sete estágios ${ }^{3}$, tal como ilustrado na figura 3.

Figura 3 - Modelo da Metodologia de Sistemas Flexíveis (SSM)

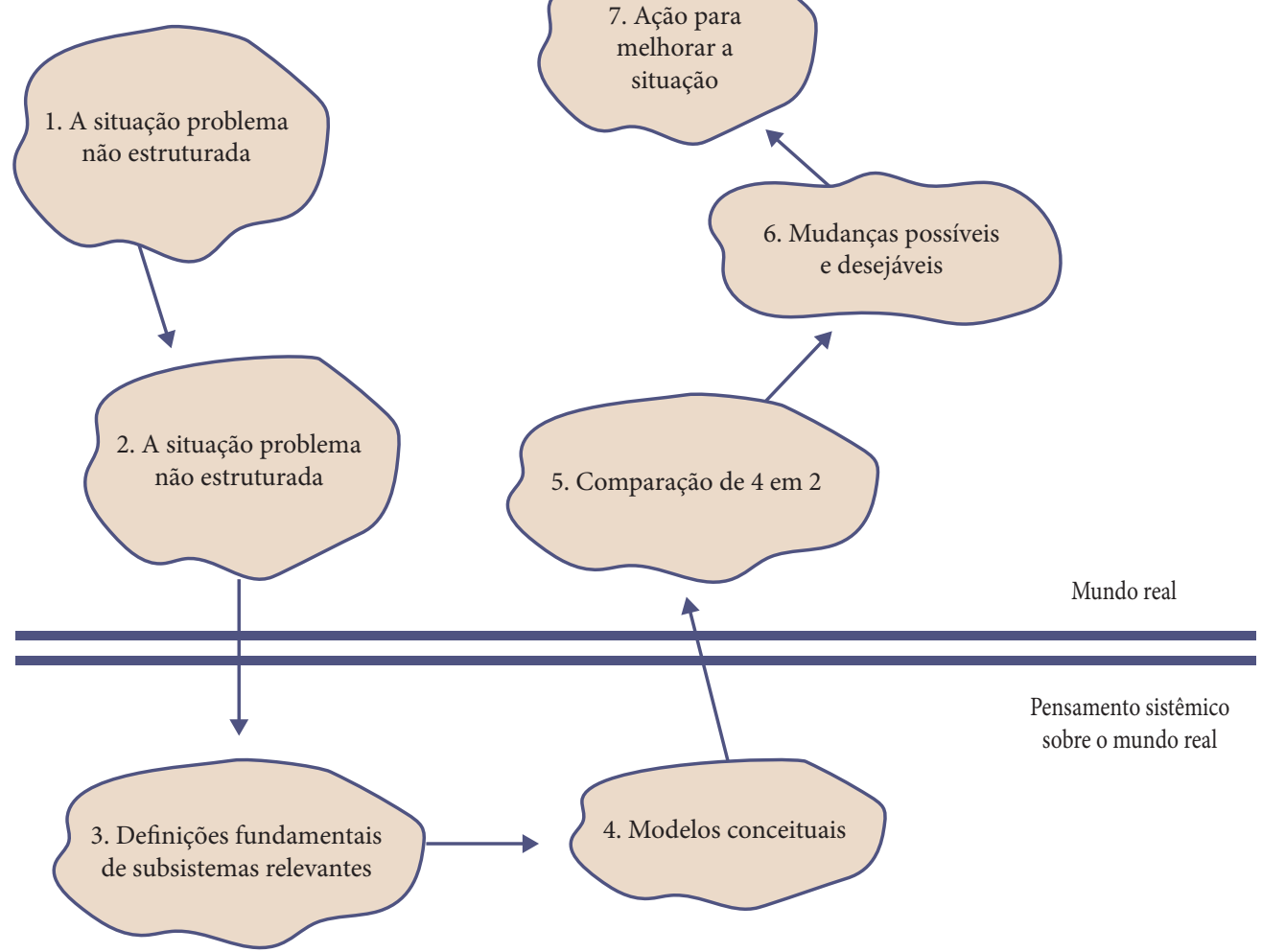

Fonte: Elaboração dos autores (2018).

O pressuposto que fundamentou o presente estudo foi o de que a audiência do portal corporativo não possuía a qualidade ${ }^{4}$ desejada por seus idealizadores. Para validação desse pressuposto, procedeu-se, inicialmente, à análise documental dos registros de acesso à internet/intranet pelos membros da organização.

3 É importante observar que, embora a SSM tenha sido definida em sete estágios iterativos, é possível utilizar somente um ou mais, dependendo do objetivo que se quer atingir.

4 O termo qualidade, neste trabalho, é usado para mensurar a relação entre a quantidade de acessos e o tempo de acesso aos diferentes sítios disponíveis na internet/intranet. Uma baixa qualidade, nesse caso, está relacionada a uma maior discrepância entre a quantidade de acesso e o tempo. 
A percepção da situação-problema, portanto, deu-se, primeiramente, a partir da análise documental, quando foram obtidos dados sobre as reais proporções da qualidade da audiência do portal corporativo. A partir desse conhecimento, foi possível direcionar a observação e subsidiar a construção do roteiro de entrevistas necessárias à definição da situação-problema e de como abordá-la, defini-la e tratá-la. Desse modo, a coleta de dados para esta pesquisa, correspondente às etapas 1 e 2 da SSM, está orientada conforme mostra a figura 4 .

Figura 4 - Etapas da coleta de dados do estudo, orientada pela abordagem da SSM

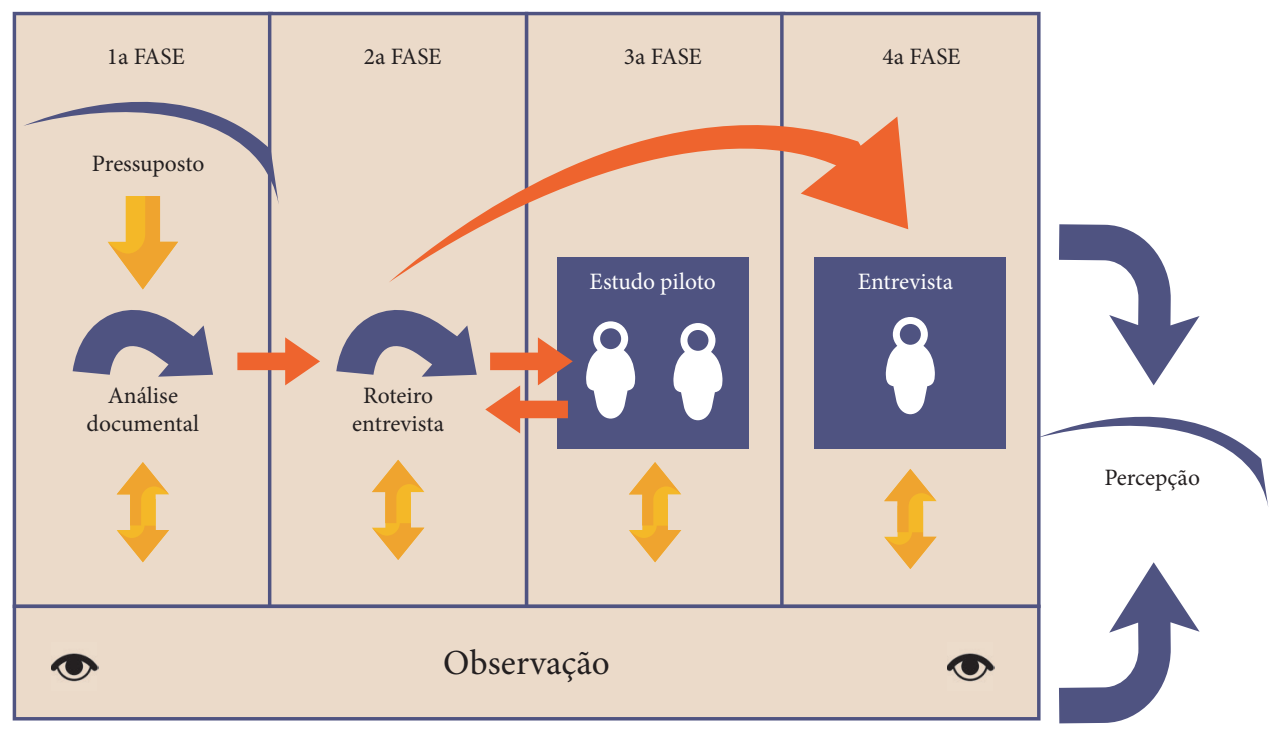

Fonte: Elaboração dos autores (2018).

Em suma, considerando que o problema organizacional de interesse desta pesquisa pode ser definido com base na abordagem da SSM, foi possível considerá-lo como, de fato, uma situação-problema. Para melhor conhecimento e identificação de como tratá-lo, foram seguidas, portanto, as recomendações da metodologia proposta por Checkland, como pode ser observado na seção a seguir.

\section{ANÁLISE DOS DADOS A PARTIR DA SSM}

A análise dos dados se inicia com uma breve descrição das características da organização estudada. Em seguida, com base na abordagem da SSM, são analisadas as questões relacionadas com os estágios da metodologia. O primeiro estágio é a descrição da situação-problema não estruturada, ilustrada no que os autores da SSM nomeiam como rich picture. Essa, por sua vez, ilustra questões estruturais, correspondendo à visão dos principais atores e elementos 
do ambiente externo à organização que impõem restrições ao sistema. Em seguida, ocorre a descrição de definições fundamentais (root definitions), as quais constituirão o sistema responsável pelas transformações necessárias na situação-problema e em seus subsistemas (quando for o caso). Em seguida, é apresentado o modelo conceitual de cada etapa a ser implementada pela transformação proposta e, finalmente, as ações sistemicamente desejáveis e culturalmente viáveis de ser implementadas.

\subsection{Caracterização da organização}

A organização na qual está inserido o departamento objeto deste estudo possui um histórico secular e mantém suas tradições e valores quase imutáveis ao longo de sua existência. Com isso, sua natureza extremamente conservadora permanece inalterada. Sua estrutura permanece engessada, muito rígida e com forte orientação vertical, tendo a hierarquia como principal pilar de sustentação.

Com isso, a comunicação entre as diversas unidades é extremamente burocrática, o que resulta na existência de uma comunicação lateral, mas em caráter sempre informal. A comunicação formal é estimulada e muitas vezes exigida como forma de resguardar as pessoas das consequências sobre ações tomadas, não tomadas ou executadas de forma errônea. Portanto, a comunicação formal hierarquicamente horizontal é de extrema importância para o funcionamento do departamento e de suas seções. Faz-se necessário ressaltar, no entanto, que, nesse caso, a comunicação formal não se restringe aos documentos impressos. Dependendo do emissor, a mensagem, mesmo que verbal, tem valor igual ao da comunicação escrita.

$\mathrm{Na}$ estrutura geral da organização como um todo, as pessoas estão divididas em três níveis: gerencial, intermediário e de execução. Características observadas na cultura organizacional mostram forte rivalidade entre os três níveis, em razão de diferenças de oportunidades de ascensão, de capacitação e de treinamento, além de questões de desvio de função. No entanto, no departamento estudado, por ser pequeno e de característica eminentemente técnica, a diferença entre os níveis da hierarquia é reduzida ao mínimo necessário para o andamento do serviço.

\subsection{A situação-problema não estruturada}

$\mathrm{Na}$ instituição como um todo existe alta rotatividade de pessoas, entre os diversos departamentos e também entre as diversas funções. Assim, transferências entre departamentos muitas vezes exigem troca de função e necessidade de novo aprendizado. Tal situação provoca perda de conhecimento organizacional, o que levou à iniciativa de criar o que se chamou de Procedimentos Padrão (PP), que consistem no mapeamento de processos, na tentativa de 
se adotar um programa de qualidade total. Apesar de a ideia ter sido útil para a criação de memória organizacional, não permaneceu em funcionamento por muito tempo.

Esse quadro levou ao desenvolvimento de um portal corporativo como forma de fornecer um único ponto de acesso e melhorar a transferência de informações entre as pessoas. A audiência do portal, em número de acessos, era superior ao de qualquer outro sítio. No entanto, sua análise mais profunda revelou que os acessos eram muito rápidos (em torno de quatro segundos, em média), revelando pouca utilização. Esses dados foram coletados por meio da análise do arquivo de $\log ^{5}$ do sistema que monitora a rede, por 45 dias, de segunda a sexta-feira, das $9 \mathrm{~h}$ às $12 \mathrm{~h}$ e das $14 \mathrm{~h}$ às $17 \mathrm{~h}$. $\mathrm{O}$ Quadro 2 traz o resultado dessa coleta.

Quadro 2 - Visão geral do acesso à internet/intranet

\begin{tabular}{|c|c|c|c|c|}
\hline & \multicolumn{2}{|c|}{ ACESSOS } & \multicolumn{2}{|c|}{ TEMPO } \\
\hline & CLIQUES & \% DO TOTAL & HORAS & \% DO TOTAL \\
\hline ABC-NET & 34.952 & $10,61 \%$ & $10: 59: 52$ & $2,24 \%$ \\
\hline $\begin{array}{c}\text { CONTEÚDO } \\
\text { ADULTO }\end{array}$ & 27.590 & $8,38 \%$ & $23: 59: 46$ & $4,89 \%$ \\
\hline $\begin{array}{c}\text { PORTAL } \\
\text { CORPORATIVO } \\
\text { - XYZ }\end{array}$ & 43.751 & $13,28 \%$ & 03:04:58 & $0,63 \%$ \\
\hline RELIGIÃO & 1.892 & $0,57 \%$ & $04: 35: 14$ & $0,94 \%$ \\
\hline $\begin{array}{c}\text { MECANISMOS DE } \\
\text { BUSCA }\end{array}$ & 8.180 & $2,48 \%$ & $17: 49: 01$ & $3,63 \%$ \\
\hline ENSINO & 5.720 & $1,74 \%$ & $15: 02: 43$ & $3,07 \%$ \\
\hline WEBMAIL & 75.121 & $22,81 \%$ & $128: 46: 07$ & $26,25 \%$ \\
\hline BANCOS & 19.934 & $6,05 \%$ & $46: 51: 45$ & $9,55 \%$ \\
\hline HARDWARE & 966 & $0,29 \%$ & 01:56:03 & $0,39 \%$ \\
\hline CONCURSOS & 8.914 & $2,71 \%$ & 09:33:50 & $1,95 \%$ \\
\hline JORNAIS & 19.435 & $5,90 \%$ & $32: 02: 57$ & $6,53 \%$ \\
\hline COMPRAS & 19.984 & $6,07 \%$ & $42: 24: 34$ & $8,64 \%$ \\
\hline ENTRETENIMENTO & 37.307 & $11,33 \%$ & $61: 39: 26$ & $12,57 \%$ \\
\hline DOWNLOAD & 3.919 & $1,19 \%$ & $05: 57: 57$ & $1,22 \%$ \\
\hline
\end{tabular}

5 O arquivo de log é onde ficam registrados os sítios acessados por cada usuário e o tempo que durou esse acesso. Também é possível, por meio da análise desses dados, identificar e traçar o caminho feito pelos usuários durante a navegação na intranet/internet. 


\begin{tabular}{|c|c|c|c|c|}
\cline { 2 - 4 } \multicolumn{1}{c|}{} & \multicolumn{2}{c|}{ ACESSOS } & \multicolumn{2}{c|}{ TEMPO } \\
\cline { 2 - 5 } & CLIQUES & \% DO TOTAL & HORAS & \% DO TOTAL \\
\hline \multirow{2}{*}{ SOFTWARE } & 9.073 & $2,75 \%$ & $65: 06: 21$ & $13,27 \%$ \\
\hline \multirow{2}{*}{ GOVERNO } & 12.654 & $3,84 \%$ & $20: 45: 34$ & $4,23 \%$ \\
\hline \multirow{2}{*}{} & 329.392 & $100,00 \%$ & $490: 36: 08$ & $100,00 \%$ \\
\hline
\end{tabular}

Fonte: Elaboração dos autores (2018).

Para tratar e organizar a massa de dados, utilizou-se o software WebSpy. As categorias foram definidas seguindo critérios estipulados pelo próprio software. Nos casos em que a ferramenta não conseguiu classificar os sítios, houve intervenção do pesquisador. Além da análise do log do sistema, foram realizadas, observações, entrevistas formais e conversas informais com 15 pessoas, quando se buscou selecionar aleatoriamente pelo menos uma pessoa em cada seção.

Os principais temas discutidos levaram à conclusão de que se tratava de questões realmente preocupantes. Assim, as principais questões ou preocupações demonstradas pelos sujeitos da pesquisa foram agrupadas em quatro temas centrais. O primeiro é o conteúdo deficiente; o segundo, a inexistência de padrões para publicação e colaboração; o terceiro, a falta de incentivo para colaborar; e, por último, a falta de divulgação das características, potencialidades e problemas do portal.

Ao término dessa coleta de dados, pôde ser observado que, apesar de a situação-problema envolver uma preocupação central, os atores posicionavam-se em diferentes pontos para observá-la. Com isso, foram identificados conflitos que estão ilustrados na rich picture (figura 5), estágio 2 da SSM, para melhor representação. Além das preocupações dos atores, foram identificadas, ainda, quatro principais restrições ambientais que influenciam diretamente a situação-problema estudada. A primeira é o orçamento da união. A segunda é a diretriz para construção de sites governamentais. A terceira constitui a estrutura e a cultura organizacionais. A quarta é a política de pessoal. 
Figura 5 - Rich Picture

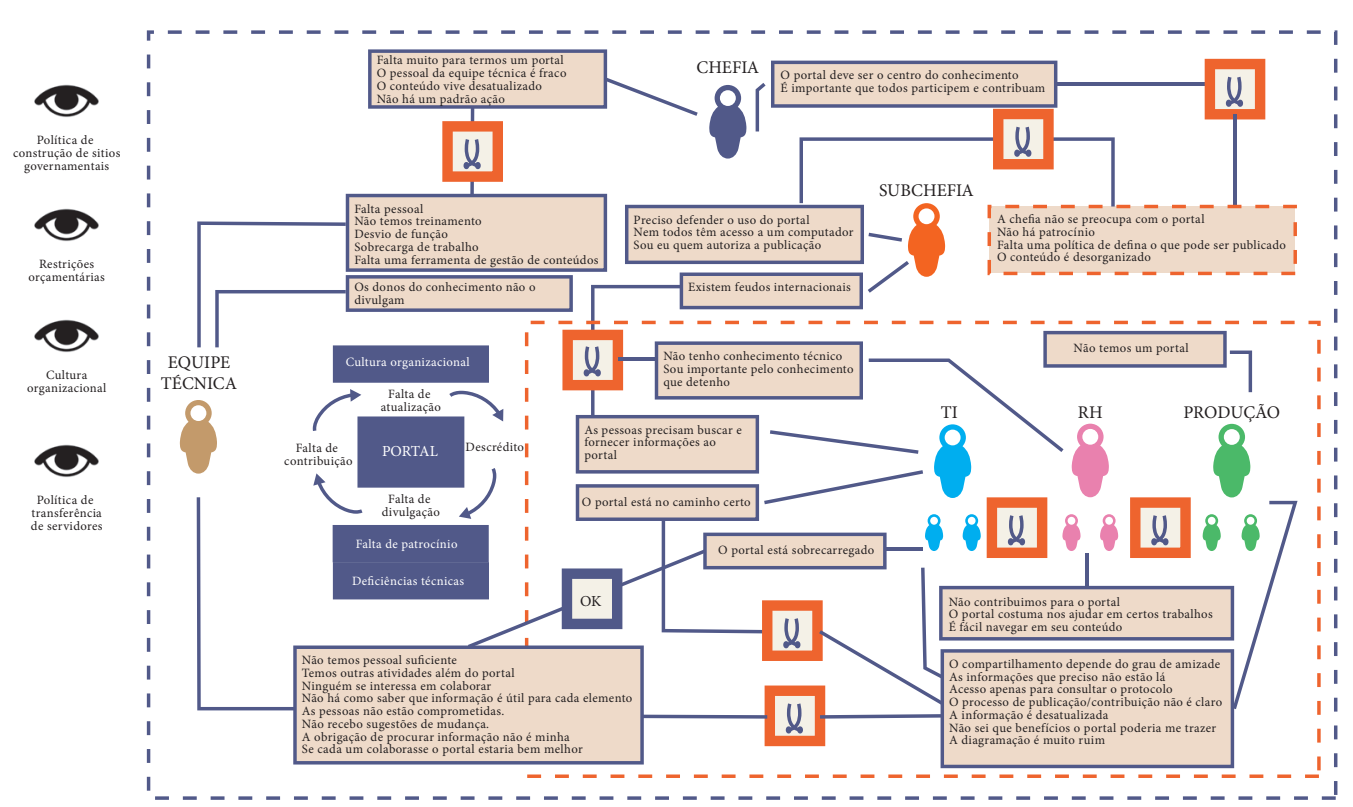

Fonte: Elaboração dos autores (2018).

Na root definition, são identificados os princípios básicos de um sistema de atividade responsável por melhorar a situação-problema. Checkland (1993) destaca que, no processo de criação de uma root definition, são reconhecidos os subsistemas tidos como relevantes pelo pesquisador, a partir das concepções percebidas nas falas dos atores, no primeiro estágio da SSM, e ilustradas na rich picture. Esses subsistemas são os elementos considerados essenciais para o funcionamento do sistema. $\mathrm{O}$ autor diz ainda que a root definition deve expressar um processo de transformação ao qual alguma entidade (entrada) seja submetida, de forma a modificá-la ou transformá-la em uma nova forma daquela mesma entidade (saída). Couprie et. al. (2004) salientam a importância dessa definição, pois ela reflete o propósito central do sistema e irá guiar todo o processo de modelagem.

Para guiar a formulação da root definition, são usados seis elementos: clientes, atores, transformação, visão de mundo, proprietário do sistema e restrições do ambiente (CATWOE, na sigla em inglês). Tais elementos, portanto, são fundamentais e devem estar presentes na root definition. O Quadro 3 apresenta a especificação de cada elemento do CATWOE a partir da percepção da situação-problema estudada, conforme destacado na rich picture. 
Quadro 3 - CATWOE da situação-problema estudada

\begin{tabular}{|c|c|c|}
\hline ITEM & SIGNIFICADO & DESCRIÇÃO \\
\hline $\mathrm{C}$ & $\begin{array}{l}\text { Consumidores ou clientes } \\
\text { (Customers or clients) }\end{array}$ & $\begin{array}{l}\text { Equipe de desenvolvimento } \\
\text { Seções de TI, de RH e de Produção }\end{array}$ \\
\hline $\mathbf{A}$ & $\begin{array}{l}\text { Atores } \\
\text { (Actors) }\end{array}$ & $\begin{array}{l}\text { Equipe de desenvolvimento } \\
\text { Seções de TI, de RH e de Produção }\end{array}$ \\
\hline $\mathbf{T}$ & $\begin{array}{l}\text { Transformação } \\
\text { (Transformation) }\end{array}$ & $\begin{array}{c}\text { Portal carente de informação } \bigotimes \text { Portal como principal fonte de } \\
\text { informação na organização }\end{array}$ \\
\hline $\mathbf{W}$ & $\begin{array}{l}\text { Visão de mundo } \\
\text { (Weltanschauung) }\end{array}$ & $\begin{array}{c}\text { Para que o portal corporativo seja uma ferramenta eficaz de } \\
\text { gestão do conhecimento, é preciso que tenha informação útil e } \\
\text { relevante para os trabalhos diários, configurando-se na principal } \\
\text { fonte de informação da organização }\end{array}$ \\
\hline $\mathbf{O}$ & $\begin{array}{l}\text { Proprietário } \\
\text { (Owner) }\end{array}$ & Departamento objeto do estudo \\
\hline $\mathbf{E}$ & $\begin{array}{c}\text { Restrições ambientais } \\
\text { (Environmental constraints) }\end{array}$ & $\begin{array}{c}\text { Política governamental de construção de páginas da web } \\
\text { Orçamento da União } \\
\text { Cultura organizacional }\end{array}$ \\
\hline
\end{tabular}

Fonte: Elaboração dos autores (2018).

Como consequência desta análise e a partir do CATWOE especificado, foi possível elaborar a seguinte root definition:

Um sistema de propriedade do Departamento XYZ, que transforma um portal corporativo carente de informações relevantes em um portal que representa a principal fonte de informação do departamento, tendo as atividades realizadas pela equipe de desenvolvimento, seção de TI de RH e de Produção, levando em conta questões estruturais, ambientais e culturais envolvidas.

Concluídas as definições fundamentais, a SSM requer a definição do estágio 4, o qual compreende o que os autores denominaram de modelo conceitual. Esses modelos são uma espécie de funcionograma das ações essenciais às mudanças identificadas como necessárias, na ordem em que devem ser implementadas. Compreendem, ainda, a definição de mecanismos de controle que garantam essa implementação. 


\subsection{Modelagem conceitual}

Para que o portal corporativo se transforme na principal fonte de informação do departamento, é necessário definir e padronizar as ações para gestão de informações no portal. Paralelamente a esse processo de padronização, devem ser elaboradas políticas e mecanismos que facilitem a colaboração e a contribuição. Uma vez que os padrões e as políticas estejam definidos, é preciso capacitar os usuários do portal com o objetivo de deixá-los familiarizados com a tecnologia e incentivados a de incentivar seu uso, colaborando para criar e manter seu conteúdo. Também devem ser formuladas estratégias de marketing para divulgação do portal, como forma de sensibilizar as pessoas quanto à importância do envolvimento de todos.

Tais ações visam a envolver as equipes, fornecendo novos conteúdos, críticas e sugestões que serão selecionados de acordo com os padrões previamente determinados e submetidos à aprovação e à modelagem para que, então, sejam publicados. É o que está definido no modelo conceitual necessário à realização do que estabelece a root definition, tal como ilustrado na figura 6

Figura 6 - Modelo conceitual de primeiro nível

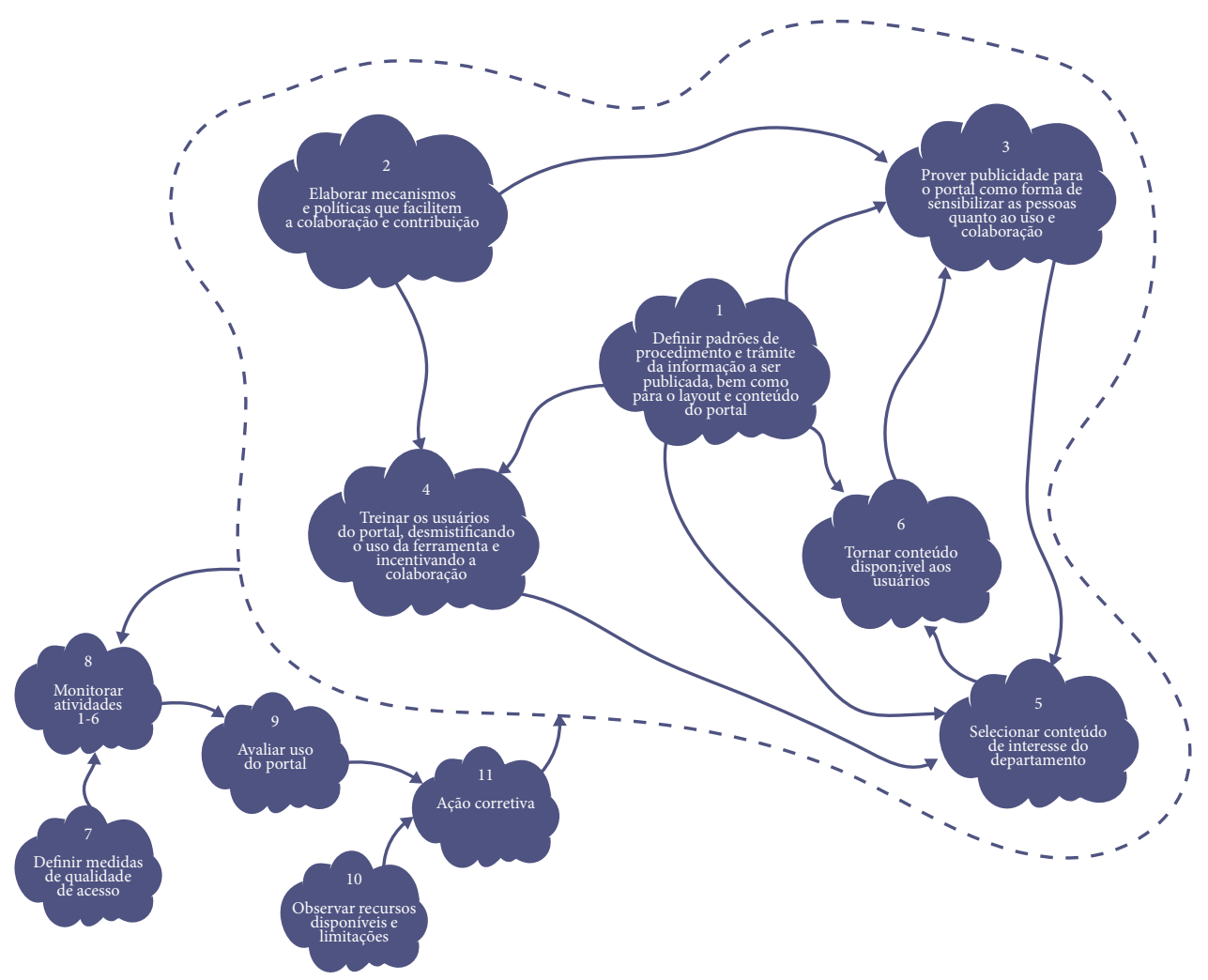

Fonte: Elaboração dos autores (2018). 
Em razão da complexidade das mudanças a serem implementadas para transformação da situação-problema, o modelo conceitual definido constituiu-se de um conjunto de ações que apontaram para a necessidade de torná-las subsistemas desse modelo. Assim, o primeiro modelo derivado da definição fundamental é considerado como de primeiro nível. Contém, portanto, o conjunto mínimo de atividades necessárias à definição do sistema. No entanto, considerando que cada atividade desse nível pode ser definida como um subsistema, foi possível identificar e definir seis principais subsistemas que compunham o modelo. O primeiro subsistema é responsável por estabelecer padrões para a publicação de conteúdo do portal. O segundo consiste em definir mecanismos ou políticas que facilitem a colaboração e a contribuição. $\mathrm{O}$ terceiro consiste em prover publicidade ao portal; o quarto, em treinar os usuários do portal; o quinto, em identificar conteúdo interessante. Finalmente, o sexto subsistema consiste em publicar informações.

Entre os subsistemas definidos, optou-se pelo detalhamento do primeiro e do quinto, no primeiro momento de aplicação da SSM. A partir da seleção dos subsistemas a serem detalhados, fez-se necessária a construção do CATWOE, da root definition e do modelo conceitual que estabelece, para cada um deles, o conjunto mínimo de atividades necessárias.

\section{Subsistema 1 - Estabelecer padrões para a publicação de conteúdo}

O Quadro 4 apresenta o CATWOE do subsistema 1, visando ao norteamento da formulação de sua root definition.

Quadro 4 - CATOWE do subsistema que estabelece padrões para a publicação de conteúdo

\begin{tabular}{|c|c|c|}
\hline ITEM & SIGNIFICADO & DESCRIÇÃO \\
\hline $\mathrm{C}$ & $\begin{array}{l}\text { Consumidores ou clientes } \\
\text { (Customers or clients) }\end{array}$ & $\begin{array}{l}\text { Equipe de desenvolvimento } \\
\text { Seção de TI, de RH e de Produção }\end{array}$ \\
\hline A & $\begin{array}{l}\text { Atores } \\
\text { (Actors) }\end{array}$ & $\begin{array}{l}\text { Equipe de desenvolvimento } \\
\text { Seção de TI, de RH e de Produção }\end{array}$ \\
\hline $\mathbf{T}$ & $\begin{array}{l}\text { Transformação } \\
\text { (Transformation) }\end{array}$ & Conteúdo despadronizado $\rightarrow$ Conteúdo padronizado \\
\hline W & $\begin{array}{l}\text { Visão de mundo } \\
\text { (Weltanschauung) }\end{array}$ & $\begin{array}{c}\text { Para que o portal corporativo seja uma ferramenta útil às } \\
\text { pessoas, é necessário que tanto o design de forma quanto o } \\
\text { processo de publicação sejam padronizados, visando a facilitar a } \\
\text { navegação e a contribuição das pessoas }\end{array}$ \\
\hline O & $\begin{array}{l}\text { Proprietário } \\
\text { (Owner) }\end{array}$ & Departamento objeto do estudo \\
\hline
\end{tabular}




\begin{tabular}{|c|c|c|}
\hline ITEM & SIGNIFICADO & DESCRIÇÃO \\
\hline E & $\begin{array}{c}\text { Restrições ambientais } \\
\text { (Environmental constraints) }\end{array}$ & $\begin{array}{c}\text { Política governamental de construção de páginas da web } \\
\text { Orçamento da União } \\
\text { Cultura organizacional }\end{array}$ \\
\hline
\end{tabular}

Fonte: Elaboração dos autores (2018).

A partir da definição dos elementos do CATWOE, foi possível elaborar a seguinte root definition para o subsistema 1:

Um sistema de propriedade do Departamento XYZ que transforma um portal com conteúdo não padronizado e processo de publicação carente de clareza em um portal com padrões sólidos de design e procedimentos bem estabelecidos para publicação. Essa transformação será feita por uma comissão formada pela direção do Departamento, juntamente com alguns integrantes de cada seção (RH, TI e Produção), levando em conta questões estruturais, ambientais e culturais que permeiam o ambiente onde o Departamento XYZ está inserido.

Um novo conjunto de ações foi identificado como necessário para implementação das mudanças no portal. A primeira é rever os objetivos do portal corporativo, para que possam ser estabelecidas metas atuais e futuras como parte de uma norma departamental para regular todas as atividades que envolvam o portal corporativo. Paralelamente, deve ser estabelecido o trâmite a ser seguido para publicação, devendo ser aplicadas, também, as normas de usabilidade e observadas as normas governamentais e organizacionais para construção de sítios web como forma de nortear a construção do layout do portal e da disposição do conteúdo. Chegou-se, então, ao modelo conceitual do subsistema 1, apresentado na figura 7. 
Figura 7 - Modelo conceitual do subsistema de padronização

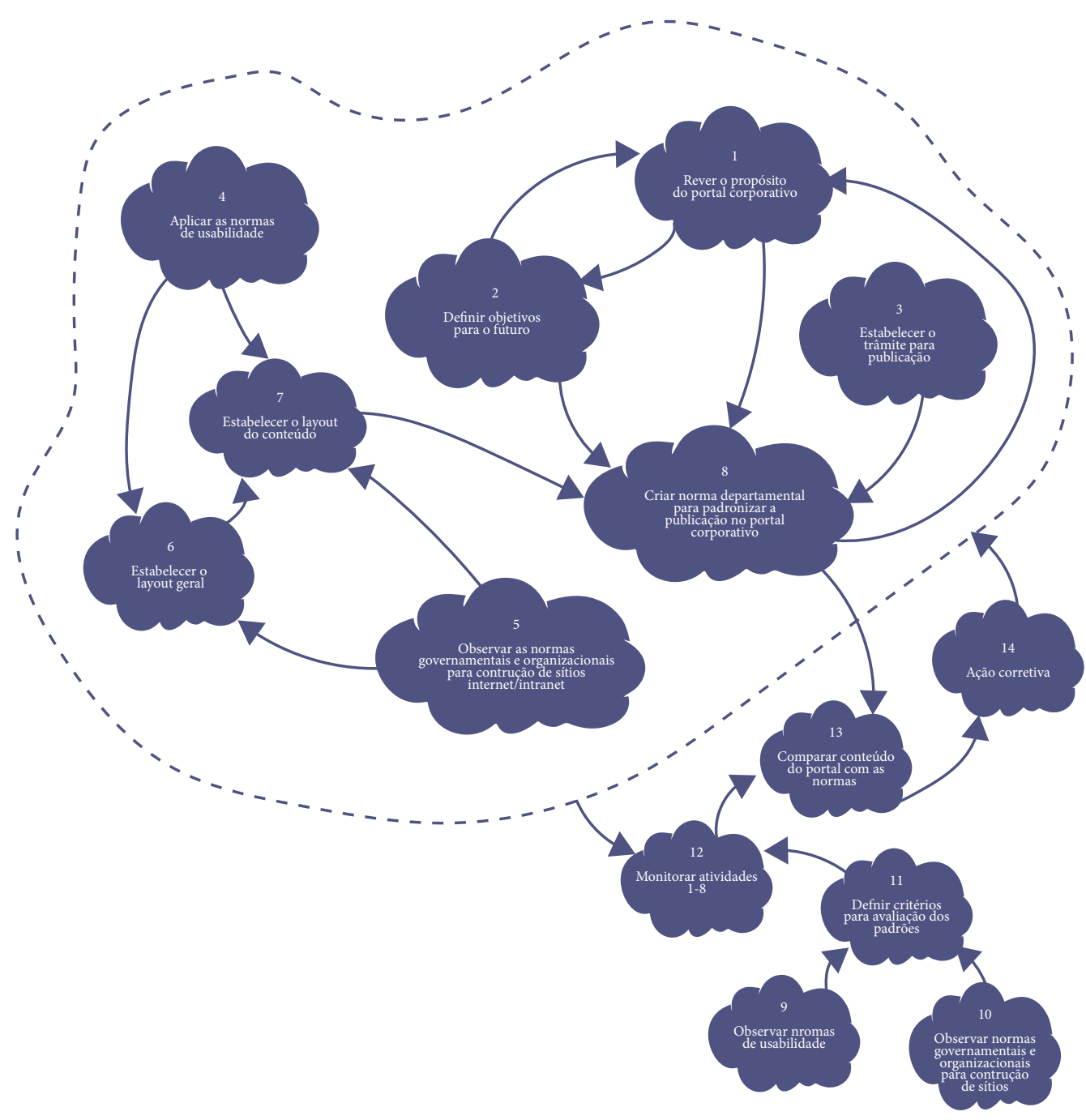

Fonte: Elaboração dos autores (2018). 


\section{Subsistema 5 - Identificar conteúdo interessante}

Para nortear a formulação da root definition do subsistema 5, foi elaborado seu CATOWE, conforme mostrado no Quadro 5.

Quadro 5 - CATWOE do subsistema que identifica conteúdo interessante

\begin{tabular}{|c|c|c|}
\hline ITEM & SIGNIFICADO & DESCRIÇÃo \\
\hline C & $\begin{array}{c}\text { Consumidores ou clientes } \\
\text { (Customers or clients) }\end{array}$ & Departamento XYZ da organização ABC \\
\hline $\mathbf{A}$ & $\begin{array}{c}\text { Atores } \\
\text { (Actors) }\end{array}$ & $\begin{array}{c}\text { Equipe de desenvolvimento do portal em conjunto com } \\
\text { comissão composta por integrantes de cada seção }\end{array}$ \\
\hline T & $\begin{array}{c}\text { Transformação } \\
\text { (Transformation) }\end{array}$ & $\begin{array}{c}\text { Excesso de informação } \text { V informação selecionada, pertinente e } \\
\text { de interesse do departamento/pessoas }\end{array}$ \\
\hline W & $\begin{array}{c}\text { Visão de mundo } \\
\text { (Weltanschaung) }\end{array}$ & $\begin{array}{c}\text { Para que se possa filtrar o excesso de informação, é necessário } \\
\text { identificar as necessidades de informação das pessoas, a partir } \\
\text { do que é preciso selecionar as informações de interesse do } \\
\text { departamento }\end{array}$ \\
\hline $\mathbf{O}$ & $\begin{array}{c}\text { Proprietário } \\
\text { (Owner) }\end{array}$ & Departamento objeto do estudo \\
\hline E & $\begin{array}{c}\text { Restrições ambientais } \\
\text { (Environmental constraints) }\end{array}$ & Cultura organizacional \\
\hline
\end{tabular}

A partir da definição do CATWOE do subsistema 5, foi possível elaborar a seguinte root definition:

Um sistema de propriedade do Departamento XYZ que transforma o excesso de informação no portal corporativo em um conjunto de informação selecionada, de interesse do departamento e de seus integrantes. Essa transformação será realizada pela equipe de desenvolvimento do portal, em conjunto com comissão composta por integrantes de cada seção, levando em conta os padrões previamente estabelecidos, bem como questões estruturais, ambientais e culturais que permeiam o ambiente onde o Departamento XYZ está inserido. 
Para que o novo conteúdo do portal seja selecionado, é preciso, em primeira instância, recebê-lo do usuário ou obtê-lo por meio do monitoramento do ambiente em busca de informações que possam ser relevantes. A partir de então, é realizada uma primeira avaliação no intuito de verificar se realmente se trata de uma necessidade de informação. Em se configurando uma necessidade real de informação, o conteúdo é selecionado e serve de base para o processo de monitoração do ambiente em busca de assuntos correlatos. Paralelamente, é executado um processo de auditoria onde são identificados os principais serviços da internet utilizados pelos integrantes do departamento, com o objetivo de tornar disponível no portal, na medida do possível, tais serviços. Desse modo, chega-se ao modelo conceitual apresentado na figura 8 , o qual é composto das ações de mudança e dos mecanismos de controle que garantam sua implementação.

Figura 8 - Modelo conceitual: identificação de conteúdo interessante

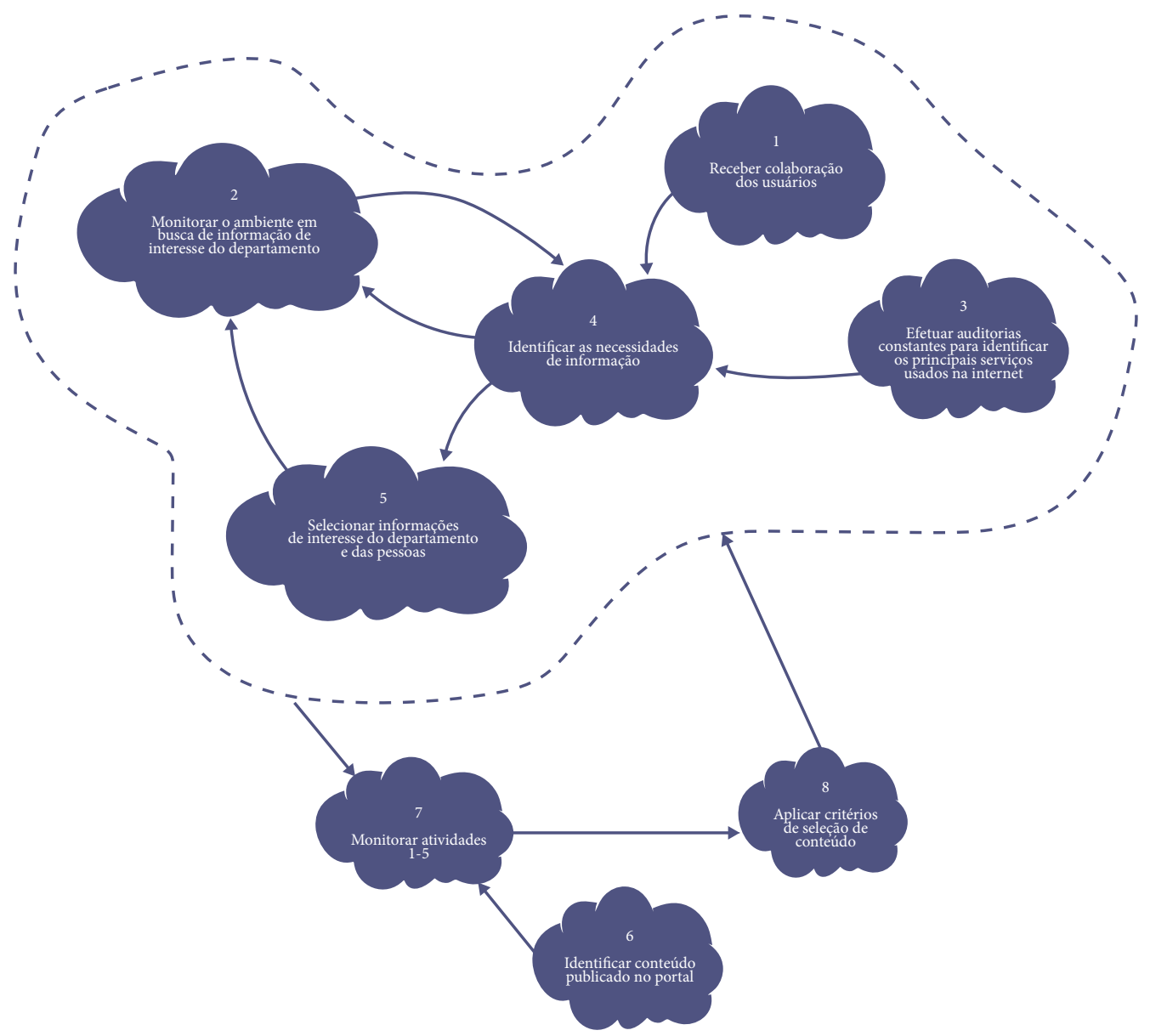

Fonte: Elaboração dos autores (2018). 


\subsection{Comparação do mundo real com o modelo conceitual}

O estágio 5 da SSM compreende a realização de uma agenda de comparação entre o que existe no mundo real da situação-problema e o que está proposto no modelo conceitual. É importante ressaltar que aquilo que se propõe nos modelos conceituais é derivado do que se identificou no estágio 2, quando foi elaborada a rich picture, a qual, por sua vez, retrata questões relevantes identificadas no mundo real. O processo de comparação é de extrema importância, pois validará o trabalho desenvolvido nos estágios anteriores, garantindo que o modelo conceitual desenvolvido no estágio 4 contempla propostas de solução para as preocupações observadas por ocasião da construção da rich picture desenvolvida no estágio 2.

Para essa comparação, elaborou-se uma agenda para cada subsistema na qual as ações propostas nos modelos conceituais foram discutidas com os integrantes da organização pesquisada (Quadros 6 e 7). O objetivo dessa discussão foi identificar as mudanças que fossem sistemicamente desejáveis e culturalmente viáveis para a melhoria da situação-problema. Uma proposta sistemicamente desejável é aquela que se torna elemento fundamental para o desempenho do sistema. A mesma proposta é culturalmente viável quando está de acordo com os papéis, valores e normas compartilhados no âmbito da situação-problema estudada.

Quadro 6 - Agenda de checagem do subsistema "padronização"

\begin{tabular}{|c|c|c|c|c|c|c|c|}
\hline \multirow{2}{*}{$\begin{array}{c}\text { Ações propostas no } \\
\text { modelo conceitual } \\
\text { (sistemicamente } \\
\text { desejáveis) }\end{array}$} & \multirow{2}{*}{$\begin{array}{l}\text { Existe } \\
\text { na } \\
\text { situação } \\
\text { atual? }\end{array}$} & \multicolumn{4}{|c|}{ Se SIM, como julga sua realização? } & \multirow{2}{*}{$\begin{array}{c}\text { Se NÃO, é } \\
\text { possívelser } \\
\text { implementada } \\
\text { ou melhorada? }\end{array}$} & \multirow{2}{*}{$\begin{array}{c}\text { A ação } \\
\text { deve ser } \\
\text { implementada? }\end{array}$} \\
\hline & & Ruim & Regular & Bom & Excelente & & \\
\hline $\begin{array}{c}\text { Rever o propósito } \\
\text { do portal } \\
\text { corporativo }\end{array}$ & Não & & & & & Sim & Sim \\
\hline $\begin{array}{c}\text { Definir os objetivos } \\
\text { atuais e metas para } \\
\text { o futuro }\end{array}$ & Não & & & & & Sim & Sim \\
\hline $\begin{array}{l}\text { Definir os requisitos } \\
\text { para publicação de } \\
\text { conteúdo }\end{array}$ & Sim & $\mathrm{X}$ & & & & Sim & Sim \\
\hline $\begin{array}{c}\text { Estabelecer o } \\
\text { trâmite que a } \\
\text { informação deve } \\
\text { seguir até que seja } \\
\text { publicada }\end{array}$ & Não & & & & & Sim & Sim \\
\hline $\begin{array}{l}\text { Aplicar as normas } \\
\text { de usabilidade na } \\
\text { construção de sítios }\end{array}$ & Não & & & & & Sim & Sim \\
\hline
\end{tabular}




\begin{tabular}{|c|c|c|c|c|c|c|c|}
\hline \multirow{2}{*}{$\begin{array}{l}\text { Ações propostas no } \\
\text { modelo conceitual } \\
\text { (sistemicamente } \\
\text { desejáveis) }\end{array}$} & \multirow{2}{*}{$\begin{array}{l}\text { Existe } \\
\text { na } \\
\text { situação } \\
\text { atual? }\end{array}$} & \multicolumn{4}{|c|}{ Se SIM, como julga sua realização? } & \multirow{2}{*}{$\begin{array}{c}\text { Se NÃO, é } \\
\text { possívelser } \\
\text { implementada } \\
\text { ou melhorada? }\end{array}$} & \multirow{2}{*}{$\begin{array}{c}\text { A ação } \\
\text { deve ser } \\
\text { implementada? }\end{array}$} \\
\hline & & Ruim & Regular & Bom & Excelente & & \\
\hline $\begin{array}{l}\text { Observar as normas } \\
\text { governamentais e } \\
\text { organizacionais para } \\
\text { construção de sítios }\end{array}$ & Sim & & & $\mathrm{X}$ & & Sim & Sim \\
\hline $\begin{array}{c}\text { Estabelecer padrão } \\
\text { para o layout geral } \\
\text { do portal }\end{array}$ & Não & & & & & Sim & Sim \\
\hline $\begin{array}{l}\text { Estabelecer padrão } \\
\text { para o layout dos } \\
\text { assuntos publicados } \\
\text { no portal }\end{array}$ & & & & & & & \\
\hline
\end{tabular}

Fonte: Elaboração dos autores (2018).

Quadro 7 - Agenda de checagem do subsistema "seleção de conteúdo"

\begin{tabular}{|c|c|c|c|c|c|c|c|}
\hline \multirow{2}{*}{$\begin{array}{l}\text { Ações propostas no } \\
\text { modelo conceitual } \\
\text { (sistemicamente } \\
\text { desejáveis) }\end{array}$} & \multirow{2}{*}{$\begin{array}{l}\text { Existe } \\
\text { na } \\
\text { situação } \\
\text { atual? }\end{array}$} & \multicolumn{4}{|c|}{ Se SIM, como julga sua realização? } & \multirow{2}{*}{$\begin{array}{c}\text { Se NÃO, é } \\
\text { possívelser } \\
\text { implementada? }\end{array}$} & \multirow{2}{*}{$\begin{array}{c}\text { A ação } \\
\text { deve ser } \\
\text { implementada? }\end{array}$} \\
\hline & & Ruim & Regular & Bom & Excelente & & \\
\hline $\begin{array}{c}\text { Receber colaboração } \\
\text { dos usuários }\end{array}$ & Sim & $\mathrm{X}$ & & & & - & Sim \\
\hline $\begin{array}{c}\text { Monitorar o } \\
\text { ambiente em busca } \\
\text { de informação } \\
\text { de interesse do } \\
\text { departamento }\end{array}$ & Sim & $\mathrm{X}$ & & & & - & Sim \\
\hline $\begin{array}{l}\text { Realizar auditorias } \\
\text { constantes para } \\
\text { identificar os } \\
\text { principais serviços } \\
\text { usados na internet }\end{array}$ & Não & & & & & Não & Não \\
\hline $\begin{array}{c}\text { Identificar as } \\
\text { necessidades de } \\
\text { informação dos } \\
\text { usuários }\end{array}$ & Não & & & & & Sim & Sim \\
\hline $\begin{array}{c}\text { Selecionar a } \\
\text { informação de } \\
\text { interesse do } \\
\text { departamento e das } \\
\text { pessoas para que } \\
\text { seja publicada }\end{array}$ & Sim & $\mathrm{X}$ & & & & - & Sim \\
\hline
\end{tabular}

Fonte: Elaboração dos autores (2018). 


\subsection{Proposição das mudanças sistemicamente desejáveis e culturalmente viáveis}

Apesar de as mudanças sistemicamente desejáveis terem suas implementações culturalmente viáveis, houve situações em que as pessoas acreditavam que não deveriam ser colocadas em prática. Por sua vez, foram identificadas mudanças sistemicamente desejáveis que, no entanto, na opinião dos membros do departamento, deveriam ser implementadas, embora fossem de encontro à cultura organizacional.

Entretanto, o trabalho de observação e as entrevistas realizadas permitiram perceber que a estrutura organizacional e a cultura que permeia o ambiente em que as pessoas estão inseridas tolhem qualquer comportamento de mudança que vá de encontro a valores e normas compartilhados. Constataram-se, ainda, casos em que uma mudança poderia ser desejada ou imposta por quem está no topo da pirâmide departamental. Assim, são discutidas, a seguir, as ações propostas nos modelos conceituais, de acordo com os resultados apresentados nas agendas de checagem. Espera-se, portanto, que se possa obter uma visão mais ampla e abrangente das nuances que envolvem a situação-problema.

\subsubsection{Subsistema de padronização}

O subsistema de padronização é o que serve de alicerce para que o portal seja a principal fonte de informação do departamento e, com isso, transforme-se em uma ferramenta para a gestão do conhecimento e para a comunicação organizacional. A padronização é iniciada por um processo de autoconhecimento, no qual se identifica o que existe para, em seguida, determinar onde se deseja chegar. Para Drucker (1986), esse planejamento é fundamental para o sucesso de qualquer atividade organizacional.

O segundo passo é determinar padrões de layout e redação, de forma que o conteúdo siga um padrão que proporcione identidade à ferramenta como um todo. É importante destacar que os padrões de layout e redação devem obedecer às normas governamentais e organizacionais para construção de sítios, bem como às normas de usabilidade. Nesse sentido, Eckerson (1999), ao definir os requisitos a serem atendidos na construção do portal corporativo, destaca que este deve ser adequado a usuários eventuais, com acesso simples e fácil às informações.

O terceiro passo para obter a padronização é determinar o trâmite que a informação deve seguir até que seja publicada. Assim, espera-se aumentar a credibilidade do conteúdo e também esclarecer aos integrantes do departamento como ocorre o processo de publicação de conteúdo. Isso posto, verifica-se que os processos organizacionais precisam ser padronizados e transparentes para que não haja margens para especulações e as pessoas sintam-se seguras (BILHIN, 2001). Para tanto, foram definidas sete ações, as quais são descritas a seguir. 


\section{Ação 1: Rever o propósito do portal}

Nenhuma das pessoas pesquisadas soube informar com clareza o motivo pelo qual o portal corporativo foi desenvolvido, tampouco seu objetivo. Portanto, a definição clara dos objetivos do portal corporativo é o primeiro passo para que seja criado um objetivo compartilhado e para que sejam estabelecidas as condições para o aprendizado. Como observa Senge (1990), a criação de um objetivo compartilhado entre os integrantes da organização é um dos pré-requisitos para proporcionar o aprendizado organizacional. Sua implementação dar-se-á por meio de três ações. A primeira consiste em analisar as características do portal para que seja possível tomar conhecimento da situação atual; a segunda, em realizar a análise do propósito do portal iterativamente, a fim de verificar constantemente seu alinhamento às normas e padrões compartilhados; e a última, em rever, sistematicamente, o propósito do portal, de preferência pelo chefe do departamento em conjunto com os chefes de seção.

\section{Ação 2: Definir objetivos para o futuro}

A definição de uma visão de futuro para o portal corporativo está diretamente relacionada com a identificação do propósito do portal. Uma vez que o portal tenha um propósito bem definido é mais fácil vislumbrar quaisquer objetivos para o futuro.

Sua implementação dar-se-á por meio de três etapas. A primeira diz respeito ao planejamento do que se deseja atingir no futuro, a partir da identificação da situação atual. A segunda relaciona-se à definição periódica dos objetivos futuros, visando sempre aos objetivos em curto (três meses) e médio (um ano) prazos. O planejamento em longo prazo é inviável, visto que a rotatividade das pessoas nas funções de chefia dificulta sua manutenção. A terceira refere-se à definição dos parâmetros de controle e indicadores de desempenho para acompanhamento do portal e controle da consecução de seus objetivos.

\section{Ação 3: Estabelecer o trâmite para a informação seguir até ser publicada}

Observou-se total desorganização na gestão da informação que chega ao portal, a qual é recebida e publicada pela equipe de desenvolvimento sem qualquer verificação, o que reflete problemas no trâmite da informação. Tal conduta reflete forte traço cultural da organização, conforme definido por Gibson (1981). São pelo menos três as situações. Na primeira, uma vez recebidas as informações de quem, em razão da posição exercida na organização, merece confiança na sua validade, elas são publicadas no portal sem questionamento. Na segunda, o desconhecimento sobre a quem sugerir uma publicação provoca desinteresse em colaborar. Finalmente, muitos não colaboram por acreditarem que, devido a sua posição 
no departamento, não podem fazê-lo, demonstrando que, como fonte de informação, não têm credibilidade, revelando um sentimento de autodesvalorização. Para implementação, é necessária a realização de três etapas. A primeira consiste em definir o caminho que a informação deve seguir para ser publicada, a fim de garantir sua validade perante a chefia e realizar um refinamento das informações, impedindo a publicação do que não deve estar no portal. A segunda refere-se a evitar a burocratização do trâmite, para não afetar a oportunidade de publicar. A última consiste em definir a quem atribuir a responsabilidade por avaliar a pertinência do conteúdo, com base em requisitos preestabelecidos, visando à redução do excesso de contribuições de conteúdos irrelevantes.

\section{Ação 4: Aplicar normas de usabilidade na construção dos sítios}

Verificou-se que o webmaster responsável pelo portal desconhecia o significado da palavra usabilidade. Esse fato prejudica a ergonomia do portal e aponta para o inverso do que Eckerson (1999) defende como característica desejável: o acesso às diversas seções do portal não é intuitivo, a combinação de cores confunde os usuários e a disposição do conteúdo não segue qualquer critério. Isso, por seu turno, reflete outro forte traço cultural do departamento, como observado anteriormente. São duas as ações necessárias para implementação. Primeiramente, deve-se identificar padrões internacionais de usabilidade como forma de garantir a adoção de critérios ergonômicos testados e reconhecidamente aceitos internacionalmente, tanto para construção do layout do portal quanto para as informações a serem publicadas. Em seguida, é necessário manter, na equipe do portal, um responsável por identificar critérios ergonômicos que deverão ser seguidos para que o portal tenha sua estrutura e conteúdo modelados de acordo. Todas as inclusões, de conteúdo ou de novos sítios, devem estar de acordo com as normas de usabilidade.

\section{Ação 5: Observar normas governamentais e organizacionais para a construção de sítios}

Existem normas governamentais, publicadas no Diário Oficial da União, que regulam a construção de sítios para internet/intranet, de forma a garantir-lhes uma identidade, complementada por normas organizacionais. Essas, por sua vez, auxiliam na pertinência da identidade de um sítio vinculado, em primeiro nível, ao governo federal, agregada à identidade da organização da qual faz parte. Assim, no acesso a qualquer sítio do portal, ficará clara sua vinculação ao governo federal e à organização em questão. São três as ações necessárias à implementação. Primeiramente, devem-se identificar normas governamentais para a construção de sítios para internet e/ou intranet, visando a garantir sua vinculação ao governo federal. Em seguida, devem-se identificar normas estabelecidas pela organização para a construção de sítios para internet e/ou intranet. Finalmente, é necessário designar um responsável por 
verificar constantemente a validade das normas governamentais e organizacionais, bem como a formatação do layout e o conteúdo do portal, de forma que ele esteja em consonância com essas normas.

\section{Ação 6: Estabelecer padrão para o layout geral do portal}

O layout principal do portal, apesar de não seguir as normas de usabilidade e governamentais/organizacionais, é bem definido e classificado como bom pelas pessoas entrevistadas. Muitos dos entrevistados, no entanto, destacaram a questão da falta de identidade latente no portal, o que requer duas ações para solucionar o problema. A primeira diz respeito à elaboração do layout do portal, a partir da identificação dos padrões de usabilidade e das normas governamentais e organizacionais para construção de sítios. A segunda consiste em definir processo de validação do layout, por meio do qual sejam oferecidos pelo menos três opções para seleção do que mais agrada, com vistas à melhor e maior participação dos usuários do portal.

\section{Ação 7: Estabelecer padrão para o layout dos conteúdos publicados}

Não há qualquer tipo de preocupação com padrões para a informação publicada, dificultando a leitura do conteúdo. Com isso, cria-se uma barreira em potencial para a comunicação da informação. Como destacado por Parry (1972) a esse respeito, se a apresentação for confusa, a informação não será recebida corretamente, ou pode, até mesmo, ser ignorada. A implementação dessa ação aponta para duas etapas. A primeira refere-se ao estabelecimento, por meio do layout de conteúdo, da formatação e da redação dos conteúdos publicados no portal, em relação aos tipos de letras, cores e efeitos especiais que podem estar presentes. A segunda consiste em garantir que o layout da informação a ser publicada não vá de encontro às normas de usabilidade, governamentais ou organizacionais.

\subsubsection{Subsistema de seleção de conteúdo}

O processo de seleção de conteúdo tem por objetivo identificar e selecionar o conteúdo que seja de interesse do departamento, requerendo que esteja sempre atualizado, disponível, correto e relevante para o desenvolvimento dos trabalhos realizados pelos integrantes do departamento (Zimmerman, 2002). A seleção de conteúdo é um processo constante, que deve ser realizado enquanto o portal existir. Assim, no intuito de prover esse serviço de prospecção informacional para manter o portal atualizado, foram definidas cinco ações, as quais estão descritas a seguir. 


\section{Ação 1: Receber colaboração dos usuários}

Uma vez que os usuários estejam sensibilizados para a importância de usar o portal e colaborar com a formação de seu conteúdo e, principalmente, comprometidos e motivados, a expectativa é que comecem a contribuir para o portal, fornecendo informações que julguem pertinentes. Desse modo, manter um canal de comunicação aberto, como definido por Parry (1972), é extremamente importante. Embora a equipe de desenvolvimento do portal afirme que exista um canal aberto para contribuições dos usuários, foram identificadas, por meio das entrevistas, três posições contrárias a essa. Em primeiro lugar, afirma-se que o processo de publicação não é transparente e que as sugestões de usuários, quando dadas, não são consideradas. A segunda posição identificada sugere que basta fornecer a informação diretamente ao webmaster para que ela seja publicada. Finalmente, os usuários afirmam que não havia conhecimento sobre como contribuir com conteúdo para o portal. Tais observações deixaram clara a necessidade de implementar duas mudanças. Primeiramente, devem-se prover mecanismos para submissão de contribuições por meio eletrônico ou impresso, deixando claro o trâmite a ser seguido pela informação até que seja publicada no portal. Finalmente, é preciso responder a todas as contribuições propostas, independentemente de seu aproveitamento ou não, a fim de demonstrar consideração e manter a motivação dos usuários em colaborar.

\section{Ação 2: Monitorar o ambiente em busca de informações de interesse do departamento}

As contribuições dos usuários auxiliam no delineamento de seus interesses e permitem que se faça um monitoramento em busca de informações que estejam relacionadas aos interesses previamente manifestados. A implementação desta ação contribuiria para que fosse possível antecipar-se às necessidades dos usuários.

Dessa forma, o monitoramento deve observar as características que determinam o valor da informação para o departamento. Davenport (1998) apresenta os seguintes indicadores para medir o valor da informação: exatidão, oportunidade, acessibilidade, envolvimento, aplicabilidade e escassez.

Atualmente esse monitoramento é feito de forma precária, pois a equipe técnica não possui competência para esse trabalho, nem a quantidade de pessoas necessárias para realizá-lo. O resultado é uma conduta de atualização reativa, quase que exclusivamente dependente das raras contribuições dos usuários. As pessoas entrevistadas demonstraram interesse na adoção de uma postura proativa, mas reconhecem que será muito difícil que isso aconteça devido às restrições já mencionadas de falta de pessoal e falta de autonomia para gerir seu pessoal. 
Para a implementação dessa ação, são necessárias duas etapas. A primeira consiste em identificar sítios confiáveis e com conteúdo relevante para o departamento; e a segunda, em visitar constantemente os referidos sítios, a fim de buscar informações atualizadas que possam invalidar parcial ou completamente o conteúdo publicado no portal.

Ação 3: Realizar auditorias constantes para identificar os principais serviços usados na internet

Uma das formas de melhorar o conteúdo e os serviços do portal é observar o comportamento informacional das pessoas com relação ao acesso à internet e à intranet da organização. $\mathrm{O}$ meio mais eficaz para mapear esse comportamento é por meio da realização de auditorias frequentes, em que os logs de acesso são estudados a fim de identificar quais sítios as pessoas costumam visitar e quanto tempo permanecem conectadas.

No entanto, ao serem perguntados sobre essa possibilidade, os entrevistados mostraram grande preocupação, argumentando que seria invasão de privacidade. Isso porque, considerados os rígidos padrões hierárquicos no departamento, condutas consideradas indesejadas poderiam culminar em sanções.

Inicialmente, foram definidas três etapas para sua implementação dessa ação. A primeira consiste em promover entrevistas individuais nas quais os usuários informem os principais serviços usados na internet/intranet (primeira etapa da ação anteriormente proposta como auditoria). A segunda consiste em estabelecer local reservado para que as entrevistas sejam realizadas sem interferências externas, minimizando circunstâncias inibidoras que possam influenciar as informações coletadas de modo a não refletirem a realidade. A terceira refere-se a definir um roteiro para as entrevistas, visando a evitar fuga do tema abordado e a manter o foco no objetivo principal de identificar os principais serviços de informação utilizados via internet ou intranet de outros departamentos. No entanto, em razão de a proposta de auditorias ter sido terminantemente rejeitada em virtude da manutenção da privacidade dos integrantes da organização, ficou estabelecida sua substituição pela primeira etapa proposta.

\section{Ação 4: Identificar as necessidades de informação dos usuários}

Para Choo (1998), é necessário conhecer os usuários no que diz respeito às informações de que necessitam e ao modo como as buscam. Wilson (1999) acrescenta que a busca por informação é guiada pela necessidade do indivíduo de resolver algum problema ou suprir um estado atípico, insuficiente ou inadequado de conhecimento. Nesse sentido, a identificação das necessidades de informação dos integrantes do departamento servirá para realimentar 
o processo de monitoramento ambiental, que busca informações correlatas com aquelas nas quais o usuário já manifestou interesse. Portanto, a implementação desta ação tornará possível um melhor mapeamento do que realmente interessa aos usuários.

Os entrevistados consideraram válida a iniciativa, manifestando interesse em sua implementação. Ressaltaram, entretanto, que tal ação seria válida se o método de identificar o comportamento informacional dos usuários fosse outro, que não a auditoria dos arquivos de log. Consequentemente, a implementação dessa ação resume-se em iniciar, por meio de entrevistas, a identificação das reais necessidades de informação dos integrantes do departamento. O resultado dessa identificação guiará o processo de monitoramento.

\section{Ação 5: Selecionar informação de interesse do departamento}

A partir do momento em que se tem a colaboração do usuário e, mais precisamente, a identificação de suas necessidades informacionais, é possível que se tenha uma sobrecarga de informações a serem tratadas por uma equipe muito reduzida, como discutido por Davenport (1998). Para evitar esse tipo de sobrecarga no portal, é necessária uma triagem do que realmente é de interesse do departamento e que deva ser publicado.

A seleção de conteúdo é feita atualmente, mas apresenta o problema de restringir ao máximo o conteúdo a ser publicado, resultando em um portal carente de informação relevante. Segundo os entrevistados, o processo de seleção é importante e deve ser mais bem trabalhado para evitar falta de conteúdo relevante ou excesso de informação inútil. Para tanto, é necessária a execução de quatro etapas. A primeira consiste em selecionar conteúdos de acordo com os tipos de informação de interesse do departamento. A segunda refere-se a obter conteúdos em local reconhecidamente idôneo para que seja possível certificar sua credibilidade. A terceira consiste em seguir todo o trâmite necessário à publicação, garantindo a confiabilidade da informação. Por fim, deve-se submeter, em tempo, a análise e publicação, assegurando o critério de oportunidade.

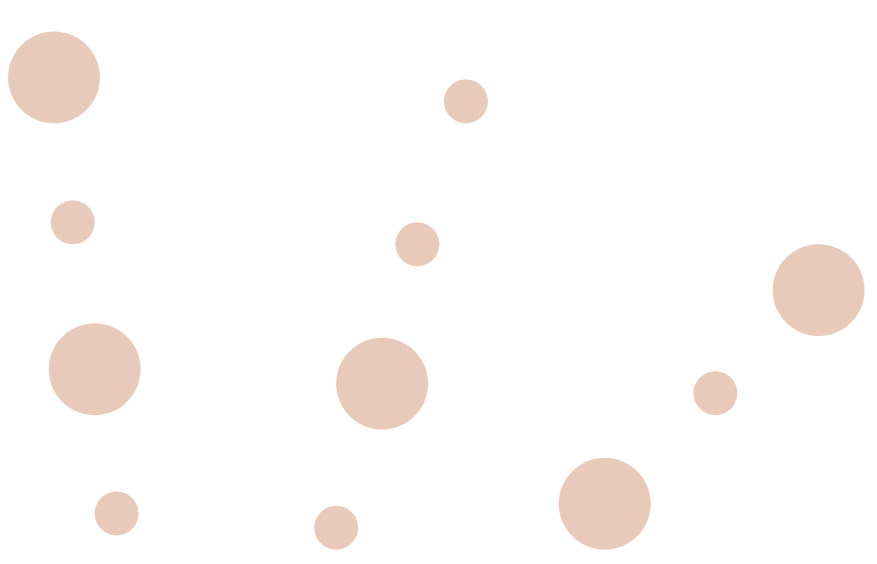


Visando à acomodação das mudanças necessárias, o modelo conceitual do subsistema de seleção de conteúdo foi redefinido, como mostra a figura 9.

Figura 9 - Modelo conceitual reformulado do subsistema "seleção de conteúdo"

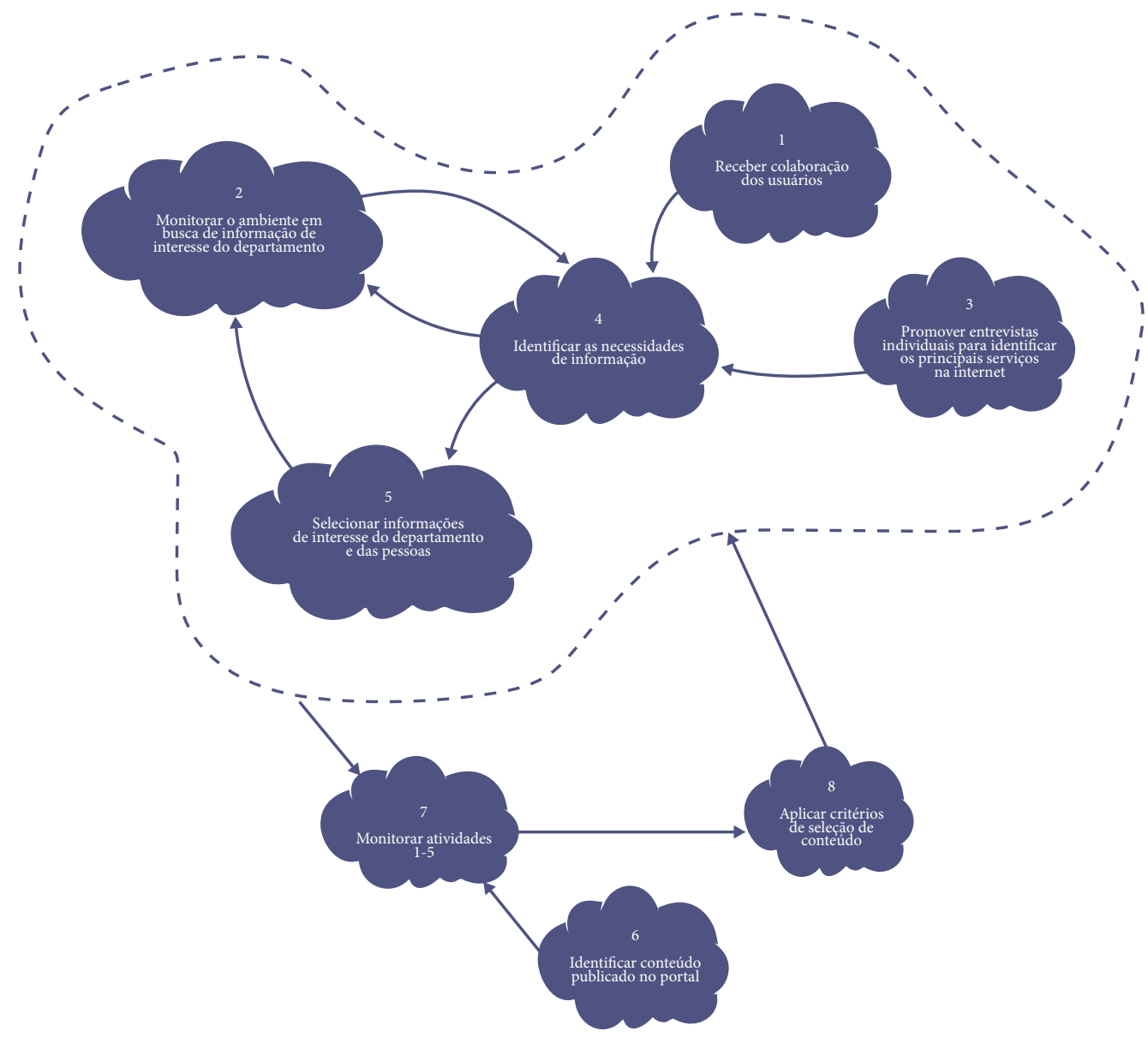

Fonte: Elaboração dos autores (2018).

\section{CONCLUSÃO}

Esta pesquisa teve dois grandes objetivos. O primeiro foi ratificar o pressuposto inicial de que portais corporativos podem ser considerados ferramentas para implementação da gestão do conhecimento organizacional. O segundo foi verificar, a partir do estudo do portal corporativo de um determinado departamento de uma entidade governamental, o motivo pelo qual a iniciativa daquele departamento não surtia os efeitos esperados. Mais que isso, este estudo 
propôs mudanças sistemicamente desejáveis e culturalmente viáveis para que a situação-problema que envolve a construção e o uso do portal corporativo fosse minimizada.

Após a implementação da Metodologia de Sistemas Flexíveis (SSM), que, per se, envolve desde o desenho metodológico da pesquisa até a coleta e análise (com a devida discussão) dos dados, é possível chegar a quatro conclusões. A primeira indica que a aplicação do modelo da SSM, em todas as suas etapas, mostrou-se extremamente válida para o atingimento dos objetivos do estudo, permitindo o entendimento da situação-problema, bem como a proposição de mudanças desejáveis e viáveis no ambiente estudado. A segunda revela que o referencial teórico construído funcionou adequadamente como lente através da qual o problema pôde ser observado. A terceira demonstra que a investigação das questões consideradas mais relevantes para estruturação e definição da situação-problema sob a forma de sistema permitiu uma percepção mais ampla, clara e útil tanto da situação-problema propriamente dita quanto das transformações necessárias ao seu melhoramento. A quarta constata que portais corporativos reúnem as características necessárias à comunicação organizacional e à gestão do conhecimento.

\section{REFERÊNCIAS}

BILHIN, J. Teoria Organizacional, estrutura e pessoas. Lisboa, Instituto Superior de Ciências Sociais e Políticas, 2001.

BOLDS, R. Enterprise information portals: portals in puberty. KMWorld. July/August 2001.

CHECKLAND, P. Systems Thinking, Systems Practice. Chichester, Wiley, 1993.

CHOO, C. ISS Seminar on knowledge management. 17/18 mar. 1998. Disponível em: <http:// choo.fis.utoronto.ca/iss/km/IN.adv.html>. Acesso em: 29 dez. 2002.

COUPRIE, D. et al. Soft System Methodology. Disponível em: <http://sern.ucalgary.ca/ courses/seng/613/F97/grp4/ssmfinal.html>. Acesso em: 14 nov. 2004.

DAVENPORT, T. Ecologia da informação: porque só a tecnologia não basta para o sucesso na era da informação. São Paulo: Futura, 1998.

DRUCKER, P. F. O novo papel da administração. São Paulo: Nova Cultural, 1986.

ECKERSON, W. 15 Rules for Enterprise Portals. Oracle Magazine. Jul. 1999. Disponível em: <http://www.oracle.com/oramag/oracle/99-Jul/index.html?49ind.html>. Acesso em: 11 jan. 2003. 
FINKELSTEIN, C. The emergence and potential of enterprise information portals (EIPs). The Data Administration Newsletter. [s.l.], set. 1999. Business Intelligence News, Articles, \& Education.Disponivel em: <http://www.tdan.com/i010fe02.htm>. Acesso em: 08 jan. 2003.

GIBSON, J. Organizações: comportamento, estrutura, processos. São Paulo: Atlas, 1981.

PARRY, J. Psicologia da comunicação humana. São Paulo: Cultrix, 1972.

SCHEIN, E. Organizational culture and leadership. 2. ed. San Francisco: Jossey-Bass, 1986.

SENGE, P. M. A Quinta Disciplina: arte, teoria e prática da organização de aprendizagem. São Paulo, Best Seller, 1990.

SHARPE, A. et al. The need for portals. KMWorld. v. 10, Issue 10. nov./dec., 2001.

TORRES, A. B. Portais corporativos como ferramentas para gestão do conhecimento: desafios de uma instituição governamental.. 2004. 100 f. Dissertação (Mestrado) - Curso de Ciências da Informação, Departamento de Informação e Documentação, Universidade de Brasília, Brasília, 2004.

WILSON, T. D. Models in information behaviour research. Journal of Documentation. v. 55, n. 3, p.249-270, jun. 1999.

ZIMMERMAN, K. Portals offer personalized windows to corporate knowledge. KMWorld, v. 11, n. 2. fev. 2002. 


\section{CAPÍTULO 16}

0

O

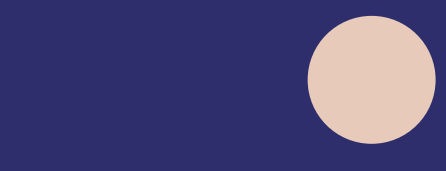

0
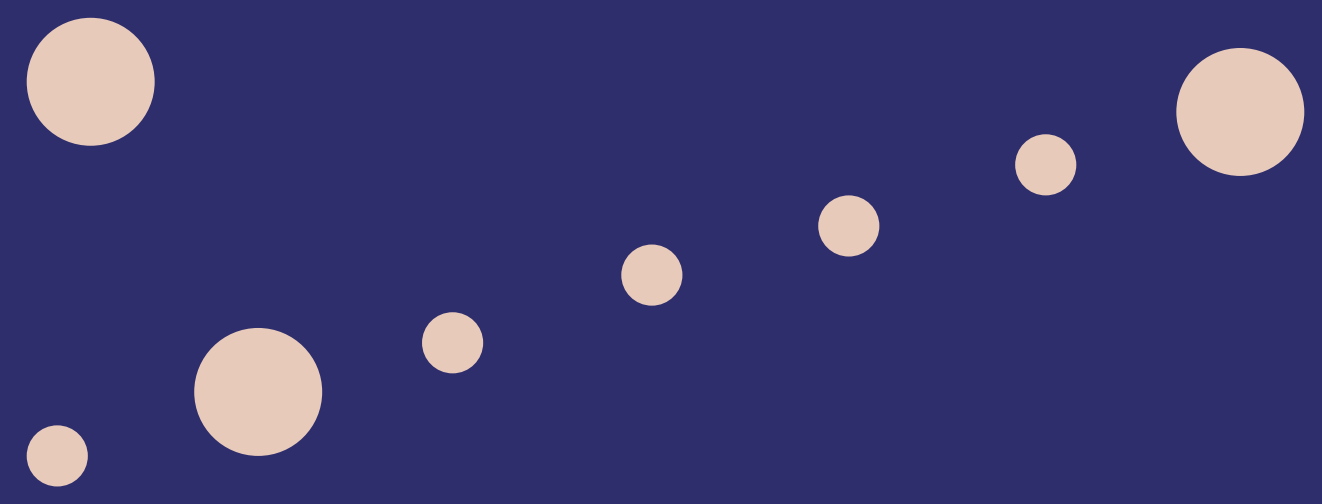

- 00

0 


\title{
COMUNICAÇÃO INFORMAL E SOCIALIZAÇÃO DO CONHECIMENTO EM INSTITUIÇÕES FINANCEIRAS
}

\author{
ANDRÉ LUIZ VALENÇA DA CRUZ \\ SELY MARIA DE SOUZA COSTA
}

\section{INTRODUÇÃO E FUNDAMENTAÇÃO TEÓRICA}

O pressente trabalho centrou o foco das discussões em questões relacionadas aos aspectos teóricos e práticos da comunicação organizacional. Por meio da análise da comunicação informal em instituições financeiras, o estudo buscou identificar os principais elementos relacionados ao processo de comunicação nesse tipo de instituição. Mais que isso, adicionou questões da gestão do conhecimento, considerando a importância da imbricação desta com a comunicação. Isso porque, tal como repetidamente citado na literatura, a comunicação em uma organização é componente fundamental da gestão do conhecimento. O estudo visou, desse modo, a contribuir para um melhor entendimento das inter-relações do processo de comunicação organizacional e da gestão do conhecimento, possibilitando uma discussão mais aprofundada. Para isso, como não poderia deixar de ser, uniu a abordagem teórica sobre o tema com a investigação empírica no ambiente estudado.

Tubbs e Moss (2003, p. 448) definem "comunicação organizacional” como a gama de eventos que envolvem a "comunicação humana ocorrendo no contexto das organizações". Para Kunsch (2003), o processo comunicacional é fundamental tanto para o processamento interno quanto para o relacionamento externo das organizações. A autora observa que a comunicação interna trata das trocas de informações ocorridas entre os empregados e administradores da instituição e deles entre si, e pode obedecer aos seguintes fluxos: descendente, ascendente, horizontal e transversal.

É importante ressaltar que a troca de informações no ambiente interno à organização tem como objetivos principais a consecução das tarefas, o bom funcionamento e o atendimento dos objetivos da instituição, ocorrendo mediante variadas iniciativas. Ainda segundo Kunsch 
(2003), tal troca ocorre tanto por meio de canais formais, representados pelos documentos oficiais, quanto informais, relacionados às pessoas.

De fato, ambas, comunicação formal e comunicação informal, são essenciais à organização. Barker e Gaut (2002, p. 180) abordam essa questão afirmando que "as estruturas de comunicação formal e informal trabalham como lâminas de uma tesoura. Sem uma delas, uma organização não pode funcionar efetivamente". Simon (apud KUNSCH, 2003, p. 82) acrescenta que "por mais detalhado que seja o sistema de comunicação formal estabelecido na organização, terá que ser sempre suplementado por canais informais através dos quais fluirão informações, aconselhamentos e, inclusive, ordens".

Outra questão a ser elencada no estudo da comunicação organizacional diz respeito ao conteúdo comunicado. Um dos enfoques possíveis no estudo do objeto é a discussão do conhecimento transmitido por meio dos canais de comunicação. Nesse contexto, surge a necessidade de sua classificação como conhecimento compartilhado. Choo (2000) propõe uma classificação para o conhecimento organizacional, considerando três tipos: explícito (expresso em documentos e coletivo), tácito (não expresso e individual) e cultural (não expresso e coletivo).

É possível destacar aqui que, consideradas as questões abordadas na literatura especializada, torna-se clara a relação entre a comunicação organizacional e a gestão do conhecimento. Isso porque é por meio da comunicação e das suas muitas possibilidades que ocorre o compartilhamento de grande parte do conhecimento organizacional.

Seguindo essa linha de pensamento, entende-se que a melhoria do processo de comunicação nas organizações implica em melhoria da gestão do conhecimento. Nesse contexto, a comunicação informal tem caráter essencial, pois é por meio dela que ocorrem as trocas do conhecimento tácito. Para tanto, faz-se necessária a busca por soluções que visem a aperfeiçoar a troca de conhecimento por via informal. Uma das possibilidades é o desenvolvimento de soluções tecnológicas que facilitem o fluxo informal e possibilitem, como consequência, maior socialização do conhecimento organizacional.

Entretanto, antes do desenvolvimento e da implementação da tecnologia, é interessante que sejam identificados os atributos essenciais que devem ser apresentados pelo instrumento para que essa atinja os objetivos propostos. Assim, o estudo aqui relatado procurou responder quais são as características desejadas em uma solução tecnológica que, utilizada como recurso de gestão do conhecimento, contribua para aumentar a socialização de conhecimento entre empregados de organizações financeiras e entre esses com o restante da organização, por meio da comunicação informal. Com essa pergunta como foco, o objetivo da pesquisa se concentrou em propor características ideais de uma solução tecnológica que contribua para aumentar a socialização de conhecimento entre os empregados de uma organização financeira, por meio 
da comunicação informal, podendo, desse modo, ser utilizada como ferramenta de gestão do conhecimento.

Em um ambiente moderno de incertezas, hiperinformação e mudanças bruscas de direção dos mercados, torna-se imprescindível às organizações a tempestividade na captação e na interpretação de informações que subsidiem ações rápidas e eficientes. Nesse ambiente, a comunicação organizacional assume papel importantíssimo, em particular a comunicação informal, pois:

O sistema formal de toda organização - o conjunto de canais e meios de comunicação estabelecidos de forma consciente e deliberada - é suplementado, no decorrer de pouco tempo, por uma rede informal de comunicações, igualmente importante que se baseia nas relações sociais intra-organizativas e é uma forma mais rápida de atender a demandas mais urgentes e instáveis. (KUNSCH, 2003, p. 82, grifo nosso)

A autora acrescenta, ainda, que a comunicação informal “[...] deve ser canalizada para o lado construtivo, ajudando as organizações a buscar respostas muito mais rápidas para as inquietudes ambientais [...]" (KUNSCH, 2003, p. 84, grifo nosso). Portanto, os canais informais, por sua natureza flexível, tornam-se um excelente meio de promover a troca de conhecimento organizacional em instituições modernas. Diante dessas afirmações, torna-se valiosa qualquer iniciativa que objetive incrementar a comunicação informal e melhorar o intercâmbio de conhecimento. Portanto, a melhora na comunicação informal implicará a intensificação das trocas informacionais, contribuindo para a maior difusão do conhecimento, característica primordial da gestão do conhecimento.

No contexto atual, as iniciativas de gestão do conhecimento são baseadas no desenvolvimento de sistemas voltados à administração do conhecimento organizacional de maneira centralizada, tornando o acesso às informações burocratizado e pouco espontâneo. Grande parte dos sistemas de gestão do conhecimento utilizados atualmente não leva em consideração o fato de que o conhecimento organizacional flui através dos canais de comunicação e, consequentemente, por meio das pessoas envolvidas nos processos.

Nessa perspectiva, Malhotra (1998, p. 59) defende uma visão de gestão do conhecimento que considere a ação conjunta entre o tecnológico e o humano. Segundo o autor, "a gestão do conhecimento é a combinação de sinergias entre dados, informação, sistemas de informação e a capacidade criativa e inovadora dos seres humanos". Na mesma linha, Teixeira Filho (2001) e Bueno (2005) acrescentam que a comunicação organizacional é um componente crucial na gestão do conhecimento. Seguindo o mesmo pensamento, Carvalho (2006, p. 7) afirma que, "mais do que coletar, tratar e disseminar a informação, é 


\section{0| 401}

necessário gerar valor e sentido [...] isso só ocorre a partir do estabelecimento de um amplo processo comunicacional".

As ideias desses autores respaldam a importância da comunicação no processo de gestão do conhecimento, tendo como consequência o desenvolvimento de instrumentos tecnológicos que facilitem as trocas informacionais. Essas trocas, por sua vez, ocorreriam entre os que detêm o conhecimento e os que precisam dele para executar suas tarefas, sem intermediários. Tais soluções, portanto, atuariam no campo da comunicação informal, servindo de canal para o compartilhamento, principalmente do conhecimento individual e não expresso (tácito).

Percebe-se, nesse contexto, que o desenvolvimento de ferramentas tecnológicas é iniciativa de significativa importância, particularmente quando se pretende implementar ou incrementar a gestão do conhecimento organizacional. Destarte, o mapeamento de trocas de informações organizacionais via canais informais, quantitativa e qualitativamente, contribuirá para o conhecimento e a discussão da dinâmica da comunicação organizacional informal. Mais que isso, permitirá aplicações práticas, nas organizações, do conhecimento acadêmico produzido no contexto da Ciência da Informação.

\section{METODOLOGIA}

O presente estudo foi realizado em uma instituição financeira pública e baseou-se tanto na abordagem quantitativa quanto na qualitativa. Partindo da premissa de que o estudo qualitativo auxilia na interpretação dos dados quantitativos e a complementa, pois adiciona explicações aos fatos observados quantitativamente (CRESWELL, 2007), adotou-se o método misto proposto pelo autor. Nesse sentido, os procedimentos metodológicos constituíram três fases distintas e complementares, as quais são descritas a seguir.

Na primeira fase, efetuou-se o mapeamento da comunicação informal no ambiente proposto, por meio da aplicação de uma lista de verificação. Na segunda fase, por meio de entrevista semiestruturada, foram coletados dados acerca da percepção dos interlocutores, identificados na primeira fase, com relação ao processo de comunicação na organização. A terceira fase caracterizou-se pela comparação dos dados coletados nas duas fases anteriores, fornecendo os insumos necessários à discussão dos resultados e às conclusões do estudo. Assim, a etapa quantitativa visou a identificar as demandas por informações recebidas em um setor organizacional via canais informais, envolvendo a participação de dez assessores, o que correspondeu a $90 \%$ do universo. A etapa qualitativa visou a identificar a percepção de solicitantes de informações com relação ao processo de comunicação na organização, em uma população composta pelos solicitantes de informações detectados nas listas de verificação aplicadas na primeira etapa. Buscou-se selecionar os usuários que mais utilizam a comunicação informal 
nas suas atividades diárias. Finalmente, a última etapa englobou a interpretação dos dados colhidos nas duas etapas, comparando-os, buscando-se respostas à pergunta da pesquisa.

\subsection{Modelo teórico-conceitual da pesquisa}

Com base na fundamentação teórica obtida a partir da revisão da literatura relevante e do estudo do ambiente de pesquisa, foi desenvolvido o modelo teórico-conceitual da pesquisa, o qual apresenta o processo de compartilhamento do conhecimento organizacional por meio da comunicação apoiada pela tecnologia (Figura 1). Parte-se do princípio de que o conhecimento global da organização, ou seja, explícito, tácito e cultural (CHOO, 2006), é compartilhado por meio da comunicação formal ou informal. O conhecimento cultural, apesar de ser componente do conhecimento organizacional, não é apresentado no modelo por não fazer parte do escopo deste estudo.

Observa-se, ainda, que tanto a comunicação formal quanto a comunicação informal (KUNSCH, 2003), apesar de suas diferenças conceituais e práticas, possuem pontos em comum (representados no modelo pela intersecção entre as circunferências). Esse entendimento deriva do fato de que há conteúdos que só podem ser transmitidos exclusivamente por um tipo de canal e há outros que podem ser compartilhados por ambos. Tal seletividade de canais é baseada na natureza do conhecimento compartilhado e nos efeitos esperados da comunicação.

O conhecimento explícito (documental) é transmitido prioritariamente por meio da comunicação formal, que, na maioria das vezes, o legitima. A comunicação informal, por sua vez, é o veículo mais adequado para o compartilhamento do conhecimento tácito (não registrado). $\mathrm{Na}$ intersecção entre os dois tipos de comunicação, há o compartilhamento do conhecimento internalizado, ou seja, o conhecimento explícito convertido em tácito mediante a internalização (NONAKA; TAKEUCHI, 1997).

Identifica-se, no centro da ilustração, o componente tecnológico. A linha sinuosa que o representa transmite a noção da flexibilidade necessária às soluções tecnológicas para que essas se adequem às variadas realidades organizacionais. A tecnologia, nesse modelo, representa a interface entre os atores do processo de comunicação e serve de apoio às trocas de conhecimento, seguindo o modelo da rede cooperativa descrito por Swan et al. (1999). Segundo o modelo, o uso de tecnologias da informação permeia o compartilhamento do conhecimento por meio de canais formais e informais de comunicação nas organizações.

Exemplificando: uma comunicação oficial (conhecimento explícito) só terá efeito prático se transmitida por meio de um canal formal, pois depende disso para garantir a sua efetividade. Por sua vez, impressões pessoais (baseadas na experiência) são conteúdos tipicamente 
informais (conhecimento tácito) que são transmitidos mais eficazmente por canais informais. Há, contudo, conteúdos que podem ser transmitidos por ambos os canais sem que percam sua legitimidade. É o caso, por exemplo, das instruções e normas contidas nos manuais internos, que podem ser acessados tanto formalmente, pelo acesso direto aos registros documentais, quanto por meio das pessoas que internalizaram seu conteúdo e o disponibilizam informalmente.

Figura 1 - Modelo teórico-conceitual da pesquisa

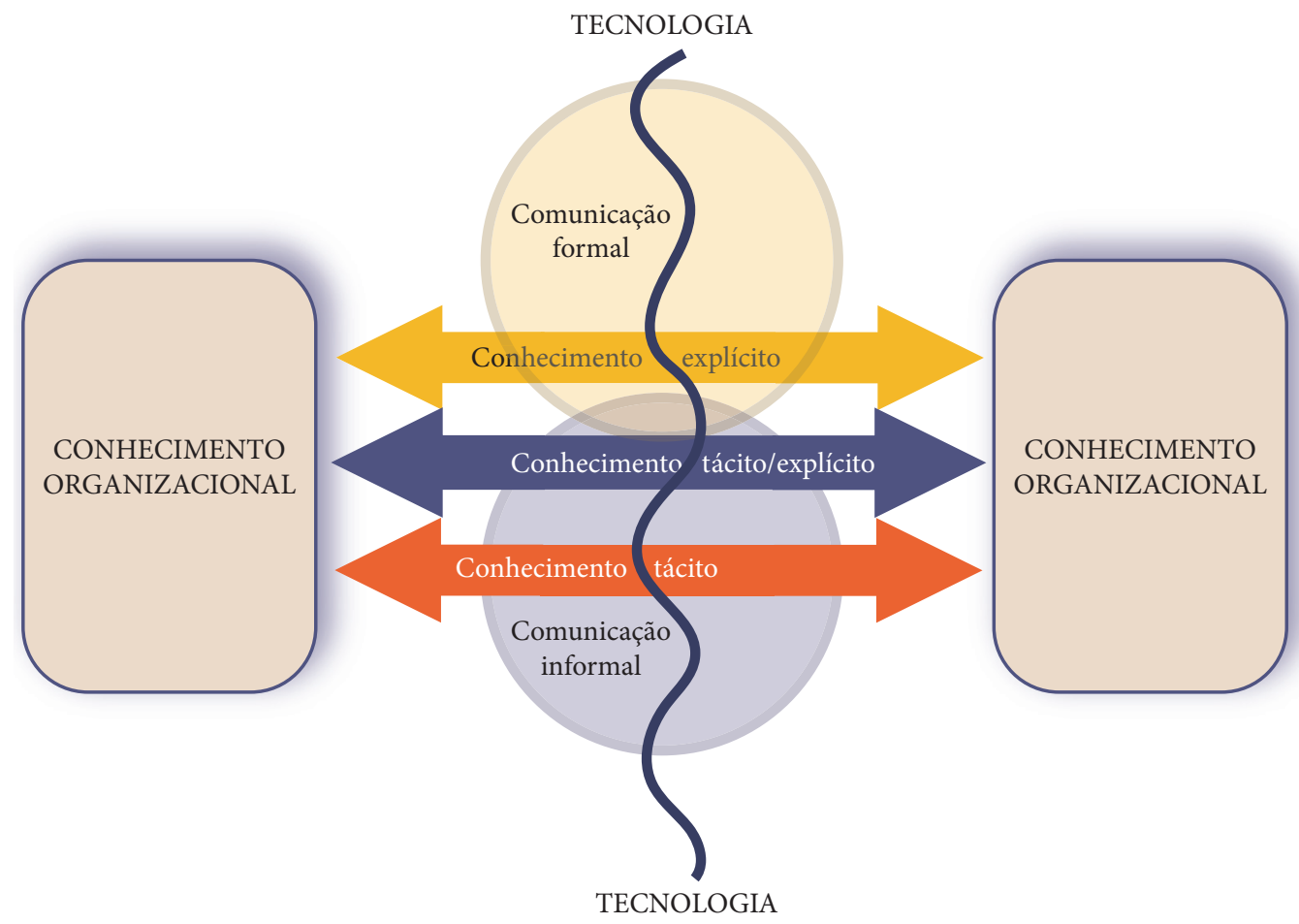

Fonte: Elaboração dos autores (2018).

\section{ANÁLISE DOS RESULTADOS}

Os resultados obtidos na presente pesquisa estão apresentados em relação às duas primeiras etapas de coleta de dados, visto que constituem, de fato, trabalho de campo. Essa estratégia visa ao melhor entendimento, e utiliza o tipo de abordagem adotado em cada etapa, nomeadamente quantitativa (listas de verificação) e qualitativa (entrevistas semiestruturadas).

Os resultados da pesquisa quantitativa revelaram seis particularidades. A primeira, relacionada aos canais de comunicação, mostrou que a maioria das solicitações informais $(88,6 \%)$ 
ocorreu via telefone e 1,9\% delas aconteceu de forma combinada por telefone/e-mail ou telefone/pessoalmente. A segunda particularidade, pertinência da solicitação de informações, revelou que $93 \%$ das demandas eram pertinentes, visto que estavam relacionadas às tarefas demandadas pela instituição. Sobre a terceira particularidade, constituída do atendimento das demandas, os resultados mostraram um percentual de $85 \%$ de demandas atendidas. A quarta, que focou o atendimento a demandas em relação à pertinência delas, revelou que $73 \%$ das demandas pertinentes foram atendidas. $\mathrm{Na}$ quinta particularidade, disponibilidade em canais formais, das informações requeridas, os resultados mostraram que $30 \%$ das informações solicitadas podiam ser encontradas em algum normativo interno da organização. Finalmente, sobre o nível funcional do demandante, verificou-se que $54 \%$ das demandas por informação foram originadas por funcionários de nível hierárquico superior ao dos demandados, 27\% representaram trocas entre o mesmo nível funcional e 19\% das solicitações foram feitas por funcionários de nível inferior ao dos respondentes.

Os resultados da pesquisa qualitativa estão descritos de acordo com cada questão apresentada aos dez respondentes das entrevistas. Boa parte da análise é quantitativa, apresentando o dado sobre o número de respondentes, para que se tenha ideia quantitativa das respostas obtidas, o que, por seu turno, visa a denotar a importância ou não do tópico, na percepção deles. A maioria tem, em média, 20 anos de trabalho na instituição com uma variação de tempo na faixa entre 6 e 33 anos. Portanto, parecem ser experientes no que fazem.

Sobre as estratégias usadas na busca por informações, foi possível perceber que a maioria (oito respondentes) utiliza dois canais de busca por informações úteis ao trabalho que realizam: sistemas internos e pessoas. Um respondente busca somente pessoas e outro somente os sistemas internos.

No que concerne às vantagens e desvantagens da comunicação formal e da comunicação informal, a maioria citou mais as vantagens, como demonstrado, a seguir, no quadro 1.

Quadro 1 - Vantagens e desvantagens da comunicação formal e informal

\begin{tabular}{|c|c|c|c|}
\hline \multicolumn{2}{|c|}{ FORMAL } & \multicolumn{2}{c|}{ INFORMAL } \\
\hline VANTAGENS & DESVANTAGENS & VANTAGENS & DESVANTAGENS \\
\hline $\begin{array}{c}\text { Segurança (4) } \\
\text { Registro (6) }\end{array}$ & Burocracia (2) & $\begin{array}{c}\text { Rapidez (6) } \\
\text { Agilidade (2) }\end{array}$ & Difícil recuperação (2) \\
\hline
\end{tabular}

Fonte: Elaboração dos autores (2018).

As situações em que os entrevistados fazem uso da comunicação informal assim como os motivos pelos quais o fazem estão resumidos no quadro 2 , em que foram incluídos os dados 
com mais citações. É interessante observar o porquê dessa utilização, que parece ser reflexo da burocracia citada em relação à comunicação formal.

Quadro 2 - Momentos/situações e motivos para o uso da comunicação informal

\begin{tabular}{|c|c|}
\hline MOMENTOS/SITUAÇÕES & MOTIVOS \\
\hline Diariamente & Rapidez \\
Para procedimentos simples & Agilidade \\
& Objetividade \\
\hline
\end{tabular}

Fonte: Elaboração dos autores (2018).

Nesta pesquisa, foi importante identificar as percepções dos respondentes sobre o que poderia garantir a fidedignidade das informações obtidas por meio de canais informais, uma vez que essas não estão registradas em normativos internos ou em documentos. Os resultados foram variados e dispersos, e correspondem a quatro fatores. O primeiro refere-se à expertise profissional da fonte. O segundo diz respeito à confiança no conhecimento do assunto por parte do demandado. O terceiro relaciona-se ao interesse do demandante; e o quarto, à utilização de discurso claro e objetivo na comunicação. Somente um dos entrevistados declarou que não é possível garantir a credibilidade das informações obtidas de maneira informal.

Independentemente dessas percepções, a totalidade dos que responderam as perguntas feitas na entrevista demonstraram a noção de que há uma relação positiva entre a comunicação informal e seu grau de confiança.

No que concerne à percepção dos entrevistados a respeito das possibilidades de utilização da tecnologia como elemento facilitador do processo de comunicação organizacional como um todo, os resultados foram variados. Segundo o ponto de vista dos entrevistados, são quatro as principais contribuições da tecnologia à comunicação organizacional: 1) possibilitar a recuperação da informação; 2) proporcionar maior rapidez, segurança, agilidade, fidedignidade e tempestividade ao processo de comunicação; 3) adequar o fornecimento de informações ao perfil do usuário, direcionando até mesmo a demanda à fonte correta; 4) unificar a comunicação formal e a comunicação informal em uma solução tecnológica.

É importante lembrar que o estudo focou especificamente a comunicação informal no ambiente organizacional. Procurou-se, portanto, identificar as principais características da comunicação informal que deveriam ser incorporadas a uma solução tecnológica que favoreça esse tipo de comunicação. As características mais citadas pelos entrevistados - duas vezes cada uma - foram a rapidez, a agilidade e a espontaneidade. Outras características, mais dispersas, também foram citadas: objetividade, participação coletiva, clareza e possibilidade de identificação das características do interlocutor. 


\section{DISCUSSÃO DOS RESULTADOS}

Iniciando a discussão sobre os meios de comunicação utilizados na busca por informações, os resultados, que evidenciaram o uso indiscriminado tanto da comunicação formal quanto da informal, podem ser comparados aos obtidos mais de duas décadas antes do presente estudo, como o de Weedman (1992). O autor realizou seu estudo com editores, revisores e críticos literários. Apesar da diferença nos ambientes pesquisados, e do caráter do ambiente estudado por Weedman, há semelhança entre os dados, uma vez que a maioria dos respondentes de seu estudo, embora em menor proporção (50\%) do que no presente estudo (80\%), utiliza tanto canais formais quanto informais. A mesma proporção nos dois estudos (10\%) utiliza exclusivamente a comunicação formal. Tais achados tendem a confirmar o entendimento de que tanto a comunicação formal quanto a informal são necessárias ao cumprimento dos objetivos organizacionais, embora essa análise careça de mais dados para que seja ratificada, de fato.

Considerando-se os resultados obtidos quantitativamente por meio da aplicação da lista de verificação, a quase totalidade das solicitações por informações eram efetivadas via telefone. Esses resultados confirmam a afirmação de Barker e Gaut (2002) de que a comunicação informal acontece principalmente via telefone, e-mail ou pessoalmente. É interessante, embora previsível, que a minoria (11\%) dos entrevistados do presente estudo utilize os dois últimos meios citados pelos autores. Isso, por sua vez, certamente está relacionado ao período investigado.

No que concerne aos fatores relacionados com o comportamento informacional, os resultados obtidos encontram respaldo no pensamento de Kraut et al. (1990), ao afirmarem que a comunicação informal pode servir a diversos propósitos, e, para cada um deles, é possível formar uma rede específica de comunicação baseada em critérios de confiança, expertise e trabalho. De fato, os resultados obtidos no presente estudo apontam para a confiança dos emissores na expertise dos receptores. Quanto ao tipo de rede de comunicação formada por essas interações, Krackhardt e Hanson (1993) as classificam como redes de consulta, utilizadas, segundo os autores, para obter informações específicas de especialistas. Foi o que se verificou nos resultados obtidos.

O trabalho de Kraut et al. (1990), já citado anteriormente, destaca a efetividade da comunicação informal, que é proporcionada pelo elemento "feedback". Nesse sentido, é possível inferir que é a tempestividade do meio informal que tende a tornar a comunicação mais efetiva. Isso porque, como ressalta Kunsch (2003), a comunicação informal constitui a forma mais rápida de atender demandas. Não parece restar dúvidas, portanto, de que essa é a motivação que faz com que os demandantes de informação no contexto estudado optem pelos canais informais de comunicação. 


\section{6| 407}

Nota-se, nesse contexto, um elevado grau de compartilhamento de conhecimento por meio de canais informais no ambiente pesquisado (conhecimento considerado como tácito). No entanto, levando em conta que esse conhecimento deve, no futuro, ser explicitado, formando um conjunto de registros formais, parece possível inferir sobre a possibilidade do uso de mecanismos de gestão do conhecimento nesse contexto. É importante notar que, de fato, a comunicação informal, na maioria dos casos, contribui mais significativamente para a construção do conhecimento nas organizações, talvez em razão da questão da confiança entre os interlocutores.

Tubbs e Moss (2003) descrevem dois componentes da confiança no âmbito organizacional: a confiança afetiva, baseada nas relações pessoais, e a confiança cognitiva, alicerçada na competência técnica do interlocutor. De fato, a confiança é fator que exerce influência no momento da escolha dos fornecedores de informações, contribuindo para a formação espontânea de redes baseadas na confiança recíproca, tal como mostram os resultados obtidos no presente estudo.

A análise do fluxo de comunicação mostra a existência dos dois fluxos (descendente e ascendente), com diferenças em relação à comunicação informal, em razão de sua influência sobre fluxos transversais, que não obedecem necessariamente às hierarquias organizacionais. A possibilidade de saltar etapas agiliza o processo de obtenção da informação, o que foi considerado positivo, pela possibilidade que a comunicação informal oferece para o estabelecimento de diferentes caminhos para aquisição da informação relevante. Nesse caso, a posição organizacional não se refere somente à hierarquia ou às relações superior-subordinado, mas também, como já discutido anteriormente, à confiança no interlocutor. Pode, ainda, estar relacionado ao posicionamento social do demandante no âmbito das redes de comunicação (KRAUT et al., 1990; MACEDO, 1999; ISAACS et al., 1997), o que também influenciará, em igual ou maior escala, a escolha do caminho a ser seguido em busca da informação importante ao trabalho diário.

Entretanto, apesar dos aspectos positivos da comunicação informal, há motivos que levam à utilização da comunicação formal, tais como a segurança e a existência de registro formal, cruciais quando é necessário comprovar informações obtidas para a tomada de decisões. Portanto, como descrito por Kunsch (2003) e por Barker e Gaut (2002), os dois canais de comunicação coexistem no ambiente organizacional e desempenham papéis específicos e complementares, colaborando, assim, para o atingimento dos objetivos da organização. Nesse contexto, as contribuições das tecnologias de informação desempenham papel crucial, especialmente quanto à possibilidade da criação de soluções tecnológicas que melhorem os fluxos de comunicação na organização.

\section{CONCLUSÕES}

O presente trabalho, realizado em uma instituição financeira federal, teve como objetivo caracterizar o processo de comunicação informal, identificando quais de suas características deveriam 
estar presentes em uma solução tecnológica que viesse a ser desenvolvida para alavancar esse tipo de comunicação na instituição. A identificação das características e dos componentes principais, de suas vantagens e do papel das tecnologias permitiu chegar a algumas conclusões, as quais são apresentadas com base nos objetivos da pesquisa. A utilização das abordagens quantitativa e qualitativa permitiu ampla visão sobre o problema investigado, tornando possíveis as conclusões a seguir.

A busca por informação por meio de canais formais e informais constitui o padrão de comunicação na organização estudada.

O telefone é o meio mais utilizado na busca por informações úteis ao trabalho diário, na comunicação informal.

As solicitações formuladas informalmente são, em sua grande maioria, pertinentes, o que está relacionado com o conhecimento claro de seus emissores a respeito da expertise dos receptores, além da confiança dos primeiros em relação aos últimos.

A confiança, técnica ou pessoal, é fator que influencia diretamente a aceitação pelo solicitante da informação obtida para a concretização de ações de trabalho.

A maior parte das solicitações por informação é atendida, independentemente de serem pertinentes ou não. Esse feedback estimula o uso da comunicação informal.

Os dois canais de comunicação oferecem tanto vantagens quanto desvantagens para a comunicação organizacional.

A comunicação informal interdepartamental acontece por meio de fluxos horizontais e transversais.

As principais características da comunicação informal que devem ser incorporadas a soluções tecnológicas desenvolvidas para esse fim são a espontaneidade, a agilidade e a rapidez.

\section{REFERÊNCIAS}

BARKER, L. L.; GAUT, D. R. Communication. 8. ed. Boston: Allyn and Bacon, 2002.

BELKIN, N. J. Information concepts for information science. Journal of Documentation, London, v. 34, n. 1, p. 55-85, Mar. 1978. 
BORKO, H. Information science: what is it? American Documentation, Washington, DC, v. 19, n. 1, p. 3-5, Jan. 1968.

BUENO, W. C. Comunicação empresarial no Brasil. São Paulo: All Print, 2005.

CARVALHO, H. A comunicação como fator crítico de sucesso nos processos de gestão da informação e do conhecimento nas organizações. UNIrevista, São Leopoldo, v. 1, n. 3, p.111, jul. 2006.

CHOO, C. W. A organização do conhecimento: como as organizações usam a informação para criar significados, construir conhecimento e tomar decisões. 2. ed. São Paulo: Editora Senac, 2006.

$\mathrm{CHOO}$, Chun W. Working with knowledge: how information professionals help organizations manage what they know. Library Management, v. 21, n.8, 2000. Disponível em: <http://choo. fis.utoronto.ca/lm/>. Acesso em: 19 nov. 2009.

CRESWELL, J. W. Projeto de pesquisa: métodos qualitativo, quantitativo e misto. 2. ed. Porto Alegre: Artmed, 2007.

CURVELLO, J. J. A. A comunicação organizacional como fenômeno, como processo e como sistema. Organicom, edição especial, n. 10-11, p. 109-114, 2009.

GUTIÉRREZ, M. P. O conhecimento e sua gestão em organizações. In TARAPANOFF, Kira (Org.). Inteligência, informação e conhecimento. Brasília: Ibict; Uneco, 2006.

ISAACS, E. A. et al. Informal communication re-examined: new functions for video in supporting opportunistic encounters. In: FINN, K.; SEUEN, A.; WILBUR, S. Video-mediated communication. Mahwah, NJ: Lawrence Erlbaum, 1997.

KRACKHARDT, D.; HANSON, J. R. Informal networks: the company behind the chart. Harvard Business Review, Boston, p. 105-111, Jul./Aug. 1993.

KRAUT, R. E. et al. Informal communication in organizations: form, function and technology. In: OSKAMP, S.; SPACAPAN, S. (Eds). Human reactions to technology. The Claremont Symposium on Applies Social Psychology. Beverly Hills, CA: Sage, 1990.

KUNSCH, M. M. K. Planejamento de relações públicas na comunicação integrada. Ed. rev. e aum. São Paulo: Summus, 2003. 
MACEDO, T. M. B. Redes informais nas organizações: a co-gestão do conhecimento. Ciência da Informação, Brasília, DF, v. 28, n. 1, p. 94-100, jan. 1999.

MALHOTRA, Y. Deciphering the knowledge management hype. Journal for Quality \& Participation. Cincinnati, Ohio, v. 21, n. 4, p. 58-60, Jul./Aug. 1998.

NONAKA, I.; TAKEUCHI, H.. Criação de conhecimento na empresa: como as empresas japonesas geram a dinâmica da inovação. São Paulo: Campus, 1997.

SARACEVIC, T. The interdisciplinanary nature of information science. Ciência da Informação, Brasília, DF, v. 24, n. 1, p. 36-41, jan./abr. 1995.

SWAN, J. A. et al. Knowledge management and innovation: networks and networking. Journal of Knowledge Management, Bingley, v. 3, n. 4, p. 262-275, 1999.

TEIXEIRA FILHO, J. Gestão do conhecimento e comunicação informal. Insight Informal, 2001. Disponível em: <http://www.informal.com.com>. Acesso em: 18 mai. 2008.

TUBBS, S. L.; MOSS, S. Human communication: principles and contexts. 9. ed. New York: Mc Graw Hill, 2003.

WEEDMAN, J. Informal and formal channels in boundary-spanning communication. Journal of the American Society for Information Science, Washington, DC, v. 43, n. 3, p. 257-267, Apr.1992. 


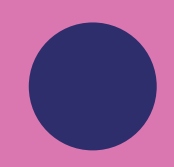

$\bullet$

○

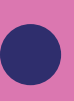

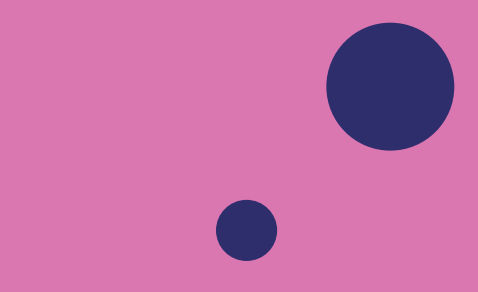

0

$.0^{\circ} \cdot \bullet$

$\cdot 0 \cdot 0$

0

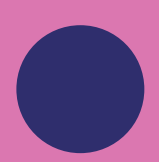

0

○

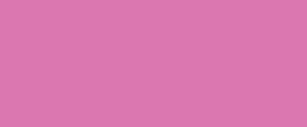

$$
.
$$

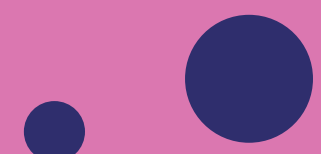$$
\text { . }
$$

$$
\text { . }
$$

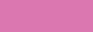

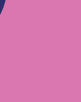




\section{AUTORES}




\section{SOBRE OS AUTORES}

O

0

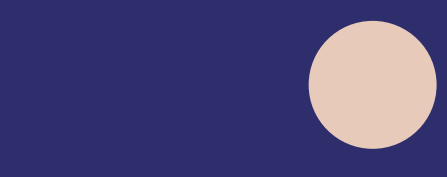

○
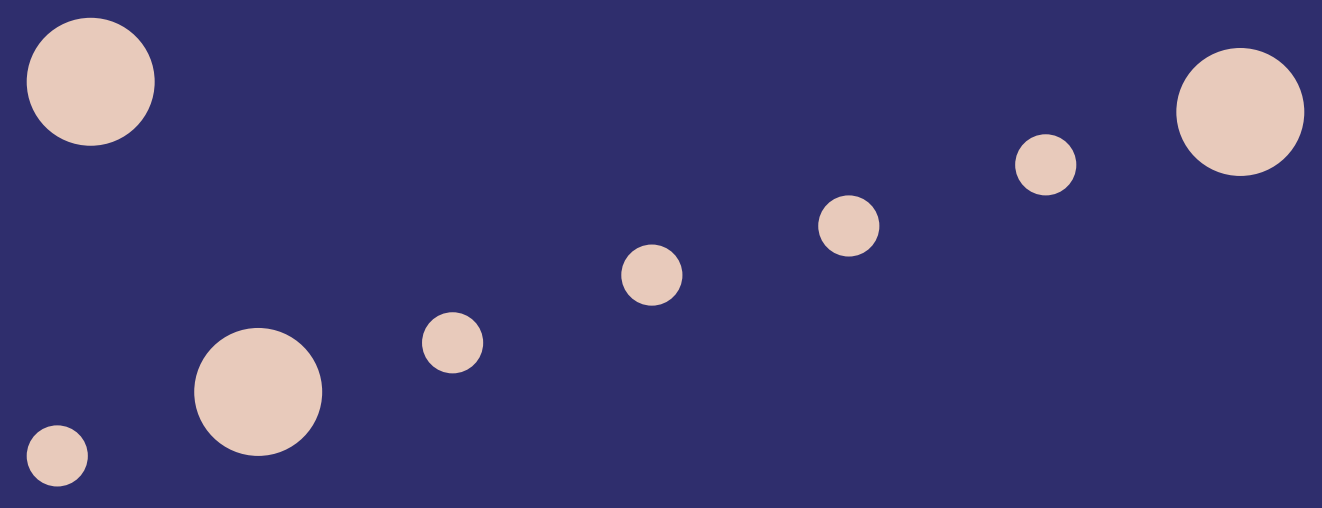

○
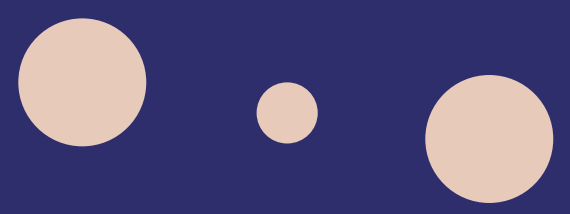
Ana Matilde Fauat: Mestre em Ciência da Informação pela Universidade de Brasília (UnB). Bacharel em Administração de Empresas. Especialização em Planejamento e Gestão de Negócios. MBA em Gestão de Riscos pela Fundação Instituto de Pesquisas Contábeis, Atuariais e Financeiras - FIPECAFI. Correio eletrônico: ana.fauat@hotmail.com

Anderson Barros Torres: Graduado em Processamento de Dados, Mestre em Ciência da Informação pela Universidade de Brasília. Oficial do Exército Brasileiro. Correio eletrônico: torres0208@gmail.com

André Luiz Valença da Cruz: Doutor e Mestre em Ciência da Informação pela Universidade de Brasília. Especialista em Gestão Estratégica da Informação pelo Centro Universitário do Distrito Federal. Gerente de Soluções da Secretaria Executiva do Banco do Brasil. Áreas de pesquisa: gestão do conhecimento, inteligência empresarial e gestão de riscos. Correio eletrônico: alvcbrasil@gmail.com

Angélica Toffano: Doutora em Ciência da Informação pela Universidade de Brasília (2008) e Mestre em Gestão do conhecimento e TI pela Universidade Católica de Brasília (2003). Atuou 28 anos como especialista de TI da Caixa Econômica Federal. Professora universitária há mais de 14 anos, atuando na graduação e pós-graduação. Pesquisadora atuando principalmente nos temas: Tecnologia da Informação e Comunicação, Medições, Qualidade de software, Qualidade da informação, Engenharia de requisitos, Metodologias ativas de aprendizagem. Correio eletrônico: angelica_toffano@yahoo.com.br

Bruno Jorge Soares: Especialista em Desenvolvimento Produtivo da ABDI (Agência Brasileira de Desenvolvimento Industrial). Graduado em Administração pela Universidade de Brasília(2000) e Mestrado pela Universidade de Brasília (2003). Atuou por mais de 10 anos como consultor na inteligência e estratégia no setor de serviços, indústria e comércio. $\mathrm{Na}$ ABDI desde 2009, coordenou o programa do setor automotivo da agência como a formulação e implementação do Programa Inovar Auto junto ao MDIC. A partir de 2016 assume o projeto indústria 4.0 que envolveu benchmarking internacional (Alemanha e EUA) e plataformas tecnológicas demonstradoras. Correio eletrônico: bjotadf@gmail.com

Carlos Alberto Batista de Sousa Pinto: Prof. Auxiliar do Departamento de Sistemas de informação da Escola de Engenharia da Universidade do Minho - Portugal. Correio eletrônico: csp@dsi.uminho.pt

Cláudia Augusto Dias: Possui graduação em Engenharia Elétrica (1987), mestrado em Ciência da Informação (2001) e doutorado em Ciência da Informação (2006), todos pela Universidade de Brasília. É servidora aposentada do Tribunal de Contas da União, onde atuou como Assessora de Ministro, Diretora de Auditoria de Tecnologia da Informação (TI), entre 
outras funções. Publicou artigos e livros sobre Usabilidade, Portal Corporativo, Métodos de Avaliação, Governo Eletrônico, Segurança da Informação e Auditoria de TI. Correio eletrônico: claudiaad@tcu.gov.br

Fernando César Lima Leite: Graduado em Biblioteconomia e Doutor em Ciência da Informação pela Universidade de Brasília. Professor da Faculdade de Ciência da Informação da Universidade de Brasília, instituição onde exerceu as funções de Coordenador do Programa de Pós-Graduação em Ciência da Informação e Diretor da Biblioteca Central. Atualmente é Bolsista de Produtividade em Pesquisa Nível 2 do CNPq. De 2007 à 2010 foi analista da Empresa Brasileira de Pesquisa Agropecuária (Embrapa). De 2006 e 2013 esteve vinculado ao Instituto Brasileiro de Informação em Ciência e Tecnologia (IBICT) como consultor e Especialista Visitante. Correio eletrônico: fernandodfc@gmail.com e fernandoc@unb.br

Kelley Cristine Gonçalves Dias Gasque: Profa. Adjunta da Universidade de Brasília, Faculdade de Ciência da Informação. Docente pesquisadora do Programa de Pós-Graduação em Ciência da Informação da UnB. Correio eletrônico: kelleycristinegasque@hotmail.com e kelley@unb.br

Joaquim Luís Costa: Licenciado em História pela Universidade Portucalense, mestre em Ciências da Informação pela Universidade do Minho e doutor em Ciências da Informação na Universidade Fernando Pessoa. Correio eletrônico: luisoc@portugalmail.com

Luciana de Deus Chagas: Mestre em Ciência da Informação pela Universidade de Brasília B (2006), possui especialização em saúde coletiva pela ABO/MG (2000) e graduação em Odontologia pela PUC/MG (1996). Oficial de Programas da OPAS/OMS no Brasil. Correio eletrônico: luchagas28@yahoo.com.br

Mark Hepworth: PhD Information Studies. Foi professor do Centre for Information Management da School of Business and Economics da Loughborough University, Inglaterra.

Milton Shintaku: Doutor em Ciência da Informação pela Universidade de Brasília. Tecnologista Sênior do Instituto Brasileiro de Informação em Ciência e Tecnologia (Ibict). Coordenador de Articulação, Aplicação e Geração de Tecnologia do IBICT. Correio eletrônico: shintaku@ibict.br

Roberto Campos da Rocha Miranda: Analista Legislativo - Recursos Humanos - Comissão do Esporte, Câmara dos Deputados. Mestrado Profissional em Poder Legislativo, Centro de Formação, Treinamento e Aperfeiçoamento - Cefor. Doutor em Ciência da Informação, UnB. Correio eletrônico: rcrmiranda@gmail.com e roberto.rocha@camara.leg.br 
Rosane Mendes Parmagnani: Graduada em Biblioteconomia, UFES. Especialista em Organização de Arquivos, USP. Mestre em Ciência da Informação, UnB. Analista "A" da Embrapa. Correio eletrônico: rosane.parmagnani@embrapa.br

Rosemeire Barbosa Tavares: Doutora em Ciência da Informação pela Universidade de Brasília. Docente pesquisadora colaboradora na Faculdade de Ciência da Informação da Universidade de Brasília. Correio eletrônico: rbtavares@unb.br

Rubi Nei Machado Oliveira: Mestre em Ciência da Informação pela Universidade de Brasília (2010). Bacharel em Informática pela Universidade da Região da Campanha (1999). Especialista em Docência do Ensino Superior pela Universidade Federal do Rio de Janeiro (2001). Especialista em Projeto e Aplicações de Redes de Comunicação pela Universidade de Brasília (2004). Especialista em Criptografia e Segurança em Redes pela Universidade Federal Fluminense (2009). Correio eletrônico: rubineimoliveira@gmail.com

Sely Maria de Souza Costa: PhD em Ciência da Informação pela Loughborough University (1999). Professora adjunta aposentada da Universidade de Brasília. Foi professora visitante da Universidade do Minho-Departamento de Sistemas de Informação. É professora convidada da Universidade Eduardo Mondlane. Pesquisadora nas áreas de comunicação científica, acesso aberto, publicações eletrônicas e comunicação organizacional, além de estudos em Gestão da informação e do conhecimento. Presidiu o comitê organizador de três conferências internacionais e participou regularmente como parecerista e membro do comitê científico de quatro conferências internacionais e de vários eventos nacionais. Correio eletrônico: profa. sely@gmail.com 
ibict

Brasilia
2018 
Este livro reúne frutos de pesquisas realizadas no âmbito da Ciência da Informação e que adotaram quadros teóricos de referência dos tópicos comunicação da informação, gestão da informação e gestão do conhecimento. Ora abordados isoladamente um do outro, ora abordados de modo associado um com o outro, todos são tangenciados pela noção de contexto. Ao longo da obra os autores oferecem aos leitores uma trama de abordagens conceituais - por meio dos modelos teóricos - métodos e resultados que compõem conjunto de conhecimentos elaborados por pesquisas realizadas ao longo de pouco mais de uma década. Constituído de dezessete capítulos, o livro é estruturado em partes sendo a primeira Introdução, e as demais intituladas, respectivamente, Comunicação da Informação Organizacional, Comunicação da Informação Científica, Comunicação da Informação em Comunidades, Gestão da Informação e Gestão do Conhecimento, Comunicação e Gestão da Informação e do Conhecimento. A expectativa dos organizadores e dos autores é oferecer contribuições úteis para fundamentação teórica de outros trabalhos que, sem dúvida, expandirão essa discussão.

Os Organizadores 